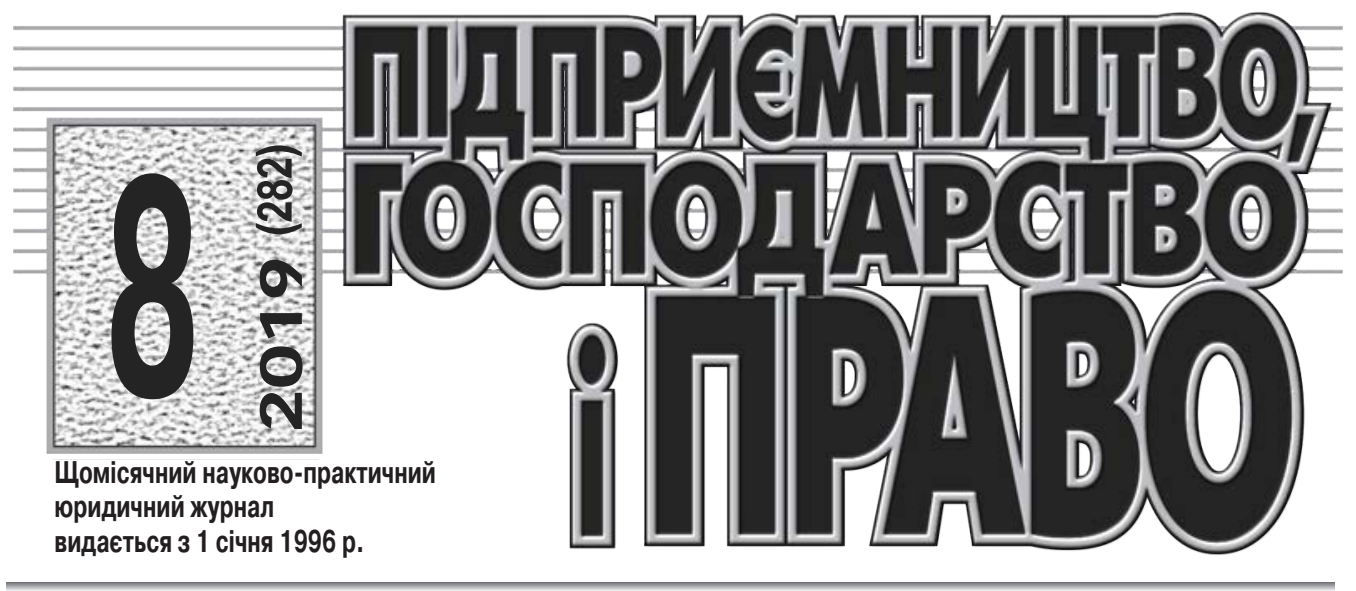

НАУКОВО-ДОСЛІДНИЙ ІНСТИТУТ ПРИВАТНОГО ПРАВА І ПІДПРИЕМНИЦТВА ІМ. АКАДЕМІКА Ф.Г. БУРЧАКА НАПрН УКРАЇНИ

Головний редактор

Крупчан

Олександр

Дмитрович

Редакційна

колегія:

Беляневич О.А

Бобрик B.I.

Бичкова С.С.

Вавженчук С.Я

Галянтич М.К

Долницький Б.

Дрозд О.Ю

Коструба А.В

Кубічек П.

Кузнєцова Н.С.

Луць В.В.

Майданик Р.А.

Махінчук B.M.

Мельник М.I.

Монаєнко А.О.

Торгашин О.M

\section{ЦИВІЛЬНЕ ПРАВО I ПРОЦЕС}

\section{Наталія Василина}

Механізм урегулювання цивільно-правового спору. 5

Марія Гудима-Підвербецька

Правова природа субсидіарних зобов’язань в цивільному праві України.....10

\section{Людмила Корнілова}

Правове регулювання іпотечних правовідносин в контексті

банкрутства фізичних осіб

\section{Наталія Навальнева}

Конфіскаційні санкції в цивільному праві за вчинення

недійсного правочину

олена Старченко

Проблемні питання процесуального статусу експерта з питань права........26

Володимир Шемонаєв

Правове значення загальної аварії

при страхуванні вантажу. ...

\section{ГОСПОДАРСЬKE ПРАВО I ПРОДЕЕ}

\section{Наталія Квіт}

Правовий статус управителя біобанку:

поняттєвий апарат і класифікація. . ...

Ганна Сандюк

Систематизація правових норм, які регулюють арешт морських суден. . . . .41

\section{Ірина Феофанова}

Трансформація інституту державної допомоги суб'єктам господарювання в контексті імплементації Угоди про асоціацію між Україною

та Європейським Союзом.

\section{ПРАВО СОЩІАЛЬНОГО ЗАБЕЗПЕЧЕННЯ}

\section{Леся Малюга}

Контроль за відповідністю проектів нормативно-правових актів соціального законодавства України праву Європейського Союзу....

\section{ЗЕМЕЛЬHЕ ПРАВО}

\section{Олександр Панасюк}

Визнання права як спосіб захисту у земельних орендних відносинах. .......58 


\section{АДМІНІСТРАТИВНЕ ПРАВО I ПРОМЕС}

\section{Світлана Бевз}

Правосвідомість у правовому регулюванні державного управління

у сфері господарської діяльності.

Артур Замрига

«Економіка країни» та «господарство країни»: адміністративно-правові аспекти співвідношення понять. ....

Лілія Золотухіна

Захист публічного інтересу в адміністративному порядку.

\section{олена Калашник}

Пріоритет сталості сімейних зв'язків та возз'єднання сім'ї у справах

про визнання шукача захисту та членів його родини біженцями або особами, які потребують додаткового захисту

\section{Олександр Константий}

До питання поняття, предмета, методу і системи

адміністративного судочинства України.

\section{олена Коротун, Олександр Світличний}

Поняття та структура адміністративно-правового забезпечення

охорони прав суб'єктів інтелектуальної власності.

Алла Половченя

Забезпечення принципу

автономії закладів вищої освіти: адміністративно-правовий аспект.

\section{Михайло Соф'̈н}

Нерівномірність податкового навантаження

в умовах євроінтеграційного курсу України.

В'ячеслав Тильчик

Онтологічний вимір правопорушення як предмета спору

у сфері публічно-правових відносин.

Андрій Федорчук

Імплементація зарубіжного досвіду адміністративно-правового регулювання правового статусу суддів.

Генадій Шевчук

Правовий статус Управління з питань запобігання корупції

та проведення люстрації в структурі МВС України.

\section{КОНСТИТУЦИЙНЕ ПРАВО}

\section{Андрій Деркач}

Міжнародно-правові стандарти захисту прав людини та їх відображення

в Конституції України....

\section{ФIHAHCOBE ПPABD}

\section{Анастасія Косенкова}

Розвиток концепції бенефіціарного власника при імплементації плану BEPS в Україні.. ...

\section{ТЕОРІЯ ДЕРЖАВИ I ПРАВА}

\section{олена Грезіна}

Зарубіжний досвід упровадження інституту освітнього омбудсмена: компаративний аналіз

Наталя Гунько

Техніка внесення змін та доповнень до законів України.

олександр Дудиенко

Сутність правоохоронної системи. 


\section{Тетяна Міхайліна}

Правосвідомість у правовій системі: кібернетичний

та синергетичний аспекти.

Людмила Міхневич

Викладання торгового права в українських

вишах раннього радянського періоду.

Юлія Назарук

Чинність правозастосовних актів органів та посадових осіб

місцевого самоврядування у просторі.

Олег Олійник

Характеристика негативного впливу на демократію в Україні............................165

Денис Тихомиров

Теоретичні аспекти правового забезпечення безпеки ....

тетяна Фулей

Застосування принципу гендерної рівності у практиці

Європейського суду з прав людини.

\section{КРИМПНАЛЬНЕ ПРАВО}

\section{Олександр Берило}

Кримінальне законодавство зарубіжних країн про відповідальність

за ненадання допомоги хворому медичним працівником. . . .

Андрій Боровик

Елементи загально соціального запобігання

окремим видам кримінальних правопорушень в Україні...

Олена Олійник

Порівняльно-правове дослідження принципів кримінального права романо-германської та мусульманської правових сімей.

\section{КРИМПНОЛОГІЯ}

\section{Сергій Рощулкін}

Співвідношення понять «одержання подарунку» та «неправомірна вигода».

\section{КРИМІНАЛЬНИЙ ПРОЦЕС}

\section{Тимур Лоскутов}

Відповідність окремих норм Кримінального процесуального кодексу

України європейським стандартам забезпечення прав людини.

Сергій Шульгін

Види процесуальних рішень слідчого та прокурора...................................208

\section{КРИМПНАЛІТТИКА}

\section{Михайло Балан, Юрій Літвін}

Особливості криміналістичного забезпечення огляду місця події

під час розслідування порушень державного кордону України.

\section{олена Самойленко}

Відкриття кримінального провадження щодо злочинів, вчинених у кіберпросторі.

\section{СУДОУСТРІЙ}

\section{Яна Шевцова}

Організаційно-правові засади системи суддівської освіти.

\section{MIЖНАРОДНЕ ПРРВО}

\section{Вікторія Демчишина}

Роль інституційного механізму європейського союзу у міграційній сфері. 
На першій сторіниі обкладинки пам'ятник

Магдебурзькому праву в м. Києві

\section{Вадим Попко}

Суспільні передумови та роль глобалізації у формуванні транснаціонального кримінального права.

\section{PELIEH引II}

\section{Олена Бусол}

Рецензія на монографію М. І. Карпенка «Військові злочини:

питання теорії, законодавства і практики». . .

\section{Оксана Васильченко}

Рецензія на монографію кандидата юридичних наук, здобувача кафедри конституційного права та порівняльного правознавства Ужгородського національного університету К. В. Головко

«Систематизація муніципального законодавства:

український досвід».

Співзасновники:

Науково-дослідний інститут приватного права і підприємництва ім. академіка Ф. Г. Бурчака Національної академії правових наук України, ТОВ «Гарантія», Адвокатське об'єднання «Gestors» Видавець: ТОВ «Гарантія»

ISSN 2663-5313 (print)

ISSN 2663-5321 (online)

Журнал є фаховим виданням з юридичних наук

на підставі Наказу МОН України № 1328 від 21.12.2015 (додаток № 8).

Журнал включено до міжнародної наукометричної бази Index Copernicus International (Республіка Польща)

Свідоцтво про державну реєстрацію друкованого засобу масової інформації серія КВ № 15779-4251ПР від 02.11.2009 р

Журнал рекомендовано до друку та поширення через мережу Internet вченою радою

Науково-дослідного інституту приватного права і підприємництва ім. академіка Ф. Г. Бурчака НАПрН України (Протокол № 7 від 24.07.2019 року)

Офіційний сайт: pgp-journal.kiev.ua

Підписано до друку 02.08.2019. Формат 70х108 1/16. Папір офсетний.

Друк офсетний. Ум. друк. арк. 14,65 .
Тираж - 255. Замовлення № 0919/181

Нааруковано: Видавничий дім «Гельветика»,

Свідоцтво субб'єкта видавничої справи ДК № 6424 від 04.10.2018 р

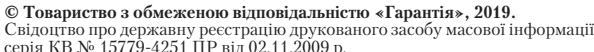
Поитова адреса редакиіi: 01032, м. Київ, вул. Назарівська, 7-Б, оф. 4. 
УДК 347.91

DOI https://doi.org/10.32849/2663-5313/2019.8.01

\section{Наталія Василина,}

канд. юрид. наук, дочент,

дочент кафедри правосуддя

Київського начіонального університету імені Тараса Шевченка

\section{МЕХАНІЗМ УРЕГУЛЮВАННЯ ЦИВІЛЬНО-ПРАВОВОГО СПОРУ}

У статті досліджуються питання змісту поняття «иивільно-правовий спір», механізму врегулювання иивільно-правового спору, що включає такі стадії, як здійснення провадження, їх характеристика, методика уникнення спору, його врегулювання та виконання досягнутих сторонами домовленостей. Змістом иивільно-процесуального спору є спір, який виникає внаслідок відсутності згоди суб'єкта иивільного права щодо умов виконання тих чи інших прав або обов'язків, що випливають 3 закону чи договору. Слід наголосити на тому, що спір виникає винятково під час виконання умов договору чи іншого правочину, за інших умов договір не можна вважати укладеним.

Провадження щодо врегулювання иивільно-правового спору складається з чотирьох стадій, а саме: підготовчої, проведення прямих переговорів, укладання та підписання досягнутих домовленостей сторонами та виконання досягнутих домовленостей. Неможливість сторонами самостійно врегулювати цивільно-правовий спір є підставою для можливого залучення ними третьої особи - посередника, медіатора тощо. При иьому в якості посередника сторони можуть залучити адвоката, нотаріуса, медіатора, а у разі якщо однією стороною подано позов до суду, і суддю. В такому разі спір вже вирішується з дотриманням норм матеріального та прочесуального права або за правилами, завчасно встановленими сторонами для врегулювання конкретних питань.

Завданням посередника є сприяння досягненню взаєморозуміння між сторонами без втручання у зміст домовленостей і рішення, що має бути ними досягнуто. Тобто метою посередника є організація самого проиесу врегулювання спору та спрямування їх намірів саме на досягнення консенсусу.

Неможливість врегулювання спору шляхом здійснення провадження щодо врегулювання иивільно-правового спору в позасудовому порядку відкриває сторонам шлях для звернення до третейського суду (арбітражного) або суду загальної юрисдикиї для його вирішення. При цьому навіть у разі звернення до суду сторони чивільно правового спору не позбавляються права на його врегулювання иляхом укладення мирової угоди (договору про примирення)

Ключові слова: провадження, врегулювання, факультативна стадія цивільного судочинства, медіатор, посередник.

Постановка проблеми. Актуальність обраної теми викликана важливістю дослідження питань врегулювання цивільноправового спору в межах розвитку його судового та позасудового врегулювання. Розвиток судового та позасудового врегулювання цивільно-правових спорів залежить від стану наукових доробок в цій сфері, аналізу наявних практик, напрацювання певних рекомендацій тощо. Задля дослідження означених питань також важливим є розкриття змісту поняття «цивільно-правовий спір», з огляду на правильне розуміння предмету спору.

Аналіз останніх досліджень. Питання наукового осмислення реалізації процесів медіації, врегулювання цивільно-правових спорів за участю судді, нотаріуса частково розкриваються в роботах Е. Carroll, К. Mackie, Д.Д. Луспеника, М.М. Дякович, Н.О. Киреєвої, О.С. Можайкіна. Так, зокре-

ма, О.С. Можайкіною запропоновано до обговорення порівняльний аналіз медіації та Collaborative Law [1, c. 55]. Водночас сьогодні відсутні комплексні дослідження фахівців щодо здійснення проваджень врегулювання цивільно-правових спорів як в судовому, так і в позасудовому порядку.

Метою статті $\mathbf{\epsilon}-$ розкрити зміст поняття «цивільно-правовий спір», надати визначення поняттю «провадження щодо врегулювання цивільно-правового спору», визначити стадії провадження щодо врегулювання цивільно-правового спору та методику їх проходження.

Виклад основного матеріалу. Домовленість сторін щодо укладання провочину, взаємного виконання законодавчих приписів має відображати вільне волевиявлення сторін на досягнення певних результатів. Крім того, волевиявлення сторін за своїм змістом 
мають бути взаємовигідними та забезпечувати інтереси кожної сторони, не порушуючи при цьому прав та інтересів інших.

У випадках встановлення правил поведінки законом слід виходити з того, що правова норма є певним приписом, що обумовлює однакові та загальні межі для виміру та соціально необхідної оцінки поведінки кожного члена суспільства [2, с. 108]. Отже, норма є вимогою щодо типової моделі поведінки особи, окреслюючи при цьому межі іï можливості та обов'язковості, спрямовуючи діяльність особи в напряму, що відповідатиме інтересам суспільства.

Слід погодитись з позицією А.С. Васильєва щодо дуалістичної природи поняття норми права. Так, ним виділяється право об'єктивне як сукупність загальнообов'язкових правил поведінки, що має свій вираз у системі юридичних норм, закладених Конституцією та законодавчими актами, та суб'єктивне право, що належить конкретній особі, тобто визначена законом можливість певного прикладу поведінки в конкретних правовідносинах [3, c. 230].

Відповідно до статті 11 Цивільного кодексу України серед підстав виникнення цивільних прав та обов'язків визначені договори та інші правочини. У випадках, встановлених актами цивільного законодавства або договором, підставою виникнення цивільних прав та обов'язків може бути настання або ненастання певної події [4]. 3 огляду на те, що цивільні обов'язки виконуються у межах, встановлених договором або актом цивільного законодавства, а їх виконання забезпечується засобами заохочення та відповідальністю, які встановлені договором або актом цивільного законодавства, саме їх невиконання або неналежне виконання породжує спір.

Враховуючи наведене, слід зазначити, що цивільно-правовим спором є спір, який виникає внаслідок відсутності згоди суб'єкта цивільного права щодо умов виконання тих чи інших прав або обов'язків, що випливають з закону чи договору.

Якщо йдеться про виконання умов договору чи іншого правочину, то спір виникає саме на момент його виконання, за інших умов договір не можна вважати укладеним.

Першим етапом виходу зі спору $є$ його уникнення, не доводячи його до протистояння. При цьому ми розуміємо, що в такому разі частіше за все йдеться не стільки про врегулювання спору, скільки про відтермінування його на певний час.

Якщо уникнути спору не можливо, сторонами мають бути проведені прямі переговори. Під час проведення перего- ворних процесів більшість спірних питань можуть бути відрегульовано, знято емоційну напруженість сторін тощо. На цьому етапі сторони часто використовують обмін претензіями, відзивами, запереченнями та пропозиціями.

У разі якщо сторони самостійно не можуть досягнути згоди, ними залучається третя особа - посередник, медіатор тощо. При цьому як посередника сторони можуть залучити адвоката, нотаріуса, медіатора, а у разі якщо однією стороною подано позов до суду, і суддю. В такому разі спір уже вирішується 3 дотриманням норм матеріального та процесуального права або за правилами, завчасно встановленими сторонами для врегулювання конкретних питань.

Завданням посередника $є$ сприяння досягненню взаєморозуміння між сторонами без втручання у зміст домовленостей і рішення, що має бути ними досягнуто. Тобто метою посередника є організація самого процесу врегулювання спору та спрямування їніх намірів саме на досягнення консенсусу.

Якщо врегулювати спір шляхом прямих переговорів або за участю посередника неможливо, сторони звертаються до суду третейського (арбітражного) або суду загальної юрисдикції для його вирішення. При цьому навіть у разі звернення до суду сторони цивільно правового спору не позбавляються права на його врегулювання шляхом укладення мирової угоди (договору про примирення).

Слід зазначити, що врегулювання спору та його вирішення є поняттями не тотожними. Так, вирішення спору передбачає складну, багатостадійну процедуру, спрямовану на усунення джерела конфлікту сторін, повне або часткове задоволення прав та інтересів контрагентів в умовах, коли сторони не лише не сприяють одна одній в успішному вирішенні предмету спору, а навпаки докладають максимум зусиль для затягування конфлікту або ж вирішення його винятково у власних інтересах.

Своєю чергою врегулювання спору передбачає активні дії сторін, спрямовані на досягнення домовленостей щодо спірних питань, при цьому таке примирення має бути добровільним. Врегулювання спору є певним компромісом, що досягається сторонами 3 метою недопущення більших втрат (емоційних, матеріальних, людських, часових тощо) внаслідок затягування конфлікту.

Отже, під провадженням щодо врегулювання цивільно-правового спору слід розуміти встановлений законом або сторонами спору порядок досягнення консенсусу щодо умов виконання домовленостей. При цьому 
встановлений законом порядок притаманний саме юрисдикційним органам (судам загальної юрисдикції, третейським (арбітражним) судам). Під час врегулювання спору юрисдикційними органами обов'язковим є сувоpe дотримання процесуального порядку досягнення консенсусу та його закріплення. Так, під час врегулювання спору за участю судді процесуальний порядок провадження закріплений главою 4 розділу III Цивільного процесуального кодексу України [5]. Слід зазначити, що питання можливого врегулювання спору за участю судді вирішується судом під час підготовчого провадження на підготовчому засіданні, тобто до початку судового розгляду. Так, відповідно до пункту 2 статті 197 Цивільного процесуального кодексу України суд з повідомленням учасників справи з'ясовує, чи бажають сторони укласти мирову угоду, передати справу на розгляд третейського суду або звернутися до суду для проведення врегулювання спору за участю судді. У разі отримання згоди від сторін суд призначає проведення процедури врегулювання спору за участю судді шляхом постановлення відповідної ухвали, якою одночасно зупиняє провадження у цивільній справі.

Метою процедури примирення за участю судді є мирне врегулювання цивільно-правового спору, укладення мирової угоди та закриття провадження у цивільній справі.

Стадією цивільного судочинства вважається визначена цивільним процесуальним законодавством сукупність процесуальних дій суду та інших учасників судового процесу, об'єднаних конкретною процесуальною метою. 3 огляду на це врегулювання спору за участю судді слід вважати стадією цивільного судочинства. Водночас, з урахуванням того, що вона не є обов'язковою і відбувається винятково за згодою сторін та за умови відсутності серед учасників справи третіх осіб із заявленням самостійних вимог, її слід вважати факультативною.

Отже, примирення сторін за участю судді є самостійною, відокремленою, факультативною стадією цивільного судочинства, провадження в якій здійснюється винятково за згодою сторін з дотриманням цивільного процесуального законодавства.

Провадження щодо примирення в неюрисдикційному порядку не має чітко визначеної законодавством регламентації іï проведення і встановлюється винятково за домовленістю сторін. Незважаючи на те, що провадження щодо примирення здійснюється в порядку, визначеному сторонами примирення, воно є спробою забезпечення сторонами належної реалізації норм цивільного законодавства (норм матеріального права). Тобто визначення предмету спору, сукупності норм права, що безпосередньо регулюють вказані правовідносини, основний акцент в яких робиться саме на визначення прав i обов'язків учасників провадження.

Першочерговим завданням провадження примирення є встановлення джерела спору. Для його з'ясування необхідним є правильне визначення сторін спору, обставин справи, суті спору (зміст претензій та заперечень), можливих шляхів врегулювання спору, який саме сторонній вплив є необхідним для врегулювання спору та на який результат розраховують сторони.

Якщо врегулювання спору відбувається за участю судді, то 3 огляду на матеріали цивільної справи суд має визначитися, зокрема, з тим, які саме питання він має поставити сторонам щодо змісту правовідносин, підстав та предмету позову, змісту заперечень тощо.

Якщо примирення відбувається в позасудовому порядку, чітке розуміння цих питань покладається безпосередньо на сторони. Зокрема, сторони можуть стикатися 3 різним розумінням предмету спору, а звідси й категоричне несприйняття обставин, якими обгрунтовуються претензії та заперечення. Отже, самостійно або за участю третьої особи (медіатора) сторони мають утворити умови, за яких ними будуть надані відповіді щодо суті взаємних претензій, чіткого розуміння власних інтересів, структуровано зміст спору та окреслено «червоні лінії», за якими вони мають досягнути консенсусу, а також запропонувати можливі альтернативні варіанти виходу із конфлікту та прийняття оптимального рішення.

E. Carroll та K. Mackie пропонують визначати три стадії медіації, а саме: підготовчу, обмін інформацією та ведення перемовин [6, с. 66]. Водночас професор К.Г. Шліффен переконаний, що таких стадій є чотири, а саме: попередня стадія (звернення сторін до медіатора, оцінка медіатором спору, забезпечення організаційних питань), установча стадія (презентація медіатором організаційних питань ведення перемовин, отримання згоди сторін на проведення врегулювання спору, врегулювання фінансових питань, що пов'язані з організацією процесу примирення, укладання договору про медіацію), основну стадію (під час якої забезпечується отримання інформації від сторін, визначення питань для обговорення, пошук можливих варіантів вирішення) та заключна стадія (на якій сторонами укладається та підписується договір та визначаються правила контролю за дотриманням його умов) [7, c. 186]. 
Частково погоджуючись 3 наведеною класифікацією, вважаємо за необхідне зауважити наступне.

Зважаючи на те, що врегулювання цивільно-правового спору сьогодні вже не є винятковою компетенцією медіаторів, правила, за якими мають провадитись процедури примирення, мають бути максимально уніфіковані. Врегулювання спору за участю судді, нотаріуса, адвоката, медіатора повинні відповідати основним вимогам, а саме прискорення процедури порівняно з судовим процесом, волевиявлення сторін на ії проведення, відносне здешевлення процедури, досягнення сторонами компромісу та швидке добровільне виконання досягнутих домовленостей.

Отже, перша стадія врегулювання спору, а саме підготовча, має включати в себе не лише звернення однієї сторони спору, а й отримання згоди другої сторони на відкриття провадження щодо врегулювання спору, надання сторонами повної інформації щодо суті спору, визначення кола учасників справи, з'ясування предмету спору, змісту претензій і заперечень, надання правої оцінки обставинам справи, якими сторони обгрунтовують власні вимоги та заперечення, напрацювання можливих шляхів для досягнення сторонами консенсусу. На цій стадії вирішуються організаційні та фінансові питання проведення врегулювання спору, сторони мають можливість додаткового обміну інформацією, проведення як спільних нарад, так і нарад за відсутності іншої сторони, отримати від судді, нотаріуса, адвоката інформацію щодо аналогічних спорів та можливих шляхів їх вирішення.

Наступною стадією є стадія проведення прямих переговорів сторін, з урахуванням вже отриманої та опрацьованої ними інформації, узгодження позицій та напрацювання змісту домовленостей.

Третьою стадією ми визначаємо стадію укладання та підписання досягнутих домовленостей сторонами. При цьому явною перевагою в цьому разі є проведення врегулювання спору за участю судді та нотаріуса, зважаючи на те, що укладену сторонами мирову угоду суд затверджує шляхом постановлення відповідної ухвали, а нотаріус має право на його посвідчення, що своєю чергою забезпечує досягнутим домовленостям сторін публічного визнання та не потребує додаткового доказування на майбутнє.

Останньою стадією має стати стадія виконання досягнутих домовленостей. Виконання домовленостей є важливою стадією врегулювання спору, зважаючи на мету, декларовану сторонами врегулювання спору.
Виконання домовленостей сторонами є важливим і обов'язковим з огляду на те, що основною метою врегулювання спору є не лише досягнення певних домовленостей сторонами щодо їх взаємних прав та обов'язків, a i їх належна реалізація. Тобто лише належна реалізація сторонами досягнутих домовленостей $є$ реальним виходом сторін $3 \mathrm{KoH}^{-}$ флікту.

\section{Висновки}

3 огляду на вищевикладене слід зазначити, що змістом цивільно-процесуального спору слід визнавати розбіжності у розумінні сторонами процесів реалізації власних прав та обов'язків, що випливають з закону чи договору, а отже, відмову від їх виконання. При цьому під провадженням щодо врегулювання цивільно-правового спору слід розуміти встановлений законом або сторонами спору порядок досягнення консенсусу щодо умов виконання домовленостей, що складається з чотирьох стадій, а саме: підготовчої, проведення прямих переговорів, укладання та підписання досягнутих домовленостей сторонами та виконання досягнутих домовленостей.

Зважаючи на важливість розвитку форм врегулювання цивільно-правових спорів та подальшого виконання досягнутих домовленостей, подальшому дослідженню підлягають переваги та недоліки кожної з форм та шляхи їх вдосконалення.

\section{Список використаних джерел:}

1. Можайкіна О.С. Деякі аспекти співвідношення медіації та Collaborative Law у вирішенні цивільно-правових спорів. Актуальні проблеми вітчизняної юриспрудениії. 2019. №1. С. 54-58.

2. Момов В. Норма и мотив поведения Вопросы философии. 1972. №8. С. 108-109.

3. Основи права и государства в вопросах и ответах /под общ. ред. А.С. Васильева. Харьков, 2002. $628 \mathrm{c}$.

4. Цивільний кодекс України. Офіційний веб-портал Верховної Ради України. URL: https://zakon.rada.gov.ua/laws/show/435-15.

5. Цивільний процесуальний кодекс України. Офіційний веб-портал Верховної Ради України. URL: https://zakon.rada.gov.ua/laws/show/ 1618-15/stru\#Stru.

6. Carroll E. International mediation - the art of business diplomacy / E. Carroll, K. Mackie. 2 edition. Kluwer Law International, Tottel, 2006. 187 p.

7. Грефин фон Шлиффен К., Вегманн Б. Медиация в нотариальной практике (альтернативные способы разрешения конфликтов). Перевод с нем. Трушникова C.C. Wolters Kluwer, 2005. 372 c. 
The paper is devoted to the content of the concept of "civil dispute", the mechanism of settlement of civil dispute, including the stages of production, their characteristics, methods of dispute avoidance, its settlement and implementation of agreements reached by the parties. The author emphasized on that the content of a civil procedure dispute is a dispute arising from the lack of consent of the subject of civil law on the conditions of performance of certain rights or obligations arising from the law or the contract.

The author noted that the dispute arises only when the conditions of the contract or other transaction, other conditions of the contract can not be considered concluded. The paper focuses on that civil law proceedings consist of four stages, namely: preparatory proceedings, direct negotiations, conclusion and signing of agreements reached by the parties and implementation of agreements reached. The inability of the parties to independently settle the civil law dispute is the basis for the possible involvement of a third party - mediator, mediator, etc. At the same time, the parties may engage an attorney, a notary, a mediator, and if one of the parties has filed a lawsuit in court and a judge. In this case, the dispute is already resolved in accordance with the substantive and procedural law or the rules of the parties' predetermined settlement of specific issues.

The author analyzed that the task of the mediator is to promote mutual understanding between the parties, without interfering in the content of agreements and decisions, and should be achieved by them. That is, the purpose of the mediator is to organize the very process of dispute resolution and to direct their intentions precisely to achieving consensus.

In conclusion the author said that the impossibility of dispute resolution through the implementation of civil law dispute settlement proceedings in an extrajudicial manner opens the way for the parties to appeal to the court of arbitration (arbitration) or the court of general jurisdiction for its decision. Thus, even in case of the reference to court the parties of civil-law dispute are deprived of the right to its settlement by conclusion of the settlement agreement (agreement on reconciliation).

Key words: proceedings, settlements, the optional stage of civil proceedings, mediator, mediator. 
УДК 347.412

DOI https://doi.org/10.32849/2663-5313/2019.8.02

Марія Гудима-Підвербецька,

канд. юрид. наук, доиент,

докторант кафедри ицвільного права

Навчально-наукового юридичного інституту

ДВНЗ «Прикарпатсъкий начіональний університет імені Василя Стефаника»

\section{ПРАВОВА ПРИРОДА СУБСИДІАРНИХ ЗОБОВ'ЯЗАНЬ В ЦИВІЛЬНОМУ ПРАВІ УКРАЇНИ}

У статті підкреслено, що формулювання вітчизняного законодавия не вносить ясність у визначення правової природи субсидіарних зобов'язань та не лише не вирішує, а й загострює наукові дискусії з цього приводу, даючи простір для прямо протилежни трактувань. Відзначено існування у вітчизняній доктрині двох основних позииї вчених, що по-різному тлумачать правову природу субсидіарних зобов'язань: одні вважають їх різновидом зобов'язань з множинністю осіб поряд із частковими $i$ солідарними зобов'язаннями (домінуюча позиція), інші заперечують можливість тлумачення субсидіарних зобов'язань як зобов'язань з множинністю осіб як у договірних, так і в позадоговірних зобов'язаннях. Проведено критичний аналіз аргументів і контраргументів обох сторін дискусї та на основі цього сформульовано виважений і однозначний висновок із зазначеної проблеми. При иьому підкреслено, що більшість аргументів прибічників множинності в субсидіарних зобов'язаннях знімається, якщо дати правильне трактування ї змісту й з'ясувати питання про існування двох взаємодоповнюючих, однак самостійних зобов'язань, що виникають між кредитором та основним боржником і між основним та субсидіарним боржниками, чи єдиного зобов'язання. Оскільки доведено, що обов'язок субсидіарного боржника не збігається за змістом $з$ обов'язком основного боржника, оскільки немає спільного об'єкта зобов'язання, підсумовується, що, вирішуючи питання про правову природу субсидіарних зобов'язань, коректно вести мову не про зобов'язання з множинністю осіб, а про самостійне зобов'язання (що є додатковим до основного, тісно пов'язане 3 останнім), яке спрямоване на гарантування прав кредитора в основному зобов'язанні, де у разі неможливості основного боржника задовольнити вимоги кредитора за його волевиявленням можуть виникати зобов'язання субсидіарного боржника з відмінним щодо основного об'єктом зобов'язання, яке так і може залишитись потениійним у разі належного виконання боржником основного зобов'язання.

Ключові слова: додаткове зобов’язання, субсидіарна відповідальність, множинність осіб у зобов'язанні, об'єкт зобов'язання, предмет зобов'язання, виконання зобов'язання.

Постановка проблеми. Субсидіарні зобов'язання не мають нормативно-правового закріпленого визначення у Цивільному кодексі (далі - ЦК) України, де йдеться про часткове та солідарне зобов'язання як види зобов'язань при множинності осіб (ст.ст. 540 544 ЦК України) і окремо про субсидіарну відповідальність як різновид цивільно-правової відповідальності (ст. 619 ЦК України). У ч. 1 ст. 619 ЦК України тільки неоднозначно формулюється, що договором або законом може бути передбачена поряд (виділення наше - М. Г.) із відповідальністю боржника додаткова (субсидіарна) відповідальність іншої особи. Що означає це законодавче «поряд»? Чи дозволяє віднести субсидіарні зобов'язання до зобов'язань 3 множинністю осіб, як це робиться доволі часто в юридичній літературі, і якщо й дозволяє, то чи коректне таке віднесення? Постановка цих питань невипадкова, адже, як показали результати проведеного дослідження, здебільшого, говорячи про зобов'язання 3 множинністю осіб, науковці зосереджують увагу на солідарних і часткових зобов'язаннях, оминаючи зобов'язання субсидіарні, на противагу цьому, говорячи про види цивільно-правової відповідальності, поряд із частковою і солідарною вчені вже віднаходять місце субсидіарній відповідальності. Ті ж напрацювання, які безпосередньо присвячені дослідженню сутності субсидіарних зобов'язань, містять прямо протилежні трактування. Таким чином не досить чітка законодавча регламентація і недостатне висвітлення в юридичній літературі питань субсидіарних зобов'язань породжує гостру полеміку серед науковців щодо їхньої правової природи в аспекті можливості чи неможливості віднесення їх до зобов'язань 3 множинністю осіб, яка потребує вирішення.

Аналіз останніх досліджень і публікацій. Більшість науковців як радянського періоду, так і сучасних, у працях яких безпосередньо чи побічно йшлося про суб'єктний склад субсидіарних зобов'язань (А. С. Бакін, М. І. Бра- 
гінський, В. В. Вітрянський, Г. Г. Гриценко, Г. Н. Іванова, О. Г. Калпін, Ю. Я. Крюкова, М. В. Кротов, О. І. Масляєв, Х. Т. Насіров, В. Ф. Попондопуло, Н. М. Сампара, С. В. Сарбаш, В. М. Слома, Д. В. Трут К. О. Храпунова, С. О. Харитонов, О. І. Чернілевська, О. С. Шевченко тощо), намагалися визначити їхню правову природу, проте здебільшого це мало вигляд констатації фактів без аргументації та обгрунтування. Проте й у незначній кількості напрацювань, автори яких підтверджують своє бачення доводами (зокрема, А. С. Бакін, Г. Г. Гриценко, О. I. Масляєв, Х. Т. Насіров, Н. М. Сампара, С. В. Сарбаш, Д. В. Трут), до сих пір немає однозначності у вирішенні питання про правову природу субсидіарних зобов'язань. Наведене вище свідчить про недостатню вивченість проблем правової природи субсидіарних зобов'язань, і насамперед їх відмежування від зобов'язань з множинністю осіб, отже, дана проблема потребує подальшої розробки.

Мета статті полягає у критичному аналізі аргументів, що наводяться вченими для обгрунтування тієї чи іншої позиції щодо правової природи субсидіарних зобов'язань, та формулюванні виваженого

й однозначного висновку щодо зазначеної ॥ проблеми.

Виклад основного матеріалу. У доктрині є дві основні позиції науковців, що по-різному тлумачать правову природу субсидіарних зобов'язань. Згідно з домінуючою думкою (незважаючи на іï пізніше в часі виникнення) вітчизняних та російських вчених субсидіарне зобов'язання є різновидом зобов'язань 3 множинністю осіб (поряд із частковими і солідарними зобов'язаннями) (О. Є. Богданова, М. В. Кротов, С. В. Сарбаш, В. М. Слома, Д. В. Трут, Є. О. Харитонов, К. О. Храпунова, О. І. Чернілевська тощо). Причому здебільшого підкреслюється, що особливістю такого зобов'язання $є$ можливість його існування або лише при пасивній [1, с. $28 ; 2$, с. $13 ; 3$, с. $629 ; 4$, с. 667-669; 5 , с. 26,$28 ; 6$, с. 11,$12 ; 7$, с. 43,164$]$ або пасивній і змішаній множинності осіб $[8 ; 9$, с. 56 ; 10, с. 92]. Наприклад, Д. В. Трут під субсидіарним зобов'язанням розуміє таке «правовідношення, де на стороні боржника є дві особи - основний боржник і додатковий (субсидіарний) і при якому кредитор буде мати право звернутися з вимогою до субсидіарного боржника у випадку відмови від виконання зобов'язання 3 боку основного боржника або неотримання від останнього відповіді на вимогу у розумний строк» [11, с. $146-148 ; 12$ с. 188]. С. О. Харитонов зазначає, що залежно від того, в якому розмірі кредитор має право вимагати, а боржник повинен виконати зобов'язання, і виокремлюють субсидіарні зобов'язання з множинністю осіб, які мають місце у пасивній або змішаній множинності, тобто множинності на стороні боржника [10, с. 92].

Заради об'єктивності зазначимо, що в межах даної позиції науковцями все ж відзначаються певні відмінності від інших зобов'язань $з$ множинністю осіб, однак їм не надається істотного значення. Так, вчені в тій чи інші формі підкреслюють, що від пасивних солідарних зобов'язань вони відрізняються неможливістю для кредитора пред'явити вимогу про виконання зобов'язання відразу до субсидіарного боржника, минувши основного [13, с. 42,14 , с. $352 ; 15$, с. $167 ; 16$, с. 626 ; 7, с. 42], однак зазначається при цьому, що важко уявити собі ситуацію, в якій би особа, яка відповідає за зобов'язанням так само, як й інша зобов'язана особа, не була би боржником цього зобов'язання тільки через те, що черговість звернення до них за виконанням зобов'язання є послідовною [7, с. 32]. Такі відмінності, на переконання авторів, не дають підстави для виключення субсидіарних зобов'язань 3 числа зобов'язань 3 множинністю осіб, але вимагають особливого правового регулювання.

На протилежну думку (про не віднесення субсидіарних зобов'язань до зобов'язань з множинністю осіб) спочатку може наштовхнути структурний аналіз ЦК України, відповідно до якого норми про солідарні й часткові зобов'язання (ст. 541-544 ЦК України) зосереджені в гл. 48 «Виконання зобов'язань», а норми про субсидіарну відповідальність (ст. 619 ЦК) як одну з іпостасей субсидіарного зобов'язання містяться в гл. 51 ЦК «Правові наслідки порушення зобов'язання. Відповідальність за порушення зобов'язання». Звісно, це не критерій не віднесення субсидіарних зобов'язань до зобов'язань з множинністю осіб, але може нам дати певне уявлення про різне законодавче призначення цих правових явищ. Справді, детальніший аналіз відповідних правових норм дає можливість простежити наділення субсидіарних зобов'язань додатковим функціональним навантаженням, що полягає не лише в регулюванні порядку виконання зобов'язання, як у солідарних та часткових зобов'язаннях, а їх значення додатково спрямоване і на більший ступінь гарантування прав кредитора в договірних і позадоговірних правовідносинах.

Ще однією причиною, що свідчить на користь неможливості перебування субсидіарнихзобов'язаньводномурядузчастковими 
і солідарними як видами зобов'язань 3 множинністю осіб, є той факт, що субсидіарна відповідальність може бути частковою або солідарною (наприклад, згідно 3 ч. 1 ст. 124 або ч. 1 ст. 133 ЦК України). Очевидно, що якщо тлумачити субсидіарні зобов'язання як різновид зобов'язань 3 множинністю осіб, поряд із частковими і солідарними зобов'язаннями, то виявляються порушеними правила логічних операцій поділу, оскільки члени поділу повинні вичерпувати поняття, що підлягає поділу, і при цьому виключати одне одного. Виходячи з цього стверджувати, що субсидіарні зобов'язання поряд із солідарними і частковими є видовими поняттями одного роду (зобов'язань 3 множинністю осіб), вважаємо неприпустимим. Тоді як аналіз наведених норм ЦК України («несуть солідарно додаткову (субсидіарну) відповідальність») дає змогу дійти висновку, що субсидіарне зобов'язання є родовим щодо солідарного, тобто два видові поняття перебувають у зв'язку «рід-вид», що очевидно некоректно. Вже з цих фактів варто припустити, що субсидіарне зобов'язання не належить до того ж роду, що й солідарні та часткові, а їхню правову природу слід шукати за рамками зобов'язань з множинністю осіб.

Серед вчених-правознавців, які стоять на інших позиціях і заперечують можливість тлумачення субсидіарних зобов'язань як зобов'язань з множинністю осіб як у договірних, так і в позадоговірних зобов'язаннях, варто назвати, зокрема, таких, як А. С. Бакін, Г. Г. Гриценко, Г. Н. Іванова, О. Г. Калпін, Ю. Я. Крюкова, О. І. Масляєв, Н. М. Сампара, С. В. Сарбаш, О. С. Шевченко [21, c. $439 ; 22$, с. $92 ; 23$, с. $150 ; 24$, с. $122 ; 25$, с. 46 ; 26, с. 98]. Ці вчені акцентують увагу на наявності в субсидіарних зобов'язаннях таких специфічних особливостей, які нівельовані в роботах прихильників віднесення субсидіарних зобов'язань до зобов'язань $з$ множинністю осіб. Насамперед науковці цієї когорти вказують на той факт, що основний і субсидіарний боржники є учасниками різних правовідношень як у договірних, так і у недоговірних зобов'язаннях [23, с. 152, $153 ; 27$, c. $366 ; 28$, c. $182 ; 29$, c. 550,551$]$. Наприклад, А. С. Бакін відзначає, що субсидіарний і основний - боржники одного і того ж кредитора, але в двох окремих, хоча і взаємозв'язаних правовідносинах, а характер відповідальності не дозволяє говорити про них як про співборжників [22, с. 92]. Н. М. Сампара висловлює таку ж думку, зазначаючи, що фактично це дві форми різних, самостійних, однак взаємопов'язаних та взаємозалежних зобов'язальних право- відносин [24, с. 122]. Г. Г. Гриценко, досліджуючи множинність осіб у цивільно-правовому зобов'язанні, чітко розмежовуючи два самостійні зобов'язання між основним додатковим боржником та між кредитором і додатковим боржником, дійшла висновку про те, що «субсидіарне зобов'язання не відповідає ні критерію множинності осіб у зобов'язанні, ні меті (призначенню) норм про множинність осіб» [25, с. 8, с. 34]. Вважаємо, що саме цей нюанс спростовує більшість доводів правників, що стоять на боці множинності осіб у суб́сидіарному зобов'язанні.

Критично оцінимо основні аргументи прибічників тлумачення субсидіарних зобов'язань як зобов'язань з множинністю осіб на прикладі аргументації позиції Д. В. Трутом, яку він будує на основі спростування доводів О. І. Масляєва, позиція якого протилежна.

По-перше, Д. В. Трут акцентує увагу на співвідношенні моменту виникнення зобов'язання і моменту виникнення множинності осіб у зобов'язанні і відзначає, що субсидіарна множинність виникає після такого юридичного факту, як відмова у задоволенні вимоги кредитора основним боржником (а не укладення договору). На обгрунтування цього науковець наводить позицію В. І. Голевінського, викладену в роботі «Про походження і ділення зобов'язань», згідно 3 якою зобов'язання бувають сукупними 3 моменту їх виникнення або ж переходять 3 одиничних у сукупні [30, с. 213]. Однак у результаті глибшого аналізу праці В. І. Голевінського стає очевидним, що автор веде мову тільки про конкретний випадок такого переходу: «в силу самого закону, у разі смерті ввірителя або боржника, коли після них залишилося декілька спадкоємців» [30, с. 213-214]. Дисонанс виявляється також і в тому, що сам науковець, праця якого цитується Д. В. Трутом, доводячи трактування субсидіарного зобов'язання як множинного, серед зобов'язань 3 множинністю осіб називає тільки пайові (часткові) і солідарні [30, с. 212-213]. Позицію щодо можливості появи множинності осіб у зобов'язанні вже після його виникнення віднаходимо в навчально-практичному посібнику під редакцією Р. А. Майданика «Аномалії в цивільному праві» [31, с. 774]. Проте тут теж ідеться про конкретний випадок переходу з простого зобов'язання в зобов'язання з множинністю осіб: смерть боржника чи кредитора [31, с. 774].

Також Т. В. Трут наголошує, що із закону не випливає, що субсидіарний боржник чи субсидіарний поручитель не може бути 
стороною в основній угоді [12, с. 187]. Хоча теоретично сконструювати таку ситуацію не видається проблематичним, однак це не змінює суті вирішення питання, оскільки основне зобов'язання виникатиме між кредитором і двома боржниками, інше ж - субсидіарне - лише в разі порушення зобов'язання боржником, що має наслідком звернення вимоги кредитора до іншого боржника, і зовсім інше зобов'язання, хоча і пов'язане з першим, виникне між кредитором і додатковим боржником в разі реалізації кредитором права на таку вимогу. Власне лише останнє з них, вважаємо, слід кваліфікувати як субсидіарне. 3 практичного боку конструювати зобов'язання, в яких додатковий боржник є одночасно і стороною в основному зобов'язанні, немає практичної доцільності, тому що аналогічний ступінь гарантування задоволення майнових інтересів кредитора надають солідарні зобов'язання, причому наділяючи кредитора не лише правом грошової вимоги, а й виконання зобов'язання в натурі.

Д. В. Трут також оспорює позицію O. I. Маслаєва зауважуючи, що «основний і субсидіарний боржники є учасниками одного зобов'язання, мотивуючи тим, що якщо слідувати логіці останнього, то це означало б, що після пред'явлення вимог субсидіарному боржнику, основний боржник автоматично перестає бути зобов'язаним, тобто «випадає» із зобов'язання». На думку ж Д. В. Трута, основний боржник нікуди не «випадає» до повного виконання зобов'язання і залишається зобов'язаним нарівні із субсидіарним боржником» [12, с. 190]. Навіть беручи до уваги бачення автором множинності осіб у субсидіарному зобов'язанні $з$ аргументом про залишення в субсидіарному зобов'язанні основного боржника і після залучення субсидіарного, виходячи 3 аналізу чинного законодавства, погодитись не видається можливим через те, що правовим наслідком невиконання основним боржником зобов язання може бути тільки звернення до додаткового боржника, на основного ж боржника ніяких додаткових обтяжень не покладається.

Далі автор, продовжуючи заперечення «випадіння» субсидіарного боржника в зобов'язанні, критикує позицію О. І. Масляєва, який вважає, що множинність у разі виникнення субсидіарної відповідальності за шкоду, заподіяну неповнолітніми, відсутня, оскільки, на думку науковця, треба говорити лише про суб'єкта правовідносин залежно від того, чи є в неповнолітнього необхідні доходи або майно. Д. В. Трут зазначає, що, заперечуючи наявність множиннос- ті в названих випадках, важко пояснити дію п. 3 ст. 1179 ЦК України, яка передбачає припинення субсидіарної відповідальності відповідних осіб у разі появи у неповнолітнього достатніх доходів чи майна. Аналогічний аргумент наводився С. В. Сарбашем $[18$, c. 24].

Ми ж субсидіарне зобов'язання батьків, інших законних представників неповнолітніх дітей від 14 до 18 років, що завдали шкоди, вважаємо за необхідне розглядати як таке, що має самостійний характер, а покладання на батьків майнового тягаря за зобов'язаннями неповнолітнього - способом розподілу ризику несприятливих наслідків, що виникли в результаті правопорушення, і санкцією за неналежне виховання, нагляд за неповнолітніми. Якщо ж іти від протилежного і припустити, що батьки чи інші законні представники неповнолітніх є стороною в первинному зобов'язанні, то це приводить до очевидно хибних висновків, що вони так само, як і неповнолітній, виступають тими, хто завдав шкоди. Проте вина їх як умова несення цього майнового тягаря за неповнолітнього пов'язана не із заподіянням шкоди ними безпосередньо, а 3 наявністю їхньої вини у заподіянні шкоди цим неповнолітнім.

Однією 3 кваліфікуючих ознак зобов'язань 3 множинністю осіб є єдність об'єкта зобов'язання $[18$, с. 7,$8 ; 31$, с. 774 ; 32 , с. $70 ; 25$, с. 10]. Власне, це і є наступним аргументом Д. В. Трута, який віднаходить в субсидіарному зобов'язанні всі ознаки цивільно-правового зобов'язання 3 множинністю осіб: «В них завжди $є$ як мінімум два суб'єкти, до яких можуть бути направлені вимоги кредитора, спільний предмет зобов'язання, а також множинність зв'язків» [12, с. 187]. Таку ж думку висловлював і С. В. Сарбаш [18, с. 23-25].

Опускаючи за межі нашого дослідження одвічну проблему вітчизняного законодавства щодо співвідношення категорій «предмет зобов'язання» та «об'єкт зобов'язання», відзначимо, що вкрай дивно, на наш погляд, виглядає ототожнення Д. В. Трутом предмета зобов'язання в основному і додатковому зобов'язанні. Підтримаємо Н. М. Сампару в критиці цитованого твердження, яку авторка мотивує тим, що до субсидіарного (додаткового) боржника неможливо пред'явити вимогу щодо виконання зобов'язання в натурі [24, с. 124]. На наш погляд, очевидним $є$ те, що предмет у первинному і субсидіарному зобов'язаннях може бути різним: якщо від первинного боржника кредитор може вимагати виконання зобов'язання в натурі (згідно зі ст. 622 ЦК України), то від 
субсидіарного - задоволення своєї вимоги, не виконаної основним боржником у грошовому еквіваленті (виходячи з положення ч. 3 ст. 619 ЦК України). Тим часом у силу свободи договору та диспозитивності цивільного законодавства основне і субсидіарне зобов'язання теоретично можуть мати однаковий предмет у разі обумовленості сторонами можливості надання того ж предмета виконання, що й основний боржник. Проте, якщо основний боржник вже частково виконав своє зобов'язання перед кредитором, обсяг зобов'язання додаткового перед кредитором буде визначатись невиконаною частиною. Отже, як відзначається в літературі, має місце різний обсяг обов'язків основного і субсидіарного боржника [33, с. 96]. Тому ми виходимо з того, що обов'язок субсидіарного боржника не збігається за змістом з обов'язком основного боржника, а отже, основне і додаткове самостійні зобов'язання.

Виходячи 3 цього, Д. В. Трут дійсно має рацію в тому, що випадіння сторони в субсидіарному зобов'язанні немає, але немає через те, що відсутня множинність як така. Ми вважаємо, що наявність не менше двох суб'єктів, до яких може бути спрямована вимога кредитора, далеко не є доказом віднесення субсидіарних зобов'язань до правовідносин з множинністю осіб на стороні боржника. Як влучно зазначає Г. Г. Гриценко щодо обрання кредитором суб'єкта звернення з вимогою про виконання зобов'язання, «схема «або-або» діє в тих ситуаціях, коли у кредитора є право вимоги до різних боржників за окремими правовідносинами. У зобов'язаннях з множинністю осіб, навпаки, кредитор може скористатися своїм правом за схемою «і-і», тобто одночасно задіяти всіх боржників у даному зобов'язанні» [25, с. 51]. I хоча вимога кредитора в субсидіарному правовідношенні пов'язана з вимогою в основному, найчастіше має відмінний характер, оскільки субсидіарне зобов'язання виступає як правова форма, що гарантує забезпечення інтересу кредитора в отриманні виконання за основним зобов'язанням.

\section{Висновки}

Отже, вирішуючи питання про правову природу субсидіарних зобов'язань, вважаємо коректним вести мову не про зобов'язання 3 множинністю осіб, а про самостійне зобов'язання (будучи додатковим до основного, тісно пов'язане з останнім), спрямоване на гарантування прав кредитора в основному зобов'язанні, де у разі неможливості основним боржником задовольнити вимоги кредитора за його волевиявленням можуть виникати зобов'язання субсидіарного боржника з відмінним щодо основного предметом зобов'язання.

\section{Список використаних джерел:}

1. Богданова Е. Е. Правовое регулирование субсидиарной ответственности : дисс. ... канд. юрид. наук : 12.00.03. Белгород, 2001. 180 c.

2. Богданова Е. Е. Субсидиарная ответственность: проблемы теории и практики. Москва, 2003. $112 \mathrm{c}$.

3. Брагинский М. И., Витрянский В. В. Договорное право. Книга первая: Общие положения. Москва, 2011. 847 с.

4. Цивільне право України : підручник : у 2 кн. / за ред. О. В. Дзери, Н. С. Кузнєцової. Київ, 2004. Кн. 1.736 c.

5. Попондопуло В. Ф. Обязательственное право: общая характеристика и проблемы. Ленингр. юрид. журн. 2009. № 1 (15). С. 7-38.

6. Цивільне право : навч. посіб. для студ. юрид. вузів та фак. Київ, 1996. 480 с.

7. Храпунова Е. А. Субсидиарная ответственность в гражданском праве : дисс. ... канд. юрид. наук : 12.00.03. Ростов н/Д, 2001. 185 с.

8. Гражданское право : учебник : в 3 т. / под ред. А. П. Сергеева. М., 2010. 1008 с. URL: http:// right777.ru/grajdan.html.

9. Российское гражданское право : учебник : в 2 т. Т. II: Обязательственное право / отв. ред. Е. А. Суханов. Москва, 2011. 1208 с.

10. Цивільне законодавство України : навчальний посібник / за заг. ред. С. О. Харитонова, К. Г. Некіт. Одеса, 2013. 388 с.

11. Трут Д. В. Цивільно-правові зобов'язання з множинністю осіб : дис. ... канд. юрид. наук : 12.00.03. Київ, 2014. 235 с.

12. Трут Д. В. Субсидіарні зобов'язання як різновид цивільно-правових зобов'язань 3 множинністю осіб. Університетські наукові записки. 2012. № 4(44). C. 186-192.

13. Тархов В. А. Гражданские права и ответственность. Уфа, 1996. 124 с.

14. Грибанов В. П. Ответственность за нарушение гражданских прав и обязанностей. Ocyществление и защита гражданских прав. Москва, $2000.411 \mathrm{c}$.

15. Гражданское право : учебник / под ред. Ю. К. Толстого, А. П. Сергеева. СПб., 1996. Ч. 1. $551 \mathrm{c}$.

16. Гражданское право : учебник в 3 т. / под ред. А. П. Сергеева, Ю. К. Толстого. Москва, 2005. Том $1.765 \mathrm{c}$.

17. Покровский И. А. История римского права. СПб., 1999. 560 с.

18. Сарбаш С. В. Обязательства с множественностью лиц и особенности их исполнения. Москва, 2004. 112 с.

19. Харитонов Е. О. Старцев А. В., Харитонова Е. И. Гражданское право Украины : учебник. Харьков, 2008. 920 c. 
20. Цивільний кодекс України: Науково-практичний коментар. Харків, 2007. 1200 с.

21. Советское гражданское право : учебник в 2 ч. / под ред. В. А. Рясенцева. Москва, 1986. Ч. 1.560 с

22. Бакин А. С. Понятие субсидиарного обязательства в гражданском праве РФ. Вестник Томского гос. ун-та. 2010. № 239. С. 91-94.

23. Иванова Г. Н., Шевченко А. С. Субсидиарная ответственность. Правоведение. 1998. № 2. C. $150-153$.

24. Сампара Н. М. До питання про визначення поняття та сутності субсидіарних зобов'язань в цивільному праві. Науковий вісник Херсонського державного університету. 2016. Випуск 6 . Том 1. С. 121-124.

25. Гриценко Г. Г. Множинність осіб у цивільно- правових зобов'язаннях : дис. ... канд. юрид. наук. за спец. 12.00.03. Харків. 2015. 234 с.

26. Крюкова Ю. Я. Субсидиарные обязательства в гражданском праве России : дисс. ... канд. юрид. наук : 12.00.03. Екатеринбург, 2013. 170 с.
27. Гражданское право. Часть вторая : учебник / под ред. А. Г. Калпина. Москва, 2002. 542 с.

28. Гражданское право: учебник в 2-х частях / отв. ред. В. П. Мозолин, А. И. Масляев. Москва, 2005. Ч.1. 719 c.

29. Гражданское право : учебник для вузов по спец. «Юриспруденция» : часть первая / отв. ред. В. П. Мозолин, А. И. Масляев. Москва, 2007.719 с.

30. Голевинский В. И. О происхождении и делении обязательств. Варшава, 1872. 263 с.

31. Аномалії в цивільному праві України : навчально-практичний посібник / відп. ред. Р. А. Майданик. Київ, 2007. 912 с.

32. Павлов А. А. Некоторые вопросы прекращения солидарных обязательств. Очерки по торговому праву : сб. науч. тр. / под ред. Е. А. Крашенинникова. Ярославль : ЯрГУ, 2006. Вып. 13. С. 70-81.

33. Сердюков К. А. О границах понятия обязательств с множественностью лиц. Общество и право. 2010. № 3 (30). С. 94-97.

This article emphasizes that the definition of the domestic legislator does not clarify the legal nature of the subsidiary obligations and not only doesn't resolve, but also sharpens, scientific discussions on this nature, giving room for directly opposite interpretations. The existence in the domestic doctrine of two main positions of scholars is mentioned, as they differently interpret the legal nature of subsidiary obligations. Noted the variety of obligations with a plurality of persons, along with partial and solidarity obligations (dominant position) and denying the possibility of interpreting subsidiary obligations, as obligations with a plurality of persons in both contractual and non-contractual obligations. A critical analysis of the arguments and counterarguments of both sides of the discussion has been made, based on which a balanced and unambiguous conclusion regarding the identified problem has been formulated. It is emphasized that the majority of the arguments of the supporters of the plurality in subsidiary obligations are removed by giving a correct interpretation of their contents and clarifying the question of the existence of two complementary, but independent obligations that arise between the creditor and the principal debtor, and between the principal and the subsidiary debtors or a single obligation. As it is proved that the obligation of the subsidiary debtor does not coincide in substance with the obligation of the principal debtor, since there is no common object of the obligation, it is concluded that in deciding the legal nature of the subsidiary obligations, it is correct to speak out of the obligation plurality of persons, but an independent obligation (being additional to the principal, closely related to the latter), which aims at guaranteeing the rights of the creditor in the principal obligation, where the principal debtor is unable to satisfy the creditor's requirements and its expression can occur commitment subsidiary debtor excellent with respect to the main object commitments.

Key words: additional liability, subsidiary liability, plurality of persons in the obligation, object of the obligation, subject of the obligation the performance of the obligation. 
УДК 347.91/95:347.27:(347.736:347.15/17(477)

DOI https://doi.org/10.32849/2663-5313/2019.8.03

\section{Людмила Корнілова,}

аспірант кафедри цивільного процесу

Наиіонального університету «Одеська юридична академія»,

адвокат, експерт Громадського иентру правосуддя Одеської області -

Грантового проекту ГО «Асоиіачія слідчих суддів України»

(за підтримкою агентства США з міжнародного розвитку)

в рамках програми «Нове правосуддя»

\section{ПРАВОВЕ РЕГУЛЮВАННЯ ІПОТЕЧНИХ ПРАВОВІДНОСИН В КОНТЕКСТІ БАНКРУТСТВА ФІЗИЧНИХ ОСІБ}

Стаття присвячена аналізу ключових моментів Кодексу України з прочедур банкрутства в аспекті законодавчого реформування кредитно-фінансових відносин в Україні. Розглянуто питання щ,до змін, які очікують законодавство після введення в дію Кодексу України з процедур банкрутства. Автор звернув увагу на новий інститут, який став новелою сучасного законодавства - банкрутство фізичних осіб, а також відновлення платоспроможності фізичних осіб. Такий інститут вже давно існує в розвинутих країнах, зокрема і $Є С$, а тому запровадження його в Украйні стало суттєвим кроком в євроінтеграчії національного законодавства. Передбачається, що саме він покликаний вирішити довготривалу проблему непогашених боргів, передусім повернення кредитів та дозволить боржникам потрапити під судовий захист. Також автором досліджено нові механізми урегулювання проблемних питань іпотечного кредитування в іноземній валюті. Детально описано механізм реструктуризаиії заборгованості за кредитом в іноземній валюті, який забезпечений іпотекою квартири або житлового будинку. Він передбачає, що склад і розмір грошових вимог забезпеченого кредитора за зобов'язаннями, які виникли з кредиту в іноземній валюті, який забезпечений іпотекою квартири або житлового будинку, що є єдиним місием проживання сім'ї боржника, визначаються в наиіональній валюті за курсом, встановленим Начіональним банком Украӥни на дату відкриття провадження у справі про неплатоспроможність фізичної особи. До розміру вимог такого забезпеченого кредитора не включаються штрафні санкиї та пеня. Визнані господарським судом вимоги забезпеченого кредитора погашаються боржником у розмірі ринкової вартості квартири або житлового будинку, що забезпечує вимоги такого кредитора, яка визначається оиінювачем, визначеним кредитором, при цьому залишок заборгованості такого кредитора підлягає прощенню (списанню). Визначено, що метою та завданнями Кодексу Украйни з проиедур банкрутства є забезпечення належного державного захисту прав та інтересів споживачів - позичальників за договорами кредиту в іноземній валюті та недопущення колапсу банківської системи України. Автором проаналізовано акти начіонального законодавства, зроблені грунтовні висновки щодо ефективності запровадження проаналізованих законодавчих нововведень.

Ключові слова: платоспроможність фізичної особи, банкрутство, іпотека, іпотечний кредит, заборгованість, реструктуризація.

Постановка проблеми. Загострення проблеми численних непогашених боргів, передусім повернення кредитів, спонукало до прийняття Кодексу України з процедур банкрутства, який вводиться в дію 321 жовтня 2019 року. На думку законодавця, Кодекс покликаний вирішити дану проблему та допоможе врегулювати проблемні питання іпотечних кредитів в іноземній валюті. Тому аналіз ефективності нових механізмів розв'язання проблем, які наразі існують в кредитно-фінансових відносинах, запропонованих Кодексом України з процедур банкрутства, наразі є вкрай актуальним.
Аналіз останніх досліджень та публікацій. Деякі питання правового регулювання процедур банкрутства розкривають у своїх наукових роботах такі вчені, як С.Ф. Платонов, Г.Ю. Семигін, В.Ю. Яковлєв, Ю.В. Чабан.

Мета статті - аналіз стану правового регулювання процедур банкрутства в Україні. Дослідження нових механізмів урегулювання проблемних питань іпотечного кредитування в іноземній валюті та оцінка ефективності їх подальшого запровадження. 
Виклад основного матеріалу. Банкрутство фізичних осіб має багату історію. Уже в XI столітті Руська Правда включала правила, за якими боржник продавався в боргове рабство [6, с. 57].

Першим систематизованим актом про банкрутство в Російській імперії (відповідно, й в Україні) став Статут про банкрутів від 18.12.1800 р. [7, с. 393]. До нього безуспішні спроби поєднати та систематизувати такі норми здійснювали Сенатський указ від 01.07.1740 р. «Про рішення вексельних справ за силою вексельного статуту», статути 1753 р., 1756 р. [8, с. 45]. Саме вони лягли в основу Статуту 1800 р. 3 цього моменту настав період активної нормотворчості в частині регулювання неспроможності.

За своєю суттю це був перший нормативний акт, що розділяє норми про банкрутство стосовно підприємницької діяльності і норми про неспроможність, не пов'язану з торгівлею [6, с. 58].

Інститут банкрутства багато років не визнавався правовою системою Радянського Союзу, не був закріплений у законодавстві та викликав критику з боку вчених.

Лише проголошення України незалежною державою та визначення економічного вектору на розвиток ринкових відносин сприяло відродженню інституту банкрутства. У зв'язку з цим виникла необхідність нормативно-правового врегулювання підстав, процедур та наслідків неплатоспроможності боржника

У 1992 році новелою у вітчизняному правовому полі став Закон України «Про банкрутство», введений в дію постановою Верховної Ради України від 14.05.1992 року № 2344-XII, який був чинний сім років, проте він окреслював лише контур системи державного регулювання сфери неплатоспроможності і мав значні недоліки.

Насамперед Закон України «Про банкрутство» не передбачав створення спеціалізованого органу державного регулювання з питань банкрутства, а також існування однієї з головних фігур процедури банкрутства арбітражного керуючого (розпорядника майна, керуючого санацією, ліквідатора). Важливим кроком на шляху до удосконалення державного регулювання у сфері відновлення платоспроможності та банкрутства підприємств та організацій стало створення Указом Президента України від 17.06.1996 року № 435/96 центрального органу виконавчої влади, підпорядкованого Кабінету Міністрів України, - Агентства з питань запобігання банкрутству підприємств та організацій.

Однак Закон України «Про банкрутство» у первинному вигляді продемонстрував низьку процесуальну здатність, а численні зміни до нього не надали необхідного ефекту. У зв'язку з цим було прийнято рішення про підготовку нового законодавчого акту 3 питань банкрутства.

01.01.2000 року набрав чинності Закон України від 30.06.1999 року № 784-XIV «Про відновлення платоспроможності боржника та визнання його банкрутом» (далі - Закон), i тим самим було розпочато наступний етап розвитку державного регулювання у сфері банкрутства. Указом Президента України від 23.10.2000 року № 1159/2000 повноваження державного органу з питань банкрутства відповідно до Закону було покладено на Міністерство економіки України. Згодом у складі Міністерства економіки України постановою Кабінету Міністрів України від 27.03.2006 року № 370 було створено Державний департамент з питань банкрутства як урядовий орган державного управління.

Сьогодні Указом Президента України від 06.04.2011 року № 395/2011 повноваження державного органу з питань банкрутства покладено на Міністерство юстиції України.

Довгий час процедури банкрутства поширювалися тільки на юридичних осіб, суб'єктів підприємницької діяльності або фізичних осіб за зобов'язаннями, які виникли у зв'язку зі здійсненням ними підприємницької діяльності.

Суттєвим кроком в євроінтеграції української держави стало прийняття 18 жовтня 2018 року Верховною Радою України Кодексу України з процедур банкрутства, який вводиться в дію з 21 жовтня 2019 року. Він прийнятий у зв'язку з необхідністю реформувати систему банкрутства, удосконалити саму процедуру банкрутства та покращити умови ведення бізнесу України, тим самим збільшивши іï інвестиційну привабливість.

Кодекс з процедур банкрутства вносить зміни до низки законодавчих актів, серед яких Цивільний кодекс України, Господарський процесуальний кодекс України, Закон України «Про заставу», Закон України «Про іпотеку» та багато інших. Варто зазначити і те, що через один рік з дня введення в дію Кодексу втратить чинність Закон України «Про мораторій на стягнення майна громадян України, наданого як забезпечення кредитів в іноземній валюті».

Отже, розглянемо детальніше, які зміни очікують законодавство після введення в дію Кодексу з процедур банкрутства.

Новелою законодавства стало запровадження Кодексом нового інституту - відновлення платоспроможності фізичної особи. Тому безсумнівно нових змін очікуе Цивільний кодекс України. Він поповниться новою 
статтею 48-1 про правові наслідки нездатності фізичної особи виконати свої майнові зобов'язання і погасити борги. Фізичних осіб - боржників очікують два шляхи: або відкриття провадження у справі про неплатоспроможність і введення процедури реструктуризації боргів боржника, або визнання банкрутом у справі про неплатоспроможність iз застосуванням процедури задоволення вимог кредиторів,

Провадження у справі про неплатоспроможність боржника - фізичної особи може бути відкрито лише за заявою самого боржника за наявності підстав, передбачених ч. 2 ст. 115 КУзПБ. 3 моменту відкриття провадження у справі про неплатоспроможність вводиться мораторій на задоволення вимог кредиторів строком на 120 днів, під час якого зупиняється виконання грошових зобов'язань, стягнення за виконавчими документами, не нараховується неустойка (пеня, штраф) та інше.

План реструктуризації боргів боржника може містити положення про: реалізацію частини майна боржника, зміну способу та порядку виконання зобов'язань, відстрочення чи розстрочення або прощення (списання) боргів чи їх частини, виконання зобов'язань боржника третіми особами та інші заходи.

У тому разі, якщо план реструктуризації не був схвалений або був схвалений, однак не був виконаний, то боржник визнається банкрутом і відкривається процедура погашення боргів боржника. Формується ліквідаційна маса, майно боржника продається та у порядку черговості задовольняються вимоги кредиторів [1].

Як бачимо, позитивні наслідки для фізичних осіб - боржників від такої процедури все-таки є. Якщо раніше прощення (списання) боргу відбувалось лише за згодою кредитора, то із запровадженням нової процедури, така згода може і не знадобитись.

Зміни торкнулись і звернення стягнення на заставне майно. Статтею 590 ЦК України та статтею 20 Закону України «Про заставу» звернення стягнення на заставлене майно незалежно від настання строку виконання зобов'язання, забезпеченого заставою, передбачається лише у разі ліквідації юридичної особи заставодавця [3]. Однак Кодекс з процедур банкрутства доповнюе ст. 590 ЦК України та ст. 20 ЗУ «Про заставу» новою частиною, в якій зазначається, що у разі схвалення судом відповідно до законодавства про банкрутство плану санації чи реструктуризації боргів боржника за основним зобов'язанням, якщо він відмінний від заставодавця, заставодержатель, який голосував проти схвалення плану санації юридичної особи чи плану реструктуризації боргів боржника - фізичної особи, набуває право звернення стягнення на заставлене майно незалежно від настання строку виконання зобов'язання, забезпеченого заставою.

Відповідно до ч. 4 ст. 604 Цивільного кодексу України новація припиняе додаткові зобов'язання, пов'язані з первісним зобов'язанням, якщо інше не встановлено договором [2]. Кодекс з процедур банкрутства доповнює дану статтю словами «крім випадків, коли первісне зобов'язання змінене планом санації або реструктуризації згідно з Кодексом України з процедур банкрутства і заставодержатель проголосував проти такого плану». Тобто у разі зміни первісного зобов'язання планом санації або реструктуризації, і заставодержатель проголосував проти такого плану, зобов'язання щодо застави не припиняються.

Наступний Закон, який зазнає змін із введенням в дію Кодексу з процедур банкрутства, - Закон України «Про іпотеку».

Вагомих доповнень даний Закон не зазнає, однак деякі положення втратить. Так, наприклад, виключається частина шоста статті 5, яка покладала ризики випадкового знищення, випадкового пошкодження або псування предмета іпотеки на іпотекодавця, якщо інше не було встановлено іпотечним договором.

Виключається також абзац сьомий частини першої статті 39 Закону, який передбачає, що у разі задоволення судом позову про звернення стягнення на предмет іпотеки в рішенні суду зазначається початкова ціна предмета іпотеки для його подальшої реалізації, за умови подання будь-якою із сторін клопотання про необхідність визначення такої ціни (крім реалізації предмета іпотеки на прилюдних торгах) [4].

Як і у разі із заставою, іпотекодержателю також надається право звернення стягнення на предмет іпотеки незалежно від настання строку виконання зобов'язання, забезпеченого іпотекою, у разі схвалення судом плану санації чи реструктуризації боргів боржника за основним зобов'язанням, якщо він відмінний від іпотекодавця, якщо іпотекодержатель голосував проти схвалення плану санації юридичної особи чи плану реструктуризації боргів боржника - фізичної особи. Тому стаття 33 ЗУ «Про іпотеку» поповниться ще однією підставою для звернення стягнення на предмет іпотеки.

Передусім слід звернути увагу, що найбільшого резонансу викликає частина 2 Прикінцевих та перехідних положень Кодексу України 3 процедур банкрутства, у якій зазначається, що через один рік з дня вве- 
дення в дію цього Кодексу втрачає чинність Закон України «Про мораторій на стягнення майна громадян України, наданого як забезпечення кредитів в іноземній валюті» [1].

Мораторій був введений в дію ще в 2014 році, який забороняв примусове відчуження рухомого і нерухомого майна позичальників (боржників), які мають кредитні зобов'язання за договорами споживчого кредиту в іноземній валюті. На момент запровадження мораторій розглядався як тимчасовий захід до законодавчого врегулювання питань погашення валютних кредитів. Однак цей процес затягнувся і це призвело до того що боржники перестали платити за іпотечними кредитами [5].

Позитивним та прогресивним кроком нового Кодексу є спроба врегулювати іпотечні кредити. Тепер у боржників, які брали іпотечні кредити, з'явився механізм реструктуризації заборгованості за кредитом в іноземній валюті, який забезпечений іпотекою квартири або житлового будинку, процедура якої детально прописана в частини 5 Прикінцевих та перехідних положень Кодексу України з процедур банкрутства.

Після скасування мораторію для фізичних осіб запроваджується п'ятирічний особливий режим реструктуризації заборгованості за іпотечними кредитами в іноземній валюті. Заборгованість по таким кредитам, забезпеченим квартирою або житловим будинком, що являється єдиним місцем проживання сім'ї боржника, реструктуризується відповідно до плану реструктуризації або мирової угоди в порядку та на умовах, визначених цими особливостями. Тобто боржник сам обирає, яка судова процедура йому більше вигідна - реструктуризація кредитних боргів чи задоволення вимог кредиторів. Своєю чергою реструктуризація боргів застосовується з метою відновлення платоспроможності боржника.

Ще однією особливістю є те, що вимоги забезпеченого кредитора, які виникли з валютного кредиту, повинні конвертуватись у гривню по курсу Національного банку України на дату відкриття провадження у справі про неплатоспроможність фізичної особи. До розміру вимог такого забезпеченого кредитора не включаються штрафні санкції та пеня. Визнані господарським судом вимоги забезпеченого кредитора погашаються боржником у розмірі ринкової вартості квартири або житлового будинку, що забезпечує вимоги такого кредитора, яка визначається оцінювачем, визначеним кредитором Залишок заборгованості такого кредитора підлягає прощенню (списанню) в порядку, визначеному цим пунктом.
Увагу привертає і той момент, що передбачено лише два варіанти реструктуризації боргів - один проводиться протягом 15 років, а другий - протягом 10 років.

На п'ятнадцять років план реструктуризації укладається у тому разі, якщо загальна площа житлового будинку, обтяжених іпотекою, не перевищує 120 квадратних метрів, або площа квартири не перевищує 60 квадратних метрів або житлова площа якої не перевищує 13,65 квадратних метрів на кожного члена сім'ї боржника. Відсоткова ставка по такому плану реструктуризації встановлюється на рівні українського індексу ставок за дванадцятимісячними депозитами фізичних осіб, збільшеному на 1 відсоток. Якщо площа житла більша, план затверджується на десять років, а відсоткова ставка по такому плану реструктуризації встановлюється на рівні українського індексу ставок, збільшеному на 3 відсотки.

Однак за спільною згодою боржника i кредитора можливо зменшити відсоткову ставку та/або відсоток від ринкової вартості квартири або житлового будинку, проте лише поза процедурою відновлення платоспроможності. При цьому боржник повинен надати кредиторам повну та достовірну інформацію про свій фінансовий стан [1].

Законодавець не оминув i питання списання залишку заборгованості. Таким залишком визначається різниця між заборгованістю боржника кредитним договором та розміром вимог забезпеченого кредитора, які підлягають погашенню. Однак слід зауважити, що таке прощення може відбутися лише після повного виконання зобов'язань боржника по реструктуризованому зобов'язанню

Якщо боржник не має фінансових можливостей погашати вимоги забезпеченого кредитора на вищезазначених умовах, господарський суд за клопотанням боржника відмовляє у затвердженні плану реструктуризації та закриває провадження у справі про неплатоспроможність.

\section{Висновки}

Звичайно Кодекс України з процедур банкрутства не вирішить усіх проблем, які існували у кредитно-фінансових відносинах, проте він зробить суттєві кроки для вирішення основної проблематики, з якою фінансові установи зіткнулися під час роботи 3 простроченою заборгованістю.

Проте вже зараз зрозуміло, що метою та завданнями Кодексу України з процедур банкрутства є забезпечення належного державного захисту прав та інтересів споживачів - позичальників за договорами кредиту в іноземній валюті та недопущення колапсу 
банківської системи України через втрату коштів, які були надані за такими договорами, тому можливість визнання фізичної особи банкрутом - величезний крок вперед.

Підсумовуючи проведений аналіз ключових моментів Кодексу України з процедур банкрутства в аспекті законодавчого реформування кредитно-фінансових відносин в Україні, можна зробити висновок, що однозначна точка зору щодо введених змін відсутня. Чи відповідатиме новий механізм відновлення платоспроможності фізичної особи реаліям нашого сьогодення, чи слугуватиме він ефективним способом для захисту та реалізації прав боржників та чи буде взагалі якісний результат проаналізованих законодавчих нововведень - зможе показати тільки його використання на практиці.

\section{Список використаних джерел:}

1. Кодекс України 3 процедур банкрутства: Закон від 18.10.2018 року № 2597-VIII. URL: https://zakon.rada.gov.ua/ laws/show/2597-19 (дата звернення: 02.07.2019).

2. Цивільний кодекс України: Закон від 16.01.2003 року № 435-IV Дата оновлення:
28.02.2019. URL: https://zakon.rada.gov.ua/laws/ show/435-15 (дата звернення: 02.07.2019).

3. Про заставу: Закон України від 02.10.1992 року №2655-XII Дата оновлення: 12.07.2018. URL: https://zakon.rada.gov.ua/laws/ show/2654-12 (дата звернення: 02.07.2019).

4. Про іпотеку: Закон України від 05.06.2003 року №898-IV Дата оновлення: 03.07.2018. URL: https://zakon.rada.gov.ua/laws/ show/898-15 (дата звернення: 02.07.2019).

5. Про мораторій на стягнення майна громадян України, наданого як забезпечення кредитів в іноземній валюті: Закон України від 03.06.2014 року №1304-VII Дата оновлення: 16.07.2015. URL: https://zakon.rada.gov.ua/laws/ show/1304-18 (дата звернення: 02.07.2019).

6. Платонов С.Ф. Учебник русской истории : учебник для вузов. Москва : Издательство Юрайт, 2016. 464 с. URL: https://biblio-online.ru/ bcode/394974 (дата звернення: 26.06.2019). с. 57-59.

7. Семигин Г.Ю., Яковлев В.Ф. Экономическое (коммерческое) правосудие в России: зарождение и развитие коммерческого правосудия (XII ХІХ вв.): в 4 т. / ред. : Алисова Л.Н. Мысль, 2004 T. 1. C. 393.

8. Чабан Ю. Історія становлення і розвитку інституту неспроможності (банкрутства) в Україні. Юридична Украӥна, 2004. № 6. С. 45.

The article is devoted to the analysis of key points of the Code of Ukraine on bankruptcy procedures in the aspect of legislative reform of credit and financial relations in Ukraine. It is considered: what changes are expected by legislation after the introduction of the Code of Ukraine on bankruptcy procedures. The author drew attention to the new institute, which became a novelty of modern legislation - bankruptcy of individuals, as well as the restoration of solvency of individuals. Such an institution has long existed in developed countries, including the EU, and, therefore, its introduction in Ukraine has become a significant step in the European integration of national legislation. It is supposed that it is he who is called to solve a long-term problem of outstanding debts, first of all, the repayment of loans and will allow debtors to get under judicial protection. The author also explored new mechanisms for settling problem issues in foreign currency mortgage lending: A detailed description of the mechanism for restructuring debt arrears in foreign currency, which is secured by mortgage of an apartment or a residential building. It stipulates that the composition and amount of the monetary claims of the secured creditor for obligations arising out of a loan in foreign currency that is secured by mortgage of an apartment or residential building, which is the only place of residence of the debtor's family, are determined in the national currency at the rate established National Bank of Ukraine on the date of opening of proceedings in the case of insolvency of an individual. The size of claims of such secured creditor does not include penalties and fines. Recognized economic court claims of a secured creditor are repaid by the debtor in the amount of the market value of an apartment or residential building, which ensures the requirements of such lender, which is determined by the appraiser designated by the creditor, while the balance of the debt of such a lender is subject to forgiveness (write-off). It is determined that the purpose and tasks of the Code of Ukraine on bankruptcy procedures is to ensure the proper state protection of the rights and interests of consumers - borrowers under foreign currency loan agreements and preventing the collapse of the banking system of Ukraine. The author analyzed the acts of the national legislation, made a solid conclusion on the effectiveness of the implementation of the analyzed legislative innovations.

Key words: solvency of an individual, bankruptcy, mortgage, mortgage loan, debt, restructuring. 
УДК 347.132

DOI https://doi.org/10.32849/2663-5313/2019.8.04

\section{Наталія Навальнева,}

аспірантка кафедри иивільного права та процесу

факультету № 6

Харківського національного університету внутрішніх справ

\section{КОНФІСКАЦІЙНІ САНКЦІЇ В ЦИВІЛЬНОМУ ПРАВІ ЗА ВЧИНЕННЯ НЕДІЙСНОГО ПРАВОЧИНУ}

Стаття присвячена аналізу конфіскаційних санкиій в чивільному праві, які можуть бути застосовані до сторін недійсного правочину, вчиненого з метою, що суперечить інтересам держави i суспільства. Автором обгрунтовано, що до конфіскаційних санкцій як визначених законом заходів иивільно-правового впливу, що полягають у припиненні права власності на майно, яке оплатно або безоплатно переходить у власність держави, належать одностороння реституиія та недопущення реституиї. Проведено історико-правовий аналіз розвитку иивільного законодавства про застосування односторонньої реституиї й аргументовано доцільність існування такої санкиї в ЦК України в сучасних умовах подолання корупиійних явищ, в Украӥні. Доведено, що одностороння реституиія та недопущення реституиї є особливими правовими наслідками недійсності правочину, вчиненого з метою, що завідомо суперечить інтересам держави $і$ суспільства, які застосовуються судом $i \epsilon$ заходами иивільно-правової відповідальності. Одностороння реституція не збігається з поняттям конфіскації майна у розумінні позбавлення права власності на майно за рішенням суду як санкцї за вчинення правопорушення. Уточнено, що односторонньою реституцією є повернення в первісний майновий стан однієі зі сторін недійсного правочину, яка не мала умислу вчинити правочин, що завідомо суперечить інтересам держави і суспільства, та стягнення за рішенням суду в дохід держави з іншої сторони, яка мала умисел вчинити правочин, визнаний судом недійсним як такий, що завідомо суперечить інтересам держави і суспільства, одержаного нею за правочином або належного їи на відикодування виконаного. Удосконалено поняття «недопущення реституиї» з уточненням, шо недопущенням реституиї є стягнення в дохід держави всього одержаного сторонами за правочином, а в разі виконання правочину не всіма сторонами - того, шо належало до одержання, за наявності умислу в обох сторін вчинити правочин, визнаний судом недійсним як вчинений з метою, що завідомо суперечить інтересам держави і суспільства.

Ключові слова: конфіскаційна санкція, недійсний правочин, публічний порядок, інтереси держави і суспільства, конфіскація, одностороння реституція, недопущення реституції.

Постановка проблеми. Прийняття Цивільного кодексу України від 16 січня 2003 р. (далі - ЦК України) [1] істотно змінило підходи в правовому регулюванні цивільно-правових наслідків недійсності правочину. Н. С. Кузнєцова зазначає, що принципова новела ЦК України 2003 року полягала в тому, що законодавець, визначаючи правові наслідки недійсності правочинів, взагалі відмовився від застосування конфіскаційних наслідків [2, с. 299]. Як стверджує 3. В. Ромовська, під час опрацювання проекту Цивільного кодексу України дебатувалося питання збереження конфіскаційної санкції (вилучення одержаного у дохід держави) у статті, що визнавала нікчемним правочин, який порушує публічний порядок, на випадок умислу однієї чи обох сторін [3, с. 388]. У частині 1 ст. 208 Господарського кодексу України від 16 січня 2003 р. [4] закріплено наслідки визнання господарського зобов'язання недійсним у вигляді стягнен- ня в дохід держави одержаного за недійсним господарським зобов'язанням, якщо його було вчинено з метою, яка завідомо суперечить інтересам держави і суспільства. Захист інтересів держави і суспільства під час вчинення правочину набув особливої актуальності у зв'язку з прийняттям Закону України від 02 грудня 2010 р. № 2756-VI «Про внесення змін до деяких законодавчих актів України у зв'язку з прийняттям Податкового кодексу України» [5], яким було внесено зміни до ст. 228 ЦК України і в частині 3 цієї статті було закріплено положення про односторонню реституцію.

Питання доцільності існування конфіскаційних санкцій у разі вчинення недійсного правочину, правова природа таких конфіскаційних заходів, їх види викликають і досі дискусію серед правників, зокрема цивілістів. У судовій практиці також виникають спірні питання щодо застосування конфіскаційних санкцій у разі вчинення правочину 
3 метою, що завідомо суперечить інтересам держави і суспільства, визначення юрисдикції суду, який має право розглядати справи про визнання правочину недійсним, якщо його було вчинено 3 недодержанням вимоги щодо відповідності правочину інтересам держави і суспільства.

Аналіз останніх досліджень і публікацій. Конфіскаційні санкції як різновид санкцій в цивільному праві вже досліджувалися в працях таких українських правників, як О. В. Дзера [6], О. О. Кот [7], Н. С. Кузнєцова [2], І. В. Спасибо-Фатєєва [8], та інших. Проте в цих дослідженнях здебільшого акцент ставився на правовій природі недійсних правочинів, їх загальних та особливих правових наслідках, а питання конфіскації найчастіше розглядалися в контексті цивільно-правової конфіскації власності як підстави припинення права власності.

Мета статті полягає у з'ясуванні сутності конфіскаційних санкцій у разі вчинення недійсного правочину, визначенні їх видів та обгрунтуванні доцільності (недоцільності) їх існування в цивільному праві.

Виклад основного матеріалу. Відповідно до ч. 1 ст. 216 ЦК України недійсний правочин не створює юридичних наслідків, крім тих, що пов'язані з його недійсністю. У разі недійсності правочину кожна зі сторін зобов'язана повернути другій стороні у натурі все, що вона одержала на виконання цього правочину, а в разі неможливості такого повернення, зокрема тоді, коли одержане полягає у користуванні майном, виконаній роботі, наданій послузі, - відшкодувати вартість того, що одержано, за цінами, які існують на момент відшкодування [1]. Н. С. Кузнєцова наголошує, що, аналізуючи наведені новели ЦК України 2003 р., можна констатувати, що вони цілком логічно вписуються в концепцію приватноправового методу регулювання майнових і особистих немайнових відносин, заснованих на юридичній рівності сторін і автономії їхньої волі. Як уже зазначалося раніше, порушення умов дійсності правочину само по собі не перетворює цю дію на правопорушення, воно позбавляє цю дію («волевиявлення», за М. М. Агарковим) статусу юридичного факту. Саме тому повернення сторін у первісний майновий стан (двостороння реституція) в цьому разі може розглядатися як найбільш адекватний правовий наслідок [2, с. 299-300]

Проте частиною 3 ст. 228 ЦК України передбачено, що в разі недодержання вимоги щодо відповідності правочину інтересам держави і суспільства, його моральним засадам такий правочин може бути визнаний недійсним. Якщо визнаний судом недійсний правочин було вчинено з метою, що завідомо суперечить інтересам держави і суспільства то за наявності умислу в обох сторін - в разі виконання правочину обома сторонами - в дохід держави за рішенням суду стягується все одержане ними за угодою, а в разі виконання правочину однією стороною 3 іншої сторони за рішенням суду стягується в дохід держави все одержане нею і все належне - 3 неї першій стороні на відшкодування одержаного. За наявності умислу лише в однієї зі сторін все одержане нею за правочином повинно бути повернуто іншій стороні, а одержане останньою або належне їй на відшкодування виконаного за рішенням суду стягується в дохід держави [1].

Такі зміни в цивільному законодавстві України викликали критику серед правників. Так, Н. С. Кузнєцова наголошує, що не менш проблематичним стало доповнення в 2010 р. ст. 228 ЦК «Правові наслідки вчинення правочину, який порушує публічний порядок». Крім зміни самої назви статті, яка зараз іменується «Правові наслідки вчинення правочину, який порушує публічний порядок, вчинений з метою, що суперечить інтересам держави та суспільства», вона була доповнена ч. 3, що фактично «реанімувала» ст. 49 ЦК УРСР, від якої розробники ЦК принципово відмовилися, замінивши механізм цивільно-правової конфіскації застосуванням реституції з можливим стягненням збитків та компенсацією моральної шкоди (ст. 216 ЦК України) [9, с. 43].

О. Дзера зазначає, що в ч. 3 ст. 228 ЦК передбачені різнопорядкові правові наслідки недійсності правочину. 3 її змісту випливає, що у разі недотримання вимог щодо відповідності правочину інтересам держави і суспільства він може бути визнаний недійсним. Отже, ця норма не зобов'язує суд визнавати такий правочин недійсним, що дає підстави відносити його до категорії оспорюваних правочинів. Якщо це так, то повинні застосовуватися загальні правові наслідки у вигляді двосторонньої чи односторонньої реституції, передбаченої ст. 216 ЦК України. У тому ж разі, якщо вищезазначений правочин вчинений також з метою, що суперечить інтересам держави і суспільства, то за наявності умислу в обох сторін або в однієї сторони повинні застосовуватися відповідно двостороння або одностороння конфіскація одержаного чи того, що належить, за таким правочином. У цьому випадку застосування конфіскаційної санкції передбачено імперативною нормою [10, с. 315]. Наведені положення свідчать, що в законодавстві відсутнє легальне визначення односторонньої реституції, 
в юридичній літературі також немає однакового тлумачення поняття «одностороння реституція».

Одностороння реституція означає приведення в первинний стан лише невинуватої сторони шляхом повернення цій стороні виконаного нею за правочином і стягнення в дохід держави одержаного винуватою стороною або того, що належить цій стороні як відшкодування виконаного нею за правочином [11, с. 177]. Саме таке розуміння односторонньої реституції є традиційним у цивілістичній літературі. Хоча, наприклад, I. СпасибоФатєєва зазначає, що у разі винесення судом рішення про повернення майна лише одній стороні правочину на іï вимогу ми матимемо своєрідну односторонню реституцію. Своєрідність іï полягає в тому, що вона не відбиває розуміння, яке закладалося в це поняття за радянських часів: тоді сформувалося уявлення про односторонню реституцію як певну санкцію, коли одній стороні правочину повертається майно, а з другої стягується одержане нею за недійсним правочином на користь держави. При цьому, на думку I. Спасибо-Фатєєвої, навіть якщо говорити про конфіскацію, що настає в певних випадках правопорушень, яких припустились сторони правочину, то вона застосовується як окремий наслідок недійсності правочинів, а не як одностороння реституція [8, с. 165].

3'ясуємо більш ретельно сутність односторонньої реституції в цивільному праві та їі співвідношення з конфіскаційними санкціями.

Одностороння реституція історично походить 3 кондикції на користь держави, як це мало місце в ЦК УСРР від 16 грудня 1922 р. [12, с. 325]. Зокрема, згідно зі ст. 147 ЦК УСРР від 16 грудня 1922 р. у разі недійсності договору, як протизаконного або спрямованого на очевидної шкоду для держави (ст. 30), жодна сторона не має права вимагати від іншої повернення виконаного за договором. Безпідставне збагачення стягується на прибуток держави (ст. 402) [13]. В. О. Кучер зазначає, що до прийняття цього Кодексу стягнення в дохід держави як наслідку учинення протиправного правочину наука та судова практика не знали, тому такі наслідки обмежувалися лише відновленням майнового становища сторін, яке існувало до вчинення правочину, а також відшкодуванням винною стороною заподіяної шкоди іншим особам [14, с. 155].

Згідно зі ст. 49 Цивільного кодексу УРСР від 18 липня 1963 р., якщо угода укладена з метою, завідомо суперечною інтересам соціалістичної держави і суспільства, то за наявності умислу в обох сторін - в разі виконання угоди обома сторонами - в доход держави стягується все одержане ними за угодою, а в разі виконання угоди однією стороною з другої сторони стягується в доход держави все одержане нею і все належне з неї першій стороні на відшкодування одержаного. За наявності ж умислу лише у однієї зі сторін все одержане нею за угодою повинно бути повернуто другій стороні, а одержане останньою або належне їй на відшкодування виконаного стягується в доход держави [15]. 3 огляду на характер цих наслідків, вони отримали назву цивільно-правової конфіскації [2, с. 298]. Відповідно до ЦК УРСР в літературі почав вживатися термін «одностороння реституція», коли поверталося те, що було передано за угодою лише однією стороною. А те, що було передано другою, винною, стороною, стягувалося в дохід держави [16, с. 150].

O. С. Йоффе зазначає, що одностороння реституція полягає в тому, що один з учасників правочину одержує виконане назад i, отже, відновлюється в попередньому стані, а виконання, одержане від другого контрагента, останньому не повертається і стягується в дохід держави [17, с. 300].

Бачиться, що доцільно дотримуватися усталених підходів цивілістів до поняття односторонньої реституції, не замінюючи це поняття на односторонню конфіскацію, зважаючи, що поняття конфіскації надано в ч. 1 ст. 354 ЦК України. Одностороння реституція $є$ санкцію в цивільному праві за вчинення недійсного правочину як протиправної дії за умови наявності умислу лише в однієї зі сторін вчинити правочин з метою, що завідомо суперечить інтересам держави і суспільства. Одностороння реституція означає повернення в первісний майновий стан однієї зі сторін недійсного правочину, яка не мала умислу вчинити правочин, що завідомо суперечить інтересам держави і суспільства, та стягнення за рішенням суду в дохід держави з іншої сторони, яка мала умисел вчинити правочин, визнаний судом недійсним як такий, що завідомо суперечить інтересам держави і суспільства, одержаного нею за правочином або належного їй на відшкодування виконаного.

Одностороння реституція в такому розумінні $є$ заходом цивільно-правової відповідальності й належить до конфіскаційних санкцій, виходячи з того, що конфіскаційними санкціями в цивільному праві є визначені законом заходи цивільно-правового впливу, що полягають у припиненні права власності на майно, яке оплатно або безоплатно переходить у власність держави.

На недоцільність існування односторонньої реституції вказували, зокрема, О. А. Пушкін та В. М. Самойленко, на думку яких, якщо 
у діях сторін будуть наявні ознаки злочину чи адміністративного правопорушення, до них повинні застосовуватися відповідні санкції, але вже ті, що містяться в нормах публічного права [18, с. 231]. Аналогічної позиції дотримується й О. В. Семушина [19].

Враховуючи необхідність захисту публічних інтересів держави і суспільства, існування односторонньої реституції як особливого правового наслідку недійсності правочину в умовах боротьби з корупційними явищами в державі є доцільним та обгрунтованим задля забезпечення виконання державою своїх завдань перед суспільством та людиною. Наявність публічно-правових норм в ЦК України жодним чином істотно не впливає на приватноправовий механізм регулювання цивільних відносин, заснованих на юридичній рівності, вільному волевиявленні, майновій самостійності іх учасників, а сприяє більш ефективному захисту цивільних прав та інтересів учасників цивільних правовідносин та захисту інтересів держави і суспільства цивільно-правовими заходами.

У частині 3 ст. 228 ЦК України йдеться про те, що за наявності умислу вчинити правочин з метою, що завідомо суперечить інтересам держави і суспільства, в обох сторін - в разі виконання правочину обома сторонами - в дохід держави за рішенням суду стягується все одержане ними за угодою, а в разі виконання правочину однією стороною з іншої сторони за рішенням суду стягується в дохід держави все одержане нею і все належне - $з$ неї першій стороні на відшкодування одержаного. О. В. Гутников зазначає, що в разі, якщо вина в скоєнні протизаконного недійсного правочину є в обох сторін цього правочину, то має місце недопущення реституції. При цьому конфіскаційні заходи у вигляді стягнення одержаного в дохід держави рівною мірою застосовуються до обох сторін недійсного правочину [20, с. 249]. Недопущення реституції в юридичній літературі визначається як стягнення в дохід держави всього одержаного сторонами за правочином, а в разі виконання правочину не всіма сторонами - того, що належало до одержання [11, с. 177].

Отже, недопущення реституції як особливий правовий наслідок недійсності правочину, вчиненого з метою, що завідомо суперечить інтересам держави і суспільства, застосовується судом, є конфіскаційною санкцією та заходом цивільно-правової відповідальності і являє собою стягнення в дохід держави всього одержаного сторонами за правочином, а в разі виконання правочину не всіма сторонами - того, що належало до одержання, за наявності умислу в обох сторін вчинити правочин, визнаний судом недійсним як вчинений з метою, що завідомо суперечить інтересам держави і суспільства.

\section{Висновки}

Підсумовуючи розгляд питання про конфіскаційні санкції в цивільному праві у разі вчинення недійсного правочину, необхідно зазначити, що до конфіскаційних санкцій як визначених законом заходів цивільно-правового впливу, що полягають у припиненні права власності на майно, яке оплатно або безоплатно переходить у власність держави, належать одностороння реституція та недопущення реституції. Одностороння реституція та недопущення реституції є особливими правовими наслідками недійсності правочину, вчиненого з метою, що завідомо суперечить інтересам держави і суспільства, які застосовуються судом і є заходами цивільно-правової відповідальності. Одностороння реституція не збігається 3 поняттям конфіскації майна у розумінні позбавлення права власності на майно за рішенням суду як санкції за вчинення правопорушення. Односторонньою реституцією є повернення в первісний майновий стан однієї зі сторін недійсного правочину, яка не мала умислу вчинити правочин, що завідомо суперечить інтересам держави і суспільства, та стягнення за рішенням суду в дохід держави з іншої сторони, яка мала умисел вчинити правочин, визнаний судом недійсним як такого, що завідомо суперечить інтересам держави і суспільства, одержаного нею за правочином або належного їй на відшкодування виконаного. Недопущення реституції являє собою стягнення в дохід держави всього одержаного сторонами за правочином, а в разі виконання правочину не всіма сторонами - того, що належало до одержання, за наявності умислу в обох сторін вчинити правочин, визнаний судом недійсним як вчиненого з метою, що завідомо суперечить інтересам держави і суспільства.

\section{Список використаних джерел:}

1. Цивільний кодекс України від 16 січня 2003 р. № 435-IV. Відомості Верховної Ради України. 2003. № 40-44. Ст. 356.

2. Кузнецова Н. Недействительность сделок (к вопросу об антисоциальных сделках и последствиях их совершения). Ежегодник украинского права. 2012. № 4. С. 293-306.

3. Ромовська 3. Українське цивільне право: Загальна частина. Академічний курс : підручник. Київ : Атіка, 2005. 560 с.

4. Господарський кодекс України від 16 січня 2003 р. № 436-IV. Відомості Верховної Ради України. 2003. № 18, № 19-20, № 21-22. Ст. 144. 
5. Про внесення змін до деяких законодавчих актів України у зв'язку з прийняттям Податкового кодексу України : Закон України від 02 грудня 2010 р. № 2756- VI. Відомості Верховної Ради Украӥни. 2011. № 23. Ст. 160.

6. Дзера О. Цивільно-правова конфіскація в контексті змін ст. 228 ЦК України. Право України. 2011. № 5. C.69-76.

7. Кот О. Природа недійсних правочинів. Вісник Національної академії правових наук Українu. 2009. № 4. C. 108-118.

8. Спасибо-Фатєєва I. Недійсні правочини та проблеми застосування реституції. Щорічник украӥнського права. 2009. № 1. С. 150-167.

9. Кузнєцова Н. С. Перспективи розвитку приватного права в контексті європейської інтеграції України. Проблеми цивільного права та прочесу : тези доп. учасників наук.-практ. конф., присвяч. світлій пам'яті О. А. Пушкіна (Харків, 25 травня 2018 р.). Харків : ХНУВС, 2018. С. 40-46

10. Дзера А. Некоторые вопросы гражданско-правовой конфискации по законодательству Украины. Ежегодник украинского права. 2012. № 4. С. $307-318$.

11. Гражданское право. Часть первая : учебник / под ред. А. Г. Калпина, А. И. Масляева. Москва : Юристь, 1997. 472 с.

12. Навальнєва Н. М. Одностороння реституція як санкція у цивільному праві. Проблеми иивільного права та процесу : тези доп. учасників наук.-практ. конф., присвяч. світлій пам'яті
О. А. Пушкіна (Харків, 19-20 травня 2017 р.). Харків : ХНУВС, 2017. С. 324-326.

13. Цивільний кодекс УСРР від 16 грудня 1922 p. URL : https://deminov.dp.ua/grazhdanskoepravo-i-process/ck-codecs-ussr-1922 (дата звернення: 25.07.2019).

14. Кучер В. О. Нікчемні правочини дис. ... канд. юрид. наук : 12.00.03. Київ, 2004. 208 с.

15. Цивільний кодекс УРСР від 18 липня 1963 р. № 1540-VI. URL : https://zakon.rada. gov.ua/laws/show/1540-06 (дата звернення: 20.06.2019)

16. Ромовська 3. В. Недійсність правочинів. Практика застосування окремих норм Цивільного кодексу Украӥни : практ. посіб. / кол. авт. Київ : Видавничий Дім «Ін Юре», 2008. С. 102-151.

17. Иоффе О. С. Советское гражданское право. Москва : Юрид. лит., 1967. 494 с.

18. Гражданское право Украины : учебник для вузов системы МВД Украины : в 2-х частях. Часть 1 / А. А. Пушкин, В. М. Самойленко, Р.Б. Шишка и др.; под. ред. проф. А. А. Пушкина, доц. В. М. Самойленко. Харьков : Основа, 1996. 440 с.

19. Семушина О. В. Недійсні правочини та правові наслідки їх недійсності : автореф. дис. ... канд. юрид. наук : 12.00.03. Київ, 2010. 16 с. URL : http://irbis-nbuv.gov.ua/cgi-bin/irbis64r_81/ cgiirbis_64.exе (дата звернення: 19.07.2019).

20. Гутников О. В. Недействительные сделки в гражданском праве. Теория и практика оспаривания. Москва : Бератор-Пресс, 2003. 576 с.

The article is focused on the analysis of forfeiture sanctions in civil law, which can be applied to the parties to an invalid transaction committed for the purpose of contradicting the interests of the state and society. The author has substantiated that unilateral restitution and denial of restriction belong to confiscation sanctions established by the law measures of civil and legal influence, which imply the termination of the ownership for property that becomes state property on a paid basis or free of charge. Historical and legal analysis of the development of civil legislation on the application of unilateral restitution has been carried out and the expediency of the existence of such a sanction in the Civil Code of Ukraine in the current conditions of overcoming corruption phenomena in Ukraine has been substantiated. It has been proved that unilateral restitution and denial of restitution are special legal consequences of the invalidity of a transaction made with the purpose to knowingly contradicting the interests of the state and society applied by the court and that are measures of civil liability. Unilateral restitution does not coincide with the concept of confiscation of property in the sense of deprivation of ownership for property by the court decision as a sanction for committing the offense. It has been clarified that unilateral restitution is the return to the original property state of one of the parties to the invalid transaction that did not have an intent to make a transaction, which is deliberately contradicts to the interests of the state and society, as well as recovery by the court decision to the income of the state from the other party that intentionally made a transaction declared invalid by the court as such, which is knowingly contradicts to the interests of the state and society obtained by the transaction or owned for the compensation of the accomplished. The concept of "denial of restitution" has been improved with the clarification that denial of restitution is the recovery of all received by the parties within the transaction to the income of the state, and in case of execution of the transaction not by all parties - everything belonging before reception, if there is the intent of both parties to make the transaction recognized by the court as invalid, committed for the purpose of knowingly contradicting the interests of the state and society.

Key words: confiscation sanction, invalid transaction, public order, interests of the state and society, confiscation, unilateral restitution, denial of restitution. 
УДК 347.91/.95(477)

DOI https://doi.org/10.32849/2663-5313/2019.8.05

\section{Олена Старченко,}

аспірант кафедри правосуддя

юридичного факультету

Київського начіонального університету імені Тараса Шевченка

\section{ПРОБЛЕМНІ ПИТАННЯ ПРОЦЕСУАЛЬНОГО СТАТУСУ ЕКСПЕРТА 3 ПИТАНЬ ПРАВА}

Стаття присвячена дослідженню иивільного процесуального статусу експерта з питань права як нової процесуальної фігури в иивільному судочинстві в світлі реформи иивільного прочесуального законодавства. Автором досліджується проблематика особливостей участі експерта з питань права в иивільному судочинстві, а саме процедури допуску в чивільне судочинство та визначення кола осіб, за ініціативою яких експерт з питань права допускається у процес. Досліджується проблематика відсутності нормативних положень, присвячених відповідальності експерта з питань права за надання завідомо неправдивого висновку. Піднімається питання відсутності правової регламентаиї відводу експерта з питань права. Акцентується увага на особливостях правової природи знань, які застосовуються експертом з питань права в ході реалізащї своєї процесуальної функцї. Так, запропоновано визначати правову природу знань експерта з питань права, основуючись на меті його процесуальної діяльності. У статті проведений аналіз повноважень експерта з питань права щодо надання висновку в галузі права, а також доказове значення даного висновку. Визначені чіткі обмеження щодо використання правових знань в якості спеціальних в цивільному судочинстві.

Ключові слова: експерт з питань права, спеціальні знання, висновок в галузі права, аналогія закону, аналогія права, законодавство іноземних держав.

Постановка проблеми. Сьогодні у зв'язку із реформуванням цивільного процесуального законодавства актуальною є проблематика участі в цивільному судочинстві експерта з питань права. Варто зазначити, що ЦПК досить поверхнево регулює процесуальний статус даного учасника судового процесу, що призводить до труднощів в ході реалізації його процесуальної функції. Між вченими-процесуалістами точаться активні наукові дискусії щодо доцільності легалізації процесуального статусу експерта з питань права та участі даного учасника судового процесу в цивільному судочинстві, оскільки сам суддя являється фахівцем у галузі права.

Стан дослідження. Враховуючи той факт, що експерт з питань права $є$ новою процесуальною фігурою в цивільному судочинстві, його процесуальний статус не набув широкого науково-теоретичного дослідження. Однак ця проблематика стала предметом наукових досліджень таких вчених процесуалістів, як А. Довгерт, О. Кармаза, Д. Кушерець, Ю. Притика, А. Штефан.

Метою статті $є$ визначення основних прогалин у правовій регламентації процесуального статусу експерта з питань права 3 метою удосконалення цивільного процесуального законодавства.
Виклад основного матеріалу. Відповідно до ч. 1 ст. 73 ЦПК як експерт 3 питань права може залучатися особа, яка має науковий ступінь та $є$ визнаним фахівцем у галузі права [1]. Дотримуємося позиції, що формулювання вказаної частини статті є досить оціночним, що призводить до різних трактувань та правозастосування на практиці. Так, щодо формулювання «визнаний фахівець у галузі права» варто зазначити, що сьогодні не передбачено чітких критеріїв встановлення рівня визнання експерта в галузі права Можна зробити висновок про відсутність процедури перевірки повноважень особи на здійснення цивільного судочинства експерта з питань права. Навіть більше, у ЦПК не визначено перелік документів, які підтверджують наявність у особи компетенції щодо можливості надавати висновок в галузі права. У зв'язку з цим дані недоліки у правовій регламентації процесуального статусу експерта з питань права призводять до ряду труднощів в ході участі експерта 3 питань права в розгляді справи по суті.

Навіть більше, виникає питання щодо порядку реалізації експертом з питань права процесуального права щодо відмови від участі у судовому процесі на підставі відсутності у останнього необхідних знань, оскільки процедура їх перевірки у ЦПК не закріплена. В такому разі вважаємо, що порядок пере- 
вірки обгрунтованості відмови експерта 3 питань права від надання висновку в галузі права повинен базуватися на встановленні відповідності між питанням, яке ставиться на вирішення конкретному експерту з питань права, та сферою його наукових досліджень. Саме тому вважаємо за необхідне встановити чіткі вимоги до експерта з питань права.

Враховуючи вищезазначене, погоджуємося із науковою позицією О. Кармазої з приводу того, що під час прийняття судом рішення про допуск експерта з питань права до участі в справі та долучення його висновку до матеріалів справи варто брати до уваги такі критерії, як досвід наукової роботи в галузі права; наявність наукових публікацій у фахових виданнях України й іноземних держав, включених до міжнародних наукометричних баз даних та опублікованих після присудження наукового ступеня; наявність документа, що підтверджує присвоєння вченого звання; ступінь активності участі в конференціях, симпозіумах, круглих столах, яка підтверджується опублікуванням тез його виступу; стажування й навчання за кордоном, які підтверджуються відповідними документами та які легалізовані в порядку, встановленому чинними міжнародними договорами України, тощо [2, с. 33].

У зв'язку з вищезазначеним вважаємо, що повноваження експерта 3 питань права на подання до суду висновку в галузі права повинні насамперед підтверджуватися дипломом про присвоєння наукового ступеню. Саме цей документ свідчить про те, що особа дійсно в установленому законом порядку захистила наукову роботу в формі публічного захисту.

Наступною прогалиною у правовому регулюванні процесуального статусу експерта з питань права є відсутність нормативного положення про відповідальності експерта 3 питань права за завідомо неправдивий висновок. Відповідно до ч. 2 ст. 115 ЦПК України суд може посилатися в рішенні на висновок експерта у галузі права як на джерело відомостей, які в ньому містяться, та має зробити самостійні висновки щодо відповідних питань. У зв'язку з цим висновок експерта з питань права може вплинути в подальшому на зміст рішення суду. Саме тому добросовісність та неупередженість експерта з питань права є важливою гарантією забезпечення законності та обгрунтованості рішення суду, що призводить до необхідності запровадження механізму примусу у вигляді відповідальності.

Також важливим недоліком у регламентації процесуального статусу експерта 3 питань права є відсутність процедури від- воду експерта з питань права. Варто зазначити, що у ЦПК не закріплено процесуального права учасників справи заявляти відвід експертові з питань права. Так, відповідно до ч. 1 ст. 38 ЦПК України, секретар судового засідання, експерт, спеціаліст, перекладач не можуть брати участі у розгляді справи та підлягають відводу (самовідводу) з підстав, зазначених у статті 36 цього Кодексу.

Вважаємо за необхідне до переліку осіб, передбачених у вищезазначеному нормативному положенні, додати і експерта з питань права. Враховуючи той факт, що діяльність експерта з питань права має важливе значення для ухвалення законного, обгрунтованого та справедливого рішення суду, питання відводу даного учасника судового процесу $€$ гарантією забезпечення неупередженого здійснення ним процесуальних функцій.

В контексті дослідження проблемних питань процесуального статусу експерта 3 питань права варто також звернути увагу i на особливості допуску експерта 3 питань права до участі в цивільному судочинстві. У ч.1 ст. 73 ЦПК України зазначено, що рішення про допуск до участі в справі експерта 3 питань права та долучення його висновку до матеріалів справи ухвалюється судом.

Дотримуємося позиції, що експерт 3 питань права повинен допускатися до участі в цивільному судочинстві не тільки за ініціативою суду, а й за ініціативою учасників справи. Оскільки інакше має місце порушення принципу змагальності.

Результатом процесуальної діяльності експерта з питань права $€$ висновок в галузі права. Відповідно до ч. 1 ст. 115 ЦПК України висновок експерта у галузі права не є доказом, має допоміжний (консультативний) характер і не є обов'язковим для суду. Погоджуємося із даним нормативним положенням в силу того, що висновок експерта в галузі права не містить результатів спеціального дослідження, на відміну від висновку експерта. Також, важливо розуміти, що даний висновок може носити винятково консультативний характер, оскільки сам суддя $є$ фахівцем в галузі права. У зв'язку з цим зміщення повноважень щодо вирішення питань правового характеру на експерта 3 питань права призведе до порушення основних засад судочинства.

Дотримуємося позиції, що назва «експерт в галузі права» досить недоцільно використовується щодо даного учасника судового процесу. Тут варто акцентувати увагу на тому, що експерт з питань права не проводить спеціального дослідження, на відміну від судового експерта. Правова природа його діяльності має зовсім інший характер та полягає у наданні 
консультативного висновку. Погоджуємося із науковою позицією С.С. Бичкової, що для з'ясування змісту норми права іноземної держави не потрібно проводити спеціального дослідження із використанням визначених методик, засобів, обладнання та іншого, що є обов'язковим складником експертизи [3, c. 329].

Саме тому можна зробити висновок про те, що експерт з питань права не є суб'єктом проведення судової експертизи, його процесуальна діяльність не пов'язана із здійсненням спеціального дослідження. У зв'язку з цим вважаємо, що поняття «фахівець в галузі права» більш обгрунтовано відображає зміст процесуальної діяльності відповідного учасника судового процесу.

Зміст процесуальної діяльності експерта з питань права розкривається у ст. 114 ЦПК. Так, згідно з ч. 1 ст. 114 ЦПК України учасники справи мають право подати до суду висновок експерта у галузі права щодо:

1) застосування аналогії закону чи аналогії права;

2) змісту норм іноземного права згідно з їх офіційним або загальноприйнятим тлумаченням, практикою застосування і доктриною у відповідній іноземній державі.

Вважаємо обгрунтованою наукову позицію А. Штефан з приводу того, що висновок експерта в галузі права не містить дослідження, яке стосується обставин справи, і є джерелом не доказової інформації, а відомостей, які можуть бути необхідними для кваліфікації судом правовідносин сторін і вибору правової норми, яка підлягає застосуванню, проте не пов'язані із встановленням обставин справи. Висновок експерта у галузі права не має здатності підтвердити чи спростувати яку-небудь обставину, яка входить до предмета доказування у справі. Саме тому цілком вірним є законодавчий підхід про неналежність висновку експерта в галузі права до доказів, про допоміжний (консультативний) характер такого висновку і відсутність його обов'язкового значення для суду (ч. 1 ст. 115 ЦПК) [4, с. 25].

У зв'язку з цим можна зробити висновок про те, що висновок у галузі права не можна розглядати як висновок експерта з права. В цьому контексті підтримуємо наукову позицію М.С. Шакарян з приводу того, що на експертизу можуть бути винесені тільки ті питання, які потребують спеціальних знань в галузі науки, техніки, мистецтва чи ремесла. Питання права, тлумачення і застосування правових норм, які належать до компетенції суду, не можуть бути винесені на експертизу [5, с. 191].

Враховуючи вищезазначене, можна зробити висновок про те, що процесуальні форми діяльності експерта з питань права та судового експерта $є$ різними. Експерт з питань права не здійснюе спеціального дослідження, він надає консультативний висновок, зміст якого складає аналіз доктрини щодо застосування норм права іноземної держави та аналогії права або аналогії закону.

Варто зазначити, що у ЦПК не зазначено такої ознаки експерта 3 питань права, як володіння спеціальними знаннями. Вважаємо, що природа знань, які використовує експерт в ході реалізації своєї процесуальної функції, випливає з мети його процесуальної діяльності. На нашу думку, метою процесуальної діяльності експерта з питань права $є$ сприяння процесу доказування. Тому експерта з питань права слід вважати суб’єктом використання спеціальних знань.

Як слушно зазначає К.В. Легких, поняття «спеціальні знання» варто застосовувати лише в галузі судочинства, а тому визначати всі правові знання в юридичній сфері як спеціальні було б нелогічним. 3 іншого боку, професійні правові знання суддів, прокурорів, слідчих треба розглядати як поняття широке й водночас таке, що може перетинатися з іншими правовими знаннями. Знання, що виходять за межі професійних знань процесуальних осіб, але потрібні їм для виконання процесуальних функцій, слід вважати спеціальними. Такими спеціальними відносно професійної компетенції судді, прокурора чи слідчого можуть бути й знання в певній галузі права [6, с. 57].

У зв'язку з вищезазначеним вважаємо, що, незважаючи на той факт, що суддя $е$ фахівцем в галузі права, існують певні сфери правової науки, знання яких не входить до компетенції судді. Так, наприклад, суддя являється фахівцем в галузі вітчизняного права. Тому знання норм іноземної держави та особливостей їх правозастосування не входить до його компетенції.

\section{Висновки}

Отже, на основі вищезазначеного дотримуємося позиції, що експерт в ході проведення судової експертизи не може надавати висновок з питань права, оскільки це порушуватиме основні засади судочинства та роль суду як незалежного арбітра. У зв'язку 3 цим предметом судової експертизи не можуть бути правові питання, оскільки надання юридичної кваліфікації спірним правовідносинам належить винятково до повноважень судді.

У зв'язку з вищезазначеним зазначимо те, що використання правових знань в якості спеціальних в цивільному судочинстві має обмежений характер. Так, відповідні знання 
відображаються у висновку в галузі права, який має рекомендаційний характер; в якості спеціальних можуть застосуватися винятково ті права, які зазначені у ч. 1 ст. 114 ЦПК.

Отже, враховуючи вищезазначене, можна зробити висновок про те, що правова регламентація цивільного процесуального статусу експерта з питань права потребує грунтовного удосконалення. Так, невирішеними залишаються питання щодо відповідальності експерта з питань права, реалізації права на відвід даного учасника судового процесу, особливостей допуску експерта з питань права в цивільне судочинство, правова природа його знань та доказове значення висновку в галузі права.

\section{Список використаних джерел:}

1. Цивільний процесуальний кодекс/ Вiдомості Верховної Ради Украйни (ВВР). 2004
№ 40-41, 42. ст.492. (Редакція від 24.02.2018). URL: http://zakon3.rada.gov.ua/laws/show/1618-15.

2. Кармаза О., Кушерець Д. Експерт із питань права в судовому процесі: новели законодавства України. Підприємнищтво, господарство $і$ право. 2017. № 10. С. 32-36.

3. Цивільний процесуальний кодекс України : науково-практичний коментар / С.С. Бичкова, Ю.В. Білоусов, В.І. Бірюков та ін. ; За заг. ред. С.С. Бичкової. Київ : Атіка, 2008. 840 с.

4. Штефан А.С. Висновок експерта у цивільному судочинстві. Теорія $і$ практика інтелектуальної власності. 2018. № 2. С. 16-28 (25)

5. Шакарян М.С. Комментарий к Гражданскому процесуальному кодексу Российской Федерации / С.А. Алехина, А.Т. Боннер, В.В. Блажеев и др. ; Отв. ред. М.С. Шакарян. Москва : ТК Велби, Изд-во Проспект, 2003. 688 с.

6. Легких К.В. Поняття «спеціальні юридичні знання» та форми їх використання у кримінальному процесі. Вісник Академії адвокатури України. 2008. Число 3. С. 54-60.

The article is devoted to the investigation of the civil procedural status of an expert on law as a new procedural figure in civil proceedings in the light of the reform of civil procedural legislation. The author explores the peculiarities of the participation of the expert on law in civil proceedings, namely the procedure of admission to civil proceedings and the determination of the number of persons at the initiative of which the expert on law is admitted to the process. The problem of lack of normative provisions on the liability of an expert in law for giving a deliberately false conclusion is investigated. The question arises of the lack of legal regulation of the expert expert's removal of the law. Attention is drawn to the peculiarities of the legal nature of the knowedge used by the legal expert in the exercise of his or her procedural function. Thus, it is proposed to determine the legal nature of a legal expert's knowledge based on the purpose of his or her litigation. The article analyzes the authority of a legal expert to provide a conclusion in the field of law, as well as the probative value of that conclusion. There are clear limitations on the use of legal knowledge as special in civil proceedings.

Key words: law expert, specialist knowledge, conclusion in the field of law, analogy of law, analogy of law, legislation of foreign states. 
УДК 342.9

DOI https://doi.org/10.32849/2663-5313/2019.8.06

\section{Володимир Шемонаєв,}

канд. юрид. наук, дочент,

капітан далекого плавання,

Національний університет «Одеська морська академія»

\section{ПРАВОВЕ ЗНАЧЕННЯ ЗАГАЛЬНОЇ АВАРІЇ ПРИ СТРАХУВАННІ ВАНТАЖУ}

У процесі перевезення вантажів з вантажним судном можуть відбутися надзвичайні події. Наприклад:

- посадка на мілину для рятування судна;

- пожежа на судні через неправильне перевезення небезпечних вантажів;

- падіння ярусу контейнерів через неправильне кріплення і неправильне декларування ваг вантажів;

- важкі погодні умови на морі, що погіршують остійність судна.

У подібних ситуачіях капітан судна зобов'язаний вжити всіх необхідних заходів для забезпечення безпеки судна на морі, вантажу і, що найбільш важливо, екіпажу.

Для порятунку може знадобитися:

- скинути за борт деякі небезпечні вантажі (ие може бути вантаж, який заважає остійності судна під час поганої погоди, або важкий вантаж, скидання якого дозволить судну спливти і зійти з мілини);

- здійснити девіачію $і$ зайти в найближчий порт укриття;

- скористатися послугами професійних рятувальників;

- провести терміновий ремонт судна, в ході якого деякі вантажі можуть бути пошкоджені.

Якщо склалася надзвичайна ситуачія і судно i/або вантажі понесли навмисні розумні збитки під час порятунку від загальної для них небезпеки, судновласник може оголосити «загальну аварію» (англ. "general average"). Наприклад, якщо судно сіло на мілину і довелося реверсирувати головний двигун, праиювати двигуном на максимальних обертах, щоб зійти з мілини, збитком буде вартість додатково витраченого палива і шкоди, заподіяної двигуну через роботу на межі можливостей. Всі сторони, які беруть участь в подібному рейсі, повинні пропориійно розділити понесені збитки.

Особливу защікавленість у правовому регулюванні цвого інституту проявляють страховики. Можна сказати, що загальна аварія має свою власну вартість для страховиків, які відикодовують збитки, що виникають у всіх сторін загального морського підприємства, як защікавлених у вантажі, так $i$ в судні, а також сторін, які ризикують фрахтом.

Що стосується загальної аварії, то необхідна надзвичайна оперативність страхових компаній, розуміння морського права, а також чималі фінансові резерви.

Ключові слова: загальна аварія, збитки, витрати, судно, фрахт, торгове мореплавство.

Постановка проблеми. Якщо надзвичайна подія оголошена загальною аварією, це означає, що власники вантажів, які перевозилися на судні, повинні сплатити роботи 3 порятунку вантажу і самого судна. Якщо вантажі застраховані, такі витрати відшкодовуються страховою компанією.

Тому найбільш важливим для нас $є$ питання показати перевагу страхування вантажу, за якого відшкодовуються не тільки збитки за пошкодження або втрату вантажу, а й обов'язкові витрати з порятунку судна в разі загальної аварії.

Актуальність теми дослідження полягає в тому, що стаття являє собою комплексне аналітичне дослідження самостійного інституту морського права - загальної аварії, а також інституту страхування i, зокрема, страхування вантажу.
Аналіз останніх досліджень і публікацій. Науковий аналіз проблем, пов'язаних із загальною аварією в Україні, здійснюється багатьма вітчизняними вченими. Серед них слід назвати В.В. Демиденко, А.Н. Шемякіна, А.О. Балобанова та інших, які створили фундаментальну базу для подальшого дослідження питань, що розглядаються.

Метою статті $\epsilon$ - встановити, які роботи і витрати бере на себе страхове товариство, в якому застрахований вантаж, власник вантажу, фрахтувальник та судновласник.

Виклад основного матеріалу. Під загальною аварією (generale average) розуміються збитки, понесені внаслідок проведених свідомо і розумно надзвичайних витрат або пожертвувань заради загальної безпеки з метою запобігання від небезпеки майна, що 
приймає участь у загальному морському підприємстві судна, фрахту та вантажу, який перевозиться судном [1, с. 7].

Загальна аварія - це наслідок якоїсь морської пригоди, що створює небезпеку загибелі судна, вантажу і фрахту: зіткнення судна, пожежі на судні, втрати судном остійності, аварії судна тощо. Для запобігання загибелі судна здійснюються необхідні заходи, що тягнуть певні витрати або пожертвування. Саме ці збитки у вигляді витрат, пожертвувань, втрат визнаються загальною аварією [2, c. 239].

Оскільки загальна аварія є як інститутом міжнародного приватного морського права, так і цивільно-правовим інститутом, існуючим в рамках національного законодавства, то відносини, що виникають під час загальної аварії, регулюються як міжнародними звичаями (Йорк-Антверпенськими правилами в різних редакціях), так і національним законодавством (Кодексом торговельного мореплавства України; морськими законами інших держав; Положенням про асоціацію диспашеров і порядок складання диспаш та іншими нормативними актами).

Приблизний, а не вичерпний характер має і перелік видів загальної аварії, що міститься в ст. 279 КТМ України. Він починається словами «зокрема і інші збитки, не названі в цій статті, які володіють усіма ознаками загальної аварії і підпадають тим самим під її загальне визначення (ст. 277 КТМ) й також повинні визнаватися загально аварійними».

Як виняток в деяких випадках, спеціально передбачених Йорк-Антверпенськими правилами, а так само і ст. 280 КТМ України, до загальної аварії прирівнюються збитки, що не володіють повною мірою всіма необхідними для цього ознаками.

Кодекс торговельного мореплавства України містить визначення поняття загальної аварії, перелік ії видів, передбачає порядок розподілу загальної аварії, а також містить вказівки на принцип визначення права, що підлягає застосуванню.

Так, ст. 277 КТМ дає визначення поняття загальної аварії, вказуючи, що загальною аварією визнаються збитки, понесені внаслідок здійснених свідомо і розумно надзвичайних пожертвувань 3 метою порятунку судна, фрахту і вантажу, який перевозиться на судні, від загальної для них небезпеки, та встановлює, що загальна аварія розподіляється між судном, фрахтом і вантажем пропорційно їх вартості [3, с. 39].

Так само за змістом, але в більш точному формулюванні, визначена загальна аварія в КТМ України, де під нею розуміються «збит- ки, понесені внаслідок здійснених свідомо і розумно надзвичайних витрат або пожертвувань $з$ метою порятунку судна, фрахту і вантажу, що перевозиться на судні, від загальної для них небезпеки» (ч. 1 ст. 277).

Разом $з$ тим слід зазначити, що навіть така повна характеристика складових частин (елементів) поняття загальної аварії не $€$ вичерпною і загальноприйнятою.

Крім того, недоліком наведеної позиції $є$ те, що тут, скоріше, міститься тлумачення поняття загальної аварії замість аналізу іï ознак. У зв'язку з цим слід звернути увагу на ту обставину, що ознаки загальної аварії зазвичай одночасно трактуються і як умови виникнення права на іï розподіл, на що спеціально зверталася увага в літературі 3 морського права. Якщо ж вести мову про «умови» загальної аварії (деякими авторами навіть використовується термін «принципи», що видається не зовсім вдалим, оскільки точніше говорити про «принципи розподілу загальної аварії, а це вже інша правова категорія), то число їх, очевидно, має бути мінімальним, оскільки сам термін «умови» орієнтує на те, що повинні бути вказані лише ті обставини, без яких виникнення даних правовідносин неможливо [4, с. 119].

Наявність в сукупності зазначених ознак дозволяє говорити про наявність загальної аварії.

Разом $з$ тим необхідно ще раз звернути увагу на обставину, що цей інститут сформований на основі поєднання казуїстичного і системно-структурного принципів. Тобто загальне визначення поняття загальної аваpiї доповнює приблизний перелік випадків (видів) дій, що призвели до збитків, які можуть бути віднесені до загальної аварії. Характеристика цих дій, відповідно до перерахованих вище ознак, є як би додатковою (допоміжною) кваліфікацією (перевіркою) збитків в якості загальної аварії. Крім того, визначення наявності загальної аварії на підставі системи ознак (умов) застосовується в тих випадках, коли конкретна ситуація відсутня в переліку.

Правило «А» в Йорк-Антверпенських правилах 2004 р. передбачає, що загальна аварія «має місце тоді і тільки тоді, коли свідомо i розумно проведені надзвичайні пожертвування або понесені надзвичайні витрати заради спільної безпеки, з метою запобігання від небезпеки майна, що бере участь в загальному морському підприємстві».

У зв'язку з цим доцільно назвати тут основні випадки загальної аварії. Оскільки в КТМ України цей перелік дано більш компактно, скористаємося цим законом, а не Йорк-Антверпенськими правилами. 
Відповідно до ст.279 КТМ України до загальної аварії у разі ознак наявності іï загальних ознак, зокрема, належать:

1) збитки, спричинені викиданням за борт вантажу або приналежностей судна, а також збитки від пошкодження судна або вантажу під час вжиття заходів для загального порятунку, зокрема, внаслідок проникнення води в трюми через відкриті для викидання вантажу люки або інші зроблені для цього отвори;

2) збитки, заподіяні судну або вантажу під час гасіння пожежі на судні, включаючи збитки від проведеного з цією метою затоплення судна, що горіло;

3) збитки, заподіяні навмисною посадкою судна на мілину і зняттям такого судна з мілини;

4) збитки від пошкодження двигунів, інших машин або котлів судна, яке знаходиться на мілині, заподіяні намаганням зняти судно з мілини;

5) надзвичайні витрати, пов'язані $з$ перевантаженням вантажу, палива або предметів постачання із судна в ліхтери, з найманням ліхтерів та із зворотним завантаженням на судно, зроблені у разі посадки судна на мілину;

6) збитки від пошкодження або загибелі вантажу, палива або предметів постачання, заподіяні переміщенням їх на судно, вивантаженням із судна, зворотним завантаженням і укладанням, а також під час зберігання тоді, коли самі витрати на виконання цих операцій визнаються загальною аварією;

7) витрати, зроблені з метою отримання допомоги як за договором про рятування, так і без нього тією мірою, якою рятувальні операції здійснювалися з метою запобігання небезпеки для судна, фрахту і вантажу;

8) збитки від забруднення навколишнього природного середовища, яке виникло внаслідок загальної аварії;

9) втрата фрахту спричинена втратою вантажу у тих випадках, коли втрата вантажу відшкодовується в порядку розподілу загальної аварії, при цьому з фрахту виключаються витрати, які були б зроблені перевізником вантажу для його отримання, але внаслідок пожертвування проведені не були.

Як зазначалося вище, наведений перелік не $є$ вичерпним. Він всього лише містить вказівки на найбільш типові в практиці торгового мореплавства ситуації, пов'язані з провадженням витрат будь-ким 3 учасників морського підприємства для запобігання загальної для судна, фрахту і вантажу, що перевозиться, небезпеки, і опис таких ситуацій. Крім того, у відповідних нормах міститься опис характеру і суті дій, що належать до загальної аварії, визначається характер і перелік витрат, які змушені провести учасники торгового підприємства в тій чи іншій типовій ситуації, тощо.

Загальновідомо, що Йорк-Антверпенські правила являють собою звід правил, що регулюють інститут загальної аварії. Нова редакція зводу правил по загальній аварії вигідно відрізняється тим, що враховує новітній досвід в сфері відносин з приводу загальної аварії, а також інтереси сторін, зацікавлених в їх врегулюванні, в тому числі страховиків, яких представляє на міжнародній арені Міжнародний союз морського страхування (IUMI-International Union of Marine Insurance). Справа в тому, що в разі виникнення надзвичайної морської події, визнаної загальною аварією, сума збитків збільшується приблизно на $10-30 \%$ у зв'язку з нарахуванням відсотків, комісійних та винагороди диспашера. Таким чином, можна сказати, що загальна аварія має свою власну вартість для страховиків, які відшкодовують збитки, що виникають у всіх сторін загального морського підприємства, як зацікавлених у вантажі, так і в судні, а також у сторін, які ризикують фрахтом. До того ж збір інформації про судно, вартість вантажу, загальноаварійні витрати та інші загальноаварійні збитки, наступний перерахунок всіх витрат і відшкодувань по загальній аварії - все це займає час майже в кілька років (за умови великої аварії), що перешкоджає швидкому врегулюванню претензій до страховика.

У 2009 році після зіткнення суден "Niritpride" i "MSC Nikita" постраждало судно "MSC Nikita". Зіткнення сталося на шляху з Клайпеди в Антверпен біля берегів Нідерландів. На судні перевозилися вантажі, застраховані в страховому товаристві, деревина, механічні деталі і гранули РЕТ.

Зіткнення суден було оголошено загальної аварією, а це значить, що власники вантажів, чиє майно перевозилося на судні, повинні сплатити роботи з порятунку вантажу і самого судна. Якщо вантажі застраховані, такі витрати відшкодовуються страховою компанією.

Страхова компанія здійснила страхову виплату, хоча вантажі були недоторканими Цю суму склала фінансова допомога $з$ порятунку потопаючого судна від трьох вантажовласників, чиї вантажі знаходилися на борту.

У разі загальної аварії скликається диспетчерська організація, відповідальна за порятунок людей, судна і вантажу. Дана організація встановлює попередні суми гарантій, які повинні заплатити власники вантажу, бажаючі повернути своє майно. Пізніше дис- 
петчер організовує продаж неповернених вантажів, підраховує суму збитку всіх сторін і витрати на відновлення судна.

Після надзвичайної події на судні витрати діляться пропорційно між власником судна і власниками вантажу, які перевозять на ньому свої вантажі. Чим більша вартість вантажу, що перевозиться, тим більше витрат на рятувальні роботи може понести його власник. Однак, якщо вантаж врятувати не вдалося, витрати на рятувальні роботи будуть менші.

Страхове товариство повинно подати гарантію за всіх клієнтів. Зазвичай в таких випадках диспетчерська організація приймає гарантії від кількох страховиків. Отримати ix дуже складно, оскільки щодо надійності і платоспроможності фірм висуваються дуже високі вимоги. Якщо компанії не отримують гарантій, їм доводиться на цей час заморозити свої оборотні кошти. Весь процес адміністрування дуже тривалий і іноді може затягнутися на кілька років. Якщо фірма не отримує гарантії, її керівництву надовго доведеться забути про мільйонні прибутки.

У разі загальної аварії необхідна надзвичайна оперативність страхових компаній, розуміння морського права, а також чималі фінансові резерви. Тисячні суми необхідні для оплати послуг адвокатів та незалежних експертів, які представляють інтереси власників вантажу в суді. Всі ці роботи і витрати бере на себе страхове товариство, в якому застрахований вантаж. Якщо власник вантажу не склав договір про страхування майна, що перевозиться, то йому самому доведеться внести чималу суму. Перевага страхування вантажу полягає в тому, що воно відшкодовує не тільки збитки за пошкодження або втрату вантажу, а й обов'язкові витрати 3 порятунку судна в разі загальної аварії.

Свого роду «хранителем» ЙоркАнтверпенських правил $є$ Міжнародний морський комітет (CMI - Comité Maritime International). Саме CMI розробляє і приймає на своїй сесії нову редакцію цього зводу правил. У 2004 році була прийнята нова редакція Йорк-Антверпенських правил (YAR 2004). Хоча YAR 2004 року отримали деяку популярність, особливо в Америці, і сприяли зниженню вартості загальної аварії більш ніж на 20\% в середньому, через певні причини вони не були включені в проформи договорів морського перевезення вантажу, які розробляе Балтійська і міжнародна морська рада (ВIMCO - Baltic and International Maritime Council). Значною мірою саме тому судновласники, особливо європейські, ігнорують YAR 2004, вважаючи за краще використовувати версію Йорк-Антверпенських правил 1994 року (YAR 1994), хоча вона i застаріла.

Мабуть саме IUMI вів найбільш широку кампанію ось уже понад 20 років по вдосконаленню редакції ЙоркАнтверпенських правил. 3 метою врегулювання питань, пов'язаних 3 інновацією Йорк-Антверпенських правил, у 2012 році робоча група СМІ вирішила повністю переглянути положення Йорк-Антверпенських правил, в результаті чого було створено новий звід правил (Йорк-Антверпенські правила 2016 року - YAR 2016). На своїй сесії в Нью-Йорку 6 травня 2016 року СМI прийняв YAR 2016. Нова редакція зводу правил по загальній аварії вигідно відрізняється тим, що враховує новітній досвід у сфері відносин з приводу загальної аварії, а також інтереси сторін, зацікавлених в їх врегулюванні, в тому числі страховиків. Задоволення в зв'язку з затвердженням YAR 2016 висловили і ВIMCO, i IUMI.

До найбільш важливих переваг нової редакції Йорк-Антверпенських правил належать такі інновації:

1. Відсотки нараховуються щорічно по ставці ЛІБОР в перший банківський день кожного року в валюті врегулювання претензії плюс 4\%. У разі врегулювання претензії в доларах США YAR 2016 передбачають ставку в 5,18\%, порівняно з 7\% відповідно YAR 1994 і 2,5\% відповідно YAR 2004

2. Комісійні збори в $2 \%$ більше не будуть відшкодовуватися. Це одна з дуже нечисленних новел, внесена YAR 2004, що збереглася і в YAR 2016.

3. Впроваджено заходи, що сприяють прискоренню процесу врегулювання загальної аварії, наприклад: виключення малоцінних вантажів 3 внеску в загальну аварію, якщо вартість їх включення перевищує вартість їх внеску, а також прозорий процес оцінювання диспашером відрахувань по загальній аварії за відсутності інформації у сторін.

\section{Висновки}

У сучасній теорії і практиці морського права під загальною аварією (generale average) розуміються збитки, понесені внаслідок вироблених свідомо і розумно надзвичайних витрат або пожертвувань заради спільної безпеки з метою запобігання небезпеці майна, що у загальному морському підприємстві судна, фрахту і вантажу, який перевозиться судном.

У разі загальної аварії необхідна надзвичайна оперативність страхових компаній, розуміння морського права, а також чималі фінансові резерви. Великі суми необхідні для оплати послуг адвокатів, 
незалежних експертів, які представляють інтереси власників вантажу в суді. Всі ці роботи і витрати бере на себе страхове товариство, в якому застрахований вантаж. Якщо власник вантажу не склав договір про страхування майна, що перевозиться, то йому самому доведеться внести чималу суму. Перевага страхування вантажу полягає в тому, що воно відшкодовує не тільки збитки за пошкодження або втрату вантажу, а й обов'язкові витрати $з$ порятунку судна в разі загальної аварії.

Таким чином, можна сказати, що загальна аварія має свою власну вартість для страховиків, які відшкодовують збитки, що виникають у всіх сторін загального морського підприємства, як зацікавлених у вантажі, так і в судні, а також у сторін, які ризикують фрахтом [5, с. 19].

\section{Список використаних джерел:}

1. Жилін І.С. Загальна аварія і питання морського права. М.: Мор. Транспорт, 1951.80 с.

2. Кодекс торговельного мореплавства України. Верховна Рада України. Відомості Верховної Ради України (ВВР). 1995. №№ 47, 48, 49, 50, 51, 52. ст. 349 .

3. Сидоренко А.В. Надзвичайні морські події (правові аспекти). Одеса : Латстар, 2001. 400 с

4. Юридичний довідник торгового мореплавання / Під ред. А.С. Кокіна. Москва : Спарк, 1998. C. 266

5. Гревцова Т.П. Відповідальність морського перевізника за незбереження вантажу. Львів, $2008.40 \mathrm{c}$.

In the process of transportation cargoes on board a cargo vessel, a number of emergencies may occur. For example:

- grounding a vessel due to save a vessel;

- fire due to improper transportation of dangerous cargoes;

- drop container tiers due to incorrect secure containers and incorrect declaration of cargo weights;

- bad weather condition that impair the stability of the vessel.

In such situations, the Captain of the vessel is obliged to take all reasonable measures to ensure the safety of the vessel, cargo and, most importantly, the crew.

For saving a vessel may need:

- dumping some cargo overboard (this may be a cargo that interferes with the stability of the vessel in bad weather, or a heavy cargo, the dumping of which will allow the vessel to bring afloat)

- make a deviation and go to the nearest shelter port;

- use the services of professional rescuers;

- carry out urgent repairs to the ship, during which some goods may be damaged.

If formed emergencies and the vessel and/or cargo tolerate whether deliberate reasonable damages at the time of salvation from their common danger, the shipowner may call "general average". For example, if the ship ran aground and had to reverse the main engine, the engine is running at maximum speed to go broke, a loss will be an additional cost and spent fuel same additional cost and the damage caused to the engine due to work at full capacity. All parties involved in a such case should share the losses incurred in proportion.

Particular interest in the legal regulation of this cases exhibit insurers. We can say that the general average has its own cost for insurers who reimburse damages arising from all sides.

The emergency efficiency of insurance companies, considerable financial reserves are necessary. Thousands of sums are needed to pay for the services of lawyers, independent experts who represent the interests of the owners of the goods in court.

The insurance company should to provide a guarantee for all customers. Usually in such cases, the dispatch organization accepts guarantees from several insurance companies.

Key words: general average, vessel, cargo, damages, insurance. 
УДК 341

DOI https://doi.org/10.32849/2663-5313/2019.8.07

\section{Наталія Квіт,}

канд. юрид. наук, доцент,

доцент кафедри чивільного права та прочесу

Львівського національного університету імені Івана Франка

\section{ПРАВОВИЙ СТАТУС УПРАВИТЕЛЯ БІОБАНКУ: ПОНЯТТЕВИЙ АПАРАТ І КЛАСИФІКАЦІЯ}

Відсутність теоретичних розробок щодо статусу управителів біобанків та аналізу правового регулювання сфери створення та використання біобанків в Україні пов'язана з тим, що відсутнє комплексне спеиіальне правове регулювання иих відносин, які безпосередньо пов'язані з охороною особистих немайнових прав фізичних осіб у сфері охорони здоров'я та розвитком медичної науки. Багато питань, що охоплює дана проблематика, досліджені не досить повно, що негативно впливає на правозастосовну практику.

У статті проаналізовано термінологію, яка використовується у різних нормативно-правових актах, що стосуються діяльності щодо створення та використання біобанків, та зроблено висновок про необхідність ї̈ уніфікації та приведення у відповідність до світових стандартів. Також на основі аналізу правової природи біобанку як об'єкта, а не суб'єкта правовідносин запропоновано дві авторські дефініції (в широкому та вузькому значенні) біобанку, які дають змогу розмежувати біобанк як об'єкт та управителя біобанку як суб'єкта правовідносин та окреслити його правовий статус.

Крім щього, запропоновано дві авторські класифікащї біобанків, які мають безпосередній вплив на визначення правового статусу їх управителів та сферу правового регулювання їхньої діяльності. Запропонованими для поділу критеріями визначено, по-перше, організачійно-правову форму та спосіб фінансування, по-друге, мету створення та використання біобанку. Також проаналізовано переваги товариства з обмеженою відповідальністю як організаційно-правової форми для приватних біобанків, виходячи із нової редакиії закону.

Також, виходячи із аналізу чинного законодавства, окреслено коло обов'язків, які запропоновано поділити на дві групи, а саме організаційні (лічензійні) обов'язки, які випливають із лічензійних умов, та персоналізовані обов'язки управителя біобанку, які є обов'язками управителя біобанку тосовно конкретного донора/поклажодавия біологічного матеріалу, а отже, мають дещо індивідуалізований характер та можуть відрізнятися в кожному окремому випадку.

Ключові слова: банки пуповинної крові, інших тканин і клітин людини, види біобанків, приватні біобанки, публічні біобанки, обов'язки.

Постановка проблеми. Діяльність у сфеpi створення та використання банків пуповинної крові, інших тканин і клітин людини сьогодні фактично набирає обертів і потребує уваги до законодавства, яке регулює цей вид господарської діяльності.

Аналіз останніх досліджень. На жаль, оскільки ця сфера почала активно розвиватися починаючи з 2009-2010 року, досліджень цієї проблематики в літературі дуже мало. Серед дослідників, які аналізували деякі питання банкування пуповинної кровi, варто назвати таких, як В. Задорожна, М. Колеснікова, С. Мартиненко, Х. Насадюк, О. Омельченко, В. Шаблій. Законодавча база, яка регулює ці відносини, на жаль, не має комплексного характеру та є дещо фрагментарною і в деяких випадках навіть суперечливою та характеризується наявністю прогалин та колізій.

\begin{abstract}
Мета статті. Саме тому аналіз поняттєвого апарату та правового статусу управителів біобанків $є$ надзвичайно актуальним та допоможе визначити слабкі місця чинного законодавства та запропонувати способи його вдосконалення, що і є метою статті.
\end{abstract}

Виклад основного матеріалу. Виходячи із аналізу поняття біобанку, зокрема визначення, яке міститься у чинних Ліцензійних умовах для банків пуповинної крові, інших тканин та клітин людини [1], український законодавець розуміє правову природу біобанку власне як суб'єкт правовідносин, тоді як законодавство інших країн світу, в тому числі європейських, розкриває поняття «біобанк» як об'єкт правовідносин, а саме як зібрання біологічних матеріалів людського походження та пов'язаної 3 ними інформації (персональних даних), а суб'єктом правовідносин виступає управитель 
біобанку, той, хто здійснює діяльність щодо перевірки, збору, зберігання, обробки та передачі третім особам (користувачам) об'єкта цих правовідносин, а саме біологічних зразків та/ або інформації. Тому ми вважаємо, що підхід українського законодавця до визначення правової природи біобанку є хибним і визначення, яке міститься у Ліцензійних умовах, повинно бути змінене з урахуванням цього положення.

Отже, ліцензуванню підлягає не діяльність біобанку, а діяльність управителя біобанку, тому запропоновано внести відповідні зміни до самої назви і загалом щодо концепції в цілому цього нормативно-правового акта, а саме «Ліцензійні умови провадження діяльності з управління банками пуповинної крові, інших тканин і клітин людини (біобанками), згідно з переліком затвердженим МО3», а також замінити в інших нормативно-правових актах формулювання «діяльність банків пуповинної крові, інших тканин і клітин людини» на «діяльність з управління банками пуповинної крові, інших тканин і клітин людини (біобанками)», зокрема у п. 16 ст. 7 (Перелік видів господарської діяльності, що підлягають ліцензуванню) Закону України «Про ліцензування видів господарської діяльності» від 02.03.2015 № 222-VIII [2], ст. 3 (Сфера дії закону) Закону України «Про застосування трансплантації анатомічних матеріалів людині» [3], також змінити назву «Перелік тканин і клітин людини, з якими дозволена діяльність банків пуповинної крові, інших тканин і клітин людини» на «Перелік тканин і клітин людини, які можуть входити до складу банків пуповинної крові, інших тканин і клітин людини (біобанків)».

Також важливо наголосити, що поняття біобанку слід трактувати в широкому розумінні, оскільки управителі біобанків можуть бути як підприємницькими (комерційні біобанки), так і неприбутковими організаціями (публічні біобанки), а останні переважно створюються у вигляді благодійних фондів або ж при наукових (дослідницьких) установах та/або окремими науковцями чи групами науковців у сфері охорони здоров'я, власне, з метою проведення досліджень, діагностичною та/або терапевтичною метою; їхня діяльність не лише підлягатиме ліцензуванню, але й біоетичній експертизі та посиленому контролю з боку держави через уповноважені органи.

Тому у запропонованому уніфікованому визначенні біобанку, яке має міститися у спеціальному законі, також підкреслюється роль управителя біобанку у відносинах, що складаються 3 приводу його створення та використання, та сформульована узагальнена вимога щодо отримання управителем дозволу, який може бути як у формі ліцензії (для господа- рюючих суб'єктів), так і додатково у вигляді отримання відповідних дозволів етичних комісій при наукових закладах. Зокрема, пропонується визначити біобанк як «зібрання людського біологічного матеріалу та пов'язаної з ним конфіденційної інформації про особу, від якої він походить (об'єкт), збирання, зберігання та управління якими у межах, встановлених законом, має право здійснювати управитель біобанку (суб'єкт), який отримав у встановленому законодавством порядку дозвіл на здійснення такої діяльності».

Варто також звернути увагу на те, що чинне законодавство містить також інші терміни, які використовуються для позначення поняття біобанку як суб'єкта, а не об'єкта. Зокрема, Порядок проведення клінічних випробувань тканинних і клітинних трансплантатів та експертизи матеріалів клінічних випробувань, затверджений Наказом МОЗ України від 10.10.2007 № 630 [4], містить визначення двох термінів: «банк клітинних та тканинних трансплантатів - заклад охорони здоров'я, у якому зберігаються клітинні та (або) тканинні трансплантати», а також «банк стовбурових клітин кордової (пуповинної) крові» - заклад охорони здоров'я, який здійснює діяльність, пов'язану з транспортуванням кордової (пуповинної) крові, виділенням з неї стовбурових клітин, їхньою кріоконсервацією та збереженням». Виходячи із аналізу змісту даного підзаконного нормативно-правового акта, ці поняття тут вживаються для позначення суб'єктів, які надаватимуть біологічний матеріал, а саме стовбурові клітини, а також клітинні та тканинні трансплантати для проведення клінічних досліджень. Сфера дії цього акта поширюється лише на біобанки, управителі яких $€$ постачальниками матеріалу для клінічного випробування, яке проводиться закладами охорони здоров'я чи їх структурними підрозділами, що відповідають вимогам, які ставляться цим актом до заявника клінічного дослідження, і це цілком виправдано, оскільки недопустимим є проведення випробувань на людях будь-якими іншими суб’єктами, крім закладів охорони здоров'я.

Отже, оскільки різниця між цими поняттями полягає лише у виді біологічного матеріалу, що постачається, видається, що практичної потреби робити такий поділ немає. Привертає увагу також і те, що обидва вищезазначені визначення чітко вказують на те, що управителі таких біобанків мають бути закладами охорони здоров'я - це частково корелює з визначенням банків пуповинної крові, інших тканин і клітин людини, даним у старій редакції Ліцензійних умов 2012 року, де вони трактувалися як «окремо створений суб'єкт господарювання заклад або структурний підрозділ закладу охо- 
рони здоров'я, який самостійно здійснює переробку (процесінг), маркування (кодування), кріоконсервацію, тестування (перевірку), зберігання пуповинної крові, інших тканин і клітин людини та виготовлених з них продуктів та/або препаратів». Натомість у чинній редакції Ліцензійних умов взагалі немає прив'язки до закладу охорони здоров'я.

Така плутанина з термінологією не сприяе розумінню змісту цих відносин та правового статусу управителя біобанку як суб'єкта, а отже, вимагає проведення уніфікації. Для усунення цієї проблеми досить буде застосувати в цьому акті термін «банк пуповинної крові, інших тканин і клітин людини (біобанк)» та дати визначення в редакції, аналогічній до тої, що запропонована для внесення до Ліцензійних умов із зазначенням, що управителі таких біобанків можуть у цих відносинах виступати у статусі постачальника біологічних матеріалів для проведення клінічних випробувань за умови наявності письмової згоди особи, від якої такий матеріал походить. Такий підхід до формулювання законодавчої термінології узгоджуватиметься зі світовими стандартами та вимогами до діяльності щодо створення та використання біобанків та буде ще одним кроком вперед на шляху до гармонізації українського законодавства з правом Свропейського співтовариства та загальносвітовими тенденціями розвитку законодавства у цій сфері.

Отже, обидва запропоновані авторські визначення біобанку, як у вузькому розумінні (коли управитель біобанку є суб'єктом господарювання), так і у широкому розумінні, яке охоплює як приватну (комерційну), так і публічну (неприбуткову) сферу роботи з біобанками, роблять наголос на тому, що суб'єктом такої діяльності є не сам біобанк, а його управитель. Крім того, запропоноване визначення для внесення до Ліцензійних умов містить також перелік видів діяльності, що можуть здійснюватися управителем біобанку. Таким чином, це визначення є засадничим для формування правильної концепції законодавчого розуміння природи та правового статусу управителя біобанку.

Важливим для розуміння правового статусу управителя біобанку є класифікація біобанків. Зокрема, ми пропонуємо два критерії, які, на нашу думку, мають не лише теоретичне, але й велике практичне значення, а саме, для визначення сфери правового регулювання діяльності управителя біобанку. банків:

За метою створення та використання біо-

- які створені при наукових установах (дослідницькі);

- які створені при лікувальних установах (терапевтичні).
Особливістю правового статусу таких біобанків є те, що у першому випадку, крім ліцензії на здійснення діяльності управителем біобанку, необхідним також є дотримання вимог щодо проведення відповідних досліджень (як правило, йдеться про біоетичну експертизу планованих досліджень), а також і те, що часто, коли створюється такий біобанк особа, від якої походить біологічний матеріал, втрачає 3 ним після його передачі до біобанку правовий зв'язок внаслідок анонімізації інформації про неї. У другому випадку особливість правового статусу такого біобанку буде проявлятися у тому, що це має бути заклад, який має право проводити терапевтичне застосування (трансплантацію) біологічного матеріалу, який входить до складу такого біобанку, а отже, на таку діяльність також поширюватимуться норми трансплантаційного законодавства.

За організаційно-правовою формою управителя та способом фінансування біобанки ми поділили на:

- приватні (комерційні) біобанки, які створюються 3 метою отримання прибутку та фінансуються управителем самостійно, цивільно-правові відносини з донором регулюються в договірному порядку, на основі принципу свободи договору, а в частині, не врегульованій договором та щодо охорони прав донора, - нормами національного та міжнародного законодавства;

- публічні біобанки, управителі яких не мають на меті отримання прибутку, а створюють їх з метою збору біологічного матеріалу для дослідження чи надання для подальших досліджень чи лікування, фінансуються державою, чи інвесторами, або ж благодійними фондами; метою діяльності є досягнення соціального ефекту; існують як самостійні структури чи як підрозділи наукових чи науководослідних, лікувальних установ; відносини 3 донором мають як приватно- так і публічноправовий характер; виникають внаслідок реалізації особою свого особистого немайнового права на донорство (ст. 290 ЦК України) та регулюються нормами Конституції, цивільного законодавства щодо особистих немайнових прав, спеціального законодавства у сфері охорони здоров'я та трансплантології, а також нормами кримінального законодавства та міжнародними нормативно-правовими актами; діяльність щодо створення та управління ними також підлягає ліцензуванню, але, якщо вони також використовують біобанк з дослідницькою чи лікувальною метою, потребують схвалення етичної комісії;

- змішані приватно-публічні біобанки, які $€$ за своєю суттю приватними, оскільки мають на меті отримання прибутку, діяльність щодо ïx створення та управління ними підлягає 
ліцензуванню, проте співпрацюють з публічними біобанками, надаючи їм інформацію (з дозволу донорів та за умови забезпечення конфіденційності інформації про них) про біологічні матеріали, що входять до їх складу, шляхом передачі фенотипічних даних до відповідних баз даних (реєстрів), і у разі виникнення потреби у наданні біологічного матеріалу, що входить до їх складу, для потреб сторонніх осіб (реципієнтів), не передбачених у договорі з донором-клієнтом, з його дозволу приватний біобанк може передати ці біологічні матеріали за плату чи безоплатно (на розсуд клієнта) для публічних потреб (переважно йдеться про трансплантацію у випадку, якщо інших можливостей для реципієнта не існує).

Отже, виходячи з наведених класифікацій, спробуємо охарактеризувати особливості правового статусу управителів таких біобанків на основі аналізу чинного українського законодавства та аналізу наявних сьогодні в Україні біобанків, управителі яких здійснюють діяльність щодо їх створення та використання.

Якщо зосередитись на особливостях організації комерційних біобанків, які натепер переважають на українському ринку біобанківських послуг, то можемо констатувати, що наявні сьогодні біобанки, зокрема організації, що здійснюють управління ними, $€$ Товариствами 3 обмеженою відповідальністю. Сюди, зокрема, можна віднести: ТзОВ «Інститут клітинної терапії», структурним підрозділом якого є Stemcellclinic (ліцензія від 2011 року), ТзОВ «Центр ембріональних тканин «ЕМСЕЛЛ» (ліцензія від 2011 року), ТзОВ «Медичний центр «Гемафонд» (ліцензія від 2011 року), ТОВ «Український банк стовбурових клітин», який сам не здійснює обробку, зберігання та іншу діяльність, що входить до компетенції управителя біобанку, а отримує та передає отриманий від українських клієнтів, що уклали із ним цивільно-правовий договір, біологічний матеріал (пуповина, плацента, пуповинна кров, плацентарна кров тощо) до AT «Польський банк стовбурових клітин» у Варшаві, який безпосередньо вже надає послуги щодо переробки, тестування, зберігання біологічного матеріалу, а також ми знайшли інформацію про комерційний британський Банк стовбурових клітин «Future Health Biobank», американські та швейцарські біобанки, управителі яких пропонують свої послуги українським споживачам, будучи іноземними суб'єктами господарювання; отже, тут виникають міжнародні приватноправові відносини та $є$ особливості щодо правового статусу таких суб'єктів, оскільки правове регулювання вимог, що до них ставляться, здійснюватиметься за особистим законом такого суб'єкта, а не українським законодавством.
3 огляду на набрання з 19.06.2018 чинності новим Законом України «Про товариства 3 обмеженою та додатковою відповідальністю» № 2275-VIII [5], який покликаний вдосконалити правове регулювання їхньої діяльності, варто визначити перспективи такої організаційно-правової форми, як ТзОВ для управління біобанками, особливо з огляду на її домінування на ринку України. Перевагами ТзОВ, на які також вказують і іноземні дослідники [6, с. $358 ; 7$, с. 126], порівняно з іншими організаційно-правовими формами здійснення управління біобанками та з огляду на новели вищезгаданого закону, є:

1) гнучкість та ефективність вирішення учасниками питань корпоративного управління. Закон, зокрема, передбачає можливість проведення зборів шляхом застосування засобів електронних комунікацій (наприклад, теле- чи відеоконференція), вводить чіткі механізми заочного голосування та опитування, а також встановлює особливості прийняття рішень Товариствами, що мають одного учасника;

2) можливість створення наглядової ради. Товариство тепер може створювати наглядову раду для контролю та регулювання діяльності виконавчого органу. Щодо цієї особливості німецькі науковці навіть допускають можливість створення наглядової ради за участю експертів з питань захисту прав та інтересів донорів, до компетенції яких входитиме не лише нагляд та контроль за діяльністю виконавчого органу біобанку, але також і можливість входити до складу загальних зборів учасників чи виконувати повноваження загальних зборів 3 метою обмеження управлінських повноважень товариства на користь інтересів донорів [6, c. 358]

3) встановлення правил погодження Товариством значних правочинів і правочинів із заінтересованістю. Ці правила захищатимуть майно Товариства та його права від можливих зловживань або некомпетентності керівництва та учасників Товариства.

Некомерційні суб'єкти, що здійснюють управління біобанками, $є$ більш рідкісним явищем на українському ринку. Сюди насамперед необхідно віднести відкритий 21 вересня 2017 року перший в Україні публічний банк стовбурових клітин, управління яким здійснює Благодійний Фонд «Банк Життя». Цей суб'єкт є яскравим прикладом негосподарюючої організації, яку визначають як організацію, створену не для здійснення чи організації господарської діяльності, а для виконання іншої діяльності, фінансованої ззовні, оскільки ї̈ результати не виступають як товар і не забезпечують самооплатності. Також до цього виду біобанків, управителями яких є неприбуткові установи, можна відне- 
сти клітинний банк ліній 3 тканин людини та тварин (отриманих із нормальних та пухлинних тканин), створений при Інститут експериментальної патології, онкології та радіології імені Р.Є. Кавецького НАН України, - це науково-дослідна установа, структурним підрозділом якої є даний біобанк, який створений та використовується виключно 3 дослідницькою метою (вивчення ракових захворювань та пошук методів їх лікування), проте інформації про його ліцензування ми, на жаль, не знайшли. Сюди також можна віднести «Банк пуповинної крові, інших тканин і клітин людини», створений як структурний підрозділ Київської міської клінічної лікарні № 4 (ліцензія від 2013 року) на виконання наказу Департаменту охорони здоров`я виконавчого органу Київської міської ради (Київської міської державної адміністрації) від 12 лютого 2014 року № 94, з урахуванням погоджувального листа Міністерства охорони здоровя України від 08 лютого 2014 року № 3.21-34/4/4053, з метою забезпечення надання висококваліфікованої медичної допомоги з використанням клітинних технологій в місті Києві. Суб'єктом ліцензування у даному випадку виступив зазначений заклад охорони здоров’я (негосподарююча організація), метою створення біобанку та діяльності управителя даного біобанку є лікування із застосуванням ембріональних стовбурових клітин, тобто це є яскравий приклад терапевтичного публічного біобанку.

Прикладів існування в Україні змішаних приватно-публічних біобанків ми не знайшли, на відміну від США, Великобританії та Німеччини. Проте, на нашу думку, створення єдиної інформаційної системи для всіх (приватних та публічних біобанків) у формі реєстру тканинних та клітинних трансплантатів могло б частково вирішити питання їх недостатньої кількості, розширивши можливості доступу до них також і для осіб, що не мають змоги користуватися послугами приватних біобанків, та вирішити етичне питання загальнодоступності таких послуг. Таким чином, клієнти приватних біобанків матимуть змогу самостійно приймати рішення щодо можливості передачі власного біологічного матеріалу для потреб реципієнтів (якщо така потреба виникатиме) за певну оплату чи на засадах донорства або ж відмовитись від такої передачі. Звісно, така схема є вигідною для публічних та невигідною для приватних біобанків, тому перспектива іï запровадження на теренах України сьогодні є дуже малоймовірною.

Обов'язки управителів біобанків можна поділити на дві групи чи категорії: а саме:

1) організаційні (ліцензійні) обов'язки
- обов'язок отримання ліцензії та інших дозвільних документів (інших ліцензій, висновку етичної комісії тощо) залежно від видів діяльності, що здійснюються управителем біобанку;

- обов'язок забезпечення якості та безпеки в ході здійснення діяльності управителем біобанку;

- обов'язок забезпечення високого рівня захисту персональних даних;

- обов'язок належного ведення документації біобанку;

- обов'язок забезпечення прозорості (оприлюднення важливої інформації про управителя біобанку та діяльність щодо управління біобанком);

- обов'язок встановлення умов щодо використання біобанку;

- обов'язок страхування діяльності управителя біобанку від банкрутства чи припинення діяльності з інших причин та визначення порядку забезпечення передачі біологічних матеріалів та пов'язаної з ними інформації до складу іншого ліцензованого біобанку (даний обов'язок не випливає з чинних норм, але, на нашу думку, є необхідним елементом правового статусу управителя біобанку, який має на меті забезпечити охорону прав осіб, які передають біологічний матеріал та персональні дані до складу біобанку).

2) персоналізовані обов'язки управителя щодо донора/поклажодавця, зокрема:

- інформаційні обов'язки, куди входить, 3 одного боку, обов'язок надання донору необхідної інформації щодо мети передачі та використання біобанком його біологічного матеріалу та іншої інформації, яка необхідна для забезпечення висловлення донором/ поклажодавцем добровільної поінформованої та зваженої письмової згоди на передачу свого біологічного матеріалу до складу біобанку, та, з іншого боку, обов'язок надання донору/ поклажодавцю інформації про результати роботи управителя біобанку з його біологічним матеріалом (виявлення певних захворювань чи патологій чи схильності до певних захворювань, особливо спадкових тощо), якщо донор не відмовився у письмовій формі в окремій заяві від повідомлення йому такої інформації та якщо зв'язок особи-донора з їі біологічним матеріалом збережений;

- обов'язок забезпечення безперешкодного доступу донора/поклажодавця до його біологічного матеріалу та виготовлених із нього біоімплантатів та забезпечення можливості відкликання його поінформованої згоди на передачу свого біологічного матеріалу до складу біобанку чи забезпечення можливості передачі біологічного матеріалу та виготовлених із нього біоімплантатів до складу іншого 
біобанку за бажанням донора/поклажодавця (такий обов'язок має місце лише у разі збереження особистісного правового зв'язку донора $з$ його біологічним матеріалом);

- обов'язок забезпечення належного зберігання біологічного матеріалу донора/поклажодавця та виготовлених із нього біоімплантатів.

\section{Висновки}

У результаті проведеного дослідження запропоновано:

1. Уніфікувати та привести у відповідність до світових стандартів розуміння поняття біобанку та розуміння правового статусу управителя біобанку як суб'єкта правовідносин зі створення та використання бібанків. Запропоновані авторські визначення біобанку у широкому та у вузькому розумінні та перелік актів, до яких необхідно внести відповідні зміни.

2. Провести класифікацію біобанків за двома критеріями, які впливають на правове регулювання статусу управителя біобанку, а саме за метою створення - на дослідницькі та терапевтичні, а також за організаційно-правовою формою та способом фінансування на приватні, публічні та змішані.

3. Як найбільш привабливу організаційно-правову форму для комерційних та змішаних біобанків визначити товариство 3 обмеженою відповідальністю.

4. Виділити дві категорії обов'язків управителів біобанків, а саме організаційні (ліцензійні) та персоналізовані.

\section{Список використаних джерел:}

1. Про затвердження Ліцензійних умов провадження господарської діяльності банків пуповинної крові, інших тканин i клітин людини згідно 3 переліком, затвердженим Міністерством охорони здоров'я : Постанова Кабінету Міністрів України від 02.03.2016 № 286. URL : https://zakon. rada.gov.ua/laws/show/286-2016-\%D0\%BF.

2. Про ліцензування видів господарської діяльності : Закон України від 02.03.2015 № 222-VIII. URL : https://zakon.rada. gov.ua/laws/show/222-19

3. Про застосування трансплантації анатомічних матеріалів людині : Закон України від 17.05.2018 № 2427-VIII. URL : https://zakon.rada. gov.ua/laws/show/2427-19

4. Про затвердження Порядку проведення клінічних випробувань тканинних і клітинних трансплантатів та експертизи матеріалів клінічних випробувань : наказ Міністерства охорони здоров'я України від 10.10.2007 № 630. URL https://zakon.rada.gov.ua/laws/show/z1206-07.

5. Про товариства 3 обмеженою та додатковою відповідальністю : Закон України від 06.02.2018 № 2275-VIII. URL : https://zakon.rada. gov.ua/laws/show/2275-19

6. Berdin J., Biobank-Governance, unter besonderer Berücksichtigung von Trust-Modellen: Dissertation, Universität Hamburg, 2016, Schriften zum Bio-, Gesundheits- und Medizinrecht; Band 29 , Nomos Verlag, 2017. $422 \mathrm{~s}$.

7. Revermann Ch., Sauter A. Biobanken für die humanmedizinische Forschung und Anwendung\& Endbericht zum TA-Projekt, 2016. 224 s.

The lack of theoretical issues in Ukraine on the legal status of biobank managers and analysis of the legal regulation of the sphere of biobanks creation and use in Ukraine is due to the lack of complex special legal regulation of these relations, which are directly related to the protection of personal immaterial rights of individuals in the field of health care and the development of medical science. The problems which are analyzed in this article have not been sufficiently investigated, which adversely affects law enforcement practice.

This article analyzes the terminology used in various legal acts relating to the activities of biobank creating and using and concludes that it is necessary to unify it and bring it into line with world standards. Also, based on an analysis of the legal nature of the biobank as an object rather than the legal entity (subject), two authorial definitions (broad and narrow) have been proposed to distinguish the biobank as an object and the biobank manager as a subject of these legal relations and outline its legal status.

In addition, two author biobank classifications have been proposed that have a direct impact on determining the legal status of their managers and the scope of legal regulation of their activities. Two criterias are proposed for this classification, firstly, the legal form and means of financing; and secondly, the purpose of creating and using a biobank. It also analyzes the benefits of a limited liability company as an organizational form for private biobanks based on the new version of the special law.

Also, based on the analysis of the current legislation, it is outlined the range of responsibilities that are proposed to be divided into two groups, namely organizational (licensing) responsibilities arising from the license terms and the personal responsibilities of the biobank manager, which are the responsibilities of the manager of the biobank relative to the specific donor / contributor of the biological material, and thus are somezhat individualized and may differ on a case-by-case basis.

Key words: cord blood and other human tissues and cells banks, types of biobanks, private biobanks, public biobanks, responsibilities. 
УДК 347.791.6

DOI https://doi.org/10.32849/2663-5313/2019.8.08

\title{
Ганна Сандюк,
}

канд. юрид.наук,

доцент кафедри морського та господарського права

Національного університету кораблебудування імені адмірала Макарова

\section{СИСТЕМАТИЗАЦІЯ ПРАВОВИХ НОРМ, ЯКІ РЕГУЛЮЮТЬ АРЕШТ МОРСЬКИХ СУДЕН}

\begin{abstract}
Авторка комплексно розглянула, виділила та систематизувала правові інститути, які регулюють арешт морського судна (на підставі законодавства Украӥни). Наведено визначення арешту судна за Кодексом торговельного мореплавства України та Міжнародною конвениією з уніфікації деяких правил щодо накладення арешту на морські судна 1952 року. Наведений перелік морських вимог за КТмУ. Підкреслено, що морські вимоги є низкою договірних та недоговірних иивільно-правових та господарсько-правових зобов'язань, зобов'язань з оплати праиі, зобов'язань з оплати зборів. Проаналізовано співвідношення поняття «арешт судна» (на морські вимоги) з поняттями «затримання судна» та «відмова у видачі дозволу на вихід судна з порту». Розглянуто, в якому контексті може застосовуватися словосполучення «арешт судна» та під які правові норми яких правових інститутів та галузей права ие підпадає. Підкреслено, що арешт судна є інститутом не лище процесуального права, але й матеріального - як спосіб забезпечення иивільно- або господарсько-правового зобов'язання. У роботі згадані зміни у Цивільному процесуальному та Господарському процесуальному кодексах України, які набули чинності в грудні 2017 року, відповідно до яких арешт морського судна, що здійснюється для забезпечення морської вимоги, вперие виділений як окремий захід забезпечення. Таким чином, ЦПК та ГПК України були наближені до КТМУ та Конвениії 1952 року. Проаналізовано адміністративне та адміністративне проиесуальне законодавство України на предмет можливості арешту судна за його нормами. З'ясовано, що арешт морського судна може бути здійснений в рамках виконавчого провадження, а також як арешт на активи, що пов'язані з фінансуванням тероризму. Зазначено, що арешт судна може здійснюватись і в порядку адміністративного арешту за податковим законодавством. Проаналізовано, в якому випадку арешт судна може здійснюватися у рамках кримінального процесу.

Зроблений висновок про те, що норми, якими врегульовано арешт морського судна, належать одночасно як до морського права, так і до иивільного, господарського права, иивільного прочесу, господарського процесу, адміністративного процесу, податкового (фінансового) права, кримінального процесу.
\end{abstract}

Ключові слова: арешт, морське судно, інститут права, Україна, захід забезпечення.

Постановка проблеми. Арешт морських суден продовжує залишатись затребуваною процедурою як у світі, так і в Україні. Арешт судна, за загальним визнанням, є ефективним засобом тиску на боржника для погашення боргу або надання іншого забезпечення виконання зобов'язання. Водночас досить часто згадується арешт суден у зв'язку з різноманітними порушеннями митних правил, правил перетину державного кордону, вчиненням інших адміністративних та кримінальних правопорушень.

Аналіз останніх досліджень і публікацій. Питання, пов'язані з арештом судна, розглядались такими авторами, як О. Балобанов, Н. Брєхов, О. Брильов, В. Воробйов, С. Голікова, О. Дробитько, І. Жорник, В. Срмолаєв, T. Короткий, А. Маковська, В. Руденко, Ю. Сергєєв, В. Серафімов, В. Сидорченко, та іншими. Здебільшого в літературі увага приділялась арешту судна на морські вимоги як окремо, так і поряд з іншими процедура- ми цивільного та господарського процесу. Небагато уваги приділялось місцю інституту арешту судна в системі права України. Під час засвоєння матеріалу з морського права у студентів виникає проблема у засвоєнні матеріалу щодо арешту морського судна. Це пов'язано з певною багатозначністю виразу «арешт судна», який застосовується і до цивільно-правових, і до цивільного-процесуальних, і до кримінально-процесуальних та інших правовідносин.

Мета роботи - комплексно розглянути, виділити та систематизувати правові інстипути, які регулюють арешт морського судна.

Виклад основного матеріалу. Під арештом судна можуть розумітися різні правовідносини. Серед таких найбільш часто предметом дослідження науковців стає арешт судна на морські вимоги. Нині з правовим регулюванням його в Україні склалася така ситуація. 
У 2011 році Україна приєдналась до Міжнародної конвенції з уніфікації деяких правил щодо накладення арешту на морські судна 1952 року (далі - Конвенція 1952 року), яка набула чинності для нашої держави 16 травня 2012 року.

Водночас у світі існує й інший міжнародно-правовий режими щодо арешту морських суден за морськими вимогами - за Конвенцією про арешт суден 1999 року. Україна не є її учасницею.

Арешту судна присвячена Глава 4 Розділу II Кодексу торговельного мореплавства України (далі - КТМУ). Термін «арешт судна» відповідно до статті 41 КТМУ означає будь-яке затримання судна або обмеження в його пересуванні, що здійснюються для забезпечення морських вимог, зазначених у статті 42 цього Кодексу, під час перебування судна в морському порту України. Арешт не включає заходів, що здійснюються для виконання рішень суду чи господарського суду, що набрали чинності. Арешт судна здійснюється за рішенням суду, господарського суду або голови Морської арбітражної комісії [3].

Водночас стаття 80 КТМУ передбачає інший інститут - затримання судна, яке може бути здійснене капітаном порту за морськими вимогами. Затримання може бути дійсне протягом трьох діб. Якщо протягом визначеного терміну не прийнято рішення суду, господарського суду або Морської арбітражної комісії про накладення на судно чи вантаж арешту, вони підлягають негайному звільненню [3].

Кожне судно зобов'язане до виходу з морського порту одержати на це дозвіл капітана порту. Капітан морського порту повинен відмовити у видачі судну дозволу на вихід із порту в разі: а) непридатності судна до плавання, порушення вимог щодо його завантаження, постачання, комплектування екіпажу і наявності інших недоліків, що становлять загрозу безпеці плавання або здоров'ю людей, які перебувають на судні, або загрозу заподіяння шкоди навколишньому природному середовищу; б) порушення вимог до суднових документів; в) несплати встановлених зборів, штрафів та інших платежів; г) рішення уповноважених законодавством державних органів (органів доходів і зборів, санітарнокарантинної служби, органів рибоохорони, центрального органу виконавчої влади, що реалізує державну політику зі здійснення державного нагляду (контролю) у сфері охорони навколишнього природного середовища, та прикордонної служби) [3].

Таким чином, аналізуючи зміст КТМУ, можна дійти висновку, що термін «арешт судна» застосовується в ньому лише у розумінні арешта судна на морську вимогу. Також цей термін слід відрізняти від термінів «затримання судна» та «відмова у видачі дозволу на вихід судна 3 порту».

Слід з'ясувати, що таке морські вимоги.

Відповідно до ст. 42 КТМУ морська вимога - це вимога, що виникає з права власності та інших майнових прав на судно, будівництва судна, управління, експлуатації або комерційного використання судна, застави судна чи здійснення заходів, пов'язаних з рятуванням судна, а саме вимога у зв'язку з: 1) заподіянням шкоди в результаті втрати або пошкодження майна у зв'язку з експлуатацією судна; 2) заподіянням шкоди в результаті позбавлення життя або ушкодження здоров'я на суші або на воді у прямому зв'язку з експлуатацією судна; 3) заподіянням шкоди навколишньому природному середовищу; 4) винагородою, що належить за здійснення рятувальних заходів або виконання вимог будь-яких договорів про рятування; 5) компенсацією та іншими сумами, що належать за усунення або спробу усунення загрози заподіяння шкоди, за вжиття запобіжних заходів чи здійснення аналогічних операцій; 6) підняттям, віддаленням або знищенням судна, що стало уламками, чи його вантажу та викликаними цим витратами; 7) будь-яким договором використання або фрахтування судна; 8) будь-яким договором перевезення вантажу або пасажирів на судні; 9) втратою чи пошкодженням вантажу, включаючи багаж, під час перевезення або у зв'язку з ним; 10) загальною аварією; 11) лоцманським проведенням та сплатою лоцманських зборів; 12) буксируванням; 13) постачанням продуктів харчування, матеріалів, палива, запасів, обладнання, включаючи контейнери, для експлуатації судна або утримання його; 14) будівництвом, ремонтом, перебудовою або переобладнанням судна; 15) зборами в порту, каналі та інших судноплавних водах, а також у доці; 16) заробітною платою та іншими коштами, що належать капітану, членам командного складу та іншим членам екіпажу у зв'язку з виконанням ними своїх службових обов'язків на борту судна, включаючи витрати на репатріацію і внески за соціальним страхуванням, що сплачуються від їхнього імені; 17) дисбурсменськими витратами, які здійснюються щодо судна капітаном, власником, фрахтувальником або агентом; 18) страховою премією, включаючи внески за взаємне страхування, що сплачуються стосовно судна його власником або фрахтувальником за бербоут-чартером; 19) будь-якою комісійною, брокерською або агентською винагородою, що сплачується стосовно судна його власником або фрахтувальником за 
бербоут-чартером; 20) будь-яким спором про право власності на судно або володіння ним; 21) будь-яким спором між двома або кількома власниками судна щодо використання судна і розподілу прибутку; 22) заставою судна; 23) будь-яким спором, що виникає 3 договору купівлі-продажу судна [3].

Стаття 1 Конвенції 1952 року, учасницею якої є і Україна, також встановлює перелік тих вимог, які належать до морських.

«Арешт» за Конвенцією 1952 року означає затримання судна за ухвалою суду для забезпечення морської вимоги, але не включає конфіскацію судна на виконання судового рішення [1].

I в КТМУ, і в Конвенції 1952 року до морських вимог віднесені певні договірні і недоговірні цивільно-правові та господарсько-правові зобов'язання; зобов'язання з оплати праці; зобов'язання у зв'язку зі сплатою зборів.

Вважається, що метою арешту за морськими вимогами, як правило, $€$ не реалізація судна для задоволення вимог, а психологічний тиск на судновласника з метою надання іншого забезпечення зобов'язання (морської вимоги). Часто таким забезпеченням стає гарантія.

Цивільний кодекс України називає такі основні способи забезпечення зобов'язань, як неустойка (штраф, пеня), порука, гарантія, завдаток, застава (в тому числі іпотека), притримання - цей перелік не є вичерпним, можуть бути й інші способи, що не суперечать закону. У Господарському кодексі України - аналогічний підхід.

До таких способів забезпечення виконання зобов'язання можна віднести арешт морських суден на морські вимоги. Таким чином, можна зробити висновок, що арешт судна на морські вимоги є інститутом матеріального цивільного та господарського права.

Інший контекст, в якому може застосовуватись вираз «арешт судна», - це цивільний та господарський процес.

3 15.12.2017 набули чинності зміни до ЦПУ та ГКУ України, які наблизили національне законодавство України щодо арешту морського судна на морські вимоги до її міжнародного зобов'язання.

За чинним законодавством як захід забезпечення позову арешт судна можливий відповідно до Глави 10 Господарського процесуального кодексу України. До внесення згаданих змін арешт судна як захід забезпечення позову потребував обов'язкового наступного подання позову лише за законодавством України. Зараз подання позову, що забезпечується, можливе і в іншій країні.

У Цивільному процесуальному кодексі України серед видів забезпечення позову виділили окремо: 1) накладення арешту на майно та (або) грошові кошти, що належать або підлягають передачі або сплаті відповідачеві і знаходяться у нього чи в інших осіб (п. 1 ч. 1 ст. 150 ЦПКУ); 2) арешт морського судна, що здійснюється для забезпечення морської вимоги (п. 9 ч. 1 ст. 150 ЦПКУ) [6]. Така норма, нарешті, відповідає нормам Кодексу торговельного мореплавства України та міжнародним конвенціям.

У переліку морських вимог є й іпотеки або морські застави судна, тому під час арешту морського судна необхідно враховувати також положення Міжнародної конвенції про морські застави та іпотеки 1993 року, яка набрала чинності 04.01.2003. Україна є їі учасницею.

Слід також проаналізувати інші законодавчі акти України з точки зору того, в яких випадках можливе використання виразу «арешт судна».

Судно може стати предметом арешту в рамках виконавчого провадження, як і інше майно, на яке може бути звернене стягнення. Це врегульоване Законом України «Про виконавче провадження». Виконавче провадження є завершальною стадією судового провадження і примусового виконання судових рішень та рішень інших органів. Тобто відмінність від арешту за КТМУ, ЦПКУ та ГПКУ в тому, що арешт судна в рамках виконавчого провадження здійснюється, коли спір вже вирішений по суті та є виконавчий документ. Різні автори відносять інститут виконавчого провадження до цивільного, господарського, а також адміністративного процесу. Більш доцільно розглядати арешт морського судна як інститут адміністративного процесу.

Кодекс України про адміністративні правопорушення не містить інституту арешту майна, хоча і передбачає серед видів стягнень оплатне вилучення предмета, який став знаряддям вчинення або безпосереднім об'єктом адміністративного правопорушення, та конфіскацію предмета, який став знаряддям вчинення або безпосереднім об’єктом адміністративного правопорушення; грошей, одержаних внаслідок вчинення адміністративного правопорушення (пункти 3 та 4 ч.1 ст. 24 КУПАП [2]. Таким предметом може виступати і морське судно, термін «арешт» щодо майна у КУпАП, однак, не застосовується.

Кодекс адміністративного судочинства України регулює особливості провадження у справах щодо накладення арешту на активи, що пов'язані з фінансуванням тероризму та стосуються фінансових операцій, зупинених відповідно до рішення, прийнятого 
на підставі резолюцій Ради Безпеки ООН (ст. 284 КАСУ [7]). До такого майна може належати і морське судно.

Частиною податкового (ширше - фінансового) права є інститут адміністративного арешту майна, яким може виступати і морське судно. Такий арешт передбачений статтею 95 Податкового кодексу України [8]. $\mathrm{y}$ цьому разі арешт виступає як винятковий спосіб забезпечення виконання платником податків його податкових обов'язків.

У рамках кримінально-процесуального провадження арешт судна може бути здійснений як захід забезпечення кримінального провадження. Так, пунктами 6 та 7 ч. 2 ст. 131 Кримінального процесуального кодексу України передбачені такі заходи забезпечення кримінального провадження, як тимчасове вилучення майна та арешт майна відповідно. Стаття 132 КПКУ встановлює загальні правила застосування заходів забезпечення кримінального провадження. Глава 16 КПКУ докладно врегульовує тимчасове вилучення майна, а Глава 17 КПКУ - арешт майна [12].

Арештом майна в кримінальному процесі $€$ тимчасове, до скасування у встановленому КПКУ порядку, позбавлення за ухвалою слідчого судді або суду права на відчуження, розпорядження та/або користування майном, щодо якого існує сукупність підстав чи розумних підозр вважати, що воно є доказом злочину, підлягає спеціальній конфіскації у підозрюваного, обвинуваченого, засудженого, третіх осіб, конфіскації у юридичної особи для забезпечення цивільного позову, стягнення з юридичної особи отриманої неправомірної вигоди, можливої конфіскації майна.

Завданням арешту майна в кримінальному процесі є запобігання можливості його приховування, пошкодження, псування, знищення, перетворення, відчуження. Арешт майна допускається 3 метою забезпечення: 1) збереження речових доказів; 2) спеціальної конфіскації; 3) конфіскації майна як виду покарання або заходу кримінальноправового характеру щодо юридичної особи; 4) відшкодування шкоди, завданої внаслідок кримінального правопорушення (цивільний позов), чи стягнення 3 юридичної особи отриманої неправомірної вигоди.

Арешт за кримінально-процесуальним законодавством може бути накладений і на майно, на яке раніше накладено арешт відповідно до інших актів законодавства.

Щодо морського судна ймовірним $є$ арешт у зв'язку з таким злочином, як контрабанда (ст. 201 Кримінального кодексу України) або контрабанда наркотичних засобів, психотропних речовин, їх аналогів чи прекурсорів або фальсифікованих лікарських засобів (ст. 305 ККУ), які передбачають конфіскацію судна як санкцію; а також із такими злочинами, як порушення порядку в'їзду на тимчасово окуповану територію України та виїзду з неї (ст. 332-1 ККУ), незаконне перетинання державного кордону України (ст. 332-2 ККУ) [4] тощо.

Арешт суден в ході реалізації кримінальної юрисдикції підпадає під регулювання Міжнародною конвенцією про уніфікацію правил про кримінальну юрисдикцію у справах про зіткнення суден та інші події, пов'язані із судноплавством 1952 року. Україна, однак, не є учасницею цієї конвенції, тому у внутрішніх водах та територіальному морі України арешт суден в рамках кримінального провадження здійснюється лише за Кримінальним процесуальним кодексом України.

\section{Висновки}

Таким чином, вираз «арешт морського судна» в Україні може застосовуватись щодо фактично різних правових інститутів, які входять до різних галузей права та регулюються різними джерелами права: 1) у цивільному праві: арешт судна за морськими вимогами як спосіб забезпечення зобов'язання, підпадає під ЦКУ та КТМУ; 2) у господарському праві: арешт судна за морськими вимогами як спосіб забезпечення зобов'язання, регулюється нормами ГКУ, ЦКУ, КТМУ; 3) у цивільному процеci: арешт як забезпечення позову, що може здійснюватися в рамках: а) накладення арешту на майно та (або) грошові кошти, що належать або підлягають передачі або сплаті відповідачеві і знаходяться у нього чи в інших осіб (п. 1 ч. 1 ст. 150 ЦПКУ); б) арешту морського судна, що здійснюється для забезпечення морської вимоги (п. 9 ч. 1 ст. 150 ЦПКУ; КТМУ); 4) у господарському процесі - як захід забезпечення позову: а) накладенням арешту на майно та (або) грошові кошти, що належать або підлягають передачі або сплаті відповідачу і знаходяться у нього чи в інших осіб (п. 1 ч. 1 ст. 137 Господарського процесуального кодексу України); б) арештом морського судна, що здійснюється для забезпечення морської вимоги (п. 9 ч. 1 ст. 137 ГПКУ; КТМУ); 5) в адміністративному процесі: а) арешт майна в рамках виконавчого провадження, регулюється Законом України «Про виконавче провадження»; б) арешт на активи, що пов'язані з фінансуванням тероризму та стосуються фінансових операцій, зупинених відповідно до рішення, 
прийнятого на підставі резолюцій Ради Безпеки ООН (ст. 284 КАСУ); 6) в податковому (фінансовому) праві, у його процесуальній частині: адміністративний арешт відповідно до Податкового кодексу України; 7) у кримінальному процесі: як захід забезпечення кримінального провадження відповідно до Кримінального процесуального кодексу України. У свою чергу, норми всіх вище зазначених інститутів різних фундаментальних галузей, які стосуються морського судна, включаються в таку комплексну галузь, як морське право.

\section{Список використаних джерел:}

1. Міжнародна конвенція з уніфікації деяких правил щодо накладення арешту на морські судна 1952 року. URL: https://zakon.rada.gov.ua/laws/ show/995_g89 (дата звернення: 05.08.2019).

2. Кодекс про адміністративні правопорушення від 07.12.1984. URL: https://zakon.rada.gov. ua/laws/show/80731-10\#n132 (дата звернення: 05.08.2019).
3. Кодекс торговельного мореплавства України від 23.05.1995 № 47-52. URL: http://zakon.rada. gov.ua/laws/show/176/95- $\% \mathrm{D} 0 \% \mathrm{~B} 2 \% \mathrm{D} 1 \% 80$

4. Кримінальний кодекс України 05.04.2001. URL: https://zakon.rada.gov.ua/go/4651-17 (дата звернення: 05.08.2019).

5. Господарський кодекс України від 16.01.2003 № 436-IV. URL: http://zakon.rada.gov. ua/laws/show/436-15 (дата звернення: 05.08.2019).

6. Цивільний процесуальний кодекс України від 18.03.2004. URL: https://zakon.rada.gov.ua/ laws/show/1618-15 (дата звернення: 05.08.2019).

7. Кодекс адміністративного судочинства України від 06.07.2005. URL: https://zakon.rada.gov.ua/ laws/show/2747-15 (дата звернення: 05.08.2019).

8. Податковий кодекс України від 02.12.2010. URL: https://zakon.rada.gov.ua/go/2755-17 (дата звернення: 05.08.2019).

9. Кримінальний процесуальний кодекс України від 13.04.2012. URL: https://zakon.rada.gov.ua/ laws/show/4651-17 (дата звернення: 05.08.2019).

10. Про виконавче провадження : Закон України від 02.06.2016 № 1404-VIII. URL: https://zakon.rada.gov. ua/laws/show/1404-19 (дата звернення: 05.08.2019).

The author has comprehensively considered, isolated and systematized the legal institutes that regulate the sea going ship arrest (based on the legislation of Ukraine). The definition of the sea-going ship's arrest is given according the Merchant Shipping Code of Ukraine and the International Convention for the Unification of Certain Rules Relating to the Arrest of Sea-Going Ships, 1952. Tle list of Maritime Claims is cited according the Merchant Shipping Code of Ukraine here It is emphasized Maritime Claims are a number of contractual and non-contractual civil and economic legal obligations, obligations on wages, obligations to pay fees. The relationship between the concept of "the sra-going arrest" (to secure a maritime claime) and the concepts of "detention of a ship" and "refusal to issue permission to leave the ship from the port" are analyzed. It is analyzed, in what context the phrases "arrest of a ship" or "sea-going ship's arrest" can be used, and what legal norms, institutes and branches of law regulate them. It was emphasized that the ship's arrest is not only an institute of procedural law, but also a material one - as a way of providing a civil or economic legal obligation. The changes in the Civil Procedural and Commercial Procedural Codes of Ukraine, which came into force in December 2017, are mentioned. According to this, the sea-going ship's arrest is carried out to secure some Maritime Claim. It was first isolated as a separate measure of protection. Thus, the Commercial and Procedural Code of Ukraine and the Civil Procedural Code of were brought closer to the Merchant Shipping Code of Ukraine and the Convention, 1952. The administrative and administrative procedural legislation of Ukraine is analyzed on the possibility of the sea-going ship's arrest according to its norms. It was clarified that the sea-going ship's arrest may be carried out in the framework of enforcement proceedings, as well as the seizure of assets related to the financing of terrorism. It is noted that the sea-going ship's arrest may also be carried out as the administrative arrest according tax law. It has been analyzed in which case the the sea-going ship's arrest may be carried out within the framework of a criminal proceeding.

It is concluded that the norms regulated the the sea-going ship's arrest have been included both the maritime law and civil, commercial law, civil process, commertial process, administrative process, tax (financial) law, criminal process.

Key words: arrest, sea-going ship, institute of law, Ukraine, security measure. 
УДК 346.542

DOI https://doi.org/10.32849/2663-5313/2019.8.09

Ірина Феофанова,

провідний юрисконсульт юридичного відділу,

аспірант кафедри господарського права і процесу

Начіонального університету «Одеська юридична академія»

\section{ТРАНСФОРМАЦІЯ ІНСТИТУТУ ДЕРЖАВНОЇ ДОПОМОГИ СУБ'ЄКТАМ ГОСПОДАРЮВАННЯ В КОНТЕКСТІ ІМПЛЕМЕНТАЦІЇ УГОДИ ПРО АСОЦАЦІЮ МІЖ УКРАЇНОЮ ТА ЄВРОПЕЙСЬКИМ СОЮЗОМ}

Інститут державної допомоги суб'єктам господарювання для Європейського Союзу (далі - ЄС) $\epsilon$ однимізмеханізмівефективного функиіонуваннявнутрішнвогоринку,залученняінвестиційтаконтролю за ефективністю витрачання державних ресурсів. Відповідно до міжнародних договорів Україна має побудувати інститут державної допомоги суб'єктам господарювання за зразком ЄС та імплементувати всі положення Угоди про асоціачію між Україною та ЄС (далі - Угода про асоиіацію) в начіональне законодавство. Угода про асоиіачію містить конкретні вимоги до України щодо трансформаиії інституту державної допомоги суб'єктам господарювання. Статтю присвячено дослідженню сучасного стану інституту державної допомоги суб'єктам господарювання в контексті імплементаиії положень Угоди про асоиіацію. Проаналізовано міжнародні зобов'язання щодо контролю за державною допомогою в Україні та їхню роль у захисті інтересів національних суб'єктів господарювання. Опращьовано програмні стратегічні документи розвитку України в контексті перевтілень інституту державної допомоги. Визначено поточний стан правового інституту державної допомоги суб'єктам господарювання та відповідність положень основного Закону України «Про державну допомогу суб'єктам господарювання» положенням Угоди про асоиіаиію. Висвітлено найбільи перспективні інструменти державної допомоги суб'єктам господарювання, прийнятні для нашої держави. На основі досліджень встановлено, що натепер неможливо говорити про завершеність формування в Україні інституту державної допомоги як з точки зору прийняття в повному обсязі начіонального законодавства та виконання інших вимог Угоди про асоціачію, необхідних для забезпечення ефективної роботи системи моніторингу $і$ контролю державної допомоги, так і щодо виконання иього законодавства всіма учасниками процесу. Зроблено висновок про те, що імплементація у вітчизняне законодавство правил ЄС щодо державноі допомоги сприятиме зменшенню обсягів витрат з бюджету держави, підвищенню прозорості державних фінансів, уможливить реструктуризацію збиткових державних компаній та створить рівні конкурентні умови суб'єктам господарювання.

Ключові слова: державна допомога, угода про асоціацію між Україною та $Є С$, державна підтримка, суб'єкт господарювання, конкуренція.

Постановка проблеми. Багаторічна практика застосування інструментів державної допомоги у країнах Свропейського Союзу в умовах ринкових принципів економічної організації сформувала ефективні механізми регулювання такої допомоги, спрямованої на мінімізацію її негативного впливу на конкуренцію. Досвід реформування інституту державної допомоги має багато країн Європи, що вступили до ЄС. Необхідність таких трансформацій викликана ідеєю, що задля спільного ринку європейських країн необхідні й спільні правила допомоги суб'єктам господарювання, які б не порушували умов конкуренції. 3 момен- ту підписання Угоди про асоціацію Україна також вступила на непростий шлях перетворень. Проте реформування інституту державної допомоги означає не лише зближення з Свропейським Союзом, а й можливість зменшення витрат з бюджету, здійснення раціоналізації державних ресурсів, реструктуризації державних підприємств та модернізації національної економіки. 3 огляду на вищенаведене, Україна впевненими кроками здійснює динамічну трансформацію сучасної системи державної допомоги суб'єктам господарювання, яка має відповідати міжнародним (насамперед європейським) стандартам та забезпечувати макси- 
мально ефективне використання виділених на цю підтримку державних коштів.

Аналіз останніх досліджень і публікацій. Розгляду питань становлення та реформування інституту державної допомоги в Україні присвятили праці чимало вітчизняних вчених. Зокрема, Д. О. Черніков розглядає тенденції у розвитку державної допомоги в Україні з урахуванням підходів $\mathrm{CC}$, на основі чого розробляє рекомендації щодо впровадження відповідної європейської практики [1]. Н. М. Бугаєнко проаналізовано систему надання державної допомоги в ЄС і виокремлено пріоритети у підтримці підприємств [2]. Наукові розробки окремих питань даної тематики можна побачити у працях таких науковців, як К. І. Апанасенко, О. О Булана, С. В. Касьянов, Т. В. Некрасова та ін. У західноєвропейській науці питанням аналізу державної допомоги присвячені роботи таких авторів, як А. Біонді, П. Еекхаут, К. Квіглей, К. Бейкон, Е. Шищчак, Х. Хьольцлер, Л. Ханчер тощо. Автори досліджують сутність поняття, етапи формування європейської системи регулювання державної допомоги, визначають передумови модифікації зарубіжного досвіду для вітчизняної економіки. Однак питання економічного змісту та значення державної допомоги, її впливу на економічний розвиток України, а також iii правового регулювання як на державному, так і на міжнародному рівні залишаються актуальними.

Метою статті є дослідження впливу імплементації законодавства ЄС стосовно державної допомоги суб'єктам господарювання, передбаченого Угодою про асоціацію, на практику державної підтримки вітчизняних підприємств.

Виклад основного матеріалу. Державна допомога суб'єктам господарювання є одним з інструментів стимулювання господарської діяльності для досягнення економічних, соціальних та політичних цілей, зокрема для підвищення конкурентоспроможності таких суб'єктів на зовнішньому і внутрішньому ринку. Проте надання державної допомоги може негативно позначатися на функціонуванні ринкового механізму попиту і пропонування та системи конкурентних переваг, яка є основою міжнародної торгівлі, спотворювати конкуренцію, призводити до торговельних конфліктів, неефективного витрачання ресурсів. Зобов'язання нашої країни щодо реформування системи державної допомоги закріплені в Угоді про асоціацію (розділ 4 «Торгівля і питання, пов'язані з торгівлею», глава 10 «Конкуренція», частина 2 «Державна допомога»). У статтях 262-267 викладе- но основні засади реформування державної допомоги, заходи щодо забезпечення їі прозорості та створення національної системи контролю державної допомоги [3].

Угода про асоціацію передбачає реформування механізму державної підтримки відповідно до правил Європейського Союзу. Суть цих правил полягає у захисті економічної конкуренції від надмірного, неефективного державного втручання в ринкову економіку. Такий підхід є досить новим для України. Разом із тим його успішне впровадження сприятиме розвитку конкуренції, реалізації дієвої промислової політики, ефективному та прозорому використанню бюджетних коштів та інших державних і місцевих ресурсів.

Згідно з Угодою про асоціацію Україна має здійснити за визначений термін такі кроки перетворень: прийняти національне законодавство у сфері державної допомоги, яке повинно узгоджуватись із правилами $\mathrm{EC}$, а вже існуючу допомогу привести у відповідність до критеріїв, визначених в ст. 262 і 264 Угоди про асоціацію; створити незалежний у своїй діяльності орган, який матиме повноваження дозволяти схеми державної допомоги та індивідуальні випадки надання допомоги відповідно до критеріїв, визначених Угодою; створити повний реєстр державної допомоги, привести всі схеми (програми та індивідуальні заходи) державної допомоги у відповідність до критеріїв, визначених У Годою [3].

Щодо прийняття національного законодавства слід зазначити, що у серпні 2017 року набув чинності Закон України «Про державну допомогу суб'єктам господарювання» (далі - Закон), який є рамковим і визначає лише загальні правила та принципи функціонування системи державної допомоги. Деталізація цих правил встановлюється на рівні актів Кабінету Міністрів України (далі - КМУ) та Антимонопольного комітету України (далі - АМКУ). Проте все ж таки в Законі надано визначення ключових для сфери державної допомоги понять, таких як державна допомога суб'єктам господарювання, надавачі та отримувачі державної допомоги, ресурси держави та місцеві ресурси тощо [4].

Одним із механізмів реалізації Закону є критерії, що затверджуються урядом та відповідно до яких встановлюються механізми оцінки допустимості державної допомоги для конкуренції, їі форми, максимальний розмір та категорії отримувачів. Вже розроблено критерії таких категорій державної допомоги: для забезпечення розвитку регіонів; підтримка середнього та малого 
підприємництва; на професійну підготовку працівників; на працевлаштування окремих категорій працівників та створення нових робочих місць; на відновлення платоспроможності та реструктуризацію суб'єктів господарювання; на проведення наукових досліджень, технічний розвиток та інноваційну діяльність. Усі вони були сформульовані з урахуванням практики та законодавства $\mathrm{CC}$. Із так званих галузевих критеріїв АМКУ розроблено, оприлюднено та проведено громадські обговорення лише щодо критеріїв у вугільній галузі та у банківській галузі.

Сьогодні ще не прийнятими залишаються критерії оцінки допустимості державної допомоги на захист навколишнього природного середовища, проект яких було оприлюднено АМКУ ще у 2017 році для громадського обговорення та який за його результатами,подавався до КМУ на затвердження.

Відповідно до статті 42 Конституції України держава має забезпечувати захист конкуренції у підприємницькій діяльності, що включає в себе контроль за наданням державної підтримки, яка потенційно впливає на конкуренцію в цілому [5]. Разом із тим стаття 16 Господарського Кодексу України, яка визначає можливість надання дотацій та інших засобів державної підтримки суб'єктів господарювання, натомість містить відсильну норму до спеціального закону, який би врегульовував відносини державної допомоги та статті 26 цього ж Кодексу, де містяться правила щодо виключних можливостей обмеження конкуренції, які також мають бути врегульовані окремим законом, як це чітко визначено у пункті 3 зазначеної статті [6]. Таким чином, цю прогалину в законодавстві України заповнює саме Закон України «Про державну допомогу суб'єктам господарювання».

Згідно зі ст. 267 Угоди про асоціацію, Україна зобов'язалась створити національну систему контролю державної допомоги, що передбачає не лише прийняття національного законодавства про державну допомогу, але й створення незалежного у своїй діяльності органу, який мав би повноваження, необхідні для застосування у повному обсязі ст. 262 Угоди (яка визначає принципи сумісності надання допомоги державою 3 використанням державних ресурсів) [3]. Законом було визначено АМКУ уповноваженим органом, якому доручається здійснювати контроль за допустимістю надання державної допомоги суб'єктам господарювання. Також у Законі визначені повноваження АМКУ, перелік нормативно-правових актів, які мають бути розроблені та прийняті АМКУ та
Кабінетом Міністрів України (далі - КМУ), основні процесуальні норми (порядок подання та розгляду повідомлень про нову державну допомогу, порядок розгляду справ, перевірку незаконної державної допомоги та неналежного використання державної допомоги, повернення незаконної державної допомоги, недопустимої для конкуренції, перегляд чинної державної допомоги, реєстр державної допомоги та звітність, та ін.) [4].

Крім того, для забезпечення контролю у сфері державної допомоги АМКУ створив реєстр державної допомоги. Ведення реєстру здійснюється за результатами моніторингу державної допомоги. Реєстр функціонує на Порталі державної допомоги, та, на жаль, інформація вноситься до нього 3 деяким запізненням [7]. Функціонування реєстру державної допомоги має допомогти населенню краще розуміти, куди саме, з якою метою та в яких обсягах надається державна допомога, тобто куди, з якою метою та в яких обсягах витрачаються сплачені ним податки тощо. Щодо суб'єктів господарювання, то реєстр надає їм можливість отримати інформацію про доступні та попередньо оцінені АМКУ програми державної допомоги, з яких вони можуть отримати допомогу для розвитку бізнесу.

Потрібно також зазначити, що АМКУ має на меті прийняти методику формування карти регіонального розподілу державної допомоги. Роль цього документа важко переоцінити під час здійснення регіонального розподілу державної допомоги. Вказану методику, відповідно до Плану пріоритетних дій Уряду на 2019 рік, затвердженого розпорядженням КМУ від 18 грудня 2018 р. № 1106-р, заплановано затвердити до жовтня 2019 [8]. Для ЄС карти регіонального розподілу державної допомоги є важливим інструментом географічного розмежування території СС на основі соціально-економічних показників, які визначають рівень добробуту тих чи інших регіонів. Це дає змогу встановити різні максимально дозволені обсяги державної допомоги окремо для забезпечених і для відсталих регіонів на підставі винятків, передбачених статтею 107 Договору про функціонування Свропейського Союзу [9]. У цій системі основним показником, який вказує на низький рівень добробуту невеликої країни або регіону більшої країни, є ВВП на душу населення на рівні нижче 75 \% від середньоєвропейського. Варто зазначити, що така карта в Україні має бути створена, відповідно до Угоди про асоціацію, до кінця 2020 року.

У частині звітування про державну допомогу Закон зазначає, що надавачі державної допомоги щороку, до 1 квітня наступного 
року, зобов'язані надавати інформацію про всю чинну державну допомогу (програми та індивідуальну державну допомогу, незначну державну допомогу, державну допомогу, звільнену від обов'язку повідомлення про державну допомогу згідно зі статтею 7 Закону), що надавалася ними протягом минулого фінансового року. А відповідно, АМКУ щороку, до 1 вересня наступного року, складає річний звіт про надання державної допомоги в Україні за попередній фінансовий рік та подає його КМУ [4]. Такий звіт публікується в газеті «Урядовий кур'єр» та розміщується на урядовому веб-сайті. Згідно зі статтею 263 Угоди про асоціацію, Сторони Угоди щорічно мають надсилати іншій Стороні повідомлення про загальний обсяг, види та галузевий розподіл державної допомоги, яка може вплинути на торгівлю між Сторонами. Відповідна інформація розміщується в мережі Інтернет на веб-сайті з вільним доступом до 31 грудня наступного календарного року. Таким чином, конкуренти вітчизняних отримувачів державної допомоги, так само як і з держав-членів СС, можуть зрозуміти, яку державну допомогу надає Україна. Перший звіт з боку України було підготовлено АМКУ в кінці серпня 2018 року з інформацією щодо надання державної допомоги та роботи АМКУ у 2017 році. Звіт доступний для ознайомлення українською та англійською мовами [10].

Нині в Україні триває активний процес модернізації інституту державної підтримки, що передбачає не тільки внесення змін та доповнень до законодавства України у цій сфері, але й вироблення нових механізмів визначення критеріїв відбору суб'єктів господарювання, яким має надаватися така підтримка.

\section{Висновки}

Імплементація положень Угоди про асоціацію щодо державної допомоги не тільки має на меті зближення з ЄС, а й сприяє підвищенню ефективності витрачання державних коштів, які виділяються на державну допомогу, забезпеченню прозорості процесу іiї надання та звітуванню щодо її використання перед громадськістю.

Слід наголосити на тому, що процес імплементації положень Угоди про асоціацію йде впевненими кроками. Проте ще неможливо говорити про завершеність формування в Україні інституту державної допомоги як з точки зору прийняття в повному обсязі національного законодавства, необхідного для забезпечення ефективної роботи системи моніторингу і контролю державної допомоги, так і щодо виконання цього законодав- ства всіма учасниками процесу. У 2014 році, завдяки прийняттю Закону, закладено фундамент для національного законодавства про державну допомогу, який має сприяти виконанню положень статті 42 Конституції України та статей 16 і 26 Господарського кодексу України. 32017 р. розпочалася робота системи моніторингу і контролю за державною допомогою, відправною точкою чого стало набуття Законом чинності в повному обсязі. Закон є базовим документом, тому потребує розробки та прийняття підзаконних нормативно-правових актів. На цей час вже зроблено певні кроки у цьому напрямі.

Законом визначено уповноважений орган з питань державної допомоги (АМКУ), його повноваження, права та обов'язки всіх заінтересованих осіб (надавачів та отримувачів державної допомоги, інших суб'єктів господарювання тощо). Вже ухвалені та набрали чинності процесуальні нормативно-правові акти у сфері моніторингу та контролю державної допомоги, за винятком методики формування карти регіонального розподілу державної допомоги, підготовки та оприлюднення офіційної звітності України у сфері державної допомоги. Частково прийнято «матеріальні» норми законодавства у сфері державної допомоги, а саме критерії оцінки допустимості державної допомоги, але, на жаль, процес їх розробки та прийняття ще не закінчено.

Функціонує Портал державної допомоги, на якому розміщується реєстр державної допомоги, що дає змогу заінтересованим особам отримувати інформацію про державну допомогу. Додатково варто зазначити, що доцільним було б також введення в Кодекс про адміністративні правопорушення відповідальності за порушення норм Закону та розмежування на законодавчому рівні випадків, коли порушення Закону України «Про захист економічної конкуренції» можуть бути допустимою або недопустимою державною допомогою.

\section{Список використаних джерел:}

1. Черніков Д.О. Модернізація системи державної підтримки суб'єктів господарювання в Україні. Київ : НІСД, 2013. 48 с.

2. Бугаєнко Н.М. Сучасні тенденції розвитку системи державної допомоги в ЄС. Статистика України. 2010. № 1 (48). С. 92-98.

3. Угода про асоціацію між Україною, з однієї сторони, та Європейським Союзом, Європейським співтовариством з атомної енергії і їхніми державами-членами, з іншої сторони: Законодавство України від 27.06.2014p. № 984_011. URL: https://zakon.rada.gov.ua/laws/show/984_011. (дата звернення: 31.07.2019). 
4. Про державну допомогу суб'єктам господарювання : Закон України від 01.07.2014 № 1555-VII. URL: https://zakon.rada. gov.ua/laws/show/1555-18. (дата звернення: 01.08.2019).

5. Конституція України від 28.06.1996 № 254K/96-BP. URL: https://zakon. rada.gov.ua/laws/show/254к/96-вр. (дата звернення: 26.07.2019).

6. Господарський кодекс України: Законодавство України від 16.01.2003 № 436-IV. URL: https://zakon.rada.gov.ua/laws/show/436-15. (дата звернення 26.07.2019).

7. Портал державної допомоги : веб-сайт. URL: http://pdd.amc.gov.ua/ (дата звернення 20.07.2019).
8. План пріоритетних дій Уряду на 2019 рік : розпорядження Кабінету Міністрів України від 18.12.2018 № 1106-p. URL: https:// www.kmu.gov.ua/ua/npas/pro-ritetnih-dij-uryaduna-2019-rik (дата звернення: 25.07.2019).

9. Консолідовані версії Договору про Європейський Союз та Договору про функціонування Європейського Союзу з протоколами та деклараціями від 25.03.1957 № 994 b06 // Законодавство України. URL: https://zakon.rada. gov.ua/laws/show/994 b06. (дата звернення: 20.07.2019)

10. Річні звіти АМКУ 2017 / Офіційний вебсайт АМКУ. URL: http://www.amc.gov.ua/amku/ control/main/uk/publish/article/140488. (дата звернення 20.07.2019).

The Institute for State Aid to Businesses for the European Union (hereinafter referred to as the EU) is one of the mechanisms for the efficient functioning of the internal market, attracting investment and controlling the efficiency of spending of public resources. According to international treaties, Ukraine is required to build an institute of state aid to EU business entities and to implement all the provisions of the Association Agreement between Ukraine and the EU (hereinafter - the Association Agreement) into national law. The Association Agreement contains specific requirements for Ukraine to transform the State Aid Institute into economic entities. The article is devoted to the study of the current state of the State Aid Institute for economic entities in the context of the implementation of the provisions of the Association Agreement. The international obligations on control over state aid in Ukraine and their role in protecting the interests of national economic entities are analyzed. Programmatic strategic documents for the development of Ukraine in the context of reincarnation of the State Aid Institute have been elaborated. The current status of the State Aid Legal Institution has been determined and compliance with the provisions of the basic Law of Ukraine "On State Aid to Business Entities" with the provisions of the Association Agreement. The most promising state aid instruments for economic entities acceptable to our country are highlighted. Based on the research it is established that at present it is impossible to state the completion of the establishment of a state aid institute in Ukraine, both from the point of view of the full adoption of national legislation and the fulfillment of other requirements of the Association Agreement necessary to ensure the effective functioning of the system of monitoring and control of state aid, and the implementation of this legislation by all parties involved. It is concluded that the implementation of the EU state aid rules in the national legislation will help reduce the amount of expenditure from the state budget, increase the transparency of public finances, enable restructuring of unprofitable state-owned companies and create a level playing field for business entities.

Key words: state aid, EU-Ukraine association agreement, state support, economic entity, competition. 
УДК 349.2:331.2(477)

DOI https://doi.org/10.32849/2663-5313/2019.8.10

\section{Леся Малюга,}

канд. юрид. наук, старший науковий співробітник,

доцент кафедри трудового права та права сочіального забезпечення

юридичного факультету

Київського начіонального університету імені Тараса Шевченка

\section{КОНТРОЛЬ ЗА ВІДПОВІДНІСТЮ ПРОЕКТІВ НОРМАТИВНО-ПРАВОВИХ АКТІВ СОЦІАЛЬНОГО ЗАКОНОДАВСТВА УКРАЇНИ ПРАВУ СВРОПЕЙСЬКОГО СОЮЗУ}

Євроінтеграчійні процеси, які відбуваються в Україні, спричинили потребу в удосконаленні начіонального законодавства Украйни з урахуванням права Європейського Союзу. Метою адаптаціі законодавства Украйни до законодавства Європейського Союзу визначено розвиток начіонального законодавства у напрямі його зближення із законодавством СС та забезпечення високого рівня підготовки в Україні проектів актів законодавства. Це означає, що съогодні кожен нормативно-правовий акт, який приймається органом законодавчої влади нашої держави, має відповідати приниипам та стандартам європейського права. Дане питання особливо актуалізується у контексті соціального законодавства України.

Країни європейської спільноти декларують належний сочіальний захист громадян як одну із першооснов функиіонування держави. Україна є соиіальною державою згідно з положеннями Основного Закону, проте на практиці ї соиіальне законодавство потребує подальшого удосконалення у тому числі й иляхом наближення до законодавства європейських держав. Тому всі нормативно-правові акти соиіального законодавства України, що нині приймаються вітчизняним законодавием, мають відповідати праву Європейського Союзу. Враховуючи кількість законодавчих актів, які щороку ухвалюються Верховною Радою України, ия прочедура потребує контролю за тим, яким є зміст законопроектів та чи не суперечить він стандартам і приниипам європейського права. Для ивого чинним законодавством в Україні низиі інституцій було надано повноваження щодо здійснення контролю за відповідністю нормативно-правових актів соціального законодавства України праву Європейського Союзу. До повноважень таких суб'єктів належить перевірка відповідності начіонального законодавства стандартам та приниипам європейського права, а також сприяння у їх подальшому наближенні.

У вітчизняній научі натепер є не так багато досліджень контролю за відповідністю проектів нормативно-правових актів законодавства України праву Європейського Союзу і фактично відсутні такі дослідження у контексті сочіального законодавства. Саме тому питання контролю за відповідністю проектів нормативно-правових актів сочіального законодавства України праву Європейського Союзу є актуальним у сучасних умовах та потребує належного наукового аналізу.

Ключові слова: контроль, соціальне законодавство, законодавство ЄС, соціальне законодавство ЄС, соціальний захист, адаптація соціального законодавства України.

Постановка проблеми. Законом України «Про Загальнодержавну програму адаптації законодавства України до законодавства Європейського Союзу» від 18.03.2004 № 1629-IV [5] метою адаптації законодавства України до законодавства Європейського Союзу встановлено розвиток національного законодавства у напрямі його зближення із законодавством ЄC та забезпечення високого рівня підготовки в Україні проектів актів законодавства. Соціальна сфера законодавства у даному нормативноправовому акті не визначена як пріоритетна, втім зрозуміло, що, виходячи з основних принципів Свропейського Союзу, без адаптації соціального законодавства України до законодавства СС не можлива інтеграція України у європейський соціально-економічний простір.

Так, у 2018 році Верховна Рада України ухвалила 158 законодавчих актів [9]. У 2016 році парламент успішно проголосував 212 проектів законів, а у 2017 році - 174 [1]. $\mathrm{y}$ таких умовах важливо, щоб кожен із законодавчих актів відповідав задекларованому напряму зближення із законодавством Європейського Союзу. Проте, враховуючи загальну чисельність нормативно-правових 
актів, які щорічно приймаються законодавчим органом нашої держави, проблематично забезпечити перевірку кожного з них на відповідність європейським стандартам. Тому необхідною умовою прийняття соціального законодавства в сучасних умовах є забезпечення контролю за відповідністю проектів нормативно-правових актів праву Свропейського Союзу.

Стан дослідження. Питання адаптації законодавства України до законодавства $\mathrm{CC}$, у тому числі й соціального, а також контролю за відповідністю проектів нормативно-правових актів соціального законодавства України праву Європейського Союзу досліджувались такими науковцями, як: Н. Б. Болотіна, І. З. Брацук, С. В. Грищак, В. В. Зелінська, С. В. Істомін, М. Г. Кравченко, П. М. Лисенко, В. Ф. Москаленко, Н. М. Мужикова, О. А. МузикаСтефанчук, Н. М. Пархоменко, О. В. Прилипчук, О. С. Проневич, В. Ф. Пузирний, П. М. Рабинович, О. В. Тищенко, I. С. Сахарук, Л. А. Семиног, Г. О. Слабкий, О. Ф. Чорномаз, Л. А. Шевченко, М. М. Шумило тощо. Попри інтенсивність досліджень проблематики адаптації законодавства України до права Європейського Союзу, залишаються недослідженими та потребують наукового аналізу питання контролю за відповідністю проектів нормативно-правових актів праву Європейського Союзу через призму діяльності усіх органів, які його здійснюють.

Саме тому метою статті нами виділено:

1) аналіз чинного соціального законодавства України та наукової літератури на предмет того, яким чином здійснюється контроль за відповідністю проектів нормативно-правових актів соціального законодавства України праву Європейського Союзу;

2) визначення переліку органів, які здійснюють контроль за відповідністю проектів нормативно-правових актів соціального законодавства України праву Європейського Союзу;

3) встановлення того, яку діяльність здійснюють ці органи під час здійснення контролю за відповідністю проектів нормативноправових актів соціального законодавства України праву Свропейського Союзу;

4) аналіз проблем забезпечення контролю за відповідністю проектів нормативноправових актів соціального законодавства України праву Європейського Союзу.

Виклад основного матеріалу. У науковій літературі контроль визначається як система спостереження та перевірки відповідності функціонування об'єкта прийнятим управлінським рішенням: законам, планам, нор- мам, стандартам, правилам, наказам, виявлення допущених відхилень і визначення шляхів їх усунення [3, с. 8]. Тобто під контролем за відповідністю проектів нормативноправових актів соціального законодавства України праву Свропейського Союзу варто розуміти таку перевірку і у разі виявлення допущених відхилень від принципів та стандартів європейського права визначення шляхів усунення таких недоліків.

Як зазначається у навчальному посібнику «Адаптація соціальної політики та трудового законодавства України до стандартів $Є C$ », механізм перевірки проектів нормативноправових актів на відповідність праву Свропейського Союзу складається з 2-х стадій:

1) оцінка відповідності розробником проекту;

2) перевірка відповідності органом, що координує адаптацію [4, с. 28].

Автори цієї концепції не розділяють механізм перевірки проектів нормативноправових актів на відповідність праву Свропейського Союзу за галузевим принципом, а тому можна зробити висновок про те, що перевірка проектів нормативно-правових актів соціального законодавства на відповідність праву Європейського Союзу також складається із цих стадій.

На першому етапі контроль за відповідністю проектів нормативно-правових актів соціального законодавства України праву Свропейського Союзу здійснює сам автор законопроекту. Згідно зі статтею 93 Конституції України [2], право законодавчої ініціативи у Верховній Раді України належить народним депутатам України, Кабінету Міністрів України, Президентові України. Отже, спочатку перевірку проектів нормативноправових актів соціального законодавства на відповідність праву Європейського Союзу здійснюють самі Президент України, народні депутати України та розробники проектів у межах Кабінету Міністрів України як суб'єкти законодавчої ініціативи та автори відповідних проектів соціальних законів.

Проте, вже на другому етапі у процедуру вступають спеціальні суб'єкти, які й здійснюють контроль за відповідністю проектів нормативно-правових актів соціального законодавства України праву Європейського Союзу. Саме під час перевірки відповідності органом, що координує адаптацію нормативно-правових актів України праву Свропейського Союзу, і відбувається реалізація функції контролю.

Так, першим із суб’єктів законодавчої ініціативи є народні депутати України. Законодавча експертиза усіх поданих на розгляд Верховної Ради законопроектів здійсню- 
ється Комітетом Верховної Ради України з питань європейської інтеграції. Для даного органу у сучасних умовах важливо, щоб ті законодавчі акти, які ним розробляються, відповідали праву Європейського Союзу, тому в його структурі і було утворено таку структурну одиницю. Виходячи 3 аналізу норм Закону України «Про Регламент Верховної Ради України» від 10.02.2010 № 1861-VI [8], Комітет Верховної Ради України 3 питань європейської інтеграції має право: 1) здійснювати експертизу на відповідність законопроектів міжнародно-правовим зобов'язанням України у сфері європейської інтеграції та надавати відповідний експертний висновок (відповідно до статті 93 Закону України «Про Регламент Верховної Ради України» від 10.02.2010 № 1861VI [8]); 2) направляти законопроекти до Кабінету Міністрів України для здійснення експертизи на предмет їх відповідності нормам, принципам, цілям та завданням Угоди (відповідно до статті 103 Закону України «Про Регламент Верховної Ради України» від 10.02.2010 № 1861-VI [8]). Проте, незважаючи на обов'язковість проходження такої експертизи, урахування висновків Комітету Верховної Ради України з питань європейської інтеграції не є обов'язковим для подальшого розгляду законопроекту, тож депутати можуть ними знехтувати. Наприклад, згідно з інформацією, оприлюдненою на веб-сайті Комітету з питань європейської інтеграції, лише 170 проектів законів Верховної Ради VIII скликання пройшли експертизу в Комітеті [12]. При цьому, як нами було встановлено раніше, лише у 2018 році Верховна Рада України прийняла 158 законодавчих актів [9]. Тобто загальна кількість проектів законів, які пройшли експертизу в Комітеті Комітету Верховної Ради України 3 питань європейської інтеграції за 5 років діяльності Верховної Ради VIII скликання, в середньому не перевищує кількості прийнятих законів в межах одного року її законодавчої діяльності.

В. В. Зелінська та Л. А. Шевченко звертають увагу на те, що популярною також є практика використання Верховною Радою скороченої процедури розгляду законопроектів, яка дозволена статтею 101 Закону України «Про Регламент Верховної Ради України» від 10.02.2010 № 1861-VI [8]. У такому разі законотворці користуються правом Президента чи Верховної Ради визначити законопроект як невідкладний та, по суті, унеможливлюють проведення його всесторонньої та якісної експертизи Комітетом Верховної Ради України $з$ питань європейської інтеграції. Дослідниці звертають увагу на те, що більшість законів, прийнятих Верховною Радою VIII скликання та схвалених Президентом, розглядалися 3 використанням скороченої процедури. Автори дослідження «Як забезпечити належну євроінтеграційну експертизу у вітчизняному законодавчому процесі?» користуються статистикою до 2015 року, і на той момент частка законопроектів, прийнятих за скороченою процедурою, становила 68 \%, проте зрозуміло, що суттєвих змін у подальші роки не відбулось [11, с. 17]. Отже, незважаючи на те, що, по суті, роль Комітету Верховної Ради України з питань європейської інтеграції полягає у перевірці на відповідність праву Свропейського Союзу, чинним законодавством це не визначено як обов'язкова умова прийняття законодавчого акта. Тому є висока ймовірність того, що не всі проекти законів соціального законодавства, прийняті протягом останніх 5 років, відповідають принципам та стандартам європейського права.

Крім того, варто враховувати те, що Комітет Верховної Ради України з питань європейської інтеграції перевіряє на відповідність праву Європейського Союзу усі проекти законів, зареєстровані в органі законодавчої влади нашої держави. Тобто, враховуючи, що право законодавчої ініціативи у Верховній Раді України належить народним депутатам України, Кабінету Міністрів України, Президентові України, Комітет Верховної Ради України з питань європейської інтеграції $є$ суб'єктом контролю за відповідністю проектів нормативно-правових актів соціального законодавства України праву Свропейського Союзу стосовно кожного суб'єкта законодавчої ініціативи.

Отже, зробимо такі висновки щодо специфіки ролі Комітету Верховної Ради України з питань європейської інтеграції як суб'скта контролю за відповідністю проектів нормативно-правових актів соціального законодавства України праву Європейського Союзу:

1) функція контролю Комітету Верховної Ради України з питань європейської інтеграції реалізується шляхом законодавчої експертизи поданих на розгляд Верховної Ради проектів законів соціального законодавства;

2) Комітет Верховної Ради України 3 питань європейської інтеграції здійснює законодавчу експертизу усіх проектів законів соціального законодавства, у тому числі й тих, ініціаторами, яких є Кабінет Міністрів України та Президент України;

3) висновки Комітету Верховної Ради України з питань європейської інтеграції не $€$ обов'язковими для подальшого розгляду законопроекту, тож депутати можуть ними 
знехтувати, i, як наслідок, проект закону соціального законодавства може бути прийнятий без урахування його невідповідності принципам та стандартам європейського права;

4) досить популярною серед народних депутатів України є скорочена процедура розгляду законопроектів, яка дозволяє оминути експертизу поданих на розгляд Верховної Ради проектів законів соціального законодавства на відповідність принципам та стандартам європейського права.

Усе вищезазначене свідчить про те, що Комітет Верховної Ради України з питань європейської інтеграції є суб'єктом контролю за відповідністю проектів нормативноправових актів соціального законодавства України праву Свропейського Союзу стосовно всіх суб'єктів законотворчої діяльності, у тому числі й Кабінету Міністрів України та Президента України. Але при цьому все ще існують законодавчі передумови, які ускладнюють реалізацію ним функції контролю щодо усіх проектів законодавства України, у тому числі й у соціальній сфері.

У Регламенті Кабінету Міністрів України [7] передбачено, що Проекти постанов підлягають опрацюванню 3 урахуванням acquis communautaire. Так, згідно зі статтею 35, проект постанови Кабінету Міністрів, а також проект розпорядження Кабінету Міністрів про схвалення концепції реалізації державної політики у відповідній сфері (у тому числі й соціальній), концепції державної цільової програми та концепції закону підлягає опрацюванню на відповідність зобов'язанням України у сфері європейської інтеграції, у тому числі міжнародно-правовим, та з урахуванням права Свропейського Союзу (acquis communautaire). Тобто, як зазначалося раніше, на першому етапі сам розробник проекту нормативно-правових актів соціального законодавства України має встановити джерела права Європейського Союзу, що регулюють правовідносини, аналогічні тим, що планується врегулювати проектом акта; наявність зобов'язань України у сфері європейської інтеграції, у тому числі міжнародно-правових, щодо предмета правового регулювання проекту акта; наявність програмних документів у сфері європейської інтеграції з предмета, що регулюється проектом акта. Результати опрацювання проекту акта Кабінету Міністрів на відповідність зобов’язанням України у сфері європейської інтеграції та праву Свропейського Союзу (acquis communautaire) відображаються розробником у довідці [7]. Тобто на першому етапі механізму перевірки проектів нормативно-правових актів соціального законодав- ства на відповідність праву Європейського Союзу, які ініціюються Кабінетом Міністрів України, контроль за відповідністю проектів нормативно-правових актів соціального законодавства України праву Свропейського Союзу здійснюється його автором.

Раніше серед прав Комітету Верховної Ради України з питань європейської інтеграції нами було відзначено його право направляти законопроекти до Кабінету Міністрів України для здійснення експертизи на предмет їх відповідності нормам, принципам, цілям та завданням Угоди про асоціацію між Україною, з однієї сторони, та Європейським Союзом, Свропейським співтовариством 3 атомної енергії і їхніми державами-членами, 3 іншої сторони [10]. Так, для контролю за відповідністю проектів нормативно-правових актів соціального законодавства України праву Європейського Союзу, суб'єктами законодавчої ініціативи яких є Кабінет Міністрів України, також створено спеціальну структурну одиницю. Урядовий офіс 3 питань європейської інтеграції (а згодом перейменовано в Урядовий офіс координації європейської та євроатлантичної інтеграції Секретаріату Кабінету Міністрів України) було створено Кабінетом Міністрів України у 2014 році передусім із метою вдосконалення роботи з імплементації Угоди про асоціацію між Україною, з однієї сторони, та Свропейським Союзом, Свропейським співтовариством 3 атомної енергії і їхніми державами-членами, з іншої сторони [10]. Як наслідок, саме офіс сьогодні забезпечує відповідність законодавства України праву Свропейського Союзу, але виключно урядових законопроектів, які подаються до парламенту. У частині 3 статті 35 Регламенту Кабінету Міністрів України [7] визначено, що організаційне, експертно-аналітичне та інформаційне забезпечення опрацювання проекту акта Кабінету Міністрів на відповідність зобов'язанням України у сфері європейської інтеграції, у тому числі міжнародно-правовим, та праву Європейського Союзу (acquis communautaire) здійснюється Урядовим офісом координації європейської та євроатлантичної інтеграції Секретаріату Кабінету Міністрів України. Тобто роль Урядового офісу координації європейської та євроатлантичної інтеграції Секретаріату Кабінету Міністрів України у забезпеченні відповідності проектів нормативно-правових актів соціального законодавства України праву Свропейського Союзу полягає в тому, що він є органом, який здійснює контроль за відповідністю тих проектів нормативно-правових актів соціального законодавства України праву Свропейського Союзу, які розро- 
бляються Кабінетом Міністрів України та подаються до Верховної Ради України. При цьому Урядовий офіс з питань європейської інтеграції перевіряє ті проекти нормативноправових актів соціального законодавства які вже були опрацьовані самим розробником.

Отже, роль Урядового офісу координації європейської та євроатлантичної інтеграціі Секретаріату Кабінету Міністрів України як суб'єкта контролю за відповідністю проектів нормативно-правових актів соціального законодавства України праву Свропейського Союзу є такою:

1) Урядовий офіс координації європейської та євроатлантичної інтеграції Секретаріату Кабінету Міністрів України забезпечує відповідність проекту нормативно-правового акта соціального законодавства України праву Європейського Союзу, але виключно урядових законопроектів, які подаються до парламенту після забезпечення відповідності проекту нормативноправового акта соціального законодавства України його розробником;

2) функція контролю реалізовується шляхом організаційного, експертно-аналітичного та інформаційного забезпечення опрацювання проекту акта соціального законодавства на відповідність зобов'язанням України у сфері європейської інтеграції, у тому числі міжнародно-правовим, та праву Європейського Союзу;

3) здійснюється експертиза законопроектів, направлених Комітетом Верховної Ради України з питань європейської інтеграції, на предмет їх відповідності нормам, принципам, цілям та завданням Угоди про асоціацію між Україною, з однієї сторони, та Європейським Союзом, Свропейським співтовариством 3 атомної енергії і їхніми державами-членами, з іншої сторони.

Таким чином, Урядовий офіс координації європейської та євроатлантичної інтеграції Секретаріату Кабінету Міністрів України здійснює контроль за відповідністю проектів нормативно-правових актів соціального законодавства України праву Свропейського Союзу, які розробляються самим Кабінетом Міністрів України, але при цьому здійснює співпрацю 3 Комітетом Верховної Ради України з питань європейської інтеграції, чим має вплив на усі проекти нормативноправових актів соціального законодавства України, зареєстровані в органі законодавчої влади нашої держави.

Автори навчального посібника «Адаптація соціальної політики та трудового законодавства України до стандартів ЄС» підкреслюють роль ще одного органу у здій- сненні контролю за відповідністю проектів нормативно-правових актів законодавства України (у тому числі й соціального), які розробляються Кабінетом Міністрів України, праву Свропейського Союзу - Міністерства юстиції України. Так, автори звертають увагу на те, що функція Міністерства юстиції України полягає в експертизі проекту нормативно-правового акта соціального законодавства та підготовці експертного висновку щодо відповідності проекту постанови acquis communautaire за встановленою формою [4, с. 28]. Але при цьому варто враховувати, що з моменту написання цієї роботи повноваження Міністерства юстиції України неодноразово змінювались. У чинному Положенні про Міністерство юстиції України [6] серед великої кількості функцій даного органу, визначених у пункті 4, звернемо увагу, передусім, на експертизу проектів нормативно-правових актів та нормативно-правових актів, що підлягають державній реєстрації, на відповідність положенням Конвенції про захист прав людини і основоположних свобод та практиці Свропейського Суду з прав людини (пункт 15) та на науково-експертне, аналітичне, інформаційне та методологічне забезпечення виконання першого етапу реалізації Загальнодержавної програми адаптації законодавства України до законодавства Європейського Союзу (пункт 13). Щодо експертизи звернемо увагу на те, що вона здійснюється виключно на відповідність положень проектів нормативно-правових актів соціального законодавства та нормативноправових актів соціального законодавства Конвенції про захист прав людини і основоположних свобод та практиці Європейського Суду з прав людини. Тобто йдеться не про загальну експертизу, яку здійснює цей орган, а виключно про контроль за відповідністю соціального законодавства принципам та стандартам, які визначені зазначеною Конвенцією та судовими рішеннями ССПЛ (які по суті являють собою джерело права).

Інша виділена нами функція пов'язана зі сприянням у різноманітні способи (здійснення науково-експертного, аналітичного, інформаційного та методологічного забезпечення) виконанню першого етапу реалізації Загальнодержавної програми адаптації законодавства України. Розділом V Закону України «Про Загальнодержавну програму адаптації законодавства України до законодавства Свропейського Союзу» від 18.03.2004 № 1629-IV [5] соціальна сфера не визначена як пріоритетна на першому етапі. Проте наявність у Міністерства юстиції України такої функції свідчить про те, що у майбутньому цей орган може стати важливим 
суб'єктом контролю за відповідністю проектів нормативно-правових актів соціального законодавства України праву Європейського Союзу, проте натепер не є таким.

Таким чином, функція контролю за відповідністю проектів нормативно-правових актів соціального законодавства України праву Свропейського Союзу Міністерства юстиції України полягає у такому:

1) Міністерство юстиції України здійснює експертизу проекту нормативно-правового акта соціального законодавства на відповідність положенням Конвенції про захист прав людини і основоположних свобод та практиці Європейського Суду з прав людини;

2) Міністерство юстиції України здійснюе науково-експертне, аналітичне, інформаційне та методологічне забезпечення адаптації національного законодавства до законодавства Європейського Союзу, проте натепер ці функції не поширюються на соціальну сферу

Тобто, по суті, функція контролю Міністерства юстиції України у досліджуваній сфері $\epsilon$ досить обмеженою. Експертиза проектів нормативно-правових актів здійснюється стосовно не усіх актів європейського законодавства, а лише Конвенції про захист прав людини і основоположних свобод. Так само проекти нормативно-правових актів соціального законодавства не можуть суперечити практиці Європейського Суду з прав людини. У свою чергу, перевірка проектів щодо інших європейських стандартів перебуває поза компетенцією Міністерства юстиції України. Так само повноваження щодо координації здійснення першого етапу адаптації законодавства України до законодавства Європейського Союзу поки не поширюється на соціальну сферу, проте у майбутньому такі повноваження цього органу можуть стати складником здійснюваного ним контролю за відповідністю проектів нормативно-правових актів соціального законодавства України праву Європейського Союзу.

\section{Висновки}

У процесі наукового аналізу нами встановлено, що контроль за відповідністю проектів нормативно-правових актів соціального законодавства України праву Свропейського Союзу полягає у здійсненні такої перевірки компетентними суб'єктами та визначенні шляхів усунення таких недоліків. Такий контроль здійснюється у два етапи: на першому етапі має місце самоконтроль, тобто сам розробник проекту нормативноправового акта соціального законодавства має забезпечити його відповідність acquis communautaire. На другому етапі перевірку здійснюють компетентні суб'єкти. Нами встановлено, що органами, які здійснюють контроль за відповідністю проектів нормативно-правових актів соціального законодавства України праву Європейського Союзу, є:

1) Комітет Верховної Ради України 3 питань європейської інтеграції - здійснюе законодавчу експертизу усіх поданих на розгляд Верховної Ради проектів нормативноправових актів соціального законодавства у тому числі й Кабінетом Міністрів України та Президентом України на відповідність міжнародно-правовим зобов'язанням України у сфері європейської інтеграції;

2) Урядовий офіс координації європейської та євроатлантичної інтеграції Секретаріату Кабінету Міністрів України - на даний орган покладено завдання 3 організаційного, експертно-аналітичного та інформаційне забезпечення опрацювання проекту акта соціального законодавства, розробником якого є Кабінет Міністрів України, на відповідність зобов'язанням України, визначеним у положеннях Угоди про асоціацію між Україною, з однієї сторони, та Європейським Союзом, Свропейським співтовариством 3 атомної енергії і їхніми державами-членами, з іншої сторони, щодо відповідності праву Європейського Союзу;

3) Міністерство юстиції України - здійснює правову експертизу проекту нормативно-правового акта соціального законодавства на відповідність Конвенції про захист прав людини і основоположних свобод та практиці Свропейського Суду з прав людини, й, окрім того, є підстави для висновку, що у майбутньому Міністерство юстиції України може здійснювати науково-експертне, аналітичне, інформаційне та методологічне забезпечення адаптації національного соціального законодавства до законодавства Європейського Союзу.

При цьому варто звернути увагу на те, що, по-перше, Комітет Верховної Ради України з питань європейської інтеграції є суб'єктом, який здійснює перевірку усіх проектів нормативно-правових актів соціального законодавства, а по-друге, ця процедура характеризується низкою прогалин. Як наслідок, натепер існують законодавчі можливості прийняття нормативно-правового акта соціального законодавства без перевірки його відповідності праву Європейського Союзу. По суті, контроль за відповідністю проектів нормативно-правових актів соціального законодавства України праву Свропейського Союзу має більшою мірою рекомендаційний характер. На практиці чинне соціальне законодавство, навіть прийняте протягом останніх років, може не відповідати стандартам та принципам європейського права. Тому, враховуючи це, подальші дослідження 
питання контролю за відповідністю проектів нормативно-правових актів соціального законодавства України праву Свропейського Союзу є необхідними.

\section{Список використаних джерел:}

1. 3,5 роки Верховної Ради. Що зробили депутати за 3,5 роки в парламенті? Веб-ресурс «Громадянська мережа Опора». URL: https: / / w w w.longread.oporaua.org/try z-polovynoju-roky-vr (дата звернення: 06.08.2019).

2. Конституція України : Закон України від 28.06.1996 № 254к/96-ВР. Відомості Верховної Ради України. 1996. № 30. Ст. 141.

3. Остапенко О. І. Стандартизація, якість продукції, метрологія, сертифікація в системі адміністративного права : навчальний посібник. Львів: [б. в.], 2011. 123 с.

4. Мужикова Н.М., Пузирний В.Ф., Семиног Л.А. Адаптація соціальної політики та трудового законодавства України до стандартів СС : навчальний посібник. Чернігів: Деснянська правда, 2007. 169 с.

5. Про Загальнодержавну програму адаптації законодавства України до законодавства Європейського Союзу : Закон України від 18.03.2004 № 1629-IV. Відомості Верховної Ради Украйни. 2004. № 29. Ст. 367.
6. Про затвердження Положення про Міністерство юстиції України : Постанова Кабінету Міністрів України від 02.07.2014 № 228. Офіиійний вісник Украӥни. 2014. № 54. С. 88. Ст. 1455.

7. Про затвердження Регламенту Кабінету Міністрів України : Постанова Кабінету Міністрів України від 18.07.2007 № 950. Офіиійний вісник Украйни. 2007. № 54. С. 21. Ст. 2180.

8. Про Регламент Верховної Ради України : Закон України від 10.02.2010 № 1861-VI. Відомості Верховної Ради України. 2010. № 14-15. № 16-17. Ст. 133.

9. Скільки законів ухвалила Верховна Рада у 2018 році: Парубій назвав кількість. Веб-ресурс «24 канал». URL: https://24tv.ua/skilki zakoniv uhvalila_verhovna_rada_u_2018_rotsi_parubiy_

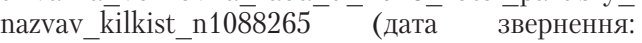
06.08.2019)

10. Угода про асоціацію між Україною, з однієї сторони, та Європейським Союзом, Європейським співтовариством з атомної енергії і їхніми державами-членами, з іншої сторони : Міжнародний документ від 27.06.2014. Офіиійний вісник Украӥни. 2014. № 75. Том 1. С. 83. Ст. 2125.

11. Шевченко Л., Зелінська О. Як забезпечити належну євроінтеграційну експертизу у вітчизняному законодавчому процесі? (Policy Paper). Київ : Європейський інформаційно-дослідницький центр, 2015. 21 с.

The European integration processes that are taking place in Ukraine have caused the need to improve the national legislation of Ukraine, taking into account the law of the European Union. The purpose of adaptation of the Ukrainian legislation to the legislation of the European Union is the development of the national legislation in the direction of its approximation with the EU legislation and ensuring a high level of preparation in Ukraine of draft legislative acts. This means that every regulatory act adopted by the legislature of our country today must comply with the principles and standards of European law. This issue is especially relevant in the context of social legislation of our country.

The countries of the European Community declare the proper social protection of citizens as one of the basic principles of the functioning of the state. Ukraine is a social state under the provisions of the Basic Law, but in practice its social legislation needs further improvement, including through approximation with the legislation of European states. Therefore, all regulations of social legislation of Ukraine, adopted today by the domestic legislator, must comply with the law of the European Union. Considering the number of legislative acts adopted annually by the Verkhovna Rada of Ukraine, this procedure requires control over what the content of the draft laws is and does not contradict the standards and principles of European law. For this purpose, the current legislation in Ukraine has given a number of institutions the power to exercise control over the compliance of the normative-legal acts of social legislation of Ukraine with the law of the European Union. The powers of such entities include the verification of compliance of national legislation with the standards and principles of European law, as well as assistance in their approximation. Today, there are not many studies in domestic science to control the conformity of draft lawes of Ukraine with European Union law, and in fact there are no such studies in the context of social legislation. That is why the issue of control over the conformity of draft lawes of social legislation of Ukraine with the law of the European Union is relevant in the current conditions and requires proper scientific analysis.

Key words: control, social legislation, EU legislation, EU social legislation, social protection, adaptation of social legislation of Ukraine. 
УДК 349.412.4

DOI https://doi.org/10.32849/2663-5313/2019.8.11

\section{Олександр Панасюк,}

аспірант кафедри господарського права та господарського прочесуального права

Донеиького національного університету імені Василя Стуса

\section{ВИЗНАННЯ ПРАВА ЯК СПОСІБ ЗАХИСТУ У ЗЕМЕЛЬНИХ ОРЕНДНИХ ВІДНОСИНАХ}

Захист права посідає одне з центральних місиь у механізмі правового регулювання. В Україні інститут захисту не зазнав суттєвих змін порівняно з тим, який існував за радянських часів. Утім зміни у зовнішніх, у тому числі правових та економічних, умовах функиіонування суспільних відносин, зокрема, у сфері оренди землі, які відбулись протягом останніх десятирічь, вимагають ревізіі чинного механізму захисту. Насамперед ие стосується ефективності засобів, які можуть застосовуватися сторонами договору оренди землі для захисту своїх прав та пов'язаних з ними інтересів.

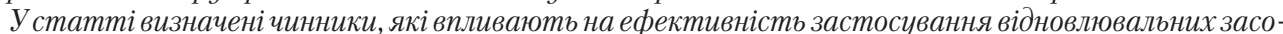
бів захисту у відносинах з оренди землі на прикладі визнання права як найбільш поширеного у судовій практииі. Обтрунтовано пріоритетність відновлювальних засобів захисту як таких, що сприяють сталості договірних відносин, завдяки чому зберігається можливість досягнення сторонами иілей, пов'язаних із конкретним договором оренди землі. Проаналізовано зміст визнання права як засобу захисту відповідно до статті 16 Цивільного кодексу Украӥни та статті 20 Господарського кодексу України, зокрема, доводиться недоиільність визначення у статті 20 Господарського кодексу України можливості вимагати не лише визнання наявності права у потерпілого, а й відсутності такого права у порушника. Звернута увага на процесуальні аспекти проблеми застосування визнання відсутності права як засобу захисту. На основі прикладів судової практики проведено аналіз визнання права як способу захисту на відповідність змісту правовідносин, що виникають з договору оренди землі.

Обгрунтовується думка, що передумовою ефективності визнання права як засобу захисту прав орендаря та орендодавия є застосування його у поєднанні з іншими відновлювальними засобами захисту. Визначено чинники, які впливають на ефективність застосування такого комплексно20 засобу захисту, як визнання права: його здатність бути виконаним у тому числі у примусовому порядку; відповідність характеру права, яке захищається, а також характеру наслідків, що спричинені порушенням.

Ключові слова: оренда землі, засоби захисту прав, відновлювальні засоби захисту прав, визнання права, чинники ефективності визнання права.

Постановка проблеми. Захист права посідає одне з центральних місць у механізмі правового регулювання. В Україні інститут захисту не зазнав суттєвих змін порівняно $з$ тим, який існував за радянських часів. Утім зміни у зовнішніх, у тому числі правових та економічних, умовах функціонування суспільних відносин, зокрема, у сфері оренди землі, які відбулись протягом останніх десятирічь, вимагають ревізії чинного механізму захисту. Насамперед це стосується ефективності засобів, які можуть застосовуватися сторонами договору оренди землі для захисту своїх прав та пов'язаних з ними інтересів.

Право на ефективний засіб захисту гарантовано Конвенцією про захист прав людини і основоположних свобод [1], яка стала підгрунтям концепції ефективного захисту, ключові положення якої використовуються під час реформування відповідного матеріального та процесуального зако- нодавства різних країн, зокрема й України. Натомість об'єктивна різниця між темпами реформування правового регулювання відносин, у тому числі з оренди землі, та розвитку суспільних відносин (поява нових форм відносин, які не можуть бути врегульовані у рамках однієї галузі права, розгалуження інтересів, що є суттєвими для сторін договору оренди землі, зміна цінності землі як активу тощо) зумовила необхідність альтернативних підходів до забезпечення ефективного захисту прав сторін, основною метою якого є не покарання порушника, а відновлення порушеного права.

Окремі аспекти ефективного захисту висвітлені у Керівних принципах ООН у сфері бізнесу та прав людини [2]. Зокрема, основна увага зазначеного документа приділена питанням щодо відповідальності бізнесу за дотримання прав людини у відносинах пов’язаних із підприємницькою діяльністю, до яких належать і відносини з оренди 
земельної ділянки, яка перебуває у приватній власності фізичної особи.

3 лютого 2014 р. в ООН розпочатий процес, спрямований на створення більш ефективної системи внутрішніх засобів правового захисту, яка здатна забезпечити якісне відновлення порушеного права. За цих умов $\epsilon$ актуальним дослідження ефективності засобів захисту прав орендаря та орендодавця землі, які спрямовані на відновлення права (відновлювальні засоби захисту).

Аналіз останніх досліджень і публікацій з даної теми. Зазначеній проблемі приділялася увага у наукових працях А. М. Мірошниченка, О. П. Подцерковного, Н. В. Ільків, Н. В. Ільницької та ін. Водночас низка питань щодо ефективності наявних відновлювальних засобів захисту прав орендаря та орендодавця землі не дістали достатнього висвітлення у літературі.

Метою цієї статті $є$ визначення чинників, які впливають на ефективність застосування відновлювальних засобів захисту, на прикладі визнання права як найбільш поширеного у судовій практиці.

Виклад основного матеріалу. Під відновлювальними засобами захисту розуміються засоби, спрямовані на відновлення придатності первинного суб' єктивного права (права, визначеного у договорі оренди) задовольняти відповідний інтерес, заради якого укладався договір оренди землі.

3 точки зору ефективності захисту застосування відновлювальних засобів $є$ пріоритетним, адже вони сприяють сталості договірних відносин, завдяки чому зберігається можливість досягнення сторонами цілей, пов'язаних із конкретним договором оренди землі. Відновлювальні засоби захисту спрямовані на нормалізацію функціонування договірних відносин, первісний зміст яких грунтувався на балансі інтересів орендодавця та орендаря землі. Сферою застосування цих засобів захисту є порушені права сторони чинного договору оренду землі. Тобто відновлювальні засоби є інструментом реалізації того способу захисту, який є реакцією на порушення зобов'язань з боку контрагента та спрямований на вплив на його юридично значущу поведінку з метою її зміни у поточному періоді (сплатити заборгованість 3 орендної плати за землю, усунути порушення режиму використання земельної ділянки, відшкодувати вартість поліпшень земельної ділянки та вчинити інші дії, зазначені у договорі оренди землі). Іншими словами, відновлювальні засоби захисту спрямовані на повернення status quo у договірних відносинах з оренди землі, яке було порушено діями (бездіяльністю) однієї зі сторін. Ключовою ознакою, яка визначає характер цих засобів захисту, є те, що їх застосування не створює нового права або обов'язку, а лише забезпечує реалізацію (примусову реалізацію) тих, що вже існують.

Право як засіб захисту передбачено ст. 16 ЦК України, ст. 20 ГК України та ст. 152 ЗК України, але його зміст у зазначених кодифікованих актах визначається неоднаково. Зокрема, у ст. 20 ГК України передбачена можливість вимагати не лише визнання наявності права у потерпілого, але й відсутності такого права у порушника.

Зазначене розширення змісту засобу захисту піддавалося критиці з боку наукової спільноти та було несхвально сприйняте правозахисною практикою, в тому числі судовою та господарською. Так, В.О. Лапач, Р.О. Халфіна звертають увагу на матеріально-правові аспекти проблеми визнання відсутності права як засобу захисту. Суб'єктивне право є елементом правового статусу особи, що як такий є об'єктивною реальністю (дійсністю). Відповідно, властивість цілого, яка переноситься на його частину, дозволяє стверджувати, що суб'єктивне право також є об'єктивною реальністю (дійсністю), яка не потребує додаткового підтвердження з боку суду [3, с. 122-132]. У цьому сенсі вимога щодо визнання відсутності права підриває сталість суб'єктивного права та ставить питання щодо здатності держави, яка гарантує визнання, дотримання та захист цього права, виконувати зазначені обов'язки у такий суперечливий спосіб.

Д. М. Притика, М. І. Тітов, В. С. Щербина звертали увагу на процесуальні аспекти проблеми застосування визнання відсутності права як засобу захисту. Вимога суб'єкта господарювання (позивача) щодо визнання за ним права у разі ії задоволення судом означає відсутність такого права в іншої особи (відповідача). Звертаючись до господарського суду з такою вимогою, позивач повинен довести наявність спірного матеріального правовідношення та належність спірного права саме йому (активна легітимація). Натомість важко уявити, як у разі звернення до суду з вимогою про визнання відсутності права (вочевидь, в іншої особи) позивач легітимує себе як заінтересовану особу, оскільки саме легітимація є процесуальним засобом вираження юридичної заінтересованості [4, с. 138-146].

Вищий господарський суд України акцентував увагу на обмеженій здатності зазначеного засобу забезпечити реальний захист порушеного права. Зокрема, судом зазначено, що вимога щодо визнання 
у позивача відсутності права є абстрактною та передбачає визнання такої відсутності взагалі на майбутнє. Втім задоволення такої позовної вимоги унеможливлене змістом ст. 84 ГПК України, оскільки господарський суд може зобов'язати вчинити лише конкретні дії, тобто визнати наявність чи відсутність права лише на здійснення конкретної дії [5].

Погоджуючись із такими позиціями науковців та суду, треба зазначити, що висловлені аргументи рівною мірою справедливі і для застосування визнання права орендаря та орендодавця землі як засобу його захисту. По-перше, визнання дійсного права судом не надає йому імунітету від порушення. По-друге, встановлення наявності права орендаря та орендодавця землі здійснюється судом на етапі оцінки обгрунтованості вимог позивача та заперечень відповідача і відображується у мотивувальній частині судового рішення, тобто зазначений процес не є результатом розгляду справи, а лише проміжним етапом на шляху до кінцевої мети - надання захисту права від порушення. Констатація факту наявності в особи суб'єктивного права (порушеного суб'єктивного права) жодним чином не впливає на можливість його захисту, не відповідає на питання, яким чином мають поводитися орендар та орендодавець землі (сплатити орендну плату, звільнити/передати земельну ділянку, відшкодувати вартість поліпшень або демонтувати об'єкти), що, у свою чергу, унеможливлює або суттєво ускладнює виконання судового рішення.

Виправленню зазначеного недоліка визнання права як засобу захисту прав орендаря та орендодавця землі сприятиме його поєднання 3 іншими відновлювальними засобами захисту, зміст яких становить певна дія (припинення дії, яка порушує право; відновлення становища, яке існувало до порушення; примусове виконання обов'язку в натурі), що має відповідним чином відображуватися у позовних вимогах (об'єднані позовні вимоги).

Разом із цим виникає питання щодо критеріїв вибору такого «другого» відновлювального засобу, який здатен забезпечити ефективний захист права орендаря та орендодавця землі. Як свідчить аналіз практики застосування засобів захисту, крім придатності до виконання, про яку йшлося вище, ефективність засобу захисту залежить від кореляції його змісту з характером права, яке захищається, а також характером правових наслідків, які спричинені порушенням права.

Залежність між ефективністю захисту та наявністю прямого змістового взаємозв'язку між змістом засобу захисту та характером nрава, що захищається, демонструють такі приклади із судової практики.

ТОВ «Агроконтракт-Н» (далі - орендар) звернулося 3 позовом до Головного управління Держгеокадастру у Кіровоградській області (далі - орендодавець) про визнання поновленим договору оренди землі від 25.08.2010. Аргументація орендаря полягала в тому, що відповідно до умов договору 09.12.2016 він звернувся до орендодавця 3 пропозицією щодо поновлення договору оренди землі та надіслав проект відповідної додаткової угоди. Орендодавець не погодився на вказану пропозицію та запропонував зменшити термін договору та збільшити розмір орендної плати, але відповідь була надана $з$ порушенням встановленого для відмови терміну. Орендар вважав, що за відсутності вчасно наданих заперечень його права та 3 огляду на те, що обов'язки, які випливають iз нового договору оренди землі, за змістом тотожні тим, що існували раніше, з метою захисту останніх вимагав їх визнати шляхом визнання поновленим відповідного договору оренди землі. Рішенням господарського суду Кіровоградської області від 14.04.2017, залишеним без змін за результатами перегляду в апеляційній та касаційній інстанціях, у задоволенні позовних вимог відмовлено повністю [6]. Зокрема, касаційною інстанцією зазначено, що, оскільки сторони не досягли домовленості щодо істотних умов договору, переважне право орендаря на укладення договору оренди землі припинилося і правові підстави для продовження строку дії договору оренди відсутні.

Таким чином, суд фактично визнав відсутність у орендаря організаційного права на переважне укладення договору оренди землі та, відповідно, наявність у орендодавця організаційного права контролю за «рухом» земельної ділянки та його умовами, але 3 урахуванням можливості виконання судового рішення, відмова стосувалась більш прийнятного засобу - примусового виконання обов'язку в натурі.

У наведеному прикладі під час застосування засобу захисту судом була врахована наявність прямого взаємозв'язку між характером організаційного права орендаря на поновлення договору та характером засобу захисту, який він обрав, - визнання переважного права на поновлення договору.

У разі нехтування забезпеченням прямого змістового взаємозв'язку між засобом захисту та характером права, що захищається, ефективність захисту знижується.

02.10.2001 між Херсонською міською радою (далі - орендодавець) та приватним підприємцем Особа-1 (далі - орендар) було 
укладено договір оренди земельної ділянки площею 17 кв.м. під розміщення кіоску терміном до 18.09.2003 з правом проводити поліпшення земельної ділянки (економікоорганізаційне право). У разі припинення або розірвання договору орендар зобов'язаний повернути орендодавцеві земельну ділянку у стані, не гіршому порівняно з тим, у якому він одержав її в оренду. Орендар розмістив кіоск, холодильне обладнання та торгівельний автомат. Після спливу зазначеного терміну договір оренди землі не продовжувався, але орендар продовжував користуватися земельною ділянкою. 31.08.2016 орендодавець звернувся до орендаря з вимогою про звільнення земельної ділянки шляхом демонтажу тимчасових споруд - кіоску та торгівельного обладнання. Орендар звернувся до суду із позовом про захист порушеного права, у якому зазначено, що орендодавець не визнає його права власності на поліпшення, а саме споруду торгівельного кіоску, яка $€$ невід'ємною від земельної ділянки 3 господарським призначенням «Під утримання торгівельного кіоску», оскільки її неможливо розібрати на частини (демонтаж) і перенести в інше місце без знецінення та зміни цільового призначення. У зв'язку з цим орендар просив суд визнати за ним право на поліпшення земельної ділянки - торгівельний кіоск, придбаний ним на підставі договору купівлі-продажу. Тобто орендар, захищаючи своє економіко-організаційне право на поліпшення земельної ділянки (зокрема, право на відшкодування вартості поліпшень), обрав засіб захисту, спрямований на захист його економічного права (права власності на кіоск). Рішенням господарського суду Херсонської області від 29.11.2016 у справі № 923/1077/16 у задоволенні позову відмовлено. Невизнання права орендаря суд мотивував тим, що у заявлений спосіб позивач фактично намагався визнати право власності на земельну ділянку, на якій розміщено кіоск, що не є правомірним [7].

Погоджуючись 3 аргументацією суду, не можна не відзначити спірність ухваленого рішення за суттю. Право власності орендаря на кіоск підтверджується договором купівліпродажу, дійсність якого не оспорювалася сторонами та не була предметом судового розгляду. Справді, орендар вдався до маніпуляції у формулюванні позовної вимоги, яка по суті ототожнювала право власності на кіоск із правом власності на земельну ділянку під ним. Утім ухваленим рішенням суд припустив «дзеркальне» відображення маніпулятивного задуму орендаря: невизнання права на поліпшення у контексті судового рішення виявилося тотожним невизнанню права власності на кіоск, що підриває конституційні гарантії непорушності права приватної власності. Таким чином, суд ухвалив правильне по суті, але несправедливе рішення. За наведених обставин з урахуванням обраного орендарем засобу захисту виправлення ситуації у площині матеріального права не є перспективним. Натомість процесуальне право надає можливість закриття провадження у справі за відсутністю спору (відсутність предмета спору, п. 2 ч. 1 ст. 255 ЦПК України, п. 2 ч. 1 ст. 231 ГПК України), що, у свою чергу, мало б мотивувальний вплив на вибір сторонами договору оренди іншого засобу захисту, який відповідав би характеру порушеного права.

Іншим фактором, який потрібно враховувати, вибираючи засіб захисту права, $€$ характер наслідків, спричинених його порушенням. Застосування відновлювальних засобів захисту, зокрема визнання права, може бути ефективним у разі, якщо порушення права не призвело до знищення обставин, на яких грунтувався відповідний договірний інтерес потерпілої сторони. В інших випадках доцільним $є$ використання засобів захисту, не спрямованих на відновлення права (припинення відносин, відшкодування збитків тощо).

Порушення наведеного правила призводить до неефективного захисту, що демонструє наступний приклад із судової практики. Між Полянською сільською радою (далі - орендодавець) та Дочірнім підприємством «Санаторій Сонячне Закарпаття» (далі - орендар) 08.08.2008 укладено договір оренди земельної ділянки площею 11,307 га для обслуговування санаторію. 25.01.2012 за згодою орендодавця між орендарем та ФОП Особа-1 (далі - суборендар) укладений договір суборенди частини земельної ділянки площею 0,22 га для розміщення ринку, яким передбачено право суборендаря на поновлення суборендного договору за умови поновлення договору оренди землі. Договір оренди землі за згодою сторін неодноразово поновлювався: у 2013 р. - до 05.02.2015; у 2015 р. - до 05.02.2016 та у 2016 р. - до 05.02.2017. Після останнього поновлення договору оренди землі, 05.02.2016, орендар повідомив суборендаря про те, що у зв'язку із запланованими ним ремонтно-будівельними роботами лінії теплотраси договір суборенди земельної ділянки не поновлюватиметься. Суборендар дізнався, що орендар не звертався до орендодавця стосовно погодження дозволів на будівельні роботи. Також орендодавець повідомив, що земельна ділянка, що була надана у суборенду, зарезервована під розширення лікувального корпусу. Суборендар звернувся до суду з 
вимогою зобов'язати орендаря вчинити певні дії шляхом укладення угоди про поновлення дії договору суборенди земельної ділянки на строк дії договору оренди земельної ділянки. Тобто фактично суборендар вимагав визнати його організаційне право на поновлення договору суборенди. Орендар проти позову заперечував, стверджуючи, що має намір використовувати земельну ділянку самостійно, зокрема, для проведення будівельних робіт та звернувся до суду із зустрічним позовом про повернення земельної ділянки з незаконного володіння. Рішенням господарського суду Закарпатської області від 30.05.2016 у справі № 907/162/16 позов суборендаря задоволено. Визнаючи організаційне право суборендаря на поновлення договору суборенди землі, суд дійшов висновку, що орендар не довів наявність у нього права на проведення будівельних робіт, отже, за таких умов не вбачається правових підстав для визнання його організаційного права на використання всієї земельної ділянки [8].

3 такою позицією суду важко погодитися. По-перше, організаційні права суборендодавця на поновлення суборендного договору є вторинними від аналогічного права орендаря за договором оренди землі. За цим договором його свобода використання земельної ділянки, з одного боку, обмежена іiї цільовим призначенням, а саме обслуговування санаторію, з іншого - передбачає право самостійно вирішувати, у який спосіб таке обслуговування буде здійснюватися. Враховуючи плани орендодавця щодо розширення лікувального корпусу, орендар бачив свою функцію у проведенні робіт з будівництва теплотраси для майбутнього розширеного лікувального корпусу, тобто мав намір реалізувати свій організаційно-економічний інтерес у здійсненні поліпшення орендованої земельної ділянки. Відсутність дозволів на будівельні роботи свідчить про те, що організаційно-економічний інтерес наразі не набув легітимації у вигляді організаційно-економічного права та задовольняється у рамках наявного організаційного права на використання земельної ділянки. По-друге, у відносинах суборенди баланс організаційних прав сторін визначений відповідним договором. Поновлення договору суборенди свідчить про те, що досягнутий баланс зберігається та сторони, як і раніше, мають можливість задоволення своїх інтересів у рамках суборендних відносин на умовах, відображених у додатковій угоді.

Втім, визнаючи організаційне право суборендаря та відмовлячи у визнанні аналогічного права орендаря, суд не врахував наслідки порушення права та наслідки, які настануть у результаті визнання права. Як свідчать матеріали справи, інтерес орендодавця зазнав суттєвих змін: він більше не сконцентрований на отриманні доходу від суборенди частини земельної ділянки, а полягає у здійснені поліпшень стану земельної ділянки $з$ метою надання її в суборенду у майбутньому за підвищеною ціною або одержання доходу у вигляді компенсації понесених витрат після закінчення орендних відносин з орендодавцем тощо. Задоволення цього зміненого інтересу в умовах суборендних відносин не є можливим. Невизнання організаційного права орендаря не поновлювати договір суборенди призводить не лише до порушення його організаційного інтересу, але й ускладнює задоволення організаційного інтересу орендодавця, який мав плани на розширення лікувального корпусу. За таких умов захист права суборендаря не може вважатися ефективним.

\section{Висновки}

Таким чином, передумовою ефективності визнання права як засобу захисту прав орендаря та орендодавця є застосування його у поєднанні з іншими відновлювальними засобами захисту. Чинниками, які впливають на ефективність застосування такого комплексного засобу захисту, є його здатність бути виконаним у тому числі у примусовому порядку; відповідність характеру права, яке захищається, а також характеру наслідків, які спричинені порушенням.

\section{Список використаних джерел:}

1. Про ратифікацію Конвенції про захист прав людини i основоположних свобод 1950 року, Першого протоколу та протоколів № 2, 4, 7 та 11 до Конвенції : Закон України від 17.07.1997 № 475/97-ВР. Відомості Верховноі Ради Украӥни. 1997. № 40. Ст. 263.

2. Guiding Principles on Business and Human Rights: Implementing the United Nations «Protect, Respect and Remedy» Framework: Annex to the Report of the Special Representative of the Secretary General on the issue of human rights and transnational corporations and other business enterprises, John Ruggie on 21 March 2011 № A/HRC/17/31 / United Nations Human Rights Office of the High Commissioner. URL http://www.un.org/ga/search/view_doc.asp? symbol $=\mathrm{A} / \mathrm{HRC} / 17 / 31 \&$ Lang $=\mathrm{E}$.

3. Лапач В. Об активной легитимации к иску об оспаривании права. Гражданское законодательство: Статьи. Комментарии. Практика. Вып. 27. Алматы: Юрист, 2007. С. 122-132.

4. Щербина В.С. Захист прав та інтересів суб'єктів господарювання (матеріально-правовий та процесуальний аспекти). Приватне право $і$ пiдприємництво. 2008. Вип. 7. С. 138-146. 
5. Постанова Вищого господарського суду України від 20.04.2005 у справі № 28/201 / Верховна Рада України. URL: https:// zakon.rada.gov.ua/ laws/show/v_201600-05.

6. Постанова Верховного Суду від 28.02.2018 у справі № 912/556/17 / Є2иний реєстр судових рішень. URL: http:// reyestr.court.gov.ua/ Review/72531722.
7. Рішення господарського суду Херсонської області від 29.11.2016 у справі № 923/1077/16 / Єдиний реєстр судових рішень. URL: http://reyestr. court.gov.ua/Review/63191494

8. Постанова Верховного Суду від 19.03.2019 у справі № 908/2484/1716. Єәиний реєстр судових рішень. URL: http:// reyestr.court. gov.ua/Review/80648586.

Protection of the rights occupies one of the central places in the mechanism of legal regulation. In Ukraine, the institute of protection did not undergo significant changes in comparison with that which existed in Soviet times. However, changes in the external, including legal and economic ones, conditions of public relations functioning, in particular, in the field of land lease that have taken place during the last decades, require revision of the existing mechanism of protection. First of all, it concerns the effectiveness of the methods that can be applied by the parties to the land lease agreement to protect their rights and interests which are connected with them.

The article defines the factors which influence the efficiency of application of restorative methods of protection in land lease relations with the help of the example of recognition of right as the most widespread in judicial practice. The priority of restorative methods is substantiated, as such that contribute to the sustainability of contractual relations, thus maintaining the possibility for the parties to achieve the goals related to a specific land lease agreement. The content of the recognition of the right as a method of protection in accordance with Article 16 of the Civil Code of Ukraine and Article 20 of the Commercial Code of Ukraine is analyzed, in particular it proves the inadvisability of determining in Article 20 of the Commercial Code of Ukraine the possibility to demand not only the recognition of the right of the victim, but also the absence of such a right to the offender. The attention is paid to the procedural aspects of the problem of recognizing the lack of law as a method of protection. On the basis of examples of judicial practice, an analysis of the recognition of the right as a method of protection of the conformity of the content of legal relationships arising from the lease of land was carried out.

It is substantiated that the prerequisite for the effective recognition of the right as a method to protect the rights of the lessee and the lessor is its application in combination with other restorative methods of protection. The factors influencing the effectiveness of the use of such an integrated method of protection as recognition of the right were identified: its ability to be executed, including in a forced order; compliance with the nature of the right protected, and the nature of the consequences of the breach.

Key words: land lease, remedies, restorative remedies, recognition of rights, factors of effectiveness of recognition of rights. 
УДК 342.95

DOI https://doi.org/10.32849/2663-5313/2019.8.12

\section{Світлана Бевз,}

канд. юрид. наук, дочент,

доцент кафедри господарського та адміністративного права

Начіонального технічного університету України

«Київський політехнічний інститут імені Ігоря Сікорського»

\section{ПРАВОСВІДОМІСТЬ У ПРАВОВОМУ РЕГУЛЮВАННІ ДЕРЖАВНОГО УПРАВЛІННЯ У СФЕРІ ГОСПОДАРСЬКОЇ ДІЯЛЬНОСТІ}

Стаття присвячена розумінню правосвідомості суб'єктів в адміністративно-правовому регулюванні державного управління у сфері господарської діяльності, ї значенню та встановленню суб'єктів, правосвідомість яких має вплив на досягнення мети адміністративно-правового регулювання у визначеній сфері. Наголошено на тому, шо правовідносини з державного управління у сфері господарської діяльності можуть мати 2 об’єкти: господарська діяльність в иілому в державі (макрорівень) та діяльність державного підприємства або підприємства, в статутному капіталі якого $\epsilon$ державна власність (мікрорівень). Залежно від иього різняться і суб'єкти, що здійснюють державне управління, правосвідомість яких впливає на здійснення адміністративно-правового регулювання. На макрорівні йдеться про правосвідомість суб'єкта (суб'єктів) владних повноважень та потениійних або реальних суб'єктів господарювання. Це насамперед державні службовиі, які діють від імені суб'єкта владних повноважень, та суб'єкти господарювання або особи, які діють від їхнього імені (фізичні особи - підприємиі (реальні або потениійні); засновники та/або представники юридичних осіб або фізичних осіб-підприємиів). На мікрорівні - правосвідомість представника суб'єкта владних повноважень, у тому числі керівника державного підприємства та представників держави в наглядових радах підприємств або господарських товариств.

На підставі аналізу чинного законодавства України, теоретичних пращь виявляються вимоги до правосвідомості учасників відносин з державного управління у сфері господарської діяльності, звертається увага на окремі заходи, які б сприяли формуванню та поглибленню правомірної правосвідомості. Виходячи з теоретичного розуміння правосвідомості, визначається їі місие в адміністративноправовому регулюванні державного управління у сфері господарської діяльності та констатується, що показником правосвідомості представника суб'єкта господарювання, його співробітників буде відповідність такого суб'єкта господарювання встановленим міжнародним та національним законодавством вимогам.

Ключові слова: правомірна свідомість, оціночні поняття в адміністративно-правовому регулюванні, державні службовці, керівники підприємства, засновники суб'єктів господарювання, комплаєнс.

Постановка проблеми. Дерегуляція та розвиток підприємництва, що визначені середньостроковою метою дальших реформ у Стратегії сталого розвитку «Україна - 2020», передбачає створення сприятливого середовища для ведення бізнесу, розвитку малого і середнього підприємництва, залучення інвестицій, спрощення міжнародної торгівлі та підвищення ефективності ринку праці. Для досягнення поставлених завдань необхідна ефективна система державного управління, адміністративно-правовому регулюванню якої відводиться першорядне місце. Утім нормативно-правовий акт може бути гарно виписаний, втілювати високий рівень юридичної техніки, але не бути ефективним лише тому, що його не враховує, не усвідом- лює особа (особи), які створили такий акт, та не використовує особа (особи), кому він адресований. Комплекс реформ, що здійснюються нині в Україні, реалізація прийнятих Стратегій та Концепцій, що передбачають інноваційний розвиток суспільства, впровадження європейських принципів і стандартів зумовлюють залучення уповноважених та компетентних суб'єктів. Тому належна, правомірна реалізація адміністративно-правових норм у практичній площині залежить від правосвідомості учасників відносин, у яких ці норми реалізуються.

Питання правосвідомості не є новими для юридичної науки в цілому та науки адміністративного права зокрема. У підручниках з адміністративного права правосвідомість 
розглядається як одна 3 функціональних складових частин механізму адміністративно-правового регулювання [1, с. 33], як елемент (засіб) механізму адміністративноправового регулювання [2, с. 38]. В адміністративно-правовій доктрині дослідження правосвідомості здійснювалося в контексті реформування державної служби та висвітлене в окремих публікаціях, здебільшого присвячених правовій культурі (монографіях «Правова культура в умовах становлення громадянського суспільства» [3], «Правові основи формування та функціонування органів державної влади у контексті євроінтеграції [4]). Тож питання правосвідомості суб'єктів - учасників відносин з державного управління у сфері господарської діяльності потребує окремого висвітлення.

Мета статті - визначити розуміння правосвідомості, її місце та суб'єктів, правосвідомість яких найбільш впливає на адміністративно-правове регулювання державного управління у сфері господар॥ ської діяльності.

Виклад основного матеріалу. Правосвідомість - багатогранне поняття, яке визначається, зокрема, як сукупність раціональних норм, які не тільки відображають усвідомлення правової дійсності, але й впливають на неї, формуючи готовність особистості до правової поведінки [5, с. 3]. 3 одного боку, право впливає на правосвідомість, з іншого - правосвідомість - на формування права [6, с. 94]; правосвідомість, з одного боку, виступає як об'єкт впливу права, а з іншого - $є$ орієнтиром у межах встановленого правового режиму [6, с. 95]. Правосвідомість як форма або область свідомості відображає правову дійсність у формі юридичних знань і оціночних відношень до права і практики його реалізації, правових настанов і ціннісних орієнтацій, що регулюють поведінку (діяльність) людей в юридично значимих ситуаціях [7, с. 379]. Отже, правосвідомість - це ідейна основа внутрішнього переконання особи і регулятор іï поведінки в межах закону.

Правовідносини з державного управління у сфері господарської діяльності можуть мати 2 об'єкти: господарська діяльність у цілому в державі (макрорівень) та діяльність державного підприємства або підприємства, в статутному капіталі якого є державна власність (мікрорівень). Залежно від цього різняться і суб'єкти, що здійснюють державне управління, правосвідомість яких впливає на здійснення адміністративно-правового регулювання державного управління у сфері господарської діяльності. На макрорівні йдеться про правосвідомість суб'єкта (суб'єктів) владних повноважень та потенційних або реальних суб'єктів господарювання. Це насамперед державні службовці, які діють від імені суб'єкта владних повноважень, та суб'єкти господарювання або особи, які діють від їхнього імені (фізичні особи - підприємці (реальні або потенційні); засновники та/або представники юридичних осіб або фізичних осіб-підприємців). На мікрорівні правосвідомість представника суб'єкта владних повноважень, у тому числі керівника державного підприємства та представників держави в наглядових радах підприємств або господарських товариств.

Законодавство, яке регламентує здійснення державного управління у сфері господарської діяльності, фактично зумовлює застосування оціночних понять та здійснення оцінки певних фактів, що визначається кожною особою індивідуально на підставі їі правосвідомості. Так, зокрема, кожне рішення про надання адміністративної послуги, індивідуального правового акта приймається суб'єктом владних повноважень на підставі оцінки наданих суб'єктом звернення документів; рішення за результатами здійснення заходів нагляду (контролю) - на підставі вивчення та оцінки певних фактів у їх правовому змісті. Вибір організаційно-правової форми господарювання, виду господарської діяльності, яким займатиметься суб'єкт господарювання, передбачає врахування ступеня участі держави у відповідній сфері на підставі аналізу вимог законодавства та практики його реалізації. Прийняття будь-якого рішення в практичній юридичній площині завжди зумовлено певним рівнем знань, їх усвідомленням, правосвідомістю суб’єкта прийняття рішення. Остання є основою для прийняття відповідного рішення.

Аналіз Закону України «Про державну службу» свідчить, що вимог до правосвідомості державних службовців не встановлено. Утім вони закладені в інших нормах Закону. У статті 4 Закону серед принципів державної служби визначено «принцип доброчесності - спрямованість дій державного службовця на захист публічних інтересів та відмова державного службовця від превалювання приватного інтересу під час здійснення наданих йому повноважень». Серед основних обов'язків державних службовців закріплено, окрім іншого, положення «2) дотримуватися принципів державної служби та правил етичної поведінки; 7) сумлінно і професійно виконувати свої посадові обов'язки; 10) запобігати виникненню реального, потенційного конфлікту інтересів під час проходження державної служби». Як бачимо, норми Закону містять оціночні 
поняття, які кожна фізична особа розуміє в силу свого внутрішнього переконання. Тож належне виконання державними службовцями покладених на них обов'язків зумовлює наявність високого рівня правосвідомості.

Покращення здійснення державної служби, підвищення ефективності державного управління передбачає необхідність уніфікованого розуміння завдань та порядку здійснення державної служби, чому сприяли б заходи щодо формування правової ідеології державних службовців. До таких слід віднести: відповідні тренінги, стажування, проходження підвищення кваліфікації, які спрямовані на засвоєння основних засад демократичного суспільства, принципів побудови та функціонування правової держави та які мають бути обов'язковими. Видання Методичних рекомендацій, Інструкцій щодо порядку здійснення певних функцій державного органу нівелюють значення правосвідомості державних службовців та зумовлюють різне тлумачення правових норм відповідних актів державними службовцями та суб'єктами господарювання. Показовим у цьому питанні є діяльність Державної регуляторної служби України, яка з метою вдосконалення методологічного забезпечення реалізації державної регуляторної політики запровадила для фахівців міністерств та інших центральних органів виконавчої влади, до функціональних обов'язків яких належить розробка проектів регуляторних актів, практику проведення навчально-методичних заходів у форматі круглих столів для обговорення проблемних питань за заявницьким принципом. Як зазначається на сайті ДРС України [8], «3 початку 2019 року ДРС провела майже 180 консультацій для розробників регуляторних актів щодо підготовки аналізу регуляторного впливу. У таких консультаціях брали активну участь фахівці 24-х центральних органів виконавчої влади».

Стосовно правосвідомості осіб на мікрорівні зазначимо також таке. Як слушно робить висновок О. О. Кравчук, кожен керівник державного підприємства, організації, установи повинен повністю усвідомлювати, що він $є$ представником держави і управляє саме державним майном (а не належним власне йому) майном, і в процесі такого управління він повинен повністю дотримуватися передбачених нормами права приписів, що зумовлює наявність у таких осіб своєрідних деонтологічних характеристик. Останні включають, зокрема, і відповідні почуття обов'язку при діях від імені держави виступати виключно в інтересах держави [9, с. 166]. Підвищені вимоги до морально- особистих якостей особи - керівника державного підприємства, на яких у тому числі базується правосвідомість, зумовлені посиленою увагою законодавця до діяльності таких підприємств. Зокрема, особливості управління ними визначені Законом України «Про управління об'єктами державної власності», окремою постановою КМУ від 3 вересня 2008 року № 777 затверджено Порядок проведення конкурсного відбору керівників суб'єктів господарювання державного сектору економіки. Тому наявність високих морально-особистих якостей, правильної правосвідомості - вимоги, що мають поширюватися не лише на керівників, а на всіх осіб, що здійснюють функції державного управління господарською діяльністю певного підприємства. До таких також належать: представники держави та незалежні члени наглядової ради державного унітарного підприємства, господарського товариства, у статутному капіталі якого більше 50 відсотків акцій (часток) належать державі. Відповідно до п. 6 Порядку визначення та затвердження кандидатур представників держави, які призначаються до наглядових рад державних унітарних підприємств, і тих, які беруть участь у загальних зборах та обираються до наглядових рад господарських товариств, у статутному капіталі яких більше 50 відсотків акцій (часток) належать державі, затвердженого постановою КМУ від 10 березня 2017 року № 143, серед обов'язкових вимог, яким повинна відповідати кандидатура представника держави, - наявність вищої освіти, знань та професійних навичок, досвіду роботи та інших характеристик, необхідних для належного здійснення повноважень члена наглядової ради підприємства. Вважаємо, що однією з інших характеристик є «правомірна» правосвідомість, що потребує визначення критеріїв, за якими можна з'ясувати наявність такої ознаки у претендента. Для вирішення цього питання можна скористатися практикою визначення особистих морально-психологічних якостей претендентів на посаду судді, яка впроваджена в Україні.

Зазначимо, що незалежний член наглядової ради у своїй діяльності має керуватися не лише інтересами відповідного державного унітарного підприємства або господарського товариства, у статутному капіталі якого більше 50 відсотків акцій (часток) належать державі, як це передбачено в абз. 3 ч. 4 статті $11^{3}$ Закону України «Про управління об'єктами державної власності», але й інтересами держави, для задоволення яких функціонує певне підприємство, що зумовлює необхідність внесення відповідних змін 
до зазначеного вище Закону. Позитивним у даному питанні було б затвердження також типового цивільно-правового договору, на підставі якого виконують повноваження незалежні члени наглядової ради, який слід прийняти за процедурами, передбаченими для регуляторних актів, та в якому закріпити обов'язок дотримуватися демократичної, правової ідеології.

Більш непередбачуваним та неврегульованим є питання правосвідомості суб'єктів господарювання (реальних та потенційних) та/або їхніх представників. Ця категорія суб'єктів є суб'єктами приватного права, яким дозволено все, що не заборонено. Тож межею їхнього розсуду є лише пряма заборона, визначена в законі. Свобода підприємництва, лібералізація бізнесу, дерегуляція підприємницької діяльності - ті фактори, що розширили межі розсуду суб'єктів господарювання та актуалізували питання їхньої правосвідомості. Остання визначає рівень правомірності здійснення ними діяльності, оцінки діяльності інших суб'єктів. До правосвідомості суб'єктів господарювання звертаються і представники органів державної влади («Держпродспоживслужба закликає бізнес бути більш свідомим і відповідальним» [10]; Мінекономрозвитку пропонує Настанови щодо етичної поведінки замовників під час здійснення публічних закупівель [11]). Одним з основних завдань Антимонопольного комітету України є сприяння розвитку добросовісної конкуренції, тоді як «недобросовісною конкуренцією є будь-які дії у конкуренції, що суперечать торговим та іншим чесним звичаям у господарській діяльності» (ст. 1 Закону України «Про захист від недобросовісної конкуренції» від 7 червня 1996 року № 236/96-ВР), що кожен розуміє, виходячи з власної правосвідомості.

Варто наголосити, що, якщо особа має намір здійснювати господарську діяльність, їй доцільно поглибити свою правосвідомість, зокрема, в контексті розуміння вимог законодавства щодо її поведінки як суб’єкта господарювання або його засновника, її прав та обов'язків та наслідків відступу від правових приписів. Високий рівень правосвідомості таких суб'єктів дозволить визначити оптимальну організаційно-правову форму здійснення господарської діяльності, передбачити перспективи ï розвитку, мінімізувати юридичні ризики, уникати конфліктних із правом ситуацій.

Зазначимо, що законодавство визначає вимоги для керівників суб'єктів господарювання державного сектору економіки. Вирішення аналогічного питання для недержавного сектору економіки передбачається здебільшого в локальних актах суб'єктів господарювання (юридичних осіб). Нормативно-правовими актами встановлені професійні вимоги для керівників лише окремих суб'єктів господарювання (для керівників банків (ст. 42 Закону України «Про банки та банківську діяльність»), керівників інших фінансових установ (Розпорядження Державної комісії з регулювання ринків фінансових послуг України [12]) та членів рад недержавних пенсійних фондів та фахівців з питань адміністрування недержавних пенсійних фондів (Розпорядження Державної комісії з регулювання ринків фінансових послуг України [13]) або суб'єктів здійснення окремих видів діяльності (п. 28 Ліцензійних умов провадження господарської діяльності 3 медичної практики [14]; п. 13 Ліцензійних умов провадження господарської діяльності 3 надання послуг і виконання робіт протипожежного призначення [15] та ін.). Утім визначені законодавством вимоги не стосуються морально-психологічних якостей особи, рівня іiі правосвідомості, але зумовлюють iii наявність. Показником правосвідомості представника суб'єкта господарювання, його співробітників буде відповідність такого суб'єкта господарювання встановленим міжнародним та національним законодавством вимогам. Адміністративно-правове регулювання у сфері господарської діяльності запроваджує нові та посилює діючі комплаєнс-процедури для юридичних осіб. Упровадження світових практик корпоративного управління, внутрішніх програм контролю відповідності певним стандартам, підвищення рівня обізнаності та свідомості співробітників є запорукою бездоганної ділової репутації суб'єкта господарювання, що неможливо досягти без правомірної свідомості його керівників.

\section{Висновки}

Виходячи $з$ вищезазначеного, правосвідомість - важливий фактор, який впливає на функціонування механізму адміністративноправового регулювання державного управління у сфері господарської діяльності. Вона $\epsilon$ внутрішнім, інтелектуальним складником суб'єкта, тому не має якості регулятора суспільних відносин. Утім застосування відповідного механізму буде ефективним за умови наявності правомірної правосвідомості у суб’єктів та учасників такого регулювання як державного, так і приватного сектора економіки - такої, що базується на засадах демократичної, правової держави, громадянського суспільства. 


\section{Список використаних джерел:}

1. Коломоєць Т.О. Адміністративне право України. Академічний курс : підручник. Київ: Юрінком Інтер, 2011. С. 33

2. Курс адміністративного права України : підручник / В.К. Колпаков, О.В. Кузьменко, І.Д. Пастух, В.Д. Сущенко та ін. ; за ред. В.В. Коваленка. Київ: Юрінком Інтер, 2012. С. 38.

3. Правова культура в умовах становлення громадянського суспільства: монографія / О. Ю. Битяк та ін.; за ред.: Ю. П. Битяка, І. В. Яковюка; Наук.-дослід. ін-т держ. буд. та місц. Самоврядування. Харків: Право, 2007. 248 с.

4. Роль верховенства права, правосвідомості та правової культури в діяльності органів державної влади: прагнення до європейських стандартів. Правові основи формування та функціонування органів державної влади у контексті євроінтеграuіï : монографія / за ред. Ю.П. Битяка, О.Г. Данильяна. Харків: Право, 2010. Розд. 2. С. 62-127.

5. Бровко Н.І. Правосвідомість людської особистості: історичні пам'ятки та наукова думка. Актуальні проблеми вітчизняної юриспрудениї. 2018. № 3. С. 3-6.

6. Голосніченко І.П. Попередження корисливих проступків засобами адміністративного права : монографія. Київ: Вища школа, 1991. 207 с.

7. Общая теория государства и права. Академический курс : в 2-х томах / под ред. проф. М.Н. Марченко. Том 2. Теория права. Москва Издательство «Зерцало», 1998. 640 с.

8. Які центральні та місцеві органи виконавчої влади дотримуються Методики проведення аналізу впливу розроблених проектів регуляторних актів. URL: http://www.drs.gov.ua/press-room/udrs-proanalizuvaly-dotrymannya-tsentralnymyta-mistsevymy-organamy-vykonavchoyi-vlady- metodyky-provedennya-analizu-vplyvu-rozroblenyh-proektiv-regulyatornyh-aktiv/

9. Кравчук О.О. Управління державною власністю: адміністративно-правові засади : монографія. Київ: НТУУ «КПІ», 2013. 444 с.

10. Стиренко Л. Суб'єкти господарювання часто свідомо ігнорують вимоги законодавства щодо інформування споживачів. URL: http://old kmu.gov.ua/kmu/control/uk/publish/article?art id $=250090225 \&$ cat id $=250388982$

11. Настанови щодо етичної поведінки замовників під час здійснення публічних закупівель. URL http://www.me.gov.ua/Files/Download?id=22b35db4cde7-49c7-a9d8-04dead728f7d

12. Про затвердження Професійних вимог до керівників та головних бухгалтерів фінансових установ : Розпорядження Державної комісії з регулювання ринків фінансових послуг України від 13.07.2004 № 1590. URL: https://zakon.rada gov.ua/laws/show/z0955-04.

13. Про затвердження кваліфікаційних вимог до членів рад недержавних пенсійних фондів та фахівців з питань адміністрування недержавних пенсійних фондів : Розпорядження Державної комісії з регулювання ринків фінансових послуг України від 27.11.2003 № 137. URL: https://zakon. rada.gov.ua/laws/show/z1164-03.

14. Про затвердження Ліцензійних умов провадження господарської діяльності 3 медичної практики : Постанова Кабінету Міністрів України від 02.03.2016 № 285. URL: https://zakon.rada.gov. ua/laws/show/285-2016-\%D0\%BF

15. Про затвердження Ліцензійних умов провадження господарської діяльності 3 надання послуг і виконання робіт протипожежного призначення : Постанова Кабінету Міністрів України від 23.11.2016 № 852. URL: https://zakon.rada.gov ua/laws/show/852-2016-\%D0\%BF\#n10

The article is devoted to understanding of the legal consciousness of subjects in administrative and legal regulation of state governance in the economic activity sphere, its importance and establishment of subjects whose legal consciousness has influence on achievement of the goal of administrative and legal regulation in a certain sphere. It is emphasized that legal relations in state governance in the economic activity sphere can have 2 objects: economic activity as a whole in the state (macro level) and activity of state enterprise or enterprise with state property in authorized capital (micro level). Depending on this, subjects of state governance whose legal consciousness affects to the administrative and legal regulation are differ. At the macro level, we are talking about the legal consciousness of the subject (s) of power authorities and potential or real entities of business. These are, first of all, civil servants acting on behalf of the subject (s) of power authorities, and economic entities or persons acting on their behalf (persons - entrepreneurs (real or potential); founders and) or representatives of legal entities or persons entrepreneurs). At the micro level, the legal consciousness of the representative of the subject $(s)$ of power authorities, including the head of the state-owned enterprise and state representatives in the supervisory boards of enterprises or business associations.

On the basis of the analysis of the current legislation of Ukraine, theoretical works, the requirements for the legal consciousness of participants of relations in state governance in the economic activity sphere are identified, certain measures that would contribute to the formation and deepening of legal consciousness. Place of legal consciousness in the administrative and legal regulation of state governance and management in the economic activity sphere is determines and states that the indicator of the legal consciousness of the representative of the business entities, its employees will be compliance of such entities to international and national legislation requirements.

Key words: legal consciousness, valuation concepts in administrative and legal regulation, civil servants, company executives, founders of business entities, compliance. 
УДК 342.951: 346.21/346.9

DOI https://doi.org/10.32849/2663-5313/2019.8.13

\section{Артур Замрига,}

канд. екон. наук, докторант

Науково-дослідного інституту публічного права

\section{«ЕКОНОМІКА КРАЇНИ» ТА «ГОСПОДАРСТВО КРАЇНИ»: АДМІНІСТРАТИВНО-ПРАВОВІ АСПЕКТИ СПІВВІДНОШЕННЯ ПОНЯТЬ}

У статті розкрито співвідношення категорій «економіка крайни» та «господарство крайни» 3 адміністративної точки зору. Визначено, що начіональна економіка має розглядатись із застосуванням сочіально-економічного підходу як сукупність відповідних правовідносин, що підлягають врегулюванню, регламентуванню та захисту, а начіональне господарство, як його частина, позначати сукупність галузей та окремих видів виробничтв, тобто відображати технологічний підхід до розуміння змістового наповнення попереднього терміна. Наголошено, що згідно з технологічним підходом національна економіка є сукупністю галузей, видів виробництв та характеризується обсягом виробленої продукції, виконаних робіт і наданих послуг, їхньою якістю, рівнем використання ресурсів тощо. Сочіально-економічний підхід розглядає начіональну економіку як сукупність виробничих відносин, яким властиві певний рівень розвитку продуктивних сил, тип економічної системи, характер суспільного відтворення, спещифічний господарський механізм, рівень життя населення, зовнішньоекономічні зв'язки. З'ясовано, що світове господарство - система взаємопов'язаних наиіональних господарств, в основі якої - міжнародний поділ пращі, різні економічні і політичні відносини. Воно охоплює всі країни, звідси - його неоднорідність і внутрішня суперечливість. Об'єктивною основою розвитку світового господарства є міжнародний поділ прачі, тобто спеціалізація окремих країн на виробництві певних видів продукції, якими вони обмінюються. Зроблено висновок, що сталий економічний розвиток крайни - основний чинник становлення держави як самодостатньої та цивілізаційної. Україна перебуває на перехідному етапі становлення, пошуку оптимальних шляхів ї̈ належного розвитку та завоювання авторитету на міжнародній арені. Наиіональне господарство крайни найяскравіше характеризує ї сутність та реальний стан внутрішніх організачійних економічних проиесів. Держава повинна підтримувати, стимулювати господарські взаємини суб'єктів, що реалізовують господарську діяльність в Україні, та мінімально втручатися в них

Ключові слова: господарство, економіка, зміст, категорії, національна економіка, національне господарство, світове господарство, співвідношення, терміни.

Постановка проблеми. Залежно від історичного розвитку країни, її соціально-політичного становища та сучасних викликів виникає потреба постійного стратегічного планування розвитку та регламентації економічних відносин країни, які грунтуються на виваженій державній політиці. Саме в процесі розробки та реалізації державних економічних стратегій (загальнонаціональних чи регіональних; довготривалих чи періодичних) закладається фундамент розуміння основних процесів, механізмів та способів створення незалежної економічної системи. Визначальне значення для цього мають наукові надбання та теоретичні розробки, зокрема ті, що спрямовані на дослідження окремих явищ, аналіз статистичних показників, визначення ефективності, пропорційності, витратності діяльності, критеріїв індексування тощо.

Однак не менш важливим є вивчення та аналіз змісту основних категорій та термі- нів, що застосовуються як законодавцем, так i вченими-правниками. Зокрема, потребує уточнення одне питання: як співвідносяться категорії «економіка країни» та «господарство країни» 3 адміністративної точки зору? Актуальність піднятого питання зумовлена тим, що сучасні та пострадянські науковці апелюють обома термінами на відміну від англо-американських, де застосовується тільки «економіка країни».

Відповідно, метою статті є аналіз, зіставлення даних термінів та розкриття їхнього змістового наповнення.

Огляд останніх досліджень. Різновиди галузевого господарства країни досліджувало багато вчених, зокрема Ю. Бараш, В. Горбаньов, І. Григорюк, О. Дегтярьова, К. Ізмайлова, В. Клапчук, Р. Леньо, А. Ситюк, М. Хмельнюк, Н. Яркіна та багато ін. Питанням галузевої структури економіки присвячені 
праці таких українських науковців, як В. Александров, Ю. Бохан, Ю. Кіндзерський, Н. Кудрицька, Н. Тарасова та інші. Однак спеціалізованих праць вчених щодо визначення співвідношення категорій «економіка країни» та «господарство країни» 3 адміністративної точки зору немає - вченими розглядаються суміжні або дотичні явища та категорії.

Виклад основного матеріалу. В Україні активний розвиток товарного виробництва розпочався у XVIII-XIX ст. Позаяк територія України тривалий час перебувала у складі інших держав, то їі господарство було складовою частиною національного господарства цих країн. Тільки зі здобуттям Україною незалежності її господарство стало національним господарським комплексом (слово «комплекс» означає сукупність взаємопов'язаних об'єктів, що становлять єдине ціле) [1]. Саме в цей період виникла проблема створення незалежної економічної системи України, яка б грунтувалася на об'єктивній науковій основі. Економічна теорія та методологія управління господарством, які існували на той час, відповідали запитам централізовано-директивної системи управління і не відповідали новим методам і потребам господарювання. Постало питання розробки відповідної економічної теорії для умов України, використання теоретичного досвіду розвинутих країн світу, практики вдосконалення структури господарства, політики інвестицій, проведення належних реформ у системі відносин власності тощо [2].

Донині офіційного визначення терміна «господарство» немає, однак здебільшого науковцями підтримується думка, що це система виробництва, обміну і розподілу та споживання продуктів, що історично склалась і розвивається на території певної країни [3]. Частіше можна побачити словосполучення «національне господарство» або «національна економіка».

Термін «економіка» (від грецьких слів «ойкос» - домогосподарство та «номос» закон) був уведений у науковий обіг давньогрецьким мислителем Ксенофонтом. Економіка - це сукупність суспільного виробництва, розподілу, обміну та споживання благ, а також виробничих відносин, які виникають між людьми у цих процесах [4].

На переконання А. Мельник, А. Васіної, Т. Желюк та Т. Попович, національна економіка $є$ історично сформованою системою суспільного відтворення країни, яка грунтується на використанні наявних національних ресурсів, забезпечує реалізацію національних економічних інтересів країни та функціонує за об'єктивними економічними законами. Поняття національної економіки в наукових дослідженнях останніх років визначається як у вузькому, так і в широкому розумінні. У вузькому розумінні національна економіка є сукупністю економічних суб'єктів і зв'язків між ними, яка має просторово визначену специфічно складену національну організаційну структуру, характеризується господарською цілісністю і спрямована на задоволення потреб суспільства у матеріальних і соціальних благах. У широкому розумінні національна економіка - це структурована в галузевому і територіальному просторі економічна діяльність у масштабах країни, що регулюється інституціональною системою, яка відповідає економічному, політичному та ідеологічному устрою (порядку), сформованому в цій країні [5, с. 21].

Також можна зустріти наукові визначення поняття «національна економіка», які базуються на двох підходах: технологічному та соціально-економічному. Згідно з технологічним підходом національна економіка є сукупністю галузей, видів виробництв та характеризується обсягом виробленої продукції, виконаних робіт і наданих послуг, їхньою якістю, рівнем використання ресурсів тощо. Соціально-економічний підхід розглядає національну економіку як сукупність виробничих відносин, яким властиві певний рівень розвитку продуктивних сил, тип економічної системи, характер суспільного відтворення, специфічний господарський механізм, рівень життя населення, зовнішньоекономічні зв'язки [5, с. 21].

Об'єктом національної економіки виступає національна господарська система, різні аспекти якої досліджуються цілим рядом економічних дисциплін, серед яких політична економія, економічна історія, економічна географія, економічна статистика, економетрія тощо [6, с. 11].

У свою чергу, науковцями радянської доктрини господарські системи розглядалися через призму удосконалення системи управління соціалістичною економікою, основна увага приділялась дослідженню центрів господарських систем - міністерств, відомств, державних комітетів (що було зумовлено об'єктивними причинами, а саме наявним суспільно-економічним устроєм (РСР), їхні теоретичні розробки мають велике значення для осягнення суті, призначення та порядку функціонування господарських систем [7, с. 72]. Сучасні господарські системи створюються для забезпечення ефективної організації господарської діяльності суб'єктів господарювання через удосконалення: 1) управління господарською 
діяльністю та 2) регулювання господарської діяльності як форм здійснення організації такої діяльності [8; 9]. І. Кравець, здійснивши власне дослідження в царині даного питання, вважає, що господарська система - це комплекс взаємодіючих суб'єктів господарювання та суб'єктів організаційно-господарських повноважень, створений/сформований в установленому порядку з метою забезпечення ефективності організації та здійснення господарської діяльності учасниками комплексу (центром системи та підпорядкованими йому суб'єктами) шляхом взаємного дотримання ними своїх прав та виконання обов'язків, який функціонує на базі матеріальних ресурсів (майна), які належать учасникам такого комплексу на праві власності та/або інших правових титулах відповідно до законодавства [7, с. 74].

Поряд 3 існуванням різних типів національних господарських систем кожна із них може характеризуватися різними моделями організації національного господарства. Вибір конкретної моделі означає вибір шляху розвитку суспільства, встановлення певної системи економічних інтересів, що лежать в основі забезпечення впливу на темпи і пропорції цього розвитку [6, с. 48].

То що таке господарство країни? I чи не відображає цей термін ті ж самі змістові складники, що й національна економіка країни? Якщо проаналізувати увесь вищенаведений матеріал, логічним буде висновок про те, що ці терміни є різними. У глобальному сенсі термін «економіка» є ієрархічно вищим, аніж «господарство», де останній є його складником. Фактично, господарство - це приналежність до суб'єктної сторони правовідносин, тобто прив'язка до суб'єкта господарювання як потенційного учасника забезпечення матеріальними ресурсами країни чи окремого споживача. Відповідно, на наш погляд, національна економіка 3 адміністративної точки зору має розглядатись 3 використанням соціально-економічного підходу як сукупність відповідних правовідносин, що підлягають врегулюванню, регламентуванню та захисту, а національне господарство, як його частина, позначати сукупність галузей та окремих видів виробництв, тобто відображати технологічний підхід до розуміння змістового наповнення попереднього терміна.

Отже, категорія «національне господарство», як самостійна, може розглядатись тільки у контексті і з розумінням її як автономної частини національної економіки. Слід констатувати пряму їх взаємозалежність та приналежність.

Однак слід уточнити, що, окрім національного господарства, існує й світове - сис- тема взаємопов'язаних національних господарств, в основі якої - міжнародний поділ праці, різні економічні і політичні відносини. Воно охоплює всі країни, звідси - його неоднорідність і внутрішня суперечливість. Об'єктивною основою розвитку світового господарства $є$ міжнародний поділ праці, тобто спеціалізація окремих країн на виробництві певних видів продукції, якими вони обмінюються. Для того, щоб сформувалася спеціалізація, потрібні певні умови. По-перше, країна, яка бере участь у міжнародному поділі праці, повинна мати переваги (наприклад, багаті природні ресурси) перед іншими країнами у виробництві відповідної продукції; по-друге, мають бути країни, які потребують цієї продукції; по-третє, витрати на доставку продукції до місця продажу мають бути вигідні країні-виробнику [10, с. 308]. Умовно це спеціалізація країни на певній галузі чи виробництві продукції, яка за відсотковим співвідношенням є домінантною на її теренах.

Якщо говорити про господарство країни, а точніше його галузеві різновиди, то слід відзначити, що в умовах сьогодення їх існує дуже багато. Зокрема, це газове, лісове, водне, сільськогосподарське, фермерське, особисте селянське, автомобільне, енергетичне, промислове, рибне, дорожнє, житлово-комунальне тощо.

Якщо систематизувати та класифікувати їх в узагальнені групи, це галузі матеріального та нематеріального виробництва, й основна різниця між ними полягає в кінцевому рахунку виробленої продукції чи наданої послуги. До сфери матеріального виробництва входять промисловість, сільське, лісове, рибне господарство і будівництво - галузі, які випускають матеріальні блага (товари). Вони поділяються на вужчі галузі, підгалузі, види виробництв. Наприклад, великою галуззю промисловості $є$ машинобудування, в складі якого виділяється транспортне машинобудування. Вужчою його галуззю $є$ автомобілебудування, а підгалуззю - виробництво легкових автомобілів. Воно ж включає численні підприємства, що виробляють окремі деталі, вузли і агрегати (наприклад, мотори), а також складальні та ремонтні підприємства. У сфері послуг створюються духовні блага та послуги невиробничого й виробничого характеру. Одні галузі цієї сфери обслуговують безпосередньо населення (культура, освіта, медичне і рекреаційне обслуговування, побутове обслуговування), інші - населення і виробництво (транспорт і зв'язок, фінанси і кредит, торгівля, страхування), треті забезпечують функціонування суспільства взагалі (наука, управління) [11]. 
Різновиди галузевого господарства країни досліджувало багато вчених, зокрема: P. Леньо визначає перспективні напрями впровадження зарубіжного досвіду в систему управління лісовим господарством України; I. Григорюк формує новий історико-науковий погляд на сільське господарство України; А. Ситюк визначає особливості формування правового механізму залучення інвестицій у житлово-комунальне господарство; О. Дегтярьова аналізує особливості організації енергоменеджменту в системі управління енергетичним господарством; Н. Яркіна визначає тенденції, проблеми та перспективи рибного господарства України як складової частини світового рибогосподарського комплексу; Ю. Бараш формує принципи побудови організаційної структури управління пасажирським господарством на різних етапах структурної реформи Укрзалізниці; В. Клапчук розглядає історичну ретроспективу рекреаційного господарства на прикладі Галичини другої половини XIX - першої третини XX ст.; К. Ізмайлова досліджує хатнє господарство шахтарських родин Донбасу у 1965-1985 рр.; В. Горбаньов розглядає історіографію питання поміщицького господарства Харківської губернії другої половини XIX - початку XX ст.; М. Хмельнюк аналізує стійкий розвиток і холодильне господарство як необхідну умову економічної безпеки України тощо.

До прикладу, О. Соколовська на підставі дослідження змісту житлово-комунального господарства з'ясувала, що це поліструктурна, комплексна, системна галузь, яка забезпечує першочергові потреби населення та суттєво впливає на створення необхідних умов для ефективності й надійності функціонування господарського комплексу відповідно до встановлених нормативів і національних стандартів. Нею встановлено, що житловокомунальне господарство наділене такими характерними ознаками: системна галузь, що грунтується на нормативах і національних стандартах; має на меті забезпечення стандартних санітарно-гігієнічних умов життя; спрямована на задоволення першочергових потреб суспільства; основним прагненням $€$ якісне функціонування житлового, комунального, господарського комплексу; реалізується завдяки системі адміністративних послуг [12, с. 11].

У свою чергу О. Руденко визначає сільське господарство однією 3 пріоритетних галузей національної економіки. Розвиток сільськогосподарської галузі сприяє підвищенню матеріального добробуту населення, зміцненню економічної та продовольчої безпеки держави, зростанню іï експортного потенціалу. Водночас сільськогосподарський сектор виробництва - один з найбільш ризикових секторів економіки, оскільки на його розвиток великий вплив має дія природних факторів і біологічних чинників [13, с. 143].

\section{Висновки}

Усе вищенаведене дає можливість сформулювати висновок про те, що сталий економічний розвиток країни - основний чинник становлення держави як самодостатньої та цивілізаційної. Україна перебуває на перехідному етапі становлення, пошуку оптимальних шляхів іï належного розвитку та завоювання авторитету на міжнародній арені. Національне господарство країни найяскравіше характеризує іï сутність та реальний стан внутрішніх організаційних економічних процесів. Держава повинна підтримувати, стимулювати господарські взаємини суб'єктів, що реалізовують господарську діяльність в Україні, та мінімально втручатися в них.

\section{Список використаних джерел:}

1. Географія. Освітній портал «Академія». 2019. URL: http://zno. academia. in.ua/mod/book/ view.php?id $=2521$

2. Макроекономіка. Бібліотека економіста 2019. URL: https://library.if. ua/book/11/1076.html

3. Заставний Ф. Д. Економічна і соціальна географія України : підручник для 9 класу. Київ, 1999. 232c

4. Основи економіки. Сумський державний університет. 2019. URL: http://fem.sumdu.edu.ua/ images/docs/abiturient/osnovi\%20econom.pdf

5. Мельник А.Ф., Васіна А.Ю., Желюк Т.Л, Попович Т.М. Національна економіка : навчальний посібник. Київ, 2011. 463 с.

6. Старостенко Г. Г., Онишко С. В., Поснова Т. В. Національна економіка : навчальний посібник. Київ : Ліра-К, 2016. 432 с.

7. Кравець I. Поняття та класифікація сучасних господарських систем. Вісник Київського нащіонального університету імені Тараса Невченка. Серія «Юридичні науки». 2013. Вип. 3. С. 71-76.

8. Пилипенко А. Я. Правовое регулирование внутрихозяйственных отношений в производственных объединениях. Київ : Наукова думка, 1978. $151 \mathrm{c}$.

9. Плекан А. М. Правовое регулирование контроля хозяйственной деятельности в СССР. Рига, 1973. 61 с

10. Олійник Я.Б., Шищенко П.Г., Степаненко А.В., Масляк П.О. Географія : навчальний посібник для старшокласників та абітурієнтів. Biдповідi на всі питання нової програми. 5-те вид., перероб. і доп. Київ: ТВО «Знання», КОО, 2006. 455 с.

11. Гілецький Й. Р. Географія України. Соціально-економічна з основами теорії : підручник для 9 класу. Львів: ВНТЛ-Класика, 2002. 192с. 
12. Соколовська О. М. Адміністративна відповідальність за правопорушення в галузі житловокомунального господарства : автореф. дис. ... канд. юрид. наук : 12.00.07. Київ, 2011. 18 с
13. Руденко О.С. Регіональні особливості інвестування в сільське господарство. Актуальні проблеми розвитку економіки регіону. 2013. Вип. 9(1). С. 143-148.

The article reveals the relation between the categories "economy of the country" and "economy" from an administrative point of view. It is determined that the national economy should be considered as a socio-economic approach, as a set of relevant legal relations, which are subject to regulation and protection, and the economy, as a part of it, denote a set of industries and certain types of production, that is, reflect the technological approach. It is emphasized that by the technological approach, the national economy is an aggregate of industries, types of production and is characterized by the volume of products produced, works performed and services rendered, their quality, level of use of resources, etc. Socio-economic approach vieres the national economy as a set of industrial relations, which is characterized by a certain level of development of productive forces, type of economic system, the nature of social reproduction, specific economic mechanism, living standards of the population, foreign economic relations. It has been found that the world economy is a system of interconnected national economies, based on the international division of labor, different economic and political relations. It covers all countries, hence its heterogeneity and internal contradiction. The objective basis for the development of the world economy is the international division of labor, that is, the specialization of individual countries in the production of certain types of products that they exchange. It is concluded that the stable economic development of the country is a major factor in the formation of the state as self-sufficient and civilizational. Ukraine is in a transitional stage of formation, finding optimal ways of its proper development and gaining authority in the international arena. The national economy of the country most clearly characterizes its essence and the real state of internal organizational economic processes. The state should support, stimulate and minimally interfere in the economic relations of the entities engaged in economic activity in Ukraine.

Key words: categories, content, economy, national economy, relations, terms, world economy. 
УДК 342.9

DOI https://doi.org/10.32849/2663-5313/2019.8.14

\section{Лілія Золотухіна,}

канд. юрид. наук, дочент,

завідувач кафедри иивільно-правових дисииллін

Дніпропетровського державного університету внутрішніх справ України

\section{ЗАХИСТ ПУБЛІЧНОГО ІНТЕРЕСУ В АДМІНІСТРАТИВНОМУ ПОРЯДКУ}

У статті автором здійснюється аналіз категорії адміністративно-правового механізму забезпечення реалізачії публічного інтересу. Під адміністративно-правовим механізмом забезпечення реалізацї̈ публічного інтересу автором розуміється складна комплексна структурована система врегулювання відносин між органами публічного управління та суб'єктами владного впливу, метою функиіонування якої є задоволення об'єктивно визначених суспільним розвитком потреб, його своєрідних «надиілей». Обгрунтовано, що ефективність адміністративно-правового механізму забезпечення публічного інтересу досягається на нормативно-правовому, організачійно-управлінському та правозахисному рівнях. Обгрунтовано, що адміністративно-процедурний складник адміністративно-правового механізму захисту публічних інтересів призначений для попередження та припинення правопорушень у сфері реалізачії конкретного публічного інтересу. Наголошено, що функиіональне навантаження реалізаиії захисту публічного інтересу в адміністративному порядку зумовлює належність до иього рівня адміністративно-правового захисту процедур окремого типу - втручальних процедур негативного характеру. Визначено, що реалізачії захисту публічного інтересу в адміністративному порядку сприяє здійснення контрольно-наглядових адміністративних проиедур, що виконують функиію превениії порушення публічного інтересу, та процедури оскарження в адміністративному порядку, що спрямована на припинення можливого порушення публічного інтересу. Підкреслено нагальну необхідність прийняття Закону України «Про адміністративну процедуру», шо сприятиме підвищенню рівня ефективності забезпечення захисту публічного інтересу в адміністративному порядку.

Ключові слова: адміністративні правовідносини, ознаки, поняття, публічне управління, публічний інтерес.

Постановка проблеми. Становлення й розвиток вітчизняної науки адміністративного права закономірно супроводжується приростом та модернізацією адміністративно-правового тезаурусу, впровадженням в термінологічне наукове поле нових категорій і понять. Одним із таких словникових нововведень є поняття публічного інтересу, яке вже досить міцно зайняло позицію загальновживаного терміна; словосполучення на кшталт «відповідає публічним інтересам», «суперечить публічним інтересам», «становить публічний інтерес» в академічній літературі та науковій публіцистиці покликані свідчити про важливість або небезпечність того або іншого правового феномена.

Попри наявність теоретичних спроб визначити публічний інтерес як адміністративно-правову категорію, одностайно сприйнятої дефініції, як і законодавчої конструкції цього поняття, досі не вироблено. При цьому останнім часом у світлі доктринальної перебудови адміністративного права актуалізуються питання співвідношення публічного і приватного, публічного й державно- го, публічного й суспільного інтересів, що потребує активізації пізнавальних пошуків у цьому напрямі.

У практичній площині проблематика публічного інтересу пов'язана передусім із пошуком тієї межі, за яку не може й не повинна переступати публічна влада у разі вимушеного втручання в приватні інтереси за необхідності збереження інтересу публічного. Тому поняття «захист публічного інтересу» набуває важливого, без перебільшення визначального значення для характеристики публічно-управлінського регулювання суспільних відносин; лише та влада може називатися демократичною, що у визначенні цього інтересу спирається на реальні потреби суспільного розвитку та гарантії забезпечення прав і свобод людини, а не намагається розширити сферу власного впливу та розсуду.

Захист публічного інтересу має відбуватися у ході здійснення адміністративнопроцедурної діяльності органів публічного управління. Взагалі, сутність та особливості юридичних процедур слугували предметом багатьох правових досліджень. I відправною 
точкою пошуків найбільш повних та точних дефініцій адміністративно-правової процедури зазвичай слугує розгляд лексичного наповнення поняття «процедура».

Стан наукової розробки проблеми. Дослідження категорії адміністративноправового механізму забезпечення реалізації публічного інтересу є надзвичайно актуальним як у наукових колах, так серед практиків. Варто виділити наукові розробки таких вчених, як В. Б. Авер'янов, Ю. П. Битяк, В. І. Васильєва, О. В. Гончарук, Б. М. Дронів, С. П. Погребняк, Р. В. Сивий, В. М. Селіванов, В. В. Галунько, Р. А. Калюжний, М. П. Кунцевич, Ю. О. Легеза, С. В. Савченко, О. М. Вінник, Є. В. Курінний, В. К. Колпаков, Т. О. Коломоєць, А. Я. Курбатов, С. Т. Гончарук та ін. Однак е дослідженнях представників адміністративної науки однозначності підходів до встановлення сутності категорії адміністративноправового механізму забезпечення реалізації публічного інтересу не простежується. Крім того, в сучасних умовах вимагається переосмислення категорії адміністративно-правових відносин з урахуванням актуальності впровадження концепції публічного управління. Усе вищезазначене зумовило мету даного дослідження, яка полягає у здійсненні характеристики сутності захисту публічного інтересу в адміністративному порядку.

Виклад основного матеріалу. Так, 3 погляду етимології слово «процедура» походить від латинського «procedo», що означає «проходжу, просуваюсь» [1, с. 470; 2, с. 234]. Лексичне значення терміна «процедура» «будь-яка тривала послідовна справа, порядок, обряд» [3, с. 526], «офіційний порядок дій, виконання, обговорення чого-небудь» [4, с. 511]. Наведені визначення дозволяють виокремити такі сутнісні характеристики процедури: 1) наявність низки послідовних дій; 2) спрямованість на досягнення певного результату (оформлення, виконання, здійснення, обговорення будь-якої справи). Отже, процедуру в такому контексті можна трактувати як офіційно встановлений порядок виконання певної діяльності; відповідно, з юридичної точки зору визначальною характеристикою цього порядку дій виступає його регламентованість та закріпленість саме правовими нормами [5].

Названі визначальні ознаки варіативно присутні майже в усіх дефініціях адміністративної процедури, запропонованих вітчизняними адміністративістами та їхніми колегами 3 країн пострадянського простору. Словосполучення «порядок розгляду й вирішення індивідуальних справ» [6, с. 24 ; 7, с. $276 ;$ 8, с. 4; 9, с. 47], «послідовно здійсню- вана діяльність щодо розв'язання індивідуальних справ» [10, с. 4], «порядок розгляду й вирішення індивідуальних справ» [8, с. 9], «визначений порядок здійснення тих або інших дій» [5, с. 173], «модель діяльності, що реалізується в межах адміністративних правовідносин» [11, с. 92], «послідовність дій суб'єктів нормотворчої й правозастосовної діяльності» [12, с. 29], що використовуються науковцями у визначеннях адміністративної процедури, можна з упевненістю вважати майже синонімічними. Другий обов'язковий атрибут адміністративних процедур - нормативно-правову регламентацію - у дефінітивних пошуках зазвичай відображують через терміни «встановленість законодавством» [6, с. $24 ; 7$, с. 276$]$, «нормативна урегульованість» [10, с. 4], «закріпленість нормами адміністративно-процесуального права» $[5$, с. 177 ; 8, с. 9] або «урегульованість адміністративнопроцедурними нормами» [8, с. 13; 12, с. 29].

Підсумовуючи результати аналізу розробленості в науковому просторі українського адміністративного права проблематики адміністративної процедури, можемо зазначити таке. Основними ознаками адміністративної процедури дослідники визнають: по-перше, iï ідеальний (еталонний) характер, тому що процедура - це попередньо визначена модель дій, застосування якої в реальному житті забезпечує досягнення необхідного результату; по-друге, юридичну силу адміністративної процедури, оскільки норми, що визначають процедурну діяльність, закріплені в законі, як і основні; нарешті, обмеженість адміністративної процедури межами регулятивного впливу процедурних норм [8, с. 13].

Щодо адміністративно-процедурних норм слід обумовити їхній тісний зв'язок та взаємозалежність 3 основними нормами. За висновками дослідників, процедурні норми, сприяючи реалізації основних норм, не торкаються змістової (внутрішньої) сторони останніх, а лише регламентують зовнішній процес їх впровадження [13, с. 6-18]; причому це не означає другорядної, обслуговуючої ролі процедурних норм, які, як і основні норми, характеризуються рівною значущістю й цінністю [14, с. 176]. Саме це, на думку науковців, забезпечує законність та обгрунтованість правозастосування в адміністративно-правовому полі. Адже, власне, адміністративні процедури призначені забезпечувати встановлення й дотримання меж дискреції суб'єктами владних повноважень під час прийняття адміністративних рішень [15, с. 167], захищаючи інших учасників адміністративних правовідносин від необмеженого адміністративного розсуду з боку зазначених суб'єктів [16, с. 9]. 
Таким чином, використовуючи здобутки вітчизняних фахівців у галузі дослідження адміністративної процедури, можемо констатувати, що адміністративна процедура в найбільш загальному розумінні являє собою встановлений адміністративно-правовими нормами порядок розгляду та вирішення справи адміністративним органом [6, с. 25], виступаючи нормативною моделлю адміністративного провадження, яке, у свою чергу, становить собою розгляд та вирішення окремої справи (тобто конкретну активну діяльність адміністративного органу) [17, с. 134-135; 18, c. 156$]$.

Декілька слів слід сказати про суб'єктів адміністративно-процедурного захисту публічних інтересів. Беручи до уваги, що зміст цієї форми адміністративного захисту становлять адміністративні процедури державного контролю та оскарження, можна зазначити, що систему зазначених суб'єктів становлять насамперед центральні органи виконавчої влади, на яких Законом України «Про центральні органи виконавчої влади» покладено завдання реалізації державного контролю [19]. Окремі функції зі здійснення державного контролю виконують також місцеві державні адміністрації [20]. Зазначимо, що діяльність у галузі розгляду адміністративних скарг також можна віднести до сфери контрольної діяльності; у цьому разі йдеться про внутрішньовідомчий контроль, що передбачає розгляд адміністративної скарги на дії нижчої структури (органу публічного управління) вищим за ієрархічним становищем органом.

Важливим елементом системи суб'єктів адміністративно-процедурного захисту публічних інтересів мали б стати органи та структури громадського контролю, адже перевірка відповідності діяльності суб'єктів публічної влади публічним інтересам та вимогам законодавства органічно виглядає головним призначенням цього виду контролю. Але наразі в Україні лише перебуває у процесі становлення законодавча база такої діяльності, формуються засади створення таких організацій, напрацьовується методологія та формуються стандарти їхньої роботи [21, с. 190]. Тому сьогодні ми можемо лише визначити організації з громадського контролю як потенційних суб'єктів адміністративно-процедурного захисту публічних інтересів.

Говорячи про контрольно-наглядові процедури, перш за все слід зазначити, що державний контроль більшість учених визначає як одну з головних функцій публічного управління. На думку В. Я. Малиновського, управлінське призначення контролю поля- гає в тому, що він слугує джерелом інформації про процеси, які відбуваються, виступае умовою підтримки законності, порядку й організованості, охорони свободи і дотримання прав громадян [22, с. 291], тобто, якщо співвіднести 3 темою нашого дослідження, є засобом охорони і збереження публічних інтересів. За переконанням В. М. Гаращука, сутність контролю полягає у перевірці відповідності діяльності учасників суспільних відносин встановленим у суспільстві приписам, у межах яких вони мають діяти [23, с. 403-408], тобто відповідає публічному інтересу збереження законності. О. Ф. Андрійко у свою чергу розуміє сутність державного контролю як проведення інформаційно-аналітичної роботи стосовно актуального стану чи ситуації, перевірку раціональності, економічності, економності, доцільності організації процесу управління та об'єктивності рішень, коли мається на увазі не лише їх правомірність (законність), але також і їх професійна обгрунтованість [24, с. 12-14].

Взагалі державний контроль - це одна iз функцій публічної влади, спрямована на забезпечення додержання громадянами норм законів та інших нормативних актів, що видаються органами держави [22, с. 293-294]. Адміністративна процедура як модель контрольно-наглядової діяльності об'єктивується у вигляді сукупності контрольно-наглядових проваджень, які є змістом адміністративної діяльності органу виконавчої влади.

Виходячи із сутності та призначення державного контролю, науковці виділяють такі функції контрольно-наглядових проваджень у сфері управління:

а) регулювання суспільних відносин коригування та спрямування дій підконтрольного органа (об'єкта) у потрібному напрямі (щодо нашої тематики - у напрямі збереження публічного інтересу) в разі виявлення порушень;

б) соціальної превенції - попередження вчинення порушення публічних інтересів;

в) правоохоронну - забезпечення поновлення порушених публічних інтересів;

г) інформаційну - отримання контрольним органом інформації про стан справ у сфері його інтересів, відповідності діяльності підконтрольного органу нормативним актам, виконанню завдань управлінського впливу щодо охорони та захисту публічних інтересів [17, с. 243]

Завдання контролю реалізується суб'єктами публічного управління через широке коло належних їм повноважень: проводити інспекційні перевірки на підприємствах та в організаціях всіх форм власності; вимагати від усіх посадових осіб, організацій, 
підприємств, громадян надання відповідної документації та інформації, що стосується інспекційної діяльності, подавати клопотання та подання до відповідних державних управлінських та правоохоронних органів про застосування адміністративних, економічних чи інших правових санкцій за результатами інспектувань [25, с. 243].

Реалізація зазначених повноважень полягає у конкретній послідовності дій, визначених процедурою контрольного адміністративного провадження. Стосовно наукового аналізу діяльнісної структури адміністративної процедури маємо зазначити, що в академічних колах не вироблено єдиного підходу до цього питання; у найбільш загальному вигляді адміністративно-контрольне провадження можна розглядати як сукупність таких стадій: 1) стадія підготовки, у межах якої збирається інформація про фактичний стан діяльності об'єкта контролю, розробляється план проведення контрольних заходів, ix ресурсного забезпечення, визначаються напрями взаємодії між суб'єктами контрольної діяльності, проводяться необхідні підготовчі дії (готуються документи, надсилаються запити тощо); 2) аналітична стадія, під час якої встановлюється відповідність діяльності об'єкта контролю, що піддана контролю, чинному законодавству. У межах цієі стадії порівнюється реальний стан речей із правилами, встановленими чинним законодавством; 3) стадія прийняття рішення (підготовки акта, висновку тощо) за результатами аналітичної діяльності, доведення його до адресата; 4) стадія перевірки виконання рішення, під час якої визначається ступінь виконання правових вимог, передбачених у рішенні [26, с. 201].

Контрольно-наглядові провадження виступають способом захисту багатьох публічних інтересів; до таких можна віднести контрольні заходи у сфері економіки, що здійснюються Антимонопольним комітетом України та покликані захищати публічний інтерес у підтримці й розвитку економічної конкуренції; заходи з контролю якості й безпеки лікарських засобів та контроль за відповідністю лікарських призначень медичним стандартам і протоколам, що здійснюються Державною службою України 3 лікарських засобів та контролю за наркотиками та захищають публічний інтерес у якісному та безпечному медичному обслуговуванні; покликаний захищати публічний інтерес у збереженні безпечного та здорового довкілля контроль за відповідністю господарської діяльності вимогам екологічної безпеки, який $є$ функцією Державної екологічної інспекції України та органів спеціальної ком- петенції, що здійснюють управління у сфері використання окремих природних ресурсів та природних об'єктів, тощо. Зрозуміло, що розглянути навіть частину із наведених прикладів у межах магістерської роботи неможливо; тому як приклад ми обрали контрольну діяльність органів публічного управління як інструмент захисту різних публічних інтересів у певних сферах суспільного життя, зокрема публічний інтерес, що полягає у збереженні культурної спадщини, та публічний інтерес у раціональному використанні природних ресурсів.

Питання захисту об'єктів культурної спадщини - один із найбільш важливих публічних інтересів в аспекті збереження національно-духовного капіталу та підтримки культурного престижу (й відповідного туристичного потенціалу) країни. Відповідно, об'єкти та пам'ятки національної архітектури та містобудування перебувають під захистом держави, елементом якого виступає контрольно-наглядова діяльність органів публічного управління за їх належним утриманням та відповідним використанням. Особливістю цієї діяльності є те, що, якщо звичайно контроль та нагляд відбуваються після проведення певної діяльності на об’єктах контролю, в даному разі вони передують здійсненню цієї діяльності, зокрема використанню земельних ділянок, на яких розташовані зазначені пам'ятки. Тобто органи публічного управління здійснюють зазначений контроль під час погодження проектної документації із землеустрою щодо містобудівних, архітектурних чи ландшафтних перетворень.

Серед проблем, що супроводжують адміністративно-контрольну діяльність у сфері захисту культурної спадщини, дослідники насамперед називають недосконалість системи органів управління у цій галузі. Так, ст. 5 Закону України «Про охорону культурної спадщини» [27] визначає уповноваженим органом єдиний центральний орган виконавчої влади, який повинен забезпечувати виконання покладених на нього законом повноважень (Міністерство культури, Управління охорони культурної спадщини). Однак відповідно до напрацьованої чинної нормативної бази передбачається здійснення повноважень 3 питань управління та контролю за збереженням і функціонуванням об'єктів культурної спадщини також і іншими відомствами: щодо частини пам'яток архітектури, містобудування - Мінрегіон; над пам'ятками садово-паркового мистецтва, ландшафтними - Мінприроди; контроль за використанням земель історико-культурного призначення - Мінагрополітики тощо 
[28, с. 13]. Водночас оптимізація зазначеної системи органів публічного управління має бути спрямована на створення єдиної системи захисту культурної спадщини, для чого потрібно визначити в системі центральних органів виконавчої влади єдиний орган 3 питань управління та контролю у сфері охорони культурної спадщини 3 відповідною управлінською вертикаллю та уточнити регулятивні (облікові, дозвільні) та захисні (контрольно-наглядові) функції, що входитимуть до його компетенції.

Щодо безпосередньо процедурних аспектів здійснення контрольної діяльності в галузі захисту публічного інтересу щодо збереження культурної спадщини слід зазначити, що її необхідним складником, згідно з Постановою Кабінету Міністрів України від 21 лютого 2018 року [29], виступає відповідність проектної документації на будівництво, реконструкцію чи капітальний ремонт історико-архітектурному опорному плану. При цьому лише 20 \% з 401 населеного пункту, включеного до Списку історичних населених місць України, мають актуальні історико-архітектурні опорні плани, які фіксують розташування всіх нерухомих пам'яток історії та культури і нововиявлені об'єкти 3 їх територіями та зонами охорони. Це дозволяє дослідникам робити припущення, що в такому разі будівельні роботи ведуться попри відсутність згаданих документів, оскільки місцева влада не володіє дієвими засобами для їх припинення і, посилаючись на потреби наповнення бюджету та необхідність розвитку міста, часто віддає перевагу домовленостям із забудовниками [30]. Зазначене свідчить про незадовільний рівень адміністративно-процедурного забезпечення захисту публічного інтересу щодо збереження культурної спадщини.

Говорячи про модернізацію сфери нормативно-правового забезпечення, ми передусім маємо на увазі ухвалення Закону України «Про адміністративну процедуру», проект якого нині перебуває на розгляді комітету Верховної Ради, що його визначено головним із підготовки і попереднього розгляду цього законопроекту [31]. Створення грунтовної нормативної бази для здійснення процедурно-адміністративної діяльності у вигляді цього Закону позитивно вплине на обидва розглянуті процедурні аспекти адміністративно-правового захисту публічних інтересів.

У світлі нашої тематики ухвалення зазначеного акта важливе не тільки в аспекті оптимізації процедурної діяльності; однією з новел цього Проекту є законодавче визначення публічного інтересу як правової категорії, згідно з яким він являє собою «інтерес держави, суспільства, громади, а також важливі для значної кількості фізичних та/або юридичних осіб інтереси та потреби» [31]. Цей момент є значним кроком не тільки з погляду на уточнення дефініції публічного інтересу; зазначеним документом фактично легалізується статус публічного інтересу як об'єкта адміністративно-процедурного захисту. Тобто адміністративна процедура стає не тільки інструментом захисту приватних інтересів від необмеженого адміністративного розсуду з боку суб'єктів публічної влади, як зазначено в більшості наукових досліджень; легітимується іï спрямованість передусім на захист публічних інтересів.

Взагалі в академічній літературі та науковій публіцистиці питання про необхідність ухвалення Закону «Про адміністративну процедуру» обговорювалося сотні разів за останні 20 років - саме стільки триває історія становлення адміністративної процедури як механізму захисту прав і свобод приватних осіб від несправедливих і протиправних рішень органів публічної влади в українському адміністративно-правовому просторі. Водночас у наукових колах протягом усього часу лунали аргументи на користь ухвалення Закону; значний внесок у справу легітимації адміністративної процедури як способу захисту приватної особи від можливого свавілля адміністрації зробили В. Б. Авер'янов, І. П. Голосніченко, І. Б. Коліушко, О. В. Кузьменко, В. П. Тимощук та інші відомі адміністративісти України.

Чергова спроба прийняття цього Закону відбувається просто зараз. Сподіваємося, що адміністративне законодавство нашої держави збагатиться за рахунок цього вкрай необхідного в сучасній ситуації правового акта, а ці законотворчі зміни дозволять посилити адміністративно-процедурний аспект захисту як приватних, так і публічних інтересів.

\section{Висновки}

Адміністративно-процедурний складник адміністративно-правового механізму захисту публічних інтересів призначений для попередження та припинення правопорушень у сфері реалізації конкретного публічного інтересу. Це функціональне навантаження зумовлює належність до цього рівня адміністративно-правового захисту процедур окремого типу - втручальних процедур негативного характеру. Як конкретні приклади зазначених процедур проаналізовані контрольно-наглядові адміністративні процедури, що виконують функцію превенції порушення публічного інтересу, та процедура оскарження в адміністративному порядку, 
спрямована на припинення можливого порушення публічного інтересу.

Розгляд стану речей у галузі застосування зазначених адміністративних процедур дозволив встановити загальну для обох напрямів проблемну зону - недосконалість нормативно-правового забезпечення реалізації зазначених процедур - і відповідний недостатній рівень ефективності адміністративно-правового захисту публічних інтересів на цьому рівні.

\section{Список використаних джерел:}

1. Словник іншомовних слів / уклад. Морозов С.М., Шкарапута Л.М. Київ : Наукова думка, 2000. C. 470 .

2. Юридичні терміни: тлумачний словник / за ред. В.Г. Гончаренка. Київ : Либідь, 2003. С. 234.

3. Даль В. И. Толковый словарь живого великого русского языка : в 4 т. Москва : Рус. яз., 1980. T. 3. C. 526 .

4. Ожегов С. И. Словарь русского языка. Москва : Рус. яз., 1987. С. 511.

5. Галіцина Н. В. Адміністративна процедура як інститут адміністративного процесу. Форум права. 2010. № 4. C. 163-177. C. 166. URL : http://www nbuv.gov.ua/e- journals/FP/2010-4/10gnviap.pdf

6. Адміністративна процедура та адміністративні послуги. Зарубіжний досвід і пропозиції для України / автор-упорядник В.П. Тимощук. Київ : Факт, 2003. 496 с

7. Адміністративне право України : підручник / за ред. Ю. П. Битяка. Київ: Юрінком Інтер, $2005.544 \mathrm{c}$.

8. Лагода О.С. Адміністративна процедура: теорія і практика застосування : автореф. дис. ... канд. юрид. наук : 12.00.07. Ірпінь, 2007. 21 с.

9. Комзюк А. Т., Бевзенко В. М., Мельник Р. С. Адміністративний процес України : навчальний посібник. Київ : Прецедент, 2007. 531 с.

10. Талапина Э.В., Тихомиров Ю. А. Административные процедуры и право. Журнал россииского права. 2002. № 4. С. 3-13.

11. Филатова А. В. Регламенты и процедуры в сфере реализации государственного контроля (надзора) : монография / под ред. Н.М. Конина. Саратов : Научная книга, 2009. 280 с.

12. Миколенко О. І. Місце адміністративного процедурного права в системі юридичних знань та системі права України. Запоріжжя, 2011. 40 с.

13. Гусаров С., Білоус В. Визначення понять адміністративної процедури та адміністративного процесу в адміністративному праві України. Вісник Академї управління МВС. 2008. № 3. C. 6-18.

14.Лукьянова Е. Г. Теория процессуального права : монография. Москва : НОРМА, 2003. 240 с.

15. Кузьменко О. В. Теоретичні засади адміністративного процесу : монографія. Київ : Атіка, 2005. $352 \mathrm{c}$.

16. Авер'янов В.Б.Значення адміністративних процедур у реформуванні адміністративного права. Часопис Київського університету права. 2009. № 3. C. 8-14.

17. Демський Е. Ф. Адміністративне процесуальне право України: навчальний посібник для вузів. Київ : Юрінком Інтер, 2008. 495 с.

18. Колпаков В. К., Коломоєць Т. О. Вступ до навчального курсу «Адміністративне право України» : навчальна лекція. Київ : ІнЮре, 2014. 240 с.

19. Про центральні органи виконавчої влади : Закон України від 17.03.2011 № 3166-VI [в ред. від 01.01.2019] // Законодавство України. URL : https://zakon.rada.gov.ua/laws/show/3166-17

20. Про місцеві державні адміністрації : Закон України від 09.04.1999 № 568-XIV [в ред. від 11.01.2019] // Законодавство України. URL : https://zakon.rada.gov.ua/laws/show/586-14

21. Участь громадськості у процесі прийняття рішень на місцевому рівні : навчально-методичний посібник. Київ : ДП «Укртех-інформ», 2013. 250 с.

22. Малиновський В. Я. Державне управління : навчальний посібник. 2-ге вид. Київ : Атіка, 2003. 576 с.

23. Правова система: історія, стан та перспективи : у 5 т. Т. 2 : Конституційні засади правової системи України і проблеми їі вдосконалення / за заг. ред. Ю. П. Битяка. Харків : Право, 2008. 576 с.

24. Андрійко О. Ф. Організаційно-правові проблеми державного контролю у сфері виконавчої влади України : автореф. дис. ... д-ра юрид. наук : 12.00.07. Київ, 1999. 38 с.

25.Легеза Ю. О. Адміністративно-правові засади публічного управління у сфері використання природних ресурсів : дис. ... д-ра юрид. наук : 12.00.07. Запоріжжя, 2018. 512 с.

26. Вітвіцький С. С. Уніфікація процедур державного контролю діяльності публічної адміністрації. Науковий вісник Дніпропетровського державного університету внутрішніх справ. 2015. № 4. C. $195-203$.

27. Про охорону культурної спадщини : Закон України від 08.06.2000 № 1805-III [в ред. від 25.01.2019] // Законодавство України. URL : https://zakon.rada.gov.ua/laws/show/1805-14

28. Про стан збереження культурної спадщини України : інф.-аналіт. матеріали до парламентських слухань «Стан, проблеми та перспективи охорони культурної спадщини в Україні» / авт.упор. С. І. Кот. Київ, 2018. 42 с.

29. Про внесення змін до Порядку визначення меж та режимів використання історичних ареалів населених місць, обмеження господарської діяльності на території історичних ареалів населених місць : Постанова Кабінету Міністрів України від 21.02.2018 № 92 // Законодавство України. URL : https://www.kmu.gov.ua/ua/npas/pro-vnesennyazmin-do

30. Інституційні та правові проблеми збереження культурно спадщини / Національний інститут стратегічних досліджень. URL : https://www.niss.gov.ua/en/node/100

31. Про адміністративну процедуру: картка проекту Закону України від 28.12.2018 № 9456 // Законодавство України. URL: http://w1.c1.rada. gov.ua/pls/zweb2/webproc4 1?pf3511=65307 
In the article the author analyzes the category of administrative and legal mechanism for ensuring the realization of public interest. Under the administrative-legal mechanism for ensuring the realization of public interest, the author understands complex complex structured system of regulation of relations between public administration bodies and subjects of power influence, the purpose of functioning of which is the satisfaction of objectively defined social development needs, its peculiar "over-goals". It is substantiated that the effectiveness of the administrative-legal mechanism of ensuring public interest is achieved at the normative-legal, organizational, managerial and human-rights levels. It is substantiated that the administrative and procedural component of the administrative-legal mechanism for the protection of public interests is intended for the prevention and cessation of offenses in the realization of a particular public interest. It is stressed that the functional load of the implementation of protection of public interest in an administrative order determines the belonging to this level of administrative legal protection of procedures of a separate type - interference procedures of a negative nature. It has been determined that the implementation of the protection of public interest in an administrative manner facilitates the implementation of control and supervision administrative procedures that serve as a preventive measure of violations of public interest, and administrative appeals procedures aimed at stopping a possible violation of public interest. Emphasis was made on the urgent need for the adoption of the Law of Ukraine "On Administrative Procedure", which will increase the efficiency of ensuring the protection of public interest in an administrative manner.

Key words: administrative relations, definitions, concept, public administration, public interest. 
УДК 342.7

DOI https://doi.org/10.32849/2663-5313/2019.8.15

\section{Олена Калашник,}

канд. юрид. наук, дочент кафедри публічного та приватного права

факультету права та міжнародних відносин

Київського університету імені Бориса Грінченка,

адвокат, илен Комітету захисту прав та гарантій адвокатської діяльності

при Раді адвокатів Харківської області

\section{ПРІОРИТЕТ СТАЛОСТІ СІМЕЙНИХ ЗВ'ЯЗКІВ ТА ВОЗЗ'ЄДНАННЯ СІМ'Ї У СПРАВАХ ПРО ВИЗНАННЯ ШУКАЧА ЗАХИСТУ ТА ЧЛЕНІВ ЙОГО РОДИНИ БІЖЕНЦЯМИ АБО ОСОБАМИ, ЯКІ ПОТРЕБУЮТЬ ДОДАТКОВОГО ЗАХИСТУ}

У статті проаналізовано права біжениів або осіб, які потребують додаткового захисту щодо сталості сімейних зв'язків та возз'єднання сім'ї у справах про визнання шукача захисту та членів його родини біжениями або особами, які потребують додаткового захисту Державною міграиійною службою України та судами. Обгрунтовано пропозииї щодо вдосконалення забезпечення прав шукачів захисту та членів їх родин на возз'єднання сім'ї та забезпечення сталості сімейних зв'язків.

Також автором наведено останні наукові дослідження щодо правового статусу біжениів або осіб, які потребують додаткового захисту. Наведений перелік та проведений аналіз основних міжнародних та начіональних нормативно-правових актів у сфері забезпечення прав шукачів захисту та членів їх родин на возз'єднання сім'ї та забезпечення сталості сімейних зв'язків.

Проаналізовано судову практику у справах за позовами шукачів захисту в Україні до Державноі міграційної служби України про визнання протиправним та скасування рішень про відмову у визнанні їх біжениями або особами, які потребують додаткового захисту. Наведено основні проблеми дотримання прав шукачів захисту шодо сталості сімейних зв'язків та возз'єднання їх сімей в Украйні.

У статті проаналізовано, що Європейський суд з прав людини притримується позииії щодо забезпечення пріоритету сталості сімейних зв'язків та возз'єднання сім'ї у справах про визнання шукача захисту та членів його родини біжениями. Автором приведено приклад рішення Європейського суду з прав людини з досліджуваної тематики.

Автором зроблені висновки, що для вирішення проблем забезпечення пріоритету сталості сімейних зв'язків та возз'єднання сім'ї у справах про визнання шукача захисту та членів його родини біжениями, судам України слід застосовувати позитивну практику Європейського суду з прав людини. В статті наведені випадки обмеження у забезпеченні сталості сімейних зв'язків та обмеження права возз'єднання сім'ї шукачів захисту в Україні.

Ключові слова: права біженців, возз'єднання сім'ї, шукач захисту, правовий статус біженця, сталість сімейних зв'язків, позов про визнання протиправним та скасування рішення.

Постановка проблеми. Часто в провадженні українських судів знаходяться справи за позовом шукачів захисту в Україні до Державної міграційної служби України про визнання протиправними та скасування рішень про відмову у визнанні іх біженцями або особами, які потребують додаткового захисту. Однак, враховуючи те, що шукач захисту зазвичай тікає від небезпеки зі своєї країни походження, а не обирає для себе більш привабливе місце проживання, зрозуміло, що він не в змозі збирати письмові докази загрози його життю.

Україна ратифікувала ряд конвенцій та міжнародних договорів, а тому іноземець, що шукає притулку, може звернутися в Україні за захистом, і це його невід'ємне право. У зв'язку з цим правом у Державної міграційної служби України виникає обов'язок перевірити надану шукачем захисту інформацію та дотриматися вимог міжнародного та національного законодавства. Здебільшого шукач захисту, якому загрожує небезпека у країні походження, прямує до України зі своєю сім'єю. Отже, якщо шукача захисту в Україні буде визнано біженцем або особою, яка потребує додаткового захисту, то члени його родини теж набувають відповідних прав. Проте на практиці з приводу цього 
виникає ряд суперечностей, не дивлячись на наукові здобутки з досліджуваної тематики.

Аналіз досліджень з тематики. Загалом проблемам правого статусу біженців на міжнародному рівні присвячені праці таких вчених, як Л. Горденкер, Дж. Вернант, А. Грал-Мегсен, Л. Холборн, Я. Макдональдс, Г. Гудвіна-Гілл, Г. Меландер, Г. Стенберг, Х. Хаковірт, П. Нобеля, та інших.

Серед вітчизняних науковців, які досліджували питання біженців, слід назвати таких, як В.І. Потапов, А.Ю. Ястребова, М.О. Баймуратов, О.І. Піскун, М.В. Буроменський, В.І. Новік, Ю.М. Тодика, Л.А. Галенська, О.А. Малиновська,Д.В.Іванов, О.А. Гончаренко,В.Д.Андрієнко,Ю.М.Білуха,С.П.Бритченко, Ю.В.Бузницький, В.С.Гринчак, В.І. Євінтов, О.Л. Копиленко, В.С.Крисаченко,О.В.Кузьменко,В.Ф.Погорілко, С.П. Ратушний, Ю.І. Римаренко, С.Г. Рубанов, О.Ф. Фрицький, С.Б. Чехович, В.М. Шаповал, Ю.С. Шемшученко, В.В. Шепель, М.О. Шульга, І.Г. Ковалишина, О.Р. Поєдинок, К.О. Нестеренко та інших.

Разом $з$ тим, враховуючи динамічність суспільних відносин в Україні та у світі, наявність війн та збройних конфліктів, сьогодні виникає необхідність у вирішенні питання пріоритету сталості сімейних зв'язків та недопущення роз'єднання сім'ї у справах про визнання шукача захисту біженцем або особою, яка потребує додаткового захисту. Не дивлячись на ряд ратифікованих Україною міжнародних правових актів та національних нормативних правових актів (Конвенція про статус біженців 1951 року, ратифікована Законом України № 2942-III від 10 січня 2002 року, яка розтлумачена у «Керівництві з процедур і критеріїв визначення статусу біженця за Конвенцією про статус біженців 1951 року та Протоколу до неї 1967 року», які $є$ обов'язковими для національних суб'єктів владних повноважень, зокрема, з огляду на положення Угоди між Урядом України та Управлінням Верховного Комісара ООН у справах біженців від 23 вересня 1999 року, ратифікованої Законом України № 1185-14 від 21 жовтня 1999 року [8]; Протокол до Конвенції 1967 року, ратифікований Законом України №2942-III від 10 січня 2002 року; Конвенція про захист прав людини і основоположних свобод 1950 року, ратифікована Законом України № 475/97-ВР від 17 липня 1997 року; Конвенція ООН «Проти катувань та інших жорстоких, нелюдських або принижуючих гідність видів поводження і покарання» від 10 грудня 1984 року, ратифікована Законами України № 3484-XI від 26 січня 1987 року та 234-XIV від 05 листопада 1998 року; Закон України «Про виконання рішень та застосування прак- тики Свропейського суду з прав людини» № 3477-IV від 23 лютого 2006 року, згідно з положеннями ст. 17 якого положення Європейської конвенції та практика Європейського Суду з прав людини є джерелом права в Україні [7]; Закон України «Про біженців або осіб, які потребують додаткового захисту або тимчасового захисту» № 3671-VI від 08 липня 2011 року) право шукачів захисту на сталість сімейних зв'язків та возз'єднання сім'ї часто порушуються в Україні.

Метою статті $є$ дослідження основних проблем, пов'язаних зі сталістю сімейних зв'язків та возз'єднанням сімей шукачів захисту в Україні, а також пошук шляхів їх вирішення.

Виклад основного матеріалу. Проаналізувавши судову практику у справах за позовами шукачів захисту в Україні до Державної міграційної служби України про визнання протиправним та скасування рішень про відмову у визнанні їх біженцями або особами, які потребують додаткового захисту, слід вказати, що основними проблемами у дотриманні прав шукачів захисту щодо сталості сімейних зв'язків та возз'єднання їх сім'ї в Україні, зокрема, є: відмова Державної міграційної служби України або суду визнавати біженцями або особами, які потребують додаткового захисту, членів сім'ї особи, яка вже визнана біженцем або особою, що потребує додаткового захисту на підставі рішення Державної міграційної служби України; відмова Державної міграційної служби України або суду визнавати біженцями або особами, які потребують додаткового захисту, членів сім'ї особи, яка отримала позитивне рішення суду про задоволення позову визнати її біженцем або особою, яка потребує додаткового захисту; відмова Державної міграційної служби України або суду визнавати біженцями або особами, які потребують додаткового захисту, членів сім'ї померлого, який був визнаний біженцем або особою, що потребує додаткового захисту на підставі рішення Державної міграційної служби України або в судовому порядку; відмова Державної міграційної служби України або суду визнавати біженцями або особами, які потребують додаткового захисту членів сім'ї, які не були включені до анкети під час звернення заявника за захистом; відмова Державної міграційної служби України або суду визнавати біженцями або особами, які потребують додаткового захисту осіб, які мають тісний зв'язок з Україною (шлюб, рідні діти тощо) та інші.

Так, О.Р. Поєдинок зазначала, що особливий характер зобов'язань у сфері міжна- 
родного захисту прав людини пояснюється обмеженням можливостей формулювати застереження та заперечення проти застережень до міжнародних договорів щодо прав людини, обмеженням застосування принципу взаємності щодо зобов'язань у сфері прав людини, специфічними правилами тлумачення норм, які стосуються захисту прав людини, сформованими практикою спеціалізованих міжнародних судових установ, наявністю спеціального (галузевого) режиму міжнародно-правової відповідальності держав [1, с. 11].

В національному законодавстві України (конституційне, адміністративне, сімейне та ін.) не визначено обмеження біженця або особи, яка потребує додаткового захисту, у забезпеченні сталості сімейних зв'язків та обмеження права возз'єднання їх сім'ї в Україні, за винятком осіб, які вчинили злочин проти миру, воєнний злочин або злочин проти людства і людяності, як їх визначено у міжнародному праві; які вчинили тяжкий злочин неполітичного характеру за межами України до прибуття в Україну з метою набуття статусу біженця, якщо таке діяння віднесено Кримінальним кодексом України до тяжких злочинів; які винні у вчиненні дій, що суперечать цілям та принципам Організації Об'єднаних Націй, визначених у Статуті Організації Об'єднаних Націй [4].

Так, згідно зі ст. 8 Конвенції про захист прав людини i основоположних свобод кожен має право на повагу до свого приватного і сімейного життя, до свого житла і кореспонденції. Органи державної влади не можуть втручатись у здійснення цього права, за винятком випадків, коли втручання здійснюється згідно із законом і є необхідним у демократичному суспільстві в інтересах національної та громадської безпеки чи економічного добробуту країни, для запобігання заворушенням чи злочинам, для захисту здоров'я чи моралі або для захисту прав $\mathrm{i}$ свобод інших осіб [2].

Отже, положення про забезпечення сталості сімейних зв'язків та право возз'єднання сім'ї фактично гарантовано шукачам захисту на міжнародному рівні.

Згідно 3 ч. 1 ст. 55 Сімейного кодексу України дружина та чоловік зобов'язані спільно піклуватися про побудову сімейних відносин між собою та іншими членами сім'ї на почуттях взаємної любові, поваги, дружби, взаємодопомоги [3].

Відповідно до ч. ч. 1, 2 ст. 3 Сімейного кодексу України сім'я є первинним та основним осередком суспільства. Сім'ю складають особи, які спільно проживають, пов'язані спільним побутом, мають взаємні права та обов'язки. Кожна особа має право на проживання в сім'ї. Особа може бути примусово ізольована від сім'ї лише у випадках і в порядку, встановлених законом [3].

Приписами ст. 5 Сімейного кодексу України визначено, що держава охороняє сім'ю, дитинство, материнство, батьківство, створює умови для зміцнення сім'ї. Держава створює людині умови для материнства та батьківства, забезпечує охорону прав матеpi та батька, матеріально і морально заохочує і підтримує материнство та батьківство. Держава забезпечує пріоритет сімейного виховання дитини. Держава бере під свою охорону кожну дитину-сироту i дитину, позбавлену батьківського піклування. Ніхто не може зазнавати втручання в його сімейне життя, крім випадків, встановлених Конституцією України [3].

Виходячи $з$ приписів Сімейного кодексу України, Україна, в особі уповноважених компетентних органів, не вправі розлучати сім'ї біженців або осіб, які потребують додаткового захисту.

Положеннями ч. 1 ст. 4 Закону України «Про біженців та осіб, які потребують додаткового або тимчасового захисту» закріплено збереження єдності сімей біженців та осіб, які потребують додаткового захисту або яким надано тимчасовий захист. Зокрема, у ч. 1 ст. 10 цього ж Закону передбачається, що центральний орган виконавчої влади, що реалізує державну політику у сфері біженців та осіб, які потребують додаткового або тимчасового захисту, приймає рішення за заявою про визнання біженцем або особою, яка потребує додаткового захисту, у тому числі стосовно перебуваючих із заявником на території України неповнолітніх дітей (членів сім'ї заявника або таких, які знаходяться під його опікою чи піклуванням), внесених до анкети заявника, на визнання яких біженцями або особами, які потребують додаткового захисту, є письмова згода заявника, висловлена в анкеті чи заяві [4].

Ця національна норма прямо забезпечує право збереження єдності сімей біженців та осіб, які потребують додаткового захисту.

Частиною другою статті 4 цього ж Закону також закріплене право біженців та осіб, які потребують додаткового захисту або яким надано тимчасовий захист на возз'єднання сімей. Зокрема, передбачено, що члени сім'ї особи, яку визнано біженцем в Україні або особою, яка потребує додаткового захисту або якій надано тимчасовий захист в Україні, мають право з метою возз'єднання сім’ї в'їхати на територію України і бути визнаними біженцями або особами, які потребують додаткового захисту, або отримати 
тимчасовий захист, крім осіб, які вчинили злочин проти миру, воєнний злочин або злочин проти людства і людяності, як їх визначено у міжнародному праві; які вчинили тяжкий злочин неполітичного характеру за межами України до прибуття в Україну з метою набуття статусу біженця, якщо таке діяння віднесено Кримінальним кодексом України до тяжких злочинів; які винні у вчиненні дій, що суперечать цілям та принципам Організації Об'єднаних Націй, визначених у Статуті Організації Об'єднаних Націй [4].

3 огляду на положення Закону України «Про біженців та осіб, які потребують додаткового або тимчасового захисту» Україна прямо гарантує шукачам захисту право на возз'єднання сімей, крім вище перелічених винятків.

Частиною третьою статті 4 цього ж Закону передбачене прийняття до уваги інших доказів, які мають бути оцінені відповідно до законодавства України у разі, якщо біженці та особи, які потребують додаткового захисту або яким надано тимчасовий захист, не зможуть надати офіційні документальні докази сімейного зв'язку з членами своєї сім'ї. Відмова у возз'єднанні сім’ї не може грунтуватися винятково на підставі відсутності документів, що підтверджують факт сімейного зв'язку [4]. Ці заявники належать до вкрай вразливої категорії населення в Україні - шукачів захисту. Такі шукачі захисту втікають із країни свого походження та їдуть до України з надією отримати притулок. І ця ситуація вже сама по собі є досить стресовою для будь-якої людини, адже часто єдиним доказом для шукача захисту є лише інформація про країну походження. Тому Україна гарантує, що відмова у возз'єднанні сім'ї не може грунтуватися винятково на підставі відсутності документів, що підтверджують факт сімейного зв'язку.

Право на возз'єднання сім'ї, тобто на в'їзд та тимчасове або постійне проживання в Україні членів сім'ї іноземця або особи без громадянства, які проживають в Україні на законних підставах, передбачено також статтею 1 Закону України «Про правовий статус іноземців та осіб без громадянства» [5]. Важливо, що це право виникає незалежно від того, коли виникли сімейні відносини - до чи після прибуття іноземця або особи без громадянства до України.

Європейський суд 3 прав людини також притримується позиції щодо забезпечення пріоритету сталості сімейних зв'язків та возз'єднання сім'ї у справах про визнання шукача захисту біженцем.

Так, у справі «Мухаджієва та інші проти Бельгії» одна із заявників, чеченка, що поки- нула м. Грозний, і четверо її малолітніх дітей в 2006 році прибули до Бельгії, де попросили притулку. 3'ясувалося, що на територію Європейського Союзу вона в'їхала через Польщу, у зв'язку з чим їй та її дітям було запропоновано покинути Бельгію. До виконання цього припису заявники протягом місяця були під вартою в Бельгії. «Лікарі без кордонів», які обстежили дітей заявниці, встановили наявність у них симптомів психологічної травми. Свропейський суд 3 прав людини визнав принципово важливим, що у даній справі діти не були відокремлені від матері, оскільки в раніше винесених рішеннях була сформульована позиція про те, що особлива вразливість дітей повинна враховуватися понад усе, це важливіше, ніж незаконність перебування іноземця на території держави [6].

\section{Висновки}

Враховуючи означене, не дивлячись на значну кількість міжнародних та національних нормативних правових актів, вагомих досліджень науковців, в Україні все ж наявні факти порушення пріоритету сталості сімейних зв'язків та возз'єднання сім'ї у справах про визнання шукача захисту та членів його родини біженцями або особами, які потребують додаткового захисту. Для вирішення цих проблем судам України слід застосовувати позитивну практику Європейського суду з прав людини під час розгляду справ про визнання шукача захисту та членів його родини біженцями або особами, які потребують додаткового захисту. Враховуючи, що шукачі захисту є особливо вразливою категорією населення в Україні, в подальших наукових дослідженнях слід розкрити особливості розгляду судом справ про визнання шукача захисту біженцем або особою, яка потребує додаткового захисту.

\section{Список використаних джерел:}

1. Поєдинок О.Р. Права біженців у контексті фрагментації міжнародного права : автореф. дис. ... канд. юрид. наук : 12.00.11. Київ, 2010. 22 с.

2. Конвенція про захист прав людини і основоположних свобод 1950 року, ратифікована Законом України № 475/97-ВР від 17 липня 1997 року. / Верховна Рада України. URL: https://zakon.rada.gov.ua/laws/show/995_004.

3. Сімейний кодекс України. Відомості Верховної Ради України (ВВР), 2002, № 21-22, ст. 135 / Верховна Рада України. URL: https://zakon.rada. gov.ua/laws/show/2947-14.

4. Про біженців та осіб, які потребують додаткового або тимчасового захисту: Закон України від 08 липня 2011 року № 3671-VI / Верховна Рада України. URL: https://zakon.rada.gov.ua/ laws/show/3671-17. 
5. Про правовий статус іноземців та осіб без громадянства: Закон України від 22 вересня 2011 року № 3773-VI / Верховна Рада України. URL: https://zakon.rada.gov.ua/laws/show/ 3773-17.

6. Практика Європейського суду з прав людини у справах, пов'язаних із захистом прав і свобод дитини. 15 серпня 2016. Судова влада України. URL: https://bpm.ko.court.gov.ua/sud1005/prescentr/news/288066/.
7. Про виконання рішень та застосування практики Європейського суду з прав людини: Закон України від 23 лютого 2006 року № 3477-IV / Верховна Рада України. URL: https://zakon.rada.gov.ua/laws/show/3477-15.

8. Угода між Урядом України та Управлінням Верховного Комісара ООН у справах біженців від 23 вересня 1999 року / Верховна Рада України. URL: https://zakon.rada.gov.ua/laws/ show/995_078

In this article analyzes the rights of refugees or persons who need of additional protection regarding the sustainability of family ties and family reunification in cases of recognition of asylum seekers and their family members by refugees or persons who need of additional protection by the State Migration Service of Ukraine and courts. Suggestions are made to improve the protection of rights of asylum seekers and their family members to reunite families and ensure the sustainability of family ties.

The author also provides recent research on the legal status of refugees or persons who need of additional protection. The list and analysis of the main international and national normative legal acts in the sphere of securing the rights of asylum seekers and their family members for family reunification and ensuring the sustainability of family ties are presented.

The judicial practice on cases of claims of asylum seekers in Ukraine to the State Migration Service of Ukraine for recognition as illegal and the cancellation of decisions refusing to recognize them as refugees or persons who need of additional protection are analyzed. The main problems are the observance of the rights of asylum seekers regarding the sustainability of family ties and the reunification of their families in Ukraine.

In the article analyzes that the European Court of Human Rights has taken the position of prioritizing the sustainability of family ties and family reunification in cases of recognition of the asylum seeker and his or her family as refugees. The author gives an example of the decision of the European Court of Human Rights on the topic of this article.

The author concludes that in order to solve the problems of ensuring the priority of the sustainability of family ties and reunification of the family in cases of recognition of the asylum seeker and his family as refugees, courts of Ukraine should apply the positive practice of the European Court of Human Rights. The article describes cases of restrictions on ensuring the sustainability of family ties and restrictions on the right of reunification of family of asylum seekers in Ukraine.

Key words: rights of refugees, family reunification, asylum seeker, legal status of the refugee, permanence of family ties, lawsuit for recognition as illegal and annulment of the decision. 
УДК 342.9

DOI https://doi.org/10.32849/2663-5313/2019.8.16

\section{Олександр Константий,}

докт. юрид. наук,

заслужений юрист Украӥни, науковий консультант судді

Конституиійного Суду України

\section{ДО ПИТАННЯ ПОНЯТТЯ, ПРЕДМЕТА, МЕТОДУ І СИСТЕМИ АДМІНІСТРАТИВНОГО СУДОЧИНСТВА УКРАЇНИ}

У статті розглядаються теоретичні питання права адміністративного судочинства як новоі процесуальної галузі права у системі права України. Викладено бачення автора щодо поняття, предмета, методу та системи иієї галузі права. Відзначається, що у статті 4 нової редакиії Кодексу адміністративного судочинства Украӥни, що прийнято 3 жовтня 2017 року, правовідносини, що складаються під час здійснення адміністративного судочинства, слушно позначені терміном «судовий процес». Адміністративне судочинство запропоновано теоретично визначати також поняттями «адміністративний судовий процес» $i$ «правосуддя в адміністративних справах». До предмета правового регулювання права адміністративного судочинства віднесено відносини, пов'язані із завданнями діяльності і компетениією адміністративних судів, з юрисдикиією і підсудністю адміністративних справ, зі складом, правами й обов'язками учасників адміністративного судочинства, з етапами і стадіями розгляду і вирішення у ивому судочинстві на основі засад диспозитивності і змагальності публічно-правових спорів, а також зі здійсненням судами контролю за виконанням їхніх рішень. Установлено, що метод правового регулювання иієї галузі є комплексним, таким, що передбачає поєднання як імперативних, так $і$ диспозитивних засобів правового упорядкування відносин адміністративного судочинства. У структурі права адміністративного судочинства виділено загальну й особливу частини. До загальної частини віднесено правові інститути, блоки норм, якими врегульовуються загальні питання організаиії та здійснення адміністративного судочинства, які стосуються усіх його стадій. До Особливої частини права адміністративного судочинства віднесено спечіальні правові інститути, нормами яких врегульовані окремі стадії та форми позовного провадження в адміністративному судочинстві, а також визначаються особливості судового розгляду окремих категорій справ. Право адміністративного судочинства пропонується визначати сукупністю правових норм, визначених Кодексом адміністративного судочинства України, що врегульовують діяльність адміністративного суду та учасників адміністративного судового процесу, пов'язану з розглядом і вирішенням справ адміністративної судової юрисдикиіі.

Ключові слова: право адміністративного судочинства, адміністративний судовий процес, публічно-правові спори, правосуддя в адміністративних справах, публічна адміністрація.

Постановка проблеми. Нині триває не тільки приведення у відповідність до європейських стандартів, acquis communautaire національного законодавства у тому числі у сфері організації та функціонування публічної влади в державі, а й осучаснення української правової системи загалом. Це водночас зумовлює потребу подальшого «якісного» реформування діяльності органів виконавчої і судової влади із застосування норм права та запровадження таких, які б відповідали сучасним реаліям, концептуальних підходів до осмислення появи нових, традиційно відомих правопорядку в європейських країнах, галузей, насамперед права адміністративного судочинства, розрахованого на визначення процедур неупередженого судового захисту прав та інтересів приватних осіб, порушених у відносинах з органами і посадовими особами публічної адміністрації.

Актуальність теми дослідження підтверджується незначною увагою вітчизняних науковців, нерозкритістю і остаточною невирішеністю проблематики поняття і місця права адміністративного судочинства у системі права України, недослідженістю питань його предмета, методу і системи.

Стан дослідження. Варто зазначити, що в сучасній українській юридичній науці і дотепер дискутуються питання місця адміністративного судочинства у системі національного права, його співвідношення з адміністративним правом та можливості розгляду суто його адміністративним процесом. Така дискусія, зокрема, ведеться в роботах В. М. Бевзенка, Т. О. Коломоєць, О. В. Кузьменко, 
Р. С. Мельника, Н. Б. Писаренко, О. П. Рябченко та деяких інших науковців. Водночас питання поняття, предмета, методу і системи права адміністративного судочинства України як процесуальної галузі права є практично не дослідженими.

Метою статті є висвітлення авторського підходу до наукового вирішення питань поняття, предмета, методу і системи права адміністративного судочинства як нової, відділеної від адміністративного права, галузі процесуального права в Україні, що вивчається у вітчизняних вищих навчальних закладах відповідно до програм підготовки правників.

Виклад основного матеріалу. На європейському просторі найбільш придатним для цілей захисту прав особи від актів «уряду» та інших органів публічного управління вважається спеціалізоване адміністративне судочинство. Його, коли воно є дієвим, ефективним, вчені вважають «вінцем» правової держави [1, с. 3]. Тому питання адміністративного судочинства нині виступають центральною темою в європейській догматиц публічного права [2, с. 88, 91].

Законодавчо запровадивши у 2005 році процесуальну основу для спеціалізованого судового контролю актів (рішень, дій, бездіяльності) публічної адміністрації, тобто прийнявши Кодекс адміністративного судочинства (далі - КАС України), Україна формально зробила перший крок на шляху «європеїзації» правової системи. Але у 20062015 роках за умов значної фінансової, матеріально-технічної, кадрової та дисциплінарної залежності суддів від суб'єктів політики та урядової адміністрації пріоритетним предметом захисту в адміністративному судочинстві України тривалий час були не порушені у царині публічного управління права особи, а державний або певний «відомчий» інтерес.

На реалізацію прийнятих у червні 2016 року змін до Конституції України, згідно 3 якими основною засадою правосуддя в державі було визначено не принцип законності, а принцип верховенства права, а також передбачено проходження усіма працюючими суддями кваліфікаційного оцінювання 3 метою підтвердження здатності фахово самостійно розглядати судові справи, 3 жовтня 2017 року було прийнято нові осучаснені редакції процесуальних кодексів, у тому числі і КАС України [3].

Порівняльно-правовий аналіз свідчить, що за своїм змістом, застосованими конструкціями, умовами та строками загальної і спрощеної форм позовного провадження, підставами апеляційного, касаційного перегляду i перегляду за нововиявленими і виключними обставинами прийнята в 2017 році редакція КАС України, яка набрала чинності з 15 грудня зазначеного року, значною мірою стала відзначатися уніфікованістю (подібністю правового регулювання) 3 положеннями Цивільного процесуального і Господарського процесуального кодексів України. Тому, ураховуючи те, що цивільне і господарське процесуальне право вже традиційно розглядаються окремими самостійними процесуальними галузями у системі права України [4, с. 11], на наш погляд, нині є достатні підстави для визнання самостійною процесуальною галуззю права в Україні і права адміністративного судочинства. Разом із тим питання поняття, предмета, методу і системи права адміністративного судочинства є практично не розробленими в юридичній науці України.

Не можна не зазначити, що ще під час дії першочергової редакції КАС України (чинної з певними змінами до 15 грудня 2017 року) адміністративне судочинство новою, відділеною від адміністративного права галуззю національного права почали визначати Т. О. Коломоєць, В. М. Бевзенко, Р. С. Мельник [5, с. 304, 305] та деякі інші науковці. Але вчені пропонували назвати цю нову галузь права терміном «адміністративно-процесуальне право» [6, с. 27-34], виходячи з того, що саме і виключно адміністративне судочинство вважали адміністративним процесом. Однак такий підхід був не зовсім точним, оскільки неповною мірою узгоджувався з реалізованою у КАС України «змішаною» (франко-німецькою) моделлю правосуддя в адміністративних справах, належністю до компетенції адміністративних судів в Україні, на відміну від ФРН, й певних категорій спорів конституційно-правового характеру (з виборчих правовідносин і з відносин референдуму, щодо дострокового припинення повноважень народного депутата України в разі невиконання ним вимог щодо несумісності, про встановлення обмежень чи усунення перешкод у реалізації права на свободу мирних зібрань, з приводу відповідності Конституції України нормативно-правових актів міністерств, інших центральних органів виконавчої влади, Ради міністрів Автономної Республіки Крим, місцевих державних адміністрацій, органів місцевого самоврядування тощо).

3 метою усунення вищенаведеної термінологічної неточності під час прийняття 3 жовтня 2017 року нової редакції КАС України законодавець (у його статті 4 «Визначення термінів») цілком слушно, на наш погляд, позначив «правовідносини, що складаються 
під час здійснення адміністративного судочинства» для потреб застосування в тексті цього Кодексу вже терміном «судовий процес» (на відміну від попередньо вживаного «адміністративний процес»). Однак, з позиції теорії права, більш точно природу адміністративного судочинства в Україні, його тісний взаємозв'язок із матеріальними нормами адміністративного права, які (і не лише вони) отримують у ньому практично примусову охорону (забезпечення), позначає, на нашу думку, поняття «адміністративний судовий процес».

«Адміністративним судовим процесом» $е$ система врегульованих нормами КАС України процесуальних дій, які вчиняються адміністративним судом, учасниками справи та іншими учасниками судового провадження 3 метою справедливого, неупередженого та своєчасного вирішення у змагальній процесуальній формі публічно-правових спорів (справ адміністративної юрисдикції).

Оскільки предметом вирішення за поданими за правилами КАС України позовами $\epsilon$ публічно-правові спори, адміністративне судочинство можна ще називати правосуддям [7, с. 164-169] в адміністративних справах, а адміністративні суди - органами правосуддя в адміністративних справах (справах адміністративної юрисдикції).

В юридичній науці поняття «галузь права» традиційно інтерпретується як найбільш велика, відособлена сукупність юридичних норм, що регулюють якісно однорідні групи суспільних відносин, яка має власний предмет і метод правового регулювання. Тобто в основі поділу системи права на галузі насамперед лежать такі категорії, як предмет і метод правового регулювання. Предмет правового регулювання відповідає на питання: що регулює галузь права, а метод - яким чином здійснюється процес такого регулювання [8, с. 143].

Як зазначалося вище, нині розглядати самостійною процесуальною галуззю права в Україні можна і право адміністративного судочинства, оскільки за чинного правового регулювання до його характерних ознак, які дозволяють розглядати сукупність визначених КАС України норм самостійною галуззю процесуального права України, належать, зокрема, такі.

По-перше, право адміністративного судочинства має свій власний предмет (сукупність однорідних суспільних відносин, які визначають компетенцію та порядок вирішення адміністративними судами справ адміністративної юрисдикції (публічно-правових спорів)) і метод (сукупність прийомів та способів визначення умов і порядку реалі- зації своїх прав та обов’язків суб'єктами правосуддя в адміністративних справах) правового регулювання.

По-друге, право адміністративного судочинства $\in$ складовим (процесуально-правовим за природою) елементом, частиною публічного права України. Воно визначає процесуальний механізм неупередженого владного (забезпеченого засобами примусового виконання судових рішень) застосування адміністративними судами до конкретних спірних правовідносин відповідних загальних і спеціальних норм матеріального адміністративного, податкового, фінансового, соціального, муніципального та деяких інших галузей публічного права (наприклад, виборчого права як елемента структури конституційного права тощо) у разі їх порушення чи виходу за межі їх приписів суб'єктами публічної адміністрації. Тим самим право адміністративного судочинства фактично визначає процедури (порядок) «судового контролю» дотримання правомірності (конституційності, законності й обгрунтованості) здійснення публічною адміністрацією, іï посадовими чи службовими особами належних їм за законодавством «втручальних», «розпорядчих», «сприяючих», «забезпечувальних» та «сервісних» публічно-владних повноважень, забезпечує «управлінську відповідальність» суб'єктів неналежного публічного адміністрування.

По-третє, право адміністративного судочинства відрізняється застосуванням тільки у ньому йому ідеологічно притаманного, на відміну від інших побудованих на позовній формі провадження судових процесів (господарського, цивільного), принципу офіційності (офіційного з'ясування обставин у справі), згідно з яким суд має вживати визначених законом заходів, необхідних для з'ясування всіх обставин у справі, зокрема щодо виявлення та витребування доказів протиправності оскарженого рішення, дії, бездіяльності суб'єкта влади з власної ініціативи (наприклад, коли відповідач - орган влади - не надає громадянину або юридичній особі необхідних документів, матеріалів, що підтверджують їхні позовні вимоги, вказують на протиправність рішень, дій, бездіяльності такого суб'єкта).

По-четверте, право адміністративного судочинства має власне завдання правового регулювання, яке полягає у визначенні спеціалізованого судового процесуального механізму неупередженого та ефективного захисту порушених у відносинах із суб'єктами владних повноважень прав та інтересів фізичних і юридичних осіб. Тобто ця процесуальна галузь права відзначається яскраво вираженим правозахисним призна- 
ченням, функціональною спрямованістю на усунення негативних для приватної особи наслідків від неправомірного («неякісного») публічного адміністрування.

По-п'яте, право адміністративного судочинства, як і цивільно- й господарсько-процесуальна галузі права, сьогодні має власну більш-менш усталену практику, підходи до застосування його норм судами, єдність яких забезпечується Верховним Судом. Прецеденти тлумачення і застосування процесуальних норм адміністративними, як і господарськими, загальними, судами розміщуються в Сдиному державному реєстрі судових рішень України (http://www.reyestr.court.gov.ua/).

Предметом правового регулювання права адміністративного судочинства виступають відносини, пов'язані із завданнями діяльності і компетенцією адміністративних судів, з юрисдикцією і підсудністю цим судам справ, складом, правами і обов'язками учасників адміністративного судочинства, з етапами і стадіями розгляду і вирішення у цьому судочинстві на основі засад диспозитивності і змагальності публічно-правових спорів, а також зі здійсненням адміністративними судами контролю за виконанням їхніх рішень.

Як у самостійної галузі права, у праві адміністративного судочинства виділяються й специфічні способи правового впливу на упорядковані відносини організації і порядку здійснення правосуддя в адміністративних справах, тобто засоби правового регулювання. Метод правового регулювання иієї галузі по суті є комплексним. Він передбачає поєднання як імперативних, так і диспозитивних засобів правового упорядкування відносин адміністративного судочинства, іншими словами, є імперативно-диспозитивним.

Із застосуванням правових засобів «влади-підпорядкування» (імперативного методу) у праві адміністративного судочинства, зокрема, врегульовуються відносини щодо: юрисдикції, підсудності справ, повноважень, складу та інстанцій адміністративних судів, порядку вчинення ними процесуальних дій, прийняття та перегляду судових рішень, судового контролю у процедурах виконання актів правосуддя; - взаємовідносин суду як носія державних владних повноважень на здійснення правосуддя з учасниками адміністративного судового процесу, контролю суду за їхніми процесуальними діями, добросовісністю поведінки, застосування засобів процесуального примусу до порушників встановлених в суді правил; - дотримання усіма суб'єктами адміністративного судочинства, в тому числі і судом, законодавчо регламентованого порядку судового розгляду і вирішення адміністративних справ.
Диспозитивні (дозвільні) складники методу цієї процесуальної галузі проявляються у визначенні у нормах права адміністративного судочинства: - рівності усіх учасників справи перед законом і судом, їх рівності у процесуальних правах і обов'язках; - вільного (непримусового) порядку реалізації учасниками справи своїх процесуальних прав, вибору варіантів своєї процесуальної поведінки, дій, тобто їхньої свободи розпоряджатися наданими правами; - можливості сторін досягнути примирення на будь-якій стадії судового процесу, якщо ці дії не суперечать закону або не порушують чиї-небудь права, свободи чи інтереси; - свободи сторін у наданні суду своїх доказів і у доведенні перед судом їх переконливості, що забезпечує відповідачу і позивачу рівні можливості для захисту своєї позиції у справі тощо.

У структурі (системі) права адміністративного судочинства можна виділяти дві частини - загальну і особливу.

До загальної частини права адміністративного судочинства можна відносити правові інститути, блоки норм, якими врегульовуються загальні питання організації та здійснення адміністративного судочинства (тобто які стосуються усіх його стадій), зокрема такі його інститути: - загальні положення, у тому числі норми щодо завдань, основних засад (принципів) і термінів (понять) адміністративного судочинства; - адміністративна юрисдикція і підсудність; - склад суду, відводи; - учасники адміністративного судового процесу, їхня адміністративна процесуальна правоздатність і дієздатність, права і обов'язки; - докази і доказування; - процесуальні строки; - судові виклики і повідомлення; - судові витрати; - заходи процесуального примусу; - забезпечення позову.

До Особливої частини права адміністративного судочинства належать спеціальні правові інститути, нормами яких врегульовуються окремі стадії та форми позовного провадження в адміністративному судочинстві, а також визначаються особливості судового розгляду окремих категорій справ, а саме такі: - загальне позовне провадження у суді першої інстанції; - розгляд справ за правилами спрощеного позовного провадження; - особливості позовного провадження в окремих категоріях адміністративних справ (складних, термінових, типових і зразкових); - апеляційне провадження; - касаційне провадження; - перегляд судових рішень за нововиявленими або виключними обставинами; - виконання судових рішень в адміністративних справах; - відновлення втраченого судового провадження. 


\section{Висновки}

Отже, нині остаточно з'явилося підгрунтя для визнання існування у сучасній системі права України нової, відділеної від адміністративного права, процесуальної галузі права адміністративного судочинства. Під «правом адміністративного судочинства» можна розуміти систему закріплених у КАС України, а також деяких інших законах України правових норм, які визначають юрисдикцію та повноваження адміністративних судів, порядок звернення до цих судів для захисту порушених у публічно-правових відносинах прав, свобод, інтересів фізичних осіб, прав та інтересів юридичних осіб, у деяких випадках публічних інтересів, а також регламентують процесуальні дії суду з розгляду та вирішення публічно-правових спорів, перегляду та виконання прийнятих судових рішень.

Більш стисло право адміністративного судочинства можна також понятійно визначати як сукупність правових норм, що врегульовують діяльність адміністративного суду та учасників адміністративного судового процесу, пов'язану з розглядом і вирішенням справ адміністративної судової юрисдикції.

\section{Список використаних джерел:}

1. Крефт Герхарт. История административной подсудности в Германии. Ежегодник публичного права. 2015: Административный процесс. Москва : Инфотропик Медиа, 2015. 464 с.

2. Кайзер Мартин. Правовая защита и контроль (часть I). URL: http://dpp.mpil.de/ 05_2016/ 05_2016_87_103.pdf.

3. Про внесення змін до Господарського процесуального кодексу України, Цивільного процесуального кодексу України, Кодексу адміністративного судочинства України та інших законодавчих актів : Закон України від 03 жовтня 2017 року № 2147-VIII. URL: https://zakon.rada. gov.ua/ laws/show/2147\%D0\%B0-19\#n2.

4. Світличний О. П. Господарський процес : підручник. 2-ге вид, перероб. і доп. Київ : НУБіП України, 2018. $342 \mathrm{c}$.

5. Адміністративний процес: загальна частина (Федеративна Республіка Німеччини, Україна) : науково-практичний посібник / Томас Манн, Роман Мельник, Володимир Бевзенко, Анатолій Комзюк. Київ : Алерта, 2013. 308 с.

6. Коломієць Т. О. Адміністративно-процесуальне право - самостійна галузь національного права (в аспекті пошуку нової моделі предмета адміністративного права України). Публічне право. 2016. № 1. URL: http://nbuv.gov.ua/UJRN/ pp $2016 \quad 15$.

7. Таликін Є.А. Зміст поняття «правосуддя» у контексті функцій господарського суду. Університетські наукові записки. 2011. № 4 (40). 123 с.

8. Гайдамака I.O. Правовий режим як критерій поділу права на галузі. Державне будівниитво та місиеве самоврядування. 2008. Вип. 16. Харків : Право, 2008

The article deals with the theoretical law issues of administrative legal proceedings as a new procedural branch of law in Ukraine. It sets out the vision of the author about the concept, subject, method and system of this branch of law. It is noted that when the new version of the Code of Administrative Proceedings of Ukraine was adopted on October 3, 2017, in its Article 4, the term "judicial process" marked the legal relations developing in the process of administrative legal proceedings. Administrative legal proceedings are also suggested to term "administrative proceedings" and "justice in administrative cases. " Relations related to the tasks of the activity and competence of administrative courts, with jurisdiction and jurisdiction of administrative cases, is the subject of legal regulation of the right to administrative legal proceedings. It also includes relations related to the composition, rights and obligations of participants in administrative proceedings, the stages of consideration and resolution of this case on the basis of the discretionary and competitive nature of public legal disputes and control of the courts in the implementation of their decisions. It is established that the method of legal regulation of this branch is complex, such that it includes a combination of both imperative and disposable means of legal regulation of relations of administrative legal proceedings. In the structure of the law of administrative legal proceedings, a general and special part is singled out. The general part includes legal institutes, blocks of norms, which regulate the general issues of organization and implementation of administrative legal proceedings, which apply to all its stages. The special part of the right to administrative legal proceedings includes special legal institutions, the norms of which regulate separate stages and forms of legal proceedings in administrative proceedings, as well as determine the peculiarities of judicial consideration of certain categories of cases. The law of administrative legal proceedings is proposed to be defined by a set of legal norms defined by the Code of Administrative Proceedings of Ukraine, which regulate the activity of the administrative court and the participants in the administrative judicial process, which is related to the consideration and resolution of cases of administrative judicial jurisdiction.

Key words: law of administrative court proceedings, administrative legal process, public law disputes, justice in administrative cases, public administration. 
УДК 342.9:347(77+78)

DOI https://doi.org/10.32849/2663-5313/2019.8.17

\section{Олена Коротун,}

канд. юрид.наук, докторант

Науково-дослідного інституту публічного права

\section{Олександр Світличний,}

докт. юрид. наук, дочент,

професор кафедри цивільного та господарського права

Начіонального університету біоресурсів і природокористування України

\section{ПОНЯТТЯ ТА СТРУКТУРА АДМІНІСТРАТИВНО- ПРАВОВОГО ЗАБЕЗПЕЧЕННЯ ОХОРОНИ ПРАВ СУБ’ЄКТІВ ІНТЕЛЕКТУАЛЬНОЇ ВЛАСНОСТІ}

Стаття присвячена поняттю, структурі адміністративно-правового забезпечення охорони прав суб'єктів інтелектуальної власності. Відсутність теоретичних узагальнень та відповідних практичних рекомендацій негативно впливають на формування та розвиток науки адміністративного права, охорону особистих немайнових та (або) майнових прав суб'єктів права інтелектуальної власності. Відповідно, відсутність основоположної теорії адміністративно-правового забезпечення охорони прав суб'єктів інтелектуальної власності, сучасне бачення розвитку суспільних відносин у досліджуваній сфері до иього часу так і не отримали свого наукового втілення.

Провідну роль у регулюванні відносин у сфері охорони прав суб'єктів інтелектуальної власності відіграє конституиійне право. Особисті немайнові та майнові права інтелектуальної власності підлягають правовій охороні нормами приватного і публічного права, провідну роль серед яких відіграє иивільне і адміністративне право - дві фундаментальні галузі національного права. Усе ие дістає відображення у диспозитивному та імперативному методі правового регулювання, які являють собою найтиповіші прийоми правового регулювання у досліджуваній сфері.

Звертається увага, що адміністративно-правове забезпечення суспільних відносин у сфері охорони прав суб'єктів інтелектуальної власності є спещифічною владною діяльністю органів публічної адміністрачії, їх посадових осіб, які наділені владними повноваженнями у сфері забезпечення охорони інтелектуальної власності. Такими публічними органами у досліджуваній сфері насамперед $є$ Міністерство економічного розвитку і торгівлі України, «Укрпатент», АМКУ та інші уповноважені органи публічної адміністрачії, які наділені повноваженнями щодо реалізації, охорони та розвитку відносин у сфері охорони інтелектуальної власності. Діяльність публічної адміністрачії передбачає використання адміністративно-правових норм, які являють собою різновид правових норм й відіграють важливу роль у регулюванні суспільних відносин у сфері охорони права інтелектуальної власності, а також виконують одну з основних функиій щодо забезпечення охорони суб'єктивних прав правовласників об'єктів права інтелектуальної власності, захисту суб'єктів господарської діяльності, прав і законних інтересів споживачів. Особливо важливим є визначення сфер впливу правового регулювання та реалізаиії норм адміністративного права органами публічної адміністраиіі.

Окрема увага приділяється змісту та структурі адміністративно-правового забезпечення, розкривається структура та надається авторське визначення поняття «адміністративно-правове забезпечення».

Ключові слова: суб'єкти, охорона, права, інтелектуальна власність, поняття, адміністративноправове регулювання, структура.

Постановка проблеми. Суспільні відносини у сфері інтелектуальної власності зумовлюють організуючий вплив держави з метою задоволення потреб суспільства, яке під впливом нових соціально-економічних викликів та загроз потребує гарантованої Конституцією України охорони суб'єктивних прав правовласників об'єктів права інтелектуальної власності та інтер- есів держави. Першоосновою цього процесу повинно стати наукове дослідження поняття «адміністративно-правове забезпечення» як важливої юридичної категорії науки адміністративного права.

Незважаючи на загальний інтерес до адміністративно-правового забезпечення у різних сферах правового регулювання суспільних відносин, у рамках проблематики 
дослідження питання щодо поняття і аналізу сутності адміністративно-правового забезпечення охорони прав суб'єктів інтелектуальної власності у вітчизняній юридичній науці практично не досліджувалось.

Аналіз останніх досліджень. Теоретикометодологічним підгрунтям написання статті послужили праці: А. Авер'янова, В. Галунька, С. Діденка, Т. Коломоєць, В. Колпакова, В. Курила, Г. Римарчук, О. Нікитенка, С. Стеценка та ін. Не заперечуючи вагомого внеску вказаних вчених, зазначимо, що натепер практично відсутні наукові дослідження, присвячені адміністративно-правовому забезпеченню охорони прав суб'єктів інтелектуальної власності. Відсутність теоретичних узагальнень та відповідних практичних рекомендацій негативно впливають на формування та розвиток науки адміністративного права, охорону особистих немайнових та (або) майнових прав суб'єктів права інтелектуальної власності. Відповідно, відсутність основоположної теорії адміністративно-правового забезпечення охорони прав суб'єктів інтелектуальної власності, сучасне бачення розвитку суспільних відносин у досліджуваній сфері до цього часу так і не отримали свого наукового втілення, що й зумовлює актуальність цієї статті.

Мета цієї статті полягає в тому, щоб з огляду на доктринальні підходи та правове регулювання розкрити поняття, структуру адміністративно-правового забезпечення охорони прав суб'єктів інтелектуальної власності.

Виклад основного матеріалу. Забезпечуючи охорону суб'єктивних прав правовласників об'єктів права інтелектуальної власності, держава забезпечує охорону інтелектуальної власності, дотримання правового порядку в суспільстві, встановлює заборону на незаконне використання майнового та особистого немайнового права інтелектуальної власності, а у разі встановлення факту порушення притягує винних осіб до юридичної відповідальності.

У чинних вітчизняних законодавчих актах є перелік об'єктів права інтелектуальної власності, у разі незаконного використання яких порушуються суб'єктивні права правовласників об'єктів права інтелектуальної власності [1, с. 6]. Як зазначає М. Потоцький, суб'єктивне право інтелектуальної власності - юридично визначена можливість особи задовольнити свої немайнові (особисті) та майнові потреби щодо об'єктів права інтелектуальної власності, які охороняються державою [2, с. 6].
Суб'єктивні права учасників правовідносин у сфері інтелектуальної власності пов'язані з володінням, користуванням і розпорядженням майновими правами інтелектуальної власності, особистими немайновими правами інтелектуальної власності, які пов'язані з правом особи на визнання результатів творчої інтелектуальної діяльності, правом перешкоджати будь-якому посяганню на право інтелектуальної власності, а також іншими особистими немайновими правами інтелектуальної власності, які встановлені законом і підлягають правовій охороні.

Особисті немайнові та майнові права інтелектуальної власності підлягають правовій охороні нормами приватного і публічного права, провідну роль серед яких відіграє цивільне і адміністративне право - дві фундаментальні галузі національного права. Усе це достає відображення у диспозитивному та імперативному методі правового регулювання, які являють собою найтиповіші прийоми правового регулювання у дослідженій сфері. Проте було б спрощенням обмежитися тільки згаданими галузями права. Юридичну першооснову в охороні майнових прав інтелектуальної власності, як і для інших галузей національного права, становить конституційне право.

При цьому правове регулювання як спеціально-юридичний вплив у будь-якому разі пов'язане з встановленням конкретних прав та обов'язків суб'єктів, з прямими приписами про належне і можливе, а правовий вплив не завжди. Якщо перше означає реалізацію правових норм через правовідносини, то друге - не обов’язково. Звідси - правове регулювання завжди означає і правовий вплив, але правовий вплив не завжди означає свідоме нормування суспільних відносин. У цьому сенсі регулювання - лише одна з форм впливу права на соціальні зв'язки, що охоплюе далеко не всі інші його форми [3, с. 27].

Необхідним елементом взаємодії держави і права $є$ юридичний обов'язок, у якому держава формулює свої вимоги до громадян. Юридичний обов'язок - це об’єктивно необхідна, встановлена законом міра належної поведінки. Першоприрода обов'язків така, що вони покликані бути зворотною стороною суб'єктивного права як стимулюючі засоби [4, с. 271].

У сфері забезпечення охорони прав суб'єктів інтелектуальної власності функціональне призначення права полягає як у забезпеченні реалізації права на результати творчої інтелектуальної діяльності, так і покладанні обов'язків на осіб приватного та публічного права. Тому з'ясування сутності «адміністративно-правового забезпечення» 
та його елементів залишається актуальним науковим напрямом дослідження.

Перш ніж перейди до аналізу адміністративно-правового забезпечення охорони прав суб’єктів інтелектуальної власності, важливо зауважити, що широта окресленого питання свідчить, що залежно від сфери регулювання відносин у юридичній науці ми можемо знайти різні підходи до змісту визначення поняття «адміністративно-правове забезпечення». Теоретична конструкція вказаного поняття спонукає науковців розглядати досліджувану категорію як через з'ясування співвідношення категорії «адміністративноправове забезпечення» 3 поняттям «адміністративно-правове регулювання»; «правове регулювання» та «правове забезпечення»; через сутнісну характеристику термінів «право» та «забезпечувати»; через «режим» забезпечення; розгляд у вузькому та широкому розумінні.

Враховуючи специфіку дослідження, звернемо свою увагу на наукову позицію Г. Римарчук, на думку якої адміністративноправове забезпечення права інтелектуальної власності - це здійснення державою за допомогою правових норм, приписів і сукупності засобів упорядкування суспільних відносин, їх юридичне закріплення, охорона, реалізація та розвиток $[5$, с. 8$]$.

Виходячи зі специфіки охорони особистого немайнового та (або) майнового права інтелектуальної власності, яке є непорушним і охороняється державою, адміністративно-правове забезпечення - це перш за все регламентована адміністративно-правовими нормами діяльність уповноважених суб'єктів публічної адміністрації, що спрямована на реалізацію конституційних гарантій охорони та захисту моральних і матеріальних інтересів правовласників об'єктів права інтелектуальної власності та інших учасників суспільних відносин, що виникають у зв'язку з різними видами інтелектуальної діяльності.

Об'єктом адміністративно-правового забезпечення є суспільні відносини у сфері охорони прав суб'єктів інтелектуальної власності, що потребує правового регулювання та реалізації норм адміністративного права суб'єктами публічної адміністрації.

Суб'єктами адміністративно-правового забезпечення у сфері охорони прав суб'єктів інтелектуальної власності є спеціально уповноважені суб'єкти публічної адміністрації, які наділені владними повноваженнями, правами та обов'язками, що встановлені адміністративно-правими нормами. Під суб'єктами публічної адміністрації ми розуміємо широке коло уповноважених суб'єктів, які наділені різними за змістом і обсягом адміністратив- ними повноваженнями. Поряд 3 органами виконавчої влади в публічному управлінні задіяні й інші суб'єкти, які організаційно не входять до системи органів виконавчої влади, а також як окремі фізичні особи, так i юридичні особи публічного та приватного права [6, с. 215].

Отже, адміністративно-правове забезпечення суспільних відносин у сфері охорони прав суб'єктів інтелектуальної власності є специфічною владною діяльністю органи публічної адміністрації, їх посадових осіб, які наділені владними повноваженнями у сфері забезпечення охорони інтелектуальної власності.

Насамперед такими публічними органами у досліджуваній сфері є Міністерство економічного розвитку і торгівлі України, «Укрпатент», АМКУ та інші уповноважені органи публічної адміністрації, які наділені повноваженнями щодо реалізації, охорони та розвитку відносин у сфері охорони прав суб'єктів інтелектуальної власності. Водночас діяльність публічної адміністрації передбачає використання адміністративноправових норм, які являють собою різновид правових норм й відіграють важливу роль у регулюванні суспільних відносин у сфері охорони права інтелектуальної власності, виконують одну з основних функцій щодо забезпечення охорони суб'єктивних прав правовласників об'єктів права інтелектуальної власності, захисту суб'єктів господарської діяльності, прав і законних інтересів споживачів. Особливо важливим є визначення сфер впливу правового регулювання та реалізації норм адміністративного права органами публічної адміністрації. За допомогою адміністративно-правових норм, які виконують різноманітні функції, здійснюється правове регулювання у досліджуваній cферi.

С. Алексєєв зауважував, що правове регулювання - головне, вирішальне поняття правової дійсності, яка розглядається в динаміці 3 активно-дієвого боку, і пропонує розуміти це поняття у двох значеннях - вузькому та широкому. У вузькому вчений характеризував правове регулювання як «дію норм права (системи правових норм), інших спеціальних юридичних засобів на поведінку особи та на суспільні відносини з метою їх упорядкування та прогресивного розвитку» [7, с. 219].

Вказане свідчить, що в практичній діяльності з метою охорони права інтелектуальної власності уповноважені державою органи публічної адміністрації, наділені владними повноваженнями, в межах визначеної компетенції приймають обов'язкові для інших суб'єктів рішення, реалізуючи в правозасто- 
совній діяльності норми адміністративного права шляхом застосування диспозиції відповідної норми закону.

У результаті реалізації норм права виникають адміністративно-правові відносини, що урегульовані нормами адміністративного права, в яких сторони беруть участь як носії прав та обов'язків, установлених і забезпечених адміністративно-правовими приписами. Власне адміністративно-правові відносини у досліджуваній сфері, передбачають виділення їх певних видів. Ними є: регулятивні та правоохоронні; двосторонні або багатосторонні; за сферою виникнення; за станом взаємної підпорядкованості суб'єктів; вертикальні та горизонтальні правовідносини [8, с. 176-179].

Регулятивні правовідносини (позитивні функції адміністративного права) у досліджуваній сфері, перш за все, пов'язані з діяльністю органів публічної адміністрації, керівництвом нижчими структурами. Регулятивні правовідносини виникають і діють під час дотримання громадянами та суб'єктами господарської діяльності правомірної поведінки щодо використання об'єктів права інтелектуальної власності і спрямовані на впорядкування існуючих суспільних відносин в межах норм адміністративного права.

Правоохоронні правовідносини відіграють найбільш важливу роль у юрисдикційній діяльності уповноважених органів публічної адміністрації і пов'язані з реалізацією правоохоронної функції адміністративного права.

За складом учасників це можуть бути відносини як між усією системою органів публічної адміністрації, так й іншими публічними і приватними органами, а також відносини, де обов'язковою стороною є посадова особа органу публічної адміністрації, з іншої сторони - громадянин, суб'єкт господарської діяльності (юридична особа, фізична особа підприємець), так і за станом взаємної підпорядкованості суб'єктів, що беруть участь у правовідносинах.

За сферою виникнення - це 1) різноманітні відносини у сфері діяльності органу (органів) публічної адміністрації, 2) ті, що знаходяться за межами їхньої діяльності.

Гарантії як елемент адміністративноправового забезпечення слід розглядати як передбачений чинним законодавством комплекс правових засобів впливу, за допомогою яких забезпечується реалізація суспільних відносин у сфері охорони прав суб'єктів інтелектуальної власності, що випливають із загально-правових гарантій (конституційні гарантії) права кожного володіти, користуватися і розпоряджатися своєю власністю, результатами своєї інтелектуальної, творчої діяльності; держава гарантує захист інтелектуальної власності, авторських прав, моральних і матеріальних інтересів, що виникають у зв’язку з різними видами інтелектуальної діяльності.

Отже, одним із важливих елементів адміністративно-правового забезпечення $€$ гарантування держави в особі органів публічної адміністрації забезпечення охорони суб'єктивних прав та законних інтересів правовласників та інших учасників правовідносин у сфері інтелектуальної власності.

Висновки. Безумовно, наведений вище перелік певних видів адміністративно-правових відносин у досліджуваній сфері не вичерпує всієї повноти проблематики адміністративно-правового забезпечення охорони прав суб'єктів інтелектуальної власності. Однак, поставивши за мету розкриття поняття та структури адміністративно-правового забезпечення охорони прав суб'єктів інтелектуальної власності, автори надають власне визначення поняття «адміністративноправове забезпечення охорони прав суб'єктів інтелектуальної власності», під яким слід розуміти регламентовану адміністративноправовими нормами діяльність публічної адміністрації, їх посадових осіб, уповноважених забезпечити конституційні гарантії охорони та захисту прав суб'єктів інтелектуальної власності, права та інтереси інших учасників правовідносин у сфері інтелектуальної власності.

До структури адміністративно-правового забезпечення охорони прав суб'єктів інтелектуальної власності слід віднести такі елементи: об'єкт адміністративно-правового забезпечення - суспільні відносини у сфері охорони права інтелектуальної власності; суб'єктів адміністративно-правового забезпечення у сфері охорони права інтелектуальної власності - органи публічної адміністрації, наділені владними повноваженнями, правами та обов'язками, що встановлені адміністративно-правими нормами; норми права - адміністративно-правові норми, що являють собою різновид правових норм, які регулюють суспільні відносини у сфері охорони права інтелектуальної власності, виконують одну з основних функцій щодо забезпечення охорони особистого немайнового та майнового права інтелектуальної власності, захисту суб'єктів господарської діяльності та прав споживачів; адміністративно-правові відносини (регулятивні правовідносини; правоохоронні правовідносини; за складом учасників; за сферою виникнення; за станом взаємної підпорядкованості суб'єктів) відображають вплив адміністративно-право- 
вих норм на суб'єктів та об'єкти публічного управління у сфері охорони права інтелектуальної власності, виникають із настанням певних, передбачених адміністративно-правовими нормами юридичних фактів; гарантії як елемент адміністративно-правового забезпечення - передбачений чинним законодавством комплекс правових засобів впливу, за допомогою яких забезпечується реалізація суспільних відносин у сфері охорони інтелектуальної власності.

\section{Список використаних джерел:}

1. Світличний О. П. Право інтелектуальної власності : підручник. 2-ге вид., змін. і доп. Київ: НУБіП України, 2017. 355 с.

2. Потоцький М. Ю. Правове регулювання інтелектуальної власності в Україні: загальнотеоретичне дослідження : автореф. дис. ... канд. юрид. наук. Харків, 2009. 21 c.
3. Комаров С. А. Механизмы правового воздействия. Теория государства и права: курс лекиий. Саранск, 1994. 314 c.

4. Малько А. В., Матузов Н. И. Теория государства и права. Москва : Юристь, 1996. 672 с.

5. Римарчук Г. С. Адміністративно-правове забезпечення права інтелектуальної власності в Україні : автореф. дис. ... канд. юрид. наук. Львів, 2013. 20 с.

6. Світличний О.П. Суб'єкти публічної адміністрації: сучасний вимір. Службове право: витоки, сучасність та перспективи розвитку : колективна монографія / за заг. ред. Т. О. Коломоєць, В. К. Колпакова. Запоріжжя: Видавничий дім «Гельветика», 2017. С. 205-217.

7. Теория государства и права : учебник для юрид. вузов и факультетов / под ред. С. С. Алексеева. Москва : БЕК, 1998. 453 с.

8. Адміністративне право України: Академічний курс : підручник. у 2-х т. Т. 1. Загальна частина / ред. колегія: В. Б. Авер'янов (голова) та ін. Київ : ТОВ «Видавництво «Юридична літератуpa», 2007. 592 c.

The article is devoted to the concept, the structure of administrative and legal support for the protection of intellectual property rights. The lack of theoretical generalizations and relevant practical recommendations adversely affect the formation and development of the science of administrative law, the protection of personal non-property and (or) property rights of subjects of intellectual property rights. Accordingly, the lack of a basic theory of administrative-legal support for the protection of intellectual property rights, the modern vision of the development of public relations in the research field have not yet received their scientific embodiment.

Constitutional law plays a leading role in regulating relations in the field of protection of intellectual property rights. Personal non-property and property rights of intellectual property are subject to legal protection by private and public law, with civil and administrative law, two fundamental branches of national law, playing a leading role. All this is reflected in the dispositive and imperative method of legal regulation, which are the most common methods of legal regulation in the field of research.

Attention is drawn to the fact that the administrative and legal support of public relations in the field of protection of the rights of intellectual property is a specific governmental activity of public administration bodies, their officials, who are vested with authority in the field of intellectual property protection. Such public bodies in the field of research are first of all the Ministry of Economic Development and Trade of Ukraine, Ukrpatent, AMCU and other authorized public administration bodies, which are empowered to implement, protect and develop relations in the field of intellectual property protection. Public administration activities involve the use of administrative and legal norms, which are a kind of legal norms and play an important role in the regulation of public relations in the field of protection of intellectual property rights, and performs one of the main functions in ensuring the protection of the subjective rights of the owners of intellectual property rights. property, protection of business entities, rights and legitimate interests of consumers. It is particularly important to identify areas of influence of legal regulation and implementation of administrative law by public administration bodies.

Particular attention is paid to the content and structure of administrative and legal support, the structure is revealed and the author defines the concept of „administrative and legal support”.

Key words: subjects, protection, rights, intellectual property, concepts, administrative and legal regulation, structure. 
УДК 378:342.9

DOI https://doi.org/10.32849/2663-5313/2019.8.18

Алла Половченя,

канд. юрид. наук,

дочент кафедри права

факультету права та соиіально-інформаиійних технологій

Миколаӥвського міжрегіонального інституту розвитку людини

Відкритого міжнародного університету розвитку людини «Україна»

\section{ЗАБЕЗПЕЧЕННЯ ПРИНЦИПУ АВТОНОМІї ЗАКЛАДІВ ВИЩОЇ ОСВІТИ: АДМІНІСТРАТИВНО-ПРАВОВИЙ АСПЕКТ}

У статті розкрито особливості забезпечення приниипу автономії закладів вишої освіти з позииіі адміністративного права шляхом визначення складу внутрішньо-організаційних адміністративних відносин вищої освіти. Зазначено, що суб'єктами внутрішньо-організачійних адміністративних відносин вищої освіти є заклади освіти, громадськість та держава, уповноважені органи якої забезпечують дотримання принципу автономії у освітньому процесі. 3 позиції адміністративного права визначено наукове поняття автономії закладів вищої освіти як основної характеристики незалежності закладу освіти, яка полягає у його можливості самостійно вирішувати внутрішньо-управлінські питання, брати участь в адміністративному управлінні, взаємодіяти з громадськістю, діяти відкрито та прозоро для дотримання високого рівня освіти, якості освітнього процесу, розвитку правосвідомості молоді в суспільстві. Доведено, що за змістом приниип автономії закладів вищої освіти виражається у можливості реалізаиії закладами вищої освіти повноважень, які умовно можна поділити на: внутрішньо-управлінські; регулятивні; кадрові; акредитаційні; науково-дослідні; аналітично-інформачійні; фінансові; координачійні. Визначено, що внутрішньо-управлінські повноваження як можливість самостійно брати участь у внутрішньому управлінні закладу освіти; регулятивні повноваження як вплив на освітній прочес через закріплення різноманітних норм та правил, наприклад, формування освітніх програм, організачія освітнвого проиесу тощо; кадрові повноваження реалізуються через залучення кадрів в освітній прочес закладу освіти; акредитаційні повноваження ие можливість приймати остаточне рішення відносно присудження наукових ступенів; науково-дослідні повноваження здійснюються шляхом проведення наукових заходів, здійснення наукових робіт, участь в грантах тощо; аналітично-інформачійні реалізуються через аналіз власної діяльності та висвітлення ї̈ на публічних майданчиках; фінансові повноваження це здійснення фінансово-господарської діяльності; координаційні здійснюються шляхом взаємодї з державою, іншими закладами освіти, міжнародними організаціями та громадськістю.

Ключові слова: адміністративно-правові відносини, вища освіта, вищий навчальний заклад, громадськість, освіта, принцип автономії.

Постановка проблеми. Вища освіта в Україні набуває нових рис, оскільки процес євроінтеграції впливає на національну освітню систему. Одним із ключових принципів провідних освітніх систем світу є принцип автономності закладів освіти. Нині принцип автономії закладів освіти лише впроваджується в Україні, набуваючи при цьому своїх власних рис та характеристик.

Реформування вищої освіти в Україні в напрямі автономізації необхідно визначати з урахуванням більш глибшої інтеграції вищого навчального закладу з економікою, процесом розвитку суспільства, ринком праці, що повною мірою дозволить вирішити питання забезпечення її якості, задоволення потреб національної економіки, соціальної справед- ливості, а також на цьому фоні побудувати сучасну систему вищої освіти, яка зможе конкурувати із будь-якою з світових систем, а головне дасть змогу залучити до управління освітою ініціативних науковців [1, с. 15].

Таким чином, враховуючи впровадження в національну освітню систему принципу автономії закладів вищої освіти, що є провідним аспектом запозичення європейських засад в українську освітню модель, дослідження принципу автономії закладів вищої освіти 3 погляду адміністративного права $\epsilon$ досить актуальним та своєчасним питанням.

Аналіз останніх публікацій. Принцип автономії закладів вищої освіти був предметом досліджень О. Деркач, В. Лугового, Ю. Фролова та інших вітчизняних науковців. 
Водночас даний інститут потребує подальших наукових досліджень 3 позиції адміністративного права як основного джерела регулювання відносин у сфері вищої освіти.

Мета статті полягає у визначенні особливостей забезпечення принципу автономії закладів вищої освіти з позиції адміністративного права.

Виклад основного матеріалу. Наявність внутрішніх відносин зумовлює здійснення відповідних суб'єктивних прав та обов'язків. До таких слід віднести права і обов’язки, пов'язані з формуванням і функціонуванням відповідних керівних органів ВНЗ як юридичної особи. У такому разі механізми утворення таких органів мають і приватноправовий характер, що зумовлюється дією принципу виборності (за певними обмеженнями) низки органів ВНЗ, а також можливістю в межах реалізації правила про автономію ВНЗ певною мірою регламентувати процедури створення та організації діяльності органів ВНЗ. Очевидно, що відносини, суб'єктом яких стає установа як юридична особа, яка провадить основну діяльність у сфері вищої освіти, не зводяться лише до цивільно-правових. Вони містять у собі також адміністративні відносини (які передбачають, на відміну від цивільно-правових, владу та підпорядкування), врегульовані іншими законодавчими актами, наприклад, законами «Про освіту» і «Про вищу освіту» [5, c. 87-95].

Ю. Фролов вважає, що адміністративноправові відносини у сфері вищої освіти за участі ВНЗ складаються з регламентованого нормами адміністративного права комплексу зовнішніх (організаційно-освітніх) внутрішніх (внутрішньо-організаційних) відносин, що виникають у процесі державного управління між органами державної влади і управління та ВНЗ як колективними суб’єктами освітнього процесу [5, с. 87-95].

Тобто автономія закладів вищої освіти виникає в площині внутрішньо-організаційних адміністративних відносин вищої освіти, оскільки суб’єктами таких відносин є заклади освіти, громадськість та держава, уповноважені органи якої забезпечують дотримання принципу автономії в освітньому процесі.

Законом України «Про вищу освіту» від 1 липня 2014 року № 1556-VII визначено, що автономія закладу вищої освіти - це самостійність, незалежність і відповідальність закладу вищої освіти у прийнятті рішень стосовно розвитку академічних свобод, організації освітнього процесу, наукових досліджень, внутрішнього управління, економічної та іншої діяльності, самостійного добору і розстановки кадрів у межах, встановлених законодавством [4].

Формування i реалізація державної політики у сфері вищої освіти забезпечуються шляхом розвитку автономії закладів вищої освіти та академічної свободи учасників освітнього процесу. Автономія закладу вищої освіти зумовлює необхідність таких самоорганізації та саморегулювання, які $€$ відкритими до критики, служать громадському інтересові, встановленню істини стосовно викликів, що постають перед державою і суспільством, здійснюються прозоро та публічно [4].

Отже, автономія закладів вищої освіти - це основна характеристика незалежності закладу освіти, яка полягає у його можливості самостійно вирішувати внутрішньо-управлінські питання, брати участь в адміністративному управлінні, взаємодіяти 3 громадськістю, при цьому діяти відкрито та прозоро для дотримання високого рівня освіти, якості освітнього процесу, розвитку правосвідомості молоді в суспільстві.

Крім того, беззаперечно, першим принципом діяльності закладу вищої освіти є принцип автономії та самоврядування.

Заклади вищої освіти мають рівні права [4], що становлять зміст їх автономії та самоврядування, у тому числі мають право: 1) розробляти та реалізовувати освітні (наукові) програми в межах ліцензованої спеціальності; 2) самостійно визначати форми навчання та форми організації освітнього процесу; 3) обирати типи програм підготовки бакалаврів і магістрів, що передбачені Міжнародною стандартною класифікацією освіти; 4) приймати на роботу педагогічних, наукових, науково-педагогічних та інших працівників; 5) формувати та затверджувати власний штатний розпис відповідно до законодавства; 6) приймати остаточне рішення щодо визнання, у тому числі встановлення еквівалентності, здобутих в іноземних закладах вищої освіти ступенів бакалавра, магістра, доктора філософії / доктора мистецтва, доктора наук і вчених звань доцента, професора під час зарахування на навчання та/або на посаду наукового чи науково-педагогічного працівника; 7) запроваджувати рейтингове оцінювання освітніх, мистецьких, науково-дослідницьких та інноваційних досягнень учасників освітнього процесу; 8) надавати додаткові освітні та інші послуги відповідно до законодавства; 9) самостійно розробляти та запроваджувати власні програми освітньої, мистецької, наукової, науково-технічної та інноваційної діяльності; 10) самостійно запроваджувати спеціалізації, визначати 
їх зміст і програми навчальних дисциплін; 11) присуджувати ступені вищої освіти здобувачам вищої освіти, які відповідно до законодавства успішно пройшли процедуру атестації після завершення навчання на відповідному рівні вищої освіти; 12) приймати остаточне рішення щодо присудження наукових ступенів акредитованими спеціалізованими вченими радами (ступеня доктора мистецтва акредитованими спеціалізованими радами з присудження ступеня доктора мистецтва); 13) утворювати заклади загальної середньої освіти за погодженням з органами місцевого самоврядування; 13-1) виступати засновником чи співзасновником закладів професійної (професійно-технічної), фахової передвищої освіти, коледжів; 14) утворювати, реорганізовувати та ліквідовувати свої структурні підрозділи; 15) провадити видавничу діяльність, зокрема видавати підручники, навчальні посібники і наукові праці, а також розвивати власну поліграфічну базу; 16) провадити на підставі відповідних договорів спільну діяльність 3 навчальними закладами, науковими установами та іншими юридичними особами; 17) розміщувати свої навчальні, науководослідні та навчально-науково-виробничі підрозділи на підприємствах, в установах та організаціях; 18) брати участь у роботі міжнародних організацій; 19) запроваджувати власну символіку та атрибутику; 20) встановлювати власні форми морального та матеріального заохочення учасників освітнього процесу; 21) звертатися з ініціативою до органів, що здійснюють управління у сфері вищої освіти, про внесення змін до чинних або розроблення нових нормативно-правових актів у сфері вищої освіти, а також брати участь у роботі над проектами; 22) провадити фінансово-господарську та іншу діяльність відповідно до законодавства та статуту закладу вищої освіти; 23) розпоряджатися власними надходженнями (для закладів вищої освіти державної і комунальної форми власності), зокрема від надання платних послуг; 24) відкривати поточні та депозитні рахунки в банках; 25) здійснювати інші права, що не суперечать законодавству [4].

Наукова, науково-технічна та інноваційна діяльність у закладах вищої освіти провадиться відповідно до законодавства про освітню, наукову, науково-технічну та інноваційну діяльність. Державні органи, до сфери управління яких належать заклади вищої освіти, формують політику наукової і інноваційної діяльності, яка здійснюється безпосередньо закладами вищої освіти на засадах автономії [4].
В. Луговий переконує, що, по-перше, автономія, особливо академічна, організаційна та кадрова, є важливим чинником досягнення університетами високих рангових позицій за провідними міжнародними рейтингами. По-друге, сама по собі автономія, не доповнена іншими розвинутими складниками діяльності, зокрема дослідницько-інноваційною, неспроможна гарантувати конкурентоспроможність закладів вищої освіти. Інакше автономія є необхідною, але недостатньою умовою успішної діяльності вищої школи. По-третє, порівняння інтегральної автономії та її диференціальних компонентів (академічної, організаційної, кадрової, фінансової) виявляе ефект автономічної синергії, за якого інтегральна автономія більш впливова, ніж її диференціальні компоненти. По-четверте, вищій освіті України бракуе як автономії, крім кадрової, так й інших ключових складників основної діяльності, насамперед дослідницько-інноваційної [3, с. 5-9; 2, c. 14-20].

Отже, за змістом принцип автономії закладів вищої освіти виражається у можливості реалізації закладами вищої освіти повноважень, які умовно можна поділити на: 1) внутрішньо-управлінські (можливість самостійно брати участь у внутрішньому управлінні закладу освіти); 2) регулятивні (вплив на освітній процес через закріплення різноманітних норм та правил, наприклад, формування освітніх програм, організація освітнього процесу тощо); 3) кадрові (залучення кадрів в освітній процес закладу освіти); 4) акредитаційні (приймати остаточне рішення відносно присудження наукових ступенів); 5) науково-дослідні (проведення наукових заходів, здійснення наукових робіт, участь в грантах тощо); 6) аналітично-інформаційні (аналіз власної діяльності та висвітлення її на публічних майданчиках); 7) фінансові (здійснення фінансово-господарської діяльності); 8) координаційні (взаємодія 3 державою, іншими закладами освіти, міжнародними організаціями та громадськістю).

\section{Висновки}

Забезпечення принципу автономії закладів вищої освіти здійснюється з позиції адміністративного права і виникає в площині внутрішньо-організаційних адміністративних відносин вищої освіти, оскільки суб'єктами таких відносин є заклади освіти, громадськість та держава, уповноважені органи якої забезпечують дотримання принципу автономії в освітньому процесі.

Загалом автономія закладів вищої освіти - це основна характеристика незалеж- 
ності закладу освіти, яка полягає у його можливості самостійно вирішувати внутрішньо-управлінські питання, брати участь в адміністративному управлінні, взаємодіяти з громадськістю, при цьому діяти відкрито та прозоро для дотримання високого рівня освіти, якості освітнього процесу, розвитку правосвідомості молоді в суспільстві.

За змістом принцип автономії закладів вищої освіти виражається у можливості реалізації закладами вищої освіти повноважень, які умовно можна поділити на: внутрішньо-управлінські; регулятивні; кадрові; акредитаційні; науково-дослідні; аналітично-інформаційні; фінансові (здійснення фінансово-господарської діяльності); координаційні.

\section{Список використаних джерел:}

1. Деркач O.A. Реформування системи вищої освіти України в контексті автономізації ВНЗ. Актуальні проблеми сочіології, психології, педагогіки. 2015. № 4(2). С. 9-16.

2. Луговий В. Автономія та лідерство в європейському просторі вищої освіти. Вища освіта України. 2014. № 1. С. 14-20.

3. Луговий В. Якість вищої освіти: виклик для України. Вища освіта України : Тематичний випуск «Европейська інтеграчія вищої освіти Украйни у контексті Болонського процесу» : у 2 т. 2012. T. 1, № 3. 134 c.

4. Про вищу освіту: Закон України від 1 липня 2014 року № 1556-VII. Відомості Верховної Ради Украӥни. 2014. № 37-38.

5. Фролов Ю.М. Особливості адміністративних правовідносин у сфері вищої освіти за участі вищих навчальних закладів. Публічне право. 2013. С. 87-95.

The article reveals the peculiarities of ensuring the principle of the autonomy of institutions of higher education from the position of administrative law by determining the composition of the internal-organizational administrative relations of higher education. Accordingly, it is noted that the subjects of the internal-organizational administrative relations of higher education are educational institutions, the public and the state, the authorized bodies of which ensure adherence to the principle of autonomy in the educational process. The scientific concept of autonomy of institutions of higher education is defined from the point of view of administrative law as the main characteristic of the independence of the institution of education, which is its ability to independently solve internal-management issues, participate in administrative management, interact with the public, while doing it openly and transparently for adherence to a high level of education, the quality of the educational process, the development of youth legal awareness in society. It is proved that the content of the principle of autonomy of institutions of higher education is expressed in the possibility of implementing institutions of higher education, which can be divided into: internal-management; regulatory personnel; accreditation; scientific research; analytical and informational; financial; coordination. It is determined that internal management powers as an opportunity to participate independently in the internal management of the educational institution; regulatory powers as an effect on the educational process through the establishment of various rules and norms, for example, the formation of educational programs, the organization of the educational process, etc; personnel powers are implemented through the involvement of staff in the educational process of the institution of education; accreditation authority is an opportunity to make the final decision regarding the award of scientific degrees; scientific research powers are carried out through scientific events, scientific works, participation in grants, etc.; analytical and informational are realized through the analysis of own activity and its coverage on public platforms; financial authority is the implementation of financial and economic activities; coordination is carried out through interaction with the state, other educational institutions, international organizations and the public.

Key words: administrative-legal relations, higher education, higher educational institution, public, education, principle of autonomy. 
УДК 342.9

DOI https://doi.org/10.32849/2663-5313/2019.8.19

Михайло Соф'їн,

канд. юрид. наук, докторант

Науково-дослідного інституту публічного права

\section{НЕРІВНОМІРНІСТЬ ПОДАТКОВОГО НАВАНТАЖЕННЯ В УМОВАХ ЄВРОІНТЕГРАЦІЙНОГО КУРСУ УКРАЇНИ}

У статті на основі аналізу наукових поглядів учених та норм чинного законодавства досліджено проблему нерівномірності податкового навантаження в контексті формування та реалізації фіскальної політики України в умовах євроінтеграційного курсу України. Наголошено, що до оцінки рівня суб'єктивного благополуччя дослідники включили не тільки пряму відповідь на питання про задоволеність, але й питання щодо позитивності/негативності щоденного досвіду людей. Прогресивність оподаткування, яку було виражено як різницю між максимальною та мінімальною податковими ставками або ж як різницю між податками, що їх сплачують індивіди, які мають дохід на рівні $167 \%$ та $67 \%$ від середнього, в обох випадках була пов'язана зі збільшенням суб'єктивного благополуччя та щоденного позитивного досвіду $i$, відповідно, зменшенням щоденного негативного досвіду. Обгрунтовано, що нині необхідність зменшення податкового навантаження в Україні не викликає жодних сумнівів, однак при иьому зниження повинно бути поступовим та супроводжуватись зниженням рівня витрат із державного бюджету. З'ясовано, що прогресивне оподаткування є необхідним кроком на шляху забезпечення рівномірного розподілу матеріальних благ між різними верствами населення та підтримання загальносуспільного блага на належному рівні. Зроблено висновок, що зменшення податкового навантаження в сучасних умовах може здатись хибним кроком, оскільки ие начебто повинно зменшувати суму коштів, які потрапляють до державного бюджету, однак ие не так. Головне призначення зниження податкового навантаження полягає у тому, щоб вивести несумлінних платників податків із тіні, а також створити умови, за яких великі платники податків будуть повністю відповідати за своїми податковими зобов'язаннями. Усе це у сукупності повинно створити «прозору» систему оподаткування та в результаті фактично збільшити надходження до бюджету. Однак, зменшуючи податкове навантаження, украйнському законодавию слід знайти чіткий баланс для того, щоб система оподаткування України була якомога оптимальнішою та такою, що здатна активізувати інвестиційні прочеси в державі.

Ключові слова: податкова система, суб'єкт господарювання, податкова ставка, матеріальні блага, фінансовий потенціал.

Постановка проблеми. Проблеми формування податкової системи, регулювання та оптимізації податкового навантаження є актуальним питанням для економіки України. На сучасному етапі розвитку показник податкового навантаження є основним критерієм ефективності системи оподаткування країни. Надмірне оподаткування разом із загальною економічною кризою сприятиме зростанню тінізації економіки, відтоку національних капіталів за кордон, зниженню ділової активності суб'єктів господарювання. Податкове навантаження є показником ефективності бюджетно-податкової політики, що характеризує сукупний вплив податків на економіку країни в цілому чи на окремих суб'єктів господарювання [1]. У цьому контексті слід погодитись із точкою зору Ю. Дроговоз та В. Дубровського, які, аналізуючи проблематику податкової системи, наголошують, що сучасна українська економіка страждає від величезного, порівняно з країнами зі схожим рівнем розвитку, податкового навантаження.

Стан дослідження. Окремі проблемні питання формування та реалізації фіскальної політики у своїх наукових дослідженнях розглядали: М. Кучерявенко, Г. Бех, В. Андрущенко, Т. Меркулова, М. Гридчина, Д. Кобильнік, В. Тропина, Н. Вдовиченко В. Білоцерківець, Я. Жаліло, О. Дмитрик, А. Крисоватий, С. Маслюченко, Я. Литвиненко та багато інших. Однак, незважаючи на чималу кількість наукових розробок, в юридичній літературі відсутні комплексні дослідження, присвячені проблемі нерівномірності податкового навантаження в контексті формування та реалізації фіскальної політики в умовах євроінтеграційного курсу України. 
Мета статті - розглянути проблему нерівномірності податкового навантаження в контексті формування та реалізації фіскальної політики в умовах євроінтеграційного курсу України

Виклад основного матеріалу. Натепер, якщо враховувати $\mathrm{CCB}$, податкове навантаження в Україні сягає майже 40 \% від ВВП. На жаль, аби зменшити цей тягар в абсолютному вимірі, треба спочатку скоротити бюджетні витрати. Утім, насправді він становить набагато менше, ймовірно близько 30 \%, завдяки широким масштабам ухилення та мінімізації податків. Фактично економіка у такий спосіб пристосовується до завеликого податкового навантаження. Але проблема насамперед у тому, що завдяки великій дискреції податкових органів це відбувається нерівномірно: тиск перекладається на сумлінних платників та тих, хто не здатен захиститися від податківців, натомість деякі інші отримують фактичні податкові привілеї. Це робить оподаткування не просто несправедливим, а перетворює його на засіб нечесної конкуренції, встановлення монополій, отримання адміністративної (корупційної) ренти тощо [2, с. 3]. Л. В. Слюсарева щодо вказаної проблеми пише, що сучасні умови господарювання характеризуються високим рівнем інтеграційних та глобалізаційних процесів, підвищенням ступеня відкритості економік різних країн та зростанням ролі міжнародних корпорацій. Це, у свою чергу, підтверджує значимість функціонування ефективної податкової системи, яка б характеризувалася високою конкурентоспроможністю та сприяла формуванню позитивного іміджу країни у світовому економічному просторі. Сьогодні проблема ефективної системи оподаткування є досить актуальною та вирішується у численних працях науковців шляхом аналізу податкового навантаження як основно категорії, що відображає результат функціонування податкової системи держави. Тому сьогодні питання податкового навантаження привертає до себе дедалі більшу увагу з боку науковців, фінансистів та практиків у сфері оподаткування [3, с. 321]. Дослідниця справедливо підкреслює, що наразі в Україні немає однозначної оцінки важкості податкового навантаження. Деякі вчені та державні діячі зазначають, що податкова система «не $\epsilon$ надмірно жорсткою, рівень оподаткування не є надто великим». Проте одночасно наголошують на існуванні досить високого рівня потенційного податкового навантаження: якщо суворо дотримуватися податкового законодавства, рівень стягнень податків наближається до 35-40 \% ВВП, що зіставний
3 рівнем розвинених європейських країн [3, с. 321-322]. М. Б. Кондратенко зазначає, що досягнення оптимального рівня податкового навантаження можливе лише за умови правильного його розподілу між платниками податків. Саме чітко визначені засади розподілу податкового навантаження сприяють його рівномірності і зменшенню обтяжливості для платників податків. Погоджуючись із Д. Харко та М.Б. Кондратенко, відзначимо, що обтяжливість податкової системи України визначається не величиною податкових ставок, а насамперед нерівномірністю податкового навантаження» [4]. Справді, легше змиритися з існуванням об'єктивно встановленого високого рівня податкового навантаження, але за умови його рівномірного розподілу [5].

Для розв'язання зазначеної проблеми необхідно:

а) по-перше, розвивати прогресивне оподаткування. А. Пігу свого часу відзначав, що якщо платників податків цікавлять не символи і гроші, а речі, які дозволяють задовольняти відповідні потреби, якщо шкала податку на доходи будується так, що збиток всіх платників податків однаковий незалежно від рівня їхнього доходу, то обсяг роботи не буде зумовлюватися очікуваннями, пов'язаними 3 вилученням податку [6, с. 335]. Корисність саме прогресивного оподаткування вже неодноразово була доведена зарубіжними дослідниками. Так, французький економіст Томас Пікетті на основі величезного масиву статистичних історичних даних досліджує динаміку економіки в різних країнах. Він доходить висновку, що капіталістичній системі притаманна постійна тенденція до концентрації капіталу в руках найбагатших та, відповідно, до збільшення нерівності. У перспективі ці тенденції, на його думку, можуть призвести до згубних наслідків для суспільства, якщо не намагатися їх зупинити. Одним із інструментів для подолання цих тенденцій і їх негативних наслідків, вважає Пікетті, і має бути прогресивне оподаткування, яке зменшить концентрацію капіталу та нерівність, а отже, допоможе уникнути катастрофічних наслідків [7]. Основним аргументом на користь прогресивного оподаткування на рівні окремих суспільних систем, пишуть О. Дцучак та А. Гладун, є те, що дохід має спадну граничну корисність. Інакше кажучи, кожна наступна гривня має для індивіда меншу користь, ніж попередня. Індивідуальні винятки можливі, але загалом для людини із заробітною платнею 2000 грн. додаткова тисяча матиме більший ефект, ніж для людини із з/п 10000 грн. Крім того, серед вищих класів зростання доходів 
набуває ознак гри з нульовою сумою, оскільки має місце демонстративне споживання. Тобто збільшення доходу не приводить до збільшення суб'єктивного благополуччя, а лише до конкуренції споживання. Виходячи 3 цього, перерозподіл частини багатства до тих, для кого воно матиме більшу користь, має сенс. Що ж стосується макрорівня, то, продовжують дослідники, загалом прогресивне оподаткування має позитивний вплив на суб'єктивне благополуччя. У статті «Прогресивне оподаткування й суб'єктивне благополуччя народів» (Oishi та ін. 2012) автори знаходять позитивний зв'язок між прогресивністю оподаткування та суб'єктивним благополуччям у 54 країнах. До оцінки рівня суб'єктивного благополуччя дослідники включили не тільки пряму відповідь на питання про задоволеність, але й питання щодо позитивності/негативності щоденного досвіду людей. Прогресивність оподаткування, яку було виражено як різницю між максимальною та мінімальною податковими ставками або ж як різницю між податками, що їх сплачують індивіди, які мають дохід на рівні $167 \%$ та 67 \% від середнього, в обох випадках була пов'язана зі збільшенням суб'єктивного благополуччя та щоденного позитивного досвіду і, відповідно, зменшенням щоденного негативного досвіду. Дослідники вказують на проміжну ланку між позитивним досвідом і прогресивним оподаткуванням - суспільні блага, такі як громадський транспорт, освіта та медицина. Доступність цих суспільних благ збільшується за рахунок прогресивного оподаткування, що, у свою чергу впливає, на суб'єктивне благополуччя й щоденний досвід громадян. Вони доходять висновку, що прогресивне оподаткування чи багатство країни не обов'язково ведуть до щасливого суспільства. Але правильне використання цього багатства, яке можна перерозподіляти, наприклад, через прогресивне оподаткування й інвестувати у суспільні блага, збільшує добробут і щастя в суспільстві [7].

Тож прогресивне оподаткування є необхідним кроком на шляху забезпечення рівномірного розподілу матеріальних благ між різними верствами населення та підтримання загальносуспільного блага на належному рівні;

б) по-друге, забезпечити належний рівень законності у сфері податкових відносин, адже прогресивне оподаткування є ефективним і призводить до реальних позитивних зрушень тільки тоді, коли платники податків сумлінно виконують свої зобов'язання перед бюджетом. Очевидно, що зміна підходу до оподаткування, а саме збільшення ставок, може i, скоріш за все, призведе до при- ховування реальних доходів для того, щоб скористатися найменшою ставкою. 3 метою запобігання такій ситуації слід:

- активно впроваджувати правовиховні та правоосвітні заходи з метою підвищення рівня правової свідомості і культури платників податків. Правосвідомість - це система почуттєвих і мислених образів комунікативно-вольової спрямованості, через які відбувається безпосереднє і опосередковане сприйняття правової реальності - ставлення до чинного, минулого і бажаного права, до діяльності, пов'язаної з правом, до правових явищ та поведінки людей у сфері права [8, с. 92]. О. Ф. Скакун наголошує, що правосвідомість пов'язана зі знанням права, ставленням до права, поведінкою у правовій сфері. Ключовий пункт правосвідомості - усвідомлення людьми цінностей права, прав і свобод людини й оцінка чинного права з огляду на його відповідність загальнолюдським цінностям, закріпленим у міжнародних документах про права людини. Це означає, що міжнародна гуманітарна правосвідомість має пріоритет перед національною. Правосвідомість є суб'єктивною формою реалізації функцій права [8, с. 92]. Правосвідомість відображає, зазначають М. В. Цвік та інші, правову дійсність, що склалася за конкретно-історичних умов у тій чи іншій країні, але водночас впливає на функціонування й розвиток правової системи. Вона є активним елементом системи правового регулювання суспільних відносин - право не може здійснювати свій регулятивний вплив інакше як через людей, безпосередньо впливаючи на їхню свідомість. За посередництвом правових ідей та теорій, почуттів та емоцій норми права, інші правові явища оцінюються з точки зору життєвих потреб та інтересів людей і суспільства, справедливості, формуються установки на правову поведінку, уявлення щодо критеріїв ефективності правового регулювання, шляхів реформування та удосконалення законодавства, судово-правової системи, юридичної практики [9, с. 235]. Щодо правової культури, то під нею розуміється зумовлений всім соціальним, духовним, політичними економічним ладом якісний стан правового життя суспільства, що виражається в досягнутому рівні розвитку правової діяльності, юридичних актів, правосвідомості і загалом у рівні правового розвитку суб'єкта (людини, різних груп, всього населення), а також ступені гарантованості державою і громадянським суспільством свобод і прав людини. Звідси правова культура - певна «якість» правового життя суспільства, рівень його розвитку [10, с. 307-308]. Одним із ключових факторів, що зумовлюють, визначають стан правової 
культури суспільства, є насамперед рівень розвитку правової свідомості населення, тобто те, наскільки освоєно їм такі правові феномени, як цінність прав і свобод людини, цінність правової процедури під час вирішення суперечок, пошук компромісів і т. д., наскільки інформоване в правовому сенсі населення, його соціальні, вікові, професійні та інші групи, яке емоційне ставлення населення до закону, суду, різних правоохоронних органів, юридичних засобів і процедур, як і установка громадян на дотримання (недотримання) правових приписів і т. д. [10, с. 308]. Отже, запроваджуючи та розвиваючи прогресивне оподаткування, контролюючі органи мають не просто нав'язувати силою нові правила оподаткування, а чітко та послідовно роз'яснити платниками податків корисність та цінність такого підходу. Вони, платники податків, мають усвідомлювати, що належне, сумлінне виконання ними своїх податкових обов'язків - необхідний внесок як у їхне індивідуальне, так і в загальносоціальне благополуччя;

- більший акцент робити на оподаткуванні нетрудових доходів. Це зумовлено тим, що значна частина прихованих доходів легалізується шляхом придбання предметів розкоші, інвестування коштів у цінні папери тощо. Звідси, як справедливо зауважує М. Б. Кондратенко, принцип рівномірності розподілу податкового навантаження в Україні слід намагатися реалізувати не через прогресивну шкалу оподаткування, а в інший спосіб. Йдеться про те, що доходи громадян, які не були оподатковані під час їх виплати, можна оподаткувати за допомогою інших податків - ПДВ, акцизний податок, податки на нерухомість, дивіденди, процентні доходи. Крім того, удосконалення потребує підхід до диференціації доходів з метою оподаткування. Йдеться про те, що джерело походження доходу має враховуватися під час встановлення ставки [5];

в) по-третє, впровадження у механізм оподаткування такого принципу, як оптимальність, що наразі відсутній у чинному українському законодавстві, зокрема у ПК України. Оптимальність як засадниче положення передбачає можливість використання платниками податків законних методів для забезпечення найбільш прийнятного для себе рівня податкового навантаження. Слід погодитися з твердженням про те, що вироблення механізму оптимізації податкового навантаження на підприємстві є головною умовою його стабільного розвитку. Використання методів оптимізації та вибір оптимального варіанту оподаткування дасть можливість підприємству сплачувати податкові платежі в необтяжливому для нього розмірі, спрямовувати зекономлені кошти на подальший розвиток та зменшити податкові ризики. Такий елемент управління податковими потоками підприємства збалансовує відносини між фіскальними органами та суб'єктами господарювання, що надає, у свою чергу, державі забезпечення повного надходження податкових платежів до бюджету [11, с. 82]. Закріплення зазначеного принципу є важливим ще й тому, що сьогодні досить часто контролюючі органи розцінюють спробу платників податків оптимізувати свої податкові виплати як ухиляння від сплати податків, тобто як протиправну діяльність. Така ситуація, вочевидь, пояснюється тим, що «оптимізація» тлумачитися контролюючими органами як абсолютна мінімізація розміру податкових зобов'язань, що є непарвильним. Як справедливо наголошує Р. В. Юрчишена, розмірковуючи про оптимізацію оподаткування, податковий менеджмент підприємства передбачає розробку управлінських рішень, спрямованих на формування фінансового потенціалу і підвищення його ефективності. Його основна мета не зводиться до абсолютної мінімізації податкових платежів, а полягає в активному впливі на максимізацію чистого прибутку підприємства при заданих параметрах податкового середовища і ринкової кон'юнктури [11, с. 80].

Висновки. Таким чином, натепер в Україні потреба зменшення податкового навантаження не викликає жодних сумнівів, однак при цьому це зниження повинно бути поступовим та супроводжуватись зниженням витрат із державного бюджету. Крім того, слід звернути увагу і на те, що, окрім вказаного вище, проведення податкової реформи, зокрема, в частині зниження податкового навантаження повинно проводитись разом зі змінами у сфері оплати праці, а також економічно обгрунтованого розширення пакета соціальних послуг і гарантій працюючому населенню. На завершення слід вказати, що зниження податкового навантаження вимагає також реформування податкових органів в Україні.

У підсумку наукового дослідження підкреслимо, що зменшення податкового навантаження в сучасних умовах може здатись хибним кроком, оскільки це начебто повинно зменшувати суму коштів, які потрапляють до державного бюджету, однак це не так. Головне призначення зниження податкового навантаження полягає у тому, щоб вивести несумлінних платників податків із тіні, а також створити умови, за яких великі платники податків будуть повністю відповідати за своїми податковими зобов'язаннями. Усе 
це у сукупності повинно створити «прозору» систему оподаткування та в результаті фактично збільшити надходження до бюджету. Однак, зменшуючи податкове навантаження, українському законодавцю слід знайти чіткий баланс для того, щоб система оподаткування України була якомога оптимальнішою та такою, що здатна активізувати інвестиційні процеси в державі.

\section{Список використаних джерел:}

1. Фєдосова В. Е. Проблеми податкової системи та податкового навантаження України. Економіка і регіон. 2015. № 2 (51). С. 90-93.

2. Дроговоз Ю., Дубровський В. Інституційні проблеми української податкової системи та шляхи їх вирішення. Київ, 2015. С. 32. URL: https:// rpr.org.ua/uploads/files/source/Policy_Tax Reform_RPR.pdf (дата звернення: 10.08.2019).

3. Соціально-економічні проблеми сучасності : матеріали II Всеукраїнської науково-практичної інтернет-конференції (м. Маріуполь, 15 червня 2018 р.). Маріуполь, 2018. 480 с.

4. Харко Д. Правова природа тіньової економіки: поняття, причини та напрями детінізації. Вісник Львівського університету. Серія «Юридична». 2011.Вип. 52. С. 351-357.
5. Кондратенко М. Б. Розподіл податкового навантаження на фізичних осіб в Україні та напрями його оптимізації. Актуальні проблеми економіки. 2014. № 3. С. 414-422. URL http://nbuv.gov.ua/UJRN/ape_2014_3_52 (дата звернення: 10.08.2019).

6. Пигу А. Экономическая теория благосостояния : в 2 т. Москва : Прогресс, 1985. Т. 1. 512 с.

7. Дцучак О. Гладун А. Прогресивне оподаткування робить людей щасливішими, але чи допоможе воно Україні? Журнал «Спільне». URL: https://commons.com.ua/uk/progresivneopodatkuvannya-robit-lyudej-shhaslivishimiale-chi-dopomozhe-vono-ukrayini/ (дата звернення: 10.08.2019).

8. Скакун О. Ф. Теорія права і держави : підручник. 2-ге видання. Київ : Алерта; КНТ; ЦУЛ, $2010.520 \mathrm{c}$.

9. Загальна теорія держави і права : підручник / М. В. Цвік, В. Д. Ткаченко, Л. Л. Богачова та ін.; за ред. М. В. Цвіка, В. Д. Ткаченка, О. В. Петришина. Харків: Право, 2002. 432 с.

10. Теория государства и права : учебник / под ред. В.К. Бабаева. Москва : Юристъ, 2003. 592 с.

11. Желєзнова Д. С., Юрчишена Р. В. Механізм оптимізації податкового навантаження в системі корпоративного податкового менеджменту. Фінанси, облік, банки. 2018. № 1(23). С. 73-83.

The article analyzes the problem of uneven tax burden in the context of the formation and implementation of fiscal policy of Ukraine in the context of the European integration course of Ukraine on the basis of the analysis of scientific viewes of scientists and the norms of the current legislation. It was emphasized that before the assessment of the level of subjective well-being, researchers included not only a direct answer to the question of satisfaction, but also the question of the positiveness/negativity of people's daily experience. The progressiveness of taxation, which was expressed as the difference between the maximum and minimum tax rates or the difference between the taxes paid by individuals who have income of $167 \%$ and $67 \%$ of the average, in both cases was associated with an increase in the sub-native well-being and daily positive experiences, as well as a decrease in the daily negative experience. It is substantiated that today in Ukraine the need to reduce the tax burden is not in doubt, but at the same time this decrease should be gradual and accompanied by a decrease in the level of expenditure from the state budget. It has been determined that progressive taxation is a necessary step towards ensuring an even distribution of material wealth between different sections of the population and maintaining the public good at an appropriate level. It is concluded that a reduction in the tax burden in modern conditions on the one hand may prove to be a false step, because it seems to reduce the amount of funds that fall into the state budget, but this is not the case. The main purpose of reducing the tax burden is to withdraw bad taxpayers from the shadow, as well as to create conditions under which large taxpayers will fully comply with their tax liability. All this in its totality should create a "transparent" tax system and as a result, actually increase revenues to the budget. However, reducing tax burden, the Ukrainian legislator should find a clear balance in order for Ukraine's taxation system to be as optimal as possible and capable of intensifying investment processes in the state.

Key words: tax system, economic entity, tax rate, material wealth, financial potential. 
УДК 340.1

DOI https://doi.org/10.32849/2663-5313/2019.8.20

В’ячеслав Тильчик, канд. юрид. наук, доиент, професор кафедри адміністративного права і прочесу та митної безпеки Університету державної фіскальної служби України

\section{ОНТОЛОГІЧНИЙ ВИМІР ПРАВОПОРУШЕННЯ ЯК ПРЕДМЕТА СПОРУ У СФЕРІ ПУБЛІЧНО-ПРАВОВИХ ВІДНОСИН}

У статті досліджено поняття правопорушення в онтологічному вимірі предмета спору у сфері публічно-правових відносин. Вказується, що сучасний період розвитку адміністративного права характеризується посиленням розробки складників його проиесуальних иентрів, оскільки поряд із теоретичними напрачюваннями важливу роль займає практика реалізації прочесуальних норм в аспекті тлумачення конкретних понять. Нині такий підхід варто використовувати під час визначення поняття «спір у сфері публічно-правових відносин». Констатується розвиток інституту «помилки» в державному управлінні чи то в діяльності публічної адміністраиії. Однією із підстав була наявність положення, яке встановлювало порядок звернення зі скаргою до органу (посадової особи), яка прийняла незаконне рішення (здійснила дію чи допустила бездіяльність). Очевидно, що нині інститут «сумлінної омани» під час реалізації суб'єктами владних управлінських функиій дещо знечінився. Це пов'язано передусім із відміною раніше діючих положень нормативно-правових актів щодо можливості звернення зі скаргою до органу (посадової особи), який прийняв таке рішення. Іншими словами, на законодавчому рівні встановлено дворівневу систему досудового оскарження, по суті «висловивши недовіру» можливості «сумлінної омани» та «добросовісного» виправлення (скасування) незаконного рішення, утримання від незаконної дії чи бездіяльності суб'єкта, що реалізує владні управлінські функиї. Поряд із зусиллями формування антикорупиійної системи питання порушень суб'єктами владних повноважень прав, свобод та законних інтересів фізичних та юридичних осіб не втрачає актуальності, а лише загострює необхідність встановлення змісту поняття «спір», оскільки в сучасному розумінні воно включає як відносини порушення, так і спірні правовідносини, співвідношення цього поняття із іншими правовими поняттями.

Ключові слова: адміністративне право, адміністративний процес, публічно-правові відносини, спір у сфері публічно-правових відносин, адміністративне правопорушення, адміністративний проступок, адміністративне судочинство.

Постановка проблеми. Сучасний період розвитку адміністративного права характеризується посиленням розробки складників його процесуальних центрів, оскільки поряд iз теоретичними напрацюваннями важливу роль займає практика реалізації процесуальних норм в аспекті тлумачення конкретних понять. Нині такий підхід використано під час визначення поняття спору у сфері публічно-правових відносин.

Метою статті $є$ аналіз поняття правопорушення в онтологічному вимірі предмета спору у сфері публічно-правових відносин.

Виклад основного матеріалу. А.О. Селіванов, розкриваючи питання онтологічного тлумачення адміністративного права, наголошує на тому, що від вченихадміністративістів рідко можна отримати ех nunc (об'єктивно-телеологічне тлумачення), яке слід пов'язувати з інтерпретацією зако- ну адміністративного права 3 урахуванням сучасних реалій, потреб суспільства. Адже за відсутності такої наукової практики тлумачення забезпечує виявлення найбільш розумного (логістичного) в сучасних умовах смислу закону, змушує суддів адміністративної юстиції орієнтуватися на реалії правозастосування і таким чином повертати законодавцю розуміння норм закону з метою наблизити його до волі справжнього законодавця. Адже є гіпотеза, що інформація про волю і цілі законодавця лише посилює необхідність суддям шукати відповіді не тільки у наукових коментарях кодексів, окремих законів, але й тлумачити букву закону, що корегує іï сенс. При цьому суддя не в змозі відмінити смисл закону, відійти від буквального значення його тексту [1, с. 79].

У такому контексті варто звернути увагу на те, що Кодекс адміністративного судочинства України визначає онтологічні 
ознаки спору у сфері публічно-правових відносин. Так, передусім аналізоване поняття тісно пов'язується із порушенням, вчиненим суб'єктом владних повноважень (частина 1 статті 2 КАС України) [2]. Відразу варто зауважити, що наведена конструкція має загалом оціночний характер, який підлягає тлумаченню у його діалектичному взаємозв'язку, а тому його змістовне наповнення залежить від встановлення сутності окремих частин із подальшим врахуванням їх загального контексту.

Онтологія «порушень суб'єктів владних повноважень» (в контексті визначення засад адміністративного судочинства) як об'єкт спорів у сфері публічно-правових відносин в процесі захисту прав свобод та інтересів фізичних та юридичних осіб видається складною з урахуванням низки обставин: 1) автономності наукових пошуків; 2) неоднорідності предметної сфери адміністративного права.

Традиційно питання «порушень» в адміністративному праві лежить у площині феноменології адміністративного делікту. Найбільш комплексно вказані питання досліджені у працях В.К. Колпакова, який, враховуючи онтологічні та гносеологічні ознаки проступку, а також базові напрацювання про предмет адміністративного права як поліструктурної юридичної субстанції, визначив як методологічну основу адміністративного права категорію «відносин адміністративних зобов'язань», під якими розуміються типи відносин, кожен з яких $€$ складником предмета адміністративного права: відносини публічного управління, адміністративних послуг, відповідальності публічної адміністрації за неправомірні дії або бездіяльність, відповідальності суб'єктів суспільства (індивідуальних і колективних) за порушення встановленого публічною адміністрацією порядку і правил [3, с. 33]. Характерною ознакою усіх названих вище адміністративно-правових відносин є те, що органи публічної адміністрації виступають у них владною стороною, яка реалізує свої виконавчо-розпорядчі повноваження. Своєю чергою відносини покладення на публічну адміністрацію відповідальності є похідними від відносин оскарження ï дій, що можуть здійснюватися у позасудовому порядку чи у судовому порядку [4, с. 33]. Загалом виділені відносини можливо представити як управлінсько-сервісні та відносини взаємної відповідальності. Однак за такого вихідного твердження постає проблема розмежування категорій правопорушення та проступку, спроба вирішення якої простежується у більшості наукових досліджень. В.К. Колпаков, оцінюючи науковий доробок I.T. Тарасова, наголошує на тому, що практика функціонування адміністративного апарату всіх держав показує, що незалежно від наявності чи відсутності явних, прямих свідомих правопорушень і відхилень від службового порядку, у діяльності будь-якої адміністрації завжди можливі такі дії і розпорядження, які істотно порушують законні права й інтереси громадян. При цьому вони не є ні злочинами, ні цивільною неправдою, ні погрішностями по службі. У такого роду діях і розпорядженнях адміністрації полягає сутність так званої «адміністративної неправди». Порівняно із «кримінальною неправдою», неправда адміністративна $є$ правопорушенням більш тонкого і складного характеру. Отже, для ефективної протидії адміністративній неправді є необхідним створення системи адміністративних судів, які забезпечать шляхом судового контролю законність розпоряджень і дій адміністрації. Функціональне ж призначення адміністративних судів полягало б не у накладанні стягнень і покарань, а винятково у касації або прямому скасуванні неправомірних актів адміністративної влади [5; 6].

Проблематика відповідальності за дії адміністрації існувала та жваво обговорювалась й в дореволюційний період. Так, A.I. Єлістратов в навчальному посібнику з адміністративного права піднімав питання про недоліки державного управління. Зокрема, писав, що закон установлює безспірність вимог адміністративних осіб до громадян. Такі вимоги, що висуваються, не допускають заперечень у порядку змагальності. Кожного разу, коли адміністративні органи у своїх вимогах до приватної особи наділені статусом юридичної особи (діють від імені органу) і захищають публічний інтерес у різних частинах адміністративного управління та з урахуванням суспільної користі, їх вимоги мають безумовний характер. Однак з огляду на те, що посадові особи мають приватноправовий статус, критерій безспірності втрачає свою сутність [7, с. 6-7]. Останнє твердження стало грунтом для припущень щодо відміни адміністративних актів у зв'язку із зловживанням встановленим законом правом здійснювати дії (приймати акти) адміністрацією по відношенню до громадян. Важливо, що догматизм монархічного регулювання історично заклав основу для «санкції» у вигляді відміни актів, а не у вигляді конкретного виду стягнення для посадових осіб.

На понятті «адміністративна неправда» як предметі адміністративної юстиції наголошував ще О.Д. Градовський, який вказував на те, що таке поняття включає в себе порушене та спірне право [8, с. 307]. По суті, «адміністра- 
тивна неправда» визнавалася окремим видом адміністративного правопорушення. Тому логічно, що питання розмежування понять «адміністративне правопорушення» та «адміністративний проступок» стало об'єктом уваги багатьох вчених, оскільки ані в теоретичному, ані в прикладному сенсі такі поняття не могли існувати у єдності їх соціального змісту, тим більше юридичної форми.

Розмежовуючи такі поняття, В.К. Колпаков робить висновок про формування двох відповідних інституційних концепцій [9, с. 120-125]. Загалом поняття «правопорушення», як наголошує Г.Ф. Шершеневич, розроблялося у напрямах їх розуміння як різновид юридичних фактів, підстава для юридичної відповідальності, правовідносини [10, с. 623]. Варто зазначити, що серед представлених напрямів найбільш складним і таким, що потребує грунтовного опрацювання, видається підхід, за якого правопорушення $\epsilon$ підставою для юридичної відповідальності, оскільки за окремі прояви протиправних діянь (адміністративних правопорушень, а не проступків) відповідальність не передбачена. Це положення стосується суб'єктів владних повноважень, які порушили права, свободи та законні інтереси фізичних та юридичних осіб.

Отже, питання «взаємної відповідальності» органів державної влади та громадян уявляється теоретичною конструкцією, яка не може повноцінно бути оцінена у площині інституту адміністративної відповідальності. Мається на увазі те, що неможливо нині втілити в життя теоретичних напрацювань В.М. Гессена, який ідентифікував адміністративні проступки як незаконні розпорядження адміністрації [11]. Зрозуміло, що такий «крок» не співпадає із сучасним доктринальним напрямом розвитку адміністративного права. Однак, не зважаючи на несприйняття зазначеної ідеї науковою спільнотою, що ідентифікує їі як локальну особливість лінгвістичної стилістики [12], в ній криється важлива думка про сутність категорії «правопорушення» як підстави виникнення спору та відмежування його від інших видів правопорушень (проступків), зокрема пов'язаних з корупцією.

Статтею 9 Кодексу України про адміністративні правопорушення встановлено поняття адміністративного правопорушення та перелік основних ознак [13]. Не вдаючись до грунтовного аналізу наведеного (нормативного) поняття, варто зазначити, що підставою для його відмежування є наявність адміністративної відповідальності за його вчинення. Беручи за основу такий факт, М.Д. Загряцьков під час встановлення сут- ності адміністративних правопорушень (не проступків - курсив В.Т.) наголошуе на необхідності виділення такого, як видання незаконного акту управління. Сутність його полягає у сумлінному та водночас помилковому застосуванні права посадовою особою. Наведене опосередковує й специфіку юридичних наслідків, спричинених вчиненням такого правопорушення, у вигляді відміни (виправлення чи скасування) такого адміністративного акта. Відповідно, виділення окремого виду адміністративних правопорушень, таких як видання незаконного адміністративного акту, поступово зникає зі сторінок наукової літератури [14]. Згодом I.C. Самощенко все ж спробував виділити вказаний вид адміністративних правопорушень. «Незнання чи невірне розуміння закону, - пише вчений в праці «Понятие правонарушения по советскому законодательству», - найбільш розповсюджена причина неправомірних діянь не лише зі сторони громадян, а й посадових осіб державних органів». Отже, санкції за скоєння проступку у вигляді видання незаконного акту чи рішення передусім слугують меті відновлення порушеного права. Таким видам правопорушень, у разі коли вони таким $є$, притаманна вина у формі необережності. Причому ознакою, яка дає можливість відмежовувати правопорушення, $€$ наявність адміністративної заборони. Загалом видання незаконних актів державними органами, іншими суб'єктами в своїй масі складають не правопорушення, а лише об'єктивно неправомірне діяння, оскільки є результатом фактичних та юридичних помилок, а не умислу чи необережності. Важливим висновком, окрім наведеного, є те, що державні органи здебільшого існують власне як сукупність посадових осіб, а тому винне видання незаконного акту одночасно є злочином чи дисциплінарним проступком, залежно від такої ознаки, як їх наслідки. Попри вказане твердження, незаконне видання такого акту скоюється саме органом, а не однією винною посадовою особою. Отже, питання встановлення вини видається проблематичним [15, с. $68,138,162,164,185,207,210]$. На існуванні правопорушень у вигляді видання незаконних актів (дій) наголошував у своїй праці «Санкции в советском праве» О.Е. Лейст, а їх скасування відносив до особливого виду правовідновлюючих санкцій [16, с. 115-117].

О.О. Жижиленко у праці «Наказание: его понятие и отличие от других правоохранительных средств», аналізуючи правові наслідки «неправди», зкласифікував їх за функціями, які вони виконують, на види: покарання, заходи захисту, 
заходи припинення, компенсації шкоди $[17$, с. 74$]$. У зв'язку із такою класифікацією, яка була підтримана багатьма вченими, питання правових наслідків «адміністративної неправди» вирішувалися у науці з урахуванням її критеріїв переважно у площині застосування адміністративної відповідальності. Так, Д.М. Бахрах вказував, що заходами адміністративного припинення $€$, зокрема, й призупинення дії незаконних адміністративних актів, а їх скасування є відновлювальними адміністративно-правовими заходами [18].

Таке твердження панувало в науці адміністративного права, а місце скасування незаконних актів державної адміністрації визначалося в розрізі вчень про адміністративне правопорушення та адміністративну відповідальність. Однак надалі, як зазначає В.К. Колпаков, поняття «адміністративне правопорушення» втратило ознаки одного з інститутів адміністративної юстиції і стало сприйматися як синонім поняття «адміністративний проступок (делікт)». Навіть більше, з перебігом часу саме словосполучення «адміністративне правопорушення» стало виконувати роль основного терміна під час визначення діянь, що порушують встановлені заборони [9, с. 144-145]. Наголос у радянському нормотворенні на терміні «адміністративне правопорушення» був зроблений у зв'язку із відсутністю подальших грунтовних розробок адміністративної відповідальності посадових (службових) осіб органів виконавчої влади та утвердження відносно оновленого адміністративно-правового інституту «скарги».

Таким чином, можливо констатувати розвиток інституту «помилки» в державному управлінні чи то в діяльності публічної адміністрації. Наведений напрям досліджень, хоча й прямо так і не називався, забезпечувавсь великою кількістю наукових праць як радянських, так і вітчизняних сучасних учених. Однією із підстав була наявність положення, яке встановлювало порядок звернення зі скаргою до органу (посадової особи), яка прийняла незаконне рішення (здійснила дію чи допустила бездіяльність). Як приклад можна навести положення нормативно-правових актів, що втратили чинність, як-от: Закон України «Про звернення громадян», Закон України «Про порядок погашення зобов'язань платників податків перед бюджетами та державними цільовими фондами» тощо). Очевидно, що нині інститут «сумлінної омани» під час реалізації суб'єктами владних управлінських функцій дещо знецінився. Це пов'язано передусім із відміною раніше діючих положень нормативно-пра- вових актів щодо можливості звернення зі скаргою до органу (посадової особи), який прийняв таке рішення. Іншими словами, на законодавчому рівні встановлено дворівневу систему досудового оскарження, по суті «висловивши недовіру» можливості «сумлінної омани» та «добросовісного» виправлення (скасування) незаконного рішення, утримання від незаконної дії чи бездіяльності суб'єкта, що реалізує владні управлінські функції.

По-друге, задекларовано реформування антикорупційних органів та створення нових інституцій запобігання та протидії корупції. Слабкість антикорупційних інститутів лише «оголила» проблематику.

Також заслуговує на увагу спроба на рівні кодифікованих нормативно-правових актів утвердити положення про індивідуалізацію відповідальності за прийняття представником (посадовою, службовою особою) органу актів. Зокрема, статтю 21 Податкового кодексу України у грудні 2017 року було доповнено пунктом 21.3 «Шкода, завдана платнику податків неправомірними рішеннями, діями чи бездіяльністю посадової або службової особи контролюючого органу, відшкодовується за рахунок коштів державного бюджету, передбачених для фінансування цього органу, незалежно від вини цієї особи» [19]. Крім того, варто вказати на загальний підхід у наведеному нормативно-правовому акті до формулювання норм, що визначають правовий статус органу та окремо його представників (посадових, службових осіб), а саме наявність окремої статті, у якій перелічено «Права контролюючих органів» (стаття 20 ПУ України), та статті 21 «Обов’язки і відповідальність посадових та службових осіб контролюючих органів»[19], у якій відсутне окреме перерахування іх прав. Щоправда наведені положення не мають завершеності, а відповідно, важко встановити їх значення для практики, оскільки вводиться окреме поняття «неправомірного рішення, дії чи бездіяльності» за відсутності наведення їх конкретних ознак. Разом із тим зі змісту наведеного пункту статті вбачається, що до них не належать адміністративні правопорушення, оскільки не потрібно встановлювати вину суб'єкта щодо прийняття неправомірного рішення.

\section{Висновки}

Наведені положення спонукають до продовження роздумів про зміст поняття «спір», оскільки в сучасному розумінні воно включає як відносини порушення, так і спірні правовідносин, співвідношення цього поняття із іншими правовими поняттями. 


\section{Список використаних джерел:}

1. Селіванов А.О. Адміністративне право в онтологічному вимірі сучасних реалій. Публічне право. № 2 (22). 2016. С. 78-82.

2. Кодекс адміністративного судочинства України : кодекс // Відомості Верховної Ради України (ВBP), 2005, № 35-36, № 37, ст.446 / URL https://zakon.rada.gov.ua/laws/show/2747-15.

3. Колпаков В.К. Предмет адміністративного права: сучасний вимір. Юридична Украйни. № 3 2008. C. 33-38.

4. Колпаков В.К. Адміністративне судочинство: співвідношення 3 адміністративним процесом і предметом адміністративного права. Право України. № 2. 2018. С. 26-38.

5. Колпаков В.К. Адміністративне правопорушення (проступок): поняття і співвідношення іншими деліктами. Підприємниитво, господарство і право. № 7. 2003. С. 47-51.

6. Колапаков В.К. Адміністративно-деліктне право у юридично-галузевій парадигмі. Право Украйни. № 4. 2002. С. 17-21.

7. Элистратов А.И. Учебник русского административного права. Выпуск 1. Издание общества взаимопомощи студентов-юристов Московского Университета. Москва : 1910.94 с

8. Градовский А.Д. Начала русского государственного права. Тома I-III. - C.-Петербург, типография М. Стасюлевича, 1876 г. Т. II. 618 с.

9. Колпаков В.К. Адміністративно-деліктний правовий феномен: Монографія. Київ : Юрінком Інтер, 2004. 528 c.

10. Шершеневич Г.Ф. Общая теория права. Философия права. Т 1. Часть теоретическая. Рига 1924.

11. Гессен В.М. Лекции по полицейскому праву. Санкт-Петербург : Тип. «Север», 1908. 196 с.

12. Козлов Ю.М. Административное право в правовой системе Российской Федерации. Часть 1. Сущность и основные институты административного права: Москва: ТЕИС, 1995. 328 с.

13. Кодекс України про адміністративні правопорушення [Текст] : Кодекс. URL: https://zakon.rada.gov.ua/laws/show/80731-10.

14. Загряцков М.Д. Административная юстиция и право жалобы: (В теории и законодательстве). Москва, 1925. 244 с.

15. Самощенко И.С. Понятие правонарушения по советскому законодательству. Издательство «Юридическая литература». Москва, 1963. 280 с.

16.Лейст О.Э. Санкции в советском праве. Москва : Государственное издательство юридической литературы, 1962. 240 с.

17. Жижиленко А.А. Наказание: его понятие и отличие от других правоохранительных средств. Петроград : Правда. 1914. 676 с.

18. Бахрах Д.Н., Россинский Б.В., Старилов Ю.Н. Административное право. Москва : Норма, 2008. 816 c

19. Податковий кодекс України [Текст]. Верховна Рада України. URL http:// zakon3.rada.gov. ua/laws/show/2755-17.

The article investigates the concept of offense in the ontological dimension of the subject of dispute in the sphere of public-legal relations. It is pointed out that the modern period of development of administrative law is characterized by an increase in the development of constituent procedural centers, because along with theoretical developments, an important role is played by the practice of implementing procedural rules in the aspect of interpretation of specific concepts. Today, this approach should be used in defining the concept of "dispute in the field of public-legal relations". The development of the institution of "error" in public administration or in the activity of public administration is noted. One of the reasons was the existence of a provision that established the procedure for lodging a complaint with an authority (official) that made an illegal decision (took an action or allowed inaction). Obviously, now the institute of "honest delusion" in the exercise of the power of management by the entities has somewhat depreciated. This is primarily due to the cancellation of the existing provisions of the legal acts regarding the possibility of appealing to the authority (official) that made the decision. In other words, a two-tier system of pre-trial appeals is established at the legislative level, essentially "expressing no confidence" in the possibility of "honest delusion" and "bona fide" correction (cancellation) of an unlaweful decision, abstaining from an illegal act or omission of an entity exercising managerial administrative functions. Along with efforts to form an anti-corruption system, the issue of violations by the subjects of power, rights and freedoms and legal interests of individuals and legal entities does not lose relevance, but only exacerbates the need to establish the meaning of the concept of disputes, since in the modern sense it includes both relations of violation and controversial, the relation of this concept with other legal concepts.

Key words: administrative law, administrative process, public-legal relations, dispute in the field of public-legal relations, administrative offense, administrative misconduct, administrative justice. 
УДК 342.9

DOI https://doi.org/10.32849/2663-5313/2019.8.21

Андрій Федорчук,

аспірант кафедри адміністративної діяльності

Національної академії внутрішніх справ

\section{ІМПЛЕМЕНТАЦІЯ ЗАРУБІЖНОГО ДОСВІДУ АДМІНІСТРАТИВНО-ПРАВОВОГО РЕГУЛЮВАННЯ ПРАВОВОГО СТАТУСУ СУ ДДІВ}

У статті проаналізовано міжнародний досвід у судовій сфері з метою запозичення кращих законодавчих практик та рекомендаиій для удосконалення правого регулювання статусу судді в Украйні. Наголошено, що досить проблемним питанням залишається саме визначення необхідності заняття суддею посади безстроково в Україні. 3 одного боку, ие забезпечує дотримання приниипу незалежності та безсторонності судової влади й окремих суддів, але з іншого - створює ілюзію вседозволеності судді та безкарності, що призводить до поширення корупиійних ризиків під час здійснення справедливого правосуддя. З'ясовано, що у Європейській Хартії про статус суддів значиться, що наявність випробувальних термінів або вимог шодо поновлення на посаді означає трудноші та навіть небезпеку незалежності та безсторонності відповідного судді, який прагне закріпитися на посаді або поновити свій контракт. Тому приклад Австрії, де передбачено проведення оцінки роботи кандидатів на посади суддів під час випробувального періоду, впродовж якого кандидат допомагає судді в підготовиі рішень, є найоптимальнішим та ефективним способом практичної підготовки кандидатів в судді до роботи у системі правосуддя. Визначено, що правові системи більшості краӥн, як показав зроблений вище аналіз, мають власні органи суддівського самоврядування, що через різні причини визначають критерії відбору суддів на посади, що здебільшого не є регламентованими та стандартизованими (наприклад, Кіпр, Естонія, Російська Федерачія, Фінляндія, Ісландія, Литва, Люксембург, Норвегія, Нідерланди та Чехія), проте деякі мають чіткі індикатори відбору суддів (наприклад, Німеччина або Словаччина). Зроблено висновок, що з точки зору адміністративно-правого регулювання правого статусу суддів за кордоном для Украйни є багато позитивних прикладів, необхідних та потрібних для імплементування у вітчизняну модель, а саме: використати у вітчизняній практиці, так званий тріал-період (випробувальний термін) для кандидатів на посаду судді; підвищення моральноетичних вимог до претендента на посаду судді; ввести поняття антикорупиійних обмежень для суддів, зокрема, необхідності здійснити самовідвід у разі наявності конфлікту інтересів та декларувати уявний конфлікт інтересів; обмежити вплив Президента Украӥни на формування суддівського корпусу.

Ключові слова: адміністративне регулювання, правове регулювання, зарубіжний, досвід, напрями, удосконалення.

Постановка проблеми. В умовах сьогодення судова система України не відповідає міжнародним вимогам та рекомендаціям, принципам верховенства права, справедливого правосуддя, а статус судді потребує змін шляхом грунтовного законодавчого регламентування та внесення доповнень.

Вироблення основних шляхів удосконалення адміністративно-правового регулювання правового статусу суддів потребує насамперед проведення змістовного аналізу досвіду зарубіжних країн у цій сфері [1, с. 78].

Аналіз останніх досліджень і публікацій. Науково-теоретичне підгрунтя для виконання дослідження склали наукові праці таких вітчизняних і зарубіжних фахівців з адміністративного права, теорії держави і права, конституційного права, інших галузевих правових наук, як В. Авер'янов, С. Алфьоров, Ю. Битяк, О. Безпалов, С. Глущенко, В. Городовенко, О. Сщук,
T. Коломоєць, А. Колодій, М. Костицький, I. Марочкін, I. Назаров, Я. Окар-Балаж, Д. Письменний, М. Погорецький, Є. Соболь, К. Чижмарь, А. Чубенко, Д. Шпенов, С. Шевчук, І. Юревич, О. Яновська та інші.

Віддаючи належне проведеним дослідженням, слід зазначити, що основна їх частина здійснювалася на основі вітчизняного законодавства. Проте треба зауважити, що значною мірою зберігає свою актуальність і наукову значущість проблема аналізу законодавства європейських країн з метою запозичення необхідного досвіду [2, с. 23].

Мета статті - проаналізувати міжнародний досвід у судовій сфері з метою запозичення кращих законодавчих практик та рекомендацій для удосконалення правового регулювання статусу судді у вітчизняній практиці. 
Виклад основного матеріалу. Правовий статус суддів відрізняється в кожній країні залежно від типу правової сім'ї. Тому ми будемо розглядати судові системи залежно від типу правової сім'ї - англосаксонської, романо-германської і мусульманської моделей судової системи.

Англо-саксонська правова сім'я (США, Великобританія, Ірландія) має досить цікаву судову систему, яка відрізняється специфічністю добору суддів на відповідні посади у різних ієрархічних ланках судової системи.

Суди Великобританії $€$ тріадою судів Англії та Уельсу, Шотландії і Північної Ірландії та включають Верховний суд і високі суди (Палата лордів, Апеляційний суд і Високий суд правосуддя) [3].

Судова система Північної Ірландії, Шотландії та Англії мають схожі риси, побудовані таким чином, що Суд графства Північної Ірландії може розглядати не тільки цивільні та сімейні, а також кримінальні справи. Система судоустрою Шотландії включає 1) Вищий суд правосуддя (High Courtof Justiciary), 2) Головний суд шерифа (Sheriff Principal), 3) Суд шерифа (Sheriff Court), нижчий рівень судової системи включає світову юстицію (Justice of the Peace Court).

Функція правосуддя в англо-саксонській сім'ї здійснюється не стільки судом як колегіальним органом, скільки професійними суддями індивідуально в кожному окремому випадку.

Правовий статус судді, як і в Україні, передбачає симбіоз наступних елементів: відбір, призначення, проходження служби та звільнення. Відбір суддів здійснюється 3 кола баристерів (barristers) та соліситоpiв (sollicitors). Під баристерами розуміють юристів так званої «вищої касти», що здійснюють розгляд справ вузької спеціалізації за певними галузями права.

Соліситори також є адвокатами, які здійснюють розгляд справ в магістратських судах графств і міст-графств. Якщо порівнювати соліситорів та баристерів, то останні є вищим класом всередині адвокатського консорціуму. Соліситори здійснюють підготовку справ до судового розгляду для баристерів [4].

1. Призначення суддів здійснюється 3 числа кандидатів соліситорів та баристерів, що служать в палаті лордів (що є вищим апеляційним судом), в Апеляційному Суді, у Високому суді (Nigh Court) і в Королівському суді (Crown Court), або як окружних чи районних суддів [5].

Континентальна система права здебільшого використовує систему конкурсного відбору суддів. Виняток становить Швейцарія, де судді обираються жителями або пар- ламентом. Загальними правилами відбору для кандидатів на посаду суддів $є$ відповідний рівень освіти юриспруденції, будь-який практичний досвід.

Насамперед претендент на посаду судді повинен пройти спеціальне навчання, тобто проходження базового курсу навчання у спеціалізованих школах права (Німеччина, Франція, Іспанія, Греція, Нідерланди і Португалія, Марокко, Сгипет, Бразилія, Японія тощо) законодавчо закріплено необхідність проходження кандидатом на посаду судді навчання в спеціалізованих навчальних закладах для суддів [6].

Навчальної підготовки суддів немає в Ірландії, Мальті та Кіпрі.

Проходження навчання та підвищення кваліфікації під наглядом органу суддівського самоврядування - Вищої ради суддів - відбувається у Австрії, Бельгії, Норвегії, Швеції, Данії.

Зокрема, Бельгія проводить такі заходи:

- спеціальне навчання юристів, які мають певний досвід робот в юриспруденції;

- здача кваліфікаційного іспиту адвокатом (стаж роботи понад 10 років у сфери юриспруденції), що може за умови успішного складання, пройти на посаду без попереднього навчання.

- усний екзамен для юристів 3 двадцятирічним стажем та для осіб, які мають 15 років стажу та принаймні 5 років працювали у сфері права.

На відміну від зазначеної системи відбору, в Англії немає конкурсного механізму, та судді призначаються в порядку закінчення навчання спеціалізованого курсу підготовки суддів, що мають відповідний час безпосередньої адвокатської судової практики [7].

Нідерланди. Добір суддів здійснюється за наступними вимогами: 1) кандидат повинен мати вищу юридичну освіту, 2) досвід роботи за юридичною спеціальністю не менше двох років після закінчення університету (не обов'язково в рамках судової системи, можливо, в якості адвоката. Схожа система Нідерландів під час добору кадрів на посаду судді з українським законодавством саме в частині перевірки аналітичних здібностей, пізнання в області права, здатність приймати рішення, комунікативні навички та моральні якості [8].

Головним органом, що здійснює атестацію претендентів на посаду, є Національний комітет з відбору суддів. До складу Комітету входять дванадцять членів, шість суддів і шість осіб, які працюють за межами судової системи (один представник прокуратури, один адвокат і ще чотири людини).

Англійська система призначення суддів здійснюється таким чином: 1) до судді вищих 
судів призначаються кандидати (з числа баристерів 3 не менш ніж десятирічним стажем) королевою за рекомендацією лорда канцлера; 2) до судді нижчих судів призначаються кандидати (з числа баристерів 3 десятирічним стажем або з числа рекордерів, що займають цю посаду не менше трьох років) призначаються лордом-канцлером.

Вимоги до кандидатів на посаду судді стосуються не тільки кваліфікаційних характеристик, але й велика увага приділяється морально-етичним якостям особи та психологічному профілю особи. Для характеристики особи обов'язково додаються рекомендації з місця попередньої роботи Для кандидатів в судді середньої та нижчої ланки (окружних і оплачуваних магістратів) перш за все необхідно отримати не менше трьох рекомендацій від суддів і провідних баристерів, що співпрацювали раніше 3 цим кандидатом на пост судді. Процедурою відбору суддів середньої та нижчої ланки займаються чиновники департаменту лорда-канцлера. Кандидатів на посади суддів Високого суду відбирає лорд-канцлер за консультування з суддями і з керівництвом адвокатської корпорації баристерів.

Технічною роботою з відбору кандидатів на посаду суддів займається голова канцлерського департаменту - постійний секретар. Він опитує суддів і адвокатів, розмовляє 3 кандидатами, а його штат збирає необхідні відомості. На підставі цих даних лордканцлер приймає остаточне рішення. Під час висування кандидатур окружних суддів, рекордерів і оплачуваних магістратів збір відомостей про кандидатів може бути доручено судді-голові того судового округу, де повинен буде працювати новий суддя. Крім ділових якостей, які свідчать про потенційну можливість претендента виконувати обов'язки судді, кандидат повинен відповідати формальним вимогам моралі. Наприклад, зовсім недавно розлучення перестало бути перешкодою до призначення. Однак якщо причиною розлучення було погане або жорстоке ставлення кандидата до членів сім'ї, він не отримає суддівської посади. призначення виключено, якщо шлюборозлучний процес ще не закінчений або з моменту розлучення не пройшов достатній період часу. Засудження за вчинення кримінального правопорушення в принципі не $є$ перешкодою для призначення, за винятком тих випадків, коли правопорушення супроводжувалося ганебною з точки зору моралі поведінкою. Засудження за вчинення транспортних правопорушень, наприклад, перевищення швидкості, неправильне паркування тощо, не враховується, якщо вони не мають систе- матичного характеру або якщо не супроводжуються будь-якою аморальною поведінкою. Навіть при виправдувальних вироках має значення, на підставі яких причин такий вирок був винесений. Для з'ясування цієї обставини відповідні особи знайомляться зі справою. Може виявитися, наприклад, що обвинувачений скористався законним «правом на мовчання» під час допиту, але не через професійні адвокатські привілеї, а для приховування будь-яких інших фактів. Такий адвокат вже не зможе розраховувати на суддівську посаду.

При фактах порушення професійної адвокатської етики призначення автоматично виключається. Це ж стосується й осіб, яких визнано банкрутами. Характеру майбутнього судді і його поведінки в суспільстві відводиться дуже велике місце. До поведінки судді в його приватному житті взагалі пред'являються в Англії досить високі вимоги, так само як і до адвокатів, що висуваються на суддівську посаду. Так, одному баррістеру було відмовлено в призначенні з тієї причини, що його бачили часто в барі, розташованому поруч з будівлею лондонських судів, іншому - за те, що, відсвяткувавши день свого народження в ресторані, він намагався видряпатися на колону, третього - за неприборкане «дике» особисте життя.

Участь в будь-якому публічному скандалі, тільки лише зі згадуванням імені у пресі, перешкоджає просуванню судді по службі і призначенню на суддівську посаду адвоката. Зменшує шанси на призначення, але не виключає повністю можливості отримати суддівську посаду діяльність, пов'язана 3 расовими відносинами. Тим часом суддя, помилковий вирок якого привів до публічного скандалу, може не побоюватися за свою кар'єру, якщо, звичайно, він не звинувачується в аморальній чи неприпустимій поведінці або корупції. Що стосується характеру, то вважається, що англійський суддя повинен володіти хорошим характером і манерами, щоб бути люб'язним з адвокатами, свідками і присяжними. Йому повинно бути властиве почуття гумору, але, однак, не надмірне. Він повинен володіти терпінням і вмінням слухати, не перебиваючи, що є основною якістю характеру судді. Він не повинен бути повільним, його інтелект повинен перевищувати середній рівень, хоча великі інтелектуали також не потрібні. Суддя не повинен постійно переривати учасників процесу, бути різким або безперестанку жартувати. Навіть за найретельнішої перевірки характеру кандидата на посаду судді неможливо, природно, передбачити, яким він буде насправді. Не випадково, як визнають англійські юристи 
(див. Нижче), що багато хто з суддів звинуватив невинних.

Судова система Австрійської Республіки передбачає дві основні групи: а) суди загальної юрисдикції; б) суди публічного права.

Основним документом, що регулює правовий статус суддів в Австрії, зокрема, вимоги, що висуваються до кандидатів на посаду судді, і порядок їх призначення на посаду, визначені в Законі «Про службу суддів і прокурорів».

Система судів загальної юрисдикції складається з чотирьох інстанцій: окружний суд (Bezirksgericht); Суд федеральної землі (Landesgericht); Верховний суд землі (Oberlandesgericht); Верховний Суд (Oberster Gerichtshof) [9].

Відбір суддів на посади передує досвіду навчання, що охоплює період в 5 років. 1) річна судова практика під керівництвом не менше трьох суддів-наставників 3 одночасним проходженням підготовчих курсів; 2) призначення на посаду судді-стажера Міністерством юстиції на підставі рекомендації колегії Вищого суду землі; 3) дворічне навчання при суді, прокуратурі чи інших органах (адвокатурі, органах управління, Міністерстві юстиції чи в органах виконання покарання); 4) навчання в судовій академії; 5) здійснення практики при суді, прокуратурі, адвокатурі; 6) складення випускного екзамену при Вищому суді однієї з земель [10, с. 18].

у Франції здійснюється призначення на посаду судді через спеціалізовану школу навчання. В системі відбору та призначення суддів у Франції беруть участь кілька органів (Вища рада магістратури, Комісія з просування по службі, Міністерство юстиції, Національна школа магістратури). Судові функції Франції здійснюють магістрати [11].

Національна школа магістратури набирає по конкурсу кандидатури для суддів. Правове регулювання навчання та добору на посаду суддів здійснюється нормами Закону «Про статус магістратури».

У Франції Вища Рада магістратури на чолі з головою Касаційного суду Франції володіє лише компетенцією надавати рекомендацію та висновки на висунутих Міністром юстиції Франції кандидатів на посаду суддів інших інстанцій і здійснює діяльність як дисциплінарний орган суддів [12].

Вимогами є відповідний диплом вищої освіти, громадянство Франції, відповідний стан здорової психіки. Добір здійснюється через оцінку есе та складання відповідного екзамену з юридичних дисциплін, іноземної мови та заліку із загально-фізичної підготовки [13, с. 61].
Наступними кроками підготовки кандидата на посаду судді є укладення контракту, що передбачає обов'язкову роботу в сфері юстиції не менше 10 років, стажування тривалістю 3 місяці в державних та недержавних установах. Черговим етапом є 8 місяців навчання в Школі, а після цього стажування вже безпосередньо в судових установах тривалістю 14 місяців [13, с. 61].

Після успішного складання іспиту претендентам пропонують зайняти ті чи інші посади у суддівському корпусі, де особа отримує можливість проходити стажування з подальшим працевлаштуванням.

В Іспанії відбір суддів здійснюється, на відміну від Франції, тільки з числа осіб, які мають вищу юридичну освіту. Головним органом, що опікає суддівську школу, є Генеральна рада судової влади. Голова Верховного суду Іспанії також головує і в даному органі. Кваліфікаційні іспити здійснюються за участь навіть пересічних громадян.

Досвід та практика Іспанії в цілому теж непогані, де такі функції здійснює Генеральна Рада судової влади суддів Іспанії.

Призначення суддів у Норвегії відбувається Урядом за рекомендацією Комітету з призначенням суддів. Особливістю призначення кандидатів на посаду судді відбувається в загальному порядку з числа як пересічних громадян, так і тих, хто має стаж на державній службі.

Відповідно до основного правого акту Закону «Про суди» судді призначаються на строк, що не перевищує два роки. Комітет складається з трьох суддів, одного адвоката, одного юриста з публічно-правового сектора та двох пересічних громадян [14].

Судова система Італії схожа 3 вітчизняною, оскільки охоплює три ланки - суди конституційної, загальної та спеціальної юрисдикції. Відбір на посаду судді в Італії здійснюється на конкурсній основі. Конкурс на заміщення суддівських посад проводиться під керівництвом Вищої ради суддів (C.S.M.) за сприяння Міністерства юстиції.

Конкурсна державна експертиза для суддів та прокурорів складається 3 трьох письмових іспитів (з цивільного, кримінального та адміністративного права) та усного іспиту з основних правових питань (див. Статтю 123 ter статуту, що регулює судову систему).

Конкурс на посаду суддів очолює Експертна комісія, призначена Вищою радою, що очолюється суддею касаційного суду. Вона складається 3 двадцяти двох суддів апеляційного суду та вісьмох професорів 3 права. Висновок складається на кожного індивідуально, що базується на загальній 
сумі голосів, наданих кожному кандидату за кожен тест [15].

Навіть така характеристика, як розлучення, була підставою відмови від посади судді, проте тільки недавно це перестало бути підставою для відмови. Але якщо причиною розлучення було жорстоке поводження 3 жінкою, насильство або інші причини, які свідчать про низькі моральні якості претендента на посаду, це стає беззаперечною причиною відмови.

Не може бути причиною відмови у посаді кандидата на посаду судді особа, що вчинила дрібні адміністративні правопорушення (вчинення транспортних правопорушень, наприклад, перевищення швидкості, неправильне паркування тощо) за умови, що не мають систематичного характеру або якщо не супроводжуються будь-якими проявами аморальної поведінки. Також не на користь майбутнього кандидата свідчить і порушена ділова репутація та одіозність фігури кандидата, про що часто згадується у 3МІ [16]

На відміну від англійської системи обмежень такого роду, в Україні такі правила не набули поширення. Оскільки навіть поява у пресі будь-якої інформації про розкішний спосіб життя, неправомірну вигоду, незаконне збагачення тощо не служить винятковою причиною для відмови кандидату під час конкурсу на посаду.

Так, прикладом недосконалості судової системи України може свідчити «справа Ємельянова» (суддя Вищого господарського суду України), що стосувалася незаконного втручання в діяльність судових органів та винесення неправомірних судових рішень. Найяскравішим прикладом «хвороби» української правої системи саме стало те, що Артур Смельянов спромігся за період роботи у «мантії» отримати у власність безпосередньо або за посередництва дружини наступні види нерухомості: частки в статутному капіталі австрійських фірм "AHL REAL PEU GmbH” (компанія-власник готелю у Відні "Prinz Eugen") та "AHL REAL KAV GmbH" (компанія-власник готелю у Відні "Kavalier") разом 3 Дмитром Мурахвером та Павлом Маліком, будинком в комплексі "Seashell Belek Elite Villas" (Туреччина), апартаментами в Об’єднаних Арабських Еміратах в комплексі "Palm Jumeirah", часткою в статутному капіталі німецької компанії AVIAWEB $\mathrm{GmbH}$ (компанія-власник Франкфуртських готелів "Fair Hote Villa Diana", "Fair Hotel an der Messe", "Fair Hotel Europaallee") [17]. Офіційно моніторинг способу життя показав, що офіційно отримані доходи не могли покрити отримані у власність майно та майнові права на нерухомість, а проведені фінан- сові операції сім'єю Смельянова є такими, що спрямовані на легалізацію (відмивання) доходів, одержаних злочинним шляхом (приховування чи маскування джерел походження коштів).

При цьому цей одіозний суддя продовжував роботу судді до 2018 року, поки Дисциплінарна палата ВРП не вирішила звільнити його за дисциплінарний проступок на підставі ст. 126 Конституції України.

Обмеженнями та заборонами для кандидатів на посади суддів у Великобританії можуть служити.

1) аморальна поведінка судді як під час професійного виконання обов'язків, так і у побутовому житті;

2) вчинення злочинів, що стосуються перевищення та зловживання службовим становищем, прийняття неправомірної вигоди, вчинення інших тяжких злочинів тощо;

3) порушення етичних правил поведінки судів;

4) необ'єктивне та упереджене відправлення правосуддя.

На першому етапі відбору в Португалії кандидат в судді проходить базову теоретичну підготовку, отримуючи юридичну освіту в бакалавраті (licenciatura) університету. Спочатку кандидат на посаду судді може пропрацювати не менше 5 років на посаді, пов'язаній 3 юриспруденцією, (адвокатура, прокуратуpa, поліція), пройти так званий професійний етап (via da experiência profissional), або отримати ступінь магістра або доктора права в університеті - академічний етап (via da habilitação académica) [18].

Загальною забороною для суддів за Конституцією Португальської республіки $\epsilon$ те, що суддя в процесі виконання власних службових обов'язків не може одночасно виконувати будь-яку іншу оплачувану роботу в державних або приватних установах і організаціях, а також призначатися без дозволу Вищої ради магістратури в будь-які комісії, що не мають відношення до судової діяльності [19].

Конституція Греції передбачила подвійну заборону: забороняється надавати суддям будь-яку іншу оплачувану посаду, а самим суддям - займатися іншою діяльністю (крім викладання в вищих навчальних закладах) [20].

Строки перебування на посад суддів різних інстанцій

Судді всіх рівнів можуть перебувати на посадах доки їх поведінка зберігатиме риси «бездоганності».

Японський законодавець встановив строк призначення судді на термін десять років. Значно частіше конституціями встанов- 
люється первинний термін перебування на посаді (свого роду випробувальний термін), після чого суддя призначається довічно.

Як ми вже зазначали, в Німеччині немає спеціальної суддівської освіти. Всі юристи отримують однакову юридичну освіту в університеті, що завершується здачею першого державного іспиту; після цього вони проходять підготовчу службову стажування що закінчується здачею другого державного іспиту [20].

На відміну від Великобританії, Франції, Італії та Іспанії, де відсутні спеціальні вимоги щодо стажу роботи на державній службі, у Німеччині діє заборона на перебування на державній службі. Часові обмеження у Франції охоплюють строк у 8 років, через які претендент може працювати на посаді судді.

Німеччина відрізняється специфікою відбору на посаду суддів саме системою теоретичної та практичної підготовки, а також серйозної психологічної та психо-емоційної підготовки.

Такі країни, як Естонія, Латвія, Литва, мають встановлений порядок, відповідно до якого для того, щоб зайняти суддівську посаду у вищій судовій інстанції треба мати певний стаж роботи на суддівській посаді в судових установах нижчого рівня.

В міжнародно-правовому акті Декларації Сінгві зазначено, що «просування судді має грунтуватися на об'єктивній оцінці його моральних якостей, незалежності, професіоналізму, досвіду, гуманності і готовності захищати принцип верховенства права. Не допускається просування суддів за неналежними мотивами» (п. 14) [21].

Схожі за своїм змістом також Основні принципи ООН, що закріплюють норму, в якій зазначено, «підвищення суддів на посаді слід здійснювати на основі об'єктивних чинників, зокрема, здібностей, моральних якостей і досвіду» (п.10) [22].

В Україні процедура відбору на посаду судді здійснюється в декілька етапів, та також відбувається оцінка моральних якостей претендента на посаду. Так, оцінка здійснюється за наступними компонентами: юридичні професійні компетенції та навички, юридичні знання, професійні юридичні навички, якість виконання (на основі професійного досвіду судді, адвоката тощо), розвиток професійної компетенції (тренінги, підвищення кваліфікації); особисті компетенції; соціальні компетенції; професійна етика, зокрема, «морально психологічні» характеристики; «сумлінність, чесність, моральність», зокрема доброчесність («власне доброчесність») Як показує практика, оцінка особистих якостей претендента на посаду судді не є доскона- лою, оскільки охоплює два рівні показників: 1) рівень знань у сфері права, що включає рівень практичних навичок та умінь у правозастосуванні, 2) рівень практичних навичок та умінь у правозастосуванні, що охоплює уміння та навички проведення судових засідань та ухвалення судових рішень.

В Аналітичному огляді «Кваліфікаційне оцінювання суддів 2016-2018: проміжні результати» наведені деякі приклади незрозумілих рішень [23].

Приклад 1. Суддя Окружного адміністративного суду м. Києва Б. Санін навів зразок наданого йому висновку: оцінка рівня компетентності склала 368 балів, професійна етика -120 балів, доброчесність - 123 бали. Сумарна сума склала 611 балів» [24] Як наслідок висновок про те, що суддя не відповідає займаній посаді. Варто зауважити, що алгоритм, за яким встановлюють критерії оцінки «морально-етичних показників», зокрема, рівень доброчесності та етики судді, відсутній або ж не підлягає розголошенню для широкого загалу. Така «таємність» інформації породжує ризики зловживання службовими повноваженнями та створює так звані дискреційні повноваження.

Ще одним прикладом «незрозумілості» прийняття такого роду рішень є висновок щодо судді В. Дев'ятка. За інформацією стосовно надання недостовірних відомостей у декларації доброчесності Комісія прийняла негативне рішення щодо цієї кандидатури. Проте залишається цікавим той факт, що аргументів на підтвердження або спростування цієї інформації комісією не надано. Таке відношення до порядку оприлюднення інформації формує негативний образ порядку з відбору та призначення суддів на посади [25].

Правовий статус суддів має певні строкові обмеження у виконанні функціональних обов'язків ними під час здійснення правосуддя.

В Україні загальний строк перебування на посаді судді Конституційного Суду України становить дев'ять років (ст. 16 ЗУ «Про Конституційний Суд України») без права бути призначеним повторно.

Судді загальних суддів України призначаються безстроково за винятком визначених Конституцією України підстав (ст. 126): 1) неспроможність виконувати повноваження за станом здоров'я; 2) порушення суддею вимог щодо несумісності; 3) вчинення істотного дисциплінарного проступку, грубе чи систематичне нехтування обов'язками, що $€$ несумісним зі статусом судді або виявило його невідповідність займаній посаді; 4) подання заяви про відставку або про звільнення $з$ посади за власним бажанням; 
5) незгода на переведення до іншого суду у разі ліквідації чи реорганізації суду, в якому суддя обіймає посаду; 6) порушення обов'язку підтвердити законність джерела походження майна і водночас повноваження судді припиняється 3 підстав: 7) досягнення суддею шістдесяти п'яти років; 8) припинення громадянства України або набуття суддею громадянства іншої держави; 9) набрання законної сили рішенням суду про визнання судді безвісно відсутнім або оголошення померлим, визнання недієздатним або обмежено дієздатним; 10) смерті судді; 11) набрання законної сили обвинувальним вироком щодо судді за вчинення ним злочину [26].

Досить проблемним питанням залишається саме визначення необхідності заняття суддею посади безстроково в Україні. 3 одного боку, це забезпечує дотримання принципу незалежності та безсторонності судової влади й окремих суддів, але з іншого - створює ілюзію вседозволеності судді та безкарності, що призводить до поширення корупційних ризиків під час здійснення справедливого правосуддя. Судді, відчуваючи гарантії своєї незмінюваності на основі безстроковості, здійснюють правосуддя в тих межах, що зручні для того чи іншого судді, тобто використовуючи принцип суб'єктивізму, приймаючи одночасно не завжди справедливі рішення. Саме безстроковість формує стабільність службової кар'єри, але саме правосвідомість, правова культура судді забезпечує неупереджене та об'єктивне прийняття рішень, тобто межа між зловживанням власним службовим становищем та використанням гарантії незмінюваності як захисту своєї професійної діяльності.

Практика безстроковості призначення суддів є у Грузії, де Вища рада юстиції Грузії у разі прийняття позитивного рішення про безстрокове призначення судді на посаду може зробити виключення [27], Конституція Республіки Польщі також визначає повноваження щодо можливості призначення Президентом Республіки Польща за пропозицією Національної Ради Судівництва суддів на невизначений термін [28], Чехія також має традицію призначати суддів на невизначений термін [29].

В У горщині судді призначаються на строк дев'ять років, теж саме стосується Японії, Швейцарії, Грузії, Румунії, а також країни Азербайджан, Таджикистан, Туркменістан [30].

Міжнародні стандарти чітко встановлюють, що рішення про направлення суддів в певний суд або про переведення з одного суду до іншого повинні прийматися судовими органами, а не представниками вико- навчої влади. Комітет з прав людини ООН зазначив, що, якщо рішення про просування суддів залежать від дискреційних повноважень адміністративних органів, це може «піддати суддів політичному тиску і поставити під загрозу їхню незалежність і неупередженість». Декларація Сінгві встановлює, що призначення судді на певну посаду «повинно проводитися судовими органами або вищою радою суддів за наявності такого» (п. 13). Аналогічним чином Європейська хартія про статус суддів рекомендує, щоб рішення про направлення судді в конкретний суд приймалося «незалежним органом» або «за його пропозицією, рекомендацією, з його згоди або відповідно до його висновку» (п. 3.1) [31]

Правовий статус судді також включає заняття політичною діяльністю. В Свропейській хартії про статус суддів підкреслюється, що «суддя вільно може займатися різними видами діяльності, крім його службових повноважень, зокрема і тими, котрі є вираженням його прав громадянина (п. 4.2.) Суддя може займатися політичною діяльністю до тих пір, поки остання не перетне межу несумісності роботи в якості судді з довірою відносно неупередженості і незалежності судді чи з професійною необхідністю уважно й у розумний строк розглядати справи» [32].

Законодавча заборона заняття політичною діяльністю існує в таких країнах, як Бельгія, Болгарія, Іспанія, Румунія, Туреччина, Хорватія. Португалія дозволяе суддям займатися викладацькою та науковою діяльністю на безоплатній основі. Цієї точки зору дотримується законодавець Німеччини, Литви, Молдавії, Словаччини [33, с. 77] В США заборона стосується лише адвокатської практики. Франція містить заборону обіймання посади 3 мандатом члена парламенту, асамблеї Європейського Союзу, Економічної і Соціальної Ради [34, с. 254]. Схожою є практика Італії, де суддівський корпус не має право займатися будь-якою оплачуваною роботою, винятки становлять тільки посада сенатора або членство у Палаті депутатів [35, с. 223].

Правові системи більшості країн, як показав зроблений вище аналіз, мають власні органи суддівського самоврядування, що за різними причинами визначають критерії відбору суддів на посади, що не є регламентованими та стандартизованими (наприклад, Кіпр, Естонія, Російська Федерація, Фінляндія, Ісландія, Литва, Люксембург, Норвегія, Нідерланди та Чехія), проте деякі мають чіткі індикатори відбору суддів (наприклад, Німеччина або Словаччина).

У багатьох європейських країнах незмінність суддів закріплена в конституціях країн 
(наприклад, Андорра, Хорватія, Франція, Ірландія, Ісландія, Македонія, Литва, Люксембург, Мальта, Норвегія, Польща, Чехія Румунія, Словаччина, Словенія та Туреччина, до цього переліку країн можна додати Італію) або у звичайних законах (наприклад, у Бельгії, Нідерландах, Швейцарії, Великобританії).

3 точки зору адміністративно-правого регулювання правого статусу суддів за кордоном для України є багато позитивних прикладів необхідних та потрібних для імплементування у вітчизняну модель.

Варто використати у вітчизняній практиці так званий тріал-період (випробувальний термін) для кандидатів на посаду судді. На підтвердження цього свідчать дані анкетування, де на запитання: «Чи підтримуєте Ви думку про те, що перед призначенням на посаду судді слід застосовувати «тріал-період» (випробувальний термін)?» 64,6\% (84) відповіли так, 35,4\% (46) - заперечили.

Натомість протилежну думку висловлено у Свропейській Хартії про статус суддів, де значиться, що існування випробувальних термінів або вимог щодо поновлення на посаді означає труднощі та навіть небезпеку незалежності та безсторонності відповідного судді, який прагне закріпитися на посаді або поновити свій контракт. Ми вважаємо, що саме приклад Австрії, де передбачено проведення оцінки роботи кандидатів на посади суддів під час випробувального періоду, впродовж якого кандидат допомагає судді в підготовці рішень, є найоптимальнішим та ефективним способом практичної підготовки кандидатів в судді до роботи у системі правосуддя.

Підвищення морально-етичних вимог до претендента на посаду судді. Як показуе практика, в Україні досить невелику роль відводять на перевірку особи претендента на посаду судді на стресостійкість та доброчесність судді в умовах використання дискреційних повноважень.

Слід ввести поняття антикорупційних обмежень для суддів, зокрема, необхідність здійснити самовідвід у разі наявності конфлікту інтересів та необхідність декларувати уявний конфлікт інтересів. Крім того, не регламентовано порядок відводу судді на етапі досудового провадження.

Обмежити вплив Президента України на формування суддівського корпусу, зокрема, це стосується переведення впродовж п'яти років на посаду судді до іншого суду (ст. 75 ЗУ «Про судоустрій та статус суддів»), а також призначення на посаду судді вперше (ст. 66 ЗУ «Про судоустрій та статус суддів»). Такого роду законодавчий механізм забезпечує необмежений вплив Президента України на формування суддівського корпусу та використання суддів під час реалізації функцій правосуддя на свою користь.

\section{Список використаних джерел:}

1. Микульця I.I. Місце та особливості функціонування органів юстиції регіонального рівня у системі суб'єктів адміністративного права. Право $i$ безпека. 2011. № 5 (42). С. 78-82.

2. Ментух Н., Шевчук О. Зарубіжний досвід адміністративно-правового регулювання діяльності органів юстиції. Актуальні проблеми правознавства. Випуск 3 (15). 2018 р. С. 23-27.

3. Назаров I.В. Судова система Великої Британії та їі реформування у зв'язку із членством у Європейському Союзі. Проблеми законності : акад. зб. наук. пр. Харків, 2011. Вип. 115. С. 179-187.

4. Апарова Т.В. Судьи и судебный процесс Великобритании. Судебные ведомости. № 3-4. 2013.

5. Злочини та покарання в Англії, США, Франції, ФРН, Японії: загальна частина кримінального права. Москва, 1991. С. 154

6. Пейсиков В. Обучение судей: международный опыт и российские перспективы. Российская юстииия. 2001. № 5. С.; № 6. С. 59-62.

7. Система державного управління Сполученого Королівства Великобританії і Північної Ірландії: досвід для України / уклад. П.І. Крайнік ; за заг. ред. Ю.В. Ковбасюка, С.В. Загороднюка. Київ : НАДУ, 2011. 48 с.

8. Скомороха Л. Питання професійно-психологічного добору кандидатів на посади суддів в Україні та міжнародний досвід. Право України. 2012. № 11-12. С. 336-348.

9. Пронин А.В. Судебная система Австрийской Республики. Электронное приложение $к$ «Российскому юридическому журналу». 2012. № 6.

10. Бутов В.Н., Власов И.С.Судьивзарубежных странах. Законодательство зарубежных стран. Обзорная информация. Вып.2. Москва : ВНИИ государственного строительства и законодательства, 2001. С. 16-21.

11. Соловьев А.А. Высший совет магистратуры как орган судейского сообщества Французской Республики [Текст]. Москва, 2014. С. 56.

12. Андреева И.А. Первоначальная профессиональная подготовка магистратов во Франции [Текст]. Право и образование. 2013. № 4. С. 97.

13. Халдеев.Л., СимкинЛ. Подготовка судей во Франции. Российская Юстииия. 1994. № 1. C. 54-62.

14. Elin Skaar, Ingrid Samset, Siri Gloppen, Aid to Judicial Reform: Norwegian and International Experiences, CIMI Reports, 2004.

15. Baschiera, Marinella (2006) "Introduction to the Italian Legal System. The Allocation of Normative Powers: Issues In Law Finding" International Journal of Legal Information: Vol. 34: Iss. 2, Article 10

16. Giacomo Oberto Recrutement et formation des magistrats en Europe: étude comparative Council of Europe, 2003. Political Science.167 pages. 
17. Досьє ЄМЕЛЬЯНОВ Артур Станіславович. URL: https://pep.org.ua/uk/person/1136.

18. Профессиональное образование судей Сравнительный анализ центров подготовки судей в Европе (Франция, Португалия, Польша) T. Бочаров, А. Дмитриева, Д. Скугаревский) URL: http://enforce.spb.ru/images/Products/reports/ IRL_Professional_education_of_judges.pdf.

19. Конституции государств (стран) мира. Конституция Португальской республики 1976 г. URL: http://worldconstitutions.ru/ 11

20. Тексты законов. Немецкий закон о судьях ИнтерНацинес Германия 1993 г. Стр.7

21. UN Draft Universal Declaration on the Independence of Justice ("Singhvi Declaration") (referenced by UN Commission on Human Rights, resolution 1989/32). URL: http://icj.wpengine. netdna-cdn.com/wp-content/uploads/2014/03/ SR-Independence-ofJudges-and-Lawyers-Draftuniversal-declaration-independence-justice-SinghviDeclarationinstruments-1989-eng.pdf

22. Основні принципи незалежності судових органів, схвал. резолюціями Генеральної Асамблеї ООН 40/32 від 29.11. 1985 р. та 40/146 від 13.12.1985 р. URL: http://www.asu. od.ua/ua/publications/mdrpns/opnso/.

23. Аналітичний огляд. Кваліфікаційне оцінювання суддів 2016-2018: проміжні результати. URL: https://prosud.info/Qualification Report Full EU.pdf/.

24. Пост Богдана Саніна у соціальній мережі «Facebook» від 1.06.2018. URL: https://www. facebook.com/permalink.php?story fbi $\mathrm{d}=2005924$ $733005183 \&$ id $=100007630276483$.

25. Висновок Громадської Ради доброчесності про невідповідність судді Оболонського районного суду м. Києва Дев'ятка Владислава Володимировича критеріям доброчесності та професійної етики. URL: https://grd.
gov.ua/data/files/conclusions/00_Qualification\%20 assessment/17.07.2018/Deviyatkavv vysn.pdf.

26. Конституція України: Закон України від 28.06.1996 № 254к/96-ВР. Відомості Верховноі Ради України (ВВР), 1996, № 30, ст. 14.

27. Constitution of Georgia. URL: https:// matsne.gov.ge/en/document/view/30346.

28. KONSTYTUCJA RZECZYPOSPOLITEJ POLSKIEJ, Rozdział VIII SADYY I TRYBUNAŁY. URL: http://www.sejm.gov.pl/prawo/konst/polski/ kon1.htm.

29. CONSTITUTION OF THE CZECH REPUBLIC of 16 December 1992. URL: https:// www.usoud.cz/fileadmin/user upload/Tiskova mluvci/Ustava EN ve zneni zak c. 98-2013.pdf.

30. Москвич Л.М., Подкопаєв С.В., Прилуцький С.В. Статус судді: питання теорії та практики : монографія. Харків : ВД «ІНЖЕК», 2004. 360 с

31. UN Draft Universal Declaration on the Independence of Justice ("Singhvi Declaration") (referenced by UN Commission on Human Rights, resolution 1989/32) URL: http://icj.wpengine. netdna-cdn.com/wp-content/uploads/2014/03/ SR-Independence-ofJudges-and-Lawyers-Draftuniversal-declaration-independence-justice-SinghviDeclarationinstruments-1989-eng.pdf.

32. Європейська Хартія про статус суддів URL: http://zakon0.rada.gov.ua/laws/ show/994_236/print 1452778112829501.

33. Савенко М. Незалежність судді Конституційного Суду України. Вісник Конституиійного суду України. 2001. № 1. С. 77, 78.

34. Французская республика. Конституция и законодательные акты / Пер. с франц. ; Ред. кол. : В.А. Туманов и др. Москва : Прогресс, 1989.448 с.

35. Судьи в зарубежных странах / Законодательство зарубежных стран. Обзо-рная информация. Москва : ВНИИ советского государственного строительства и законодательства, 1991. Вып. 2. 49 с.

The article analyzes the international experience in the judicial sphere with the purpose of borrowing the best legislative practices and recommendations for improving the legal regulation of the status of a judge in Ukraine. It is stressed that the very issue of the question remains the determination of the necessity to occupy a position of a judge indefinitely in Ukraine. On the one hand, it ensures adherence to the principle of independence and impartiality of the judiciary and individual judges, but on the other creates an illusion of judicial permissiveness and impunity, which leads to the spread of corruption risks in the pursuit of equitable justice. It is found out in the European Charter on the Status of Judges, which states that the existence of trial terms or requirements for resuming office imply difficulties and even the danger of the independence and impartiality of the judge who seeks to establish himself or renew his contract. Therefore, the example of Austria, which provides for an assessment of the work of candidates for judges during the probationary period, during which the candidate assists the judge in preparing decisions, is the most effective and effective way of practically preparing candidates for a judge to work in the justice system. It has been determined that the legal systems of most countries, as demonstrated by the above analysis, have their owen bodies of judicial self-government that, according to various factors, determine the criteria for selecting judges for positions that are not in most cases regulated and standardized (eg Cyprus, Estonia, Russian Federation, Finland, Iceland, Lithuania, Luxembourg, Norway, the Netherlands and the Czech Republic), but some have clear indications of selection of judges (eg Germany or Slovakia). It is concluded that from the point of view of the administrative-legal regulation of the right status of judges abroad for Ukraine there are many positive examples of necessary and necessary for implementation in the domestic model, namely: to use in the domestic practice, the so-called trials (training) period for candidates for office judges; increase moral and ethical requirements to the candidate for the position of judge; introduce the notion of anticorruption restrictions for judges, in particular the need for self-rejection in the event of a conflict of interests, in particular the need to declare an apparent conflict of interest; to restrict the president's permission to form a judiciary corps.

Key words: administrative, legal, regulation, foreign experience, directions, improvement. 
УДК 351.(477):328.185

DOI https://doi.org/10.32849/2663-5313/2019.8.22

\section{Генадій Шевчук,}

канд. юрид. наук,

доцент кафедри полічейського права

Начіональної академії внутрішніх справ

\section{ПРАВОВИЙ СТАТУС УПРАВЛІННЯ З ПИТАНЬ ЗАПОБІГАННЯ КОРУПЦІЇ ТА ПРОВЕДЕННЯ ЛЮСТРАЦІЇ В СТРУКТУРІ МВС УКРАЇНИ}

У статті досліджено правовий статус Управління запобігання корупиї та люстраиії в структурі Національної поліції України. Встановлено, що зазначений орган є самостійним та функціонально незалежним структурним підрозділом у держсавному органі, який несе відповідальність виключно за впровадження та реалізацію заходів щодо виявлення корупиійних правопорушень та правопорушень, пов 'язаних з корупиією, і запобігання їм. Визначено, що основу правового статусу Управління становлять завдання та функиії. Основними завданнями Управління є: підготовка, забезпечення та контроль за виконанням заходів з попередження та виявлення корупиї в Національній поліиї України; надання методичної та консультативної допомоги з дотримання антикорупиійного законодавства в Національній поліиіі України; участь в інформаційному та досліднищькому забезпеченні заходів щодо попередження та виявлення корупиї в Національній поліиї України, а також міжнародної співпрачі у иій сфері; проведення організаиійної та роз'яснювальної роботи щодо запобігання, виявлення та протидії корупції в Національній поліції України тощо. Визначено, що з метою належного функціонування вказаного підрозділ, доиільним було б затвердження на законодавчому рівні приниипів діяльності Управління, до яких можна віднести такі спеціальні принципи, як: принцип прозорості діяльності Управління, забезпечення довіри до поліиії, дотримання антикорупиійного законодавства, формування ідеології служби в поліції, пріоритет антикорупиійної політики тощо. На основі аналізу наявних функиій Управління запропоновано запровадити політичну функиію, призначену для визначення та подальшого впровадження внутрішньої політики Управління як иентрального підрозділу Начіональної поліиії України, що здійснює антикорупційну діяльність, реалізує антикорупційну політику в системі начіональної поліиії. Зроблено висновок, шо повний спектр наявних законодавчих прогалин у сфері запобігання та протидії корупиії в межах діяльності Національної полічії України не можна охопити в одній науковій статті, але ие є подальшими науковими дослідженнями та практичними рішеннями проблем, що існують съогодні в реалізащії антикорупиійної політики в Україні.

Ключові слова: правовий статус, корупція, діяльність, Управління з питань запобігання корупції та проведення люстрації, Національна поліція, Україна.

Актуальність теми дослідження. Після подій Революції Гідності для Міністерства внутрішніх справ розпочався новий етап власної історії та докорінних змін у самій системі державного органу: відбулася не лише зовнішня зміна колишньої міліції відбувся внутрішній колапс, наслідки якого ми маємо змогу спостерігати і сьогодні.

Водночас неможливо оминути увагою суттєві зміни у самій структурі новоствореної Національної поліції України, що зумовлені рядом причин: взяттям Україною курсу на євроінтеграцію, імплементацією міжнародного законодавства, гуманізацією та приведенням вітчизняного законодавства у відповідність до міжнародних стандартів. У цьому контексті, враховуючи міжнародну успішну практику державотворення, було створено ряд принципово нових органів (спеціалізованих), які покликані виконувати окремі, але досить важливі завдання та функції від імені держави.

Одним із таких державних органів стало Управління з питань запобігання корупції та проведення люстрації Національної поліції України (далі - Управління), що був створений на виконання затвердженої Антикорупційної стратегії, що передбачена Законом України «Про засади державної антикорупційної політики в Україні (Антикорупційна стратегія) на 2014-2017 роки» від 14 жовтня 2014 року № 1699-VII [1]. Створення нового органу у складі Національної поліції України зумовлено новим напрямом діяльності держави - антикорупційною політикою, що особливо активізувалася з 2014 року та реалізація якої весь час перебуває під наглядом з боку міжнародних партнерів та експертів 3 питань проведення реформ. 
Хоча Управління й налічує приблизно 2 роки свого функціонування, але вже визначилися певні напрями, які необхідно удосконалити і які потребують законодавчого врегулювання.

Метою статті є дослідження правового статусу Управління з питань запобігання корупції та проведення люстрації Національної поліції України як суб’єкта у сфері запобігання та протидії корупції.

Аналіз останніх досліджень і публікацій. Враховуючи вітчизняну практику сьогодення, слід зазначити, що здебільшого наукові праці вітчизняних науковців присвячені визначенню таких питань, як: антикорупційна політика, визначення явища «корупції», оцінка корупційних ризиків. Так, вказаними питаннями у своїх наукових працях опікувалися такі представники різних галузей права, як: О. М. Бандурка, Р. І. Благута, Ю. В. Баулін, О. Ю. Бусол, В. А. Завгородній, Е. В. Звягіна, Л. А. Зубкова, Л. С. Купріянова, С. І. Марченко, М. І. Мельник, А. В. Мовчан, С. В. евмержицький, В. В.Чумак та інші. Водночас питання визначення Національної поліції як суб'єкта протидії корупції досліджено досить поверхнево. А питання визначення ролі, місця, особливостей діяльності Управління з питань запобігання корупції та проведення люстрації Національної поліції України ще досліджено не було, що зумовлює особливу наукову цінність досліджуваної тематики.

Виклад основного матеріалу. Корупція сьогодні не лише в Україні, але й у світі визнана найбільшою соціальною загрозою XXI століття, що стає перешкодою для нормального функціонування демократії та завдає шкоди правам, свободам та законним інтересам не лише людини й громадянина, але й суспільству та державі в цілому. Адже, як слушно зазначає Р. І. Благута, вона сприяє «тінізації» економіки, підриву довіри громадян до влади, зниженню міжнародного авторитету нашої держави, зменшенню іноземних інвестицій в економіку тощо [2, с. 8$]$. На жаль, корупційні прояви сьогодні спостерігаються майже у всіх сферах суспільного життя та подекуди стають звичною умовою функціонування суспільно-політичного, економічного чи навіть духовного життя країни. Корупція сьогодні перетворилася на досить серйозну проблему, що загрожує національній безпеці України, під загрозу ставляться iï цілісність та збереження конституційного ладу.

Саме тому в Україні створені та постійно вдосконалюються різні органи державної влади, що покликані здійснювати заходи із запобігання та протидії корупції. В Україні суб'єктів у сфері протидії корупції, до яких можна звернутися щодо порушень антикорупційного законодавства, належать:

1) Національне агентство з питань запобігання корупції (далі - НАЗК) - центральний орган виконавчої влади України зі спеціальним статусом, який забезпечує формування та реалізує державну антикорупційну політику;

2) Національне антикорупційне бюро України (далі - НАБУ) - це правоохоронний орган $з$ широкими силовими повноваженнями, на який покладається попередження, виявлення, припинення та розкриття корупційних злочинів;

3) Генеральна прокуратура України (далі - ГПУ);

4) Національна поліція України.

Відповідно до Постанови Кабінету Міністрів України «Про затвердження Положення про Національну поліцію» від 28 жовтня 2015 року № 877 (далі - Положення), Національна поліція з метою організації своєі діяльності: 1) забезпечує в межах повноважень, передбачених законом, здійснення заходів щодо запобігання корупції, порушень законності, службової дисципліни і контроль за їх реалізацією в центральному органі управління Національної поліції, територіальних органах, на підприємствах, в установах та організаціях, що належать до сфери їі управління [3].

Відповідно до вказаного Положення у складі Національної поліції України було створено спеціалізований уповноважений підрозділ з питань запобігання та виявлення корупції - Управління з питань запобігання корупції та проведення люстрації Національної поліції України. Його діяльність регламентована Наказом Голови Національної поліції України «Про затвердження Положення про Управління з питань запобігання корупції та проведення люстрації Національної поліції України» від 23 лютого 2017 року № 160 (далі - Наказ) [4].

Управління як уповноважений підрозділ з питань запобігання та виявлення корупції - це самостійний, відокремлений та функціонально незалежний структурний підрозділ в державному органі, на який покладено виключно функції впровадження та реалізації заходів щодо запобігання та виявлення корупційних правопорушень та правопорушень, пов'язаних із корупцією.

Відповідно до вказаного Наказу, Управління $є$ уповноваженим підрозділом Національної поліції України з питань запобігання та виявлення корупції та безпосередньо підпорядковане керівникові Національної 
поліції України. До основних завдань Управління віднесено:

1) підготовку, забезпечення та контроль за здійсненням заходів щодо запобігання виявлення корупції у Національній поліції України;

2) здійснення заходів щодо забезпечення вимог Закону України «Про очищення влади» в діяльності Національної поліції України;

3) надання методичної та консультативної допомоги 3 питань дотримання вимог антикорупційного законодавства в Національній поліції України

4) участь в інформаційному та науководослідному забезпеченні здійснення заходів щодо запобігання та виявлення корупції в Національній поліції України, а також міжнародному співробітництві в зазначеній сфері;

5) проведення організаційної та роз'яснювальної роботи із запобігання, виявлення і протидії корупції в Національній поліції України;

6) здійснення контролю за дотриманням вимог законодавства щодо врегулювання конфлікту інтересів у Національній поліції України;

7) здійснення контролю за дотриманням вимог антикорупційного законодавства в Національній поліції України [4].

Вказані завдання Управління мають переважно програмний характер, водночас прикладний характер мають функції Управління, оскільки завдання визначають зміст діяльності, а функції є своєрідним засобом реалізації завдань у практичній площині. Як відомо із теорії права, завдання тісно пов'язані з функціями, що визначають пріоритетні напрями діяльності відповідного органу державної влади.

Так, до функцій Управління належать такі:

1) розробляе та проводить заходи щодо запобігання корупційним правопорушенням, а також здійснює контроль за їх проведенням у Національній поліції України;

2) надає структурним підрозділам апарату центрального органу управління Національної поліції України, територіальним органам Національної поліції в Автономній Республіці Крим та м. Севастополі, областях та м. Києві, міжрегіональним територіальним органам поліції, підприємствам, закладам, установам, що належать до сфери управління поліції, та їх окремим працівникам роз'яснення щодо застосування антикорупційного законодавства;

3) уживає заходів щодо виявлення конфлікту інтересів та сприяє його усуненню, контролює дотримання вимог законодавства щодо врегулювання конфлікту інтересів, а також виявляє сприятливі для вчинення корупційних правопорушень ризики в діяльності посадових і службових осіб Національної поліції України, уносить їх керівникам пропозиції щодо усунення таких ризиків;

4) надає допомогу поліцейським, державним службовцям та іншим працівникам Національної поліції України в заповненні декларацій особи уповноваженої на виконання функції держави або місцевого самоврядування;

5) повідомляе в письмовій формі керівникові Національної поліції України та спеціально уповноваженим суб'єктам у сфеpi протидії корупції про факти, що можуть свідчити про вчинення корупційних або пов'язаних з корупцією правопорушень працівниками органів та підрозділів поліції;

6) веде облік працівників Національної поліції України, притягнутих до відповідальності за вчинення корупційних правопорушень;

7) взаємодіє 3 підрозділами 3 питань запобігання та виявлення корупції державних органів, органів влади Автономної Республіки Крим, органів місцевого самоврядування, підприємств, установ та організацій, спеціально уповноваженими суб'єктами у сфері протидії корупції та інші [4].

Дотримуючись класифікації функцій державного органу, зазначимо, що вказані вище функції Управління за своїм характером є внутрішніми та стосуються безпосередньо працівників органів та підрозділів Національної поліції України. На цій основі 3 метою вдосконалення діяльності Управління має бути сформована політична функція, що покликана визначити розробку та подальше впровадження внутрішньої політики Управління як центрального підрозділу Національної поліції України, що здійснює антикорупційну політику в системі Національної поліції.

Враховуючи викладене, відповідно до покладених завдань та функцій Управління має такі повноваження:

1) уживає заходів щодо виявлення конфлікту інтересів та сприяє його усуненню;

2) контролює дотримання вимог законодавства щодо врегулювання конфлікту інтересів, а також виявляе сприятливі для вчинення корупційних правопорушень ризики в діяльності посадових і службових осіб Національної поліції України;

3) вносить їх керівникам пропозиції щодо усунення таких ризиків;

4) надає допомогу поліцейським, державним службовцям та іншим працівникам 
Національної поліції України в заповнені декларацій особи, уповноваженої на виконання функцій держави або місцевого самоврядування, організовує проведення спеціальних перевірок стосовно осіб, які претендують на зайняття посад, що передбачають зайняття відповідального або особливо відповідального становища, та посад з підвищеним корупційним ризиком у Національній поліції України;

5) координує роботу структурних підрозділів апарату центрального органу управління Національної поліції України, органів та підрозділів поліції, підприємств, закладів та установ, що належать до сфери управління поліції щодо здійснення заходів, спрямованих на запобігання і виявлення корупції;

6) розробляє та проводить заходи щодо запобігання корупційним правопорушенням у Національній поліції України.

Окрім переліченого вище, Управління забезпечує взаємодію з населенням, різними об'єднаннями громадян, громадськими організаціями, іншими інститутами громадянського суспільства з питань, що належать до сфери компетенції Управління. Зокрема, це питання антикорупційного законодавства, формування негативного ставлення громадян до корупційних проявів, комунікативні заходи 3 питань реалізації антикорупційної політики, спільні наради, семінари, круглі столи, конференції, практичні навчання тощо.

Зазначимо, що на сучасному етапі функціонування даного підрозділу працівниками Управління систематично здійснюються різноманітні заходи, що спрямовані на недопущення корупційних правопорушень, виявлення ризиків вчинення корупційного правопорушення, їх оцінку та аналіз. Так,

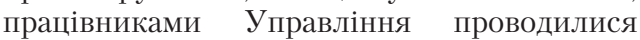
семінари для працівників органів та підрозділів Національної поліції з питань запобігання корупції для керівників особового складу різних областей [5]. Також це семінари з антикорупційного законодавства [6], висвітлення у засобах масової інформації та на офіційному сайті Національної поліції України міжнародного досвіду вжиття заходів запобігання та протидії корупції, особливостей кримінальної відповідальності за вчинення корупційних злочинів [7; 8; 9].

У підсумку зазначимо, що діяльність Управління з питань запобігання корупції та проведення люстрації є ще одним кроком до зменшення ризиків корупційних правопорушень, висвітлення та роз'яснення антикорупційного законодавства, що є складовою частиною антикорупційної стратегії України. Заходи, що успішно реалізуються співро- бітниками Управління, сприяють формуванню нетерпимості до корупційних проявів та формують належний рівень правової свідомості співробітників поліції.

\section{Висновки}

Сучасний стан розвитку державного будівництва у сфері запобігання та протидії корупції дає підстави говорити про інтенсивне створення спеціалізованих суб'єктів протидії корупції, серед яких одне із провідних місць у системі органів Національної поліції України відведене Управлінню з питань запобігання корупції та проведення люстрації Національної поліції України.

Враховуючи законодавче забезпечення діяльності вказаного підрозділу, ми дійшли висновку про те, що Управління як структурний елемент Національної поліції України здійснює заходи на «внутрішньосистемному» рівні, тобто його дії (заходи) реалізуються всередині апарату Національної поліції України, в його територіальних органах, закладах та установах поліції. Водночас 3 метою належного функціонування вказаного підрозділу, на наш погляд, доцільним було б затвердження на законодавчому рівні принципів діяльності Управління, до яких можна віднести такі спеціальні принципи, як: принцип прозорості діяльності Управління, забезпечення довіри до поліції, дотримання антикорупційного законодавства, формування ідеології служби в поліції, пріоритету антикорупційної політики тощо.

У підсумку зазначимо, що повною мірою охопити весь діапазон наявних законодавчих прогалин у сфері запобігання та протидії корупції у Національній поліції України в одній науковій статті неможливо, проте викладене наштовхує на подальші наукові пошуки та практичне вирішення наочних проблем, що є сьогодні у реалізації антикорупційної політики в Україні.

\section{Список використаних джерел:}

1. Про засади державної антикорупційної політики в Україні (Антикорупційна стратегія) на 2014-2017 роки : Закон України 14 жовтня 2014 р. № 1699-VII. URL: https://zakon.rada.gov.ua/laws/ show/1699-18 (дата звернення: 30.05.2019).

2. Благута Р. I. Протидія корупції - крок до розвитку цивілізованої держави. Проблеми вдосконалення діяльності правоохоронних органів щодо виявлення, попередження та припинення корупиійних проявів : матеріали постійно діючого наук. практ. сем. (Львів, 7 квітня 2017 р.). Львів: Львівський державний університет внутрішніх справ, 2017. С. 8-10.

3. Про затвердження Положення про Національну поліцію : Постанова Кабінету Міністрів 
України від 28 жовтня 2015 р. № 877 . URL: https:// zakon.rada.gov.ua/laws/show/877-2015-\%D0\%BF? find $=1 \&$ text $=\% \mathrm{EA} \% \mathrm{EE} \% \mathrm{~F} 0 \% \mathrm{~F} 3 \% \mathrm{EF} \% \mathrm{~F} 6 \% \mathrm{~B} 3 \% \mathrm{BF}$ \#w11 (дата звернення: 30.05.2019).

4. Про затвердження Положення про Управління 3 питань запобігання корупції та проведення люстрації Національної поліції України : Наказ Голови Національної поліції України від 23 лютого 2017 р. № 160. URL: https://www.npu. gov.ua/assets/userfiles/files/protydiya-korupcii/ nakaz160.pdf (дата звернення: 02.06.2019).

5. Представники Управління з питань запобігання корупції та проведення люстрації провели для поліцейських Рівненщини семінар з питань запобігання корупції. Новини УПЗКПл сайт. URL: https://www.npu.gov.ua/materials/ novini-upzkpl/predstavniki-upravlinnya-zpitan-zapobigannya-korupcziji-ta-provedennyalyustracziji-proveli-dlya-policzejskix-rivnenshhiniseminar-z-pitan-zapobigannya-korupcziji/ (дата звернення: 01.06.2019).
6. На Донеччині представники Національної поліції провели для поліцейських семінар з антикорупційного законодавства. Новини УПЗКПЛ : сайт. URL:https://www.npu.gov.ua/materials/noviniupzkpl/na-donechchini-predstavniki-naczpoliczijiproveli-dlya-policzejskix-seminar-z-antikorupczijnogozakonodavstva/ (дата звернення: 01.06.2019).

7. Найсуворіші покарання за корупцію в світі. Новини УПЗКПЛ : сайт. URL: https://www. npu.gov.ua/materials/novini-upzkpl/najsuvorishipokarannya-za-korupcziyu-v-sviti/ (дата звернення: 02.06.2019)

8. Італійська модель боротьби 3 корупцією. Новини УПЗКПЛ : сайт. URL: https://www. npu.gov.ua/materials/novini-upzkpl/Italijskamodel-borotbi-z-korupczijeyu/ (дата звернення: 02.06.2019).

9. Досвід Швеції у боротьбі з корупцією. Новини УПЗКПЛ : сайт. URL: https://www.npu.gov.ua/ materials/novini-upzkpl/dosvid-shvecziji-u-borotbiz-korupczijeyu/ (дата звернення: 03.06.2019).

The article investigates the legal status of the Office for the Prevention of Corruption and Lustration in the structure of the National Police of Ukraine. It is determined that the said body is an independent separate and functionally independent structural subdivision in a state body, which is solely responsible for the implementation and implementation of measures for the prevention and detection of corruption offenses and offenses related to corruption. It is determined that the basis of the legal status of the Office consists of tasks and functions. The main tasks of the Office are: to prepare, provide and monitor the implementation of measures to prevent and detect corruption in the National Police of Ukraine; providing methodological and advisory assistance on compliance with anti-corruption legislation in the National Police of Ukraine; participation in information and research provision of measures to prevent and detect corruption in the National Police of Ukraine, as well as international cooperation in this area; conducting of organizational and explanatory work on prevention, detection and counteraction of corruption at the National Police of Ukraine, etc. It has been determined that for the proper functioning of this unit, it would be advisable to approve at the legislative level the principles of the Office's activities, which may include such special principles as: the principle of transparency of the Office's activities, the provision of trust in the police, adherence to anti-corruption legislation, the formation of the ideology of service in the police, the priority of anti-corruption policy, etc. Based on the analysis of the existing functions of the Office, the Police proposed to introduce a political function designed to determine the development and further implementation of the internal Policy of the Office as the central unit of the National Police of Ukraine, which carries out anticorruption policy in the National Police System. It is concluded that full range of existing legislative gaps in the field of prevention and counteraction of corruption within the National Police of Ukraine within the framework of one scientific article can not be covered, but this poses a further scientific researches and practical solutions to the visual problems that exist today in the implementation of anticorruption policy in Ukraine.

Key words: legal status, corruption, activity, Department for the Prevention of Corruption and Lustration, National Police, Ukraine. 
УДК 321.244

DOI https://doi.org/10.32849/2663-5313/2019.8.23

\section{Андрій Деркач,}

канд. юрид. наук, народний депутат України,

докторант Інституту законодавства Верховної Ради України

\section{МІЖНАРОДНО-ПРАВОВІ СТАНДАРТИ ЗАХИСТУ ПРАВ ЛЮДИНИ ТА ЇХ ВІДОБРАЖЕННЯ В КОНСТИТУЩІЇ УКРАЇНИ}

У статті аналізується низка глобальних міжнародних актів, що містять стандарти забезпе чення та захисту прав і основоположних свобод людини і громадянина, що знайшли своє відображення в розділі II Конституиії України. Проаналізовано роль судової практики Європейського суду з прав людини та Міжнародного суду ООН у становленні та процесі впровадження стандартів захисту прав і свобод людини. Наголошено, що Всесвітня конференція з прав людини у преамбулі до декларачії враховує, що заохочення $i$ захист прав людини є питанням першорядного значення для міжнародно20 співтовариства, і шо Конферениія надає унікальну можливість для проведення всебічного аналізу міжнародної системи прав людини і механізму захисту прав людини з метою зміцнення $і$ заохочення більш повного дотримання иих прав справедливим і збалансованим чином, визнає і стверджує, що всі права людини є наслідком гідності і цінності, притаманних людській особистості, і що людська особистість є центральним суб'єктом прав людини і основних свобод $i$, відповідно, повинна бути основним бенефічіаром иих прав і свобод і активно брати участь в їх реалізачії, підтверджуючи свою прихильність цілям і принципам, що містяться в Статуті Організацї̈ Об'єднаних Націй і у Загальній декларації прав людини. Наголошено, що прецедентна практика Європейського суду з прав людини нині фактично є елементом національної правової системи, оскільки сама Свропейська конвенція про захист прав людини та основоположних свобод дає Суду право тлумачити положення Конституції України, а начіональні судові органи починають дедалі більще посилатися на його судові рішення під час вирішення питань у межсах наиіональної судової юрисдикиї̈. Зроблено висновок, що законодавство України з прав людини і насамперед Конституція нашої держави відповідають міжнародно-правовим стандартам. Так, незважаючи на прогрес у законодавчій сфері, в Україні існує потреба у вдосконаленні правозастосовної практики та впровадженні в дію названих міжнародних стандартів, зокрема через використання судової практики Європейського суду з прав людини та Міжнародного суду ООН. До того ж вступ України до Ради Європи зобов'язує дотримуватися міжнародних норм $і$ принципів у галузі захисту прав людини.

Ключові слова: захист прав людини, конституційна процедура захисту прав людини, міжнародні стандарти, глобальні міжнародні стандарти, Конституційний Суд України.

Постановка проблеми. Сфера захисту прав і свобод людини більше не є полем діяльності винятково однієї країни. Наразі ця сфера належить до напряму діяльності більшості міжнародних організацій. Сьогодні нараховується більше 300 декларацій, конвенцій, хартій, що мають за мету задекларувати та закріпити на глобальному світовому рівні основоположні права та свободи людини і їх захисту та відновлення у випадку їх порушення. Такі міжнародно-правові акти в галузі прав людини зазвичай розглядаються як міжнародні стандарти, оскільки засновані на звичаєвих нормах, що сформувалися внаслідок визнання державами юридичної сили правил поведінки, які були проголошені Генеральною Асамблеєю ООН у вигляді декларацій чи рекомендацій. Саме ця низка міжнародно-правових актів стала базисом для Конституції України та закріплює гарантії забезпечення і дотримання прав і свобод людини і громадянина в Україні.

Метою статті є дослідження особливостей глобальних міжнародно-правових стандартів захисту прав і свобод людини в рамках конституційної юстиції.

Виклад основного матеріалу. Міжнародні стандарти в галузі прав людини - це загальновизнані міжнародно-правові норми, які закріплюють на загальнолюдському рівні статус особистості і встановлюють перелік основоположних прав і свобод, обов'язок держав дотримуватися цих прав і свобод, а також межі можливого або припустимого їх обмеження [1, с. 2]. Так, до основних актів, що містять глобальні стандарти прав і сво- 
бод особи та стосуються правового статусу людини і громадянина та 3 якими узгоджуються приписи Конституції України і відповідних нормативно-правових актів, можна віднести: Загальну декларацію прав людини (1948), Міжнародний пакт про громадянські та політичні права (1966), Міжнародний пакт про економічні, соціальні та культурні права (1966), Європейську конвенцію про захист прав людини та основоположних свобод 3 протоколами (1950), Європейський соціальний стандарт (1961), Заключний акт Наради 3 питань безпеки та співробітництва в Європі (1975), Підсумковий документ Віденської зустрічі представників держав - учасниць Наради з питань безпеки та співробітництва в Свропі (1989), Документ Копенгагенської наради - конференції з людського виміру НБСЕ (1990) тощо.

Слід також зупинити увагу на Статуті ООН від 26 червня 1945 р., який дозволяе стверджувати, що питанням прав людини присвячені декілька положень цього документу. Насамперед це теза преамбули Статуту щодо нового затвердження «віри в основні права людини, в гідність та цінність людської особистості» та приписи ст. 55 Статуту, за якими, з метою утворення умов сталості та добробуту, необхідних для мирних та дружніх відносин між націями, заснованих на повазі принципу рівноправ'я та самовизначення народів, ООН має сприяти загальній повазі та дотриманню «прав людини та основних свобод для усіх, без розрізнення раси, статі, мови та релігії». Тотожне визначення прав та свобод людини формулювання містить й п. «b» ч. 1 ст. 13 Статуту, за яким Генеральна Асамблея ООН (далі - ГА ООН) повинна організовувати дослідження та робити рекомендації з метою сприяння міжнародній співпраці, зокрема, в сфері сприяння здійсненню цих прав. За ч. 2 ст. 62 Статуту Економічна та Соціальна Рада ООН також уповноважена робити рекомендації з метою «заохочення поваги та дотримання прав людини та основних свобод для усіх» [2].

Основний Закон нашої держави зорієнтований на міжнародно-правові стандарти. 3 огляду на це в них значна увага приділяється регулюванню співвідношення і взаємодії норм внутрішнього і міжнародного права. Україна, дотримуючись загальновизнаних принципів і норм міжнародного права, на конституційному рівні встановила чіткий порядок введення в дію цих норм. Так, норми міжнародного права, у тому числі і ті, що стосуються прав і свобод людини, стають частиною національного законодавства за умови надання згоди на обов'язковість міжнародних договорів Верховною Радою України.
Наприклад, розділ II Конституції присвячений правам і свободам людини і громадянина, а в цілій низці статей знайшли своє відображення положення Загальної декларації прав людини [3]. Виходячи з положень Декларації «усі люди народжуються вільними і рівними у своїй гідності і правах» (ст. 1), а згідно зі ст. 2 кожній людині належать права і свободи, проголошені цією Декларацією, незалежно від раси, кольору шкіри, статі, мови, релігії, політичних або інших переконань, національного або станового походження, майнового чи іншого стану тощо. Вкажемо на приписи її окремих статей, що безперечно вплинули на подальший розвиток національних моделей конституціоналізму та на глобалізацію цього правового феномену, зокрема та насамперед у сфері захисту прав особи [4].

Так, можна із неї виокремити такі загальні міжнародні стандарти щодо прав людини, як рівність прав всіх людей та їх рівний захист законом, не дискримінація, право людини на ефективне поновлення у правах компетентними національними судами в разі порушення іï̈ основних прав, гарантії кримінально-процесуальних прав людини (ст. ст. 7, 8, 10 і т.д. ЗДПЛ) [4].

Серед документів універсальної дії варто навести й Віденську декларацію та Програму дій, схвалені на Всесвітній конференції 3 прав людини 25 червня 1993 р. Так, Всесвітня конференція 3 прав людини у преамбулі до декларації враховує, що заохочення і захист прав людини є питанням першорядного значення для міжнародного співтовариства, і що Конференція надає унікальну можливість для проведення всебічного аналізу міжнародної системи прав людини і механізму захисту прав людини з метою зміцнення і заохочення більш повного дотримання цих прав справедливим і збалансованим чином, визнає і стверджує, що всі права людини $€$ наслідком гідності і цінності, притаманних людській особистості, і що людська особистість є центральним суб'єктом прав людини і основних свобод і, відповідно, повинна бути основним бенефіціаром цих прав і свобод і активно брати участь у їх реалізації, підтверджуючи свою прихильність цілям і принципам, що містяться в Статуті Організації Об’єднаних Націй і у Загальній декларації прав людини. Крім того, у ст. 83 Віденської декларації міститься припис урядам - зміцнити національні структури, інститути й органи суспільства, які відіграють певну роль у справі заохочення та захисту прав людини та водночас імплементувати в законодавстві міжнародні стандарти прав людини [5].

Також слід визнати значущість резолюції ГА ООН 48/137 від 20 грудня 1993 р. «Права 
людини в адмініструванні юстиції» за якою вичерпну значущість для захисту прав людини мають незалежність судочинства, суддів та юристів, право на справедливий вирок, habeas corpus та дотримання прав людини за надзвичайних обставин, аспекти попереднього ув'язнення, покарання неповнолітніх та безкарності винних у порушенні прав людини [6]. На тій самій сесії резолюцією ГА ООН 48/134 було затверджено Принципи стосовно статусу національних інститутів сприяння та захисту прав людини (Паризькі принципи) [6].

У резолюції 48/134 підкреслювалося, що ефективна імплементація міжнародних стандартів прав людини є можливою винятково за наявності заходів та інституцій на національному рівні. Такі інституції мають не тільки підтримувати та захищати права людини, але й розвивати публічну свідомість щодо таких прав та свобод. При цьому саме ООН відводилася роль сприяння розвитку таких інституцій в якості місця обміну інформацією та досвідом; важливими для таких інституцій визначалися їх незалежність та плюралізм у формуванні складу, констатувалася потреба їх утворення чи посилення спроможності [6].

Крім того, Конституція України передбачила можливість звернення громадян України до спеціальних міжнародних установ із питань вирішення спорів, що стало посиленням права на захист порушених прав і свобод національними засобами захисту [3]. До таких установ належать Міжнародний Суд ООН, Свропейський суд з прав людини тощо. Згідно із ст. 55 Конституції кожен має право після використання всіх національних засобів правового захисту звертатися за захистом своїх прав і свобод до відповідних міжнародних установ чи до відповідних органів міжнародних організацій, членом або учасницею яких є Україна.

Найважливішу роль у запровадженні відповідних стандартів відіграє Європейський суд 3 прав людини, який діє відповідно до Європейської конвенції про захист прав людини та основоположних свобод 1950 р., що набула чинності в Україні у вересні 1997 р. Саме з цього часу започатковано якісно новий підхід до імплементації правозахисних стандартів, яким надається конкретна правова форма. Прецедентна практика Європейського суду з прав людини нині фактично є елементом національної правової системи, оскільки сама Європейська конвенція про захист прав людини та основоположних свобод дає Суду право тлумачити положення Конституції України, а національні судові органи починають дедалі більше посилатися на його судові рішення під час вирішення питань у межах національної судової юрисдикції [1, с. 2]. Слід також наголосити, що зазначеному стану речей сприяє практика численних звернень громадян України до нього.

\section{Висновки}

Підсумовуючи, вкажемо, що сьогодні законодавство України 3 прав людини i насамперед Конституція нашої держави відповідають міжнародно-правовим стандартам. Так, незважаючи на прогрес у законодавчій сфері, в Україні існує потреба у вдосконаленні правозастосовної практики та впровадженні в дію названих міжнародних стандартів, зокрема, через використання судової практики Європейського суду з прав людини та Міжнародного суду ООН. До того ж вступ України до Ради Європи зобов'язує дотримуватися міжнародних норм і принципів у галузі захисту прав людини.

\section{Список використаних джерел:}

1. Шевчук С. Судовий захист прав людини: Практика Європейського суду з прав людини у контексті західної правової традиції. Київ : Реферат, 2006. С. 2

2. Статут Організації Об'єднаних Націй і Статут Міжнародного Суду від 26 червня 1945 p. URL: https://zakon.rada.gov.ua/laws/show/995_010.

3. Конституція України: затверджена Законом України від 28 червня 1996 р. № 254к / 96ВР (із змінами, внесеними Законом України від 1 лютого 2011 р. № 2952-VI (2952-17). Відомості Верховної Ради України. 1996. № 30. Ст. 141 ; 2011. № 10. Ст. 68.

4. Загальна декларація прав людини від 10.12.1948. URL: https://zakon.rada.gov.ua/laws/ show/995_015.

5. Віденську декларацію та Програму дій, схвалені на Всесвітній конференції з прав людини 25 червня 1993 p. URL: https://zakon.rada.gov.ua/ laws/show/995 504.

6. National Institutions for the Promotion and Protection of Human Rights : Resolution 48/134 adopted by the UN General Assembly on 20 December 1993 [on the report of the Third Committee (A/48/632/Add.2)]. URL: https://undocs.org/en/A/RES/48/134.

The article analyzes a number of global international acts containing standards for the protection and defense of the rights and fundamental freedoms of man and citizen, which are reflected in Section II of the Constitution of Ukraine. The role of judicial practice of the European Court of Human Rights and the International Court of Justice in the development and implementation of standards for the protection of human rights and freedoms is analyzed. It is emphasized that the World Conference on Human Rights in the preamble 
to the Declaration takes into account that the promotion and protection of human rights is a matter of paramount importance to the international community and that the Conference provides a unique opportunity for a comprehensive analysis of the international human rights system and the mechanism for the protection of human rights in order to strengthen and thus encouraging the full respect of these rights in a fair and balanced manner, recognizes and asserts that all human rights are a consequence of the dignity and worth of the human dignity and that the human person is a central subject of human rights and fundamental freedoms and, accordingly, should be the main beneficiary of these rights and freedoms and actively participate in their implementation, Reaffirming their commitment to the purposes and principles contained in the Charter of the United Nations and in the Universal Declaration of Human Rights. It has been pointed out that the case law of the European Court of Human Rights is actually an integral part of the national legal system, since the European Convention on Human Rights protects the right to interpret the provisions of the Constitution of Ukraine and the national courts increasingly rely on its judgments resolving issues within national jurisdictional jurisdiction. It is concluded that the legislation of Ukraine on human rights and, above all, the Constitution of our country comply with international legal standards. Thus, in spite of legislative progress, there is a need for improved enforcement practice in Ukraine and the introduction of the named international standards, in particular through the use of the jurisprudence of the European Court of Human Rights and the International Court of Justice. In addition, Ukraine's accession to the Council of Europe obliges to adhere to international norms and principles in the field of human rights protection.

Key words: protection of human rights, constitutional procedure for the protection of human rights, international standards, global international standards, the Constitutional Court of Ukraine. 
УДК 336.227:341

DOI https://doi.org/10.32849/2663-5313/2019.8.24

\section{Анастасія Косенкова,}

аспірант кафедри фінансового права

Київського національного університету імені Тараса Шевченка,

старший консультант групи People Advisory Services в ЕY Україна

\section{РОЗВИТОК КОНЦЕПЦІЇ БЕНЕФІЦІАРНОГО ВЛАСНИКА ПРИ ІМПЛЕМЕНТАЦІї ПЛАНУ ВЕРS В УКРАЇНІ}

Кониепиія бенефініарного власника отримала розвиток не лише на рівні міждержавних угод про уникнення подвійного оподаткування, але й поступово імплементується в національне податкове законодавство України. Автор зазначає, що така кониепиія вже відома Податковому Кодексу (ПК) України, але з урахуванням потреб реалізачії плану BEPS в Україні розроблені відповідні заходи, метою яких є розширення законодавчого закріплення чієї кониепиії. Хоча, на думку автора, таке розширення повинно відбуватися виходячи з чітко обгрунтованих та науково і практично виважених концептів різних аспектів категорій «бенефічіарна власність» та «бенефічіарний власник». У зв'язку з иим у статті розглядаються процеси формування й розвиток концепиії бенефіціарного власника в ході імплементаиї плану ВЕРS в Україні, що відбувається головним чином через прийняття та імплементаиію в начіональне законодавство відповідних заходів BEPS. Автор розглядає такі кроки, необхідність імплементачії яких визначено та розроблено відповідною програмою, як: кроки № 3; № 4; № 6; № 7; № 8-10; № 13. Автор визначає, що їхня иінність полягає в тому, що результатом їх запровадження має стати якісно нова система реалізащії фінансових та господарських відносин. У процесі дослідження автором було виявлено, що розкриття інформачї та посилення заходів моніторингу діяльності суб'єктів господарювання у сфері зовнішньоекономічної діяльності здатне поста вити під належний рівень контролю фінансові операції, в тому числі ті, метою яких є ухилення від оподаткування. Хоча такий перелік заходів вже є для України значним кроком на шляху до досягнення високого рівня транспарентності системи оподаткування, їх реалізація на сучасному етапі потребує суттєвого коригування та розширення. Натомість у статті пропонується розширити такий перелік шляхом імплементаиї̈ таких кроків плану BEPS у законодавство України, як крок № 1 «Вирішення податкових проблем «цифрової економіки» та крок № 2 «Нейтралізачія наслідків гібридних податкових схем».

Ключові слова: розмивання податкової бази, зменшення податкового навантаження, мінімальні стандарти, автоматичний обмін інформацією, агресивне податкове планування.

Постановка проблеми. План BEPS (Base Erosion and Profit Shifting) - «Розмивання оподатковуваної бази й виведення прибутку 3-під оподаткування» - є глобальним планом дій, основною метою якого є унеможливлення ухилення від оподаткування. Його прийняття стало реакцією більшості провідних держав світу на політику застосування агресивних схем податкового планування, які використовуються глобальними корпораціями та мають на меті виведення прибутків із країни, де вони генеруються в іншу країну, податкове навантаження в якій є суттєво меншим, ніж у першій. Такий інструмент дозволяє транснаціональним корпораціям суттєво економити на податкових відрахуваннях, але при цьому створює передумови для втрат в економіці, у якій генерується прибуток, у зв'язку з недостатніми надходженнями від податків, що виступають певною платою за адміністративні та інші послуги, пов'язані зі створенням ринкової, фінансової інфраструктури, умовами ведення бізнесу, лібералізацією системи державного контролю тощо. Водночас впровадження плану BEPS в Україні тягне за собою внесення змін до податкового законодавства у частині визначення концепції бенефіціарного власника як ключової фігури у запобіганні розмиванню податкової бази. На жаль, натепер концепцію бенефіціарного власника не можна вважати цілком вивченою та зрозумілою українському законодавцю.

Аналіз останніх досліджень і публікацій. Концепція бенефіціарного власника є предметом досліджень багатьох вітчизняних і закордонних вчених, таких як П. О. Селезнь, В. О. Гідірім, Ш. дю Шот, К. Фогель, Л. де Бро, О. Крижанівська тощо. Але, незважаючи на наявність достатньої кількості науко- 
вих досліджень, питання концепції бенефіціарного власника в ході імплементації плану BEPS в Україні не є дослідженим, що негативно впливає на розвиток наукової думки та відсутність єдиного підходу до розуміння концепції.

Мета статті $€$ вивчення особливостей закріплення концепції бенефіціарного власника в українському податковому законодавстві в ході імплементації плану BEPS в Україні.

Виклад основного матеріалу. Механізм, на дію якого спрямовується BEPS, полягає в такому: під час здійснення зовнішньоекономічної діяльності суб'єкти господарювання резиденти стикаються з необхідністю сплати податку на прибуток, який генерується внаслідок проведення конкретної ЗЕД-операції у двох різних юрисдикціях - національній та тієї країни, у якій генерується прибуток. У такий спосіб обидві держави намагаються отримати власний економічний ефект від процесу створення доданої вартості або приросту прибутку від діяльності суб'єктів господарювання. Натомість такі суб'єкти мають протилежну мету - мінімізацію податкового навантаження, причому вибирають для цього не завжди законні методи з погляду законодавства однієї з країн. Фактично суб'єкти господарювання виводять власні прибутки в країни $з$ найменшим або взагалі відсутнім податковим навантаженням, що порушуе інтереси великих розвинутих економік.

Але для такого агресивного податкового планування необхідне включення до цього механізму окремого суб'єкта - економічного агента, бенефіціарного власника, який буде вважатися отримувачем доходів, але не завжди буде їх реальним титульним власником. Тому концепція бенефіціарного власника $є$ важливим елементом регулювання міждержавних відносин у податковій сфері засобами міждержавних двосторонніх угод про уникнення подвійного оподаткування, метою яких є стимулювання суб'єктів господарювання сплачувати податки в одній із юрисдикцій або розподіляти податкові платежі між різними юрисдикціями таким способом, який відповідатиме їхнім власним інтересам мінімізації або оптимізації податкового навантаження.

У цьому контексті для оптимізації податкового планування та легального зменшення податкових платежів з дотриманням принципу законності під час провадження господарської діяльності та отримання прибутку найбільш прогресивним інструментом є BEPS.

Для України імплементація Плану BEPS означає прийняття та законодавче закріплення мінімального стандарту, який вклю- чає «чотири з п'ятнадцяти кроків: боротьба 3 податковими зловживаннями, пов'язаними з використанням спеціальних режимів оподаткування (крок 5); уникнення зловживань при застосуванні податкових конвенцій (крок 6); удосконалення вимог до документації з трансфертного ціноутворення (крок 13) і збільшення ефективності механізмів вирішення суперечок щодо застосування договорів про уникнення подвійного оподаткування між країнами (крок 14)» [1], причому, на думку Л. Рубаненко, найбільш важливим та актуальним у сучасних умовах для України $\epsilon$ «запобігання створенню штучних структур (схем) із метою використання переваг, що надаються угодами про уникнення подвійного оподаткування. Зокрема, необхідно на законодавчому рівні передбачити запровадження до чинних договорів з уникнення подвійного оподаткування додаткових вимог до резидентів договірних країн, які мають право на використання угоди. Мета цих вимог - дискваліфікувати компанії посередників, які фактично не ведуть діяльність у відповідній країні і створені лише для використання переваг, що надаються угодою про усунення подвійного оподаткування» [2]. Слід наголосити, що запровадження таких вимог необхідно одночасно передбачити й в угодах про уникнення подвійного оподаткування.

У цьому контексті найбільш дієвим інструментом є так звана MLI Конвенція (Багатостороння конвенція 3 імплементації пов'язаних з податковими угодами заходів для запобігання BEPS), підписання якої Україною відбулося в 2017 році. Її мета унеможливити ухилення від оподаткування та зловживання положеннями угод про уникнення подвійного оподаткування. Сутність та механізм дії MLI Конвенції полягає в тому, що вона виключає спроби пошуків інструментів мінімізації податкового навантаження засобами набуття такого статусу учасниками відносин, який дає можливість уникати оподаткування. Наприклад, деталізується категорія постійного представництва, його юридичний статус, запроваджується відмінність від концепції «бенефіціарний власник», створюються нові засоби врегулювання податкових спорів, підвищується роль та юридична визначеність самої бенефіціарної власності з метою унеможливлення виведення її з бази оподаткування.

М. Захарченко зазначає, що «багатостороння конвенція MLI є 15 кроком Плану дій BEPS. Підписавши та ратифікувавши Багатосторонню конвенцію, Україна одночасно виконує кроки 6 і 14 Плану BEPS, які входять до мінімального стандарту Плану BEPS 
та є обов'язковими до виконання Україною» [3].

Слушною є точка зору Н. Бец, яка акцентує увагу на тому, що «впровадження Україною Плану BEPS в національне законодавство є умовою ОЕСР в аспекті боротьби з ухиленням від оподаткування та підвищення податкової прозорості. Тому для ефективної реалізації плану BEPS Україні необхідно приєднатися до CRS стандарту (Common Reporting Standard) - автоматичного обміну інформацією про фінансові рахунки нерезидентів за міжнародним стандартом» [4]. Для цього Україна повинна приєднатися до Багатосторонньої угоди ОЕСР про співпрацю між компетентними органами 3 питань автоматичного обміну інформацією.

Цей етап сьогодні розпочато: на стадії ухвалення перебуває відповідний проект Закону № 6503 від 25.05.2017 «Про внесення змін до Податкового кодексу України (щодо міжнародного автоматичного обміну інформацією $з$ податкових питань)». «Обмін податковою інформацією є важливою складовою міжнародної боротьби з розмиванням бази оподаткування, з офшорними технологіями, які суттєво зменшують доходи бюджету будь-якої країни. Імплементація стандарту CRS, взаємодія з CША в межах FATCA потребує законодавчих змін в частині процедур отримання та відкриття даних про стан рахунків фізичних осіб органам ДФС, встановлення принципів обробки та передання податкової інформації компетентним органам інших країн тощо» [5]. Головний здобуток проекту Закону «Про внесення змін до Податкового кодексу України (щодо міжнародного автоматичного обміну інформацією з податкових питань)» - пропозиції щодо доповнення Податкового кодексу України новим Розділом 101 «Міжнародне співробітництво щодо автоматичного обміну інформацією 3 податкових питань», який регулюватиме загальні засади здійснення міжнародного автоматичного обміну інформацією з податкових питань; визначатиме коло суб'єктів ринку та фінансових установ, на які покладається обов'язок надавати таку інформацію; пропонує межі стандартів та вимог до інформації з податкових питань, яка підлягає міжнародному обміну; визначає права та обов'язки суб'єктів подання та учасників процесу обміну інформацією [6]. На нашу думку, основні здобутки прийняття цього закону полягатимуть у такому:

- по-перше, Україна отримує доступ до дієвих механізмів міжнародного моніторингу та контролю за рухом фінансів, що суттево підвищить якість податкової політики у сфері протидії ухиленню від оподаткування; деофшоризації; легалізації доходів, отриманих злочинним шляхом;

- по-друге, Україна, запровадивши стандарти CRS, наблизиться до такого стану національної податкової політики, який відповідатиме вимогам не лише BEPS, а й EC. Таким чином, досягатиметься необхідний рівень транспарентності та стабільності податкового законодавства та системи адміністрування податкових надходжень.

Останнє дає нам усі підстави стверджувати, що План BEPS повинен розглядатися Україною в тому числі або навіть головним чином як засіб наближення вітчизняного законодавства у сфері оподаткування до стандартів законодавства ЄС. Такий синергетичний ефект від запровадження Плану BEPS 3 одночасним досягненням певних здобутків на рівні євроінтеграційних перетворень.

Кабінет Міністрів України відреагував на потребу долучення України до Плану BEPS, та станом на середину 2017 року було розроблено відповідну дорожню карту реалізації Плану дій BEPS, що дає змогу «ефективно протидіяти агресивному податковому плануванню, розмиванню податкової бази і виведенню прибутку з-під оподаткування та розвиває ініціативу стосовно подальшої імплементації всіх заходів Плану дій BEPS у партнерстві з ОЕСР» [7]. Слід наголосити на тому, що сам по собі процес імплементації Плану дій BEPS розпочато в Україні ще в 2016 році.

Так, однією 3 основних новел, що пропонуються для імплементації до Податкового Кодексу України, $є$ норма пп. 9.3.2.12 п. 39.3 .2 ч. 36.3 ст. 39 ПК України, відповідно до якої «витрати, пов’язані 3 обслуговуванням материнської компанії міжнародної групи компаній, або витрати на користь (в інтересах) їх бенефіціарних власників не вважаються витратами, що здійснюються у внутрішньогрупових операціях, та відповідно, не можуть розглядатись як такі для інших компаній-учасників міжнародної групи, якщо ці компанії компенсують відповідні витрати» [8]. Таке формулювання свідчить, що витрати як на користь, так і в інтересах бенефіціарних власників не вважаються витратами, здійсненими у внутрішньогрупових операціях, та фактично вони не беруться до уваги, коли формується база оподаткування. 3 одного боку, такий підхід демонструє ототожнення юридичного та економічного змісту власності та титулу власності на грошові кошти, які витрачаються. 3 іншого боку, витратна частина фінансових потоків суб'єкта господарювання впливає на процес формування бази оподаткування, а отже, зна- 
чення бенефіціарного власника поширюється не лише на категорію «прибуток/дохід» та спосіб його розподілу чи використання, але й на сам процес формування безпосередньої величини оподатковуваного прибутку, доходу, капіталу, економічного результату.

Важливим є обов'язкове включення даних про «фізичних осіб, які є кінцевими бенефіціарними власниками (контролерами) платника податків, у такі звітності та документи, як: документація з трансфертного ціноутворення (сукупність документів або єдиний документ, складений у довільній формі) (п. 39.4.6 ч. 39.4 ст. 39 Проекту змін до ПК України); спрощена документація для контрольованих операцій з придбання (продажу) послуг з низькою доданою вартістю (п. 39.4 .6 ч. 39.4 ст. 39 Проекту змін до ПК України); звіт у розрізі країн міжнародної групи компаній (п. 39.4.10 ч. 39.4 ст. 39 Проекту змін до ПК України) [8]. Це цілком поширена практика за кордоном, але раніше норма про необхідність розкриття інформації щодо фізичних осіб, які є кінцевими бенефіціарними власниками (контролерами) платника податків, не була відома вітчизняному податковому законодавству. Така вимога формує транспарентні умови діяльності суб'єктів господарювання, створює передумови для підвищення ефективності системи адміністрування податків та демонструє готовність держави вести реальну боротьбу із суб'єктами господарювання, що мають наміри займатися фіктивним або удаваним підприємництвом.

Ще одна новела ПК України полягає в імплементації концепції, що міститься в статті 39-2 «Контрольовані іноземні компанії, яка раніше не була відома ні вітчизняному законодавству, ні вітчизняній доктрині фінансового права. Так, відповідно до п. 39-2.1.1 ч. 39-2.1 ст. 39-2, під контрольованою іноземною компанією пропонується розуміти «будь-яку юридичну особу, зареєстровану в іноземній державі або території, яка визнається такою, що знаходиться під контролем фізичної особи-резидента України відповідно до правил, визначених цим ПК України» [8]. Тому цілком логічно, що Проект Закону України про реалізацію Плану BEPS визначає контролюючою особою такої компанії «фізичну особу-резидента України, яка визнається кінцевим бенефіціарним власником (контролером) контрольованої іноземної компанії у значенні, наведеному в Законі України «Про запобігання та протидію легалізації (відмиванню) доходів, одержаних злочинним шляхом, фінансуванню тероризму та фінансуванню розповсюдження зброї масового знищення» [8]. Таким чином, Проект Закону України про реалізацію Плану BEPS у сфері регулювання діяльності контрольованої іноземної компанії ув'язує положення Плану BEPS із заходами у сфері протидії легалізації доходів, отриманих злочинним шляхом.

На нашу думку, такий зв'язок аналізованого законопроекту із законодавством у сфері протидії ухиленню від оподаткування $€$ надзвичайно прогресивним засобом законодавчого регулювання системи адміністрування податків та зборів. Але через те, що він передбачає обмін, контроль та постійний моніторинг фінансових потоків суб'єктів господарювання, виникає проблема, що в сучасних умовах та реаліях української владної системи такі повноваження, які за всією логікою потрібно покласти на органи ДФС у країні, призведуть до створення монопольного органу неконтрольованого тиску на бізнес. Відсутність прозорості в діяльності фіскальних органів в Україні, недостатній рівень довіри з боку бізнесу, постійні корупційні скандали та схеми, що донедавна стосувались навіть найвищого керівництва ДФС України, - усе це робить наведені зміни в частині розробки концепції контрольованих іноземних компаній занадто передчасними.

Найбільш значущою новелою ПК України передбачено трансформування поняття «бенефіціарний власник». Так, Проект Закону України про реалізацію Плану BEPS передбачає зміну п. 103.3 ст. 103 ПК України та викладення його в такій редакції:

«103.3. Бенефіціарним (фактичним) отримувачем (власником) доходу для цілей застосування пониженої ставки податку згідно з правилами міжнародного договору України до дивідендів, процентів, роялті, винагород тощо нерезидента, отриманих із джерел в Україні (якщо відповідна умова передбачена міжнародним договором), вважається особа, що має право на отримання таких доходів та є вигодоотримувачем щодо них (фактично розпоряджається доходом)» [8].

Системний аналіз положень цієї норми та норми, яку пропонується змінити, показав:

- раніше для ідентифікації бенефіціарного власника досить було лише такої ознаки, як наявність права «на отримання дивідендів, процентів, роялті, винагород тощо нерезидента, отриманих із джерел в Україні» [9]. Натомість сам по собі План BEPS суттєво розширює ознаки бенефіціарного власника, а тому в аналізованому вище Проекті змін до ПК України додається ще одна ознака для визначення бенефіціарного власника: він повинен бути вигодоотримувачем щодо наведених вище доходів, тобто фактично 
розпоряджатися ними. Така норма свідчить про розшарування, розщеплення юридичного та економічного змісту категорії «власність», а тому відбувається запровадження нової категорії для національного законодавства, що потребує, на наш погляд, суттєвої доктринальної розробки всіх аспектів бенефіціарної власності;

- п. 103.3 ст. 103 ПК України не містив раніше перелік ознак, які висувалися законодавцем до особи, що не може бути бенефіціарним власником. $\mathrm{y}$ поточній редакції ПК України всі ознаки зводяться до того, що «бенефіціарним (фактичним) отримувачем (власником) доходу не може бути юридична або фізична особа, навіть якщо така особа має право на отримання доходу, але є агентом, номінальним утримувачем (номінальним власником) або $є$ тільки посередником щодо такого доходу» [9]. Але Проект Закону України про реалізацію Плану BEPS розширює та деталізує таку особу, додаючи низку важливих ознак: «така особа не має достатньо повноважень користуватися та розпоряджатися таким доходом, та/або передає отриманий дохід або переважну його частину на користь іншої особи незалежно від способу оформлення такої передачі, та зазначена особа не виконує суттєвих функцій, не використовує значні активи та не несе суттєві ризики у операції з такої передачі, та/або не має відповідних ресурсів, необхідних для фактичного виконання функцій, використання активів та управління ризиками, пов'язаних з отриманням відповідного виду доходу, які лише формально покладаються на зазначену особу у зв'язку із здійсненням операції з такої передачі» [8].

Таким чином, засобами Проекту Закону України про реалізацію Плану BEPS пропонується імплементувати в національне законодавство розширене тлумачення категорій «бенефіціарний власник» та «бенефіціарна власність». При цьому таке тлумачення передбачатиме певну трансформацію самої концепції власності на доходи, дивіденди чи роялті, оскільки дещо відрізнятиметься від того розуміння власності, яке закріплено в положеннях ЦК України. Тобто концепція бенефіціарного власника передбачає наявність у нього повноважень з використання та розпорядження отриманих доходів. Про юридичний титул та володіння ними не йдеться. 3 погляду міжнародних угод про уникнення подвійного оподаткування така позиція є цілком слушною, але 3 погляду адміністрування податків вона, на нашу думку, викликає певні занепокоєння та ризики щодо використання таких положень закону суб'єктами господарювання з метою виведення доходів в інші юрисдикції, з меншими податковими ставками, ніж в Україні. Тому сьогодні важливим є не лише запровадження Плану BEPS, але й одночасне вдосконалення системи оподаткування, перегляд податкових ставок та взагалі бази й об'єктів оподаткування.

\section{Висновки}

Таким чином, підбиваючи підсумки, слід зауважити, що сучасні заходи у сфері запровадження плану BEPS одним із своїх результатів мають продовження та розширення законодавчого закріплення концепції бенефіціарного власника у вітчизняному податковому законодавстві. Натомість розширення запровадження самого плану BEPS призводить до певних доктринальних проблем у цій сфері, вирішити які можливо шляхом отримання синергетичного ефекту від доктринальної розробки та практичного запровадження законодавчих положень щодо визначення ознак, змісту та механізмів реалізації концепції бенефіціарної власності. Важливо розуміти, що ця концепція хоча й нетипова для українського законодавства, однак має важливе значення для системи міжнародних угод, учасником яких є Україна, а тому потребує якщо не детермінації, то хоча б номінального закріплення в українському законодавстві.

\section{Список використаних джерел:}

1. Лівак А. Імплементація плану BEPS в Україні: проблеми та перспективи для бізнеcy. URL: http://imgpartners.com.ua/company/ publications/ implementacija-planu-beps-v-ukrainita-perspektivi-biznesu-738-738-738/ (дата звернення: 04.08.2019).

2. Рубаненко Л. Стосовно дій бізнесу в зв'язку з прийняттям Україною зобов'язання імплементувати мінімальний стандарт Плану BEPS. URL: http://www.taxadvisers.org.ua/user files/BEPS0412-2017.pdf (дата звернення: 04.08.2019).

3. Захарченко М. Імплементація плану BEPS в Україні. URL: http://yur-gazeta.com/publications/ practice/podatkova-praktika/implementaciyaplanu-beps-vukrayini.html (дата звернення: 04.08.2019).

4. Бец Н. План BEPS: надія на прозоре оподаткування бізнесу. URL: https://lb.ua/blog/nina bets/414186_plan_beps_nadiya_prozore.html (дата звернення: 04.08.2019).

5. Пояснювальна записка до проекту Закону України «Про внесення змін до Податкового кодексу України (щодо міжнародногоавтоматичногообмінуінформацієюзподаткових питань)». URL: http://w1.c1.rada.gov.ua/ pls/zweb2/webproc4_1?id=\&pf3511=61889 (дата звернення: 04.08.2019). 
6. Проект Закону про внесення змін до Податкового кодексу України (щодо міжнародного автоматичного обміну інформацією з податкових питань). URL: http://w1.c1.rada.gov.ua/pls/ zweb2/webproc4_1?id=\&pf3511=61889 (дата звернення: 04.08.2019).

7. Мінфін розробив дорожню карту реалізації Плану дій BEPS. URL: https://www.kmu.gov.ua/ ua/news/249982923 (дата звернення: 04.08.2019).
8. Проект Закону України «Про внесення змін до Податкового кодексу України з метою імплементації Плану протидії розмиванню бази оподатковування та виведенню прибутку з-під оподаткування». URL: https://www.minfin.gov.ua/uploads/ redactor/files/Законопроект\%20БЕПС.pdf (дата звернення: 04.08.2019).

9. Податковий кодекс України. Відомості Верховної Ради Украӥни (ВВР). 2011. № 13-14, № 15-16, № 17. Ст. 112.

A beneficial owner is a person who enjoys the benefits of ownership even though title to some form of property is in another name. It also means any individual or group of individuals who directly or indirectly, has the power to vote or influence the transaction decisions with respect to specific security, such as shares in a company. The concept of beneficial owner has evolved not only in the international double tax treaties, but is also gradually being implemented to the Ukrainian national tax law. The author determines that the Tax Code of Ukraine already notes the concept, but for the concept's extension a lot of provisions are needed to be implemented. Therefore, the article considers the process of development of the beneficial owner concept in course of implementation of BEPS plan in Ukraine, which is mainly due to the adoption and implementation of relevant BEPS measures to the national tax legislation. The author also considers the steps, which have been identified and developed in this respect, such as: steps 3; № 4; № 6; № 7; № 8-10; № 13. The author notes that value of those steps is reduced and the result of their implementation should create new system of development of financial and economic relations. It is also found that disclosure of information and strengthening of monitoring measures in the sphere of foreign economic activities (including those directed to elimination of tax evasion) can make the financial transaction much controlled. Although it might help to achieve a high level of transparency of the taxation system. Additionally, the author proposes to extend the list of implemented steps from BEPS plan with step 1 "Solving tax problems of "digital economy" and step 2 "Offsetting the effects of hybrid tax schemes".

Key words: tax base erosion, reduction of tax burden, minimum standards, automatic exchange of information, aggressive tax planning. 
УДК 340.115 .7

DOI https://doi.org/10.32849/2663-5313/2019.8.25

Олена Грезіна,

аспірант кафедри загальнотеоретичної юриспрудениії

Національного університету «Одеська юридична академія»

\section{ЗАРУБІЖНИЙ ДОСВІД УПРОВАДЖЕННЯ ІНСТИТУТУ ОСВІТНЬОГО ОМБУДСМЕНА: КОМПАРАТИВНИЙ АНАЛІЗ}

У статті розглянуто зарубіжний і вітчизняний досвід діяльності освітнього омбудсмена. Автор наводить приклади дії освітнього омбудсмена в європейських крайнах та акиентує увагу на особливостях практики Сполучених Штатів Америки. Наводиться перелік передумов виникнення в Украйні інституту освітнього омбудсмена. Наголошується на необхідності детального вивчення механізму діï освітнього омбудсмена. Надається характеристика обов'язків омбудсмена зі спеціальної освіти у Сполучених Штатах Америки. Омбудсмени з питань освіти в Сполучених Штатах Америки є професіоналами з великим досвідом розв'язання конфліктів, посередництва та залучення сім'ї до освіти. Автор за допомогою компаративного аналізу звертає увагу на зарубіжну практику функиіонування інституту освітнього омбудсмена, наявність різноманітних моделей омбудсмена. Нині у багатьох країнах інститут освітнього омбудсмена став невід'ємною частиною механізму державної влади. Він виступає додатковим засобом захисту прав людини стосовно інших правозахисних механізмів, заповнює правові прогалини та компенсує ряд певних недоліків судових засобів захисту прав людини. Для порівняння, в Україні освітній омбудсмен, який на законодавчому рівні з'явився досить недавно, має розглядати скарги про порушення прав учнів і приниження власної гідності учасників освітнього процесу. Запровадження інституту освітнього омбудсмена, який має забезпечувати права особи на освіту, розглядати порушення таких прав і приймати відповідні рішення - своєчасна відповідь на зміни в освітньому законодавстві України та особливо актуальний крок. Автором зроблено висновок, що діяльність освітніх омбудсменів за кордоном має багату історію та вражаючий досвід. У багатьох крайнах вони називаються «омбудсмени з питань освіти» - професіонали у галузі освіти, які мають великий досвід розв'язання конфліктів. Украйна тільки починає розвиватись у цьому напрямі. Тому слід ретельно вивчати практику інших країн, щоб вивести діяльність освітнього омбудсмена на високий рівень і знизити кількість скарг учасників освітнього процесу про порушення їхніх прав.

Ключові слова: омбудсмен, освітній омбудсмен, спеціалізований омбудсмен, право, стейкхолдери, захист прав учасників освітнього процесу.

Постановка проблеми. 3 огляду на актуалізацію питань щодо захисту прав у сфері освіти, розширення кола учасників освітнього процесу, прагнення держави побудувати партнерські відносини з усіма стейкхолдерами у сфері освіти, у наукових колах дедалі частіше обговорюється необхідність появи посади освітнього омбудсмена в Україні. Такі думки зумовлені різними чинниками, зокрема й вивченням європейського досвіду функціонування спеціальних студентських офісів (служб) із забезпечення та реалізації прав і свобод відповідної категорії осіб, наявності спеціальних шкільних омбудсменів, а також спеціалістів із захисту прав учасників освітнього процесу.

Аналіз останніх досліджень. Зважаючи на постійну увагу наукової громадськості до проблеми захисту прав і свобод людини та громадянина, мусимо констатувати, що діяльність освітніх омбудсменів не зацікавила достатньою мірою вітчизняних дослідників. Деякі відомості щодо їхнього статусу містяться в наукових працях учених Т. Коваль, О. Кулинич, О. Марцеляк, О.Ф. Мельничук, Т. Оболенської, Ю. Рижук, Я. Тицької, О. Чабанюк. Серед зарубіжних вчених, навпаки, вибрана тема досить актуальна. Як приклад можна згадати розгорнуте дослідження британського вченого, практика Роба Беренса, в якому подано унікальну інформацію про розвиток інституту університетського омбудсмана в країнах Північної Америки, Австралії та Європи.

Мета статті. Слід зазначити, що в Україні натепер інститут освітнього омбудсмена освіти не вивчений у повному обсязі. Для забезпечення роботи цього інституту в Україні необхідно детально вивчити практику країн, що активно рухаються в цьому напрямі. Практика Сполучених Штатів Америки в цій сфері заслуговує на належну увагу. 
Виклад основного матеріалу. Зарубіжній практиці відомі багато моделей омбудсмена - парламентські (представницькі), виконавчі та квазіомбудсмени, одноособові та колегіальні омбудсманівські служби, наднаціональні (наддержавні), регіональні та місцеві омбудсмени, спеціалізовані омбудсмени Серед останніх можна виділити військових, дитячих омбудсменів, омбудсменів із захисту прав людей похилого віку, омбудсменів у сфері охорони здоров'я, у справах споживачів, у справах преси, з питань інформації, із захисту особистих даних, з офіційних мов, з питань боротьби з етнічною дискримінацією, із забезпечення рівності статей, вузівських (студентських) та учнівських омбудсменів тощо.

У багатьох країнах інститут омбудсмена став невід'ємною частиною механізму державної влади. Він влився в нього без порушення компетенції, існуючих процедур організації роботи інших органів, інститутів, які забезпечують захист і поновлення порушених прав і свобод людини, без зміни функціонування їхньої діяльності. Цей інститут став доповненням наявних форм контролю та нагляду за дотриманням прав і свобод людини та громадянина. Він виступає додатковим, а не альтернативним засобом захисту прав людини стосовно інших правозахисних механізмів, заповнює прогалини та компенсує недоліки судових засобів захисту прав людини, парламентського, президентського та іншого відомчого контролю за адміністративними органами [1, с. 98].

Наприклад, у Сполучених Штатах інститут омбудсмена 3 освіти існує вже багато років. Це величезний досвід, усталена практика, яку необхідно впровадити в практику України.

Як зазначає Олег Марцеляк, у Сполучених Штатах Америки, крім студентських омбудсманів, існують омбудсмани у справах учнів. У Сполучених Штатах Америки вони діють у середній школі Енн-Арбор (штат Мічиган), у Далласі (штат Техас), у школі графства Монтгомері (штат Меріленд), у Ніагара-Фолс (штат Нью-Йорк), Філадельфії (штат Пенсільванія), Сіетлі (штат Вашингтон) та Уічіто (штат Канзас). Функції, компетенція та повноваження омбудсманів Сполучених Штатів Америки у справах учнів нагадують функції, повноваження та компетенцію студентських омбудсманів $[1$, c. 100$]$.

Омбудсмени з питань освіти в Сполучених Штатах Америки - це професіонали 3 великим досвідом у сфері освіти, розв'язання конфліктів, посередництва та залучення сім'ї до освіти. Вони виступають за справедливий процес для студентів у державних школах.
Омбудсмени розмовляють з усіма залученими сторонами, щоб зрозуміти проблему, дослідити застосовані закони та політику, сприяти та/або опосередкувати розмови між батьками та шкільними посадовцями, а також керувати всіма сторонами щодо вирішення проблеми якнайкраще для студента [2].

Роль Омбудсмена зі спеціальної освіти полягає в тому, щоб служити ресурсом для надання інформації та підтримки батькам, учням та вихователям щодо прав та послуг у сфері спеціальної освіти. Призначений уповноваженим 3 питань освіти омбудсмен виконує обов'язки, які включають службу як джерело інформації для батьків, студентів, викладачів та зацікавлених представників громадськості, що допомагає їм краще розуміти закони та положення про федеральну освіту. Омбудсмен також надає інформацію та підтримку батькам учнів з обмеженими можливостями, щоб допомогти їм зрозуміти та орієнтуватися в процесі отримання спеціальних оцінок освіти та послуг.

Обов'язки Омбудсмена зі спеціальної освіти включатимуть, як мінімум, таке:

- надавати інформацію та підтримку батькам учнів з обмеженими можливостями, щоб допомогти їм зрозуміти та орієнтуватися в процесі отримання спеціальних оцінок та послуг;

- надавати інформаційну та комунікаційну стратегію батькам та шкільним округам для вирішення розбіжностей у питаннях спеціальної освіти, а також ознайомлювати батьків 3 можливими варіантами вирішення таких спорів;

- визначити моделі скарг, які виникають щодо прав та послуг у сфері спеціальної освіти, та рекомендувати Департаменту освіти відповідні стратегії вдосконалення процесу надання освітніх послуг;

- допомагати Департаменту у створенні програм публічної інформації, які інформують батьків та громадськість щодо обов'язків омбудсмена;

- служити ресурсом інформації для осіб з інвалідністю та направлення їх до інших доступних програм та послуг, включаючи раннє втручання та перехід до дорослого життя [3].

Омбудсмен подає щорічний звіт до Державної ради $з$ питань освіти та Уповноваженого $з$ питань освіти, який містить резюме послуг, наданих омбудсменом протягом року, а також рекомендації щодо виконання державою процедур та послуг спеціального навчання.

Для порівняння, в Україні освітній омбудсмен, який на законодавчому рівні з'явився досить недавно, має розглядати скарги про 
порушення прав учнів і приниження власної гідності учасників освітнього процесу. Скарга має бути подана омбудсману в письмовій чи усній формі протягом двох тижнів із моменту порушення прав, чи 3 моменту приниження гідності заявника, або з того моменту, коли йому стало про це відомо. Отримавши скаргу, омбудсмен може прийняти іï до розгляду або відмовити в прийнятті скарги, мотивуючи своє рішення та зазначаючи, яких заходів варто вжити скаржнику.

Уряд України нині пішов більш правильним i ефективним шляхом, передбачивши національний статус освітнього омбудсмана. Відповідно до Положення про освітнього омбудсмена, яке затверджене Постановою Кабінету Міністрів України від 6 червня 2018 р. № 491 «Деякі питання освітнього омбудсмена», він призначається на посаду та звільняється з посади Кабінетом Міністрів України за поданням Міністра освіти і науки строком на п'ять років без права повторного призначення [4].

Освітнім омбудсменом може бути особа, яка є громадянином України, проживає в Україні останні п'ять років, має вищу освіту, досвід роботи у сфері освіти або науки не менш як п'ять років, вільно володіє державною мовою. Не може бути освітнім омбудсменом особа, яка має судимість, обмежена у дієздатності або визнана недієздатною за рішенням суду. Освітній омбудсмен не має права суміщати свою посаду з будьякою посадою в органі державної влади або органі місцевого самоврядування, зі статусом народного депутата України, депутата, обласної, районної, міської, районної у місті, сільської, селищної ради, з підприємницькою діяльністю, обіймати будь-яку іншу оплачувану посаду, виконувати будь-яку іншу оплачувану роботу або отримувати іншу заробітну плату, крім заробітної плати керівника Служби освітнього омбудсмена (за винятком здійснення викладацької, наукової чи творчої діяльності та отримання винагороди за неї), а також входити до складу керівного органу чи наглядової ради юридичної особи, що має на меті одержання прибутку [4].

На нашу думку, враховуючи тенденції розвитку освіти в Україні, беручи до уваги відсутність шляхів вирішення певного кола проблем, зокрема бюрократизації управління навчальним та науковим процесами; 3 огляду на важке становище таких соціально незахищених верств населення, як студенти, учні, а часто й учителі та викладачі, запровадження такої моделі освітнього омбудсмена $€$ необхідним та своєчасним. Це необхідний крок, без якого є загроза дискредитації та провалу освітньої реформи в Україні.
Коло проблем, з якими доводиться стикатися студентським омбудсманам, дуже різноманітне. 3 огляду на мінімальний досвід роботи освітнього омбудсмена в Україні, слід звернутись до європейської практики. Роб Беренс називає діяльність студентського омбудсмана «цікавою сумішшю повсякденного та серйозного». 3 одного боку, це щоденна ознайомча робота, діяльність із забезпечення вимог навчального процесу, а з іншого - розв'язання серйозних проблем в університетському середовищі, як-от: дискримінація (особливо у сфері психічного здоров'я й інвалідності), насильство, необ'єктивна оцінка знань студентів, плагіат у наукових дослідженнях тощо. Наприклад, у Німеччині, окрім власне університетських омбудсменів, $\epsilon$ так звані наукові омбудсмани (Orabudsraan $\mathrm{fr}$ die Wissenschaft), до повноважень яких належать питання академічної доброчесності. Останнім часом омбудсмани із прав студентів Німеччини, Польщі, Швеції, Англії відзначають ще один важливий і делікатний напрям власної роботи - розгляд скарг, пов'язаних із сексуальними домаганнями [5, с. 29].

Беренс у своїй фундаментальній праці вказував, що в 1960-х роках в Північній Америці у відповідь на рухи за громадянські права, публічні протести і пропаганду студентства виникли омбудсмени вищої освіти, які стали засобом захисту прав студентів від поганого управління. Беренс описує ОІА в Англії і Уельсі як «порівняльного новачка у сфері омбудсмена у сфері вищої освіти», створеного тільки в 2004 році. Однак відтоді омбудсменів у Великобританії називають «благословенням».

У чесній і відкритій спробі підняти авторитет професії, якою він пишається, Беренс підкреслює центральну роль омбудсмена в наданні допомоги співробітникам і студентам, не задоволеним своїм досвідом вищої освіти. Скарги, з якими вони мають справу, варіюються від рутини (наприклад, суперечки 3 приводу паркувальних квитків) до серйозних (в тому числі спори з приводу володіння персоналом, сидячі страйки й арешти). Беренс чудово використовує свої глибокі знання професії, щоб читач знав про серйозність і потенційну здатність змінювати життя подій, з якими стикаються омбудсмени у вищій освіті. Він визнає, що омбудсмени повинні бути доступні і давати поради, іноді «звичайним скаржникам», і бути готовими вирішувати складні і делікатні питання, включаючи питання психічного здоров'я i випадки сексуальних домагань. Дослідження Беренса показує, що серед практиків є одностайна думка про те, що роблять омбудсмени вищої освіти. Багато омбудсменів виходять за рамки простого консультування, а деякі 
пропонують консультації, посередництво або виконують представницькі функції в дисциплінарних радах. Велика кількість омбудсменів вищої освіти в дослідженні Беренса вважають себе не просто «вирішувачами скарг», a й «агентами змін». Дослідження академічного досвіду студентів 2017 року, опубліковане НЕРI і Академією вищої освіти, показує, що роль омбудсменів вищої освіти може стати більш важливою в майбутньому, оскільки сприйняття студентами співвідношення ціни і якості освітньої послуги продовжує падати, а рівень добробуту студентів знижується. Написавши свій звіт, Беренс ефективно продемонстрував цінність і якість роботи омбудсменів вищої освіти, їхню роль, яка, без сумніву, стане ще більш важливою в нинішніх умовах «ринкового розвитку» [6].

Щодо порядку звернення до університетського омбудсмана, то в Сполучених Штатах Америки він може різнитися - від електронного до особистої зустрічі. Деякі омбудсмани ведуть особисті прийоми, інші віддають перевагу електронним зверненням, які певним чином можуть гарантувати анонімність заяви. Звернення можуть бути індивідуальними або колективними. Попри різні порядок і види, омбудсман зобов'язаний розглянути всі звернення, дати офіційну відповідь і вжити всіх необхідних заходів для вирішення порушених у них проблем.

\section{Висновки}

У підсумку зазначимо, що діяльність освітніх омбудсменів за кордоном має бага- ту історію та вражаючий досвід. У багатьох країнах вони називаються «омбудсмени 3 питань освіти» - професіонали у галузі освіти, які мають великий досвід розв'язання конфліктів, посередництва та залучення сім'ї до освіти. Україна тільки починає розвиватись у цьому напрямі. Тому слід ретельно вивчати практику інших країн, щоб вивести діяльність освітнього омбудсмена на високий рівень і знизити кількість скарг учасників освітнього процесу про порушення їхніх прав.

\section{Список використаних джерел:}

1. Марцеляк О. Місця освітнього омбудсмена в механізмі захисту прав людини в України. Visegrad Journal on Human Rights. 2018. Vol. 1, №5. P. 97-106.

2. Office of the Education Ombudsman in Was hington State. URL: https://www.digitalarchives. wa.gov/GovernorGregoire/oeo/default.asp

3. Special Education Ombudsman. URL: https:// www.nj.gov/education/specialed/ombudsman/

4. Деякі питання освітнього омбудсмена : Постанова Кабінету Міністрів України від 6 червня 2018 р. № 491. URL: http://zakon2.rada.gov.ua/ laws/show

5. Коваль Т.В. Омбудсман із прав студентів: вітчизняний та європейський досвід. Право $і$ суспільство. 2018. № 4. С. 26-31.

6. Behrens R. Being an Ombudsman in Higher Education. A Comparative Study. Vienna: European Network of Ombudsmen in Higher Education. 2017. 100 p. URL: h t t p://www.enohe.net/w p-content/ uploads/2017/06/Being-anombudsman.pdf

The article examines the foreign and domestic experience of the educational ombudsman. The author gives examples of actions of educational ombudsman in European countries and emphasizes the peculiarities of the practice of the United States of America. The list of prerequisites for the emergence of the Institute of Educational Ombudsman in Ukraine is given. The need for a detailed study of the mechanism of action of the educational ombudsman is emphasized. Provides a description of the responsibilities of the Special Education Ombudsman in the United States of America. The United States Educational Ombudsmen are professionals with extensive experience in conflict resolution, mediation and family involvement in education. The author, by means of comparative analysis, draws attention to the foreign practice of functioning of the Institute of Educational Ombudsman, the presence of various models of the Ombudsman. Currently, in many countries, the Ombudsman Institute has become an integral part of the mechanism of government. It serves as an additional remedy for other human rights mechanisms, fills legal loopholes and compensates for a number of shortcomings of judicial remedies. In comparison, in Ukraine, the educational ombudsman, who has recently appeared at the legislative level, has to consider complaints about violations of students' rights and humiliation of participants in the educational process. Establishing an educational ombudsman institute, which should ensure the rights of the individual to education, address violations of such rights and make appropriate decisions is a timely response to changes in the educational legislation of Ukraine and is a particularly urgent step. The author concluded that the activities of educational ombudsmen abroad have a rich history and impressive experience. In many countries, they are called "education ombudsmen" - education professionals who have extensive experience in conflict resolution. Ukraine is just beginning to develop in this direction. Therefore, the practice of other countries should be carefully scrutinized to bring the Ombudsman's activities to a high standard and reduce the number of complaints by participants in the educational process about their rights being violated.

Key words: ombudsman, educational ombudsman, specialized ombudsman, law, stakeholders, protection of the rights of participants in the educational process. 
УДК 340.113

DOI https://doi.org/10.32849/2663-5313/2019.8.26

\section{Наталя Гунько,}

асистент кафедри теорії та філософії права

Львівського начіонального університету імені Івана Франка

\section{ТЕХНІКА ВНЕСЕННЯ ЗМІН ТА ДОПОВНЕНЬ ДО ЗАКОНІВ УКРАЇНИ}

Стаття присвячена питанням законотворчої техніки, зокрема технічі внесення змін та доповнень до законів України. У ній аналізуються зміни та доповнення до законів України, виявляється співвідношення між поняттями «зміни до законів» та «доповнення до законів», а також між поняттями «зміни та доповнення до законів» та «техніка внесення змін та доповнень до законів». Зазначається, що поняття «зміни та доповнення до законів України» не є легалізованим і залишається малодослідженим попри те, що деякі технологічні питання прочедури внесення змін та доповнень до законів Украӥни висвітлені в науковій та довідковій літературі.

Виявляються такі основні ознаки коригуючої законотворчої техніки: вона є різновидом законотворчої техніки, способом коригування законів в Украйні; складається із загальних (притаманних для законотворчої техніки загалом) та спечіальних засобів і прийомів; ї̈ спечіальними засобами є зміни i доповнення, прийомами - внесення змін $і$ внесення доповнень; зміни та доповнення фіксуються у законі про внесення змін та доповнень до закону, який виконує обслуговуючу функиію; вона спрямована на оновлення та/або виправлення змісту законів Украйни; має видові особливості. На підставі иих ознак формулюється визначення поняття техніки внесення змін та доповнень до законів (техніки коригування законів) як системи загальних та спеціальних засобів та прийомів законотворчої техніки, що спрямовані на виправлення та/або оновлення законів Украйни. У статті аналізуються висловлені в юридичній літературі точки зору щодо класифікаиї̈ змін та доповнень до законів, а також техніки внесення змін та доповнень до законів. Здійснюється диферениіація техніки внесення змін та доповнень до законів (техніки коригування законів): за прийомами та засобами - на техніку внесення змін та техніку внесення доповнень до законів; а також за видами законів - на техніку внесення змін та доповнень до Конституиії України, конституиійних законів, звичайних законів, кодифікованих законів, закону про Державний бюджет України. Констатується, що така диференціація техніки внесення змін та доповнень до законів має пізнавальну та практичну значимість.

Ключові слова: юридична техніка, правотворча техніка, законотворчість, законотворча техніка, техніка внесення змін та доповнень до законів України.

Постановка проблеми. Реформування сучасної правової системи України, зокрема системи законодавства, потребує не лише потужних зусиль уповноважених суб'єктів, а й відповідних професійних знань, вмінь та навичок у контексті застосування законотворчої техніки.

Хоча питання законотворчої техніки в сучасних умовах і не обійдені увагою як зарубіжної, так і вітчизняної юридичної науки, проте деякі з них потребують більш глибокого наукового аналізу. До таких, зокрема, належать питання техніки внесення змін та доповнень до законів України. Особливо актуальними вони $є$ у період підвищеного динамізму вітчизняної законотворчості, в процесі якої створюються необхідні засоби правового регулювання суспільних відносин. Хоча поряд із цим спостерігаються і значні деформації у системі законодавства, що спричинені стихійністю законотворчості, а іноді відсутністю професійної культури законотворення, зокрема, й у сфері застосування техніки внесення змін і доповнень до законів України.

Аналіз останніх досліджень та публікацій. Як у зарубіжній, так і у вітчизняній юридичній літературі питання законотворчої техніки висвітлювалися у працях: С. Алєксєєва, В. Баранова, Ж. Дзейко, М. Власенка, Т. Кашаніної, В. Косовича, В. Риндюк, П. Рабіновича, Ю. Тихомірова, О. Ющика та інших. Деякі питання техніки внесення змін та доповнень до законів аналізувалися в працях В. Риндюк, В. Косовича, Ю. Арзамасова, С. Ушакової, О. Петрова і М. Кохан, у дослідженнях М. Гущева і К. Преподобного, що присвячені питанням змін законодавства та техніки змін юридичних актів. Проте до сьогодні залишається нерозкритим питання співвідношення між поняттями «зміни та доповнення до законів» та «техніка внесення змін та доповнень до законів», не виявлені характерні ознаки коригуючої законодавчої 
техніки, якою і є техніка внесення змін та доповнень до законів, а також її видові особливості.

Метою цієї статті є з'ясування співвідношення між поняттями «зміни та доповнення до законів» та «техніка внесення змін та доповнень до законів», виявлення основних ознак цієї техніки та деяких її видо„ вих особливостей.

Виклад основного матеріалу. Характеризуючи законотворчу техніку як систему прийомів та засобів, що забезпечують створення, опублікування, коригування законів та припинення їх чинності, слід звернути увагу і на те, що конструктивним іiі різновидам притаманні відповідні особливості, зокрема і техніці коригування законів (техніці створення законодавчих актів, якими вносяться зміни і доповнення до чинних первинних законів). У юридичній літературі iii іменують підвидом законодавчої техніки, що разом з іншими видовими особливостями об'єднується загальним поняттям «спеціальна законодавча техніка» [1, с. 76]; компонентом нормопроектної техніки [2, с. 426] тощо.

Термін «внесення змін та доповнень» фіксувався і в чинних законах України та інших документах стосовно правотворчої, зокрема законотворчої, техніки. Так, у Розділі XIII Конституції України «Внесення змін до Конституції України» (ст. 154-159) передбачено умови та процедуру розгляду законопроекту про внесення змін до Конституції України в процесі здійснення законотворчої діяльності Верховної Ради України [3].

Певні загальні положення щодо оформлення законопроектів, якими пропонується внести зміни до законів, містяться в ст. 90, 91 Закону України «Про Регламент Верховної Ради України», спеціальні ж - у ст. 160 (визначено порядок внесення змін до Закону України «Про Державний бюджет України») та в главі 26 «Розгляд законопроектів про внесення змін та доповнень до Конституції України» [4]. У главі 2 Регламенту Кабінету Міністрів України, затвердженого Постановою Кабінету Міністрів України від 18 липня 2007 р. № 950, також передбачені деякі загальні вимоги щодо підготовки проектів законів, якими змінюються чинні норми [5]. У Методичних рекомендаціях щодо розроблення проектів законів та дотримання вимог нормопроектної техніки зазначається, що під час підготовки законопроектів про внесення змін до законів слід використовувати певні прийоми і способи нормопроектної техніки [6, с. 233]. Проте легалізовані поняття «зміни та/або доповнення до законів», «техніка внесення змін та/або доповнень до законів» відсутні і нині. Про це йдеться, зокрема, і в зарубіжних дисертаційних дослідженнях М. Гущева та К. Преподобного, які присвячені змінам законодавства та техніці змін до юридичних актів. У них зазначається, що ці питання є малодослідженими, а поняття змін законодавства та техніки їх внесення не легалізовані і часто ототожнюються з категоріями «удосконалення», «реформування», «розвиток», «модернізація» тощо [7, с. 4].

Аналіз позицій, висловлених у юридичній літературі, дозволяє зробити висновок про необхідність з'ясування насамперед змісту понять «зміни та доповнення до законів» $\mathrm{i}$ «техніка внесення змін та доповнень до законів», а також виявити їх співвідношення.

У Юридичній енциклопедії зміни і доповнення до законів визначаються як вид законодавчої діяльності, передбаченої Конституцією України, Законами України і Регламентом Верховної Ради, що здійснюється шляхом прийняття відповідного закону [8, с. 672].

М. Гущев під зміною законодавства розуміє техніко-юридичний метод приведення змісту, форми та (або) функціональної дії окремих положень закону (групи законів) у відповідність до актуальних потреб соціальної практики, що реалізується у правотворчій, правореалізаційній та правотлумачній сферах [7, с. 9].

Деякі автори заперечують позначення всіх коригувань терміном «зміни» і називають помилковою позицію щодо віднесення законодавчих доповнень до методики внесення змін [9, с. 313]. Натомість у Методичних рекомендаціях з розробки та прийняття законодавчих актів зазначається, що доповнення також є зміною тексту законодавчого акта та вказує на характер змін [10, с. 84].

Щоб уникнути тих чи інших ототожнень, слід звернутися до значення термінів «зміна» та «доповнення». Зокрема, у словниках під «зміною» розуміється перетворення чогонебудь у щось якісно інше; зміна кого-, чогонебудь кимось, чимось іншим [11, с. 373]; а під «доповненням» - те, що доповнює що-небудь, виступає додатком до чогось [12, с. 817]. Отже, змістове значення термінів «зміна» і «доповнення» є різним. У першому випадку йдеться про заміну нормативноправового припису та ін., а у другому - про додаток.

Як зазначав В. Баранов, з позицій законотворчої техніки внесення змін - це засіб виправлення допущених чи виявлених законотворчих помилок [13, с. 384-385]. Хоча автор також ототожнює зміну законодавства (як засіб) та техніку внесення змін до законодавства (прийоми), а це відносно самостійні 
явища. Прийомами (моделями використання цих засобів), які дозволяють здійснити коригуючу законотворчу діяльність, є внесення змін та внесення доповнень до законів.

Таким чином, техніка коригування законів (внесення змін та доповнень до них) складається із таких спеціальних юридичних засобів, як зміни та доповнення, а також прийомів - внесення змін та/або внесення доповнень до законів.

Слід зауважити, що, окрім цих прийомів та засобів, до складу коригуючої законодавчої техніки (внесення змін та доповнень до законів) входять прийоми та засоби законотворчої (юридичної) техніки: мовні, логічні тощо, адже коригуюча техніка є іiі різновидом. Вона також є способом коригуючої законотворчої діяльності, що втілюється прийомами внесення змін та доповнень та спрямована на виправлення та/або оновлення законів. Як підсумок, техніка внесення змін та доповнень до законів України складається із загальних для законотворчої техніки засобів і прийомів та спеціальних засобів зміни і доповнення - та прийомів - внесення їх до законів.

Таким чином, внесення змін та доповнень до законів і самі зміни та доповнення - це відносно самостійні явища, що тісно взаємопов'язані між собою як прийоми та засоби у межах більш широкого поняття техніки коригуючої законотворчої діяльності (чи коригуючої законотворчої техніки).

У науковій літературі висловлювалися різні позиції щодо техніки змін до юридичного акта (в широкому розумінні i, зокрема, щодо законів). Зокрема, техніка зміни юридичного акта інтерпретується як сукупність послідовних взаємопов'язаних засобів, прийомів та способів цілеспрямованого оновлення (заміни) змісту або підвищення ефективності дії правових установок та норм, що дозволяє їх адаптувати до тієї, що склалася, чи передбачуваної конфігурації соціальних потреб та інтересів особи, мети та завдань держави [14, с. 10].

Погоджуючись із тим, що до складу техніки внесення змін та доповнень до законів входять прийоми та засоби коригуючої законотворчої техніки, водночас не можна погодитися, що сюди ж можна віднести і спосіб. Адже, вище було зазначено, що саме сукупність прийомів і відображає відповідний спосіб законотворчої діяльності, а техніка внесення змін та доповнень до законів, своєю чергою, складається із прийомів та засобів.

Аналіз позицій в частині класифікації змін до законодавства та техніки змін юридичних актів є ще одним аргументом щодо відмінності цих явищ, оскільки критерії диференціації обох явищ та їх різновиди є різними.

Так, М. Гущев класифікує зміни законодавства таким чином: за сферою правового регулювання (в публічному та приватному праві); за галузевою належністю (конституційно-правові, адміністративно-правові, цивільно-правові, кримінально-правові та ін.); за поширюваністю (загальні та спеціальні); за генезою змісту (відновлювальні, модернізаційні, інноваційні) та інші $[7$, с. 9, 17-21]. Інші автори зазначають, що, аналізуючи природу різноманітних змін, що вносяться до нормативних правових актів, слід розмежовувати текстуальні зміни нормативних правових актів та інші, нетекстуальні $[15$, c. 55$]$.

Що ж до класифікації техніки змін юридичних актів, то К. Преподобним вона здійснюється за: суб'єктами, що вносять зміни (органи законодавчої, виконавчої, судової влади, органи місцевого самоврядування та ін.); їх кількісним складом (одноосібна та колективна); нормативною природою (зміни нормативних та ненормативних юридичних актів); характером лексично-технічного опрацювання (технічне редагування, коректура, уточнення, формалізація); наявністю повноважень щодо внесення змін (аутентичні повноваження чи делеговані) та ін. [14, с. 11, 22-25].

Водночас слід звернути увагу не лише на згадані вище відмінності, а й на пізнавальну значимість диференціації коригуючої законодавчої техніки. Найбільш важливими критеріями класифікації (як і законотворчої техніки загалом) є складові ї̈ частини прийоми і засоби внесення змін та прийоми i засоби внесення доповнень. Отже, значимим є виокремлення техніки внесення змін до законів і техніки внесення доповнень до законів. А за видами законів - техніки внесення змін та доповнень до Конституції України, конституційних законів, звичайних законів, кодифікованих законів, законів про Державний бюджет України тощо. Кожна із них має видові особливості.

Деякі автори зазначають, що підготовка певних видів законів має певну специфіку, яку слід враховувати [16, с. 102]. Під час вироблення конкретного законодавчого акта залежно від його видових особливостей, поряд із загальними прийомами законодавчої техніки, будуть використовуватися й особливі (спеціальні) прийоми законодавчої техніки $[17$, с. 76$]$. Тобто для техніки внесення змін та доповнень до законів важливими загальними засобами є юридична термінологія, юридичні конструкції та інше. Необхідною умовою є формування і спеціальних 
для цієї техніки засобів - змін і доповнень до законів.

У п. 6 ст. 89 Закону України «Про Регламент Верховної Ради України» розкривається значення термінів, які використовуються у розділі IV «Законодавча процедура», серед яких під пропозиціями розуміється внесення змін до тексту законопроекту (статей, їх частин, пунктів, речень), зміни порядку розміщення, об'єднання розділів, глав, статей, ïх частин і пунктів, а також виділення тих чи інших положень в окремі розділи, глави, статті. А поправка інтерпретується як внесення виправлення, уточнення, усунення помилок і суперечностей у тексті законопроекту [4]. Щоправда, у цьому законі не йдеться про зміни та доповнення до чинних первинних законів, а лише про внесення змін до законопроектів.

Водночас у п. 2 розділу III «Внесення змін до законів» Методичних рекомендацій щодо розроблення проектів законів та дотримання вимог нормопроектної техніки зазначається, що до закону можуть вноситися такі зміни: нова редакція закону, його розділів, глав, статей, частин статей, пунктів, підпунктів, абзаців, речень, заміна слів та їх виключення; доповнення закону розділами, главами, статтями, частинами статей, пунктами, підпунктами тощо [6, с. 223].

Не кращий стан розв’язання цих проблем і в юридичній літературі, хоча в деяких роботах спостерігається намагання охарактеризувати таке явище, як зміни та доповнення до законів, а також прийоми їх внесення до законів. Зокрема, деякі автори зазначають, що у конструюванні законів застосовуються правила і засоби законодавчої техніки (викладення всього закону у новій редакції, доповнення тексту закону окремими структурними елементами, заміни одних іншими; внесення змін до кількох змістовно взаємопов'язаних актів тощо [17, с. 317] Способами внесення текстуальних змін інші автори називають зміну символьної одиниці, доповнення новими лексичними одиницями, виключення з тексту законодавчого акта символьних одиниць та прийняття нормативного акта в новій редакції [15, с. 57].

Проте видається, що більш значимим є поділ засобів коригуючої законотворчої техніки саме на зміни та доповнення. Способами ж раціонального використання тих чи інших засобів юридичної техніки С. Алєксєєв називав техніко-юридичні прийоми [18, с. 281]. Якщо зміни та доповнення стають складовою частиною первинного закону, то належно застосовані прийоми внесення змін та доповнень дозволяють правильно та якісно створити закон про внесення змін та доповнень, яким вони вносяться до тексту первинного закону. Такий закон виконує обслуговуючі функції, оскільки його призначенням є внесення змін та доповнень до первинних законів.

$\mathrm{y}$ юридичній літературі прийоми доволі часто ототожнюють із правилами або не розмежовують їх. Так, Ж. Дзейко під правилами законодавчої техніки розуміє допустимі правом вимоги та дозволи для законодавця та спрямовані на створення та систематизацію якісних за формою та змістом законів [19, с. 30]. Видається, що такі вимоги можуть висуватися і до засобів, і до прийомів, а тому прийомами коригуючої законотворчої техніки є внесення змін та доповнень до законів, які легалізовані у чинному законодавстві. Звичайно, суб'єкт, що готує законопроект про внесення змін та доповнень до законів, має враховувати ці вимоги - як змістові (відповідність змісту нормативно-правового припису, що містить зміни чи доповнення до законів, соціальним факторам, законам логіки та мови, змісту чинної системи джерел права), так і формальні (прийняття уповноваженим суб'єктом, відповідність ієрархічних та інших взаємозв'язків у системі джерел права юридичній формі права, структурнореквізитним параметрам).

Втім, як зазначає Т. Васильєва, вносячи зміни до закону, проектант має значно меншу свободу угляду, ніж у разі створення нового акта, оскільки правова регламентація у відповідній сфері вже склалася і її слід врахувати [16, с. 103], а тому вона пропонує низку вимог при застосуванні прийому внесення змін до законів [16, с. 102-109].

Виокремлюе певні вимоги до прийомів формування правових актів (зокрема, i законів) і Т. Кашаніна, котрі також позначає терміном «правила»: досягнення соціальної адекватності права, дотримання логічних, мовних, структурних, реквізитних, процедурних правил [20, с. 34-36].

В. Риндюк характеризує особливості мовної, логічної та процедурної форм техніки внесення змін до законодавчих актів, які, на iï думку, зумовлені ï спрямованістю на зміну правового регулювання відповідних суспільних відносин [1, с. 84].

Про особливості внесення змін до Конституції України йдеться у главі 26 Закону України «Про Регламент Верховної Ради України». Так, п. 2 ст. 145 передбачає перевірку головним чи іншими комітетами правильності застосування змістових чи формальних прийомів внесення змін до Конституції України, а саме: подання законопроекту про внесення змін до Конституції України належним суб'єктом; наявність 
потреби одночасного внесення змін до інших розділів Конституції; відповідність законопроекту вимогам Конституції; відповідність законопроекту міжнародним зобов'язанням; політичну, соціальну, економічну доцільність; наявність чи відсутність в законопроекті положень, що скасовують чи обмежують права та свободи людини та громадянина або спрямовані на ліквідацію незалежності чи на порушення територіальної цілісності України; правові наслідки для суб'єктів правовідносин тощо [4].

Ці та інші положення свідчать про певні особливості окремих видів техніки внесення змін та доповнень до законів України.

Проте такі засоби, як зміни та доповнення, а також прийоми - внесення змін та внесення доповнень до законів - залишаються не чітко розмежованими та охарактеризованими. Фіксуються, як правило, лише положення про процедуру розгляду законопроектів, про внесення змін та доповнень до відповідних законів та певні структурнотекстуальні зміни. При цьому в закордонній довідковій літературі 3 нормотворчої (законотворчої) техніки [21] більш детально і послідовно аналізуються головні і супутні зміни, основні форми внесення змін до діючого права (прийняття закону на заміну раніше чинного, видання окремої новели, прийняття звідного закону), характеризується техніка внесення змін, а також наводиться детальна структура закону, яким вносяться відповідні зміни [21, с. 148-149].

Тож належним чином закріплені положення щодо коригуючої законотворчої техніки загалом, а також щодо її основних прийомів і засобів в Україні відсутні, хоча деякі технологічні питання викладені в контексті процедури розгляду окремих законопроектів про внесення змін та доповнень до законів України. Хоча ще С. Алєксєєв зазначав, що послідовний ланцюг юридичної техніки має бути таким: засоби, прийоми, правила [18, c. 281].

\section{Висновки}

Аналіз техніки внесення змін та доповнень до законів в Україні дозволив встановити, що в юридичній літературі відсутне типове та легалізоване поняття такої техніки, не розмежовані поняття «зміни до законів» і «доповнення до законів», як і не розмежовані поняття «зміни та доповнення до законів» і «техніка внесення змін та доповнень до законів». Це не дозволяє чітко сформувати уявлення про природу техніки внесення змін та доповнень до законів України, виявити видові особливості, посилити ï практичну значимість.
У процесі цього дослідження виокремлено такі характерні ознаки техніки внесення змін та доповнень до законів: вона $є$ різновидом законотворчої техніки, способом коригування законів в Україні; складається із загальних та спеціальних засобів і прийомів; складається із таких засобів, як зміни (заміна і виключення) та доповнення до законів (збільшення закону чи його елементів); складається із прийомів внесення змін та доповнень до законів; зміни та доповнення фіксуються у законі про внесення змін та доповнень до закону, який виконує обслуговуючу функцію та вносить відповідні нормативно-правові приписи у первинний закон; вона спрямована на виправлення чи/та оновлення законів України; має видові особливості.

Таким чином, техніка коригування законів (внесення змін та доповнень до законів) це система загальних та спеціальних засобів та прийомів законотворчої техніки, які спрямовані на виправлення та/або оновлення законів України. Серед основних її різновидів пізнавальну та практичну значимість мають техніка внесення змін та техніка внесення доповнень до законів, а також техніка внесення змін і доповнень до Конституції України, конституційних законів, звичайних законів, кодифікованих законів, закону про Державний бюджет України. Важливими та такими, що потребують подальшого наукового дослідження, є питання порядку (правил) застосування відповідних прийомів і засобів техніки внесення змін і доповнень до законів України.

\section{Список використаних джерел:}

1. Риндюк В. І. Проблеми законодавчої техніки в Україні : теорія та практика : монографія / відп. ред. Ющик О. І. Київ, 2012. 272 с.

2. Косович В. М. Удосконалення нормативно-правових актів України : техніко-технологічні аспекти : монографія. Львів, 2015. 568 с.

3. Конституція України : Закон України від 28 червня 1996 р. № 254к/96-BP / Верховна Рада України. URL: https://zakon. rada.gov.ua/laws/show/254\%D $\quad 0 \% \mathrm{BA} / 96$ \%D0\%B2\%D1\%80\#n4931 (дата звернення: 03.08.2019).

4. Про регламент Верховної Ради України : Закон України від 10 лютого 2010 р. № 1861-VI / Верховна Рада України. URL: https://zakon.rada. gov.ua /laws/show/1861-17\#n743 (дата звернення: 03.08.2019)

5. Регламент Кабінету Міністрів України : Постанова Кабінету Міністрів України від 18 липня 2007 р. № 950. URL: https://zakon.rada. gov.ua/ laws/show/950-2007-\%D0\%BF\#n428 (дата звернення: 03.08.2019).

6. Методичні рекомендації щодо розроблення проектів законів та дотримання вимог нормопроектної техніки. Нормотвориа діяльність: зб. 
нормативно-пр. актів та методичних рекомендацій. Київ, 2001. 288 с.

7. Гущєв М. Е. Изменение законодательства России : автореф. дис. ... канд. юрид. наук: 12.00.01. Н. Новгород, 2006. 32 с.

8. Юридична енциклопедія : в 6 т. / редкол. Ю. С. Шемшученко (голова редкол.) та ін. Київ, 1998. Т.2: Д-Й. 1999. 744 с.

9. Ушакова Э. И. Дефекты внесения дополнений в российское законодательство. Вестник Нижегородской академии МВД Росии. 2010. № 1 (12). С. 312-316.

10. Методичні рекомендації з розробки та прийняття законодавчих актів (законодавча техніка) / за заг. ред. Ю. С. Шемшучека, О. І. Ющика. Київ, Інститут д-ви і права ім. В. М. Корецького НАН України, 2012.92 с

11. Великий тлумачний словник сучасної української мови / уклад. і голов. ред. В. Т. Бусел. Київ, 2004. 1440 c.

12. Новий тлумачний словник української мови : в 4-х т. Т.1 / укл.: В. В. Яременко, О. М. Сліпушко. Київ, 1998. 910 с

13. Баранов В. М., В. М. Сырых Законотворческие ошибки: понятие и типология. Законода- тельная техника современной России: состояние, проблемы, совершенствование. Н. Новгород, 2001. T. 1. С. $386-389$

14. Преподобный К. А. Техника изменения юридических актов : автореф. дис. ... канд. юрид. наук: 12.00.01. Н. Новгород, 2006. 32 с.

15. Петров А. А., Кохан М. В. К вопросу о понятии и структуре текстуальных изменений нормативных правовых актов. Мониторинг правоприменения. 2014. № 3 (12). С. 54-60.

16. Васильева T. А. Как написать закон. Москва, 2012. 148 с

17. Курс лекцій з питань законотворчості : навчальний посібник. Київ, 2001. 456 с.

18. Алексеев С. С. Общая теория права : в 2-т. Т. 2. Москва, 1982. 360 с.

19. Дзейко Ж. О. Законодавча техніка в Україні (теоретико-історичне дослідження) : автореф. дис. ... д-ра юрид. наук : 12.00.01. Київ, 2011. 39 с.

20. Кашанина Т. В. Юридическая техника в сфере частного права : учебное пособие. Москва, 2009.287 c

21. Справочник по нормотворческой технике / перевод с немецкого. 3-е переработанное издание. Берлин, 2008. 274 с.

The article is devoted to the issues of legislative drafting, particularly to the amending legislation drafting to the lawes of Ukraine. The article analyzes amendments to the lawes of Ukraine identifies relation between concepts «substitutions to the lawes» and «additions to the laws», as well as between concepts «amendments to the lares» and «amending legislation drafting». It is noted that concept «amendments to the lawes of Ukraine» is not legally fixed and remains scarcely explored even though some technological procedural rules of amending legislation drafting to the laws of Ukraine were outlined in the scientific and drafting guidance publications.

The article outlines such main features of adjusting legislation drafting as: it is a type of legislative drafting; it is a mode of adjustment of the lawes of Ukraine; consists of common (typical in the overall legislative drafting) and special means and methods; its special means are substitutions and additions, methods are substituting and adding; amendments are enshrined in the amending law which has a serving function; this function is to update and/or correction of the content of lawes of Ukraine; each type has its own features. According to features mentioned above, it is formulated definition of the concept amending legislation drafting (adjusting legislation drafting), which is a system of common and special means and methods of legislation drafting, that are intended to update and/or to correct the content of lawes of Ukraine.

The article analyzes scientific viewpoints concerning amendments to the laws and amending legislation drafting classification. Amending legislation drafting (adjusting legislation drafting) is differentiated: based on means and methods to the substituting amending legislation drafting and adding amending legislation drafting; as well as based on the type of law as amended - to the amending legislation drafting of Constitution of Ukraine, constitutional laws, ordinary lawes, codified laws, the Law of the State Budget. It is stated that such differentiation of amending legislation drafting has cognitive and practical value.

Key words: legal writing, law drafting, law-making process, legislative drafting, amending legislation drafting to the laws of Ukraine. 
УДК 351.74;342.56

DOI https://doi.org/10.32849/2663-5313/2019.8.27

\section{Олександр Дудиенко,}

канд. юрид. наук

асистент кафедри судоустрою та прокурорської діяльності

Начіонального юридичного університету імені Ярослава Мудрого

\section{СУТНІСТЬ ПРАВООХОРОННОЇ СИСТЕМИ}

У статті охарактеризовано стан наукової розробки проблеми функиіонування правоохоронної системи. Досліджено наявні в юридичній науиі наукові підходи до розуміння і тлумачення поняття «правоохоронна система»; зазначається, що більшість наукових підходів з приводу правоохоронної системи умовно поділяються на дві групи: до першої належать погляди дослідників, які розглядають правоохоронну систему як сукупність органів, котрі здійснюють правоохоронну діяльність, до другоі - дослідників, котрі розглядають правоохоронну систему як складне явище, що структурно включає поряд із правоохоронними органами й інші елементи.

Автором робиться наголос на другому підході до розуміння правоохоронної системи, акиентується увага на тому, що не можна ототожнювати поняття «система правоохоронних органів» та «правоохоронна система».

Зроблено висновок, що правоохоронна система є сукупністю тісно пов'язаних між собою елементів, які взаємодіють та утворюють певну иілісність, вона базується на відповідних приниипах, засадах. Ï̈ головними складовими елементами необхідно вважати інституціональну та нормативну підсистеми. Інституціональну підсистему утворюють об'єкти правоохоронного впливу та правоохоронні органи, для яких основним завданням є правоохоронна діяльність. Нормативна підсистема складається $з$ правових приниипів та норм, що здійснюють регулювання відносин між суб'єктами охорони права; своє вираження вони знаходять у нормативних актах, які регулюють правоохоронну діяльність.

На підставі аналізу наявних наукових підходів до розуміння правоохоронної системи запропоновано авторське розуміння поняття правоохоронної системи, а саме: правоохоронна система - ие багаторівнева соціальна система, що існує в державі та об'єднує органи й інститути, які на підставі та в межах правових норм здійснюють правоохоронну та правозахисну діяльність з метою забезпечення законності в державі.

З урахуванням висловлених у сучасній науковій літературі думок стосовно правоохоронної системи вказано ї̈ особливості (ознаки, властивості)

Ключові слова: система, правоохоронні органи, правоохоронна діяльність, правозахисна діяльність.

Постановка проблеми. Аналіз наукової літератури в галузі права свідчить, що коло питань правоохоронної проблематики в юриспруденції вже сформувалось. Однак натепер відсутні підстави для твердження про те, що дослідження в цій галузі вичерпали свою актуальність. Навпаки, без подальших спеціалізованих i фундаментальних досліджень правоохоронної теоpiї подолати проблеми та суперечливість у правоохоронній практиці не видається можливим.

Одним з актуальних наукових та практичних завдань було і залишається формування в сучасній Україні ефективної правоохоронної системи. У теоретичному плані його рішення передбачає, перш за все, розробку й уточнення відповідного категоріального апарату, аналіз структурних і функціональних особливостей правоохоронної системи, виявлення її закономірних зв'язків з іншими елементами політико-правової системи сучасного суспільства і держави.

Поняття «правоохоронна система» активно використовується як вітчизняними, так і зарубіжними науковцями та практиками, хоча й не завжди належним чином розкриваючи його зміст. Зазначимо, що в юридичній літературі точиться дискусія не лише $з$ приводу трактування категорії «правоохоронна система», а й щодо її структурних елементів. Водночас, рухаючись у напрямі реформування правоохоронної системи, дослідники володіють сьогодні вже чималим обсягом цікавого й надзвичайно корисного матеріалу, присвяченого вивченню найрізноманітніших аспектів цієї проблематики. Зокрема, ознайомлення з відповідними науковими працями М. Ануфрієва, О. Бандурки, В. Білоуса, М. Вербенського, В. Галунька, В. Грохольського, С. Гусарова, І. Зозулі, В. Ковальської, А. Комзюка, 
А. Куліша, О. Мартиненка, Н. Матюхіної, В. Олефіра, Т. Плугатара, В. Пєткова, Т. Проценка, О. Синявської, С. Стеценка, І. Шопіної, О. Ярмиша та інших науковців показує, що зазначені напрями наукових розвідок актуальні з наукової точки зору і важливі та своєчасні 3 практичних позицій, однак, не применшуючи ролі й значущості доробки цих науковців, зауважимо, що окремі аспекти цієї проблематики потребують підвищеної уваги, переосмислення й внесення уточнень, адже іï невирішеність ставить під сумнів ефективність подальшого реформування правоохоронної системи в цілому.

Мета статті полягає в проведенні загальнотеоретичного аналізу поняття «правоохоронна система», з'ясуванні сутності та визначенні змісту цього поняття, розкритті його структурних елементів та висвітленні головних ознак.

Виклад основного матеріалу. Більшість наукових підходів щодо правоохоронної системи можна умовно поділити на дві групи: до першої необхідно віднести погляди дослідників, які розглядають правоохоронну систему як сукупність органів, які здійснюють правоохоронну діяльність, до другої - дослідників, котрі розглядають правоохоронну систему як складне явище, що структурно включає поряд із правоохоронними органами й інші елементи.

Представник першого підходу С. Терешко у своїй роботі «Актуальні проблеми та напрями реформування правоохоронних органів України» неодноразово застосовуе поняття «правоохоронна система», однак його визначення не надає, водночас вчений акцентує увагу на необхідності удосконалення саме системи правоохоронних органів України [1]. Співзвучною вищезазначеній є позиція В. Півненко, який у своїй роботі до державних правоохоронних органів відносить суд, а також інші державні органи, створені спеціально для підтримки режиму законності в Україні. Дослідник не надає авторського визначення правоохоронної системи, втім характеризує ії як систему правоохоронних органів, що розосереджені по всіх гілках державної влади, та акцентує увагу на тому, що не слід її ототожнювати з кримінальною юстицією [2, с. 39-42]. Схожої позиції щодо розуміння правоохоронної системи у своїх дослідженнях дотримуються О. Їжак [3], О. Котелянець, О. Маркєєва [4], О. Міхеєва [5], М. Сатуріна [6] та інші вчені.

Отже, можна констатувати, що за першого підходу йдеться про повне ототожнення понять «система правоохоронних органів» та «правоохоронна система», 3 чим погодитись повною мірою не можна, оскільки вживати ці поняття як однакові не зовсім правильно 3 методологічної позиції. Підтвердженням цього є розробки вчених, які дотримуються другого підходу.

У деяких випадках робляться спроби визначити правоохоронну систему в широкому і вузькому сенсі та таким чином розмежувати поняття «правоохоронна система» $\mathrm{i}$ «система захисту прав людини». Так, А. Мовчан вважає, що зміст категорії «правоохоронна система» може аналізуватися як у широкому, так і у вузькому сенсі. У першому випадку як об'єкт захисту слід розглядати не тільки права людини, а й саме право, а також інші складники правової системи. Однак завжди одним з основних об'єктів захисту залишаються права людини. У такому ракурсі поняття «система захисту прав людини» $€$ найважливішим компонентом поняття «правоохоронна система» [7, с. 160].

О. Братко розкриває поняття правоохоронної системи як більш об'ємне, ніж система правоохоронних органів. Вчений зазначає, що до правоохоронної системи належать не тільки спеціальні правоохоронні органи, а й інші органи держави правоохоронного призначення, а також юридичні засоби та методи правової охорони і правові норми [8, с. 48]. Слід зазначити, що, зважаючи на різноплановість суспільних відносин, що виникають у правоохоронній сфері, більш доцільно аналізувати правові норми (як нормативну підсистему правоохоронної системи) не лише як охоронні, а й регулятивні норми, оскільки вони виступають як правові засади організації правоохоронних органів та здійснення ними правоохоронної діяльності.

Погляд на правоохоронну систему як на складно організоване явище поділяє В. Карташов, який підкреслює в запропонованої ним дефініції правоохоронної системи, що під правоохоронною системою слід розуміти єдиний комплекс взаємопов'язаних державних і недержавних організацій та окремих осіб (правозахисників) і юридичних явищ (права, правосвідомості, правової культури, різноманітних видів юридичної практики тощо), за допомогою якого ефективно і якісно здійснюється охорона (захист) прав і законних інтересів громадян та їх об'єднань $[9$, c. 12$]$

T. Плугатар об'єднує запропоновані елементи правоохоронної системи та зазначає, що правоохоронна система становить цілісний комплекс відмежованих, взаємопов'язаних та взаємодіючих елементів, які утворюють певну єдність, що базується на відповідних принципах та нормах. Основними складовими елементами право- 
охоронної системи є охоронні правові норми, мета, принципи, функції, завдання, суб'єкти, об'єкти правоохорони, правоохоронна діяльність, а також правоохоронні відносини [10, c. 26].

Дуже вдалим, на наш погляд, є підхід О. Соколенко, яка визначає правоохоронну систему як соціальну систему, що відображує єдність та взаємопов'язаність нормативно-правового регулювання у правоохоронній сфері, організацію системи правоохоронних органів та інших суб'єктів правоохоронної діяльності та самої правоохоронної діяльності, спрямованої на охорону й захист основ конституційного ладу, в тому числі прав, свобод та законних інтересів людини і громадянина, законності й правопорядку. О. Соколенко зазначає, що система правоохоронних органів виступає підсистемою інституціональної системи правоохоронної діяльності, яка виступає підсистемою правоохоронної системи, що своєю чергою є підсистемою по відношенню до системи вищого порядку правової системи.

Дослідник вказує, що система правоохоронних органів відображує перш за все саме інституціональний аспект правоохоронної діяльності, функціонування й існування якого неможливе поза зв'язком 3 іншими елементами організації правоохорони, зокрема нормативно-правовим забезпеченням побудови системи таких правоохоронних органів та реалізації ними відповідної правоохоронної діяльності. Оскільки лише єдність та пов'язаність правового регулювання суспільних відносин у сфері правоохорони, організації правоохоронних органів та здійснюваної ними правоохоронної діяльності в умовах правової, соціальної, демократичної держави може розглядатись як єдино прийнятний спосіб організації правоохорони $[11$, c. $92,95-96]$.

Таким чином, представники другого підходу доходять спільного висновку стосовно правоохоронної системи. Вони зазначають, що вказане поняття не можна розкривати лише через систему правоохоронних органів, а її слід характеризувати з позицій широкого розуміння як багатоаспектне комплексне явище. На нашу думку, слід погодитисz з такою позицією. А також необхідно зауважити, що недостатне дослідження наукового підгрунтя правоохоронної системи як у працях вітчизняних науковців, так і в зарубіжних наукових джерелах потребує подальшого грунтовного аналізу та узагальнення наявних підходів. Такf необхідність зумовлена якостями правоохоронної системи як внутрішньо неоднорідного, складного утворення.
Отже, можна зробити висновок, що правоохоронна система $€$ сукупністю тісно пов'язаних між собою елементів, які взаємодіють та утворюють певну цілісність, вона базується на відповідних принципах, засадах. Ї̈ї головними складовими елементами необхідно вважати інституціональну та нормативну підсистеми. Інституціональну підсистему утворюють об'єкти правоохоронного впливу та правоохоронні органи, для яких основним завданням є правоохоронна діяльність. Нормативна підсистема складається 3 правових принципів та норм, що здійснюють регулювання відносин між суб'єктами правоохорони; своє вираження вони знаходять у нормативних актах, які регулюють правоохоронну діяльність. Окремо треба наголосити на засадах (принципах), до яких належать: науковості; системності; гласності; демократизму; законності; рівності всіх перед законом; справедливості і моральності; пріоритетного ставлення до інтересів людини порівняно 3 інтересами держави; діяльності правоохоронних органів виключно на підставі та в межах повноважень, а також у спосіб, що передбачено Конституцією і законами України тощо.

На підставі вищевикладеного аналізу наявних наукових підходів до розуміння правоохоронної системи можна сформулювати поняття правоохоронної системи, яке розкриває її сутність, а саме: правоохоронна система - це багаторівнева соціальна система, що існує в державі та об'єднує органи й інститути, які на підставі та в межах правових норм здійснюють правоохоронну та правозахисну діяльність 3 метою забезпечення законності в державі.

Зазначене, а також й інші визначення, безумовно, дають узагальнене уявлення про ті чи інші сторони правоохоронної системи як специфічного явища сучасної політикоправової дійсності. Проте жодне з них не може претендувати на абсолютну універсальність і повноту. І це не дивно. Як відомо, чим складніший досліджуваний об'єкт, тим більше визначень можна йому дати. А правоохоронна система, безсумнівно, належить до таких складних утворень. Тому, поряд зі спробами виробити загальнотеоретичне визначення цього явища, не можна випускати з виду й інший шлях наукового осмислення правоохоронної системи - виділення й аналіз притаманних їй специфічних ознак і властивостей. Як свідчить практика наукового пізнання правової системи, права, держави та інших політико-правових явищ, саме останній підхід дає найбільш відчутні результати.

3 урахуванням висловлених у сучасній науковій літературі думок стосовно право- 
охоронної системи можна вказати такі їі особливості (ознаки, властивості).

По-перше, правоохоронна система являе собою необхідний елемент сучасної правової держави і громадянського суспільства, $є$ показником їхньої зрілості, сформованості, цивілізованості. Між ними існують не тільки функціональні, але й генетичні зв'язки. Здається, зовсім не випадково, що питання стосовно правоохоронної системі було поставлено в нашій науці одночасно 3 проголошенням в країні офіційного курсу на побудову правової держави, утвердження принципів гуманізму, демократії тощо.

Навряд чи сьогодні знайдеться робота, присвячена правоохоронній тематиці, в якій так чи інакше не ставилося би питання про співвідношення таких понять, як «забезпечення права», «охорона права», «захист права». Хотілося б звернути увагу на той момент, що в основному полеміка не виходить за рамки суто формальних визначень, у зв'язку з чим часто перетворюється на суперечку суто термінологічного плану (який термін вужчий, який ширший тощо). Тим часом проблема формування і обгрунтування правоохоронної системи має не тільки формально-юридичний, а й конкретно-історичний вимір. Питання про зміст і призначення правоохоронної системи не можна вирішити у відриві від реальних процесів державно-правового розвитку. Правоохоронна система і їі складові явища відображають якісно новий етап у розвитку сучасної держави і права, який характеризується переосмисленням основних соціально-правових цінностей. Категоріальний апарат охорони права, що склався в радянській правовій доктрині, був зорієнтований на інші реалії, з характерним для них домінуванням державно-партійних інтересів. Слід підкреслити, що за такого орієнтиру склався не тільки категоріальний апарат, а й фактично склалася система правоохоронної діяльності, яка була спрямована перш за все на захист інтересів держави, часто за рахунок обмеження прав і свобод особи. Як свідчить історичний досвід підпорядкування правоохоронних органів виключно політичним інтересам апарату держави $\epsilon$ ризикованою справою. Так, за допомогою органів Народного комісаріату внутрішніх справ - Міністерства державної безпеки СРСР - в Україні здійснювалась небезпечна антинародна діяльність, яку з історико-правової точки зору визнати правоохоронною не можна. Спеціальне дослідження, яке проведене Верховним Судом, підтверджує, що масовим репресіям за часів радянської влади було піддано майже всі прошарки суспільства. Тоталітарна система охорони суспіль- них відносин, через яку відбувався виключно примусовий вплив на діяльність людини, була характерною для зазначеного часу істоpiї країни. Сучасна демократична система регулювання суспільно-соціальних відносин вимагає зміни такого засобу впливу на поведінку особистості, як заборона. Поступово в Українській державі утверджуються нові принципи, за якими формуються взаємовідносини між людиною та державою: дозволено лише те, що не забороняється законом. За такого підходу правовий порядок грунтується на засадах, за якими жодна особа не може бути примушена робити те, що не передбачено законодавством, а органи державні органи та їх посадові особи повинні діяти у межах своїх повноважень і у спосіб, що не заперечує законам та Конституції України [12].

Конституція України, заклавши фундамент демократичної, правової, соціальної держави, значно розширила коло прав і свобод людини та привела їх у відповідність до загальновизнаних міжнародних норм і принципів. Україна офіційно визнала людину, iї життя і здоров'я, честь і гідність, недоторканість і безпеку вищою соціальною цінністю, а їх забезпечення - головним своїм обов'язком. Закріплення прав і свобод людини в Основному Законі й інших основоположних джерелах прав людини визначає орієнтацію на їх забезпечення всіх правоохоронних органів, а суспільство - на здійснення контролю за тим, як ці права і свободи забезпечуються владою в повсякденному практичному житті.

Сучасна демократизація суспільних відносин зумовила пріоритетність додержання прав і свобод громадян, що знайшло своє закріплення у Конституції України, а також у низці законодавчих актів, що регулюють діяльність правоохоронних органів. У зв'язку з цим структура правоохоронної системи повинна будуватися на системі принципів, інститутів, механізмів і процедурно-правових правил, прямо чи опосередковано призначених для захисту прав і свобод людини і громадянина. Переорієнтація зазначеної діяльності на якісно інші цінності, проголошені, зокрема, Конституцією України, не могла бути досягнута в рамках все тих же правоохоронних категорій і інститутів. Права і свободи людини і громадянина, правоохоронне законодавство, правоохоронні функції, правоохоронні відносини, правоохоронна система - все це поняття і явища, що відображають якісно новий етап державно-правового розвитку, в центрі якого перебуває (повинна перебувати) людина як соціальна і правова цінність. У такому контексті розкривається справжній зміст і призначення самої правової держави. Останнє 
не самоціль, а лише необхідний засіб забезпечення прав людини. Призначення правової держави - створювати політико-правові умови для гідного життя і вільного розвитку людей, захищати їхні права і свободи.

По-друге, правоохоронна система - це елемент (підсистема) і різновид правової системи держави як більш загальної, інтегральної категорії. Тут, як видається, потрібні деякі уточнення. Річ у тому, що поширене уявлення про правоохоронну систему як елемент або частину правової системи $є$ справедливим лише частково. Справедливість вказаного твердження полягає в тому, що правова система здійснює не тільки правоохоронні, а й інші завдання і функції. І оскільки функція правоохорони є однією з багатьох функцій правової системи (поряд з інформативною, регулятивною, комунікативною та ін.), то і правоохоронні елементи (норми, відносини, рішення тощо) можуть бути виділені в особливий блок або підсистему. Але в цьому полягає і обмеженість зазначеного підходу. Він ніби замикається на частинах і не дозволяє осмислити правоохоронний потенціал правової системи в цілому. Тим часом елементи правової та правоохоронної систем (норми, відносини, акти застосування права, правосвідомість, правова культура та ін.) значною мірою збігаються і відрізняються не кількістю, а якістю, особливостями функціональної настройки. I це дозволяє застосовувати правоохоронну термінологію і використовувати правоохоронні оцінки не обмежено, а стосовно правової системи в цілому. Ми вважаємо, що це дуже важливий аспект розуміння правоохоронної системи. Важливий не тільки в науковому, але і практичному плані. Він дозволяє вийти за рамки окремих рішень і побачити проблему цілком. Можна скільки завгодно вдосконалювати окремі правоохоронні законодавчі акти і норми, державні органи тощо, але при загальній орієнтації правової системи на інші цінності такі часткові заходи навряд чи здатні суттєво вплинути на правоохоронну ситуацію в країні.

По-третє, специфіка правоохоронної системи полягає також у тому, що вона характеризується власним системоутворюючим початком. Як відомо, наявність такого початку характеризує будь-яку систему. Для правової системи в цілому - це право (висловлюються й інші точки зору), для політичної - державна влада, тощо. Що стосується правоохоронної системи, то тут системоутворюючим початком виступає вимога безумовного захисту прав і свобод людини як найвищої цінності. Відповідно, і призначення правоохоронної системи полягає в реалі- зації зазначеної вимоги і досягненні стану правової захищеності людини. Саме функціональна спрямованість усіх елементів правоохоронної системи на реалізацію зазначеного принципу надає їм необхідний ступінь єдності та взаємодії в складі цілого. До такої мети необхідно прагнути державам і іншим політичним організаціям. Мета будь-якого політичного союзу, згідно зі ст. 2 Декларації прав людини і громадянина 1789 року, полягає в збереженні природних і невід'ємних прав людини.

По-четверте, правоохоронна система має складно організований, комплексний характер. Дана особливість також відзначається практично всіма авторами, що досліджували правоохоронну систему. Однак що стосується конкретного розуміння структури зазначеної системи, її елементного складу, то на цей рахунок у науковій літературі не склалася якась єдина думка. Втім, єдність не спостерігається і в розумінні структури правової системи в цілому, яка натепер отримала набагато більшу грунтовну наукову розробку.

\section{Висновки}

Таким чином, правоохоронна система є сукупністю тісно пов'язаних між собою елементів, які взаємодіють та утворюють певну цілісність, вона базується на відповідних принципах, засадах. Її головними складовими елементами необхідно вважати інституціональну та нормативну підсистеми. Інституціональну підсистему утворюють об'єкти правоохоронного впливу та правоохоронні органи, для яких основним завданням $є$ правоохоронна діяльність. Нормативна підсистема складається з правових принципів та норм, що здійснюють регулювання відносин між суб'єктами охорони права; своє вираження вони знаходять у нормативних актах, які регулюють правоохоронну діяльність.

На підставі аналізу наявних наукових підходів до розуміння правоохоронної системи запропоновано авторське розуміння поняття правоохоронної системи, а саме: правоохоронна система - це багаторівнева соціальна система, що існує в державі та об'єднує органи й інститути, які на підставі та в межах правових норм здійснюють правоохоронну й правозахисну діяльність із метою забезпечення законності в державі.

\section{Список використаних джерел:}

1. Терешко С. В. Актуальні проблеми та напрями реформування правоохоронних органів України. URL: www.niisp.org/vydanna/ panorama/ go/ $2 / 2014$. 
2. Півненко В. П. Правоохоронна система України: визначення і функціонування. Вісник прожуратури. 2003. № 2. С. 39-45.

3. Їжак О. I. Порівняльно-правовий аналіз поняття правоохоронних органів за вітчизняним та зарубіжним законодавством, їх характерн ознаки, види та місце в системі органів виконавчої влади. URL: http://old.niss.gov.ua/Monitor/ Juli2009/29.htm.

4. Котелянець О. О., Маркєєва О. Д. Український досвід реформування кримінального правосуддя та правоохоронних органів. Аналітична доповідь. URL: https://www.niss.gov.ua/ articles $/ 486 /$.

5. Міхеєва О. К. Методологічні підходи до вивчення правоохоронної системи України часів HEПy. URL: http://www.nbuv.gov.ua/portal/soc gum/Iipd/20092Z13Miheeva.htm.

6. Сутурина М. Н. Правоохранительная система государства: Теоретико-правовой аспект автореф. дис. ... канд. юрид. наук. СПб., 2008. 23 с.
7. Основные принципы международного права : Курс лекций международного права / гл. ред. В. Н. Кудрявцев. Москва : Наука, 1989. 240 с.

8. Братко А. Г. Правоохранительная система (вопросы теории) : монография. Юридическая литература, 1991. 208 с

9. Карташов В. Н. Правозащитные системы: понятия, основные типы и принципы. Российская и европейская правозашитные системы: соотношение и проблемы гармонизации. 2003. С. 12.

10. Плугатар Т. А. Визначення сутності та змісту поняття «правоохоронна система». Наука і правоохорона. 2014. № 2(24). С. 21-28.

11 Соколенко О. Л. Поняття і структура правоохоронної системи. Актуальні проблеми вітчизняної юриспрудениіі. 2013. Вип. 4. C. 91-96.

12. Принципи, мета, завдання, функції правоохоронної системи. URL: http://pidruchniki. com/2008021545047/pravo/printsipi meta zavdannya_funktsiyi_pravoohoronnoyi_sistemi.

The condition of scientific development of the problem of law enforcement system functioning are characterized in the article. A number of scientific approaches to understanding and interpreting the concept of "law enforcement system" are investigated, and it is noted that most scientific approaches to the law enforcement system are conditionally divided into two groups: the first are the views of researchers who view the law enforcement system as a collection of bodies which carry out law enforcement activities, the second, researchers who consider the law enforcement system as a complex phenomenon that structurally includes other elements alongside law enforcement agencies.

The author emphasizes the second approach to understanding the law enforcement system, and accents that it is impossible to identify the concepts of "law enforcement system" and "law enforcement system" as the same.

It is concluded that the law enforcement system is a totality of closely interconnected elements that, interacting and forming a certain integrity, it is based on appropriate principles. Institutional and regulatory subsystems should be considered as its main components. The institutional subsystem is comprised of law enforcement and law enforcement agencies whose main task is law enforcement. The regulatory subsystem consists of legal principles and norms that regulate relations between legal entities. They find expression in normative acts that regulate law enforcement. The normative subsystem consists of legal principles and norms that regulate relations between subjects of protection of rights; it find expression in normative acts that regulate law enforcement.

The author's understanding of the concept of the law enforcement system that based on the analysis of the existing scientific approaches to understanding the law enforcement system is proposed, namely: the law enforcement system is a multilevel social system existing in the state and unites bodies and institutions which, on the basis and within the limits of legal norms, exercise law enforcement and human rights activities to ensure the rule of law in the state.

Specifics (features, characteristic) of the law enforcement system taking into account the expressed opinions in the modern scientific literature about it are concidered in the article.

Key words: system, law enforcement system, law enforcement bodies, law enforcement activity. 
УДК 340.114 .5

DOI https://doi.org/10.32849/2663-5313/2019.8.28

\section{Тетяна Міхайліна,}

докт. юрид. наук,

доцент кафедри теорії та історії держави і права та адміністративного права

Донецького національного університету імені Василя Стуса

\section{ПРАВОСВІДОМІСТЬ У ПРАВОВІЙ СИСТЕМІ: КІБЕРНЕТИЧНИЙ ТА СИНЕРГЕТИЧНИЙ АСПЕКТИ}

Статтю присвячено інтегративній ролі правосвідомості у правовій системі суспільства. У тому числі розкрито ї̈ кібернетичний та синергетичний аспект.

У статті зроблено висновок, що, поряд із традииійно визначеними складниками правової системи (система права, правова ідеологія та юридична практика), функиіонує відносно самостійний елемент правової реальності - правосвідомість, який не можна у повному обсязі включити до будь-якого з перелічених базових елементів через постійний вихід правосвідомості за їх межі. Також не є можливим повноцінне виділення досліджуваної категорії в окремий компонент, оскільки у будь-який момент часу через правосвідомість забезпечується уся множина зв'язків, які відбуваються всередині системи права. На підставі зазначеного констатується існування правосвідомості як розумово-психологічноі категорії як відносно незалежного елемента правової системи, що забезпечує ї̈ інтегративно-синергетичні властивості та відображає сукупність знань, уявлень та емоцій щодо фактичного і бажано20 стану правових феноменів.

Наголошується на тому, що всі елементи правової реальності набувають балансу та взаємоузгодженості, заломлюючись у свідомості законодавия, судді, пересічного громадянина як суб'єкта права, тим самим надаючи правовій реальності ознак самоуправління. А отже, синергетика правової системи виявляється у ї самоузгодженні, саморозвитку, які відбуваються за рахунок безперервної взаємодії правової ідеології, системи права та юридичної практики. Але зазначений взаємозв'язок виникає не сам по собі. Логічно передбачити певні сполучні ланки, що відіграють роль «провідника», забезпечуючи взаємопроникнення та взаємовплив усіх елементів правової системи. I однією з таких ланок виступає правосвідомість, яка формує можливість утвердження кониептуальних підходів до права, втілення їх у самій сутності правових приписів з наступним відбиттям форми і змісту иих приписів на фактичній поведінчі особи.

у статті відзначається, що взаємозв'язок правової системи з іншими системами соиіуму здійснюється за кібернетичним приниипом та характеризує їхній зовнішній обопільний вплив одна на одну.

Ключові слова: правосвідомість, правова система, кібернетика, синергетика, інтеграція

Постановка проблеми. Фактичні правові системи держав останнім часом зазнають суттєвих трансформацій, пов'язаних із глобалізаційними процесами, посиленням впливу чинників неюридичного середовища (зокрема, інформаційного), об'єктивним пожвавленням суспільного життя. На підставі цього в науковій літературі все частіше переосмислюється і традиційний склад загальної моделі правової системи, додаються нові елементи 3 окресленням їхньої ролі, серед яких нерідко називається саме правосвідомість. Підтримуючи таке розширення елементного складу правової системи за рахунок правосвідомості, вважаємо за доцільне не лише констатувати цей факт, а й розкрити специфіку правосвідомості як інтегративного елемента правової системи, що реалізує свої функції на засадах синергетики та кібернетики. Зазначені питання майже не ставали предметом наукових досліджень, що вказує на актуальність вибраної тематики та необхідність її розробки.

Аналіз останніх досліджень і публікацій. Дане дослідження базується на наукових працях, присвячених загальному аналізу правової системи та правосвідомості. Серед науковцівправників, які зробили значний внесок у розробку зазначеної проблематики, можна згадати таких, як: С. Алексєєв, Ю. Калиновський, О. Скакун, Т. Огаренко, Н. Оніщенко, О. Петришин, Д. Тихомиров, Ю. Тихомиров, М. Цвік, М. Цимбалюк, М. Черкас та багато інших. Проте, як зазначалося вище, в окресленому аспекті правосвідомість раніше не розглядалася.

Метою наукової статті є аналіз кібернетичного та синергетичного аспектів правосвідомості, які зумовлюють її інтегративність щодо правової системи суспільства. 
Виклад основного матеріалу. Якщо використовувати загальнодоктринальний комплекс знань про системність та системні утворення, з'являється можливість перейти до аналізу ознак правової системи, яку T. Огаренко характеризує як «каркас, на якому існує правова держава» [1, с. 12], що насправді правильно лише частково, оскільки на каркасі правової системи існує будьяка держава без винятків, але характерні ознаки «каркасу», як і держави, будуть змінними одиницями залежно від їхньої типології та взаємного безперервного впливу.

Еволюцію підходів до розуміння правової системи (змістову, а не хронологічну) можна проілюструвати, починаючи від «сукупності правових норм, що регулюють суспільні відносини, і комплексу взаємопов'язаних та узгоджених юридичних засобів, спрямованих на реалізацію цих норм, а також юридичних явищ, що виникають внаслідок правового регулювання і реалізації норм права» [2, с. 6], що видається дещо неповним через виключення з правової системи явищ, які передують створенню правових норм у суспільстві або зумовлюють їх.

Другою групою доктринальних підходів до правової системи (правової реальності) $е$ іiї визначення як «правової організації суспільства, сукупності усіх юридичних інститутів та засобів, що існують та функціонують в державі» [3, с. 251], або «сукупності усіх правових явищ, що виникають у суспільстві» [4, с. $118 ; 5$, с. 409], або «історично обумовленої, взаємопов'язаної та взаємозалежної, ієрархічно структурованої правової цілісності, що включає право, пануючу правову ідеологію, юридичну практику та правову культуру, що здійснює регулятивний вплив на суспільні відносини з метою їх впорядкування» [6, с. 315-316], які дуже близькі за своїм змістовим наповненням та майже стандартним виділенням ключових компонентів.

Крім того, на хвилі популяризації природно-правових ідей виділяються підходи до правової системи як такого соціального феномену, що базується на принципах природного права, політичного плюралізму, пріоритету прав людини, відповідальності держави перед особою, забезпечення політико-правових процесів на основі компромісу співробітництва $[7$, с. 6], а до методологічних основ розробки поняття правової системи у цьому контексті відносять: 1) широке застосування системно-цілісного підходу до правових явищ; 2) затвердження соціологічного підходу до права; 3) розвиток порівняльного правознавства; 4) становлення і зміцнення в юридичній науці руху за багатоаспектне бачення права [8, с. 14]. I це є абсолютно пра- вильним, якщо йдеться про правову систему демократичної, соціальної держави, з орієнтацією на гуманістичні цінності, але навряд чи є прийнятним для узагальненої характеристики моделі правової системи.

I нарешті, підходи до визначення правової системи останніх років характеризуються виділенням у ній, поряд із класичними, таких елементів, які раніше «розмивалися» дослідниками, включалися до інших груп. Так, згідно з Т. Огаренко, правова система виступає як відносно самостійне цілісне, впорядковане соціальне утворення правових суб'єктів (осіб, організацій, держави) й інститутів, соціально-правових відносин i процесів, власне права (норм, принципів), що грунтується на джерелах права, зумовлюється специфічними особливостями правосвідомості нації як результату історично-суспільної діяльності, культурного розвитку та функціонує завдяки законодавчій системі і юридичній практиці з метою забезпечення та утримання правопорядку [1, с. 8]. Нескладно помітити, що це визначення $€$ досить універсальним, оскільки дійсно включає розуміння правової системи незалежно від її типу, а крім того, виділяє як базовий елемент правосвідомості, як такий, що зумовлює усі інші компоненти правової реальності.

Визнаючи переваги наведеного вище підходу, звернімося до ролі правосвідомості та ï̈ місця у функціональній єдності складників правової системи, тим більше, що теорія правосвідомості, оскільки вона є загальновизнаною та фундаментально розробленою, зі стрімким розвитком суспільних відносин та тенденціями глобалізації, останніми десятиліттями розкривається в новому аспекті.

Так, головною рисою правосвідомості та такою, що ставить її у специфічне положення серед усіх інших елементів правової реальності, $€$ те, що множина вхідних та вихідних чинників, стикаючись на межі правосвідомості, трансформується в іншу множину передумов існування права, його фактичного буття та наслідків цього.

Правосвідомість як феномен соціокультурного світу є сукупністю поглядів на ідеї, що виражають ставлення до законності й правопорядку та уявлення про те, що є правомірним або неправомірним. Правосвідомість особистості є, з одного боку, одним з елементів іiї правової культури, а з іншого - правової культури суспільства в цілому (поряд із такими елементами, як: право, правові відносини, правова наука, правові установки, правотворча діяльність тощо) [9, с. 8], а крім того, правосвідомість формує уявлення про бажане право, що суттєво розширює її межі 
порівняно з визначенням поведінки як правомірної чи неправомірної.

3 позиції представників юридичної науки (О. Скакун, Ю. Тихомиров та ін.) [10; 11, с. 93] правосвідомість визначено як систему відображення правової дійсності в поглядах, теоріях, концепціях, почуттях, уявленнях людей про право, його місце й роль у забезпеченні свободи особистості та інших загальнолюдських цінностей. I саме останні якості, що ними виділяються, на наш погляд, $є$ визначальними щодо місця правової свідомості у правовій дійсності, оскільки такі їі властивості характеризують правосвідомість не лише як уособлення знань та відчуттів щодо правових явищ, а рушійну силу змін як у правовій системі, так і в суміжних підсистемах соціуму.

I враховуючи, що кожній цивілізації притаманна власна соціорегулятивна система, яка має у співвіднесенні з іншими загальні та відмінні властивості, причому їі своєрідність зумовлюється домінуючим соціальним регулятором (правом, релігією, звичаями, традиціями) [12, с. 22], правосвідомість виступатиме одночасно як засіб формування зазначених регуляторів, засіб їх сприйняття та трансформацій, іншими словами, можна стверджувати факт відсутності правосвідомості як такої, натомість вона існує лише стосовно інших правових явищ чи категорій і розвивається паралельно з ними.

Повною мірою визнаючи те, що генеза правосвідомості зумовлена спонтанними соціальними процесами, пов'язаними з конструюванням правил, зразків, норм та вибором тих або інших варіантів поведінки, засобів комунікації, саморепрезентації, побудови мікросвітів соціально-правової реальності на основі горизонтальних, а не вертикальних зв’язків, і те, що правосвідомість виявляється не стільки в намірах, побажаннях та настановах, скільки в конкретних діях різноманітних соціальних суб’єктів [13, с. 8], - для конкретизації уявлення хотілося б додати складність відстеження руху правосвідомості виключно у горизонтальному чи вертикальному напрямі, оскільки горизонтальні зв'язки будуть властиві правосвідомості під час циклічного та безперервного сприйняття інших елементів правової реальності, але елемент вертикальності з'являється тоді, коли через правосвідомість відбувається взаємозв'язок із системою більш високого порядку (а саме, соціальною) або коли різні чи відносно різні прояви характеризують різні рівні правосвідомості (соціальний, груповий, індивідуальний).

Звідси випливає, що для результативної оцінки місця та ролі правосвідомості у правовій системі будь-якої держави слід визнати іï динамічний характер, схильність до розвитку або інволюції разом з іншими складниками правової дійсності, але навіть, попри істотний динамізм правосвідомості, вона здатна створити атмосферу, в якій діє право, забезпечити стійкість правової системи, що трансформується, завдяки наявності в її підставі якоїсь константи [14, с. 611-612], насамперед моральних установок - справедливості, обов'язковості, солідарності, взаємодопомоги, толерантності, колективізму та ін. [15, с. 86-87]. Особливого значення наведене твердження набуває в розрізі сучасної суспільної орієнтації у більшості розвинених країн світу на формування інституцій правової держави та громадянського суспільства, які у своєму підсумку спираються на процеси рефлексії у правосвідомості.

Для орієнтації на окреслення об'єктивної ролі правосвідомості та іï місця серед інших правових явищ уваги заслуговуе теза I. I. Коваленка про те, що феноменологічна редукція полягатиме у фіксації меж традиційних уявлень про право та заданні напряму пошуку предметного смислу права. Такий смисл виникає у свідомості правового суб'єкта під час безпосереднього сприйняття та освоєння правових явищ [16, с. 107]. Але, конкретизуючи зазначений підхід, можна констатувати виникнення уявлення про певні юридичні феномени не окремо, а в комплексі, або щодо інших, причому трансформація кожного елемента спричинятиме видозміну не лише його, а й інших компонентів правової реальності у свідомості особи.

Знову звертаючись до загальної теорії систем, їхньої цілісності й одночасно неоднорідності елементного складу, зазначимо, що справедливою видається ідея оцінки основних напрямів сучасного «синтезованого» праворозуміння, в межах яких правові явища вивчаються 3 позиції їхньої «різновимірності». Причому для побудови інтегральної теорії правосвідомості необхідне комплексне дослідження структури, функцій та динаміки останньої в плані багаторівневого іï вивчення: філософсько-правового (що включає онтологію, логіку, гносеологію, антропологію та аксіологію осмислення й реалізації права), соціологічного, психологічного, культурно-історичного, теоретико-правового, системно-динамічного та ін. [17, с. 13]. А для достовірності окреслення місця та ролі правосвідомості у правовій системі у будь-якому разі видається необхідним визнання не лише iї діалектичного характеру, а й інтегративних властивостей, інакше кажучи, інтегративне праворозуміння актуалізується не саме по собі, а через правосвідомість. Усі елементи 
правової реальності набувають балансу та взаємоузгодженості, заломлюючись у свідомості законодавця, судді, пересічного громадянина як суб'єкта права, тим самим надаючи правовій реальності ознак самоуправління Абстрагуючись від регулятивної ролі права щодо суспільних відносин та виходячи з продемонстрованих ознак правосвідомості, які власне і визначають їі місце серед інших елементів правової системи, не варто обмежуватись лише констатацією інтегративності усіх правових феноменів у суспільстві, а слід звернутись до законів кібернетики, через призму якої можна конкретизувати місце та роль правової свідомості.

Кібернетика (з грецької kybernetike мистецтво управління) - наука про загальні риси процесів та систем управління в технічних пристроях, живих організмах та людських організаціях [18, с. 196]. Причому чим складніший об'єкт, що управляється, чим більшою є множина його можливих станів, тим складніше слід будувати систему управління [19, с. 93-94]. Відзначаючи ж різновимірність та різновекторність юридичних процесів у суспільстві, які перебувають у постійному русі та взаємодії, виходимо на синергетичність правової системи, оскільки «синергетика вивчає механізми самоорганізації окремого класу систем (а саме, відкритих та нелінійних) найрізноманітнішої природи» [20, с. 28].

Теза про синергетичність правової системи не $є$ новою у вченні про право та державу. Так, І. С. Кривцовою фундаментально досліджувався аспект синергетики під час здійснення компаративного аналізу - було виявлено, що «ефект самоорганізації» на рівні правової системи залежить від ступеня самоорганізації на рівні іï компонентів і $є$ результатом прояву тенденції ієрархічного керування внутрішньосистемними самоорганізаційними процесами. Самоорганізація на рівні правової системи в цілому і на рівні її компонентів зокрема, тобто правова самоорганізація, виявляє своє джерело в соціальній самоорганізації. Цим же автором вперше обгрунтовано, що правова система $е$ комплексом порядків, які самоорганізуються, перебувають у погодженій взаємодії під впливом внутрішньосистемного детермінанта - правосвідомості, яка визначає форму правової самоорганізації і є квінтесенцією самоорганізації правової системи, яка здатна забезпечити когерентність самоорганізаційних процесів і «алгоритм» саморуху правової системи в цілому [21, с. 5,11$]$. А отже, синергетика правової системи виявляється у її самоузгодженні, саморозвитку, які відбуваються за рахунок безперервної взаємодії правової ідеології, системи права та юридичної практики. Але зазначений взаємозв'язок виникає не сам по собі. Логічно передбачити певні сполучні ланки, що відіграють роль «провідника», забезпечуючи взаємопроникнення та взаємовплив усіх елементів правової системи. I однією з таких ланок, безумовно, виступає правосвідомість, яка формує можливість утвердження концептуальних підходів до права, втілення їх у самій сутності правових приписів 3 наступним відбиттям форми і змісту цих приписів на фактичній поведінці особи. Таким чином, визнаючи синергетичність правової системи, як відкритої та нелінійної, і розкривши роль у ній правосвідомості, можна акцентувати увагу на праксеологічному аспекті цього дослідження завдяки виявленню інтегративно-синергетичної ролі правосвідомості [22, с. 142]. 3 огляду на висвітлену концепцію та використовуючи ефективні механізми впливу на правову свідомість, можна забезпечити позитивні зміни в інших складниках правової реальності, що за законами системності приведе до якісних змін у системі в цілому. Тому цілком природно, що трансформації ідеологічних уявлень про значення й роль права у конкретній державі будуть відбиватися як у самій сутності правових приписів, так і на рівні юридичної техніки. Поліпшення ж або погіршення стану законодавства відбиватиметься на ефективності реалізації правових норм. Це складається у безперервний і циклічний процес та вимагає тонких механізмів впливу для удосконалення функціонування правової системи. I особливо слід враховувати можливість збоїв у функціонуванні правової системи у разі застосування помилкових, неефективних, науково не обгрунтованих методів впливу.

Синергетичну роль правосвідомості у правовій системі держави легко простежити, заглибившись в онтологічні та функціональні особливості всіх їі уявних компонентів. Оскільки правова норма без її відбиття у свідомості особи залишиться лише словами на папері, а відповідно, не виконуватиме свого регулятивного призначення. I лише якщо буде сприйнятим особою, цей припис створює внутрішній імператив, який може суттєво варіюватися залежно від позитивного чи негативного його сприйняття, що у кінцевому результаті втілюється у фактичній правовій поведінці особи. 3 наведеного очевидним стає висновок про фундаментальну роль правосвідомості у правовій системі будь-якої країни. Правосвідомість виступає у вигляді сполучної ланки, що збалансовує роботу елементів правової системи, забезпечує їі самокерованість, передає зміни у кожному 
компоненті правової системи на наступний рівень [23, с. 308].

\section{Висновки}

Виходячи із вищезазначеного, підсумуємо: поряд із традиційно визначеними складниками правової системи (система права, правова ідеологія та юридична практика), функціонує відносно самостійний елемент правової реальності - правосвідомість, який не можна у повному обсязі включити до будь-якого з перелічених базових елементів через постійний вихід правосвідомості за їх межі. Також не $є$ можливим повноцінне виділення досліджуваної категорії в окремий компонент, оскільки у будь-який момент часу через правосвідомість забезпечується уся множина зв'язків, які відбуваються всередині системи права. Тому можна констатувати існування правосвідомості як розумово-психологічної категорії, відносно незалежного елемента правової системи, що забезпечує її інтегративно-синергетичні властивості та відображає сукупність знань, уявлень та емоцій щодо фактичного і бажаного стану правових феноменів.

Разом із тим, зазначимо, що взаємозв'язок правової системи з іншими системами соціуму здійснюється за кібернетичним принципом та характеризує їхній зовнішній обопільний вплив одна на одну.

\section{Список використаних джерел:}

1. Огаренко Т. Структура та функції правової системи. Підприємництво, господарство і право. 2013. № 5. C. $12-15$.

2. Шевчук О. М. Засоби державного примусу у правовій системі України : автореф. дис. ... канд. юрид. наук. Київ, 2003. 22 с

3. Теория государства и права : учебник / под ред. Р. А. Ромашова. СПб.: Юридический центр «Пресс», 2005. 630 c

4. Цыганов В. И. Теория государства и права: тезисы лекций. Н. Новгород, 2007. 142 с

5. Теория государства и права : учебник / под ред. В. К. Бабаева. Москва: Юристъ, 2003. 592 с.

6. Васецький В. Ю. Доктрина прав людини в романо-германській правовій системі : автореф. дис. ... канд. юрид. наук. Київ, 2006. 21 с.

7. Оніщенко Н. М. Теоретико-методологічні засади формування та розвитку правової системи : автореф. дис. ... доктора юрид. наук. Київ, 2002. 26 с.

8. Кухарук Т. В. Правовая система и систематика законодательства: автореф. дисс. ... канд. юрид. наук. СПб., 1998. 22 с.
9. Макар Л. М. Формування правосвідомості майбутнього вчителя правових дисциплін у педагогічних університетах : автореф. дис. ... канд. пед. наук. Запоріжжя, 2009. 23 с.

10. Скакун О. Ф. Правосознание в правовой системе Украины: эволюционные особенности, профессиональное и региональное измерение. Право Украины. 2013. № 1. С. 9-116.

11. Тихомиров Ю. А. Правовое регулирование: теория и практика. Москва: Формула права, 2010. $400 \mathrm{c}$.

12. Тихомиров О. Д. Юридична компаративістика: філософсько-методологічні засади : автореф. дис. ... доктора юрид. наук. Київ, 2006. 37 с.

13. Калиновський Ю. Ю. Правосвідомість українського суспільства як соціокультурний феномен: філософсько-правова рефлексія : автореф. дис. ... доктора філософ. наук. Харків, 2010. 37 с.

14. Правосвідомість у правовій системі України: еволюційні особливості, професійний і регіональний виміри. Правова система Украӥни: історія, стан та перспективи: у 5-ти т. / за ред. М. В. Цвіка, О.В. Петришина. Харків: Право, 2008. Т. 1: Методологічні та історико-теоретичні проблеми формування і розвитку правової системи України. 728 с.

15. Черкас М. Є. Правосвідомість та эï функції в механізмі правового регулювання : монографія. Харків: Право, 2014. 156 с.

16. Коваленко I. I. Правове життя в інтегративному праворозумінні: смислові обриси. Вісник Національного університету «Юридична академія України імені Ярослава Мудрого». 2016. № 1 (28) C. 106-118.

17. Цимбалюк М. М. Онтологічні основи теорії правосвідомості : автореф. дис. ... доктора юрид. наук. Київ, 2009. 38 с.

18. Философский словарь / под ред. И. Т. Фролова. Москва: Изд-во политической литературы, 1987.590 c.

19. Кудрявцев В. И., Самощенко И. С., Никитинский В. Н., Глазырин В. В. Эффективность правовых норм. Москва, 1980. 280 с.

20. Князева Е. Н., Курдюмов С.П. Основания синергетики. Режимы с обострением, самоорганизация, темпомиры. СПб.: Алетейя, 2002. 414 с.

21. Кривцова I. С. Методологічна роль синергетики у порівняльно-правовому пізнанні : автореф. дис. ... канд. юрид. наук. Одеса, 2008. 22 с.

22. Міхайліна Т. В. Синергетика правосвідомості в контексті екологічної культури. Екологія Донбасу: уроки історії та виклики сьогодення: збірн. тез доп. (Вінниця,10-11 жовтня 2017 р.). Вінниця, ТОВ «Нілан-ЛТД», 2017. С. 141-143.

23. Міхайліна Т. В. Синергетична роль правосвідомості. Economic and law paradigm of modern society. 2016. № 1. P. 305-309.

The article is devoted to the integrative role of legal consciousness in the legal system of society. In particular, revealed its cybernetic and synergetic aspect.

The article concludes that along with the traditionally defined components of the legal system (system of law, legal ideology and legal practice), there is a relatively independent element of the legal reality of legal consciousness, which can not be fully included in any of these basic elements through the constant exit 
of legal consciousness beyond them. It is also not possible to fully allocate the studied category in a separate component, because at any time through the sense of justice provided the whole set of links that occur within the system of law. On the basis of this, the existence of legal consciousness as a mental-psychological category, as a relatively independent element of the legal system is stated, which provides its integrative and synergetic properties and reflects a set of knowledge, ideas and emotions regarding the actual and desired state of legal phenomena, has been disclosed.

It is emphasized that all the elements of legal reality acquire balance and mutual agreement, refracted in the minds of the legislator, judge, ordinary citizen as a subject of law, thereby providing the legal reality of the signs of self-government. This means that the synergy of the legal system is manifested in its self-coordination, self-development, which occur due to the continuous interaction of legal ideology, system of law and legal practice. But this relationship does not arise by itself. It is logical to provide for certain connecting links that play the role of a "guide", ensuring the interpenetration and mutual influence of all elements of the legal system.

The article notes that the relationship of the legal system with other systems of society is carried out according to the cybernetic principle and characterizes their external mutual influence on each other.

Key words: legal consciousness, legal system, cybernetics, synergetics, integration. 
УДК $340+001$

DOI https://doi.org/10.32849/2663-5313/2019.8.29

Людмила Міхневич,

канд. юрид. наук, доиент

завідувач кафедри конституційного та мунічипального права

Київського національного економічного університету імені Вадима Гетьмана

\section{ВИКЛАДАННЯ ТОРГОВОГО ПРАВА В УКРАЇНСЬКИХ ВИШАХ РАННЬОГО РАДЯНСЬКОГО ПЕРІОДУ}

Здійснено аналіз викладання та обсягів вивчення торгового права на правових факультетах інститутів народного господарства в 1920-1930-х роках. Встановлено, що в епоху нової економічної політики торгове право перебувало в стані розквіту. Юристи вивчали як загальний курс торгового права, так і різноманітні спечкурси, назви яких та обсяги навчального часу часто змінювалися. Показано, що в Київському інституті народного господарства обов'язковими курсами були «Торгове право» та «Промислове право», згодом - «Торгово-промислове право». Інтенсивність занять була досить високою: по 6 годин лекиії та по 4 години практичних занять шотижня. Додатково вели й спечкурси: вексельне, конкурсне, біржове, морське та річкове право. Практичні навички студенти здобували на семінарах підвищеного типу із господарського права та біржового права.

З'ясовано, що у Харківському інституті народного господарства навантаження з торгового права становило третину всвого навчального часу. Тут вивчали дві базові дисиипліни: «Торгове право» та «Промислове право». В переліку спеикурсів містилися торгове транспортне право та вексельне право. Особлива увага приділялася практичним заняттям, факультативам та семінарам підвищеного типу. Важливо, що для торгово-правового семінару підвищеного типу планувалося 10 годин на тиждень. Встановлено, що в Одеському інституті народного господарства, крім торгового та промислового права, обов'язковою дисиипліною було «Морське право». Його викладали по 4 години на тиждень. Традиційними формами занять були лекиї, практичні заняття, семінари, факультативи. Діяв і семінар підвищеного типу з торгового права.

Виявлено, що хоч торгове право було широко представлене в начальних планах правових факультетів інститутів народного господарства Києва, Харкова та Одеси, вже до 1930 р. його викладання було зведено лише до однієї дисиипліни - «Торгово-промислове право», а згодом і зовсім припинено.

Ключові слова: торгово-промислове право, господарське право, біржове право, вексельне право, конкурсне право, морське право.

Постановка проблеми. У XIX ст. торгове право як наука і навчальна дисципліна активно розвивалося в стінах юридичних факультетів університетів та ліцеїв. Вже на початку XX ст. його вивчали студенти спеціалізованих вишів (юридичних і комерційних інститутів) та юридичних факультетів жіночих курсів [1]. Принципово нові підходи до розуміння торгового права сформувалися в умовах радянської політики. Якщо в дореволюційний час тривала дискусія про дуалізм цивільного та торгового права та ідеї виокремлення вексельного, біржового, акціонерного права в окремі галузі, то нові методи радянського господарювання в 1920 -х роках виявили проблему співвідношення цивільного, торгового та господарського права. Торгове право розглядалося як складник господарського права, а сам термін «господарське право» використовували для механічного перенесення західноєвропейської концепції торгового права на радянський грунт, а іноді як рівнозначний терміну «цивільне право». Не було єдності думок й щодо місця в системі права промислового, вексельного, біржового, акціонерного, морського торгового права. Іноді вони розглядалися як окремі інститути цивільного права, іноді як складові частини торгового права чи господарського права, іноді - як самостійні галузі. Ці дискусії в тогочасній літературі сформували низку ідей і концепцій. Однак в процесі заперечення приватної власності торгове право стало неактуальним і поступово було вилучене 3 навчальних планів радянських вишів. Однак для сучасників корисним може стати досвід викладання юристам цієї галузі права в ранній радянський період.

Аналіз публікацій. Хоча в літературі зустрічаються окремі розвідки про провідних комерціоналістів (праці О.П. Подцерковного) чи творчі здобутки київських учених [2], 
становлення та розвиток торгового права як навчальної дисципліни на правових факультетах інститутів народного господарства Києва, Харкова та Одеси, які презентували юридичну освіту в 1920 -х р., не вивчалося.

\begin{abstract}
Метою статті $є$ виявлення особливостей викладання торгового права вченими правових факультетів інститутів народного господарства Києва, Харкова та Одеси в $20-30$-х pp. XX ст. та введення в науковий обіг маловідомих наукових джерел із даної проблеми, що дозволить відтворити досвід тогочасних освітян у сфері торгового права
\end{abstract}

Виклад основного матеріалу. Насамперед зазначимо, що торгове право в 1920 -х роках в епоху нової економічної політики перебувало в стані розквіту. На правових факультетах трьох інститутів народного господарства (Київського (далі - КІНГ), Харківського (далі - ХІНГ), Одеського (далі - ОІНГ)) в досить великому обсязі викладали як загальний курс дисциплін, так і різноманітні спецкурси. Проте, як свідчать архівні джерела навчальні плани інститутів майже щороку змінювалися, отже, назви цих дисциплін та обсяги навчального часу часто корегувалися.

Так, спочатку навчальний план правового відділення КІНГ відтворював класичну університетську освіту, отже, торгове право було обов'язковим для його студентів. Водночас, зберігаючи традиції Київського комерційного інституту (КІНГ став його правонаступником), студенти інших факультетів вивчали ще й вексельне, конкурсне, морське та річкове право [3, арк. 2-32]. 3 1922/23 н. p. студенти-другокурсники обох (судового та адміністративного) відділень тоді вже окремого правового факультету КІНГ слухали лекції 3 «Торгово-промислового права» (перший триместри по 4 години щотижня наступні два триместри - по 2 години щотижня). 3 другого триместру розпочиналися й практичні заняття (по 2 години щотижня), які читали два триместри на другому курсі та один триместр - на третьому. Студенти судового відділення додатково ще два триместри вивчали вексельне та конкурсне право (по 2 години щотижня) [4, арк. 80]. У 1923/24 н. р. торгово-промислове право перенесли на третій курс (читали по 4 години лекцій та по 2 години практичних занять щотижня). Такий же обсяг дисциплін вивчали студенти нового господарсько-юрисконсультського відділення.

Наступного року на судовому відділенні години були збільшені (лекції 6 годин щотижня один триместр та практичні заняття по 4 години щотижня два триместри), а для адміністративного відділення зменшені (лекції 4 щотижневі години один триместр, практичні заняття по 2 години щотижня два триместри) [5, арк. 189-190]. Господарсько-юрисконсультське відділення того року не працювало. У навчальних планах на 1925/26 н. р. вже знаходимо дві самостійні дисципліни: «Торговельне право» та «Промислове право», які вивчали третьокурсники. Відтепер студенти судового відділення слухали щотижневі шестигодинні лекції 3 торгового права в першому триместрі. На семінари ж відводилося по 4 щотижневі години в першому і третьому триместрах та 2 години - в другому. Студенти об'єднаного адміністративно-юрисконсультського відділення торгове право вивчали по 2 години лекцій щотижня два триместри і мали семінари (по 2 години в першому і другому триметрі та 4 години в третьому). Їм читали й промислове право (2 години лекцій один триместр і три триместри семінари - по 2 години) та вели підвищений семінар із біржового права [6, арк. 74].

Із введенням чотирирічного курсу навчання у 1926/27 н. р. знову читали об'єднаний курс «Торгово-промислове право» для всіх третьокурсників (два триместри по 4 години щотижневих лекцій та практичних занять). Додатково на господарсько-юрисконсультському відділенні два триместри читали спецкурси «Банкове, біржове, вексельне право» та «Промислове право» (по 4 години щотижневих лекцій і семінарів). У літньому триместрі ці студенти готували кандидатські роботи із цих дисциплін (аналог курсових). Студенти судового та господарсько-юрисконсультського відділень також відвідували 16-годинний семінар із господарського права, який також закінчувався кандидатською роботою (для ï̈ підготовки відводилося 12 годин) [2, с. 278].

У навчальному плані на 1929/30 н. р. значиться обов'язковий для всіх третьокурсників предмет «Торгово-промислове право» (читався два семестри в обсязі 4 години лекцій та 3 години семінарів щотижня). Юристам господарського фаху пропонували ще й спецкурс «Промислове право», а на новоутвореному міжнародному циклі вводили нову дисципліну «Правові питання зовнішньої торгівлі» [2, с. 279-280]. Однак вже у жовтні 1930 р. правовий факультет КІНГ припинив свою діяльність.

Викладали ці предмети в КІНГ M.I. Мітіліно, О.С. Добров, В.В. Карпеко, В.I. Лабейковський, I.M. Шумилін, Б.О. Язловський. Професор М.I. Мітіліно читав лекції, на яких практикував дискусії та колективне вирішення казусів із найпоширеніших видів торгово-промислових 
угод. Натомість на практичних заняттях він вів індивідуальну роботу зі студентами, колективний аналіз торгових угод за діючим правом та проектом Торгового зводу СРСР. Жвавий інтерес викликали семінарські заняття, де розглядали досвід рецепції розвиненого західноєвропейського торгового права для правового регулювання торгового обороту радянської держави. Студенти працювали не лише з вітчизняним нормативним матеріалом, а й вивчали торгове законодавство зарубіжних країн, зокрема Германське торгове уложення [7, арк. 68]. Викладач Б.О. Язловський заняття з промислового права проводив у формі колективної проробки нормативного матеріалу та аналізу нормативних актів [2, с. 121]. Навички наукової роботи студенти відточували не лише під час підготовки кандидатських робіт, а й працюючи на семінарі підвищеного типу та на юридичному семінарі. Семінари підвищеного типу із господарського і біржового права вів В.І. Лабейковський. Торгово-промисловою секцією юридичного семінару керував професор М.І. Мітіліно. Згодом тематика юридичного семінару була розширена, в 1927/28 н. р. діяли такі напрями: «Проблеми сучасного господарського права» (керівник С.I. Кельман), «Основні питання міжнародного торгового права» (керівник M.I. Мітіліно), «Вчення про промислові підприємства 3 юридичної точки зору» (керівник - Б.О. Язловський), «Право власності в радянському праві» (керівник - В.В. Карпеко) $[2$, с. 108,261$]$.

Аналіз наявних навчальних планів ХІНГ дає підстави стверджувати, що торгове право вивчали студенти всіх факультетів інституту. Окрім того, на торговому факультеті обов'язковим було «Торгове транспортне право», на промисловому факультеті «Промислове право», для окремих спеціалізованих груп фінансово-банково-страхового факультету - «Вексельне право». Натомість харківські правники вивчали дві базові дисципліни: «Торгове право» та «Промислове право». 3 року в рік змінювався лише обсяг навчальних годин цих дисциплін. Так, у 1921/22 н. р. третьокурсники впродовж року (4 години щотижня) слухали лекції з торгового права, тоді як промислове право було додатковою дисципліною для студентів спеціальних груп адміністративістів і цивілістів. Його читали впродовж року по 2 години щотижня [8, арк. 42].

Наступного року навантаження 3 торгового права зменшилося. Третьокурсники судового відділення вивчали загальну та спеціальну частини торгового права по 2 години щотижня, а на адміністративно- му відділенні вели лише загальну частину (по 2 години щотижня). Викладання ж промислового права для всіх студентів звели до одного триместру (2 щотижневі години) [9, арк.178-179].У 1923/24н.р.наторговеправовідводилосяпо4годинищотижнявпершому триместрі, та по 2 години - в другому. Водночас двічі на місяць працював господарськоправовий семінар, який діяв як факультатив [10, арк. 23-26]

У 1924/25 н. р. за новим навчальним планом, розробленим тодішнім деканом правового факультету професором В.М. Гордоном, третьокурсники судово-господарського відділення в осінньому триместрі вивчали торгово-промислове право (6 годин лекцій і практичних занять), а у весняному - відвідували 10-годинний торгово-правовий семінар. Зауважимо, що це навантаження становило третину всього навчального часу. Натомість студенти адміністративно-господарського відділення на третьому курсі в осінньому триместрі вивчали «Елементи цивільного і торгового права» (по 4 години лекцій і практичних занять) [11, арк. 102-104].

Важливо, що практичні заняття стали обов'язковими, були включені до навчального плану, методи їх ведення чітко окреслені, а їх програми затверджував Методком Наркомату освіти. Водночас все частіше стали впроваджуватися семінари, де студенти під керівництвом досвідченого вченого освоювали теоретичний курс дисципліни, тобто поглиблено вивчали теорію та набували навиків використовувати її в практичній роботі. Порівняно з іншими формами занять, семінар вимагав від студентів досить високого рівня самостійності, ініціативи, вміння працювати з літературою, вести дискусії, а також навичок індивідуальної та колективної роботи. Спочатку господарсько-правовий семінар вів професор В.М. Гордон, згодом С.Н. Ландкоф, В.І. Сливицький та Г.С. Семенова [12, ар. 143,145].

Загалом за роки діяльності ХІНГ дисципліни торгово-правового циклу викладали такі відомі вчені, як В.М. Гордон, Б.В. Попов, С.С. Сабінін, В.І. Сливицький, B.М. Корецький, А.С. Ратнер, С.Н. Ландкоф, О.М. Гладстерн, В.I. Серебровський, С.И. Вільнянський, Я.І. Рапопорт, М.В. Гордон, І.Л. Цьокан, І.І. Жагелєв, С.Л. Фукс.

В ОІНГ студенти обох факультетів (правового та зовнішніх торгових відносин) торгове право вивчали на третьому курсі (лекції і практичні заняття по 2 години щотижня) [13, ap. 4]. У 1922 р. О.А. Бугаєвський організував й семінар із торгового права. Вже у навчальному плані на 1923/24 н. р., окрім торгового права (обсяг якого збільшився до 
4 годин щотижня), з'явилося промислове право (2 години щотижня один триместр) [14, арк. 3]. Наступного року студенти-юристи вивчали базову дисципліну «Торгово-промислове право» (по 4 години щотижня лекцій і практичних занять - перший триместр та по 2 години - другий триместр). Третій триместр відводився для обов'язкового семінару підвищеного типу.

Одеські правознавці, які викладали ці дисципліни в ОІНГ (П.С. Кравцов, О.А. Бугаєвський, В.М. Рикачев, Є.А. Шрабштейн) значну увагу приділяли семінарам, які в ОІНГ поділялися на обов'язкові та факультативні. Факультативи діяли як семінари підвищеного типу для поглиблення спеціалізації. Це були групові заняття, де влаштовувалися дискусії за тезами студентських доповідей. Господарсько-правовий семінар підвищеного типу (6 годин щотижня) діяв для третьокурсників у третьому триместрі [15, арк. 100].

За навчальним планом 1925/26 н. р. торгове і промислове право читали як окремі дисципліни, значно збільшивши години занять. Так, торгове право вивчали три триместри (по 4 години щотижня), а промислове - один триместр (по 4 щотижневі години). Продовжував працювати й господарськоправовий семінар підвищеного типу [16, арк. 584-585]. Такий обсяг цих дисциплін на правовому факультеті зберігався кілька років. У 1926/27 н. р. для студентів одного зі спеціалізованих ухилів (утворені замість факультативів) додатково було запроваджено спецкурс «Морське право», який читали по 2 щотижневі години два триместри [17, арк. 15-16]. 3 1928/29 н. р. морське право стало обов'язковою дисципліною для студентів 4 курсу (другий триместр по 4 години щотижня, третій - по 2 години щотижня).

Кардинальних змін зазнав уже навчальний план на 1929/30 н. р. Для студентів другокурсників мали викладати «Господарське право СРСР / цивільний кодекс» (8 щотижневих годин), а на третьому курсі - «Торгово-промислове право» (4 години щотижня). На судовому та адміністративно-господарському циклах (мали утворюватися на 4 курсі) започатковували додаткові дисципліни. На судовому циклі вводили «Торговельне право / фаховий курс», «Морське право» та «Практику торговельного права», а на адміністративно-господарському циклі «Спецкурс торгово-промислового права» та «Морське право» [18, арк. 126-128]. Однак реалізувати цей план вже не вдалося, правовий факультет ОІНГ у жовтні 1930 р. був ліквідований.

\section{Висновки}

Отже, на правових факультетах радянських вишів у 1920-х роках торгово-правові дисципліни були представлені курсами: «торгове право», «промислове право», «вексельне право», «морське право», «біржове право» тощо. Для їх викладання, окрім лекцій, практикували практичні заняття, семінари та семінари підвищеного типу. Обсяги курсів вражають, подекуди вони складали третину всього навчального часу. Студенти працювали 3 нормативним матеріалом, цікавилися рецепцією західноєвропейського торгового права для регулювання радянського торгового обороту, вивчали Германське торгове уложення. Однак поступово перелік і обсяги цих дисциплін скорочувалися і вже у навчальних планах на 1929/30 н. р. вивчення торгового права було зведено до однієї дисципліни - «Торгово-промислове право». Лише в ОІНГ залишився спецкурс «Морське право». 3 ліквідацією інститутів народного господарства у 1930 р. викладання торгово-правових дисциплін зовсім припинено. Однак правники інститутів народного господарства у 1920-х роках досить активно вивчали проблеми у сфері торгового права. Аналіз їх наукових розробок та їх вплив на сучасність можуть бути цікавими для дослідників та активізувати подальші пошуки.

\section{Список використаних джерел:}

1. Міхневич Л.В. Торгове право в неуніверситетських навчальних закладах на українських теренах (XIX - початок XX ст.). Підприємниитво, господарство і право. 2019. № 2. С. 176-181.

2. Міхневич Л.В. Розвиток юридичної науки і освіти в Київському комерційному інституті - Київському інституті народного господарства (1906-1930 рр.). Київ : КНЕУ, 2011. 286 с.

3. Учебные планы на 1920-1921 гг. ДАК (Держ. архів м. Києва). Ф. Р-871. Оп. 1. Спр. 2.

4. Отчет о деятельности Киевского института народного хозяйства за 1922 г. ЦДАВОУ (Центр. держ. архів вищих органів влади та управ. України). Ф. 166. Оп. 5. Спр. 576.

5. Проект Учебного плана правового цикла КИНХа на 1924/25 учб. год. ЦДАВОУ. (Центр. держ. архів вищих органів влади та управ. України). Ф. 166. Оп. 4. Спр. 566.

6. Навчальний план юридичного факультету Київського інституту народного господарства на 1925/26 навч. рік. ЦДАВОУ. (Центр. держ. архів вищих органів влади та управ. України). Ф. 166. Оп. 5. Спр. 558.

7. Отчет за 1923-1924 гг. преподавателя М.И. Митилино. ДАК (Держ. архів м. Києва). Ф. Р-871. Оп. 1. Спр. 54.

8. Учебный план правового факультета ИНХ в 1921-1922 гг. ЦДАВОУ (Центр. держ. архів 
вищих органів влади та управ. України). Ф. 166. Оп. 2. Спр. 1139

9. Учебный план Правового факультета Харьковского института народного хозяйства на 1922 1923 уч. г. ЦДАВОУ (Центр. держ. архів вищих органів влади та управ. України). Ф. 166. Оп. 2. Спр. 1512.

10. Учебный план на 1923/24 год. ЦЦАВОУ (Центр. держ. архів вищих органів влади та управ. України). Ф. 166. Оп. 4. Спр. 580.

11.Нормальный учебный план правового факультета института народного хозяйства. ЦДАВОУ (Центр. держ. архів вищих органів влади та управ. України). Ф. 166. Оп. 4. Спр. 580.

12. Річний звіт Харківського інституту народного господарства за 1927/28 шк. р. ЦЦАВОУ (Центр. держ. архів вищих органів влади та управ. України). Ф. 166. Оп. 8. Спр. 132

13. Доклад о деятельности Одесского института народного хозяйства за I триместр и начало II-го трим. 1922/23 уч. г. ЦДАВОУ (Центр. держ. архів вищих органів влади та управ. України). Ф. 166. Оп. 2. Спр. 1506
14. Одесский институт народного хозяйства. Учебный план юридического факультета на 1923/1924 учебный год. ЦДАВОУ (Центр. держ. архів вищих органів влади та управ. України) Ф. 166. Оп. 4. Спр. 574.

15. Учебный план юридического факультета Одесского института народного хозяйства на $1924-25$ уч. год. ЦДАВОУ (Центр. держ. архів вищих органів влади і управ. України). Ф. 166. Оп. 4. Спр. 574.

16. Учебный план на 1925-26 учебный год. Юридический факультет. ЦДАВОУ (Центр. держ. архів вищих органів влади і управ. України) Ф. 166. Оп. 5. Спр. 562.

17. Учебный план юридического факультета на 1926-27 уч. г. ЦДАВОУ (Центр. держ. архів вищих органів влади та управ. України). Ф. 166. Оп. 6. Спр. 5641.

18. Проект нормального учебного плана юридического факультета Одесского института народного хозяйства в 1929/1930 учеб. году. ЦДАВОУ (Центр. держ. архів вищих органів влади та управ. України). Ф. 166. Оп. 6. Спр. 5641.

There was carried out the analysis of the teaching and the scope of the study of trade law at the law faculties of the national economy institutions in the 1920-1930's. There was established that trade law was in its prime in the era of the new economic policy. Lawyers studied both the general course of commercial law and various special courses, the names and amounts of study time were often changed. There was shown that "Commercial Law" and "Industrial Law", then "Commercial and Industrial Law" were compulsory courses at the Kiev Institute of National Economy. The intensity of the classes was quite high: 6 hours of lectures and 4 hours of practical classes per week. In addition, special courses such as bill, competition, exchange, maritime and river law were conducted. Students gained practical skills in seminars of advanced type in business law and stock exchange law.

There was found that the load on trade law was a third part of the study time at Kharkiv Institute of National Economy. "Commercial Law" and "Industrial Law" were two basic disciplines were studied there. The list of special courses included commercial transport law and promissory note law. Particular attention was paid to practical classes, electives and higher-level seminars. It is important that a high-level trade seminar was scheduled for 10 hours per week. There was found that in the Odessa Institute of National Economy "Maritime Law" was the obligatory discipline in addition to commercial and industrial law. It was taught 4 hours per week. Lectures, practical classes, seminars, electives were traditional forms of classes. There also was an advanced seminar on trade law.

There was found that despite the wide representation of trade law in the curriculum of the Law Departments of the Institutes of National Economy of Kyiv, Kharkiv and Odessa its teaching had been reduced by 1930 to only one discipline - Commerce and Industry Law, and completely stopped subsequently.

Key words: commercial and industrial law, commercial law, bill of exchange right, competitive law, maritime law. 
УДК 340.113 .2

DOI https://doi.org/10.32849/2663-5313/2019.8.30

Юлія Назарук,

аспірант кафедри теорії та історії держави і права

Східноєвропейського начіонального університету імені Лесі Украйнки

\section{ЧИННІСТЬ ПРАВОЗАСТОСОВНИХ АКТІВ ОРГАНІВ ТА ПОСАДОВИХ ОСІБ МІСЦВОГО САМОВРЯДУВАННЯ У ПРОСТОРІ}

У статті розглянуто основні приниипи територіальної чинності правозастосовчих актів органів та посадових осіб місиевого самоврядування. Проаналізовано ие питання в контексті чинного законодавства України та міжнародних норм. Розглянуто питання щодо важливості доведення до відома населення (адресата) правозастосовних актів органів та посадових осіб місиевого самоврядування. Надано визначення територіальному (просторовому) критерію чинності правозастосовних актів органів та посадових осіб місиевого самоврядування загалом та в Україні зокрема, а також охарактеризовано шляхи вирішення певних прогалин у законодавстві щодо визначення просторової чинності актів індивідуальної дії.

Варто зауважити, що близькими за правовою природою до правозастосовних актів органів та посадових осіб місиевого самоврядування вважаємо адміністративні акти, якими завершується розгляд та вирішення справи по суті. Саме тому нами було взято до уваги дослідження інших правників, які пропонують розглядати адміністративний акт як волевиявлення адміністративного органу щодо вирішення адміністративної справи, спрямоване на виникнення, зміну чи припинення прав та обов'язків конкретних фізичних або юридичних осіб.

Крім того, свогодні доволі часто поза увагою залишають визначення питання критерію просторової чинності правозастосовного акта, оскільки більшості на перший погляд че питання видається доволі очевидним, однак з вказаним твердженням не можна повністю погодитися, саме тому в межах нашої статті ми проаналізували нормативне закріплення в Конституиії України та Європейській хартії місиевого самоврядування від 15 жовтня 1985 року просторового критерію чинності актів органів та посадових осіб місиевого самоврядування, його особливості та основні характеристики.

Ключові слова: територіальний принцип чинності, правозастосовний акт, чинність актів індивідуальної дії, акти органів місцевого самоврядування.

Постановка проблеми. Розвиток місцевого самоврядування в Україні передбачає децентралізацію влади, розширення можливостей для участі громадян в управлінні справами держави й суспільства, реалізацію права територіальної громади самостійно вирішувати питання місцевого значення Останнім часом наша держава намагається надати місцевому самоврядуванню можливість для реалізації безпосередніх потреб мешканців населених пунктів, узгодження загальнодержавних і місцевих інтересів, що є невіддільною рисою системи сучасного демократичного правління. Отже, правозастосовчі акти органів місцевого самоврядування та їх посадових осіб стають вагомим інструментом досягнення зазначеної мети.

Аналіз останніх досліджень і публікацій. Слід дійсно констатувати той факт, що питанню чинності правозастосовних актів органів та посадових осіб місщевого самоврядування до цього часу не приділялася належна увага ані науковцями, ані законодавцем. Водночас, на противагу правозастосовним актам, питання щодо просторової чинності нормативно-правових актів неодноразово підіймалося в наукових працях О. Пушняка, С. Алексєєва, А. Папірної, В. Тимощука, Ю. Ведєрнікова тощо. Саме тому на основі аналогії з нормативно-правовими актами пропонуємо провести це дослідження.

Мета статті - надати визначення територіальному критерію чинності правозастосовних актів органів та посадових осіб місцевого самоврядування загалом та в Україні зокрема, а також охарактеризувати шляхи вирішення певних прогалин в законодавстві щодо визначення просторової чинності актів індивідуальної дії.

Виклад основного матеріалу. Варто зауважити, що будь-який правовий акт (нормативно-правовий, правоінтерпретаційний, правозастосовчий) в контексті визначення чинності може характеризуватися за трьома ключовими параметрами своєї дії: просторовим, часовим та за колом осіб. 
Сьогодні доволі часто поза увагою залишають визначення питання критерію просторової чинності правозастосовного акта, оскільки більшості на перший погляд це питання видається доволі очевидним. Так, зокрема, за загальним правилом, територіальний принцип чинності акта - це його здатність створювати юридичні наслідки на певній території.

Як вказується в літературі, всі нормативно-правові акти мають визначені часові та просторові межі свого існування і дії, а також поширення на певне коло осіб. Дія нормативно-правового акту в просторі пов'язана 3 поширенням його на територію всієї держави або на визначену його частину (Автономна Республіка Крим). Територія України включає в себе: земну територію, внутрішній водний простір, надра; територіальні води в межах 12 морських миль; повітряний простір у межах кордонів держави (на висоті до 35 кілометрів); території посольств і консульств; повітряні та морські судна військового і цивільного флоту, які перебувають у відкритому морі або в повітрі під прапором і гербом держави [7, с. 136-137].

Територіальні межі дії нормативно-правових актів закріплюють суверенітет держави і його юрисдикцію [7, с. 136-137].

Крім того, багато вчених-правників звертають увагу на те, що нормативно-правові акти діють за територіальним і екстериторіальним принципами.

Щодо конституційного закріплення питання чинності нормативно-правових актів, то слід виокремити положення ст. 57 Конституції України, яким встановлено, що кожному гарантується право знати свої права і обов'язки. Закони та інші нормативно-правові акти, що визначають права і обов'язки громадян, мають бути доведені до відома населення у порядку, встановленому законом. Також варто згадати положення ст. 12 Конституції України - суверенітет України поширюється на всю їі територію [1].

Як вказує О.О. Житний, у міжнародному праві під територією розуміють природні простори Землі (сухопутні й водні простори, морське дно, надра), повітряний простір, космічний простір, небесні тіла, штучні об'єкти й споруди (космічні апарати, стаціонарні морські платформи та інше) [8, с. 61]. Одночасно правник зауважує, що в науковій літературі доволі часто виокремлюють умовну територію держави («квазідержавну територію»), під цим терміном розуміють територію дипломатичних представництв держави за кордоном, торгові судна у відкритому морі, повітряні судна й космічні апарати під прапором або знаком цієї держави, підводні трубопроводи й кабелі, надводні споруди у відкритому морі (над шельфом). Поміж цих об’єктів (які називаються також «плавуча», «літаюча», «космічна» територія тощо) розрізняють абсолютну (військові судна повсюдно прирівнюються до території певної держави) та відносну, або умовну, територію (наприклад, транспорт глави дипломатичного представництва) [8, с. 62]. Вважаємо, що дані положення доречно застосовувати до фактора територіальної чинності правозастосовчих актів органів та посадових осіб місцевого самоврядування, оскільки територія, на яку поширюється повноваження органів місцевого самоврядування, є складовою частиною території держави.

Щодо питання просторової чинності правозастосовних актів органів та посадових осіб місцевого самоврядування, то для початку варто звернути увагу на положення до ч. 1 ст. 140 Розділу ХІ Конституції України, в якому зазначено, що місцеве самоврядування є правом територіальної громади жителів села чи добровільного об'єднання у сільську громаду жителів кількох сіл, селища та міста - самостійно вирішувати питання місцевого значення в межах Конституції законів України [1].

Як вбачається із статті 4 Європейської хартії місцевого самоврядування від 15 жовтня 1985 року (ратифікована Законом України «Про ратифікацію Свропейської хартії місцевого самоврядування» № 452/97-ВР від 15.07.1997), органи місцевого самоврядування в межах закону мають повне право вільно вирішувати будь-яке питання, яке не вилучене зі сфери їхньої компетенції і вирішення якого не доручене жодному іншому органу. Крім того, наголошено на тому, що публічні повноваження зазвичай здійснюються переважно тими органами публічної влади, які мають найтісніший контакт з громадянином [2].

Так, з огляду на ті завдання та сферу компетенції органів місцевого самоврядування, які визначені Хартією та Конституцією, дійсно можна стверджувати, що посадові особи місцевого самоврядування мають найбільш тісну взаємодію $з$ громадянами в межах певної територіальної громади, тобто мають певні умовні територіальні межі для здійснення своєї діяльності. Оскільки органи та посадові особи місцевого самоврядування є суб'єктом владних повноважень, будь-які його дії повинні мати своє формальне вираження. I таке вираження повинно мати чітке визначення свої чинності.

Близькими за правовою природою до правозастосовних актів органів та посадових осіб місцевого самоврядування вважаємо адміні- 
стративні акти, якими завершується розгляд та вирішення справи по суті. В.П. Тимошук пропонує розглядати адміністративний акт як волевиявлення адміністративного органу щодо вирішення адміністративної справи, спрямоване на виникнення, зміну чи припинення прав та обов'язків конкретних фізичних або юридичних осіб [10, с. 33].

Своєю чергою О.О. Мандюк стверджує, що дія адміністративно-правових актів у просторі охоплює територію, на яку ця дія поширюється, але адресатом правових актів $€$ не сама територія, а особи, які на ній знаходяться. Науковець зауважує, що цей параметр (межа) дії актів є більш актуальним для нормативно-правових актів, а не для індивідуальних, оскільки в індивідуальних актах зазвичай адресат чітко визначений у самому акті. Особливою ознакою індивідуальних адміністративних актів є їх індивідуальний характер, тобто спрямованість на вирішення конкретних питань адміністративної діяльності, а тому сфера дії цих актів за колом осіб та в просторі не є дискусійним питанням у науковій літературі [6, с. 109].

Однак з вказаним твердженням правника в межах діяльності місцевого самоврядування неможливо повністю погодитися, оскільки з огляду на сферу компетенції, на яку поширюються повноваження основних муніципальних структур відповідно до Розділу II Закону України «Про місцеве самоврядування в Україні» (№ 280/97-ВР від 21 травня 1997 року), є вирішення питань, що стосуються виділення земельних ділянок, містобудування, виділення коштів тощо [4].

Крім того, слід наголосити, що у вищенаведених нормативно-правових актах, які безпосередньо регулюють діяльність місцевого самоврядування, визначена лише сфера його компетенції, однак питання чинності формального вираження цієї компетенції (правозастосовна діяльність - як спосіб вираження - правозастосовний акт) взагалі законодавцем не піднімалося.

Для прикладу можна навести положення ст. п. 12 ст. 11 Закону України «Про житловий фонд соціального призначення» (№ 3334-IV 12.01.2006), відповідно до якого сім'ї, які мають п'ятьох і більше дітей, та у разі народження у однієї жінки одночасно трьох і більше дітей, мають право позачергового отримання квартир або садибних (одноквартирних) жилих будинків із житлового фонду соціального призначення, за наявності в них права на отримання такого житла [9]. Так, на підставі рішення міської ради про виділення квартири багатодітній сім’ї суб'єкт певної територіальної громади набуває право на житло. Однак з огляду на сферу компетенції та «територіальних» повноважень суб'єкта владних повноважень треба зважати, що житловий фонд соціального призначення визначається також певними територіальними межами та має закріплення до певної територіальної громади.

Отже, під територіальним (просторовим) критерієм дії правозастосовних актів органів та посадових осіб варто розуміти правову можливість суб'єкта владних повноважень в межах певного чітко окресленого простору здійснювати правозастосовну діяльність.

\section{Висновки}

Підсумовуючи, слід наголосити на тому, що суттєву прогалину у вітчизняному законодавстві становить відсутність формального врегулювання загальних постулатів чинності правозастосовних актів органів та посадових осіб місцевого самоврядування. Для правомірності та дієвості правозастосовної діяльності місцевого самоврядування, на нашу думку, є важливим комплексне встановлення чинності його актів, зокрема, вагомим $є$ визначення меж дії такого акта в часі: від моменту вступу в дію до моменту припинення чинності, територіальний принцип (просторова дія), і безумовно, виходячи із ключової характеристики такого акту, є визначення суб'єкта, якому акт адресований. Залишення поза увагою будь-якого $з$ трьох критеріїв чинності таких актів може бути підставою для скасування такого акту як незаконного в судовому порядку.

\section{Список використаних джерел:}

1. Конституція України від 28.06.1996 № 254k/96-BP. URL: http://zakon0.rada.gov.ua/ laws/show/254\%D0\%BA/96-\%D0\%B2\%D1\%80.

2. Європейська хартія місцевого самоврядування від 15 жовтня 1985 року. URL: https://zakon.rada.gov.ua/laws/show/994_036.

3. Закон України «Про ратифікацію Європейської хартії місцевого самоврядування» № 452/97-BP від 15.07.1997 $\quad$ BP. URL: https://zakon.rada.gov.ua/laws/show/452/97$\% \mathrm{D} 0 \% \mathrm{~B} 2 \% \mathrm{D} 1 \%$.

4. Закон України «Про місцеве самоврядування в Україні» № 280/97-

5. ВР від 21.05.1997. URL: http://zakon3.rada. gov.ua/laws/show/280/97-\%D0\%B2\%D1\%80.

6. Загальна теорія держави і права / М.В. Цвік, О.В. Петришин, Л.В. Авраменко та ін. ; за ред. д-ра юрид. наук, проф., акад. АПрН України М.В. Цвіка, д-ра юрид. наук, проф., акад. АПрН України О.В. Петришина. Харків : Право, 2009. 584 с.

7. Мандюк О.О. Індивідуальні адміністративні акти: теорія та практика застосування : дис.. канд. юрид. наук : спец.12.00.01 / Олексій Орестович Мандюк. Львів, 2017. 213 с. 
8. Кравчук М.В.Теоріядержавиіправа.Проблеми теорії держави і права: уавчальний посібник. 3-тє вид., змін. й доп. Тернопіль : Карт-бланш, 2002. 247 с.

9. Житний О.О. Просторові аспекти чинності національного кримінального закону: деякі проблеми регламентації. Вісник кримінологічної асоиіащії України. № 3(11). 2015. С. 59-69.
10. Закон України «Про житловий фонд соціального призначення» № 3334-IV від 12 січня 2006 року. URL: https://zakon.rada.gov.ua/laws/ show/3334-15.

11. Тимошук В.П. Адміністративні акти: процедура прийняття та припинення дії: Монографія. Київ : «Конус-Ю», 2010. 296 с.

In this article author made comprehensive study of the concept of the validity of law-enforcement acts of bodies and officials of local self-government. In addition, should admit, that one of the most important question about action of law and rules of law is installation theoretical and practical value it in Ukraine and abroad. That's why, first of all, we tried to explain the main territorial principles of validity of law-enforcement acts in time according to the direction of action and we tried to offer some ways to overcome collisions in the national law.

Should admit, that law-enforcement acts are so like administrative acts, which ending all case essentially. That's why, we tried to analyzed some another points, which consist most general principle about administrative acts. In this article we do research in our national law and in another side we do research in international law. In fact, you can see that some international principles are the same in Ukraine, and another is totally different.

Besides, today very often most of scientists adhere to an opinion that this problem isn't so actual in Ukraine. But we can't agree with that. That's why in this article we analyzed all legal principles of validity of law-enforcement acts according to the direction of their validity in Constitution of Ukraine and in European Charter of Local Self-Government of 15 October 1985. Therefore, the main point of this article is making one general principle of validity of law-enforcement acts according to the direction of their validity for our national law.

Key words: territorial principle of action, law enforcement act, action of acts of individual action, acts of organs of bodies and officials of local self-government. 
УДК 321.7

DOI https://doi.org/10.32849/2663-5313/2019.8.31

\section{Олег Олійник,}

канд. юрид.наук,

старший викладач кафедри права

факультету права та сочіально-інформачійних технологій

Миколаївського міжрегіонального інституту розвитку людини

Відкритого міжнародного університету розвитку людини «Україна»

\section{ХАРАКТЕРИСТИКА НЕГАТИВНОГО ВПЛИВУ НА ДЕМОКРАТІЮ В УКРАЇНІ}

У статті розкрито сучасні важелі негативного впливу на демократію в Украӥні. Визначено поняття демократії як сукупності керівних ідей, форм та особливостей управління в державі, за яких влада належить народові, тобто з використанням правових механізмів обов'язкової участі народу в державно-управлінських та суспільних процесах, з метою розвитку соиіального, політичного та культурного життя населення, приниипів правової держсави, забезпечення прав, свобод та інтересів осіб та суспільства в державі. Розкрито, що основними сучасними важелями негативного впливу на демократію в Украӥні є: 1) проведення військових дій на території України; 2) нестабільність політичного життя; 3) сочіально-економічна, політична, культурна криза; 4) часті порушення прав, свобод та законних інтересів осіб в українському суспільстві; 5) корупиія та відсутність ефективних антикорупиійних органів; 6) неефективна судова система; 7) неякісна інформаційна політика в державі, внаслідок чого триває гібридна війна; 8) низький розвиток локальної демократіі; 9) посягання на свободу слова, в тому числі посягання на життя та здоров'я журналістів, правозахисників та активістів, що пов'язані з професійною діяльністю; 10) недосконалість правового регулювання, несправедливі та негуманні правові норми або їх відсутність; 11) відсутність взаємозв'язку та сочіального діалогу між державою та громадськістю; 12) порушення у виборчих процесах; 13) переважання захисту інтересів більш фінансового-сталих верств населення, нерівність у суспільстві. Доведено, що важелі негативного впливу на демократію в Україні можна прибрати шляхом проведення ефективної державної політики у всіх сферах суспільства, припинення військових дій на території України, розвитку освіти та правосвідомості в суспільстві, дотримання приниипу рівності, створення тісного взаємозв'язку між державою та громадськістю, забезпечення захисту прав, свобод та законних інтересів осіб, особливо журналістів, активістів та правозахисників, та загалом формування демократії як форми народовладдя.

Ключові слова: демократія, інформаційна політика, народовладдя, політика, права, свободи, фактори впливу.

Постановка проблеми. Україна перебуває на складному етапі суспільного життя, що підкреслюється економічною, політичною та соціальною кризою. Революційні виклики в українському суспільстві зумовили необхідність проведення різноманітних реформ, які повинні забезпечити основні права, свободи та законні інтереси осіб у суспільстві. Реформи в Україні повинні проводитися з дотриманням провідної форми управління державою демократії. Основним суб'єктом демократії є народ, який обов'язково бере участь у суспільно-політичному житті держави.

Революція Гідності вказала, що диктаторський режим у правовій державі неможливий, українська демократія показала свою волю та змінила тодішню владу. Однак нині в Україні все-таки є проблеми в дотриманні демократії, пов'язані 3 несправедливістю в суспільстві, посяганнями на свободу слова та загальною незахищеністю осіб у суспільстві.

Таким чином, враховуючи проведення євроінтеграційних процесів в українському суспільстві, реформ у суспільному житті, необхідно комплексно дослідити негативні важелі впливу на демократію в Україні та розкрити шляхи їх уникнення.

Аналіз останніх публікацій. Проблеми забезпечення демократії в Україні досліджували такі науковці, як В. Береза, В. Богатирець, С. Власенко, М. Головатий, О. Громико, О. Долженков, В. Кривошеїн, Н. Латигіна та інші. Однак сучасна політична, економічна та соціальна нестабільність в Україні зумовлює необхідність дослідження важелів негативного впливу на демократію в Україні. 
Мета статті полягає в тому, щоб на основі теорії права, позицій юристів та сучасних публіцистичних джерел визначити сучасні важелі негативного впливу на демократію в Україні.

Виклад основного матеріалу. Для визначення важелів негативного впливу на демократію варто коротко охарактеризувати загальне поняття «демократія». Тлумачний словник визначає демократію (від грецької народовладдя, від народ і влада) як форму управління, політичний лад, при якому верховна влада належить народові; форму, принцип керівництва яким-небудь колективом, при якому забезпечується активність і широка участь цього колективу у здійсненні всіх заходів [2, с. 239]. Теорія демократії не має єдиного наукового джерела. Ї̈̈ витоки простежуються в працях теоретиків Античності (Платон, Арістотель, Перікл, Цицерон та ін.), Нового часу (Ш. Монтеск'є, Дж. Локк, Ж.-Ж. Руссо), великий внесок у iï становлення був зроблений батьками-засновниками США (Т. Джефферсон, А. Гамільтон, Д. Медісон, Дж. Джей, Б. Франклін). Сучасна демократична теорія представлена безліччю шкіл і напрямів, кожна з яких володіє солідною методологією і користується значним авторитетом серед певних сегментів наукової спільноти [14; 8, с. 221-229].

Щодо сучасних понять «демократія», то, наприклад, В. Береза вказує, що демократія є сутністю громадянського суспільства й основою держави, його становлення відбувається у тісному зв'язку зі становленням правової, соціальної, демократичної держави. Сутність демократії полягає у забезпеченні законних прав людини. Особа в такому суспільстві має гарантоване право вільного вибору нею тих чи інших форм економічного і політичного буття, ідеології, світогляду, а також можливість вільно висловлювати свої думки, обмінюватися поглядами [1, с. 151]. У політико-правовій теорії, як вказує Н. Латигіна, визначення поняття демократії має кілька вимірів, які виявляють іï сутність повною мірою: по-перше, демократія - це форма держави; по-друге, демократія - це форма плюралістичної організації громадянського суспільства і політичних партій, що репрезентують його інтереси, профспілок та інших громадських організацій; по-третє, демократія виступає як політичний світогляд і відповідний суспільно-політичний рух [11, с. 29].

М. Головатий переконує, що демократія може і розглядається фактично в трьох основних інтерпретаціях. Перша інтерпретація: демократія подається і пояснюється як народовладдя. Друга інтерпретація: демократія - це те, що пов'язане і характеризується відповідним державним влаштуванням. Йдеться про визнання народом джерела влади на принципах рівності і свободи. Третя інтерпретація демократії має місце тоді, коли йдеться про колективну діяльність усіх громадян, їхні рівні права та обов'язки в партії, об'єднанні, групі тощо. У найзагальнішому плані поняття «демократія» використовується як: а) характеристика історичних типів державно-політичного устрою; б) означення політичного процесу з відповідними методами і процедурами, що забезпечують участь народу в управлінні державою, всіма суспільними справами; стосовно організації та діяльності окремих політичних і соціальних структур у різних сферах суспільного життя [5, с. 32-33].

Таким чином, демократія як правове явище - це сукупність керівних ідей, форм та особливостей управління в державі, при якому влада належить народові, тобто з використанням правових механізмів обов'язкової участі народу в державно-управлінських та суспільних процесах з метою розвитку соціального, політичного та культурного життя населення, принципів правової держави, забезпечення прав, свобод та інтересів осіб та суспільства в державі.

Якщо звернутися до важелів негативного впливу на демократію, то для початку варто зазначити, що за роки незалежності в Україні прагнення до утвердження європейських демократичних цінностей перетворилося на фікцію, оскільки був відсутній діалог між владою та громадянським суспільством; відносини правлячої еліти й опозиції перетворилися на фарс, бо кожна сторона намагалася перетягнути увагу на себе, що посилювало делегітимізацію влади; влада й пересічні громадяни існували незалежно один від одного - вони нібито існували в паралельних світах. «Революція гідності» продемонструвала нездатність органів державної влади вести діалог із громадянським суспільством. Відмова керівництва держави від публічних обговорень та експертних консультацій у процесі ухвалення рішення про зміну євроінтеграційного стратегічного курсу України, грубе порушення прав і свобод людини і громадянина, застосування сили для врегулювання конфлікту інтересів спричинили загрозу існуванню України як конституційної держави. За таких умов відбулося згортання соціально-економічних реформ у тому числі у сфері місцевого самоврядування та розвитку локальної демократії. Нині під впливом Революції гідності відбувається трансформація політичної і правової культури як мас, так і правлячої еліти у бік європей- 
ських демократичних цінностей [9, с. 37-58].

Щорічний звіт міжнародної правозахисної організації Freedom House «Свобода у світі 2019» [12] вказує на зниження рівня глобальних політичних і громадянських свобод [13].

2019 року Freedom House визнала Україну «частково вільною» країною, а її окуповану Росією частину Крим - «невільною територією». Дослідники стверджують, що хоча наша країна і роком раніше була в такому статусі, рівень свобод у державі ще більше знизився. Це відбулося, зокрема, через такі ключові моменти 2018 року: 1. Правозахисні групи задокументували понад 50 нападів на активістів i правозахисників протягом перших 9 місяців року. Також мали місце жорсткі збройні напади на ромську меншину 3 боку націоналістичних угруповань. Розслідування цих випадків взагалі відбувалося тільки після значного тиску з боку суспільства. 2. Парламентарі і президент ухвалили законодавчі акти про створення Антикорупційного суду. Проте внутрішні і міжнародні спостерігачі висловили стурбованість процесом відбору 39 суддів, які повинні увійти до складу суду. 3. На Донбасі продовжилися нерегулярні бойові дії. Організація Об'єднаних Націй доповіла про загибель понад 3 тис. цивільних осіб від часу початку конфлікту в 2014 році. 4. У листопаді в 10 регіонах України було на 30 днів запроваджено воєнний стан після захоплення Росією 24-х українських моряків біля берегів Криму. Положення указу про воєнний стан призвели до обмеження свободи слова та зібрань, хоча їх і не було на практиці [12; 7].

Freedom House, як і десятки років до цього, вірить, що ситуацію зі свободою у світі можна змінити, якщо: - дотримуватися прав людини і закону щодо мігрантів та біженців; інвестувати у громадянську освіту; - заохочувати і захищати журналістів та свободу слова; - посилити заходи щодо захисту від іноземного впливу; - припиняти спроби порушення виборчого законодавства; - запроваджувати адресні санкції за порушення прав людини та корупцію; - створювати альянси 3 іншими демократичними країнами; - протистояти зловживанням міжнародних інститутів (маніпуляції Інтерполом, Радою ООН та ін.) [12; 7].

Синтезувавши основні причини деінституціоналізації демократії в Україні, С. Власенко визначив іï основні ризики, які вона має подолати для функціонування вітчизняної системи державного управління. До таких ризиків вчений відносить: фактичне відмежування громадськості від державної влади, що суттєво знижує ії легітимність, та несформованість демократії як форми народовладдя; бюрократизацію та олігархізацію, які утверджуються в результаті запровадження жорсткої ієрархічної системи державного управління; потужний вплив на процеси формування та реалізації державної політики найбільш вагомих фінансово-економічних груп суспільства, що призводить до зрощення бізнесу з органами державної влади; поширення в суспільстві тоталітарних тенденцій, унаслідок чого органи виконавчої влади перебирають на себе основні законодавчі ініціативи; зростання політичної нерівності у суспільстві, що позбавляе громадян можливості вільної участі у політичних та державно-управлінських процесах, а також суттєво розширює параметри свободи представницьких органів державної влади; політичне маніпулювання громадськістю з метою реалізації власних вузькокорпоративних інтересів [4, с. 131-137].

Щодо особливостей побудови демократії в Україні, то Н. Латигіна виокремлює такі проблеми: 1) демократичні зміни розпочалися на тлі несформованості багатьох передумов переходу до демократії: в економіці, соціальній сфері, культурі, політиці; 2) гетерогенність українського суспільства (структурованість за соціально-економічними, ідеологічними, етнічними, релігійними, регіонально-культурними, мовними ознаками, відмінності у зовнішньополітичних орієнтаціях тощо) ускладнює побудову стабільної демократії; 3) драматизм ситуації посилює те, що Україні необхідно одночасно розв'язувати два складних завдання: долати безліч негативних наслідків авторитарного минулого, розбудовуючи демократію, і одночасно вирішувати складні соціально-економічні проблеми; 4) безпорадність влади в умовах соціально-економічної кризи девальвує демократичні цінності і принципи владарювання в очах пересічних громадян; показником розчарування у демократії можна назвати тенденцію до «полівіння» електорату, зростаючу аполітичність молоді; 5) не сприяє зміцненню демократії і політична еліта, яка не спромоглася встановити між собою консенсус навіть заради визнання спільної та рівної зацікавленості в забезпеченні демократичних інститутів і виробленні спільної програми демократичних реформ; 6) відсутність всенародного обговорення комплексних проектів демократичних перетворень, нерозвиненість форм контролю за владою та посадовими особами відводить населенню роль пасивного спостерігача кулуарних зіткнень та соціально-економічних експериментів у суспільстві, посилюючи цим масове соціальне відчуження; 7) демократія форму- 
ється протягом тривалого часу, і брак в українському суспільстві реальних позитивних змін породжує масове соціальне нетерпіння, фрустрації [10, с. 53-62].

Таким чином, міжнародні незалежні громадські інституції, аналізуючи стан дотримання демократії в українському суспільстві, вказують на активні спроби підвищити рівень забезпечення демократії в країні, однак об'єктивні причини (війна на території України, зміни в політичному житті, олігархія, укорінена корупція) негативно впливають на дотримання прав, свобод та законних інтересів осіб в українському суспільстві.

Перехід до інформаційного суспільства передбачає системні зміни в соціальній, економічній, політичній, правовій, культурній структурі суспільства. 3 огляду на масштабність і глибину передбачуваних змін стає зрозумілим, що вони можуть бути здійснені тільки за умови активного сприяння органів державного управління, оскільки роль держави завжди полягає в координації всіх процесів, що стосуються суспільства. Разом із цим роль організатора реалізації проекту має належати не тільки органам державного управління, а й громадським організаціям, громадській ініціативі. В Україні всі ці процеси відбуваються хаотично, несистемно, інколи спонтанно та ситуаційно, ще й досі надзвичайно важливою проблемою, яка стоїть на заваді становлення е-демократії в Україні, є відсутність належного бюджетного фінансування [6, с. 42-47].

Також натепер недостатньо вивчено i конкретизовано структуру політичної системи суспільства, що, у свою чергу, породжує різні точки зору на роль масмедіа в цій підсистемі суспільства. Іншою передумовою для існування громадських 3МІ є правові гарантії й переваги, що формуватимуть умови діяльності таких медіа в суспільстві й забезпечуватимуть необхідний для функціонування справжньої демократії громадський контроль за владою, на противагу заангажованим ЗМІ (державним, партійним, приватним). Водночас поєднання грамотного правового регулювання і реального функціонування передбачає наявність розвинутого громадянського суспільства і високого рівня політичної культури [3, с. 12-16].

Таким чином, в умовах проведення інформаційної, гібридної війни на території України необхідно комплексно розвивати інформаційну політику держави, створювати механізми протидії пропагандистським закликам, відкрито, прозоро та публічно поширювати об'єктивну інформацію, всебічно захищати журналістів та активіс- тів від посягань на їхнє життя та здоров'я, пов'язаних із професійною діяльністю, розширювати громадський контроль як складник демократичного суспільства.

\section{Висновки}

Основними сучасними важелями негативного впливу на демократію в Україні є: 1) проведення військових дій на території України; 2) нестабільність політичного життя; 3) соціально-економічна, політична, культурна криза; 4) часті порушення прав, свобод та законних інтересів осіб в українському суспільстві; 5) корупція та відсутність ефективних антикорупційних органів; 6) неефективна судова система; 7) неякісна інформаційна політика в державі, внаслідок чого триває гібридна війна; 8) низький розвиток локальної демократії; 9) посягання на свободу слова, в тому числі посягання на життя та здоров'я журналістів, правозахисників та активістів, що пов'язані з професійною діяльністю; 10) недосконалість правового регулювання, несправедливі та негуманні правові норми або їх відсутність; 11) відсутність взаємозв'язку та соціального діалогу між державою та громадськістю; 12) порушення у виборчих процесах; 13) переважання захисту інтересів більш фінансового-сталих верств населення, нерівність у суспільстві.

Усі вищевказані важелі негативного впливу на демократію в Україні можна прибрати шляхом проведення ефективної державної політики у всіх сферах суспільства, припинення військових дій на території України, розвитку освіти та правосвідомості в суспільстві, дотримання принципу рівності, створення тісного взаємозв'язку між державою та громадськістю, забезпечення захисту прав, свобод та законних інтересів осіб, особливо журналістів, активістів та правозахисників, та загалом формування демократії як форми народовладдя.

\section{Список використаних джерел:}

1. Береза В. О. Поняття демократії і демократизації суспільства в сучасному політичному дискурсі. Науковий часопис НПУ імені М. П. Драгоманова. Серія 7 «Релігієзнавство. Культурологія. Філософія». 2015. Вип. 34. С. 143-151.

2. Білодід І.К. Словник української мови : в 11 т. Т. 2 : Г-Ж / ред. тому: П. П. Доценко, Л. А. Юрчук. Київ : Наук. думка, 1970 - 1980. 1971. $550 \mathrm{c}$.

3. Богатирець В. Вплив ЗМІ на демократичні трансформації та процес формування громадської думки. Історико-політичні проблеми сучасного свіmy. 2014. T. 27-28. C. 12-16.

4. Власенко С. Г. Основні причини та ризики деінституціоналізації демократії в Україні та 
шляхи їх подолання. Вісник Національної академіі державного управління при Президентові України. 2015. № 3. С. 131-137.

5. Головатий М. Ф. Демократія: історія, теорія, практика : навчальний посібник. Київ : ДП «Вид. дім «Персонал», 2011. 230 с

6. Громико О. I. Вплив е-демократії на трансформацію системи державного управління в Україні. Актуальні проблеми державного управління. 2016. № 2. С. 42-47.

7. Демократію вбивають 13-й рік поспіль: Чому це відбувається у світі та в Україні за версією Freedom House. 112: інформаиійний веб-сайт. 2019. URL: https://ua.112.ua/golovni-novyni/ demokratiiu-vbyvaiut-13-i-rik-pospil-chomutse-vidbuvaietsia-u-sviti-i-v-ukraini-za-versiieiufreedom-house-479786.html (дата звернення: 06.08.2019).

8. Долженков О. О. Сучасна демократія: проблеми та перспективи. Актуальні проблеми політики : зб. наук. пр. / редкол.: С. В. Ківалов (голов ред.), Л. І. Кормич (заст. голов. ред.), М. А. Польовий (відп. секр.) [та ін.]. Одеса : Фенікс, 2015. Вип. 54. С. 221-229
9. Кривошеїн В. В. Вплив «революції гідності» на політичну та правову культуру українського суспільства. Вісник Начіонального університету «Юридична академія Украӥни імені Ярослава Мудрого». Серія «Політологія». 2016. № 2. С. 37-58.

10.Латигіна H. А. Українська демократія сьогодні: спроби і помилки. Гуманітарний вісник Запорізъкої державної інженерної академї. 2008. Вип. 34. С. 53-62.

11. Латигіна Н. До визначення феномена демократії. Політичний менеджмент. 2004. № 3. C. $20-29$.

12. Freedom House: Democracy in Retreat. Freedom in the world 2019. Freedom House: oфiційний веб-сайт. 2019. URL: https://freedomhouse. org/sites/default/files/Feb2019 FH FITW 2019

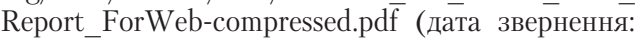
06.08.2019)

13. Freedom House: демократія продовжує свій «відступ». Радіо Собода: інформаційний веб-сайт. 2019. URL: https://www.radiosvoboda. org/a/29750546.html (дата звернення: 06.08.2019).

14. Held David. Models of Democracy. Stanford, California: Stanford University Press, 2006. 234 p.

The article reveals modern levers of negative influence on democracy in Ukraine. The concept of "democracy" is determined as a set of guiding ideas, forms and peculiarities of governance in a state in which the power belongs to the people, that is, with the use of legal mechanisms of compulsory participation of the people in state-management and social processes, with the aim of developing social, political and cultural life of the population the principles of the rule of law, the protection of the rights, freedoms and interests of individuals and society in the state. It is disclosed that the main modern levers of negative influence on democracy in Ukraine are: 1) conducting of military actions on the territory of Ukraine;2) the instability of political life;3) socio-economic, political, cultural crisis; 4) frequent violations of the rights, freedoms and legitimate interests of persons in the Ukrainian society; 5) corruption and lack of effective anti-corruption bodies; 6) ineffective judicial system; 7) inadequate information policy in the state, as a result of which there is a hybrid war; 8) low development of local democracy; 9) attacks on freedom of speech, including attacks on the life and health of journalists, human rights activists and activists related to professional activities; 10) imperfection in legal regulation, unfair and inhumane legal norms, or their absence; 11) the lack of interconnection and social dialogue between the state and the public; 12) violation in election processes; 13) predominance of protection of interests of more financially-stable segments of the population, inequality in society. It is proved that the levers of negative influence on democracy in Ukraine can be eliminated through effective state policy in all spheres of society, the cessation of hostilities in Ukraine, the development of education and legal awareness in society, respect for the principle of equality, the establishment of a close relationship between the state and the public, ensuring the protection of the rights, freedoms and legitimate interests of individuals, especially journalists, activists and human rights defenders, and, in general, the formation of democracy as a form of democracy.

Key words: democracy, information policy, democracy, politics, law, freedom, factors of influence. 
УДК 34.09

DOI https://doi.org/10.32849/2663-5313/2019.8.32

\section{Денис Тихомиров,}

канд. юрид. наук,

докторант докторантури та аспірантури

Начіональної академії внутрішніх справ

\section{ТЕОРЕТИЧНІ АСПЕКТИ ПРАВОВОГО ЗАБЕЗПЕЧЕННЯ БЕЗПЕКИ}

Стаття присвячена науковому осмисленню забезпечення безпеки та ї нормативно-правовому конструюванню. Поза межами уваги вчених часто залишаються деякі питання загальнотеоретичного дослідження співвідношення правового впливу, правового регулювання з правовим забезпеченням, правовою охороною та захистом. Саме тому метою иієї статті є осмислення окремих аспектів розуміння правового забезпечення як теоретичної та нормативно-правової конструкиії. Правове забезпечення безпеки аналізується у співвідношенні з такими загальнотеоретичними поняттями, як правовий вплив, правове регулювання, функиї права, та іншими. При и,ьому робиться спроба зіставити та співвіднести їх для виявлення їх взаємодії та взаємозв'язку між собою.

Незважаючи на значні здобутки вчених у розробиі питань правового впливу, правового регулювання, відповідних механізмів та процесів діі, поза межами уваги вчених залишилися деякі питання загальнотеоретичного дослідження їх співвідношення з правовим забезпеченням, правовою охороною та захистом. Тому метою статті є осмислення окремих аспектів розуміння правового забезпечення як теоретичної та нормативно-правової конструкиї.

Під час здійснення дослідження використовувались такі методи: порівняльний, герменевтичний, інтерпретаиійний, методи аналізу та синтезу та іниі.

Результатом дослідження є такі висновки:

- правове забезпечення безпеки є однією із форм забезпечення безпеки у разі поділу їх за критерієм сочіальної діяльності та теоретичною правовою конструкцією, що поєднує елементи правового впливу, регулювання, функиій права, механізму правового регулювання тощо;

- правове забезпечення безпеки досить близьке до правового регулювання, оскільки використовує ті самі правові засоби та має, по суті, схожу мету - відсутність загроз та правомірну поведінку, шо не порушує інтереси інших;

- розподіляючи функиї правового забезпечення безпеки, використовуючи схожість з правовим регулюванням виділяємо охоронну та регулятивну функиї, що, відповідно, можна вважати правовою охороною безпеки та правовим регулюванням безпеки.

Ключові слова: безпека, забезпечення безпеки, правове регулювання, правовий вплив, правове забезпечення, функції права.

Постановка проблеми. Забезпечення безпеки є одним з основних напрямів життєдіяльності будь-якого суспільства та особи. У сучасний період в Україні це питання значно актуалізувалося та є одним із пріоритетних та важливих напрямів діяльності держави. Незважаючи на значні здобутки дослідників з питань безпеки, залишається нерозв'язаною низка питань. Це пов'язано, зокрема, і з такими об'єктивним факторами, як зміна суспільних відносин, поява нових, зміна пріоритетів у діяльності держави тощо.

Огляд літератури. Теоретичну основу становлять праці таких учених, як: С. С. Алексєєв, Ю. В. Баулін, В. М. Горшенєв, П. М. Рабінович, Н. І. Козюбра, В. В. Копєйчиков, А. М. Колодій, В. В. Кузнецов, М. I. Мельник, О. Ф. Скакун, Т. І. Тарахонич та ін.
Незважаючи на значні здобутки вчених у розробці питань правового впливу, правового регулювання, відповідних механізмів та процесів дії, поза межами уваги вчених залишилися деякі питання загальнотеоретичного дослідження їх співвідношення з правовим забезпеченням, правовою охороною та захистом.

Метою цієї статті є осмислення окремих аспектів розуміння правового забезпечення як теоретичної та нормативно-правової конструкції.

Виклад основного матеріалу. Забезпечення безпеки. Значення розуміння безпеки полягає в тому, що його своєрідність у співвідношенні з іншими подібними поняттями впливає на тлумачення таких теоретичних конструкцій, як правове забезпечення безпеки, правове регулювання безпеки, правовий 
вплив на безпеку, правова охорона безпеки, правовий захист безпеки та інші, що зумовлює доцільність їх загальнотеоретичного аналізу в контексті таких фундаментальних понять загальної теорії держави та права, як правовий вплив, правове регулювання, дія права, функції права тощо, які були в минулому і є нині предметами наукового осмислення, стосовно яких існують різні думки вчених щодо їх інтерпретації, співвідношення, механізмів здійснення тощо.

Під забезпеченням безпеки у широкому сенсі, як стверджує В.Ф. Смолянюк стосовно національної безпеки України, доцільно розуміти «сукупність теоретико-методологічних, нормативно-правових, інформаційно-аналітичних, організаційно-управлінських, розвідувальних, контррозвідувальних, оперативнорозшукових, кадрових, науково-технічних, ресурсних та інших заходів, спрямованих на мінімізацію загроз і небезпек, гарантування розвитку національних інтересів, духовного і матеріального добробуту народу України та ефективного функціонування системи національної безпеки України» [1, с. 114-115], що спрямовані на створення достатніх умов для «збалансованого співіснування інтересів особи, суспільства і держави через моніторинг, діагностування, виявлення та ідентифікацію, запобігання й припинення, мінімізацію та нейтралізацію дії внутрішніх та зовнішніх загроз і небезпек. Реагування на загрози має бути адекватним не лише їх характерові та масштабам, а й рівню бажаного і можливого стану забезпечення національної безпеки» [1, с. 115].

Правове забезпечення безпеки. Такі та подібні інтерпретації забезпечення безпеки дає підстави її правове забезпечення розглядати, з одного боку, в полі соціально-гуманітарних наук як вид забезпечення безпеки, причому в контексті інших форм забезпечення безпеки: економічних, політичних, психологічних, інформаційних та інших, а 3 іншого - як правове поняття за допомогою таких теоретичних конструкцій, як правовий вплив, правове регулювання та функції права, та інших.

Правове забезпечення може класифікуватися за низкою чинників:

1) за територією поширення його компетенції: глобальне, міждержавне, національне;

2) за характером суспільних відносин, на регулювання яких воно спрямоване: у сфері освіти, у соціальні сфері; у сфері землекористування, у сфері комунікацій тощо;

3) за галузями права, залежно від механізмів правового регулювання: конституційно-правове, цивільно-правове, кримінально-правове, адміністративно-правове тощо [2, c. 498].
Правове забезпечення безпеки охоплює різні форми впливу права на суспільні відносини, що становлять сферу безпеки, для закріплення і розвитку суспільно-корисних відносин, а також попередження, протидії, припинення суспільно-небезпечних діянь, ліквідації їх наслідків, а правове регулювання на відміну від інших форм здійснюється за допомогою правових засобів і спрямоване не на всі суспільні відносини сфери безпеки, а тільки на ті, що входять до предмета правового регулювання.

Водночас неоднозначне розуміння вченими як правового впливу, так і правового регулювання призводить до плюралізму думок щодо їх співвідношення, що впливає й на розуміння правового забезпечення:

- одні вчені вважають, що більш об’ємним поняттям є правовий вплив, який охоплює як правове регулювання, так й інші види (форми) впливу права на суспільні відносини, наприклад такі, як ідеологічний, комунікативний, інформаційний тощо [3, с. 436];

- другі орієнтується на їх розрізнення, оскільки вони зорієнтовані на використання різних форм порядкування та відновлення суспільних відносин, наголошуючи, що між ними є спільне та відмінне [4, с. 21-27];

- треті не вбачають доцільності розрізнювати ці поняття, таким чином ототожнюючи ïx.

Інші вчені наголошують на домінуючому значенні дії права, вбачаючи, що це поняття охоплює правовий вплив і правове регулювання [5, с. 154].

3 огляду на таку плюралістичність розуміння цих понять та їх співвідношення, напевно, ця проблема не може мати лише один варіант її розв'язання [6, с. 6-9], особливо якщо врахувати, що різноманітність таких варіантів зумовлена й різноманітністю підходів до праворозуміння, зокрема інструментального, позитивістського, інституційного, природно-правового діяльнісного й інших [7].

Подальше осмислення правого впливу, правового регулювання в контексті їх співвідношення із забезпеченням безпеки, зокрема правовим, доцільно конкретизувати з використанням таких загальнотеоретичних конструкцій, як відповідні предмети, механізми та процеси.

За всієї знову-таки різноманітності інтерпретацій понять «механізм» і «процес» правового регулювання чи правового впливу більшість вчених дотримуються позиції, що поняття «механізм» відбиває більше статичні їх аспекти, «процес» - динамічні. Тому механізм - це сукупність (система) засобів правового регулювання чи впливу, 
а процес - послідовність їх дії. У механізмі правового регулювання виокремлюються правові засоби, а в механізмі правового впливу - як правові, так і позаправові [8].

Механізм правового регулювання складається переважно з таких спеціально-правових засобів, як норми права, юридичні факти, правові відносини (суб'єктивні права та кореспондуючі їм юридичні обов'язки), акти правозастосування та договори, акти реалізації суб'єктивних прав та юридичних обов'язків у вигляді правомірної поведінки.

Процес правового регулювання, який пов'язаний з механізмом останнього, поділяється на стадії - правотворчості, виникнення суб'єктивних прав та юридичних обов’язків, їх реалізації, факультативну стадію - правозастосування або індивідуалізації суб'єктивних прав та юридичних обов'язків, кожна 3 яких пов'язана 3 дією певних основних правових засобів відповідно до норм права, що сформульовані в нормативно-правових актах або нормативно-правових договорах, виникненням юридичних фактів та на підставі їх, а також норм права та у певних випадках актів застосування норм права чи договорів суб'єктивних прав та юридичних обов'язків, їх втіленням у суспільне життя, реалізацією у формі правомірної поведінки, що тягне за собою відповідні правові наслідки. Якщо реалізація суб'єктивних прав та юридичних обов'язків у вигляді правомірної поведінки не відбувається, а, навпаки, здійснюється протиправна поведінка, тобто виникають юридичні факти правопорушення, процес правового регулювання набуває конкретно-ситуативного охоронного (захисного) спрямування - відновлення порушених суб'єктивних прав та юридичних обов'язків, відшкодування нанесених збитків та покарання правопорушників. Причому процес правового регулювання регламентується процесуальними чи процедурними правовими нормами.

Оскільки правовий вплив, окрім правового регулювання, охоплює й інші форми дії права на суспільні відносини - виховну, ідеологічну, комунікативну, психологічну, ціннісно-орієнтуючу тощо [9, с. 16], кожна з них має властивий їй механізм і процес, які, однак, суттєво відрізняються від механізму і процесу правого регулювання.

Подібним чином і розрізнюються функції права, під якими розуміються як правило, основні напрями впливу права на суспільні відносини $[10$, с. 4] і які не існують ізольовано одна від одної, а тісно взаємопов'язані та утворюють систему функцій права [11, с. 27], серед яких виокремлюються загальні (ідеологічна, виховна, психологічна тощо) та спеці- альні функції права - регулятивна (статична та динамічна $[10$, с. $6 ; 12$, с. 88$]$ ) та охоронна [13, с. 15-19; 14]. Причому, на відміну від інтерпретацій спеціальних функцій права, відсутня єдність та чітка позиція науковців щодо поділу загальних функцій права [15].

Такий висновок підтверджує й аналіз співвідношення предметів правового впливу та правового регулювання. Стосовно предмета останнього більшість учених вважає, що право регулює не всі суспільні відносини [16, с. 19], оскільки вони впорядковуються всім комплексом соціальних норм (правових, моральних, політичних, економічних, естетичних та інших), а тільки ті з них, які за своїми властивостями можуть, а з позицій суспільних потреб та інтересів повинні бути врегульовані саме правовими засобами [17] Тоді як правовий вплив поширюється й на інші суспільні відносини [18, с. 62], а їх упорядкування здійснюється не тільки правовими засобами.

Зазначене дає підстави не ототожнювати, але й не розривати правовий вплив та правове регулювання. У разі ототожнення зникає своєрідність саме правового регулювання по відношенню до інших форм впливу на суспільні відносини, а розривання неможливе, оскільки правове регулювання, як й інші форми правового впливу, спрямоване на впорядкування суспільних відносини, але своєрідним чином.

Така діалектична єдність забезпечення присутності позитивного (безпечного) і відсутності негативного (небезпечного) у правовій сфері має значення не тільки для розуміння забезпечення безпеки, але й, що частіше аналізувалося в юридичній літературі, для забезпечення правопорядку та протидії злочинності. Якщо правопорядок та злочинність пов'язуються з правомірними та протиправними діяннями і тільки суб’єктів права, то безпека та небезпека охоплює не тільки такі діяння, але й діяння, що не регулюються правом (позаправові діяння), а також події, що не є діяннями. Частково такі складники безпеки та небезпеки охоплюються поняттям юридичних фактів, що за вольовою ознакою поділяються на діяння та події, але які тягнуть за собою правові наслідки, натомість діяння та події, що становлять обсяг безпеки та небезпеки можуть і не мати таких наслідків.

У такому ракурсі обсяг безпеки та небезпеки ширший, ніж обсяг предмета правового регулювання, оскільки містить і позаправові діяння та події, які є предметами регулювання моральних, економічних, політичних норм тощо, що зумовлює й необхідність інших (не тільки правових) форм забезпечення безпе- 
ки (ідеологічних, економічних, політичних та інших). Так, наприклад, правопорядок та злочинність охоплюються поняттями безпеки та небезпеки, а останні містять і явища та процеси, що не регулюються правом або на які право може впливати тим чи іншим чином або взагалі не впливати. Так, до небезпек належать діяння та події, які тягнуть за собою несприятливі наслідки; зокрема, в Кодексі цивільного захисту України небезпечна подія визначається як подія, у тому числі катастрофа, аварія, пожежа, стихійне лихо, епідемія, епізоотія, епіфітотія, яка за своїми наслідками становить загрозу життю або здоров’ю населення чи призводить до завдання матеріальних збитків [19].

Це зумовлює необхідність і доцільність виокремлення у сферах безпеки і небезпеки тих їх складників, що можуть і повинні регулюватися правом. У самому загальному вигляді можна зазначити, що, оскільки право регулює найбільш важливі суспільні відносини, як суспільно корисні, так і суспільно небезпечні, сфера безпеки та небезпеки охоплює як предмети правового регулювання та правового впливу, так й інші сфери суспільного життя (або предмети забезпечення безпеки - ідеологічного, економічного тощо).

Враховуючи зазначене, можна висловити думку, що в предметі правового регулювання (залишаючи за межами такого осмислення правовий вплив у цілому) можна виокремити предмети як регулятивних, так й охоронних функцій права, які є відповідно складниками предметів забезпечення безпеки і протидії небезпеці, що відповідає розумінням безпеки як нормального існування явищ і процесів та безпеки як відсутності загроз (небезпеки), а в такому варіанті безпека як нормальне існування явищ та процесів у межах правового регулювання забезпечується дозвільними та зобов'язуючими нормами права (регулятивна функція), а безпека як відсутність загроз (небезпеки) - забороняючими нормами (охоронна функція).

Це певною мірою пояснює особливості нормативно-правового формулювання безпеки та небезпеки (іх складників). Оскільки безпека та її складники забезпечуються всім масивом нормативно-правових актів регулятивної спрямованості, які й забезпечують нормальне існування та розвиток явищ та процесів, то й відсутня необхідність ix окремого визначення. Ця необхідність з'являється тоді, коли так чи інакше безпека пов'язується 3 потенційною чи наявною небезпекою (загрозами, ризиками тощо), іï захищеністю від небезпек тощо, причому безпека виникає й існує тоді, коли виникають і існують небезпеки.
Подібним чином можливо й інтерпретувати функції правового забезпечення безпеки, причому якщо загальні функції більше відбивають спільне 3 іншими формами забезпечення безпеки, то спеціальні функції права - саме своєрідність правового регулювання: регулятивні функції орієнтовані на створення умов для нормального існування суспільно-значущих явищ та процесів, а охоронні - на протидію небезпечним для них явищам та процесам (небезпекам), їх витіснення із суспільного життя, припинення їх існування, ліквідацію негативних наслідків.

\section{Висновки}

Отже, підводячи підсумок, можна стверджувати, що правове забезпечення безпеки є однією із форм забезпечення безпеки у разі поділу їх за критерієм соціальної діяльності та теоретичною правовою конструкцією, що поєднує елементи правового впливу, регулювання, функцій права, механізму правового регулювання тощо.

Правове забезпечення безпеки досить близьке до правового регулювання, оскільки використовує ті ж самі правові засоби та має, по суті, схожу мету - відсутність загроз та правомірну поведінку, що не порушує інтереси інших.

Розподіляючи функції правового забезпечення безпеки, використовуючи схожість із правовим регулюванням, виділяємо охоронну та регулятивну функції, що відповідно можна вважати правовою охороною безпеки та правовим регулюванням безпеки.

\section{Список використаних джерел:}

1. Смолянюк В. Ф. Системні засади національної безпеки України. Вісник Наміонального університету «Юридична академія України імені Ярослава Мудрого». 2018. № 2 (37). С. 107-126.

2. Савінова Н.А. Про сутність кримінальноправового забезпечення розвитку національного сегмента глобального інформаційного суспільства в Україні. Актуальні проблеми держави і права. 2010. C. $498-502$

3. Алексеев С. С. Общая теория права : в 2 т. Т. 2. Москва : Юрид. лит. 1982. 360 с.

4. Іщенко І. Проблеми співвідношення понять «правове регулювання і «правовий вплив» в сучасній теорії права. Юридична Україна. Теорія та історія держави і права. 2011. № 8. С. 21-27.

5. Гойман В.И. Действие права (методологический анализ) : монография. Москва, 1992. 180 с.

6. Васильева Н.В. К вопросу об идентичности понятий «правовое воздействие» и «правовое регулирование». Преемственности и новащии в юридической науке : материалы научной конференции адъюнктов и соискателей. 2009. Вып. 5. C. $6-9$ 
7. Шопіна I. М. Щодо концептуальних підходів до визначення поняття правового регулювання. Форум права. 2011. № 2. С. 1055-1061. URL: http://www.nbuv.gov.ua/e-journals/FP/20112/11simvpr.pdf

8. Скакун О.Ф. Теорія держави і права : підручник. Харків : Консум, 2001. С. 345. (дата звернення: 08.08.2019)

9. Тарахонич T.I. Механізм дії права, механізм правового регулювання, механізм реалізації права: особливості взаємодії. Держава і право. Серія «Юридичні і політичні науки». Київ : Ін-т держави і права ім. В. М. Корецького НАН України, 2010. Вип. 50. С. 11-17.

10. Заморська Л. І. Функції права: змістовнотеоретичний аналіз. Актуальні проблеми вітчизняної юриспрудениії. 2015. № 6. С. 3-9.

11.Зварич Р. В., Гривнак Б. Л. Регулятивна функція права у системі функцій права. Науково-інформачійний вісник Івано-Франківського університету права імені Короля Данила Галищького. Серія «Право». 2017. № 4(16). С. 20-28.

12. Сіньова Л.М. Теоретико-правові аспекти охоронної функціїправа соціальногозабезпечення.
Порівняльно-аналітичне право. 2016. № 2 . C. 87- 90 .

13. Ковальський В. Охоронна функція права: питання історичної обумовленості Юридична Украӥна. 2010. № 2. С. 15-19. URL http://nbuv.gov.ua/UJRN/urykr 201022 5. (дата звернення: 08.08.2019).

14. Ковальський В. Охоронна функція права : монографія. Київ : Юринком Інтер, 2010. 336 с.

15. Миронець О.М. Функції права: поняття та класифікація. Юридичний науковий електронний журнал. 2014. № 2. C. 15-17. URL: http://lsej.org. ua/2 2014/5.pdf (дата звернення: 08.08.2019).

16. Городецька I.A. Предмет правового регулювання: окремі аспекти. Науковий вісник Херсонського державного університету. 2014. Вип. 3 Toм 1. C. 17-21. URL: http://www.lj.kherson. ua/2014/pravo03/part_1/5.pdf (дата звернення: 08.08.2019)

17. Алексеев С.С. Теория права. Москва : БЕК, 1995. 320 c. C. 211.

18. Сильченко Н. В. Проблемы предмета правового регулирования. Государство и право. 2004 № 12. С. 61-64.

The article is devoted to the scientific understanding of security and its normative-legal construction. Outside the attention of scientists, often, there are some issues of general theoretical study of the correlation of legal influence, legal regulation with legal provision, legal protection and protection. That is why the purpose of this article is to comprehend the individual aspects of understanding the legal framework as a theoretical and legal construct. Legal security is analyzed in relation to such general theoretical concepts as legal influence, legal regulation, functions of law and others.Legal security is analyzed in relation to such general theoretical concepts as legal influence, legal regulation, functions of law and others.

At the same time, an attempt is made to compare and correlate them to reveal their interaction and interconnection.

In view of the considerable achievements of scientists in the development of issues of legal impact, legal regulation, relevant mechanisms and processes of action, outside the attention of scientists there are some issues of general theoretical study of their relationship with legal protection, legal protection and protection. Therefore, the purpose of the article is to comprehend the individual aspects of understanding the legal framework as a theoretical and normative-legal construct.

During the research, the following methods were used: comparative, hermeneutic, interpretation methods, methods of analysis and synthesis, and others.

The result of the study is the following conclusions:

- legal security is one of the forms of security in the case of their division according to the criterion of social activity and the theoretical legal structure, which combines the elements of legal influence, regulation, functions of law, the mechanism of legal regulation, etc.

- legal security is fairly close to legal regulation, since it uses the same legal means and has, in essence, a similar goal - the absence of threats and legitimate behavior that does not violate the interests of others.

- By distributing the functions of legal security, using a similar resemblance to legal regulation, a security and regulatory function is allocated, which can accordingly be considered legal protection of security and legal regulation of security.

Keywords: safety, security, legal regulation, legal influence, legal support, functions of law. 
УДК 340.13:341.64+305

DOI https://doi.org/10.32849/2663-5313/2019.8.33

\section{Тетяна Фулей,}

канд. юрид. наук, начальник відділу наукових досліджень проблем судочинства

та науково-методичного забезпечення суддівської освіти

Національної школи суддів України

\section{ЗАСТОСУВАННЯ ПРИНЦИПУ ГЕНДЕРНОЇ РІВНОСТІ У ПРАКТИЦІ ЄВРОПЕЙСЬКОГО СУДУ 3 ПРАВ ЛЮДИНИ}

Стаття присвячена характерним особливостям застосування приниипу гендерної рівності Європейським судом з прав людини. На підставі аналізу рішень Європейського суду з прав людини зазначається, шо кониепиія гендерної рівності як однієї з иілей Ради Європи застосовується ЄСПЛ з початку 1990-х років. Характеризуються підходи ЄСПЛ до розгляду справ, що стосувалися проблематики гендерної рівності: по-перше, крізь призму заборони дискримінаиії, тобто застосуванням статті 14 Конвениії про захист прав людини і основоположних свобод у поєднанні з іншими «субстантивними» статтями; по-друге, через розгляд скарг про стверджуване порушення прав, гарантованих іншими статтями Конвенції, без застосування статті 14 Конвениії. Окреслюється широке коло правовідносин, шо охоплюється сферами дї ст. 2 (право на життя), ст. 3 (заборона катування), . 3 (d) cm. 4 Конвенції (заборона примусової прачі), ст. 6 (право на справедливий суд), ст. 8 (право на повагу до приватного і сімейного життя), 9 (свобода думки, совісті і релігіï) та Першого протоколу до Конвенції (захист права власності), щодо яких заявники скаржилися на дискриміначію за ознакою статі. Наголошується, що гендерно чутливі ситуації ЕСПЛ аналізував з точки зору як дотримання негативних, так і виконання державами свойх позитивних зобов'язань за Конвениією. Автором за результатами аналізу рішень ЄСПЛ виявлено усталену практику Європейського суду з прав людини у справах, правовідносини у яких охоплюються щонайменше двома пріоритетними напрямами Стратегії гендерної рівності Ради Європи, а саме: запобігання насильству щодо жінок $i$ домашньому насильству та боротьба з иими явищами, а також запобігання гендерним стереотипам і сексизму та боротьба з такими явищами. Підкреслюється, що необхідність забезпечення гендерної рівності може розглядатися ЄСПЛ як правомірна мета і може слугувати належною підставою для втручання у здійснення деяких прав і свобод, закріплених у Конвениї. Водночас, щоб втручання не призводило до порушення Конвениії, воно має відповідати іншим критеріям трискладового тесту, зокрема законності та «необхідності в демократичному суспільстві».

Ключові слова: гендерна рівність, гендер, стать, практика ЄСПЛ, дискримінація, домашнє насильство, гендерні стереотипи, правомірна мета.

Постановка проблеми. Незважаючи на те, що досягнення гендерної рівності $є$ ключовим елементом у реалізації місії Ради Європи, суть якої - захищати права людини, підтримувати демократію та забезпечувати принцип верховенства права [1, п. 1, с. 5] аналіз ситуації в Україні, наприклад дослідження «Гендерна рівність і розвиток: погляд у контексті європейської стратегії України», проведене в 2016 році Центром Разумкова що $є$ авторитетним аналітичним центром (think tank) не лише в Східній Європі, але й у світі, засвідчив, що, попри реальну існуючу гендерну нерівність в українському суспільстві, проблема гендерної дискримінації не досить актуалізована в суспільній свідомості і має фоновий характер. Як чоловіки, так і жінки визнають загалом гірше становище жінок порівняно з чоловіками, але не оці- нюють це становище через призму гендерної нерівності [2, с. 208]. Водночас Україна має низку міжнародних зобов'язань, зокрема у рамках членства у Раді Свропи, стосовно впровадження принципу гендерної рівності. Це актуалізує потребу у дослідженнях різноманітних аспектів проблематики гендерної рівності, в тому числі застосування принципу гендерної рівності міжнародними юрисдикційними органами, яким є Європейський суд з прав людини (далі - ССПЛ).

Аналіз останніх досліджень та публікацій. На дисертаційному рівні окремі аспекти гендерної рівності в юридичних науках досліджували Н. В. Аніщук (правові засоби викорінення гендерного насильства в Україні: історико-теоретичний аналіз), О.Р.Дашковська (правове становище жінки в аспекті гендерної рівності: загальнотеоретичний 
аналіз), Т. С. Ганзицька (принципи права в механізмі забезпечення гендерної рівності в Україні), Ю. В. Івченко (філософсько-правовий аналіз гендерної політики в Україні), К. Б. Левченко (управління процесами формування гендерної політики в Україні (організаційно-правові аспекти), О. М. Руднєва (гендерна рівність у праві України). Питання міжнародно-правових стандартів гендерної рівності порушувалося у працях О. Р. Дашковської, Т. М. Мельник, О. О. Уварової, Г. О. Христової, К. І. Чижмарь. Водночас питання застосування Європейським судом 3 прав людини принципу гендерної рівності потребують подальшого наукового аналізу.

Мета статті - на підставі аналізу рішень ЄСПЛ, які стосувалися проблематики гендерної рівності, узагальнити характерні риси та особливості застосування принципу гендерної рівності Свропейським судом з прав людини.

Виклад основного матеріалу. Насамперед наголосимо, що приклади, коли ЄСПЛ у своїх рішеннях наголошує на забезпеченні гендерної рівності як однієї з цілей Ради Європи, є непоодинокими і мають щонайменше чверть столітню історію. Так, ще у 1993 році у рішенні у справі «Шулер-Цграгген проти Швейцарії» (Schuler-Zgraggen v. Switzerland), заява № 14518/89, оцінюючи аргументи, наведені в рішенні федерального страхового суду, а саме припущення про те, що жінки залишають роботу після народження дитини (а саме це припущення, на думку ЄСПЛ, становило єдину мотивацію рішення про відмову у задоволенні скарги заявниці про скасування виплати пенсії), ЄСПЛ наголосив на забезпеченні гендерної рівності у державах - членах Ради Свропи як одному 3 головних завдань. Щоправда, самого терміна «гендерна рівність» у той час у рішенні не було використано, натомість використано термін «рівність статей» (англ. equality of the sexes) [3, п. 67], так само як кілька років потому у подібній цитаті у рішенні у справі «Петровіч проти Австрії» (Petrovic v. Austria), заява № 20458/92 [4, п. 37]. Водночас вже на початку 2000 -х років у рішеннях Великої Палати використовуються терміни «гендерна рівність» та «принцип гендерної рівності», як це було, наприклад, у рішенні у справі «Лейла Шахін проти Туреччини» (Leyla ahin v. Turkey), заява № 44774/98 [5, п. 111]. У подальшій практиці ЄСПЛ принцип гендерної рівності отримав широке застосування, і враховуючи, що у відносно недавніх рішеннях, наприклад, у справі «Карвальйо Пінто де Соуса Мораіс проти Португалії» (Carvalho Pinto de Sousa Morais v. Portugal), заява № 17484/15, наголошуючи на гендерній рівності як одній з головних цілей Ради Європи, ЄСПЛ посилається на справу «Шулер-Цграгтен проти Швейцарії» [6, п. 46], це дозволяє зробити висновок, що йдеться про ту саму концепцію.

Доречно зауважити, що у національному законодавстві використовується термін «гендерна рівність» і наводиться його значення (у статті 1 Закону України «Про забезпечення рівних прав та можливостей жінок чоловіків» від 8 вересня 2005 року № 2866IV), однак при цьому не використовується термін «гендер», натомість «стать» та похідні (наприклад, «дискримінація за ознакою статі», «насильство за ознакою статі») [7].

Враховуючи, що огляд практики ЄСПЛ у справах, що стосуються гендерної рівності, уже здійснювався [8, с. 134-171], у цій статті узагальнимо характерні риси застосування принципу гендерної рівності Європейським судом з прав людини.

1. Справи, які стосувалися проблематики гендерної рівності, ЄСПЛ найчастіше розглядав крізь призму заборони дискримінації, тобто застосовуючи статтю 14 Конвенції про захист прав людини і основоположних свобод (далі - Конвенція) у поєднанні з відповідною «субстантивною» статтею Конвенції. Враховуючи, що стать є однією із захищених ознак, прямо згаданих у статті 14 Конвенції, ЄСПЛ розглядав такі справи, застосовуючи тест на дискримінацію. Зауважимо, що заявниками у таких справах були як жінки (справи «Шулер-Цграгген проти Швейцарії», «Емел Бойраз проти Туреччини», «S.A.S. проти Франції», «Карвальйо Пінто де Соуса Мораic проти Португалії» та ін.), так і чоловіки («Карлгайнц Шмідт проти Німеччини», «Ван Раалте проти Нідерландів», «Петровіч проти Австрії», «Константін Маркін проти Росії» та ін.), а також трансгендери («Крістін Гудвін проти Сполученого Королівства» (Christine Goodwin v. the United Kingdom) та ін.).

2. Проблематика гендерної рівності стосувалася широкого кола правовідносин, що охоплюються сферою дії багатьох статей Конвенції.

Так, заявники скаржилися на дискримінацію за ознакою статі, заборонену ст. 14 Конвенції, у поєднанні з такими статтями Конвенції:

- ст. 2 (право на життя) та ст. 3 (заборона катування) - у справах, пов'язаних з домашнім насильством («Опуз проти Туреччини» (Opuz v. Turkey), заява № 33401/02; «Беваква та С. проти Болгарії» (Bevacqua and S. v. Bulgaria), заява № 71127/01. та ін.);

- ст. 6 (право на справедливий суд) стосовно дотримання вимог справедливого 
суду у провадженнях, що стосувалися гендерно чутливих справ («Шулер-Цграгген проти Швейцарії» (Schuler-Zgraggen v Switzerland), заява № 14518/89; «Гарсія Матеос проти Іспанії» (Garcia Mateos v. Spain), заява № 38285/09 та ін.);

- ст. 8 (право на повагу до приватного сімейного життя) стосовно обов'язкової зміни прізвища після шлюбу ( «Унал Текелі проти Туреччини» (Ünal Tekeli v. Turkey), заява № 29865/96)); надання відпустки для догляду за дитиною («Константін Маркін проти Роciï (Konstantin Markin v. Russia) [Велика палата], заява № 30078/06); доступу до публічної служби (рішення у справі «Емел Бойраз проти Туреччини» (Emel Boyraz v. Turkey), заява № 61960/08); умов надання дозволу на проживання в країні для возз'єднання з партнером (рішення у справі «Абдулазіз, Кабалес та Балкандалі проти Сполученого Королівства» (Abdulaziz, Cabales and Balkandali v. the United Kingdom), заяви № 9214/80; 9473/81; $9474 / 81)$; визнання рішення іноземного суду про усиновлення для набуття статусу дитиною (рішення у справі «Вагнер та J.M.W.L. проти Люксембургу» (Wagner and J.M.W.L. v. Luxembourg), заява № 76240/01) та ін.;

- ст. 8 та ст. 9 (свобода думки, совісті та релігії) стосовно носіння в громадських місцях мусульманського одягу: хустки («Лейла Шахін проти Туреччини» (Leyla Sahin v. Turkey), заява № 44774/98; одягу, що приховує обличчя («S.A.S. проти Франції» (S.A.S. v. France), заява № 43835/11);

- ст. 1 Першого протоколу (право на мирне володіння майном) стосовно різноманітних платежів (податків, зборів), соціальних виплат та допомог, пенсійного забезпечення тощо ( «Ван Раалте проти $\mathrm{Hi}$ дерландів» (Van Raalte v. the Netherlands), заява № 20060/92; «Вілліс проти Сполученого Королівства» (Willis v. the United Kingdom), заява № 36042/97; «Стек та інші проти Сполученого Королівства» (Stec and Others v. UK) [Велика палата], заяви № 65731/01 та 65900/01 та інші; «Андрле проти Чеської Республіки» (Andrle v. The Chech Republic), заява № 6268/08 та ін.);

- п. 3 (d) ст. 4 Конвенції (заборона примусової праці) - рішення у справах «Карлгайнц Шмідт проти Німеччини» (Karlheinz Schmidt v. Germany), заява № 13580/88; «Зарб Адамі проти Мальти» (Zarb Adami v. Malta), заява № 17209/02.

3. Розгляд справ крізь призму заборони дискримінації - не єдиний спосіб розгляду Європейським судом з прав людини гендерно чутливих справ. Іноді заявники не подавали прямої скарги на дискримінацію і зазначали порушення прав, гарантованих іншими статтями Конвенції. Найчастіше скарги стосувалися статті 8 Конвенції, а тому ЄСПЛ обмежувався розглядом лише у цьому аспекті. Так, у справі «Коновалова проти Росії» (Konovalova v. Russia), заява № 37873/04, порушення ст. 8 Конвенції було визнано через присутність під час пологів студентівмедиків без згоди заявниці. Хоча у цій справі заявниця не скаржилася на гендерну дискримінацію, ця справа, безперечно, стосується гендерної проблематики та є гендерно чутливою.

Також непоодинокими $є$ випадки, коли ЄСПЛ розглядав справу спершу за «субстантивною» статтею Конвенції, наприклад, як це було у справах «Лейла Шахін проти Туреччини» та «S.A.S. проти Франції», а вже потім вирішував питання необхідності аналізувати наявність чи відсутність порушення за статтею 14 Конвенції. Наприклад, в обох справах не було визнано порушення статті 9 Конвенції (у справі «S.A.S. проти Франції» $Є C П Л$ розглядав заяву щодо статей 8 і 9 Конвенції разом, оскільки вона стосувалася одягу, призначеного для приховування обличчя), проте у першому випадку ЄСПЛ визнав, що немає необхідності розглядати справу за статтею 14 Конвенції, у другому - розглянув та встановив відсутність порушення.

4. Гендерно чутливі ситуації ССПЛ аналізував з точки зору як дотримання негативних, так і виконання державами своїх позитивних зобов'язань за Конвенцією.

Іноді в одній справі ЄСПЛ визнавав порушення Конвенції (щодо тієї самої чи різних статей) як щодо негативних, так і позитивних зобов'язань держави. Наприклад, у справі «V.C. проти Словаччини» (V.C. v. Slovakia), заява № 18968/07, яка стосувалася стерилізації жінки ромського походження без їі усвідомленої згоди, ССПЛ встановив порушення ст. 3 Конвенції, оскільки стерилізація становила значне втручання в репродуктивне здоров'я особи і мала у багатьох аспектах наслідки для її особистої недоторканності, в тому числі для її фізичного та психічного благополуччя і емоційного, духовного та сімейного життя. Тобто йшлося про невиконання негативних зобов'язань, про втручання у права, що гарантовані статтею 3 Конвенції, а отже є абсолютними, і втручання у які, на відміну, наприклад, від статті 8 Конвенції, не можуть бути виправдані «необхідністю в демократичному суспільстві». Водночас ЄСПЛ визнав також порушення ст. 8 Конвенції з огляду на відсутність гарантій, які би приділяли особливу увагу репродуктивному здоров'ю заявниці як жінки ромського походження, що свідчило про невиконання державою-відповідачем свого 
позитивного зобов'язання щодо забезпечення права на повагу до приватного і сімейного життя.

Серед інших рішень, у яких було констатовано невиконання державою позитивних зобов'язань за статтею 8 Конвенції, доречно виокремити справу «К.X. та інші проти Словаччини» (К.H. and Others v. Slovakia), заява № 32881/04, щодо ненадання особі можливості зробити копії її медичної документації, а також «Гьозюм проти Туреччини» (Gözüm v. Turkey), заява № 4789/10, яка стосувалася права одинокої прийомної матері на зазначення свого імені в документах на усиновлену дитину.

У кількох справах, пов'язаних із домашнім насильством (наприклад, «Опуз проти Туреччини» (Opuz v. Turkey), заява № 33401/02, «Беваква та С. проти Болгарії» (Bevacqua and S. v. Bulgaria), заява № 71127/01. та ін.), ССПЛ визнав несумісним $з$ позитивними зобов'язаннями держави забезпечити повагу до прав заявників, гарантованих Конвенцією, ставлення національних уповноважених органів до таких справ як до «приватних», неможливість національних органів застосувати санкції до кривдника та захистити жертву. У рішенні у справі Опуз проти Туреччини» (Opuz v. Turkey), заява № 33401/02, у якому було констатовано порушення ст. 2, 3 та 14 Конвенції, ССПЛ вперше визнав, що гендерне насильство $€$ формою дискримінації та дав характеристику зобов'язань держави у зв'язку з насильством у сім'ї, визнавши серйозність проблем домашнього насильства в Свропі, а також проблем, що виникають через латентність та нереагування на це правопорушення з боку уповноважених державних органів. Уперше в своєму рішенні ЄСПЛ наголосив, що насильство в сім'ї не $є$ приватною чи сімейною справою, а питанням, що стосується суспільних інтересів, що, у свою чергу, вимагає ефективних дій з боку держави. Суд також зазначив, що не досить мати закони щодо протидії домашньому насильству - більш важливою $є$ наявність ефективних механізмів реалізації таких дій. ССПЛ установив, що кримінальне право не справляло адекватного стримуючого ефекту, здатного забезпечити ефективне запобігання насильству щодо жінок, і що пасивність з боку поліції та прокуратури у відповідь на скарги жертв насильства була дуже поширеним явищем, і зазначив, що безвідповідальність судової системи та безкарність кривдників засвідчують, що зобов'язання вжити належних заходів для вирішення проблеми насильства в сім'ї не було виконане належним чином.

5. ЄСПЛ неодноразово застосовував принцип гендерної рівності у справах, право- відносини в яких охоплюються щонайменше двома пріоритетними напрямами Стратегії гендерної рівності Ради Свропи.

Так, боротьба 3 насильством щодо жінок і домашнім насильством та запобігання цим явищам є однією зі стратегічних цілей Ради Європи, досягненню якої буде приділятися значна увага найближчими роками. Як наголошується у Стратегії гендерної рівності Ради Європи на 2018-2023 роки, «насильство щодо жінок і домашнє насильство залишаються поширеним явищем у всіх державахчленах Ради Свропи та має руйнівні наслідки для жінок, суспільства та економіки. Конвенція Ради Свропи про запобігання насильству щодо жінок і домашньому насильству та боротьбу із цими явищами (Стамбульська конвенція) отримала широке визнання як найбільш всеосяжна міжнародна угода для боротьби з таким серйозним порушенням прав людини жінок. Важливі заходи безпеки також викладено в Європейській конвенції з прав людини та відповідній судовій практиці» [1, п. 46, с. 22].

Ще однією стратегічною ціллю Ради Свропи є запобігання гендерним стереотипам і сексизму та боротьба з такими явищами, і ЄСПЛ неодноразово висловлювався з цього приводу. На цьому варто наголосити, оскільки саме гендерні стереотипи є серйозною перешкодою для досягнення реальної гендерної рівності, вони призводять до дискримінації за ознакою статі. [1, п. 38, с. 18] Як показує практика ЄСПЛ, стереотипні уявлення, які $\epsilon$ результатом і причиною глибоко вкорінених ставлень, цінностей, норм і упереджень, можуть бути покладені в основу мотивації рішень національних органів, у тому числі судів, зокрема, у традиційних патріархальних суспільствах. Найбільш відоме у цьому плані рішення Великої палати у справі «Константін Маркін проти Pociï» (Konstantin Markin v. Russia), заява № 30078/06, проте розлогу оцінку негативному впливу стереотипів ЄСПЛ дав також у справах «Карвальйо Пінто де Соуса Мораіс проти Португалії» $[6$, п. 46, 54] та «S.A.S. проти Франції» [9, п. 149].

6. Необхідність забезпечення гендерної рівності, на думку ССПЛ, є легітимною метою і може слугувати належною підставою для втручання у здійснення деяких прав i свобод, закріплених у Конвенції [9, п.119]. Наприклад, у справі «S.A.S. проти Франції» ЄСПЛ зазначив, що «Договірна держава, яка заради забезпечення гендерної рівності забороняє будь-кому примушувати жінок приховувати свої обличчя, намагається таким чином досягти мети, яка відповідає інтересам «захисту прав і свобод інших осіб» у зна- 
ченні других пунктів статей 8 і 9 Конвенції» [9, п.119], а, оцінюючи намагання Уряду довести, що носіння паранджі деякими жінками шокує більшість населення Франції, оскільки порушує загальноприйнятий у Франції принцип рівності чоловіків і жінок, ССПЛ виходив зі своєї позиції щодо двох інших цінностей, на які послався Уряд Франції, а саме принципу «жити разом» та важливої ролі, яке відіграє обличчя у соціальній взаємодії.

Таким чином, можемо зробити висновок, що необхідність забезпечення гендерної рівності може розглядатися як правомірна мета, для досягнення якої можуть встановлюватися певні обмеження, тобто вона може слугувати належною підставою для втручання у здійснення деяких прав і свобод, закріплених у Конвенції. Проте виправданість такого втручання оцінюватиметься Європейським судом 3 прав людини 3 точки зору інших критеріїв трискладового тесту, і щоб втручання не призводило до порушення Конвенції, воно має відповідати усталеній практиці ЄСПЛ щодо законності та «необхідності в демократичному суспільстві».

\section{Висновки}

На підставі проведеного дослідження можна зробити висновки, що концепція гендерної рівності як однієї з цілей Ради Європи застосовується ЄСПЛ уже понад чверть століття. Справи, які стосувалися проблематики гендерної рівності, ЄСПЛ найчастіше розглядав крізь призму заборони дискримінації, тобто застосовуючи статтю 14 Конвенції у поєднанні з багатьма статтями Конвенції, сферою дії яких охоплювалося широке коло правовідносин щодо права на життя, заборони катування, права на справедливий суд, права на повагу до приватного і сімейного життя, свободи думки, совісті і релігії, заборони примусової праці, захисту права власності. Гендерно чутливі ситуації ЄСПЛ аналізував з точки зору як дотримання негативних, так і виконання державами своїх позитивних зобов’язань за Конвенцією. За результатами аналізу рішень ЄСПЛ виявлено усталену практику Європейського суду з прав людини у справах, правовідносини в яких охоплюються щонайменше двома пріоритетними напрямами Стратегії гендерної рівності Ради Європи, а саме: боротьба 3 насильством щодо жінок і домашнім насильством та запобігання цим явищам, а також запобігання гендерним стереотипам і сексизму та боротьба 3 такими явищами. Необхідність забезпечення гендерної рівності може розглядатися Свропейським судом з прав людини як правомірна мета, що може слугувати належною підставою для втручання у здійснення деяких прав і свобод, закріплених у Конвенції. Водночас виправданість такого втручання ССПЛ оцінює у світлі інших критеріїв трискладового тесту, зокрема законності та «необхідності в демократичному суспільстві».

\section{Список використаних джерел:}

1. Стратегія гендерної рівності Ради Свропи на 2018-2023 роки. URL: https://rm.coe.int/prems041318-gbr-gender-equality-strategy-2023-ukrnew2/16808b35a4 (дата звернення: 04.08.2019).

2. Гендерна рівність і розвиток: погляд у контексті європейської стратегії України. Київ, 2016. 244 c. URL: http://razumkov.org.ua/upload/ Gender-FINAL-S.pdf (дата звернення: 04.08.2019).

3. Шулер-Цграґген проти Швейцарії (SchulerZgraggen v. Switzerland) : рішення ЄСПЛ у справі від 24.06.1993, заява № 14518/89. URL: http:// hudoc.echr.coe.int/eng?i=001-57840 (дата звернення: 04.08.2019).

4. Петровіч проти Австрії (Petrovic v. Austria) : рішення ЄСПЛ від 28.02.1998, заява № 20458/92. URL: http://hudoc.echr.coe.int/ eng?i=001-58146 (дата звернення: 04.08.2019).

5. Лейла Шахін проти Туреччини (Leyla Şahin v. Turkey) : рішення ЄСПЛ від 10.11.2005, заява № 44774/98. URL: http://hudoc.echr.coe.int/ eng?i=001-70956 (дата звернення: 04.08.2019).

6. Карвальйо Пінто де Соуса Mораiс проти Португалії (Carvalho Pinto de Sousa Morais v. Portugal) : рішення ЄСПЛ від 25.07.2017, заява № 17484/15. URL: http://hudoc.echr.coe.int/ eng?i=001-175659 (дата звернення: 04.08.2019).

7. Про забезпечення рівних прав та можливостей жінок і чоловіків : Закон України від 08.09.2005 № 2866-IV / Верховна Рада України. URL: https://zakon.rada.gov.ua/laws/ show/2866-15 (дата звернення: 04.08.2019).

8. Фулей T.I. Гендерна рівність при здійсненні правосуддя. 2-ге вид., випр. Київ : ВАITE, 2016. $180 \mathrm{c}$.

9.S.A.S. проти Франції(S.A.S.v. France):рішення ЄСПЛ від 01.07.2014, заява № 43835/11. URL: http://hudoc.echr.coe.int/eng?i=001-145466 (дата звернення: 04.08.2019).

The article is devoted to the principle of gender equality in the ECtHR case-law. Since early 1990s, the European Court of Human Rights reiterates that the advancement of gender equality is a major goal for the member States of the Council of Europe. Two approaches that has been used by ECtHR to examine applications on alleged violation of the European Convention of Human Rights in gender sensitive case are distinguished - the first is under Article 14 (prohibition of discrimination) of the Convention taken in conjunction with relevant substantive Article, the second is under any relevant Article of the Convention, taken separately, without the above-mentioned Article 14. On the results of the analysis of the ECtHR case-law in gender 
sensitive cases the author concluded that principle of gender equality applied to variety of cases where applicants - men, women and transgender persons - complained about violation of Article 14 of the Convention taken in conjunction with relevant substantive article, i.e. Art. 2 (right to life), Art. 3 (prohibition of torture), Art. 4 para. 3 (d) (prohibition of forced labour), Art. 6 (right to a fair trial), Art. 8 (right to respect for private and family life), Art. 9 (freedom of thoughts, conscience and religion) Article 1 of Protocol No. 1 (protection of property); the Court assesses the parties' submissions not merely from the point of view whether the State is to abstain from arbitrary interference by public authorities. In addition to this primarily negative undertaking, there may be positive obligations so the Court may find it appropriate to analyze a case from the angle of the State's positive obligations. It is emphasized on at least two strategic areas covered by the ECtHR case-law, i.e. preventing and combating violence against women and domestic violence and preventing and combating gender stereotypes which has been listed among strategic objectives of the Council of Europe gender equality strategy. The author stressed that the ECtHR is of the view that it does not doubt that gender equality might rightly justify an interference with the exercise of certain rights and freedoms enshrined in the Convention, however a limitation or interference will not be compatible with the Convention unless it is "prescribed by law" and is "necessary in a democratic society" to achieve the legitimate aim or aims concerned.

Keywords: gender equality, gender, sex, ECtHR case-law, discrimination, domestic violence, gender stereotypes, legitimate aim. 
УДК 343.222.4:343.347

DOI https://doi.org/10.32849/2663-5313/2019.8.34

\section{Олександр Берило,}

канд. юрид.наук,

викладач кафедри професійних та спещіальних дисциплін

Херсонського факультету

Одеського державного університету внутрішніх справ

\section{КРИМІНАЛЬНЕ ЗАКОНОДАВСТВО ЗАРУБІЖНИХ КРАЇН ПРО ВІДПОВІДАЛЬНІСТЬ ЗА НЕНАДАННЯ ДОПОМОГИ ХВОРОМУ МЕДИЧНИМ ПРАЦІВНИКОМ}

Актуальність теми дослідження визначається гостротою проблеми якості надання медичних послуг співробітниками відповідних установ України під час здійснення ними своїх професійних обов'язків. Ця проблема є загальносвітовою, оскільки існують поодинокі випадки неякісного медичного обслуговування або взагалі ненадання допомоги хворому медичним прачівником майже у всіх країнах світу. Отже, питання вказаної проблематики потребують вирішення на державному рівні. Впроваджувати новаиї та вдосконалювати вітчизняне законодавство у відповідній сфері не можливо без вивчення зарубіжного законодавства. Питання, пов'язані з кримінально-правовою характеристикою ненадання допомоги хворому медичним прачівником, $є$ складними за суттю й актуальними не лише для кримінального законодавства України, а й для держав пострадянського та європейського простору. Вказана проблематика для України зростає особливо в умовах реформачійних процесів системи охорони здоров'я в Україні та чинного кримінального законодавства.

Конкретну міру покарання за злочинне протиправне діяння призначають за загальним правилом в межах відповідної санкиї (вони покликані захищати суспільство, відображаючи ступінь морального осуду щодо осіб, які вчинили злочини). Призначення покарання об'єктивного та достатнього залежить від побудови санкції кримінально-правової норми Особливої частини КК України.

Санкиія - ие частина статті Особливої частини Кодексу, яка встановлює вид і розмір покарання за злочин, вказаний у диспозииії статті [119].

Відповідно до чинного кримінального законодавства є два види кримінально-правових санкиій: 1) відносно визначена санкція, яка передбачає покарання лише одного виду і в конкретних межах, вказуючи або не вказуючи його нижню межу, але із зазначенням його верхнвої межі; 2) альтернативна санкиія, що передбачає два та більше видів основного покарання, з яких суд може призначити лише одне.

Ключові слова: тяжкі тілесні ушкодженння, небезпечний для життя стан, смерть хворого, бездіяльність, невтручання, суспільно небезпечні наслідки, медичний співробітник.

Постановка проблеми. Для того, щоб належним чином проаналізувати дію та зміст будь-якої кримінально-правової норми, слід порівняти іiї із зарубіжним законодавством країни $з$ відповідною системою права. Це дасть змогу розширити бачення можливих моделей іiї конструкції. Правотворчим вітчизняним традиціям щодо встановлення відповідальності за злочини, учинені медичними працівниками, загалом відповідає кримінальне законодавство зарубіжних країн, у чому переконує порівняльно-правовий аналіз відповідних кримінальноправових норм, хоча, звісно, в законодавстві тих чи інших країн $\epsilon$ певна специфіка. Дану проблематику було розглянуто такими вітчизняними та зарубіжними вченими, як В. І. Акопов, В.В. Балабко, Ф. Ю. Бердичевський, В.О. Глушков, І.В. Івшин, М.І. Ковальов, А.І. Коробєєв,
Я.О. Миц, С.П. Мокринський, А.А. Мохов, I.О. Нікітіна, О.В. Родін, А.Н. Савицька, I.А. Сенюта, С.Г. Стеценко, С.В. Фесенко, С.А. Химченко, Г.В. Чеботарьова, О.В. Червоних, М.Д. Шаргородський, А.Н. Язухін та інші.

Метою статті $\epsilon$ порівняльно-правове дослідження кримінального законодавства зарубіжних країн у частині кримінальної відповідальності за ненадання допомоги хворому медичним працівником. 3 метою досягнення вказаної мети варто сформулювати та обгрунтувати вихідні положення, на яких й базуватиметься дослідження, що у підсумку дасть змогу сформувати певні пропозиції щодо ефективних змін чинного кримінального законодавства в цій сфері.

Виклад основного матеріалу. Метод порівняння завжди був в арсеналі методології науки 
кримінального права. Особливо затребуваним нині він $є 3$ огляду на те, що сьогодні відмова від вузькокласового підходу в порівняльно-правових дослідженнях передбачає ознайомлення з позитивним досвідом, накопиченим у зарубіжному кримінальному праві, а отже, можливість його використання (звісно, не механічного) у вітчизняних умовах [1, с. 34-35]. Розвиток сучасного кримінального законодавства України передбачає імплементацію норм міжнародного законодавства та 3 розвитком кримінального законодавства багатьох країн в умовах глобалізації дасть змогу успішно гармонізувати КК України 3 кримінальним законодавством сучасної Європи.

Порівняльно-правове дослідження кримінального законодавства зарубіжних країн у частині кримінальної відповідальності за ненадан ня допомоги хворому медичним працівником вимагає сформулювати та обгрунтувати вихідні положення, на яких саме й базуватиметься дослідження та дасть змогу сформувати певні пропозиції щодо ефективних змін чинного кримінального законодавства в цій сфері. Першим серед них $є$ аргументоване вище положення щодо необхідності й доцільності дослідження особливостей кримінальної відповідальності за ненадання допомоги хворому медичним працівником саме за законодавством країн континентальної Європи та країн, які раніше входили до складу СРСР. Важливо й те, що в аспекті дослідження кримінальної відповідальності за ненадання допомоги особі ми не розділяємо законодавство цих країн на окремі підгрупи. Кримінальне законодавство зарубіжних країн ми досліджуємо в контексті порівняння 3 нормами вітчизняного кримінального права, що дасть змогу сформулювати висновки про наявність чи відсутність у КК України відповідних положень, що стосуються кримінальної відповідальності за ненадання допомоги хворому медичним працівником.

На думку В.В. Балабко, КК України із розглядуваної проблематики має більше спільного 3 кримінальним законодавством постсоціалістичних країн Східної Європи та СНД, ніж країн Балтії, Західної та Центральної Європи та азійсько-тихоокеанського регіону [2, с. 46-47]. Так, згідно з твердженням авторки у більшості цих країн, як і в Україні, передбачено відпові дальність за невиконання лікарем своїх професійних обов'язків, проведення незаконного аборту, ненадання медичним працівником допомоги хворому, розголошення конфіденційної інформації медичним працівником, незаконну трансплантацію або примушування до вилучення органів чи тканин людини. Водночас якщо відповідальність за вчинювані медичними працівниками злочини, які посягають на життя та здоров'я особи, у нашій державі передбачені в межах одного розділу Особливої частини КК України, то в законодавстві зарубіжних країн ситуація $є$ інакшою [2, с. 47].

Кримінальне законодавство щодо відповідальності за ненадання допомоги хворому медичним працівником інших країн ближнього зарубіжжя суттєво різниться.

У ст. 161 КК Білорусі передбачено кримінальну відповідальність за ненадання допомоги хворому медичним працівником без поважних причин особою, яка займається медичною або фармацевтичною практикою, або іншою особою, яка зобов'язана її надати відповідно до закону або за спеціальним правилом. Те саме діяння, яке спричинило через необережність смерть хворого або тяжке тілесне ушкодження, карається згідно 3 ч. 2 зазначеної статті.

Варто зазначити, що і за КК України, і за КК Білорусії основний склад злочину ненадан ня допомоги хворому медичним працівником $\epsilon$ формальним. Своєю чергою настання наслідків у вигляді смерті хворого чи заподіяння йому тяжкого тілесного ушкодження $є$ кваліфікованим складником цього протиправного діяння. При цьому під час характеристики суб'єктивної сторони не виділяється умисної форми вини щодо наслідків, отже, фактично медичний працівник їх не усвідомлює.

Схоже формулювання ненадання допомоги хворому медичним працівником передбачається у КК Грузії (ст. 130), КК Республіки Болгарія (ст. 141) [3], КК Республіки Сан-Марино (ст. 379) [7].

Кримінальні кодекси країн СНД - Азербай джану (ст. 142), Республіки Казахстан, Киргизької Республіки (ст. 119, ст. 120) [6], Латвійської Республіки (ст. 138), Таджикистану, Узбекистану, Естонської Республіки (ст. 126) - передбачають кримінальну відповідальність за ненадання допомоги хворому лише за умов настання тяжких наслідків або смерті.

Таким чином, зарубіжний законодавець забезпечує кримінально-правову охорону належного надання допомоги хворому за допомогою таких прийомів:

1) об'єктом підвищеної кримінально-правової охорони є суспільні відносини у сфері забезпечення життя та здоров'я особи під час виконання або у зв'язку з виконанням професійних обов'язків медичними працівниками;

2) виокремлення спеціального потерпілого - хворого, тобто особи, яка потребує медичної допомоги;

3) конструювання складу злочину як матеріального 3 огляду на необхідність настання суспільно небезпечних наслідків, або загроза настання тяжких наслідків чи смерті, або реальне настання таких тяжких наслідків чи смерті;

4) суб'єктом злочину $\epsilon$ безпосередньо медичний працівник або особа, що займається 
медичною або фармацевтичною практикою у зв'язку з виконанням професійних обов'язків i наявністю спеціального обов'язку надавати медичну допомогу відповідно до закону або спеціальних правил;

5) необхідність встановлення прямого умислу та завідомості щодо настання суспільно небезпечних наслідків як ознаки суб'єктивної сторони досліджуваного злочину;

6) використання однотипних кваліфікуючих ознак, пов'язаних із настанням тяжких наслідків або смерті потерпілого.

У ст. 141 КК Республіки Болгарія [3] передбачено відповідальність за ненадання допомоги хворому. Відповідно до ч. 1 цієї статті за ненадання допомоги без поважних причин особу, що займається медичною практикою та яку викликали до хворого чи породіллі, карають виправними роботами або штрафом до трьох левів. Якщо винному було відомо, що хворий або породілля перебували в небезпечному для життя стані, то, відповідно до ч. 2 цієї статті, карання передбачає позбавлення волі до одного року або виправні роботи. У ч. 3 цієї статті закріплено кримінальну відповідальність за ненадання допомоги хворому без поважних причин [3].

Зі змісту норми слідує, що потерпілим від зазначеного злочину, на відміну від ст. 139 КК України, $\epsilon$ не лише хвора особа, але й породілля.

Загалом у кримінальному законодавстві багатьох зарубіжних країн як пострадянського простору, так і європейських країн існують спеціальні норми про відповідальність за ненадан ня допомоги хворому медичним працівником.

Кримінальні кодекси багатьох зарубіжних країн, аналогічно як і КК України, містять норми, які передбачають кримінальну відповідальність за ненадання допомоги хворому медичним працівником. Однак слід зазначити, що зміст та структура зазначених норм суттєво відрізняються від злочину, передбаченого ст. 139 КК України. Наприклад, відповідальність за аналогічні діяння за кримінальним законодавством Австрії, Данії та Нідерландів регулюється не нормою, а подекуди цілими розділами.

Так, спеціальна норма, яка в тому чи іншому вигляді передбачає відповідальність за ненадання допомоги особі, закріплена в КК Австрійської Республіки, Азербайджанської Республіки, Грузії, Королівства Данія, Королівства Іспанія, Королівства Нідерландів, Латвійської Республіки, Республіки Білорусь, Республіки Болгарія, Республіки Вірменія, Республіки Казахстан, Республіки Молдова, Республіки Польща, Республіки Таджикистан, Російської Федерації, Федеративної Республіки Німеччина, Французької Республіки, Швейцар ської Конфедерації та Пенітенціарному кодексі Естонської Республіки $[3 ; 4 ; 5 ; 6 ; 7 ; 8]$.
Особливості їх розміщення в системі кримінального законодавства зарубіжних країн $\epsilon$ досить подібними, оскільки досліджувані норми переважно розташовані в главах (розділах) особливих частин КК, що передбачають відповідальність за посягання на життя і здоров'я особи. Однак такий варіант розміщення вказаних норм у системі кримінального законодавства зарубіжних країн, хоча i $є$ найбільш поширеним, проте не єдиним варіантом. У всіх спеціальних нормах законодавства зарубіжних країн, які передбачають кримінальну відповідальність за «загальний вид» ненадання допомоги особі (хворому), конкретизовано, що ненадання такої допомоги має стосуватися особи, яка її потребує, тобто особи, яка перебуває в загрозливому для життя чи здоров'я стані [9, с. 165-169].

Таким чином, законодавством зарубіжних країн встановлено основні правові засади правової охорони осіб від ненадання допомоги хворому медичним працівником. Аналіз законодавства засвідчує узгодженість більшості правових актів України та зарубіжних країн, проте наявні й певні особливості. По-перше, джерела кримінального права зарубіжних країн здебільшого передбачають більш сувору кримінальну відповідальність за ненадання допомоги хворому медичним працівником, ніж КК України. По-друге, у всіх країнах є спеціальні норми про відповідальність за ненадання допомоги хворому медичним працівником. По-третє, на конструкцію законодавства стосовно досліджуваної кримінально правової норми тієї чи іншої країни впливають не тільки особливості законодавчої техніки, а й криміногенної обстановки в державі в цій сфері. По-четверте, в більшості вивчених джерел наявна згадка про потерпілого як особу, яка потребує медичної допомоги, тобто особу, яка перебуває в загрозливому для життя чи здоров'я стані. По-п'яте, виникнення й наявність цього стану можуть бути зумовлені абсолютно різними факторами.

Отже, на підставі здійсненого аналізу кримінального законодавства зарубіжних країн про відповідальність за ненадання допомоги хворому медичним працівником можна зробити висновки про те, що в кримінальному законодавстві зарубіжних країн норма про відповідальність за ненадання допомоги хворому медичним працівником міститься в розділах (главах) про відповідальність за злочини проти життя та здоров'я особи. Це дає підстави констатувати, що родовим об'єктом досліджуваного злочину за зарубіжним законодавством здебільшого слід визнавати суспільні відносини у сфері охорони життя та здоров'я особи.

Описання ознак об'єктивної сторони ненадання допомоги хворому медичним працівником полягає у наступних формах: 1) у тексті 
кримінально-правової норми чітко конкретизовано ознаки об'єктивної сторони ненадання допомоги хворому медичним працівником; 2) у тексті норми щодо відповідальності медичних працівників за ненадання допомоги хворому додатково виокремлені ознаки об'єктивної сторони додаткових складів злочинів; 3) у тексті норми описано ознаки додаткових потерпі лих, окрім хворого; 4) ненадання допомоги хворому визначено як один зі способів учинення іншого злочину

Суб'єкт спеціальний - медичний працівник. При цьому ознаки суб'єкта злочину не висвітлені у змісті диспозицій досліджуваних норм, що передбачають відповідальність за ненадан ня допомоги хворому медичним працівником. Такий підхід, зокрема, втілено в КК Грузії, КК Республіки Австрія, КК Республіки Білорусь, КК Республіки Болгарія, КК ФРН.

Суб'єктивна сторона ненадання допомоги хворому медичним працівником, відповідно до кримінального законодавства зарубіжних країн, характеризується виною у формі прямого умислу щодо діяння та необережності щодо наслідків. Тобто це $\epsilon$ особливостями закріплення ознак суб' єктивної сторони досліджуваних. Тут, зокрема, йдеться про такі факультативні ознаки суб'єктивної сторони, як мотив та мета злочину.

Мотивами ненадання допомоги хворому медичним працівником за зарубіжним законодавством зарубіжних країн можуть бути як корисливі, так і особистісні. Водночас у КК деяких зарубіжних країн корисний мотив ненадан ня допомоги хворому медичним працівником визначають як кваліфікуючу ознаку.

\section{Висновки}

Як підсумок можна зазначити, що особливості розміщення досліджуваних норм в системі кримінального законодавства зарубіжних країн видаються досить подібними, оскільки зазвичай їх зазначають у главах (розділах) Особливих частин КК, що передбачають відповідальність за посягання на життя і здоров'я особи. Однак такий варіант розташування вказаних норм у системі кримінального законодавства зарубіжних країн $є$ найбільш розповсюдженим, проте не єдиним варіантом. У всіх спеціальних нормах законодавства зарубіжних країн, які передбачають кримінальну відповідальність за «загальний вид» ненадання допомоги особі (хворому), конкретизовано, що ненадання такої допомоги повинно стосуватися особи, яка потребує іiі, тобто особи, яка перебуває в загрозливому для життя чи здоров'я стані. Водночас виникнення та існування цього стану може бути зумовлено абсолютно різними факторами: нещасний випадок, наслідки стихійного лиха, умисні протиправні діяння інших осіб тощо. Описання ж цієї ознаки в диспозиціях досліджуваних кримінально-правових норм також $€$ різним. В одних випадках законодавець акцентує увагу тільки на стані небезпеки, у якому перебувають особи, які потребують допомоги (КК Австрійської Республіки, Грузії, Королів ства Данії, Республіки Польща), у других - на самітності таких осіб (КК Королівства Іспанії), у третіх - на джерелі виникнення небезпечного для життя і здоров'я особи стану (КК Федеративної Республіки Німеччини).

\section{Список використаних джерел:}

1. Науково-практичний коментар Кримінального кодексу України / [Д.С. Азаров, В.К. Грищук, А.В. Савченко та ін.] ; за заг. ред. О.М. Джужі, А.В. Савченка, В.В. Чернєя. Київ : Юрінком Інтер, 2016. $1064 \mathrm{c}$

2. Балабко В.В. Злочини проти життя та здоров'я особи: кримінальна відповідальність медичних працівників : монографія. Запоріжжя : Дніпров. металург, 2017. 288 с.

3. Уголовный кодекс Болгарии. URL http://www.wipo.int/wipolex/ru/details.jsp?id=149.

4. Уголовный кодекс Австрии / пер. с нем. Москва : Зеркало-М, 2001. 144 с.

5. Уголовный кодекс Дании / науч. ред. C.С. Беляев ; пер. с датск. и англ. С. С. Беляева, А. Н. Рычевой. Санкт-Петерург : Юрид. центр Пресс, 2001. 230 c.

6. Уголовный кодекс Кыргызской Республики. Санкт-Петербург : Юрид. центр Пресс, 2002. 384 с. 7. Уголовный кодекс Республики СанМарино / науч. ред., вступ. ст. С.В. Максимова пер. с итал. В.Г. Максимова. Санкт-Петербург : Юрид. центр Пресс, 2002. 253 с.

8. Уголовный кодекс Федеративной Республики Германии / [Берило О.Г. Історичні аспекти становлення та розвитку кримінальної відповідальності за ненадання допомоги хворому медичним працівником у період з IX ст. до середини XVIII ст. Право і суспільство. 2017. № 3. Ч. 2. C. $165-169$.

Thesis presents complex research of issues related to criminal responsibility for refusal to provide medical treatment to patients by medical staff. Timeliness of topic is defined with current problems of medical treatment provision by the staff of relevant entities in Ukraine arising in the course of their professional duties performance and considerable social and legal impact of cases when medical staff refuses to provide medical treatment to patients, as this is a general social problem that needs to be solved at the state level. Implementing innovations and improving domestic legislation in the relevant field is impossible without studying foreign law. Questions, un grants of help to the patient related to criminal-legal description, by a medical worker, are difficult after essence and actual not only for the criminal legislation of Ukraine but also for the states of 
post-soviet and European space. The indicated range of problems for Ukraine growes especially in the conditions of reform processes of the system of health protection and current criminal legislation in Ukraine.

A specific measure of punishment for criminal wrongdoing is prescribed as a general rule within the appropriate sanction (they are intended to protect society by reflecting the degree of moral condemnation of the perpetrators). The imposition of an objective and sufficient punishment depends on the construction of a sanction of the criminal law of the Special part of the Criminal Code of Ukraine.

The sanction is part of the article of the Special Part of the Code, which establishes the type and amount of punishment for a crime specified in the article's disposition.

Under current criminal law, there are two types of criminal sanctions: 1) a relatively defined sanction that provides for punishment of only one species and within specific limits, indicating or not specifying its lower limit, but indicating its upper limit; 2) an alternative sanction that provides for two or more types of capital punishment, of which the court may only appoint one.

Key words: refusal to provide medical treatment to patients, dangerous condition, inactivity and noninvolvement, socially dangerous consequences, patient, death, medical staff. 
УДК 343.93

DOI https://doi.org/10.32849/2663-5313/2019.8.35

\section{Андрій Боровик,}

кандидат юридичних наук,

член-кореспондент Академії економічних наук України,

дочент кафедри кримінального права і правосуддя

Міжнародного економіко-гуманітарного університету імені академіка Степана Дем'янчука

\section{ЕЛЕМЕНТИ ЗАГАЛЬНО СОЦАЛЬНОГО ЗАПОБІГАННЯ ОКРЕМИМ ВИДАМ КРИМІНАЛЬНИХ ПРАВОПОРУШЕНЬ В УКРАЇНІ}

У статтіз'ясовано сутність ізміст загальносоиіального запобігання злочину, пов'язаному зі злісною непокорою засуджених у місиях позбавлення волі, а також запропоновані науково обгрунтовані заходи, спрямовані на удосконалення правового механізму із зазначених питань. У кримінологї під загальносоиіальним запобіганням злочинам розуміють діяльність, спрямовану на усунення або нейтралізачію причин і умов злочинності загальносуспільного рівня [1, с. 326]. На переконання В. В. Голіни, запобіжний потениіал иієї діяльності полягає в тому, що вона протидіє негативним явищам і прочесам, які сприяють відтворенню або збільшенню рівня злочинів, стимулює законослухняну поведінку людини [2, с. 143]. Крім цього, загальносочіальне запобігання злочинам зменшує сочіальні суперечності, криміногенне протистояння різних верств населення, рівень безробіття, підвищує стандарт життя людей, створює інші необхідні умови для підвищення рівня правопорядку загалом у державі [2, с. 143]. Більш того, саме ией вид запобіжної діяльності створює сочіально-економічні та культурні підвалини для ефективного здійснення спечіально-кримінологічного та індивідуального запобігання злочинам [2, с. 144].

У контексті визначення змісту загальносочіального запобігання злісній непокорі вимогам адміністрачї УВП ще означає, що, вирішивши наявні натепер нагальні проблеми життєдіяльності у сфері виконання покарань (зокрема, щорічне недофінансування з боку державного бюджету; тривале не модернізування та не будівниитво нових слідчих ізоляторів та установ виконання покарань європейського зразка (одиничне камерне утримання засуджених); високий рівень сочіальної незахищеності прав засуджених до позбавлення волі та ін.), можна було значно знизити рівень конфліктності відносин між персоналом УВП та засудженими, у тому числі й кількість випадків злісної непокори вимогам адміністрації установ виконання покарань.

Ключові слова: загальносоціальне, запобігання, злочин, злісна непокора вимогам адміністрації установи виконання покарань, засуджений, персонал, виправна колонія, позбавлення волі.

Постановка проблеми. У науковій статті з'ясовано сутність і зміст загальносоціального запобігання такому злочину, як злісна непокора засуджених у місцях позбавлення волі вимогам адміністрації та нормативно-правових актів щодо їх утримання. На підставі проведення низки емпіричних досліджень з даного напряму у роботі також запропоновані науково обгрунтовані заходи, спрямовані на удосконалення правового механізму із зазначених питань.

Аналіз останніх досліджень і публікацій з даної теми, виділення не вирішених раніше частин загальної проблеми, яким присвячується стаття. Як показало вивчення наукової літератури, досить активно займаються розробкою питань, що стосуються змісту злісної непокори засуджених в УВП, такі науковці, як: К. А. Автухов, В. А. Бадира, В. В. Василевич, Т. А. Денисова, О. М. Джужа, О. Г. Колб, В. О. Меркулова, О. І. Плужнік, А. Х. Степанюк, В. М. Трубников, І. С. Яковець та ін.
Поряд із цим слід визнати, що в сучасних умовах реформування сфери виконання покарань проблеми, які мають прямо стосуються даного виду злочинів, досліджені неповною мірою, а тому тема цієї наукової статті є досить актуальною та такою, що має теоретичне і практичне значення.

Мета статті. Виходячи із вищевикладеного, головним завданням даної наукової статті стало визначення основних проблем, що стосуються тематики дослідження, а також розробка науково обгрунтованих шляхів їх подолання, нейтралізації, блокування тощо.

Виклад основного матеріалу. Як показали результати аналізу наукової літератури та практики зміст даного виду соціальної профілактики злочинів [1, с. 323] у сфері виконання покарань України визначається комплексом перспективних соціально-економічних, куль- 
турно-виховних, фінансових і технічних заходів, спрямованих на удосконалення правового механізму та практики виконання - відбування покарання у виді позбавлення волі на певний строк. До цих заходів, виходячи з отриманих у ході даного дослідження результатів, можна віднести такі.

1. Забезпечення $100 \%$ фінансовими, матеріально-технічними, кадровими та іншими ресурсами діяльності відповідних суб'єктів із реалізації на практиці Концепції реформування (розвитку) пенітенціарної системи України, яка $є$ натепер однією з пріоритетних програм у сфері виконання покарань [3]. При цьому, як видається, більш логічно та правильно, з урахуванням нинішньої законодавчої бази та організаційно-управлінських структур виконання покарань в Україні, зазначену концепцію було б назвати Концепцією реформування кримінально-виконавчої системи України. Поряд із цим варто зазначити, що автори зазначеної Концепції видали бажання за дійсне не тільки у її назві, але й у тих заходах, які вони затвердили на рівні спеціальної постанови Кабінету Міністрів України у вересні 2017 року [3]. Водночас серед цих заходів відсутні ті, які б мали реальний вплив на зміну стану правопорядку, зокрема, в місцях позбавлення волі та які мали б системний характер видозмін у контексті загальнодержавних програм реформування правоохоронної системи і правосуддя в Україні [4] та в цілому - інших державних органів України [5]. Зокрема, враховуючи процеси децентралізації, що здійснюються в нашій державі у різних сферах суспільної діяльності, варто було створити відповідні соціально-правові умови для такої ж діяльності у сфері виконання покарань.

Йдеться про те, що, згідно з вимогами ч. 1 ст. 93 КВК України, засуджений до позбавлення волі весь строк відбуває в одній виправній колонії, як правило, у межax адміністративно-територіальної одиниці відповідно до його місця проживання до засудження або місця постійного проживання родичів засудженого. Враховуючи зазначене та системно використовуючи процеси децентралізації, сфера виконання покарань України могла б таким чином вирішити одну 3 ключових проблем, а саме щорічне недофінансування (60 \%) з державного бюджету, за рахунок фінансування з боку органів місцевого самоврядування, на території яких функціонують СІЗО та УВП. Таке стратегічне завдання (децентралізація) сьогодні визначено в стратегії сталого розвитку «Україна - 2020», яка затверджена Указом Президента України від 12 січня 2015 року № 5 [6].
Для реалізації цього завдання у сфері виконання покарань, крім цього, варто внести зміни у відповідні закони, що стосуються діяльності органів місцевого самоврядування та ДКВС України, а саме: а) Бюджетний кодекс України; б) Податковий кодекс України; в) Закон України «Про Державну кримінально-виконавчу службу України»; г) Закон України «Про місцеве самоврядування в Україні»; ін.) - ввести фінансування сфери виконання покарань $з$ державного бюджету та бюджету органів місцевого самоврядування у пропорції 50х50. Такий підхід, крім цього, дасть змогу використовувати у кримінально-виконавчої діяльності й інші можливості та потенціал органів місцевого самоврядування та громад, які позитивно зарекомендували себе на практиці (територіальні програми працевлаштування засуджених [7, с. 70-71]; облаштування будинківпритулків; діяльність спостережних комісій [8]; ін.).

2. Моральне та психологічне оздоровлення суспільства в цілому та засуджених до позбавлення волі зокрема. Як із цього приводу зауважили деякі науковці, здавна дослідники небезпідставно звертають увагу на те, що місця позбавлення волі, зокрема кримінальна субкультура, часто впливають на особистість як криміногенний фактор [9, с. 12]. Із цього можна зробити висновок про те, що запобігати злісній непокорі вимогам адміністрації УВП можна лише у разі комплексного системного підходу, який би стосувався реформування не лише загальних соціальноправових засад, але й видозміни кримінально-виконавчого та кримінально-правового складників політики у сфері боротьби зі злочинністю в Україні [10, с. 25]. При цьому слід враховувати ту обставину, що процес демократизації українського суспільства, нова економічна політика кінця 80-х - початку 90-х років ХХ століття відбились і на змісті «законів» злочинного середовища [10, с. 24]. Саме в цей період різноманітні лідери та авторитети зазначеного протиправного товариства прийняли рішення про участь у комерційній та подібній діяльності, а також у приватизації власності. Крім цього, на даному етапі завершилось «узаконення» прийому в злочинне співтовариство осіб, які за формальними критеріями не відповідали, зокрема, статусу «злодія в законі», але які могли принести злочинній спільноті матеріальну чи іншу користь. Разом із тим головний критерій - відданість «злочинному» товариству - залишився обов'язковим (це, наприклад, проявляється й у способі дотримання змісту кримінальної субкультури [10, с. 24]. Як результат, аналіз змін, 
що відбулися останнім часом (особливо у 2014-2018 рр.) у моральній та духовній сфеpi нашого суспільства, включаючи питання релігійного характеру та позбавлення волі, дозволяє констатувати той факт, що серед населення України відбулась певна переорієнтація цінностей, що формувалась і відшліфовувались поколіннями протягом багатьох століть (порядність, чесність, працьовитість сьогодні, зокрема, підміняються нахабством, безкультурністю, вседозволеністю тощо) [10, c. 25].

Особливо небезпечним є те явище, яке сформувалось у 2014 році та триває нині а саме повна підміна правоохоронних органів юристами так званих «активістів» (а це, по суті, напівбандитські формування), які перебрали на себе функції народного правосуддя та забезпечення правопорядку в державі, залишаючись безкарними за вчинення самосуду та інших кримінально караних діянь. Звичайно, така кримінальна субкультура не може не відбитися на стані правопорядку в УВП та запобіжній діяльності з питань злісної непокори вимогам адміністрації УВП. У таких умовах актуальним загальносоціальним заходом у контексті досліджуваної в цій роботі проблематики $є$ прийняття Стратегії морального відродження українського суспільства за аналогією 3 тими стратегіями, які вже затвердженні на рівні Указів Президента України, та відповідними Планами дій щодо їх реалізації, що схвалюються та забезпечуються Кабінетом Міністрів України. При цьому одним зі структурних елементів зазначеної Стратегії мають стати заходи щодо протидії кримінальній субкультурі на всіх рівнях суспільної діяльності (освітній, науковий, культурний, релігійний і т. ін.), Зокрема, у школах I-III рівня акредитації, профтехучилищах, коледжах та вищих навчальних закладах у навчальних планах має бути закріплена як обов'язкова навчальна дисципліна «Запобігання та протидія кримінальній субкультурі», одним із проявів якої є сьогодні молодіжний екстремізм, хуліганство, насильницькі принизливі дії щодо слабших від себе тощо.

3. Стабілізація та підвищення рівня правопорядку в Україні.

Досягнення цієї мети можливе лише шляхом введення, а подекуди підвищення, юридичної відповідальності за вчинення самовільних дій, пов'язаних зі змістом правоохоронної, судової та іншої державної влади. Недопустимим у зв'язку з цим є блокування митниць, прикордонних постів, автомобільних і залізничних шляхів державного значення, а також проведення так званої «народної люстрації», що за формальними ознаках містять такі склади кримінальних правопорушень, як: «Хуліганство» (ст. 296 КК); «Групове порушення громадського порядку» (ст. 293 КК); «Закликання до вчинення дій, що загрожують громадському порядку» (ст. 295 КК); «Втягнення неповнолітніх у злочинну діяльність» (ст. 304 КК); «Опір представникові влади, працівникові правоохоронного органу, державному виконавцю, приватному виконавцю, члену громадського формування з охорони громадського порядку і державного кордону або військовослужбовцеві, уповноваженій особі фонду гарантування вкладів фізичних осіб» (ст. 342 КК) й інші. Відсутність реагування з боку держави правовими формами і заходами, у тому числі й шляхом застосування до правопорушників передбачених законом заходів юридичного примусу, не тільки зумовлює рецидив такої протиправної діяльності, але й детермінуе у тому числі злісну непокору вимогам адміністрації УВП («якщо можна діяти свавільно та безкарно на волі, то чому не можна це робити у місцях позбавлення волі»). У зазначеній ситуації проявляється не тільки діалектичний, органічний та природній зв'язок загального (на рівні суспільства), особливого (у межах сфери виконання покарань) та одиничного (на рівні конкретного засудженого, який вчиняє злочин, склад якого закріплений в ст. 391 КК України), але й реальна загроза основам національної безпеки України, враховуючи, що громадський порядок є одним 3 iї невід'ємних складових елементів [11]. Саме тому в такій обстановці, що склалась в Україні сьогодні, як зазначено в п. 1 Постанови Пленуму Верховного Суду України «Про судову практику у справах про хуліганство», «своєчасний і правильний розгляд кримінальних та адміністративних справ про хуліганство є дієвим засобом захисту нормальних умов життя людей, поновлення порушених прав потерпілих» [12, с. 370].

Враховуючи зазначене, актуальним та ефективним загальносоціальним заходом запобігання злісній непокорі вимогам адміністрації УВП має стати прийняття спеціального Указу Президента України «Про стратегію забезпечення правопорядку в Україні» та відповідної постанови Кабінету Міністрів України, яка б затвердила відповідний План дій з цих питань, включаючи й підвищення рівня забезпечення правопорядку в місцях позбавлення волі.

4. Підвищення рівня соціального захисту та забезпечення населення України, включаючи й засуджених до позбавлення волі.

Вирішення даного завдання дозволить зменшити рівень напруженості у відносинах засуджених і персоналу УВП, який виконуе 
кримінальні покарання не від свого імені, а $є$ представником держави, а отже, несе, своєрідну солідарну відповідальність за діяльність останньої. Актуальним та необхідним у зв'язку 3 цим є прийняття спеціальної Постанови Верховної Ради України «Про підвищення рівня охорони трудових, соціальних, економічних та інших пов'язаних з ними прав громадян України», що не тільки стане одним із антикриміногенних заходів запобігання злочинам в Україні, але й суттєвим чином знизить рівень злісної непокори вимогам адміністрації УВП з боку засуджених до позбавлення волі, однією з детермінант якої є саме соціально-економічне підгрунтя життєдіяльності особи в умовах місць позбавлення волі.

5. Встановлення реального, а не формального, як це встановлено натепер, громадського контролю за сферою виконання покарань. Зокрема, важливим заходом у цьому контексті було б доповнення ст. 25 КВК «Участь громадськості у виправленні і ресоціалізації засуджених. Громадський контроль за дотриманням прав засуджених під час виконання кримінальних покарань» частиною третьою такого змісту: «1. 3 метою інформування громадськості про діяльність органів та установ виконання покарань їх керівники один раз на рік готують та опубліковують на офіційних веб-порталах органів та установ виконання покарань відповідний звіт про свою діяльність, форма якого затверджується Кабінетом Міністрів України. 2. Керівники органів та установ зобов'язані регулярно оприлюднювати статистичні та аналітичні дані, крім інформації з обмеженим доступом, про вжиті заходи щодо виявлення, припинення порушень правопорядку у сфері виконання покарань та запобігання їм».

Прикладом такого нормативного підходу є Закон України «Про національну поліцію», у розділі VIII якого «Громадський контроль поліції» закріплені зазначені та інші заходи соціально-правового характеру з цих питань, у тому числі прийняття резолюції недовіри керівникам поліції (ст. 87); спільні проекти з громадськістю (ст. 89); залучення громадськості до розгляду скарг на дії чи бездіяльність поліцейських (ст. 90) та заходи щодо взаємодії між керівниками територіальних органів поліції та місцевого самоврядування (ст. 88 Закону).

Звичайно, закріплення аналогічних норм у КВК України значно зменшить кількість потенційних жертв застосування до засуджених, позбавлених волі, ст. 391 КК, а також знизить рівень зловживань з боку персоналу із зазначених питань.

6. Застосування інших загальносоціальних заходів запобіжного характеру, які прямо стосуються запобігання злісній непокорі вимогам адміністрації УВП. Насамперед ідеться про заходи соціального захисту та охорони суттєвих прав персоналу УВП. Зокрема, прийнявши у квітні 2014 року Закон України «Про приведення умов відбування покарання у виді позбавлення волі до Європейських стандартів» та розширивши при цьому права цих осіб [13], законодавець досі не здійснив жодних кроків, спрямованих на розширення прав персоналу УВП, що $є$ обов'язковою умовою у прийнятті нормативно-правових актів дуалістичного змісту, коли право одного суб'єкта правоохоронних відносин має кореспондуватись та забезпечуватись обов'язком іншого суб'єкта, і навпаки [14, с. 158-164]. Прикладом такої правової неузгодженості є, зокрема, вимоги ст. 154 КВК, в якій визначено порядок дострокового звільнення засудженого від відбування покарання. Згідно з вимогами ч. 3 ст. 154 КВК цей порядок грунтується на положеннях ст. ст. 81, 82 КК, основу яких становить такий критерій, як сумлінне ставлення засудженого до праці, тоді як, з одного боку, праця стала правом останнього, а 3 іншого боку, адміністрація не зобов'язана будь-яким чином залучати засуджених до оплачуваної роботи. Якщо є така правова колізія [14, с. 275-278], навряд чи можна визнати правомірним умовно-дострокове звільнення особи від відбування покарання i, навпаки, незастосування цього інституту права $з$ причин, що не залежать від засудженого, $€$ порушенням його права на таке звільнення [15, с. 172]. У цій ситуації, крім цього, порушено й принципи нормотворчості, якими має керуватись і законодавець [14, с. 212-214]. Зокрема, принцип системності передбачає, що, створюючи нормативно-правовий акт, слід враховувати системні властивості законодавства. Цей принцип спрямовано також на забезпечення логічної послідовності, узгодженості, збалансованості положень нормативно-правових актів [14, с. 214].

Отже, ще одним загальносоціальним заходом запобігання злісній непокорі вимогам адміністрації УВП можна визнати й діяльність суб'єктів та учасників нормотворчості, яка має грунтуватись на чітко визначених на доктринальному та правовому рівнях принципах.

Щодо інших загальносоціальних заходів запобіжного характеру з вказаної проблематики, то до таких слід віднести всі ті, що прямо стосуються процесу виконання та відбування покарань, а саме: а) підвищення відповідальності підрозділів Уповноваженого Верховної Ради з прав людини [16]; б) концептуальну зміну діяльності Превентивного механізму 
із запобігання катуванням, нелюдському або такому, що принижує гідність, поводженню в Україні, який створений на підставі вимог Конвенції проти катувань та інших жорстоких, нелюдських, або таких, що принижують гідність, видів поводження і покарання [17], який має у тому числі вивчати й питання, що пов'язані зі злісною непокорою вимогам адміністрації УВП; в) більш предметне та цілеспрямоване відвідування УВП тими суб'єктами, які визначені в ст. 24 КВК, а саме: організація в обов'язковому порядку особистого прийому засуджених, які переведені в ПКТ за вчинення тих чи інших правопорушень, позаяк саме зазначене дисциплінарне стягнення є однією із підстав притягнення засуджених до кримінальної відповідальності за ст. 391 КК України; г) більш ефективне використання у запобіганні злісній непокорі вимогам адміністрації УВП можливостей релігійних організацій (ст. ст. 128, 128-1 КВК), а також потенціалу загальноосвітнього та професійно-технічного навчання в місцях позбавлення волі, що значно знижує вплив на особу, як свідчать результати спеціальних наукових досліджень [18, с. 401-402], криміногенної детермінанти, яка спричинює та зумовлюе вчинення даного злочину; г) постійне та предметне залучення до процесу виправлення та ресоціалізації засуджених їхніх близьких родичів та інших осіб з їхнього оточення, які позитивно впливають на цих осіб. Особливо це актуально для тих, які тримаються в ПКТ, для того щоб запобігти надалі вчиненню ними злісної непокори вимогам адміністрації УВП; д) інші загальносоціальні заходи запобіжного змісту, що викладені в науковій літературі 3 питань протидії злісній непокорі вимогам адміністрації УВП та які позитивно зарекомендували себе на практиці.

\section{Висновки}

Таким чином, якщо узагальнити всі наведені вище заходи загальносоціального змісту, що стосуються запобігання злісній непокорі вимогам адміністрації УВП, то до таких можна віднести такі: 1) 100 \% забезпечення фінансовими, матеріально-технічними, кадровими та іншими ресурсами відповідних суб'єктів діяльності з реалізації тих програмних документів, що приймаються на державному рівні та стосуються сфери виконання покарань; 2) моральне та психологічне оздоровлення суспільства та засуджених до позбавлення волі, лейтмотивом якого, зокрема, має стати активна та ефективна протидія поширенню кримінальної субкультури на різні сфери суспільної діяльності, включаючи органи державної влади та органи місцевого самоврядування; 3) стабілізація та під- вищення рівня правопорядку як загалом в Україні, так і у сфері виконання покарань, у тому числі й шляхом посилення юридичної відповідальності за діяння, що за змістом є аналогічними злісній непокорі вимогам адміністрації УВП (хуліганство; опір представнику влади; масові заворушення й т. ін.); 4) руйнування економічних засад злісної непокори вимогам адміністрації УВП шляхом підвищення соціальних стандартів для населення та засуджених до позбавлення волі зокрема; 5) якісна видозміна громадського контролю за діяльністю у сфері виконання покарань, у тому числі з боку тих осіб, які мають право безперешкодно відвідувати УВП (ст. 24 КВК України) (Уповноважений Верховної Ради України; представники Національного превентивного механізму; релігійні організації; близькі родичі засуджених; ін.; 6) більш ефективне застосування інших загальносоціальних заходів із запобігання злісній непокорі вимогам адміністрації УВП, що викладені в науковій літературі та позитивно зарекомендували себе (системний підхід до підготовки та прийняття нормативно-правових актів з питань кримінально-виконавчої діяльності; зміна порядку дострокового звільнення засуджених з УВП; підвищення соціальних стандартів для персоналу УВП; інші).

\section{Список використаних джерел:}

1. Закон України «Про Національну поліцію». Положення про Національну поліцію: офіц. текст. Київ: Алерта, 2016. 84 с.

2. Кримінологія: Особлива частина : навчальний посібник / за ред. I. М. Даньшина. Харків: Право, 1999. 232 с.

3. Концепція реформування (розвитку) пенітенціарної системи України : схвалена розпорядженням Кабінету Міністрів України від 13 вересня 2017 року № 654-p. URL: https://zakon.rada. gov.ua/laws/show/654-2017-\%D1\%80 (дата звернення: 24.11.2018).

4. Стратегія реформування судоустрою судочинства та суміжних правових інститутів на 2015-2020 роки : затверджена Указом Президента України від 20 травня 2015 року № 276/2015. URL: https://zakon2.rada.gov.ua/ laws/show/276/2015 (дата звернення: 24.11.2018).

5. Про затвердження Національної стратегії у сфері прав людини : Указ Президента України від 25 серпня 2015 року № 501/2015. URL: https:// zakon.rada.gov.ua/laws/show/501/2015 (дата звернення: 24.11.2018).

6. Стратегія сталого розвитку «Україна-2020» : затверджена Указом Президента України від 12 січня 2015 року № 5/2015. URL: https://zakon. rada.gov.ua/laws/show/5/2015 (дата звернення: 24.11.2018)

7. Оперативно-службова і виробничо-господарська діяльність установ кримінально-виконав- 
чої системи у 1997 році. Інформачійний бюлетень. 1998. № 20. Київ: ГУВП МВС України. 113 с.

8. Синьов В. М., Севєров О. П. Особливості сформованості у засуджених психологічної готовності до сприйняття виховного впливу. Проблеми пенітениіарної теорії і практики. 1999. № 4. С. 68-72.

9. Муравйов В. К. «Арештанська спільнота» як суспільно-психологічний феномен у місцях позбавлення волі. Проблеми пенітениіарної теорії і практики. 2000. № 5. Київ: КІВС. С. 151-157.

10. Кримінальна субкультура: поняття, суспільна небезпека, форми та засоби впливу на правопорядок в установах виконання покарань: навчальний посібник / О.Г. Колб, О.М. Литвинов, I.О. Колб та ін.; за заг. ред. д. ю. н., проф. О.Г. Колба. Київ: Кондор-Видавництво, 2016. 222 с.

11. Про основи національної безпеки України : Закон України від 19.06.2003 № 964-IV // База даних «Законодавство України». URL: https:// zakon.rada.gov.ua/laws/show/964-15 (дата звернення: 24.11.2018).

12. Про судову практику у справах про хуліганство : Постанова Пленуму Верховного Суду
України від 22.12.2006 № 10. Постанови Пленуму Верховного Суду Украйни в кримінальних справах. Київ: ПАЛИВОДА А.В., 2011. С. 370-374.

13. Про оптимізацію системи центральних органів виконавчої влади : Указ Президента України від 9 грудня 2010 року. Офічійний вісник України. 2010. № 94. Ст. 3334.

14.Теорія держави і права : підручник / за ред. О. В. Петришина. Харків: Право, 2014. $368 \mathrm{c}$.

15. Про умови дострокового звільнення від відбування покарання і заміну невідбутої частини покарання більш м'яким : Постанова Пленуму Верховного Суду України від 26.04.2002 № 2. Постанови Пленуму Верховного Суду Украйни в кримінальних справах. Київ: ПАЛИВОДА А.В., 2011. C. $172-175$.

16. Про Уповноваженого Верховної Ради України з прав людини : Закон України від 23.12.1997 № 776/97-ВР // База даних «Законодавство України». URL: https://zakon.rada.gov.ua/ laws/show/776/97-\%D0\%B2\%D1\%80 (дата звернення 24.11.2018).

The article clarifies the essence and content of the general social prevention of a crime connected with malicious disobedience of convicts in places of deprivation of liberty, as well as proposed scientifically grounded measures aimed at improving the legal mechanism on the specified issues. In criminology under the general social prevention of crimes are understood as activities aimed at eliminating or neutralizing the causes and conditions of crime of the general social level. According to V.V. Goliny, the preventive potential of this activity is that it counteracts the negative phenomena and processes that promote the reproduction or increase of crime, stimulates law-abiding human behavior. In addition, the general social prevention of crimes reduces social contradictions, crime-fighting confrontation of various segments of the population, unemployment, raises standard of living of people, creates other necessary conditions for raising the level of law and order in general in the state. Moreover, it is this kind of preventive activity that creates socio-economic and cultural foundations for the effective implementation of special-criminological and individual prevention of crime

In the context of defining the content of the general social prevention of malicious disobedience to the requirements of the administration of the Ministry of Internal Affairs, this means that by solving the existing urgent problems of life in the field of execution of sentences (in particular, the annual lack of financing from the state budget; the continued modernization and construction of new investigative detention facilities and penal institutions European sample (single cell deprivation of prisoners), high level of social insecurity of prisoners' rights to imprisonment, etc.), could be significant ynom reduce the level of conflict relations between staff and inmates of penal institutions, including the number of cases of malicious disobedience to the requirements of the administration of penitentiary institutions.

In addition, it should be admitted that in today's conditions of reforming the scope of punishment, problems that are directly related to this type of crime are not fully explored, and therefore the subject of this scientific article is very relevant and of a theoretical and practical value.

Keywords: general social, prevention, crime, disobedience to the requirements of the administration of the penal institution, condemned, personnel, correctional colony, imprisonment. 
УДК 342.2

DOI https://doi.org/10.32849/2663-5313/2019.8.36

\section{Олена Олійник,}

канд. юрид. наук, доцент,

доцент кафедри кримінального права та процесу

Київського начіонального економічного університету імені Вадима Гетьмана

\section{ПОРІВНЯЛЬНО-ПРАВОВЕ ДОСЛІДЖЕННЯ ПРИНЦИПІВ КРИМІНАЛЬНОГО ПРАВА РОМАНО-ГЕРМАНСЬКОЇ ТА МУСУЛЬМАНСЬКОЇ ПРАВОВИХ СІМЕЙ}

У статті здійснюється порівняльний аналіз сутності приниипів кримінального права романогерманської та мусульманської правових сімей. Автор вивчає природу, походження та основні ознаки принципів кримінального права згаданих правових систем. Наголошено, що в доктрині кримінального права переважає думка, відповідно до якої в разі відсутності прямого закріплення приниипу в законі він не є юридичною презумпиією. Особливо гостро ие питання постає з огляду на закріплення таких принципів у міжнародно-правових актах, до яких приєдналися країни, в кримінальному законодавстві яких відсутнє законодавче закріплення останніх. З'ясовано, що важливим аспектом зближення кримінального законодавства країн всіх правових систем є укладання міжнародноправових конвениій щодо боротьби з кримінальними злочинами. Їх необхідність зумовлюється завданням боротьби зі злочинами проти миру $i$ безпеки людства (геноцид, найманство) $i$ злочинами міжнародного характеру (корупиійні злочини, незаконний обіг наркотиків, викрадення повітряного судна, фальшивомонетниитво). Держави-учасниці відповідної конвениії зобов'язуються передбачити в своєму національному кримінальному законодавстві відповідні кримінально-правові норми (безпосередньо иі конвениії не можуть бути застосовані з огляду на те, що вони позбавлені кримінально-правових санкиій). Зроблено висновок, що кодифікачія та уніфікачія норм, які являють собою приниипи кримінального права, ие такий процес, який покликаний впорядкувати та систематизувати їх та має як позитивні, так і негативні риси. На наш погляд, якщо говорити з позииї глобалізачії та універсалізачії норм (приниипів) кримінального права, то такий процес є неминучим. 3 іншого боку, кожна із систем, яка буде намагатися робити кроки в заданому напрямі, може втратити свої визначальні начіональні властивості. Кожна держава, в яку би правову систему вона не входила - в мусульманську, романогерманську тошо, повинна самостійно вибрати для себе свій шлях та визначитись, чи готова вона пожертвувати самобутністю своєї власної правової системи на користь всезагальної євроінтеграції, універсалізації тощо. При иьому зовнішній тиск з боку міжнародних партнерів у вирішенні такого питання повинен бути мінімальним.

Ключові слова: принципи кримінального права, романо-германська та мусульманська правова сім’я, кодифікація, уніфікація.

Постановка проблеми. Як зазначається в науковій літературі, принципи кримінального права становлять собою основоположні засади, керівні ідеї, які випливають зі змісту правових норм та положень, закріплених у законодавстві про кримінальну відповідальність. Згадане поняття є одним з основних та визначальних для будь-якої правової системи. Сутність та зміст принципів права спочатку намічається самим життям, спонтанно, у суспільних соціальних відносинах, що складаються в реальному житті та отримують пізніше регламентацію і захист з боку держави у комплексах суб'єктивних прав учасників правовідносин.
Принципи права спрямовують і надають синхронності всьому механізму правового регулювання суспільних відносин, краще за інших розкривають місце права в суспільному житті і його розвитку. Саме принципи права є критерієм законності та правомірності дії громадян і посадових осіб, адміністративного апарату і органів юстиції та за відомих умов мають велике значення для зростання правосвідомості населення, його культури й освіти.

Кримінальне ж право будь-якої країни має свою специфіку. Воно проявляється в змісті основних кримінально-правових інститутів (кримінальний закон, принципи кримінального права, злочин, покарання), 
зумовлених історичними, національними i культурними традиціями, особливостями політичного устрою суспільства, його економіки і багатьох інших факторів.

На нашу думку, сьогодні можна спостерігати суперечливі тенденції розвитку як законодавства окремих держав, так і, відповідно, його принципів. Зазвичай саме принципи права стають заручниками політики держави.

Аналіз останніх досліджень. Окремим питанням з'ясування природи принципів кримінального права романо-германської та мусульманської правових сімей у своїх роботах приділяли увагу такі вітчизняні та зарубіжні науковці, як: Х.М Ахметшин, П.С. Берзін, С. Бек, Л.В. Вай ден Берг, О.Н. Ведернікова, В.О. Гацелюк, П.А. Гусенова, К.В. Дядюн, О.О. Житній, А.В. Наумов, О.Г. Кибальник, С. Погребняк, Н.А. Сарафанов, Н.В. Стойко, Л.Р. Сюкіяйкен, Н. Торнау, В.Д. Філімонов, Д.Ю. Фісенко, Хакан Хакеpi, Є.Є. Чередніченко та інші.

Публікації перелічених вище науковців переважно стосувались з'ясування сутності окремих принципів кримінального права кожної з існуючих правових систем певних держав, а також їх класифікації, кодифікації, уніфікації тощо. Порівняльний аналіз принципів кримінального права різних правових систем згаданими авторами не здійснювався.

Метою статті $є$ виокремлення (встановлення) загальних та відмінних рис принципів кримінального права на прикладі таких правових систем, як мусульманська та романо-германська.

Викладення основного матеріалу. На початку свого дослідження зазначимо, що сутність кримінально-правових принципів завжди має кримінально-політичну природу, а їх зміст є тією змінною величиною, яка залежить у кінцевому результаті від волі суб'єктів кримінально-правової політики, але в сучасний історичний період рідко можна побачити правову систему конкретної держави, яка була би абсолютно ізольована від впливу світової спільноти. Суб'єктам кримінально-правової політики необхідно враховувати безліч факторів, у тому числі принципи міжнародного кримінального права.

Також необхідно пам'ятати, що принципи права навіть такої найбільш стабільної галузі права, як кримінальне право, не залишаються раз і назавжди даними і незмінними. Разом із розвитком держави, права і суспільства вони також розвиваються і змінюються. Деякі з них при цьому у зв'язку з кардинальними змінами матеріального та політико-соціального середовища втрачають свою актуальність. Інші, навпаки, набувають і підсилюють iii. Разом же вони, створюючи і підтримуючи на всьому шляху розвиток правової системи та її цілісність, динамізм і цілеспрямованість, забезпечують, поряд із нормами та іншими компонентами права, іï дієвість і практичну значимість. Важливим є положення й про те, що практично у всіх правових системах вони є одним з джерел права.

У доктрині кримінального права переважає думка, що в разі відсутності прямого закріплення принципу в законі він не $€$ юридичною презумпцією. Особливо гостро це питання постає з огляду на закріплення таких принципів в міжнародно-правових актах, до яких приєдналися країни, в кримінальному законодавстві яких відсутнє законодавче закріплення останніх.

Справді, принципи сучасного кримінального права різних держав багато в чому схожі. Певна уніфікованість цих принципів зумовлена тим, що вони закріплені в міжнародних правових актах. Найбільш докладно вони прописані в розділі 3 Римського статуту Міжнародного кримінального суду (1998 г.), який отримав назву «Загальні принципи кримінального права». Відображення принципів у згаданому документі свідчить насамперед про міжнародну тенденцію з кодифікації принципів кримінального права. Однак аналіз законодавчої регламентації принципів в конституціях і кримінальних кодексах сучасних держав дозволяє говорити про те, що деякі відмінності у відображенні, тлумаченні та розумінні досліджуваних нами принципів все ж такі є. Так, окремі принципи кримінального права отримали своє законодавче закріплення. Водночас в ряді країн світу принципи права загалом, як і принципи кримінального права, випливають із сутності норм права.

Серед загальноправових (загальних або основних) принципів, які властиві в тому числі й кримінальному праву, які відображають природу, якісну своєрідність права в цілому і переважають в романо-германській правовій системі, можна назвати: $\boldsymbol{n p u н -}$ ции гуманізму - домінування в формулюванні та функціонуванні правової системи невід'ємних природних прав і свобод людини; принцип рівності громадян перед законом, згідно з яким всі громадяни незалежно від національності, статі, раси, релігійної та іншої приналежності, посадового становища мають рівні загальногромадянські права i обов'язки, несуть рівну відповідальність перед законом; приниип демократизму, який означає, що право, законодавство адекватно відображає волю народу (загальну волю), формується через демократичні інститути народовладдя; принцип законності 
(правозаконності) - здійснення всіх форм державної діяльності, функціонування громадянського суспільства на основі і відповідно до вимог права, природних прав і обов'язків людини; принцип справедливості, що конкретизує вимоги справедливості стосовно правових форм діяльності держави, їі органів і посадових осіб, правової діяльності учасників, регульованих правом відносин і виражений у рівному юридичному масштабі поведінки, в суворій відповідності юридичної відповідальності допущеному правопорушенню. Як джерела права загальні принципи застосовуються практично у всіх правових системах, хоча і зовсім не однаковою мірою. Законодавство, що сформувала практика (правові традиції) країн як загального, так і континентального права, допускають у процесі правозастосовчої діяльності у разі відсутності в законі конкретного юридичного припису, а також правового звичаю або прецеденту посилатися на загальні принципи: справедливості, доброї совісті, загальних засад права і т. п. Для мусульманських правових систем характерно розв'язання судами справ за наявності прогалини в законодавстві відповідно до принципів шаріату (вонито якраз і визнаються основними джерелами права).

Серед спеціальних принципів кримінального права можна виокремити: принцип вини, принцип «незнання закону не звільняе від відповідальності», принцип неприпустимості притягнення до кримінальної відповідальності двічі за один і той самий злочин (non bis in idem) тощо.

Романо-германська правова система. До цієї системи входить більшість правових систем європейських країн (Франція, Бельгія, Іспанія, Італія, Люксембург, Монако, Нідерланди, Румунія, Україна тощо). Відмінною рисою цієї системи кримінального права є яскраво виражене прагнення до писаного права, визнання закону єдиним нормативним джерелом кримінального права, до кодифікації норм кримінального закону і відмови від прецедентного і звичаєвого права. Другою характерною рисою цієї системи слід визнати специфічний спосіб формулювання кримінально-правових заборон, які відрізняються прагненням до абстрактного їх опису, що виражається в граничній лаконічності мови кримінального закону, яка передбачає максимально узагальнене формулювання кримінально-правових норм. Такі норми розраховані на застосування щодо широкого кола діянь.

Мусульманське право ж являє собою складову частину релігії - ісламу. У правову систему ісламських держав вбудовані норми ісламу (шаріату), що виступають не тільки як джерела права, але й як законодавча та правозастосовча практика. Шаріат - це не тільки право; він регламентує всі сторони життя мусульманина, включаючи як правові, так і моральні і суто релігійні норми, обов'язкові для всіх мусульман. Джерелами шаріату є Коран, Сунна (перекази), иджма, кияс і урф (звичай).

Найбільш повна ісламізація кримінального права проведена в Саудівській Аравії, Пакистані, Судані, Ірані і ряді інших мусульманських країн, офіційно проголошених ісламськими. Виокремити мусульманське право з правової системи названих країн неможливо, і неправомірно у зв'язку з тим, що вся діяльність цих держав покликана відповідати духу і букві шаріату. Так, відповідно до Конституції Ірану все законодавство, в тому числі й кримінальне, має відповідати нормам ісламу. Сучасне мусульманське кримінальне право характеризується можливістю застосування жорстоких покарань, у тому числі і таких, що спричиняють каліцтво. Наприклад, у кримінальному праві Ірану вбивство і тілесні ушкодження тягнуть покарання у вигляді смертної кари або покарання за принципом «око за око, зуб за зуб»; перелюбство карається забиванням камінням до смерті; за кримінальним законодавством Саудівської Аравії за крадіжку застосовується відрубування руки.

Незважаючи на видимі відмінності згаданих вище правових систем (особливо за своїм змістом), останнім часом спостерігається тенденція кодифікації мусульманського кримінального права, що більш характерно для романо-германської правової системи. Так, у 1981 р. в Ірані прийнятий Кодекс, заснований на мусульманському праві, який складається зі 199 статей. У ньому широко передбачається смертна кара та тілесні покарання, відбивається нерівність чоловіка і жінки.

Таким чином, здійснена кодифікація кримінального законодавства, з одного боку, зблизила ці правові системи, а 3 іншого норми, які закріплені згаданим нормативним актом, відрізняються своїм подекуди середньовічним характером, походять із часів, коли людське життя не вартувало практично нічого. Тому в цьому разі видається, що законодавцем був здійснений процес кодифікації законодавства про кримінальну відповідальність та приведено його у відповідність до визнаної форми. Водночас зміст норм, яке містить таке законодавство, переважно залишився на попередньому (незмінному) рівні. Домінують у мусульманській правовій системі стародавні (іноді й дикі) звичаї, які панують у суспільстві й сьогодні. Це що 
стосується кримінального права. Водночас зазначимо, що інші сфери все ж таки зазнають помітних змін, особливо це стосується випадків, коли, внаслідок зміни традицій або поступки щодо їх дотримання, східна мусульманська держава має можливість залучити інвестиції та поліпшити своє економічне становище. Наприклад, за загальним правилом, в ОАЕ мусульманам заборонено вживати алкоголь під загрозою застосування до них суворого покарання. Однак на території цієї країни є райони, де це зробити можна, особливо це стосується туристів, які не підпадають під дію таких вимог мусульманського права. Отже, в мусульманських країнах домінує принцип громадянства у вирішенні питання притягнення винних осіб до відповідальності.

Окрім цього, норми мусульманського права, на відміну від норм, які входять до романо-германської правової системи, регулюють практично всі сфери суспільного життя, не залишаючи простору для вільного розвитку особистості.

Як вбачається з аналізу норм кримінального права мусульманської правової сім'ї, принципи релігійного права не втілюються в жодній правовій сфері настільки мало, як у кримінальному праві.

Частини кримінального права, котрі через ісламську релігію вважалися обов'язковими, здавна були обмежені кількома правопорушеннями, всі ж наступні правопорушення повинна була в рамках ісламських принципів визначити влада. До принципів мусульманської правової системи відносять:

1. Nullum Crimen Sine Lege, Nulla Poena Sine Lege. В ісламському кримінальному праві одностайно визнається принцип прецеденту, що більш характерний для континентальної правової сім'ї. Серед більшості ісламських правознавців, котрі займалися цим питанням, переважало таке визначення правопорушення: правопорушення - це заборонені законом дії, від яких Господь утримує шляхом покарань.

2. Заборона зворотної дї̈ закону. До основних принципів ісламської кримінальноправової науки також належать положення про дію кримінально-правових норм у часі. Ісламське кримінальне право визнає принцип заборони зворотної дії закону в чітко визначених кримінально-правових приписах та спирається в ньому на слово Боже.

3. Принцип рівності полягає в тому, що у застосуванні кримінально-правових норм ісламське правознавство виходить з принципу абсолютної рівності усіх людей. Не існуе відмінностей за расою, релігією або соціальним статусом.
4. Особиста відповідальність. Особиста відповідальність є основним принципом. Він грунтується на віршах з Корану: «I ніхто не буде нести ношу іншого».

5. Пропориійність. Цей принцип у різних віршах Корану пояснюється так: «Проте для тих, що зло чинили, уготована така сама кара (як сам злий вчинок).

6. Превентивний вплив покарань. Покарання в ісламському кримінальному праві є спрямованими, тобто вони мають цілі, 3 яких виходить їхнє обгрунтування та виправдання [1].

Також необхідно відзначити, що приблизно з 1970-х років за деякими, в тому числі і дуже принциповими, позиціями почалося на перших порах досить боязке, а потім і цілком видиме зближення відповідних правових систем [2].

Визначені вище принципи кримінального права мусульманської правової системи мають сучасний, так би мовити, характер і не суперечать положенням та керівним ідеям, закріпленим у міжнародних конвенціях, підписантами яких виступають численні європейські держави, які входять до романо-германської правової сім'ї.

Це і стало другою точкою певного зближення позицій розглядуваних нами правових систем, що включала й переосмислення ставлення до жорсткої кодифікації кримінального права.

Важливим аспектом зближення кримінального законодавства країн усіх правових систем є укладання міжнародноправових конвенцій з боротьби з кримінальними злочинами. Їх необхідність зумовлюється завданням боротьби зі злочинами проти миру і безпеки людства (геноцид, найманство) і злочинами міжнародного характеру (корупційні злочини, незаконний обіг наркотиків, викрадення повітряного судна, фальшивомонетництво). Держави-учасниці відповідної конвенції зобов'язуються передбачити в своєму національному кримінальному законодавстві відповідні кримінальноправові норми (безпосередньо ці конвенції не можуть бути застосовані з огляду на те, що вони позбавлені кримінально-правових санкцій). У цьому випадку однорідні норми містяться в кримінальному законодавстві країн і романо-германської, і англосаксонської, і мусульманської, і соціалістичної систем права.

Отже, розглядувані правові системи доволі схожі за своїми принципами, які поширюються на сферу кримінально-правових відносин. Водночас зміст норм, які безпосередньо регулюють такі відносини, суттєво різниться. 


\section{Висновки}

Таким чином, кодифікація та уніфікація норм, які являють собою принципи кримінального права, це такий процес, який покликаний впорядкувати та систематизувати їх та має як позитивні, так і негативні риси. На наш погляд, якщо говорити 3 позиції глобалізації та універсалізації норм (принципів) кримінального права, то такий процес $\epsilon$ неминучим. 3 іншого боку, кожна із систем, яка буде намагатися робити кроки в заданому напрямі, може втратити свої визначальні національні властивості (самобутність). Як показало дослідження джерел кримінального права вибраних нами правових систем, певні принципи, такі як «рівність усіх людей перед законом», «повага до прав та свобод мусульман», існували задовго до сучасного європейського законодавства, яке сьогодні претендує на лідерство у цьому питанні [3]. А як показує практика, цей процес не завжди $є$ безболісним і плідним. Навпаки, він може посприяти втраті національної самобутності правом окремих держав, які більшою мірою, ніж це необхідно, захопилися процесом євроінтеграції.

Отже, кожна держава, в яку би правову систему вона не входила - в мусульманську, романо-германську тощо, повинна самостійно обрати для себе свій шлях та визначитись, чи готова вона пожертвувати самобутністю своєї власної правової системи на користь всезагальної євроінтеграції, універсалізації тощо. При цьому зовнішній тиск з боку міжнародних партнерів у вирішенні такого питання повинен бути мінімальним.

\section{Список використаних джерел:}

1. https://lj.oa.edu.ua/articles/2012/ n1/12hhhnkp.pdf

2. https://publications.hse.ru/mirror/pubs/ share/direct/222420513

3. Ganzuri, 45, zitiert bei Forstner, Martin, Der Allgemeine Teil des ägyptischen Strafrechts, BadenBaden 1986, S. 31, fn. 18, 19.

4. Кибальник А. Г. Тенденции развития мировых уголовно-правовых систем. Правоведение. 2007. № 2. С. 25-27.

5. Кибальник A. Г. Универсализация уголовно-правовых систем и национальный интерес. Уголовное право. 2005. № 5. С. 34-37.

6. Наумов А. В. Сближение правовых систем как итог развития уголовного права XX в. и его перспектива в XXI в. Государство и право. 1998. № 6. С. 12-14.

7. Бек С. Примирение английской и немецкой концепций уголовной ответственности корпораций. Правоведение. 2012. № 2. СС. 17-18.

8. А.Н. Игнатов, Ю.А. Красиков. Уголовное право России : учебник для вузов : в 2-х т. Т. 1 . Общая часть. Москва : Издательство НОРМА, $2000.639 \mathrm{c}$.

9. h t t p s : / / p i d r u c h n i k i. com/1441071356158/pravo/printsipi_ kriminalnogo prava

The article provides a comparative analysis of the essence of the principles of criminal law of the Roman-German and Muslim legal families. The author studies the nature, origin and main features of the principles of criminal law of the mentioned legal systems. It is emphasized that in the cover criminal law the opinion dominates, according to which, in the absence of direct consolidation of the principle in the law, it is not a legal presumption. Particularly acute this question arises from the view of consolidation of such principles in international legal acts, which are joined by countries in criminal law which lacks the legislative consolidation of the latter. It was clarified that the important aspect of convergence of criminal legislation of the countries of all legal systems is the conclusion of international legal conventions on combating criminal offenses. Their need is determined by the task of combating crimes against the peace and security of mankind (genocide, mercenariness) and crimes of an international character (corruption crimes, drug trafficking, aircraft abduction, counterfeiting). The States Parties to the relevant convention are obliged to provide the relevant criminal law in their national criminal law (these conventions can not be applied directly because they are deprived of criminal sanctions). It is concluded that the codification and unification of norms that are the principles of criminal law is a process that is designed to organize and systematize them and has both positive and negative features. In our view, if we talk about the position of globalization and the universalization of the norms (principles) of criminal law, then such a process is inevitable. On the other hand, each system that tries to take steps in a given direction may lose its decisive national qualities. Each state, whatever legal system it does not belong to, Muslim, Romano-Germanic, etc., should independently choose its own path and determine whether it is ready to sacrifice the originality of its own legal system in favor of universal Euro-integration, universalization, etc. In this case, external pressure from international partners in solving such a question should be minimal.

Key words: principles of criminal law, romano-germanic and muslim legal family, codification, unification. 
УДК 342.924:342.841+343.415

DOI https://doi.org/10.32849/2663-5313/2019.8.37

\section{Сергій Рощупкін,}

аспірант кафедри полічейського права

Національної академії внутрішніх справ

\section{СПІВВІДНОШЕННЯ ПОНЯТЬ «ОДЕРЖАННЯ ПОДАРУНКУ ТА «НЕПРАВОМІРНА ВИГОДА»}

У статті розглянуті ключові ознаки предмета юридичного складу порушення встановлених законом обмежень щодо одержання подарунку як обов'язкового елемента об'єкта правопорушення. На основі порівняльного методу та методу герменевтики здійснено аналіз судової практики з притягнення до адміністративної відповідальності за адміністративне правопорушення, пов'язане 3 корупиією, передбачене ст. 172-5 КУпАП, в частині розгляду предметів зазначеного правопорушення. Розглянуто доктринальні бачення та законодавчі визначення понять «подарунок» та «неправомірна вигода» через призму ознак матеріальних та нематеріальних речей. Визначені спільні та відмінні риси подарунку та неправомірної вигоди як предметів адміністративного правопорушення, пов'язаного з корупиією, та корупиійних правопорушень відповідно. З'ясована відмінність пільг, привілеїв та переваг у контексті аналізу антикорупчійного законодавства, зокрема, як складників дефініиій «подарунок» та «неправомірна вигода». На підставі проаналізованого сформульовано власне визначення поняття «подарунок» та визначені ключові елементи для формування доказової бази 3 метою притягнення до адміністративної відповідальності за ст. 172-5 КУпАП. Виокремлено ключові ознаки, що розмежовують подарунок та неправомірну вигоду, на основі аналізу судової практики визначені проблемні питання правової кваліфікацї за ст. 172-5 КУпАП. З'ясовано, що встановлення предмета подарунку не є доконаним фактом вчинення правопорушення обмежень щодо одержання подарунку, а аналіз юридичного складу довів необхідність детального вивчення факту події та складу правопорушення, передбаченого ст. 172-5 КУпАП. Зроблено висновок, що розмежування дефінічій «подарунок» та «неправомірна вигода» повинно проходити через декілька аспектів: встановлений розмір допустимого подарунку становить одна мінімальна заробітна плата, встановлена на день прийняття подарунка, одноразово, а сукупна вартість таких подарунків, отриманих від однієї особи (групи осіб) протягом року, не має перевищувати два прожиткові мінімуми, встановлені для працездатної особи на 1 січня поточного року; спосіб передачі подарунку є безкоштовним або ж за чіною, нижчою за ринкову на той час, коли передача неправомірної вигоди відбувається за умови відсутності законних на те підстав; прийняття пропозииї, обіиянки або одержання неправомірної вигоди у різних ї̈ варіаціях має виключно корисливий мотив, а одержання подарунку може розиінюватися за певних обставин як загальновизнане уявлення про гостинність, що підлягає встановленню в судовому порядку.

Ключові слова: подарунок, нематеріальні та матеріальні активи, неправомірна вигода, привілеї, пільги, причинно-наслідковий зв'язок.

Постановка проблеми. Виконуючи завдання держави, посадові особи постійно перебувають у зоні виникнення корупційних ризиків, що походить від делегованих державно-владних функцій. Саме від довіри суспільства до транспарентності виконання службових обов'язків і залежить ефективність функціонування та демократичність процесів у державному механізмі.

Актуальність вибраної тематики визначається також статистичними показниками, які свідчать про те, що загальна кількість протоколів за ст. 172-7 КУПАП, спрямованих до суду НАЗК, становить більше $74 \%$, за ст. 172-6 КУпАП - близько $22 \%$, за ст. 172-4 і ст. 172-5 КУПАП - лише
2,8 \% та 1,2 \% відповідно [1]. Таким чином, найнижчий показник питомої ваги протоколів припадає саме на правопорушення, пов'язане $з$ обмеженням щодо одержання подарунку, а це може бути пов'язано 3 1) низьким рівнем виявлення та документування такого роду правопорушення; 2) неефективною роботою уповноважених органів з питань протидії та запобігання корупції - Національної поліції, органів прокуратури, Національного агентства 3 питань запобігання корупції; 3) низьким рівнем правозастосовної практики та праворозуміння тощо. У статті ми зробили спробу розглянути проблемні питання кваліфікації за статтею 172-5 КУпАП. 
Мета статті - визначити об'єктивні характеристики юридичного складу порушення встановлених законом обмежень щодо одержання подарунків; на підставі порівняльного аналізу розкрити зміст подарунку як предмета адміністративного правопорушення, пов'язаного 3 корупцією, та неправомірної вигоди як предмета корупційного правопорушення.

Останні дослідження. Питанням корупційних правопорушень займалися О. Банчук, О. Боднарчук, О. Гудков, В. Гвоздецький, О. Дрозд, В. Колпаков, М. Мельник, Є. Невмержицький, Л. Шестопалов, В. Ортинський. Адміністративні правопорушення, пов'язані з корупцією, у своїх дисертаційних дослідженнях розглядали В. Авер'янов, I. Діденко, Д. Иосифович, О. Клок, А. Титко, В. Шамрай, С. Шепітько, М. Хавронюк та інші.

Виклад основного матеріалу. Обмеження щодо одержання подарунку, що містяться у переліку адміністративних правопорушень, пов'язаних із корупцією, є правопорушенням, що посягає на порядок державного управління та встановлені правила поведінки публічних посадових осіб, а також правила протидії та запобігання корупції. Предмети подарунка та неправомірної вигоди є схожими за своєю правовою природою та мають спільні риси, відповідно, відмежування понять здійснюється на підставі законодавчого визначення та аналізу юридичних складів злочинів та правопорушень, предметом якого є речі майнового та немайнового характеру.

На практиці встановити відмінність між подарунком та неправомірною вигодою (хабарем) досить важко, тому питання отримання та передачі подарунків публічними службовцями 3 метою запобігання виникненню корупційних проявів у їхній діяльності повинно бути обов'язково врегульовано на законодавчому рівні з урахуванням найбільш конфліктних ситуацій, що виникають в процесі реалізації державно-владних повноважень

Для відмежування понять «подарунок» та «неправомірна вигода» слід звернутися до бази законодавчих актів, де наводяться дефініції зазначених понять із характерними ознаками та властивостями, а також вивчити наукові дискусії та доктринальні бачення 3 цього приводу.

У проекті Закону України «Про заходи державного фінансового контролю публічної служби» термін «подарунок» визначено як будь-які блага, в тому числі прояви гостинності, які публічний службовець безоплатно або за вартістю, істотно меншою від ціни таких благ, одержує від фізичних чи юридичних осіб [2].

Закон України «Про запобігання корупції» подарунок трактує як грошові кошти або інше майно, переваги, пільги, послуги, нематеріальні активи, які надають/одержують безоплатно або за ціною, нижчою від мінімальної ринкової [3].

Виходячи із визначення поняття, подарунок може передаватися безоплатно або за ціною, нижчою від мінімальної ринкової. Виникає питання: якщо ми говоримо про подарунок-перевагу, то відповідно до семантичного аналізу поняття «перевага» не можна говорити про безоплатність надання того, що не має матеріального чи грошового виміру.

Перевага за своїм змістом тотожна поняттю пільги, оскільки семантика трактує перевагу як 1. Якість, властивість, що вигідно відрізняє кого-, що-небудь від когось, чогось. 2. Більша, ніж у кого-небудь, кількість (війська, техніки і т. ін.); переважання в кількості. 3. Виключне, особливе право на що-небудь; привілей [4].

Перевага - це відступ від загального правила на користь окремих осіб або соціальних груп, що може полягати у звільненні тих чи інших осіб від відповідних обов'язків, достроковому присвоєнні звань, підвищенні у посаді під час конкурсу, наданні додаткових гарантій тощо.

Цікавою $є$ окрема думка судді Конституційного Суду України І. Д. Сліденка, який стверджував, що пільги тотожні поняттю «привілей», а основна властивість привілею - бути винятком із загального правила (норми) [5].

Зважаючи на це та те, що 3 погляду семантики поняття «перевага» і «пільга» $е$ тотожними, а пільга є свого роду привілеєм, можна зробити висновок про те, що за своїм смисловим навантаженням ці дефініції $€$ однаковими, тому, керуючись правилом юридичної визначеності, пропонуємо внести зміни до ст. 1 Закону України «Про запобігання корупції» щодо поняття «подарунок», зокрема, виключивши переваги та пільги 3 поняття «подарунок», оскільки така ознака, як «безоплатно чи за ціною, нижчою за мінімальну ринкову», має суто майновий характер [6, с. 67-70].

У свою чергу, нематеріальний актив розуміють по-різному, відповідно до положень низки нормативних актів. На нашу думку, найбільш вдалим визначенням є тлумачення Повідомлення Комісії, де нематеріальні активи розглядають як активи, що не мають матеріального або фінансового втілення, такі як патенти, ліцензії, ноу-хау та інша інтелектуальна власність [7]. 
Що ж до визначення неправомірної вигоди, то під останньою розуміють грошові кошти або інше майно, переваги, пільги, послуги, нематеріальні активи, будь-які інші вигоди нематеріального чи негрошового характеру, які обіцяють, пропонують, надають або одержують без законних на те підстав [3].

Кримінальне законодавство тлумачить неправомірну вигоду як кошти чи інше майно, переваги, пільги, послуги або нематеріальні активи, вартість яких перевищує три відсотки розміру прожиткового мінімуму для працездатних осіб, які пропонують, обіцяють, надають чи одержують без законних на те підстав [8].

M. I. Хавронюк предметом неправомірної вигоди вважає грошові кошти, інше майно, переваги, пільги, послуги, нематеріальні активи, а отже, й будь-які інші вигоди нематеріального чи негрошового характеру [9, с. 123].

Цю ж позицію поділяє О. В. Ярошенко, на думку якої неправомірну вигоду слід вважати незаконною (неправомірною) послугою, пільгами і перевагами (вигодами) (матеріальними чи нематеріальними) [10, с. 105-112].

M. I. Мельник в поняття неправомірної вигоди включав лише чітко визначені предмети матеріального світу, зокрема незаконну винагороду матеріального характеру (майно (гроші, матеріальні цінності та інші речі), право на майно (документи, які надають право отримати майно, користуватися ним або вимагати виконання зобов'язань тощо), будь-які дії майнового характеру (передача майнових вигод, відмова від них, відмова від прав на майно, безоплатне надання послуг, санаторних чи туристичних путівок, проведення будівельних чи ремонтних робіт тощо) [11, с. 1074].

Також цю думку підтримував О. О. Дудоров, який вважав, що за ринкової економіки, коли будь-яка послуга (надання консультації, інтимний зв'язок, знайомство з квартирним маклером тощо), в принципі, може розглядатись як така, що підлягає оплаті і має певний грошовий еквівалент, існує нагальна необхідність у тому, щоб законодавець чітко зафіксував майновий характер предмета хабара безпосередньо у тексті [12, с. 11].

Окрема думка щодо виключного майнового характеру неправомірної вигоди з вартісними характеристиками свідчить також дослідження О. Бабікова [13].

Зважаючи на корисливі мотиви прийняття пропозиції, обіцянки або одержання неправомірної вигоди, остання має майновий характер [14, с. 470].
Предметом хабара не можуть визнаватися послуги, вигоди немайнового характеру (наприклад, позитивні статті про ту або іншу особу в засобах масової інформації). Їх отримання може розцінюватися як інша заінтересованість (некорислива) при зловживанні владою чи службовим становищем $[15$, c. 420$]$.

Ст. 179 ЦК визначає, що річчю є предмет матеріального світу, щодо якого можуть виникати цивільні права та обов'язки. Виходячи з положень цивільного законодавства, можна говорити про індивідуальні ознаки, що вирізняють її з-поміж інших однорідних речей, індивідуалізуючи їі, тобто в цьому випадку ми говоримо про чітко визначені індивідуалізовані ознаки матеріального світу, що визначають якісно-кількісні характеристики речей [16].

На користь думки про те, що неправомірна вигода має ознаки майнового характеру, свідчать також положення Постанови Пленуму Верховного Суду України № 5 «ро судову практику у справах про хабарництво» від 26 квітня 2002 р., де зазначається, що предмет одержання хабара має виключно майновий характер, а послуги, пільги і переваги, які не мають майнового характеру, не можуть визнаватися предметом хабара [17].

Як бачимо, одностайного підходу до визначення предмета неправомірної вигоди та подарунку у законодавстві немає, тому варто звернутися до судової практики, аби аргументувати власну позицію що визначення подарунку та неправомірної вигоди.

C. В. Якимов згрупував ознаки неправомірної вигоди та навів власну систематизацію неправомірної вигоди, під якою слід розуміти: 1) грошові кошти; 2) інше майно; 3) переваги; 4) пільги; 5) послуги; 6) нематеріальні активи; 7) будь-які інші вигоди нематеріального чи негрошового характеру [18].

Спільним для предмета подарунку та неправомірної вигоди є одержання саме як матеріально визначених, так і речей, які не мають грошового еквіваленту та матеріального відображення.

Ознакою, шо відділяє подарунок від неправомірної вигоди є ознака «без законних на те підстав» для одержання неправомірної вигоди та «безоплатність та одержання/дарування за иіною, нижчою від мінімальної ринкової». Саме остання частина складника дефінічї подарунка свідчить про вартісні характеристики подарунку.

I хоча сьогодні предметом обмеження щодо одержання подарунку відповідно до законодавства виступають також і нематеріальні активи, пільги, переваги, привілеї, ми дотримуємося тієї точки зору, що 
предметом адміністративного правопорушення, пов'язаного 3 корупцією, повинна бути матеріально окреслена річ, що має відповідні економічні ознаки.

Предмет подарунку є досить широким поняттям та охоплює не тільки визначені законодавством речі. Так, відповідно до справи № 534/98/19 від 14.02.2019 ОСОБА 4, будучи начальником Управління Державної казначейської служби України Полтавської області, суб'єктом відповідальності, порушила обмеження щодо одержання подарунків, а саме 27.01.2017 одержала від Благодійного фонду «Полтавського гірничозбагачувального комбінату» подарунок у вигляді нецільової одноразової благодійної допомоги в сумі 2000 грн, що перевищує один прожитковий мінімум, встановлений на день прийняття подарунка (1600), чим умисно вчинила адміністративне правопорушення, пов'язане з корупцією, передбачене ч. 1 ст. 172-5 КУПАП .

У судовому засіданні ОСОБА_4 свою вину у вчиненому правопорушенні не визнала та пояснила, що до Благодійного фонду «ПГЗК» в січні 2017 вона у зв'язку зі скрутним матеріальним становищем звернулась як фізична особа із заявою про укладання договору та отримання одноразової матеріальної допомоги для вирішення соціальнопобутових потреб. Вважає, що нею не було порушено чинне законодавство України у зв'язку з тим, що укладання цього договору не може бути пов'язане зі здійсненням нею державної діяльності та функцій місцевого самоврядування, оскільки благодійний фонд не є державним чи комунальним підприємством і, відповідно, жодної підпорядкованості між сторонами договору стосовно їі професійної діяльності не було. Адже допомогу отримують й інші фізичні особи, які звертаються до зазначеного фонду, тому що потребують допомоги [19].

Поняття «подарунок» та «благодійна допомога» не є тотожними, вони мають різні визначення, правове регулювання, різне оподаткування

У справі відсутній умисел та корупційний інтерес щодо одержання подарунку, що автоматично виключає суб'єктивну сторону юридичного складу правопорушення щодо обмеження одержання подарунку.

Згідно 3 п. 1 ч. 1 ст. 247 КУпАП провадження в справі про адміністративне правопорушення підлягає закриттю за відсутністю події і складу адміністративного правопорушення, передбаченого ч. 1 ст. 172-5 КУпАП.

У зазначеному випадку бачимо, що справа була закрита у зв'язку з відсутністю суб'єктивної сторони, що суддею зведено до наявності корупційного інтересу та умислу.
Наступним прикладом судової практики є справа № 569/3500/17 Рівненського міського суду. ОСОБА 1, який, працюючи на посаді старшого оперуповноваженого в особливо важливих справах (підполковник) 3 сектору відділу контррозвідувального захисту інтересів держави у сфері економічної безпеки Управління Служби безпеки України в Рівненській області, будучи особою, уповноваженою на виконання функції держави, службовою особою 3 виконанням організаційно розпорядчих обов'язків у зв'язку з можливістю виконання таких функцій, діючи умисно, маючи особисті інтереси, усвідомлюючи протиправний характер своїх дій, порушив встановлену законом заборону щодо одержання дарунка (пожертви).

Так, 26.08.2015 року ОСОБА_1, користуючись своїми повноваженнями посадової особи контролюючого органу, в службовому кабінеті начальника служби автомобільних доріг у Рівненській області отримав у подарунок талон на 20 літрів бензину А-95 [20].

$\mathrm{y}$ цьому випадку говоримо про талон на бензин як предмет подарунку, проте встановлення останнього ще не є підставою для притягнення до адміністративної відповідальності за правопорушення щодо обмеження одержання подарунків, оскільки надалі встановленню підлягає наявність умислу, причинно-наслідкового зв’язку між одержанням подарунку та вчинення дій в межах державно-владних повноважень.

У конкретній справі предметом правопорушення щодо обмеження одержання подарунку є отримання одноразової цільової благодійної допомоги, проте для встановлення юридичного складу повинен бути причинно-наслідковий зв'язок між одержанням такого подарунку суб'єктом відповідальності безпосередньо або через інших осіб, а саме: 1) у зв'язку зі здійсненням такими особами діяльності, пов'язаної з виконанням функцій держави або місцевого самоврядування; 2) якщо особа, яка дарує, перебуває у підпорядкуванні такої особи; 3) доведено причинно-наслідковий зв'язок як складовий елемент об'єктивної сторони порушення щодо одержання подарунку в отриманні публічним службовцем у власних інтересах подарунку; 4) з'ясовано мотив і характер вчиненого діяння, повноваження особи, яка його вчинила, а також інші обставини, які мають значення для справи; 5) здійснено належну оцінку доказів у справі.

Як бачимо, встановлення предмета подарунку не є доконаним фактом порушення обмежень щодо одержання подарунку, аналіз юридичного складу продемонстрував необхідність детального вивчення факту події 
та складу правопорушення, передбаченого ст. 172-5 КУПАП.

Загалом одержання подарунків у власних інтересах та у зв'язку з виконанням функцій держави та органів місцевого самоврядування, на нашу думку, варто розцінювати безпосередньо як корупційне правопорушення, оскільки одержання подарунків як предмета правопорушення варто розцінювати як причину, що надалі призводить до появи фактів корупції.

Також на користь внесення законодавчих змін в частині передбачення одержання подарунку як корупційного правопорушення свідчить і Постанова Пленуму Верховного суду України від 26 квітня 2002 р. № 5 «Про судову практику у справах про хабарництво», де вказується, що хабар може даватися та отримуватися й у замаскованій формі - під виглядом укладення законної угоди, нарахування й виплати заробітної плати чи премій, нееквівалентної оплати послуг різного характеру (консультації, експертизи тощо) [21].

У цьому випадку виникає спірне питання щодо процедури доказування мети вчинення дій, які підпадають під ознаки неправомірної вигоди, оскільки в судовому порядку досить складно довести наявність предмета вчинення правопорушення через одержання пільг, переваг, привілеїв тощо, тому здебільшого такі справи закінчуються закриттям справи за відсутності складу та події правопорушення.

Висновки. На користь власного бачення тлумачення подарунку через призму лише матеріальних речей свідчить і той факт, що антикорупційне законодавство чітко визначило межі допустимого подарунку особам, уповноваженим на виконання функцій держави та органів місцевого самоврядування, тому можна говорити про суперечність положень ст. 172-5 КУПАП та ст. 1 Закону України «Про запобігання корупції», оскільки предметом обмеження щодо одержання подарунка також є нематеріальні речі (вигоди, привілеї, пільги, переваги тощо), а останні за законодавчим визначенням здебільшого не мають грошового еквіваленту, що унеможливлює встановлення шкоди для суспільних відносин державного управління.

Відмежування дефініцій подарунок та неправомірна вигода повинно проходити через декілька аспектів:

- встановлений розмір допустимого подарунку становить одна мінімальна заробітна плата, встановлена на день прийняття подарунка, одноразово, а сукупна вартість таких подарунків, отриманих від однієї особи (групи осіб) протягом року, не має перевищувати два прожиткові мінімуми, вста- новлені для працездатної особи на 1 січня поточного року. Неправомірна вигода немає чітко визначеного розміру;

- передача подарунку відбувається безкоштовно або ж за ціною, нижчою за ринкову, тоді передача неправомірної вигоди відбувається за умови відсутності законних на те підстав;

- прийняття пропозиції, обіцянки або одержання неправомірної вигоди у різних їі варіаціях має виключно корисливий мотив, а одержання подарунку може розцінюватися за певних обставин як загальновизнане уявлення про гостинність, що підлягає встановленню в судовому порядку.

\section{Список використаних джерел:}

1. Моніторинговий звіт щодо ефективності реалізації Національним агентством 3 питань запобігання корупції у 2016-2018 роках адміністративно-юрисдикційної функції в частині протидії адміністративним правопорушенням, які пов'язані 3 корупцією (станом на 1 червня 2018 року). URL: http://pravo.org.ua/img/books/ files/1531464560dudorov_nazk_report.pdf (дата звернення: 03.08.2019).

2. Про основні засади діяльності органів державного фінансового контролю : проект Закону України від 17.09.2018 № 9086. URL: http:// search.ligazakon.ua/1_doc2.nsf/link1/JH70E00A. html (дата звернення: 03.08.2019).

3. Про запобігання корупції : Закон України від 14.10.2014 № 1700-VII. Відомості Верховної Ради України. 2014. № 49. Ст. 2056.

4. Словник української мови : в 11 тт. / за ред. І. К. Білодіда. Київ : Наукова думка, 1970-1980.

5. Окрема думка судді Конституційного Суду України Сліденка І.Д. стосовно Рішення Конституційного Суду України у справі за конституційним поданням 49 народних депутатів України щодо відповідності Конституції України (конституційності) пункту 12 розділу I Закону України «Про внесення змін та визнання такими, що втратили чинність, деяких законодавчих актів України» від 28.12.2014 № 76-VIII. URL: https://zakon.rada.gov.ua/ laws/show/nd05d710-18 (дата звернення: 03.08.2019).

6. Титко А. В. Ознаки обмеження одержання подарунків як різновиду адміністративного правопорушення, пов'язаного з корупцією. Прикарпатський юридичний вісник. 2018. № 4-3. С. 67-70.

7. Повідомлення Комісії. Рамковий документ щодо державної допомоги на наукові дослідження, технічний розвиток та провадження інноваційної діяльності від 27.06.2014. URL: https://zakon.rada. gov.ua/laws/show/984_006-14/ed20140627 (дата звернення: 03.08.2019).

8. Кримінальний кодекс України Закон від 06.04.2001 № 2341-III. URL: https:// zakon.rada.gov.ua/laws/show/2341-14 (дата звернення: 03.08.2019).

9. Хавронюк M. I. Науково-практичний коментар до закону України «Про засади запобігання і протидії корупції». Київ : Атіка, 2011. С. 35 
10. Ярошенко О. Д. Предмет юридичних складів злочинів, передбачених статтею 369 Кримінального кодексу України в аспекті його відповідності визначенню, що дається у Кримінальній конвенції Ради Європи про боротьбу з корупцією. Бюлетень Міністерства юстииї України. 2013. № 7. C. 105-112.

11. Науково-практичний коментар до Кримінального кодексу України / за ред. М. І. Мельника, М. І. Хавронюка. 9-те вид., переробл. та допов. Київ : Юридична думка, 2012. С. 1074.

12. Дудоров О. О. Проблемні питання кримінальної відповідальності за одержання хабара : автореф. дис. ... канд. юрид. наук. Київ, 1994. С. 11.

13.Бабіков О. Майновий характер неправомірної вигоди. Вісник Начіональної академії прокуратури України. 2013. № 4. С. 35-38.

14.Криміналістика : навчальний посібник / за заг. ред. Є. В. Пряхіна. Львів: ЛьвДУВС, 2010. $540 \mathrm{c}$.

15. Шепітько В. Ю. Криміналістика : підручник для студ. вищ. навч. Київ: Ін Юре, 2010. 496 с.
16. Цивільний кодекс України. Харків, 2018. 446с 17. Постанови Пленуму Верховного Суду України в кримінальних справах / упоряд В. В. Рожнова, А. С. Сизоненко, Л. Д. Удалова. Київ : ПАЛИВОДА А. В., 2012. С. 195.

18. Якимова С. В. Про систематизацію ознак неправомірної вигоди як предмета підкупу за Кримінальним кодексом України. Вісник Національного університету "Львівська політехніка". Серія «Юридичні науки». 2015. № 813. С. 292-298.

19. Архів справ Комсомольського міського суду Полтавської області. URL: http://www. reyestr.court.gov.ua/Review/79980226 (дата звернення: 03.08.2019).

20. Архів Рівненського міського суду Рівненської області. URL: http://www.reyestr.court.gov. ua/Review/65834090 (дата звернення: 03.08.2019)

21. Про судову практику у справах про хабарництво : Постанова Пленуму Верховного Суду України від 26.04.2002 № 5. URL: http://www. scourt.gov.ua/clients/vs.nsf (дата звернення: 03.08.2019).

In the article to consider the key features of the subject of the legal structure violation of the restrictions established by law for obtaining a gift as a mandatory element of the object of the offense. On the basis of the comparative method and the method of hermeneutics, an analysis of the judicial practice of bringing to administrative responsibility for an administrative offense related to corruption provided for in Art. 172-5 $C A O$ as part of the consideration of the objects of the said offense. Doctrinal visions and legal definitions of the concepts of "gift" and "unlaweful profit" are considered through the prism of signs of material and intangible things. The common and distinctive features of a gift and unlaw ful gain are identified as subjects of an administrative offense related to corruption and corruption offenses, respectively. The distinction between benefits, privileges and benefits in the context of analysis of anti-corruption legislation, in particular as a component of the gift definitions and unlaw ful profit, is clarified. On the basis of the analyzed, the actual definition of the gift is formulated and the key elements are defined for the formation of the evidence base in order to bring to administrative liability under Art. 172-5 CAO. The key features that distinguish the gift and the unlawful benefit are outlined, on the basis of the analysis of judicial practice, certain problematic issues of legal qualification under Art. 172-5 CAO. It was found out that the installation of a gift object is not a committed fact of committing a violation of the restrictions on the receipt of a gift, and the analysis of the legal composition has demonstrated the need for a detailed study of the facts of the event and the offense stipulated in Art. 172-5 CAO. It is concluded that the distinction between definitions of gifts and unlaw ful benefits should take place in several aspects: the size of the allowable gift is one minimum wage established on the day of acceptance of the gift, once, and the aggregate value of such gifts received from one person (group of persons) during the year, must not exceed two living wages, established for an able-bodied person on January 1 of the current year; the method of gift transfer is free of charge or at a price below the market at a time when the transfer of the unlawful benefit occurs in the absence of legal grounds for that; the acceptance of a proposal, a promise or the receipt of unjust benefits in its various variations has an exclusively mercenary motive, and the receipt of a gift can be regarded in certain circumstances as a generally accepted notion of hospitality that is subject to judicial review.

Key words: gift, intangible and tangible assets, improper benefits, privileges, benefits, causal relationship. 
УДК 343.1

DOI https://doi.org/10.32849/2663-5313/2019.8.38

\section{Тимур Лоскутов,}

докт. юрид. наук, дочент,

професор кафедри кримінально-правових дисииллін та судових експертиз

Донецького юридичного інституту Міністерства внутрішніх справ Украйни

\section{ВІДПОВІДНІСТЬ ОКРЕМИХ НОРМ КРИМІНАЛЬНОГО ПРОЦЕСУАЛЬНОГО КОДЕКСУ УКРАЇНИ ЄВРОПЕЙСЬКИМ СТАНДАРТАМ ЗАБЕЗПЕЧЕННЯ ПРАВ ЛЮДИНИ}

Стаття присвячується дослідженню відповідності окремих норм Кримінального прочесуального кодексу України вимогам європейських стандартів забезпечення прав людини. У прочесі постановки проблеми підкреслюється, що невідповідність норм Кримінального процесуального кодексу України вимогам міжнародних $і$ європейських стандартів забезпечення прав людини може зумовлювати неправомірне обмеження та порушення прав учасників кримінального судочинства. На підставі аналізу останніх досліджень та публікацій наголошується, що змістом досліджень науковиів не були охоплені всі проблемні кримінальні процесуальні норми, котрі не узгожуються з європейськими стандартами забезпечення прав людини. Їх наявність у Кримінальному процесуальному законі Украйни не сприяє реалізації прав людини у перебігу досудового та судового провадження. У ході дослідження розглядається співвідношення деяких кримінальних процесуальних норм і положень Конвениї про захист прав людини і основоположних свобод, практики Європейського суду з прав людини. Зазначається, що не відповідає вимогам європейських стандартів забезпечення прав людини положення ст. 211, 492 Кримінального процесуального кодексу Украӥни, що уможливлюють затримання неповнолітньої особи без судового рішення аж до шістдесяти годин. Вказується, що не узгоджуються з положеннями європейських стандартів захисту прав людини зміст ст. 197, 492 Кримінального процесуального кодексу України, що передбачають можливість продовження строку досудового тримання під вартою неповнолітнього аж до дванадияти місяиів. Зазначається, що прикладом неузгодженості норм кримінального прочесуального закону та європейських стандартів забезпечення прав $\epsilon$ положення ч. $1 \mathrm{~cm} .351$ Кримінального прочесуального кодексу України, що уповноважують прокурора (сторону обвинувачення) першим у суді допитувати обвинуваченого - основного представника сторони захисту. Визначається, що законодавчою нормою, котра неповною мірою відповідає європейським стандартам забезпечення прав людини щодо визначення терміну «житло», є положення ч. 2 ст. 233 Кримінального процесуального кодексу України. Використання у иій нормі словосполучення «яке знаходиться у постійному чи тимчасовому володінні особи» звужує поняття «житло», а тому $i$ зменшує гарантії права особи на недоторканість житла. Під час дослідження пропонуються нормативні зміни стосовно приведення у відповідність положень кримінального процесуального закону до вимог європейських стандартів забезпечення прав людини.

Ключові слова: права людини, строк, затримання, тримання під вартою, неповнолітній, обвинувачений, допит, житло.

Постановка проблеми. Рівень забезпечення прав людини під час кримінального провадження в Україні залежить від якості норм вітчизняного кримінального процесуального законодавства, і передусім від положень основного кримінального процесуального акта - Кримінального процесуального кодексу України (далі - КПК). Невідповідність норм останнього вимогам міжнародних і європейських стандартів забезпечення прав людини може зумовлювати неправомірне обмеження та порушення прав учасників кримінального судочинства. Тому особли- вого значення та актуальності набувають дослідження узгодженості (неузгодженості) нормативних положень КПК з європейськими стандартами забезпечення прав людини.

Аналіз останніх досліджень та публікацій. Окремі питання змістового співвідношення норм КПК та європейських стандартів забезпечення прав людини досліджували такі вчені, як О. А. Банчук, І. В. Гловюк, В. О. Гринюк, О. М. Дроздов, О. В. Капліна, Л. М. Лобойко, С. В. Меркулов, М. А. Погорецький, О. М. Толочко, О. Г. Шило та інші. Водночас змістом 
досліджень науковців не були охоплені всі проблемні кримінальні процесуальні норми, котрі не узгоджуються з європейськими стандартами забезпечення прав людини. Їх наявність у Кримінальному процесуальному законі України не сприяє реалізації прав людини у перебігу досудового та судового провадження.

Метою статті $є$ визначення узгодженості (неузгодженості) окремих норм КПК 3 нормативними вимогами європейських стандартів забезпечення прав людини. Для досягнення цієї мети необхідно проаналізувати співвідношення окремих норм КПК i європейських стандартів забезпечення прав людини та визначити їх узгодженість або неузгодженість.

Виклад основного матеріалу. У попередніх роботах ми вже досліджували питання щодо відповідності деяких норм чинного КПК європейським стандартам забезпечення прав людини. Тоді нами було підсумовано, що норми КПК не відповідають європейським стандартам забезпечення прав людини в частині регламентації початку досудового розслідування, вільного вибору захисника, реалізації права на захист від первісного кримінального переслідування (обвинувачення), проведення примусового освідування, продовження строків досудового розслідування [1, с. 94], доставлення затриманої особи до органу досудового розслідування, підстав затримання, вибору запобіжного заходу у вигляді тримання під вартою та продовження строку останнього під час досудового розслідування та судового провадження, нерівності сторін обвинувачення і захисту щодо виклику і допиту (одночасного допиту) учасників кримінального провадження, зупинення досудового розслідування [2, с. 82-103].

У цій публікації ми проаналізуємо інші норми чинного КПК на предмет відповідності їхнього змісту нормативним вимогам європейських стандартів забезпечення прав людини. У результаті здійсненого дослідження сформулюємо висновок стосовно узгодженості або неузгодженості аналізованих кримінальних процесуальних норм вказаним стандартам забезпечення прав людини.

Почнемо розгляд співвідношення окремих норм КПК та європейських стандартів забезпечення прав людини.

1. Не відповідає вимогам європейських стандартів забезпечення прав людини положення ст. 211, 492 КПК, що уможливлюють затримання неповнолітньої особи без судового рішення аж до шістдесяти годин. Ці норми не узгоджується з положеннями п. 15 Рекомендації N Rec (2003) 20 про нові підходи до злочинності серед неповнолітніх і про значення правосуддя у справах неповнолітніх, у якому зазначається, що неповнолітні не можуть перебувати від вартою у поліції довше ніж сорок вісім годин, а для самих молодих даний строк має бути по можливості знижений [3, с. 347].

У п. b ст. 37 Конвенції про права дитини наголошується, що затримання дитини застосовується протягом якомога коротшого відповідного періоду часу. Інакше кажучи, у даному міжнародно-правовому документі вимагається, щоб часові параметри затримання неповнолітніх були мінімальними. Аналогічні положення містяться у рішенні «Корнейкова проти України» (2012), де Європейський суд зазначив, що попередне тримання під вартою неповнолітніх має використовуватися лише протягом найкоротшого періоду [4]. Попри наведені стандарти забезпечення прав неповнолітньої особи, приписи КПК не зменшують максимальний строк досудового затримання неповнолітніх. Стосовно останніх, як і щодо повнолітніх осіб, унормовується крайня часова межа затримання - шістдесят годин.

Зазначений варіант правової регламентації граничного строку досудового затримання неповнолітнього за підозрою у вчиненні злочину не сприяє забезпеченню прав і свобод неповнолітніх осіб. Недоліки цього регулювання посилюються через відсутність у процесуальному законі обов'язку щодо невідкладного доставлення затриманого неповнолітнього до суду. Тому ризик свавілля органів розслідування щодо неповнолітніх збільшується.

За відсутності норми стосовно негайного доставлення затриманого неповнолітнього до суду максимальний строк досудового затримання зазначеної категорії осіб у КПК повинен бути зменшений. Видається, що цей строк повинен бути хоча б таким, який закріплювався проектом КПК, що був підготовлений Національною комісією зі зміцнення демократії та утвердження верховенства права. Цим проектом КПК від Нацкомісії (станом на грудень 2008 року) передбачалося (ст. 174), що клопотання про застосування або зміну запобіжного заходу розглядається слідчим суддею, судом невідкладно, але не пізніше двадцяти чотирьох годин з моменту фактичного затримання підозрюваного, обвинувачуваного за відсутності ухвали суду про дозвіл на затримання. Статтею 194 проекту встановлювалося, що строк затримання особи без ухвали суду не може перевищувати двадцяти чотирьох годин з моменту затримання [5, с. 123]. 
Граничний строк досудового затримання неповнолітнього у двадцять чотири години $\epsilon$ набагато кращим для забезпечення прав і свобод осіб, які не досягли вісімнадцятирічного віку, аніж строк у шістдесят годин. Проте навіть строк затримання у двадцять чотири години може повністю використовуватися тільки у виняткових випадках, за інших обставин він повинен зменшуватися.

2. Не узгоджується з положеннями європейських стандартів захисту прав і свобод людини зміст ст. 197, 492 КПК, що передбачають можливість продовження строку досудового тримання під вартою неповнолітнього аж до дванадцяти місяців. Такий же граничний строк для продовження тримання під вартою законодавцем встановлюється стосовно дорослих осіб, які підозрюються у скоєнні тяжких чи особливо тяжких злочинів. Тобто КПК не зменшує максимально можливого строку тримання під вартою з огляду на вразливу категорію осіб - неповнолітніх.

Відповідно до п. 16 Рекомендації N Rec (2003) 20 про нові підходи до злочинності серед неповнолітніх і про значення правосуддя у справах неповнолітніх, якщо як останній захід до неповнолітніх, які підозрюються у вчиненні злочину, застосовується попередне ув'язнення, то строк даного заходу не повинен перевищувати шість місяців до початку судового розгляду [3, с. 347]. Таким чином, приписами цього міжнародного документа передбачається значно менший граничний строк досудового тримання під вартою неповнолітніх підозрюваних порівняно з аналогічним строком, що закріплюється у КПК

Досліджуючи міжнародне право у галузі прав дитини, Джеральдіна ван Б’юрен зазначає, що, незважаючи на те, що Європейська Конвенція про права людини не передбачає чітко того, що затримання та ув'язнення дітей слід застосовувати протягом якомога коротшого належного періоду часу, Свропейський суд з прав людини дійшов висновку, що період часу, протягом якого дитина може бути затримана або ув'язнена, може виступати як відповідний, але не вирішальний чинник для відповіді на питання про законний характер акту позбавлення волі [6, с. 260]. Дійсно, для прийняття рішення про тримання неповнолітнього під вартою на стадії досудового розслідування мають існувати правові підстави, якими є обгрунтована підозра у вчиненні злочину та наявність одного чи кількох ризиків неналежної поведінки. Без підтвердження фактичною інформацією цих процесуальних підстав взяття під варту неповнолітнього підозрюваного є очевидно незаконним. Разом із тим часові межі утримання непо- внолітнього під вартою також впливають на законність, правомірність зазначеного запобіжного заходу. Якщо строк перебування неповнолітнього підозрюваного під вартою є занадто великим, то втрачається сутність запобіжного заходу - забезпечення належної поведінки до судового розгляду. У такому разі тримання під вартою може сприйматися неповнолітнім як вид покарання, а не захід забезпечення кримінального провадження. Це є неприпустимим з огляду на презумпцію невинуватості, що не може бути спростована на досудовому розслідуванні.

Отже, крайня часова межа досудового тримання під вартою - дванадцять місяців щодо неповнолітніх підозрюваних - має бути знижена, наприклад, до шести місяців. Таке удосконалення законодавства приведе у відповідність положення ст. 197, 492 КПК до вимог європейських стандартів забезпечення прав людини в частині максимального строку досудового тримання під вартою неповнолітніх

3. Наступним прикладом неузгодженості норм кримінального процесуального закону та європейських стандартів забезпечення прав є положення ч. 1 ст. 351 КПК. Останні уповноважують прокурора (сторону обвинувачення) першим у суді допитувати обвинуваченого - основного представника сторони захисту.

Вказана норма ч. 1 ст. 351 КПК не відповідає європейським стандартам забезпечення прав людини у частині регламентації конвенційного права на справедливий суд, що закріплюється ст. 6 Конвенцією про захист прав людини і основоположних свобод.

У рішенні «Тарасов проти України» (2013) Європейський суд зазначив, що, в принципі, право обвинуваченого за ст. 6 на ефективну участь у розгляді включає право не тільки бути присутнім, але й слухати і стежити за ходом засідань. Притаманне самому поняттю змагального процесу, це право може бути також виведене з права обвинуваченого «захищати себе», що згадується, зокрема, у ст. 6 § (3). «Ефективна участь» у цьому контексті передбачає, що обвинувачений повинен мати можливість пояснити своїм адвокатам свою версію подій, вказати на які-небудь заяви, з котрими він не згоден, та інформувати їх про будь-які факти, що повинні бути висунуті на його захист [7].

Після закінчення прокурорського допиту обвинуваченого в останнього залишається право дати показання захиснику (адвокату) та звернути його увагу на виправдувальні обставини справи, навести свій варіант перебігу подій (ч. 1 ст. 351 КПК). Але ефект таких захисних показань (наданих захиснику) 
обвинуваченого може суттєво зменшуватися, оскільки прокурор у попередньому допиті може «зіграти на випередження» щодо версій подій захисту, тим самим унеможливити наведення обвинуваченим виправдувальних фактів, а отже, обмежити право обвинуваченого на ефективну участь у судовому розгляді.

Крім того, у рішенні «Рудніченко проти України» (2013) Європейський суд підкреслив, що термін «свідок» має «самостійне» значення в розумінні Конвенції. Отже, якщо письмові показання значною мірою покладено в основу обвинувачення, то незалежно від того, чи це показання свідка в прямому розумінні цього слова чи показання співобвинуваченого, ці показання є доказами для обвинувачення, на які поширюються гарантії, передбачені п. 1 та підп. (d) п. 3 ст. 6 Конвенції [8, с. 258]. Останні нормативні положення передбачають право обвинуваченого на допит свідків захисту та свідків обвинувачення в однакових умовах. Не може бути винятком допит самого обвинуваченого, який $з$ точки зору забезпечення правових гарантій у практиці Європейського суду ототожнюється з допитом свідка. Проте КПК регламентує різний порядок допиту обвинуваченого та свідків під час судового розгляду.

Таким чином, правове регулювання у КПК допиту обвинуваченого у судовому розгляді може погіршувати процесуальне положення сторони захисту та негативно впливати на ефективність реалізації прав і свобод обвинуваченого.

Для приведення кримінальних процесуальних норм щодо регламентації допиту обвинуваченого у суді у відповідність до вимог європейських стандартів, що передбачають ефективну участь обвинуваченого у судовому засіданні, необхідно змінити зміст ч. 1 ст. 351 КПК. Зокрема, стосовно зазначеного допиту слід унормувати процедуру, відповідно до якої обвинуваченого перший допитує захисник, а потім прокурор.

Аналогічний порядок допиту у суді ч. 6 ст. 352 КПК встановлюе щодо свідків. Залежно від характеристики останніх (свідки обвинувачення, свідки захисту) вони спочатку допитуються або стороною обвинувачення (прокурор), або стороною захисту (захисник, обвинувачений). Але у будь-якому разі першою допитує сторона кримінального провадження «своїх» свідків, а свідків протилежної сторони - другою. Такий процесуальний порядок допиту учасників різних сторін кримінального провадження $€$ справедливим, оскільки враховує реалізацію їх ефективної участі у судовому розгляді.

4. Ще однією законодавчою нормою, котра не повністю відповідає європейським стан- дартам забезпечення прав людини, є положення ч. 2 ст. 233 КПК. Зміст цієї норми щодо визначення терміна «житло» є обмеженим через використання у ньому словосполучення «яке знаходиться у постійному чи тимчасовому володінні особи». Ця формальна умова звужує поняття «житло», а тому і зменшуе гарантії права особи на недоторканість житла.

Європейський суд 3 прав людини термін «житло» тлумачить досить широко, не акцентуючи увагу на його володільцеві. У рішенні «Глоба проти України» (2012) Суд повторює, що «житло»- самостійне поняття, яке не залежить від класифікації за національним законодавством. Питання про те, чи $є$ конкретне приміщення «житлом», яке захищається п. 1 ст. 8 Конвенції, залежатиме від фактичних обставин, а саме існування достатнього та тривалого зв'язку з певним місцем [9]. Свропейським судом визнається житлом офіс [10], службові приміщення [11] тощо. 3 таким широким підходом до визначення поняття «житло» важко не погодитися, тому що особа може не володіти приміщенням (житлом), але фактично проживати у ньому. Це зумовлює поширення усіх конвенційних гарантій «житла» на будь-які приміщення, в яких особа мешкає.

Отже, трактування терміна «житло» за європейськими стандартами забезпечення прав людини є більш прогресивним, аніж його нормативне визначення у КПК.

3 метою узгодження визначення терміна «житло», що сформульоване у ч. 2 ст. 233 КПК, з положеннями європейських стандартів забезпечення прав людини пропонуємо виключити зі змісту даної норми словосполучення «яке знаходиться у постійному чи тимчасовому володінні особи».

\section{Висновки}

Норми КПК не узгоджуються 3 європейськими стандартами забезпечення прав людини в частині правової регламентації максимального строку затримання та досудового тримання під вартою неповнолітнього, порядку допиту обвинуваченого у суді, визначення поняття «житло».

Перспективними напрямами наукових розвідок можна визначити такі: 1) дослідження інших нормативних положень КПК на предмет їх відповідності європейським стандартам забезпечення прав людини; 2) аналіз норм КПК через призму міжнародних стандартів захисту прав людини.

\section{Список використаних джерел:}

1. Лоскутов Т.О. Аналіз окремих положень Кримінального процесуального кодексу Украї- 
ни крізь призму європейських стандартів забезпечення прав людини. Підприємниитво, господарство і право. 2013. № 11 (215). С. 91-95.

2. Лоскутов Т.О. Предмет регулювання кримінального процесуального права : монографія Київ : Юридичний світ, 2016. 416 с.

3. Янова Г. Міжнародне та національне законодавство у сфері захисту прав дитини. Київ : ПП «Видавництво «Сучасний письменник», 2015. 704 с

4.Решение «Корнейковапротив Украины» от 19апреля 2012г.URL:https://hudoc.echr.coe.int/ app/conversion/pdf?library $=\mathrm{ECHR} \& \mathrm{id}=001$ $112561 \&$ filenam e $=$ C A S E \% 200 F \% 20 KORNEYKOVA\%20v.\%20UKRAINE\%20-\%20 [Russian\%20Translation].pdf.

5. Лобойко Л.М. Реформування кримінально-процесуального законодавства в Україні (2006-2011 роки). Частина 1. Загальні положення і досудове розслідування : монографія. Київ: Істина, 2012. 288 с.

6. Ван Б'юрен Дж. Міжнародне право в галузі прав дитини / пер. з англ. Г.Є. Красно- кутського ; наук. ред. М.О. Баймуратов. Одеса: АО БАХВА, 2006. $524 \mathrm{c}$.

7. Решение «Тарасов против Украины» вот 31 января 2014 г. URL: http://hudoc.echr.coe. int/eng\#\{"fulltext":["тарасов"],"documentcollect ionid2":["GRANDCHAMBER","CHAMBER"],"i temid":["001-152483"]\}.

8. Макбрайд Дж. Свропейська конвенція 3 прав людини та кримінальний процес. Практика Європейського суду з прав людини. 2-ге вид. Київ : К.І.С., 2019. 558 с.

9. Рішення «Глоба проти України» від 19 листопада 2012 p. URL: https://zakon.rada. gov.ua/laws/show/974 911.

10. Решение «Нимитц против Германии» от 16 декабря 1992 г. URL: https://hudoc. echr.coe.int/app/pdf?library=ECHR\&id=001$104030 \&$ filen a m e $=$ C A S E \% 200 F \% 20 NIEMIETZ\%20v.\%20GERMANY\%20-\%20 [Russian\%20Translation].pdf.

11. Решение «Бак против Германии» от 28 апреля 2005 г. URL: http://hudoc.echr.coe. int/eng?i=001-185724.

The article is devoted to investigating the compatibility of certain norms of the Criminal Procedure Code of Ukraine with the requirements of the European standards of human rights. In the process of raising the problem, it is emphasized that the non-compliance with the norms of the Criminal Procedure Code of Ukraine with the requirements of international and European human rights standards may lead to the unlawful restriction and violation of the rights of participants in criminal proceedings. Analyzing recent research and publications, it has been pointed out that the content of research has not covered all problematic criminal procedural rules that do not conform to European human rights standards. Their presence in the Criminal Procedure Code of Ukraine does not contribute to the realization of human rights in the course of pre-trial and judicial proceedings. The study examines the ratio of some criminal procedural rules and provisions of the Convention for the Protection of Human Rights and Fundamental Freedoms to the case law of the European Court of Human Rights. It is noted that the provisions of Art. 211, 492 of the Criminal Procedure Code of Ukraine, allowing detention of a minor without a court decision up to sixty hours. It is stated that the content of Art. 197, 492 of the Criminal Procedure Code of Ukraine, which provide for the possibility of extending the term of pre-trial detention of a minor up to twelve months. It is noted that an example of the inconsistency of the rules of criminal procedure law and European standards of rights is the provision of Part 1 of Art. 351 of the Criminal Procedure Code of Ukraine, authorizing the prosecutor (the prosecution party) to be the first in court to interrogate the accused - the main representative of the defense party. It is determined that a legislative provision that does not fully comply with European human rights standards for the definition of the term «housing» is the provision of Part 2 of Art. 233 of the Criminal Procedure Code of Ukraine. The use of the phrase «permanently or temporarily owned by a person» in this provision narrows the concept of «housing» and therefore reduces the guarantees of a person's right to privacy. The study proposes regulatory changes to align the provisions of criminal procedural law with the requirements of European human rights standards.

Key words: human rights, term, detention, detention, minor, accused, questioning, housing. 
УДК 343.13

DOI https://doi.org/10.32849/2663-5313/2019.8.39

\section{Сергій Шульгін,}

аспірант кафедри кримінального права та правосуддя

Міжнародного економіко-гуманітарного університету імені академіка Степана Дем'янчука

\section{ВИДИ ПРОЦЕСУАЛЬНИХ РІШЕНЬ СЛІДЧОГО ТА ПРОКУРОРА}

У статті проведено наукову класифікацію процесуальних рішень слідчого і прокурора за їх вида ми, доведено, що вона має вагоме теоретичне і практичне значення, оскільки дозволяє більш глибоко з'ясувати їхню правову природу, механізм прийняття, ознаки, елементи та структуру, визначити їхн місие та завдання у системі кримінальних проиесуальних рішень

У статті зазначено, що, незважаючи на відсутність у КПК України вимоги складення будь-яких процесуальних актів як підстави для внесення відомостей до ЄРДР, ие є першим кримінальним процесуальним рішенням слідчого або прокурора, яке дає початок досудовому розслідуванню кримінального провадження.

Указано, що найпоширенішим проиесуальним рішенням слідчого і прокурора є постанова, однак у зв'язку зі змінами, які відбулись у кримінальному процесуальному законодавстві, основною ї метою $\epsilon$ збирання доказів, виконання інших завдань кримінального провадження.

Обгрунтовано, що повідомлення про підозру є процесуальним рішенням прокурора, слідчого за погодженням з прокурором. Воно характеризується як мінімум двома причинами: зміна етапу (у законі вказано стадіі) кримінального провадження; поява особи з процесуальним статусом підозрюваного.

Доведено, що клопотання слідчого, прокурора, адресоване слідчому судді, є особливим видом процесуального рішення з відповідними ознаками та елементами, яке має ініціативний характер щодо подальшого проведення досудового розслідування.

Обгрунтовано тезу про те, що письмова вказівка прокурора - ие процесуальне рішення, яке виноситься в ході здійснення проиесуального керівниитва досудовим розслідуванням кримінального провадження, спрямоване на координацію дій слідчого у кримінальному провадження для досягнення завдань кримінального провадження.

Зазначено, що обвинувальний акт є підсумковим процесуальним рішенням у кримінальному провадженні на стадії досудового розслідування, яким прокурор робить підсумок проведеного досудового розслідування, визнає, що докази винуватості підозрюваного є належними, допустимими, достовірними, їх сукупності досить для доведення винуватості особи у суді.

Ключові слова: процесуальні рішення слідчого прокурора, процесуальні рішення на досудовому розслідуванні, види процесуальних рішень, постанова слідчого, прокурора, письмові вказівки прокурора, обвинувальний акт.

Постановка проблеми. Загальновідомо, що кримінальне процесуальне право - не тільки галузь права, а й галузь науки, яка теоретично узагальнюе досвід кримінальної процесуальної діяльності, аналізує актуальні питання застосування кримінального процесуального законодавства, що мають місце у практиці правоохоронних органів та суду, розробляє науково-практичні рекомендації, спрямовані на підвищення ефективності кримінальної процесуальної діяльності всіх суб'єктів кримінального процесу $[9$, с. 9]. 3 огляду на прийняття у 2012 році нового кримінального процесуального кодексу, значення науки кримінального процесуального права стає значно зростає, особливо щодо нових правових інститутів, запроваджених у сферу правового регулювання.

На законодавчому рівні визначено, що рішення слідчого, прокурора приймається у формі постанови. Обвинувальний акт є процесуальним рішенням, яким прокурор висуває обвинувачення у вчиненні кримінального правопорушення і яким завершується досудове розслідування (ч. 3, ч. 4 ст. 110 КПК України). 3 наведеного вбачається, що законом виділено два види процесуального рішення слідчого і прокурора - це постанова, прокурора - обвинувальний акт. Разом із тим закон не надає визначення цих процесуальних рішень. Як пише Д.С. Кротков, рішення, які приймаються в ході кримінально-процесуальної діяльності, за формою можуть бути досить різноманітними. Найбільш поширеною формою їх закріплення є постанова. Під постановою прийнято розуміти документ, у якому фіксується рішення слідчого. Тобто в цьому разі якраз йдеться про один із процесуальних актів, який складається на стадії 
досудового розслідування і є письмово-документальним вираженням органу досудового розслідування [10, с. 27].

Разом із тим ми не можемо погодитися з таким приписом закону та вважаємо, що процесуальними рішеннями слідчого і прокурора є внесення відомостей до Єдиного реєстру досудових розслідувань, постанова, клопотання, повідомлення про підозру, письмові вказівки прокурора, погодження (санкціонування) прокурора та обвинувальний акт.

Аналіз досліджень та публікацій. Вагомий внесок у дослідження класифікації видів процесуальних рішень слідчого і прокурора зробили Ю.П. Аленін, В.Д. Берназ, В.В. Вапнярчук, Н.В. Глинська, І.В. Гловюк, В.О. Гринюк, О.В. Капліна, Д.С. Кротков, П.А. Лупинская, Ю.В. Манаев, О.І. Марочкін, А.Б. Муравин, А.І. Палюх, С.М. Смоков та інші, однак у їхніх працях здебільшого приділена увага класифікації видів процесуальних рішень слідчого, значно менше увага - процесуальним рішенням прокурора та практично не досліджено спільні рішення слідчого і прокурора крізь призму їхніх процесуальних повноважень у контексті положень КПК України 2012 року.

Метою статті є здійснення наукової класифікації процесуальних рішень слідчого i прокурора за їх видами, обгрунтування тези про те, що вона має вагоме теоретичне і практичне значення, оскільки дозволяе більш глибоко з'ясувати їхню правову природу, механізм прийняття, ознаки, елементи та структуру, визначити їхне місце та завдання у системі кримінальних процесуальних рішень.

Виклад основного матеріалу. Відповідно до ч. 2 ст. 214 КПК України досудове розслідування розпочинається з моменту внесення відомостей до Єдиного реєстру досудових розслідувань (далі за текстом ЄРДР - кур сив мій. С.Ш.). Згідно з частиною 1 цієї статті слідчий, прокурор невідкладно, але не пізніше 24 годин після подання заяви, повідомлення про вчинене кримінальне правопорушення або після самостійного виявлення ним з будь-якого джерела обставин, що можуть свідчити про вчинення кримінального правопорушення, зобов'язаний внести відповідні відомості до Єдиного реєстру досудових розслідувань, розпочати розслідування.

У наведених положеннях кримінального процесуального закону не визначено, що внесення відомостей до ЄРДР є процесуальним рішенням. Сдиними нормативним актом, який опосередковано на це вказує, $€$ Положення про порядок ведення Єдиного реєстру досудових розслідувань, зокрема абзац 5 п. 1, де зазначено, що унесення відомостей до Реєстру здійснюється з дотриманням строків, визначених КПК України та цим Положенням, а саме про передачу матеріалів та відомостей (ч. 7 статті 214 КПК України) протягом 24 годин 3 моменту прийняття процесуальних рішень, а також мета цього Положення - облік прийнятих під час досудового розслідування рішень [15]. Крім того, внесення відомостей до ЄРДР відповідає рисам, характерним для кримінальних процесуальних рішень, які запропонував А.Б. Мурівін, вони: 1) являють собою правовий висновок 3 конкретного питання, яке виникає в ході розслідування; 2) є індивідуальними актами правозастосування; 3) являють собою юридичні факти, які породжують виникнення, зміну чи припинення кримінально-процесуальних відносин і підтверджують наявність чи відсутність матеріально-правових відносин; 4) виносяться слідчим в межах його кримінально-процесуальної компетенції; 5) реалізують процесуальні повноваження слідчого i виконувані ним функції; 6) мають владний і обов'язковий характер; 7) відображають рівень пізнання (доказування) обставин справи, який досягнутий на момент прийняття рішення; 8) виражають внутрішнє переконання слідчого у його правомірності; 9) наділені властивостями законності, обгрунтованості, вмотивованості і справедливості [12, с. 8].

Кримінальний процесуальний закон не вимагає від слідчого, прокурора видання будь-якого документа як підстави внесення відомостей до СРДР. На практиці здебільшого такою підставою є резолюція керівника відповідного органу досудового розслідування, прокуратури, однак Комплексний аналіз наведених законодавчих приписів та теоретичних наукових розробок дає підстави зробити однозначний висновок: внесення відомостей до СРДР є першим кримінальним процесуальним рішенням слідчого або прокурора, яке дає початок досудовому розслідуванню кримінального провадження.

Найпоширенішим процесуальним рішенням слідчого і прокурора є постанова. Вказаний правовий акт визначений законодавцем як процесуальне рішення. Протягом багатьох років постанови слідчого і прокурора досліджувалися науковцями. 3 огляду на зміни, які відбулись у зв'язку з реформою кримінального судочинства, можна констатувати, що постанова посідає важливе місце у системі кримінальних процесуальних рішень, основною її метою є збирання доказів, виконання інших завдань кримінального провадження.

Слід зупинитися на такому процесуальному рішенні слідчого і прокурора, як 
повідомлення про підозру. Важливість цього процесуального рішення характеризується як мінімум двома чинниками. По-перше, це зміна етапу (хоча закон його визначає як нову стадію) кримінального провадження, по-друге, поява особи зі статусом підозрюваного. Як пише Н.П. Черняк, повідомлення особи про підозру - це одне із важливих процесуальних рішень, яке приймає прокурор або слідчий за погодженням із прокурором до закінчення розслідування у кримінальному провадженні. У цьому процесуальному рішенні на основі доказів, зібраних у ході проведення досудового розслідування, конкретна особа набуває статусу підозрюваного [18, с. 556]. Слід зазначити, що закон не відносить повідомлення про підозру до процесуальних рішень, однак комплексний аналіз положень КПК України та практики застосування цього процесуального акту дає підстави зробити висновок, що повідомлення про підозру є саме процесуальним рішенням.

Як із цього приводу зазначають Ю. П. Аленін та І. В. Гловюк, юридичне значення акту повідомлення особи про підозру полягає також і в тому, що на стадії досудового розслідування настає певний етап, пов'язаний 3 тим, що в процесі розслідування зібрано досить доказів для підозри конкретної особи у вчиненні кримінального правопорушення. Ця підозра вперше чітко сформульована в офіційному документі - письмовому повідомленні особи про підозру. У ньому слідчий, прокурор викладає висновок про наявність і суть кримінального діяння, вчиненого конкретною особою. Прийняте рішення щодо повідомлення про підозру ще не означає, що мета розслідування досягнута і його можна завершити, оскільки потрібно ще допитати підозрюваного з приводу підозри, перевірити його показання, виконати інші слідчі і процесуальні дії, наслідком чого може бути також і зміна, доповнення повідомлення про підозру (ст. 279 КПК) [1, с. 163]. В. О. Гринюк зазначає, що підозра - це процесуальне рішення прокурора, слідчого (за погодженням із прокурором), яке грунтується на зібраних доказах під час досудового розслідування та у якому формується припущення про причетність конкретної особи до вчинення кримінального правопорушення з повідомленням про це такій особі та з роз'ясненням іï прав і обов'язків [6, с. 36-37].

Погоджуючись із думкою про те, що повідомлення про підозру є процесуальним рішенням з усіма притаманними йому ознаками та елементами, I. Г.Івасюк пише, що підозра - це результат розумової діяльності слідчого, прокурора щодо оцінки наявних у справі доказів, які з достатньою переконли- вістю вказують на ймовірність вчинення кримінального правопорушення певною особою, що виражається у процесуальному документі, який складається із зазначених у законі підстав і вручається особі, яка підозрюється у вчиненні кримінального правопорушення [7, с. 77]. У свою чергу А. І. Палюх повідомлення особі про підозру розглядає: як важливе процесуальне рішення, яке приймає прокурор або слідчий за погодженням із прокурором; як процесуальну дію; як інститут кримінального процесуального права; як форму повідомлення у кримінальному провадженні; як процесуальний акт [14, с. 114-115].

Досліджуючи повідомлення про підозру у контексті процесуального рішення, слід погодитися з думкою О. В. Капліної, що підозра - це ймовірне судження, припущення, попередній висновок про причетність конкретної особи до вчинення кримінального правопорушення. У разі отримання нових доказів раніше повідомлена підозра може бути змінена. Це відрізняє підозру від підсумкового висновку слідчого чи прокурора про винуватість особи, який формулюється в обвинувальному акті та має бути 3 точки зору сторони обвинувачення обгрунтованим, достовірним та остаточним. Саме тому обвинувачення, відповідно до п. 13 ч. 1 ст. 3 КПК України, є твердженням про вчинення певною особою діяння, передбаченого Законом України про кримінальну відповідальність, висунуте в порядку, установленому КПК України. Підозра не може бути твердженням, iї сутність полягає в тому, що це тільки припущення, яке необхідно перевірити під час нового етапу досудового розслідування, який настає після повідомлення про підозру конкретної особи [8, с. 240].

У ході проведення досудового розслідування для проведення окремих слідчих чи процесуальних дій слідчому необхідно отримати дозвіл слідчого судді. Аналіз положень КПК України дає підстави стверджувати, що рішення про проведення такої слідчої чи процесуальної дії приймається слідчим і прокурором, а слідчий суддя дає дозвіл на iii проведення. При цьому процесуальним документом, яким ініціюється отримання дозволу на проведення цієї слідчої чи процесуальної дії, є клопотання. Як слушно $з$ цього приводу зазначає М. В. Чорноусько, для подання клопотання до слідчого судді прокурором необхідною $є$ наявність у слідства фактичних даних, з огляду на які в його задоволенні існує обгрунтована потреба i без якого подальший хід розслідування буде об'єктивно неможливим [20 с. 79].

У Кримінальному процесуальному кодексі відсутні «універсальні» вимоги до 
клопотання, яке подається слідчому судді, натомість у законі конкретизовані вимоги до кожного клопотання, зокрема: про здійснення приводу (ст. 141), про накладення грошового стягнення (ст. 145), про тимчасове обмеження у користуванні спеціальним правом (ст. 150, про відсторонення від посади (ст. 155), про тимчасовий доступ до речей і документів (ст. 160), про застосування запобіжних заходів (ст. 184) тощо. Це можна пояснити тим, що кожне 3 них має різні правові наслідки щодо обмеження прав і свобод людини і громадянина, а тому кожне клопотання містить окремі, притаманні тільки йому вимоги.

3 огляду на викладене, не можна погодитися з B.I. Чорнобуком у тому, що рішення слідчого, які викладені у клопотанні, не мають ознаки, притаманної іншим рішенням, - обов'язковості для виконання іншими посадовими особами й органами [19, с. 44], оскільки закон зобов'язує слідчого суддю розглянути це клопотання та прийняти відповідне рішення за результатами його розгляду, обов’язок сторін провадження бути присутніми під час його розгляду, тощо. Подібної точки зору дотримується й Н.В. Глинська, яка пише, що хоча само рішення про обрання запобіжного заходу у вигляді взяття під варту, продовження строків тримання під вартою, проведення слідчої дії виносить суд, відповідне клопотання слідчого також тягне як певні правові наслідки для суду, зобов'язаного розглянути таке клопотання і прийняти одне з передбачених у законі рішень, так і можливі несприятливі наслідки для особи, стосовно якої таке клопотання порушується. Звідси закономірно випливає висновок про те, що названі рішення слідчого повинні бути законними і неодмінно належним чином обгрунтованими [3, с. 30].

Аналогічний погляд із цього питання має й О. I. Марочкін, який пише, що, хоча всі процесуальні рішення слідчий приймає одноособово, а здебільшого і самостійно, без попереднього чи наступного погодження 3 прокурором чи іншою посадовою особою, окремі такі його рішення набувають законної сили тільки після санкціонування їх прокурором або за згодою суду [11, с. 257].

Варто погодитися 3 подвійною правовою природою реалізації процесуальних рішень, прийнятих слідчим чи прокурором, які потребують дозволу слідчого судді, на що вказують В. Д Берназ та С. М.Смоков. Так, науковці пишуть, що усі процесуальні рішення у стадії досудового слідства приймаються слідчим одноособово, крім рішень, що підлягають затвердженню, санкціонуванню чи погодженню з прокурором і суддею. У цих випадках мають місце два послідовні акти прийняття рішення: спочатку особою, яка провадить розслідування, а потім особою, яка затверджує це рішення, або висловлює згоду з ним, або виносить постанову щодо подання слідчого [12, с. 63].

3 наведеного вбачається, що клопотання слідчого, прокурора, адресоване слідчому судді, є особливим видом процесуального рішення з відповідними ознаками та елементами, яке має ініціативний характер щодо подальшого проведення досудового розслідування.

Важливе місце у системі процесуальних рішень прокурора належить його письмовим вказівкам. Оскільки саме прокурор є ключовою особою, яка визначає необхідну сукупність достатніх доказів для прийняття рішення про закінчення досудового розслідування та складання обвинувального акта, а надалі на нього покладається обов'язок доводити винуватість особи у суді, абсолютно логічним є наділення його правовим механізмом щодо керівництва діями слідчого у ході проведення досудового розслідування щодо збирання доказів.

Відповідно до п. 4 ч. 2 ст. 36 КПК України прокурор, здійснюючи нагляд за додержанням законів під час проведення досудового розслідування у формі процесуального керівництва досудовим розслідуванням, уповноважений доручати слідчому, органу досудового розслідування проведення у встановлений прокурором строк слідчих (розшукових) дій, негласних слідчих (розшукових) дій, інших процесуальних дій або давати вказівки щодо ïx проведення чи брати участь у них, а в необхідних випадках - особисто проводити слідчі (розшукові) та процесуальні дії в порядку, визначеному цим Кодексом. У свою чергу, ч. 4 ст. 40 КПК України покладає на слідчого обов'язок виконувати доручення та вказівки прокурора, які даються у письмовій формі.

Слід звернути увагу, що закон не встановлює, у якій процесуальній формі закріплюють вказівки прокурора; єдина вимога, яку закон до них висуває, - це законність та письмова форма, а тому погоджуємося з думкою О. Д. Гринів про те, що вказівка прокурора - це процесуальне рішення прокурора, яке виноситься в ході здійснення процесуального керівництва досудовим розслідуванням кримінального провадження слідчому, керівнику органу досудового розслідування 3 метою досягнення всебічності, повноти та об'єктивності досудового розслідування, спрямоване на усунення прогалин та неповноти слідства, вказівка наділена ознаками імперативності і є обов'язковою до виконання [5, с. 211], [4, с. 272]. 
Підсумковим процесуальним документом стадії досудового розслідування є обвинувальний акт. Відповідно до ч. 4 ст. 110 КПК України обвинувальний акт $є$ процесуальним рішенням, яким прокурор висуває обвинувачення у вчиненні кримінального правопорушення і яким завершується досудове розслідування. Актуальність дослідження обвинувального акта полягає ще й у тому, що він замінив підсумковий акт досудового слідства за КПК України в редакції 1960 року та, на відміну від нього, не $є$ актом аналізу доказів, зібраних слідчим, а тому варто дослідити підстави прийняття такого процесуального рішення.

Як правильно зазначає М. М. Стоянов, основою прийняття підсумкових процесуальних рішень $є$ достовірне встановлення обставин, які підлягають доказуванню у кримінальному провадженні. Навіть у разі прийняття проміжних рішень законодавець орієнтує правозастосовувача на досягнення максимально можливого в умовах здійснюваного провадження рівня ймовірного знання [16, с. 507]. Такою, що заслуговує на підтримку щодо прийняття рішення про закінчення досудового розслідування, є позиція М. С. Туркота, який пише, що, вивчаючи матеріали досудового розслідування, прокурор повинен надати їм оцінку не лише на предмет повноти доказів, а й з точки зору обгрунтованості прийнятого слідчим рішення про наявність складу інкримінованого злочину з огляду на ознаки малозначності діяння (ч. 2 ст. 11 КК України). При цьому треба враховувати, що, відповідно до ст. 94 КПК України, до прийняття рішення про відкриття матеріалів іншій стороні слідчий та прокурор - процесуальний керівник зобов'язані за своїм внутрішнім переконанням, яке грунтується на всебічному, повному й неупередженому дослідженні всіх обставин кримінального провадження, керуючись законом, оцінити кожний доказ з точки зору належності, допустимості, достовірності, а сукупність зібраних доказів - з точки зору достатності та взаємозв'язку для прийняття процесуального рішення про початок виконання вимог ст. 290 КПК України. При цьому оцінка доказів на предмет їх належності, допустимості, достовірності, достатності є правом (одночасно й обов'язком) лише слідчого, прокурора, слідчого судді та суду. Інші учасники досудового розслідування та судового провадження (включаючи сторону захисту) не є суб'єктами оцінки доказів [17, с. 236].

Обвинувальний акт складається слідчим та/або прокурором, коли зібрано досить доказів для того, щоб передати його до суду, коли сторона обвинувачення впевнена, що проведеним досудовим розслідуванням встановлено особу, яка вчинила кримінальне правопорушення, процес доказування завершений, повно та всебічно встановлені та досліджені обставини, які підлягають доказуванню у кримінальному провадженні (ст. 91 КПК України). Проте, перш ніж переконатися у необхідності складання підсумкового процесуального рішення - обвинувального акта, слідчий та/або прокурор проходять складний шлях, пов'язаний із кропітким збиранням, перевіркою, оцінкою доказів, із висуненням та перевіркою версій, формулюванням певних висновків та прийняттям низки процесуальних рішень. Цей процес пізнання неминуче пов'язаний із нагромадженням доказів, просуванням від майже повного незнання про подію кримінального правопорушення та особу, яка його вчинила на етапі внесення відомостей до ЄРДР, до знання все більш повного та точного [8, с. 239].

$$
\text { Привертає }
$$

$$
\text { увагу }
$$

положення

ч. 1 ст. 291 КПК України, якою передбачено, що обвинувальний акт складається слідчим, після чого затверджується прокурором. Обвинувальний акт може бути складений прокурором, зокрема, якщо він не погодиться з обвинувальним актом, що був складений слідчим. 3 вказаного законодавчого припису випливає, що на завершальній стадії досудового розслідування прокурор приймає декілька процесуальних рішень, зокрема:

- самостійно або через доручення слідчому повідомляє підозрюваному або його захиснику про завершення досудового розслідування та надання доступу до матеріалів досудового розслідування;

- затверджує обвинувальний акт складений слідчим;

- самостійно складає обвинувальний акт.

3 огляду на викладене, слушною є думка В. Т. Нора та В. В. Луцика, які пишуть, що прийняття прокурором рішення про затвердження обвинувального акта і направлення кримінального провадження до суду означає солідаризацію прокурора з висновками органів досудового розслідування. Затверджуючи обвинувальний акт, прокурор бере на себе всю повноту відповідальності за правильність розслідування кримінального провадження [13, с. 66].

\section{Висновки}

За результатами проведеного нами дослідження можна констатувати, що процесуальними рішеннями слідчого, прокурора на стадії досудового розслідування є внесення 
відомостей до СРДР; постанова, повідомлення про підозру, письмові вказівки прокурора, погодження (санкціонування) прокурора та обвинувальний акт.

Незважаючи на те, що КПК України не вимагає від слідчого, прокурора складення будь-яких процесуальних актів як підстави для внесення відомостей до ЄРДР, заніз законодавства дає підстави стверджувати, що внесення відомостей до СРДР є першим кримінальним процесуальним рішенням слідчого або прокурора, яке дає початок досудовому розслідуванню кримінального провадження.

Найпоширенішим процесуальним рішенням слідчого і прокурора є постанова У зв'язку зі змінами, які відбулись у кримінальному процесуальному законодавстві, можна констатувати, що постанова посідає важливе місце у системі кримінальних процесуальних рішень. Основною їі метою є збирання доказів, виконання інших завдань кримінального провадження.

Важливе місце у системі процесуальних рішень слідчого і прокурора посідає повідомлення про підозру. Важливість цього процесуального рішення зумовлена як мінімум двома чинниками. По-перше, це зміна етапу (хоча закон його визначає як нову стадію) кримінального провадження, по-друге, поява особи зі статусом підозрюваного.

Запровадження інституту слідчого судді у сферу кримінального судочинства відповідним чином відобразилось на процесуальних повноваженнях слідчого та прокурора. Оскільки закон для застосування окремих заходів забезпечення кримінального провадження вимагає відповідної ухвали слідчого судді, можна стверджувати, що рішення про проведення такої слідчої чи процесуальної дії приймається слідчим і прокурором, а слідчий суддя надає дозвіл на її проведення.

3 наведеного вбачається, що клопотання слідчого, прокурора, адресоване слідчому судді, $є$ особливим видом процесуального рішення з відповідними ознаками та елементами, яке має ініціативний характер щодо подальшого проведення досудового розслідування.

Щодо письмових вказівок прокурора слід зазначити, що це процесуальне рішення прокурора, яке виноситься в ході здійснення процесуального керівництва досудовим розслідуванням кримінального провадження, спрямоване на координацію дій слідчого у кримінальному провадженні для досягнення завдань кримінального провадження.

Обвинувальний акт є підсумковим процесуальним рішенням у кримінальному провадженні на стадії досудового розслідування, яким прокурор підбиває підсумок проведеного досудового розслідування, визнає, що докази винуватості підозрюваного є належними, допустимими, достовірними, їх сукупності досить для доведення винуватості особи в суді.

\section{Список використаних джерел:}

1. Аленін Ю. П., Гловюк І. В. Повідомлення про підозру: загальна характеристика та проблеми удосконалення. Вісник Південного регіонального иентру Начіональної академії правових наук України. 2014. № 1. С. 161-169.

2. Берназ В. Д., Смоков С. М. Рішення слідчого (криміналістичний, процесуальний та психологічний аспекти) : монографія. Одеса, 2005. 150с.

3. Глинська Н.В. Обгрунтування рішень у кримінальному процесі : дис. ... канд. юрид. наук. Х.арків : Б. в., 2003. 238 с.

4. Гринів О.Д. Вказівка прокурора як одна 3 форм процесуального керівництва досудовим розслідуванням та обов'язковість її виконання. Проблеми порівняльного правознавства : зб. тез наук. доп. III міжнар. наук. конф. «Компаративістські читання». Львів - Київ : Львів. держ. ун-т внутр. справ, 2011. С. 271-274.

5. Гринів О. Вказівка прокурора як форма процесуального керівництва досудовим розслідуванням. Університетські наукові записки. 2016. № 1. С. 205-212.

6. Гринюк В. О. Спростування стороною захисту підозри (первинного обвинувачення) під час досудового розслідування. Вісник кримінального судочинства. 2015. № 3. С. 34-39.

7. Івасюк І. Г. Інституту «повідомлення про підозру» нового кримінального процесуального законодавства України. Митна справа. 2013. № 4(2.2). C. 74-79.

8. Капліна О.В. Підозра у кримінальному провадженні: поняття, ознаки, сутність. Юридичний часопис Начіональної академії внутрішніх справ. 2013. № 1. C. 238-242.

9. Кримінальний процес : підручник / Ю.М. Грошовий, В.Я. Тацій, В.П. Пшонка та ін.; за заг. ред. В.Я. Тація, В.П. Пшонки. Харків : Право, 2013. $824 \mathrm{c}$

10. Кротков Д.С. Уголовно-процессуальные решения и субъекты их принятия в стадии возбуждения уголовного дела : дисс. ... канд. юрид. наук : 12.00.09. Москва, 2011. 200 с.

11. Марочкін O.I. Щодо системи процесуальних рішень слідчого. Проблеми законності : акад. зб. наук. пр. / відп. ред. В. Я. Тацій ; редкол. В. Тацій [та ін.]. Харків : Нац. юрид. акад. України, 2010. Вип. 110. С. 255-263.

12. Муравин А.Б. Проблемы мотивировки процессуальных решений следователя : автореф. дис. ... канд. юрид. наук. Харьков, 1987. 18 с.

13. Нор В., Луцик В. Правові засоби прокурорської діяльності згідно з новим Законом України «Про прокуратуру». Право Украӥни. 2015. № 6. C. 60-69. 
14. Палюх А. І. Участь прокурора в доказуванні під час досудового розслідування : дис. ... канд. юрид. наук : 12.00.09. Львів, 2016. 206 с.

15. Про затвердження Положення про порядок ведення Єдиного реєстру досудових розслідувань : наказ Генерального прокурора України від 06.04.2016 № 139. URL: https://zakon.rada. gov.ua/laws/show/z0680-16 (дата звернення: 14.07.2019).

16. Стоянов М. М. Достовірність доказів у кримінальному провадженні: аналіз нормативного регулювання. Правове життя сучасної Украӥни : матеріали Міжнар. наук. конф. проф.-викл. та аспірант. складу (м. Одеса, 16-17 травня 2013 р.) відп. за вип. В. М. Дрьомін. Одеса : Фенікс, 2013. T. 2. C. 506-508.
17. Туркот М.С. Процесуальна діяльність військового прокурора $з$ відкриття матеріалів іншій стороні. Порівняльно-аналітичне право. 2015. № 3. C. 234-238.

18. Черняк Н. П. Процесуальні особливості повідомлення особі про підозру. Науковий вісник Дніпропетровського державного університету внутрішніх справ. 2013. № 1. С. 555-561.

19. Чорнобук В. І. Законність та обгрунтованість процесуальних рішень судді в порядку судового контролю у досудових стадіях кримінального процесу : дис. ... канд. юрид. наук : 12.00.09. Одеса, 2007. 211 с.

20. Чорноусько М. В. Здійснення прокурором процесуального керівництва досудовим розслідуванням: теорія та практика : монографія. Київ : Алерта, 2017. 294 с

In the article the scientific classification of the procedural decisions of the investigator and the prosecutor according to their types is conducted, it is proved that it has an important theoretical and practical significance since it allows one to find out more deeply their legal nature, the mechanism of acceptance, signs, elements and structure, to determine their place and tasks in the system of criminal procedural decisions.

The article states that despite the absence in the CPC of Ukraine of the requirement to complete any procedural acts as the basis for making information to the EIDHR, this is the first criminal procedural decision of the investigator or prosecutor, which initiates a pre-trial investigation of criminal proceedings.

It is specified that the most widespread procedural decisions of the investigator and the prosecutor are the ruling, but because of the changes that took place in the criminal procedural law, the basis of its purpose is the gathering of evidence, the fulfillment of other tasks of criminal proceedings.

It is substantiated that notification of suspicion is a procedural decision of the prosecutor, an investigator in agreement with the prosecutor. It is characterized by at least two reasons: the change of the stage (the law indicates the stage) of the criminal proceedings; the appearance of a person with the procedural status of the suspect.

It is proved that the petition of the investigator, the prosecutor addressed to the investigating judge is a special type of procedural decision with the relevant features and elements, which is of an initiative nature for further pre-trial investigation.

The thesis is based on the fact that the written instructions of the prosecutor are a procedural decision made in the course of the implementation of procedural guidance by the pre-trial investigation of criminal proceedings aimed at coordinating the investigator's actions in criminal proceedings in order to achieve the objectives of criminal proceedings.

It is noted that the indictment is the final procedural decision in the criminal proceedings at the stage of pre-trial investigation, which the prosecutor concludes with the pre-trial investigation, acknowledges that the evidence of the guilty of the suspect is valid, permissible, reliable, their aggregate is sufficient to prove the guilt of the person in court.

Key words: procedural decisions of the investigator of the prosecutor, procedural decisions on pre-trial investigation, types of procedural decisions, decree of the investigator, prosecutor, written instructions of the prosecutor, indictment. 
УДК 343.3

DOI https://doi.org/10.32849/2663-5313/2019.8.40

\section{Михайло Балан,}

заступник військового прокурора Західного регіону України,

здобувач Начіональної академії Державної прикордонної служби України

імені Богдана Хмельнииького

Юрій Літвін,

канд. юрид. наук, доцент,

старший науковий співробітник науково-дослідного відділу

Національної академії Державної прикордонної служби Украйни імені Богдана Хмельнищького

\section{ОСОБЛИВОСТІ КРИМІНАЛІСТИЧНОГО ЗАБЕЗПЕЧЕННЯ ОГЛЯДУ МІСЦЯ ПОДІї ПІД ЧАС РОЗСЛІДУВАННЯ ПОРУШЕНЬ ДЕРЖАВНОГО КОРДОНУ УКРАЇНИ}

У статті розглянуто особливості та сучасний стан протидії злочинності на державному кордоні Украӥни, що являе собою складну динамічну систему, ефективність якої значною мірою залежить від належного криміналістичного забезпечення. Звернуто увагу на те, що задоволення потреб криміналістики як науки та практики розслідування потребує подальших наукових досліджень та розроблення криміналістичних рекомендаиій з урахуванням змін у загрозах прикордонній безпеиі та у кримінальному і кримінальному процесуальному законодавстві. Прогалини у розробиі криміналістичної класифікаиії злочинних порущень державного кордону не сприяють відповідній розробиі криміналістичної характеристики та методики розслідування порушень державного кордону як робочих інструментів практики. Звернуто увагу на потребу у розробленні позавидових та міжвидових методик розслідування, які враховували б особливості порушення державного кордону нелегальними мігрантами із вчиненням контрабанди, незаконного переміщення підакиизних товарів тощо. Сформульовано поняття криміналістичного забезпечення огляду місия події та визначено прогалини його нормативно-правового регулювання у чинному кримінальному процесуальному законодавстві. За підсумками дослідження внесено пропозииї щодо розширення повноважень слідчого-криміналіста $з$ метою належного криміналістичного забезпечення та підтримання його у «робочому стані» практики розслідування порушень державного кордону, щодо внесення змін до чинного КПК Украйни з метою нормативно-правового закріплення огляду місия подї̈ як слідчої (розшукової) дії шляхом викладення ч. 1 cm. 237 КПК України у новій редакиії.

Ключові слова: державний кордон, порушення державного кордону, нелегальна міграція, незаконне перетинання державного кордону, криміналістичне забезпечення, розслідування, огляд місця події.

Постановка проблеми. Протидія злочинності на державному кордоні України (ДКУ) являє собою складну динамічну систему, ефективність якої значною мірою залежить від належного криміналістичного забезпечення. Аналіз стану злочинності на державному кордоні України свідчить, що у результаті впливу різноманітних факторів, у тому числі пов'язаних із «гібридною війною» РФ проти нашої країни, стала реальною загроза прикордонній безпеці - це широкий спектр посягань на недоторканість ДКУ - від злочинів проти національної безпеки та загальнокримінальних злочинів до адміністративних деліктів [1], [2]. Особливістю цих загроз є те, що їх об'єднують однорідні діяння за їх об`єктивною стороною - незаконне пере- тинання ДКУ, яке може виступати як самостійний склад злочину (з кваліфікуючими ознаками), як реалізація волі пособника (організатора, керівника), що скеровують дії нелегальних мігрантів або ж у сукупності 3 іншими злочинами чи незлочинними правопорушеннями [3].

Останні десятиліття характеризуються значними змінами у системі протидії посяганням на недоторканість ДКУ, на ефективність функціонування якої значною мірою впливають досягнення науки криміналістики та практика реалізації її досягнень. Більшість порушень ДКУ залежно від низки факторів (особливості ділянки ДКУ, розвиненість інфраструктури, кліматичні умови, напрямки функціонування каналів нелегальної 
міграції, місце сусідніх країн у системі геополітики та ін.) вчиняється на «зеленій ділянці» ДКУ. Як свідчать матеріали кримінальних проваджень, вироків, анкетувань слідчих Національної поліції України (НПУ), Служби безпеки України (СБУ) та працівників Державної прикордонної служби України (ДПСУ), огляд місця події (ОМП) у разі порушення ДКУ поза пунктами пропуску одна 3 найважливіших за криміналістично значимою інформацією слідча (розшукова) дія $(\mathrm{C}(\mathrm{P})$ Д).

Аналіз стану правоохоронної діяльності у сфері протидії злочинності на ДКУ свідчить про наявність невідповідності між станом криміналістичного забезпечення ОМП та його сучасними потребами. Поза увагою науковців залишається криміналістичне забезпечення розслідування порушень ДКУ в умовах чинного кримінального процесуального кодексу України (КПК), технікокриміналістичне, інформаційно-аналітичне та інформаційно-довідкове забезпечення виявлення, розкриття та розслідування кримінальних правопорушень, вчинення яких пов'язане з незаконним перетинанням ДКУ, криміналістичне забезпечення оперативно-розшукової діяльності, зокрема тактики негласних слідчих (розшукових) дій та ін. [4, c. 291-294].

Огляд останніх досліджень і публікацій. Методологічну основу статті становлять роботи В. П. Бахіна, Р. С. Бєлкіна, В. Г. Гончаренка, Т. Ф. Дмитрієвої, А. В. Іщенка, Л. Ю. Капітанчук, Н. С. Карпова, Н. І. Клименко, О. Н. Колесніченко, В. Г. Коломацького, В. О. Коновалової, В. С. Кузьмічова, В. К. Лисиченко, Ю. І. Літвіна, О. І. Онисько, А. М. Притули, В. О. Сича, А. З. Сороки, В. Ю. Шепітько та інших вітчизняних і зарубіжних вчених-криміналістів [5-8].

Мета статті - розглянути особливості сучасного стану криміналістичного забезпечення ОМП у разі порушення ДКУ, визначити його проблеми, сформулювати пропозиції щодо їх вирішення.

Виклад основного матеріалу. Із набуттям Україною незалежності науковці постійно звертаються до питань щодо задоволення потреб практики у сфері забезпечення недоторканості ДКУ. Зміни у законодавстві, тактики злочинної діяльності та інших факторах, які впливають на стан прикордонної безпеки, свідчать про необхідність своєчасного корегування криміналістичного забезпечення виявлення, розкриття, розслідування та попередження порушень ДКУ. Криміналістичному забезпеченню різних аспектів діяльності правоохоронних органів у сфері боротьби зі злочинністю в останній період приділяється все більше уваги в Україні та за кордоном. Однак необхідно відзначити різноманітність підходів учених щодо самого поняття, його змісту та системи, а також відставання наукових розробок криміналістичного забезпечення від потреб практики [9]. Не є винятком у цьому і стан криміналістичного забезпечення органів охорони державного кордону України (ООДКУ) у протидії злочинності на ДКУ [10, с. 29-32; 11, c. 208-212].

Аналіз практики протидії порушенням ДКУ свідчить про те, що її ефективність значною мірою залежить від стану криміналістичного забезпечення слідчої (розшукової) дії (С(Р)Д ОМП.

У 1969 році була захищена єдина кандидатська дисертація, предмет якої - ОМП у разі порушення державного кордону (I. I. Єлисєєв «Осмотр места происшествия по делам об особо опасных государственных преступлениях»). Питання, що стосувались огляду місця події у разі порушення державного кордону, розглядались у розрізі методики розслідування окремих видів злочинів: це кандидатські дисертації І. Ф. Пантелєєва «Расследование измены Родине в форме бегства за границу» (1958 рік), М. А. Белянського «Вопросы предварительного расследования особо опасных государственных преступлений» (1959 рік), Л. Д. Самыгына «Расследование незаконного перехода государственной границы СССР» (1965 рік), В. А. Мальцева «Расследование измены Родине в форме отказа возвратиться из-за границы» (1966 рік) [12].

У 1999 році під керівництвом професора В. П. Бахіна були захищені кандидатські дисертації Ю. І. Літвіним на тему «Огляд місця події при порушенні державного кордону України» і В. О. Сичом - «Методика розслідування злочинів, пов'язаних з порушенням державного кордону». У 2003 році під керівництвом професора Н. І. Кліменко захищена кандидатська дисертація О. I. Ониськом на тему «Види слідів та їх використання при розслідуванні незаконного перетинання державного кордону (За матеріалами органів дізнання Прикордонних військ України)», у якій було зроблено висновок про те, що визначальним для збору криміналістичної значимої інформації зі слідів у разі незаконного перетинання державного кордону є огляд місця події. У монографії «Методика розкриття незаконного переправлення осіб через державний кордон України» (автори А. С. Саінчин, І. Б. Похіла, А. М. Притула, 2008 рік) та у дисертаційних дослідженнях Л. Ю. «Капітанчук Особливості розслідуван- 
ня нелегальної міграції» (2011 рік, керівник професор В. П. Бахін), А. 3. Сороки «Розслідування незаконного переправлення іноземних громадян через державний кордон України» (2012 рік, керівник професор В. С. Кузьмічов) окремі питання огляду місця події розглядались у системі слідчих дій під час розслідування незаконного переправлення нелегальних мігрантів через державний кордон [13] - [18].

Сучасні загрози національній та прикордонній безпеці викликають необхідність корегування кримінальних та кримінальнопроцесуальних засад прикордонної політики нашої держави [19-20]. Відповідно до Стратегії державної міграційної політики України на період до 2025 року, обмеження каналів нелегальної міграції як ефективний засіб запобігання їй можливе шляхом розширення можливостей відповідних органів державної влади та забезпечення міжвідомчої співпраці. 3 цією метою необхідно: послідовно впровадити ефективну методологію виявлення нелегальної міграції всередині держави, аналізу ризиків, а також розслідування справ про організовану нелегальну міграцію [21].

Аналіз криміналістичного забезпечення практики розслідування порушень ДКУ, у т. ч. організованої злочинної діяльності (нелегальної міграції), свідчить про нагальну необхідність його вдосконалення. Це стосується розробки криміналістичної класифікації, криміналістичної характеристики, методики розслідування незаконного переправлення осіб через державний кордон (ст. 332 ККУ), незаконного перетинання державного кордону (ст. $332^{2}$ ККУ), а також міжвидових методик розслідування, коли під час порушення ДКУ одночасно вчинюються й інші злочини (ст. 201,204, 305 ККУ та ін.).

Криміналістична класифікація - це засіб упорядкування окремих категорій злочинів за їх криміналістично значущими ознаками. Здійснення криміналістичної класифікації не є самоціллю, оскільки вона розглядається як підстава для побудови системи окремих криміналістичних методик [22, с. 162]. Щодо структури криміналістичної класифікації злочинних порушень ДКУ, то вважаємо, що вона має включати порушення ДКУ як злочинні діяння, а також особливості їх виявлення, розкриття і розслідування порушень ДКУ, механізм, обстановку приготування, вчинення і приховування, способи, типологію особи злочинця тощо.

Криміналістична класифікація, криміналістична характеристика та методика розслідувань порушень ДКУ, на нашу думку, має містити два рівні: перший включає загальнотеоретичні основи та особливості механізму злочинної діяльності на ДКУ і практики розслідування цієї категорії справ, а другий «робочий», практичний інструмент суб'єктів протидії злочинності на ДКУ - має включати ті особливості, які є визначальними та мають суттєве значення у розслідуванні, які притаманні певній ділянці ДКУ, особливостям злочинних посягань на ній тощо. Підтримання у «робочому стані» криміналістичного забезпечення другого рівня та своєчасне, системне та інколи прогностичне надання криміналістичних рекомендацій має бути сконцентровано у постійно діючому органі.

Криміналістична класифікація незаконного переправлення осіб через ДКУ (ст. 332 ККУ) має включати елементи, які стосуються особливостей об'єкта посягання, характеристики особи та осіб, яких переправляють через ДКУ, способу переправлення та суб'єктивної характеристики діяння. Що стосується криміналістичної класифікації незаконного перетинання ДКУ (ст. $332^{2}$ ККУ), то у зв'язку з незначним досвідом правозастосовної практики по ній (з 18.10.2018) у прогностичному аспекті, на нашу думку, вона має включати особливості щодо суб'єкта (особа, якій заборонено в'їзд на територію України, представник підрозділів збройних сил чи інших силових відомств держави-агресора, група осіб), способу незаконного перетинання ДКУ (поза пунктами пропуску через державний кордон України - будь-який; у пунктах пропуску через ДКУ без відповідних документів або за документами, що містять недостовірні відомості, повторність, у поєднанні з насильством чи застосуванням зброї). Складність розслідування цієї категорії справ вбачається у встановленні обов'язкової ознаки суб'єктивної сторони діяння - оціночного поняття, а саме «завдання шкоди інтересам держави». Як свідчить практика протидії підривній діяльності, діяльності диверсійно-розвідувальних формувань, специфіка їх підготовки, настанови з подолання державного кордону містять низку особливостей, які відображаються через особливості типового способу подолання ДКУ у слідовій картині відповідної ділянки ДКУ. А тому серед найважливіших напрямів розробки криміналістичного забезпечення ОМП - категорія справ, передбачених ст. $332^{2}$ ККУ.

Криміналістичну характеристику злочинів (КХЗ) В. П. Бахін визначав як систему узагальнених відомостей про найбільш типові ознаки певного виду (групи) злочинів, що проявляються у способі та механізмі діяння, обстановці його вчинення, особі суб'єкта злочину, інших обставинах, закономірний взаємозв'язок яких є основою наукового та 
практичного вирішення завдань розкриття і розслідування злочинів з урахуванням узагальнених даних про ті, які були раніше розслідувані. На його думку, до змісту криміналістичної характеристики злочинів як практичного інструменту розслідування, а не наукової категорії криміналістики мають бути віднесені тільки ті елементи, які відрізняються чіткою пошуково-розшуковою спрямованістю - предмет злочинного посягання, спосіб скоєння злочину, слідова картина події та характеристика злочинця. КХЗ стане робочим інструментом тільки тоді, коли вона виступає системним узагальненням даних розслідування значного масиву кримінальних справ по кожній окремій категорії злочинів із встановленням взаємозв'язку усіх криміналістично значущих ознак цих видів злочинів [23, с. 179,184-185], інакше, як вважає Р. С. Белків, КХЗ перетворюється на «криміналістичний фантом» [24, с. 223].

Особливості злочинної діяльності на ДКУ дають підстави виділити у рамках видової методики розслідування (МР) порушень ДКУ позавидову МР нелегальної міграції, оскільки їі особливості проявляються в основних складниках вчинення злочинів та особливостях їх розслідування.

У наукових розробках, автори яких звертались до МР порушень ДКУ (Ю.І.Літвін, В. О. Сич), МР нелегальної міграції (Л. Ю. Капітанчук), кореляційні зв'язки між елементами КХЗ розглядались на підставі статистичних даних на час наукових досліджень в основному стосовно всього ДКУ, коли нелегальні мігранти виступали як суб'єкти злочину. Результати цих досліджень натепер можуть слугувати підгрунтям для подальшої розробки теоретичної концепції КХЗ, окремих МР злочинів.

Однак виникає питання: як забезпечити розслідування його робочим інструментом, системою зібраних та узагальнених даних про криміналістично значущі ознаки певного виду (групи) злочинів. Працюючу модель КХЗ у середині 70-х років минулого століття на підставі узагальнення значного масиву матеріалів кримінальних справ по вбивствам в умовах неочевидності було запропоновано прокурором-криміналістом Л. Г. Відоновим [25].

Дискусії щодо поняття «криміналістичне забезпечення», які започатковані В. Г. Коломацьким наприкінці 70-х років XX століття, не припиняються дотепер [11; 26]. Ми поділяємо думку тих вчених, які вважають, що криміналістичне забезпечення - це не діяльність щодо розробки криміналістичних рекомендацій, а система криміналістичних знань (рекомендацій, науково-технічних засобів, методик), яка сприяє у разі їх застосування (звернення до них практиків) успішному вирішенню завдань кримінального провадження. У цій дефініції ми вважаємо за необхідне звернути увагу на те, що сама діяльність - це динамічний процес, а тому процес розробки криміналістичного забезпечення - це не той «продукт», який цікавить слідчих (практиків). Їх насамперед цікавить результат цієї діяльності - сукупність (система) криміналістичних рекомендацій, які сприяють (можуть сприяти) успішному розслідуванню, а тому криміналістичне забезпечення - це результат поетапної розробки наукового забезпечення (криміналістичних засобів, прийомів, методів) [27, с. 49]. Впровадження розроблених рекомендацій у практику, на думку В. П. Бахіна, має здійснюватися перш за все криміналістичними науково-практичними підрозділами [23, с. 93-94].

Натепер, на нашу думку, розробку КХЗ як працюючого інструменту можуть здійснювати слідчі-криміналісти, посади яких введені у ГСУ (СУ) НПУ відповідно до Положення про органи досудового розслідування Національної поліції України. До їхної сфери діяльності віднесено, зокрема, запровадження у слідчу практику наукових рекомендацій щодо організації роботи і тактики проведення слідчих (розшукових) дій, негласних слідчих (розшукових) дій, застосування техніко-криміналістичних засобів і розповсюдження позитивного досвіду розслідування кримінальних правопорушень; розроблення методики розслідування окремих категорій кримінальних правопорушень у тому числі з урахуванням оперативної обстановки в регіоні [28].

На нашу думку, криміналістичне забезпечення протидії злочинності на ДКУ являе собою систему криміналістичних рекомендацій, засобів, прийомів та методів, які адресовані відповідним суб'єктам правоохоронної діяльності у сфері забезпечення прикордонної безпеки та сприяють у разі їх застосування ефективному розслідуванню порушень державного кордону [29].

Особливістю порушень «зеленої ділянки» ДКУ є те, що їм притаманна така ознака, як неочевидність, а тому основою виявлення ознак порушення (спроби порушення) ДКУ становить дослідження слідової картини у рамках службового огляду та ОМП, що відповідає послідовній кореляції елементів КХЗ «слідова картина у місці незаконного перетинання (порушення) ДКУ - спосіб незаконного перетинання ДКУ (переправлення нелегальних мігрантів через ДКУ) - порушник ДКУ (суб'єкт переправлення порушника ДКУ)». 
Як зазначає Н. І. Клименко, огляд місця події - це здебільшого найперша слідча дія, найближча в часі та просторі, коли слідчий стикається з подією злочину, дія найбільш трудомістка (може тривати довгий час), найпродуктивніша (дозволяє встановити значний обсяг інформації стосовно всіх сторін складу злочину) і найскладніша (вимагає застосування цілої низки тактичних прийомів і засобів криміналістичної техніки) [5, c. 11].

Під криміналістичним забезпеченням огляду місця події у разі порушення державного кордону, на нашу думку, необхідно розуміти систему науково обгрунтованих та апробованих на практиці криміналістичних знань, техніко-криміналістичних засобів, тактико-криміналістичних прийомів і способів їх реалізації, які необхідні для ефективного розслідування порушень ДКУ.

Однак аналіз сучасного стану нормативно-правового забезпечення ОМП свідчить про суттєву прогалину у КПК, оскільки ОМП у ньому як слідча (розшукова) дія не врегульована.

У КПК ОМП згадується двічі - у ч. 3 c. 214, де сказано, що огляд місця події у невідкладних випадках може бути проведений до внесення відомостей до Єдиного реєстру досудових розслідувань, що здійснюється негайно після завершення огляду, та у ч. 2 ст. 238 , згідно 3 якою огляд трупа може здійснюватися одночасно 3 оглядом місця події, житла чи іншого володіння особи $з$ додержанням правил цього Кодексу про огляд житла чи іншого володіння особи.

Ч. 1 ст. 237 КПК, у якій визначено мету та види огляду, сказано: з метою виявлення та фіксації відомостей щодо обставин вчинення кримінального правопорушення слідчий, прокурор проводять огляд місцевості, приміщення, речей та документів. А тому не зрозуміло, що Законодавець розуміє під словосполученням «огляд місця події» у рамках ч. 3 ст. 214 та ч. 2 ст. 238 КПК, чи належить воно до слідчої (розшукової) дії. Якщо так, то чому ОМП не закріплений у переліку видів оглядів у ч. 1 ст. 237 КПК?

Невнесення відповідних змін до КПК, на нашу думку, не дає правових підстав говорити про ОМП у кримінально-процесуальному, а тому, відповідно, й у криміналістичному аспекті; дає підстави для визнання недопустимими доказів, які отримані під час кримінальних проваджень, які здійснюються (здійснювались) на підставі КПК 2012 року.

\section{Висновки}

Обсяг публікації не дає змоги розглянути всі аспекти особливостей криміналістичного забезпечення розслідування порушень ДКУ та ОМП, однак на підставі викладеного ми можемо запропонувати такі висновки:

- стан криміналістичного забезпечення натепер не відповідає потребам практики протидії злочинності (нелегальній міграції), яка посягає на недоторканість ДКУ, а тому потребує подальшої наукової розробки;

- розроблення та вдосконалення криміналістичної класифікації злочинів (ст. 332, $332^{2}$ ККУ) та на їх основі - криміналістичної характеристики i методики розслідування можуть здійснювати слідчі-криміналісти СУ НПУ на підставі нової редакції повноважень, закріплених у Положенні про органи досудового розслідування Національної поліції України;

- для усунення прогалин у КПК, враховуючи значення та незамінність огляду місця події у встановленні обставин порушення ДКУ, ч. 1 ст. 237 КПК, у якій закріплені різновиди огляду як С(Р)Д, необхідно терміново доповнити двома видами оглядів - місця події та трупа - і викласти її у новій редакції: «3 метою виявлення та фіксаиї̈ відомостей щодо обставин вчинення кримінального правопорушення слідчий, прокурор проводять огляд місия подіï, трупа, місиевості, приміщення, речей та документів».

Таке закріплення буде виступати як базова правова норма щодо інших, спеціальних у КПК, де ці огляди унормовані.

\section{Список використаних джерел:}

1. Притула А. М. Теоретико-правові засади оперативно-службової діяльності Державної прикордонної служби України : монографія. Одеса: Фенікс, 2019. 331 с.

2. Державна прикордонна служба України. Інфографіка (Результати оперативно-службової діяльності за 2018 рік). URL: https://dpsu. gov.ua/ua/photo-infografika-rezultati-operativnosluzhbovoi-diyalnosti. (дата звернення: 14.06.2019).

3. Притула А. М. Щодо проблем у кваліфікації незаконного переправлення осіб через державний кордон України та порушення порядку в'їзду на тимчасово окуповану територію України та виїзду з неї. Актуальні проблеми кримінального права, прочесу, криміналістики та оперативно-розшукової діяльності : тези II Всеукраїнської науково-практичної конференції, м. Хмельницький, 2 березня 2018 року. Хмельницький : НАДПСУ. 2018.580 c.

4. Капітанчук Л. Ю. Криміналістичний аспект правоохоронної діяльності ДПСУ. Актуальні проблеми кримінального права, процесу, криміналістики та оперативно-розшукової діяльності : тези II Всеукраїнської науково-практичної конференції, м. Хмельницький, 2 березня 2018 року. Хмельницький : НАДПСУ. 2018. 580 с.

5. Огляд місця подіїпри розслідуванні окремих видів злочинів : науково-практичний посібник / 
за ред. Н. І. Клименко. Київ : Юрінком Інтер, 2005. $216 \mathrm{c}$.

6. Лисиченко В.К. Следственный осмотр как специальный метод исследования объектов в процессе доказывания по уголовным делам. Криминалистика и судебная экспертиза: Республиканский межведомственный сборник научных и научнометодических работ. Вып. 10. Киев, 1973. 90 с.

7. Бахін В.П, Капітанчук Л.Ю., Літвін Ю.І. Виявлення та розслідування нелегальної міграції : монографія. Хмельницький : Видавництво Національної академії прикордонної служби України імені Б. Хмельницького, 2013. 164 с.

8. Дмитриева, Т.Ф. Криминалистическое обеспечение осмотра места происшествия : монография. Витебск. ВГУ им. П.М. Машерова, 2016. 307 c.

9. Іщенко А.В., Ієрусалимов І.О., Удовенко Ж. В. Теорія і практика криміналістичного забезпечення процесу доказування в розслідуванні злочинів : навчальний посібник. Київ: Центр учбової літератури. 2007. 160 с.

10.Балан М. В., Літвін Ю. І. Щодо окремих питань стану криміналістичного забезпечення огляду місця події при порушенні державного кордону України та актуальності потреб його подальшого вдосконалення. Актуальні проблеми кримінального права, проиесу, криміналістики та оперативно-розшукової діяльності : тези III Всеукраїнської науково-практичної конференції, м. Хмельницький, 1 березня 2019 року. Хмельницький : НАДПСУ, 2019. 760 с.

11. Капітанчук Л.Ю., Літвін Ю.І. Щодо поняття криміналістичного забезпечення діяльності органів охорони державного кордону України Досудове розслідування: актуальні проблеми та шляхи їх вирішення : матеріали постійно діючого наук.-практ. семінару, м. Харків, 20 жовтня 2017 року. Вип. 9. Харків. Право. 2017. С. 208-212.

12. Тематика диссертаций по юридическим, философским, психологическим и педагогическим наукам, защищенным в Высшей школе КГБ СССР имени Ф. Э. Дзержинского в 19541988 годах / сост. Чесноков В.Ф. Москва : РИО ВКШ КГБ СССР, 1989. $116 \mathrm{c.}$

13. Литвин Ю. И. Осмотр места происшествия при нарушении государственной границы Украины : дис. ... канд. юрид. наук : 20.02.03. Хмельницкий, 1998. 189 л.

14. Сич В. О. Методика розслідування злочинів, пов'язаних з порушенням державного кордону : автореф. дис. ... канд. юрид. наук : 20.02.03. Хмельницький, 1998.18 с.

15. Онисько О. І. Види слідів та їх використання при розслідуванні незаконного перетинання державного кордону (за матеріалами дізнання органів ПВУ) : автореф. дис. ... канд. юрид. наук : 12.00.09. Київ, 2003. 21 с.

16. Саінчин А. С., Похіла І.Б., Притула A.M. Методика розкриття незаконного переправлення осіб через державний кордон України (криміналістичні та оперативно-розшукові аспекти) : монографія. Одеса : Фенікс : 2008. 368 с.
17. Капітанчук Л. Ю. Особливості розслідування нелегальної міграції : дис...канд. юрид. наук : 12.00.09. Київ, 2011. 250 с.

18. Сорока А.З. Розслідування незаконного переправлення іноземних громадян через державний кордон України : дис. ... канд.. юрид. наук : 12.00.09. Київ, 2012. 262 с.

19. Огнєв Т.Є. Незаконна міграція: кримінально-правові та кримінологічні аспекти : автореф. дис. ... канд. юрид. наук : 12.00.08. Київ, 2017. 20 с.

20. Дорош Л. В., Фєдосєєв В. В. Кримінальна відповідальність за порушення недоторканності державного кордону України : монографія. Харків : Право, 2014. 304 с.

21. Стратегія державної міграційної політики України на період до 2025 року : схвалено розпорядженням Кабінету Міністрів України від 12 липня 2017 р. № 482-p. URL: https://zakon, rada.gov.ua/laws/show/482-2017 (дата звернення: 14.06.2019).

22. Журавель В. Криміналістична класифікація злочинів: засади формування та механізм застосування. Вісник академії правових наук України. 2002. № 3 (30). С. 160-166.

23. Бахин В. П. Криминалистика. Проблемы и мнения (1962-2002 гг.). Киев. 2002. 266 с.

24. Белкин Р. С. Криминалистика: проблемы сегодняшнего дня. Злободневные вопросы российской криминалистики. Москва : НОРМА-ИНФPA, 2001. 240 c.

25. Видонов Л.Г. Криминалистические характеристики убийств и системы типовых версий о лицах, совершивших убийство без очевидцев. Горький, 1978 г. URL:// kriminalisticheskayaharakteristika-lichnosti-ubiytsy-1.pdf. (дата звернення: 01.08.2019).

26. Коломацкий В. Г. Криминалистическое обеспечение деятельности органов внутренних дел по расследованию преступлений. Криминалистика: История, общая и частные теории : в 3-х т. / под ред. Р. С. Белкина, В. Г. Коломацкого, И. М. Лузгина. Москва: Академия МВД РФ, 1995. T. $1.232 \mathrm{c}$.

27. Чорноус Ю. М. Криміналістичне забезпечення розслідування злочинів : монографія Вінниця : «Нілан - ЛТД», 2017. 492 с.

28. Про організацію діяльності органів досудового розслідування Національної поліції України : наказ Міністерства внутрішніх справ України від 06.07.2017 № 570. URL://https://zakon.rada. gov.ua/laws/show/z0918-17. (дата звернення: 01.08.2019).

29. Балан М. В., Літвін Ю. І. Криміналістичне забезпечення протидії злочинності на державному кордоні як елемент національної безпеки України: проблеми та шляхи вдосконалення. Правове забезпечення інтеграчії України в європейський політичний, економічний, безпековий, інтелектуальний простір : матеріали Всеукраїнської науково-практичної конф. м. Хмельницький, 23 квітня 2019 року, Вінниця, Донецький національний університет імені Василя Стуса, 2019. C. 9-13. 
The article deals with the peculiarities and the current state of counteraction of crime on the state border of Ukraine, which is a complex dynamic system, the effectiveness of which depends to a great extent on proper forensic support. It is noted that meeting the needs of forensics as a science and practice of investigation requires further research and the development of forensic recommendations that take into account changes in border security threats and in criminal and criminal procedural legislation. The gaps in the development of forensic classification of criminal violations of the state border do not contribute to the proper development of the forensic characteristics and methods of investigation of state border violations as working tools of practice. Attention is drawn to the need to develop out-of-species and interspecific investigative techniques that would take into account the peculiarities of violations of the state border by illegal migrants, smuggling, illegal movement of excisable goods, etc. The concept of forensic provision of the scene inspection was formulated and the gaps of its regulatory regulation in the existing criminal procedural legislation were identified. Based on the results of the study, proposals were made to expand the powers of the criminal investigator in order to ensure the practice of investigating violations of the state border with proper forensic support and maintain it in "working order", to amend the current CPC of Ukraine for the purpose of normative-legal fixing of the scene investigative) actions, by laying out part 1 of Article 237 of the CPC of Ukraine in the new edition.

Key words: state border, violation of state border, illegal migration, illegal crossing of state border, forensic security, investigation, location inspection. 
УДК 343.98.06

DOI https://doi.org/10.32849/2663-5313/2019.8.41

\section{Олена Самойленко,}

канд. юрид. наук, дочент,

доцент кафедри криміналістики

Начіонального університету «Одеська юридична академія»

\section{ВІДКРИТТЯ КРИМІНАЛЬНОГО ПРОВАДЖЕННЯ ЩОДО ЗЛОЧИНІВ, ВЧИНЕНИХ У КІБЕРПРОСТОРІ}

У статті з позичій криміналістичної науки характеризуються чотири форми початку кримінального провадження щодо злочинів, що вчиняються у кіберпросторі, зокрема:

1) кримінальне провадження розпочинають в результаті отримання заяви потерпілого / повідомлення особи про кримінальне правопорушення;

2) кримінальне провадження розпочинають в результаті ознайомлення з матеріалами оперативного підрозділу щодо перевірки оперативної інформаиії;

3) кримінальне провадження розпочинають в результаті роботи за оперативно-розшуковою справою $(\mathrm{OPC})$;

4) кримінальне провадження розпочинають в результаті виявлення безпосередньо слідчим іншо20 кримінального правопорушення під час здійснення досудового розслідування в уже дорученому для здійснення розслідування кримінальному провадженні. Перша форма властива кожній класифікаиійній підгрупі злочинів, вчинених у кіберпросторі. Окрема увага приділяється другій та третій з указаних форм початку кримінального провадження як таким, що свідчать про ключову роль взаємодії слідчого і спечіалізованих оперативних підрозділів у визначенні оптимального моменту початку досудового розслідування. Внесення інформаиії про злочин до Єдиного реєстру досудових розслідувань иілком залежить від майстерності слідчого / прокурора оиінювати матеріали первинної перевірки. Тому слідчому необхідно орієнтуватися в умовах оперативної обстановки в кіберпросторі для того, щоб рекомендаиї слідчого можна було реалізувати оперативному співробітнику. Наголошується на проблемі фактичного позбавлення можливості здійснювати оперативно-розшукових заходів під час перевірки оперативної інформачії щодо вчинення невеликої або середнвої тяжкості злочинів.

у результаті розгляду форм автор висновує про те, що більшість випадків кримінальних проваджень даної категорії злочинів відкриваються саме за матеріалами оперативно-розшукової діяльності. Сформульовані автором положення свідчать про потребу поглибленого розгляду питань здійснення оперативно-розшукової діяльності щодо визначеної категорії злочинів та розуміння слідчим специфіки такої діяльності.

Ключові слова: злочин, інформація, кримінальне провадження, кіберзлочин, кіберпростір, оперативно-розшукова діяльність, початок провадження, форма.

Постановка проблеми. Специфічність механізму вчинення злочинів у кіберпростоpi, зокрема, особливості їх слідів, які можуть бути легко фальсифіковані або взагалі знищені, зумовлює й особливості початку кримінального провадження щодо цих злочинів. У чинному КПК України (ч. 1 ст. 214) визначена правова процедура початку досудового розслідування [1], однак конкретизація специфіки відкриття кримінального провадження щодо певного виду злочинів надасть можливість ефективно використовувати результати оперативно-розшукової діяльності як докази, забезпечить повноту досудового слідства та перспективу судового розгляду матеріалів таких кримінальних проваджень.

Аналіз останніх досліджень і публікацій з даної теми. В.А. Журавель відзначає потре- бу у виділенні самостійного етапу розслідування «відкриття кримінального провадження» [2, с. 141]. Однак більшість науковців, що досліджують методики розслідування окремих видів злочинів, намагаються уникати розгляду питань початку кримінального провадження, не висвітлюючи завдань слідчого з виявлення кримінального правопорушення, сучасних реалій реформування правоохоронних органів і перспектив діяльності «детективів» у структурі Національної поліції України.

Мета даної статті полягає у характеристиці основних форм початку кримінального провадження щодо злочинів, вчинених у кіберпросторі.

Виклад основного матеріалу. 3 огляду на особливий комплексний i транснаціо- 
нальний характер злочинної діяльності в кіберпросторі, спираючись на класифікаційні підгрупи таких злочинів, на підстав аналізу матеріалів слідчо-судової практики виділимо чотири форми початку кримінального провадження щодо злочинів, вчинених у кіберпросторі.

1. Кримінальне провадження розпочина ють в результаті отримання заяви потер пілого / повідомлення особи про кримінальне правопорушення. Типова заява складається власником певного інформаційного продукту / майна, особи, що став предметом злочинного посягання, жертвою насильницько-дискримінаційних дій у кіберпросторі, повідомлення особи про кримінальне правопорушення - представником установи-жертви, Інтернет-сервісу, власником вебсайту, що зазнав злочинного впливу. В арсеналі способів дії слідчого є опитування, огляд місця події та організаційні заходи у формі звернення до відкритих джерел інформації 3 метою підтвердження отриманих відомостей.

Така форма властива кожній класифікаційній підгрупі злочинів, вчинених у кіберпросторі, зокрема: інтелектуальному піратству та злочинам, пов'язаним із комунікаційними діями (90\% аналізованих проваджень); злочинам, пов'язаним із насильницько-егоїстичними діями $(70 \%)$; злочинам, пов'язаним з анархістськими діями в кіберпросторі (40\%); злочинам, що спрямовані на заволодіння чужим майном, і пов'язаним із ними злочинам у сфері функціонування електронних розрахунків (40\%); злочинам, що пов'язані 3 насильницько-дискримінаційними діями (40\%); злочинам, що порушують механізми захисту від монополізму та недобросовісної конкуренції (25\%); злочинам, що порушують встановлений порядок обігу певних речей (10\%), і злочинам, що пов'язані з антидержавницькими діями (10\%).

Акцентуємо, що під час організації розслідування на підставі неперевіреної, первинної, інформації про злочин слідчому вкрай потрібні знання основ оперативної роботи, адже це, по суті, «безальтернативний» для слідчого шлях розпочати провадження. Часто після відкриття кримінального провадження за ознаками тяжкого або особливо тяжкого злочину, вчиненого в кіберпростоpi, суб'єкт, який зазнав шкоди, через небажання розголошувати свою неспроможність захистити інформацію, перспективу втратити довіру клієнтів не бажає співпрацювати зі слідчим. Аналогічно й потерпілі, які на момент подання заяви про кримінальне правопорушення не були обізнані, що «близька» людина (чоловік (дружина), інший член сім’ï), найманий працівник учинили тяжкий злочин проти них. Це провокує створення потужних важелів протидії розслідуванню, для подолання яких слідчий використовує арсенал засобів оперативно-розшукової діяльності.

2. Кримінальне провадження розпочинають в результаті ознайомлення з матеріалами оперативного підрозділу щодо перевірки оперативної інформації. Аналіз матеріалів слідчо-судової практики дає підстави для визначення специфіки цієї форми початку кримінального провадження щодо злочинів, вчинених у кіберпросторі. 3 одного боку, можливість встановлення первинної кваліфікації події за результатами ознайомлення з матеріалами оперативного підрозділу щодо перевірки оперативної інформації надали можливість слідчому внести відповідні дані до ЄРДР і розпочати розслідування щодо: $40 \%$ злочинів, що спрямовані на заволодіння чужим майном, і пов'язаних із ними злочинів у сфері функціонування електронних розрахунків; 40\% злочинів, пов'язаних 3 анархістськими діями в кіберпросторі (розділ XVI КК України); 10\% злочинів, що порушують встановлений порядок обігу певних речей, і злочинів, пов'язаних із насильницько-егоїстичними діями (ст. 301 КК України); 10\% злочинів, пов'язаних із насильницько-егоїстичними діями (ст. 301 КК України). 3 іншого боку, ці показники поширеності форми мають бути вищими за рахунок показників безальтернативної форми початку провадження, адже в половині аналізованих матеріалів кримінальних проваджень констатовано формалізовану наявність повідомлення про вчинення злочинів, попередження, виявлення та припинення яких належить до завдань Департаменту кіберполіції Національної поліції України. Більшість практиків визначають складність реалізації матеріалів перевірки щодо нетяжких і середньої тяжкості злочинів, вчинених у кіберпросторі. Зазначене зумовлено декількома чинниками.

По-перше, у регіонах України досі немає слідчих або прокурорів, які були б спроможні оцінити достовірність інформації, отриманої під час реалізації заходів ініціативного пошуку в кіберпросторі, що, власне, й здійснюють перевірку оперативної інформації. Спеціалізація слідчих щодо розслідування злочинів цієї категорії регламентована лише на рівні Головного слідчого управління НП України.

По-друге, в умовах надмірного навантаження слідчого / прокурора суб'єкт початку провадження не має часу на пізнання сутності джерела оперативної інформації в кіберпросторі. Тому він з підстав «неможливості здійснити первинну кваліфікацію події» повертає такі матеріали в оперативний 
підрозділ з вказівками щодо конкретизації певних обставин події (особи злочинця та мотиву, наслідків вчинення правопорушення, розміру шкоди тощо).

По-третє, оскільки оперативні підрозділи фактично позбавлені можливості здійснювати оперативно-розшукові заходи під час перевірки оперативної інформації щодо вчинення невеликої або середньої тяжкості злочинів, а попередження, виявлення та припинення більшості таких злочинів належать саме до завдань Департаменту кіберполіції, то повернення матеріалів перевірки інформації про них дедалі частіше зводиться до віднесення їх до категорії «латентна злочинність».

Внесення відповідної інформації до ЄРДР цілком залежить від майстерності слідчого / прокурора оцінювати матеріали первинної перевірки. Тому слідчому необхідно орієнтуватися в умовах оперативної обстановки в кіберпросторі для того, щоб рекомендації слідчого можна було реалізувати оперативному співробітнику. Із цих позицій важливим є значення Закону України «Про внесення змін до деяких законодавчих актів України щодо спрощення досудового розслідування окремих категорій кримінальних правопорушень». Із 1 січня 2020 року кримінальні правопорушення поділятимуть на кримінальні проступки і злочини, невеликої та середньої тяжкості злочини буде об'єднано в нову кримінально-правову категорію - «нетяжкі кримінальні правопорушення». Згідно із змінами ст. 12 КК України кримінальним проступком буде дія чи бездіяльність, за вчинення якої передбачено основне покарання у виді штрафу в розмірі не більше ніж три тисячі неоподатковуваних мінімумів доходів громадян або інше покарання, не пов'язане з позбавленням волі. Такі правопорушення розслідуватимуть за спрощеною процедурою здійснення досудового розслідування.

Це нововведення призначене розвантажити слідчих правоохоронних органів, адже провадження щодо проступків здійснюватиме спеціальний суб'єкт - дізнавач, який буде співробітником новоствореного органу дізнання або іншого підрозділу Національної поліції, уповноваженим на здійснення дізнання. 3 метою спрощення процесу розслідування буде логічним уповноважити на це співробітника оперативного підрозділу, який виявив відповідний факт вчинення проступку та знає обставини його події краще, ніж будь-хто з працівників правоохоронного органу. Однак аналіз санкцій статей КК України засвідчує, що злочини, попередження, виявлення та припинення яких належать до завдань Департаменту кіберполіції, не будуть проступками, більшість із них визначатимуться як «нетяжкі злочини». Тому вони не будуть підслідні суб'єкту здійснення дізнання.

Розв’язанню окресленої вище проблеми реалізації цієї форми початку провадження щодо виявлених кіберполіцейськими злочинів могла б сприяти новація законодавця щодо створення можливостей здійснення розслідування у формі дізнання не лише стосовно проступків, а й щодо нетяжких злочинів. Адже за такої умови кіберполіцейський щодо виявлених ним нетяжких злочинів буде вправі відкривати кримінальне провадження та здійснювати розслідування у формі дізнання.

3. Кримінальне провадження розпочинають в результаті роботи за оперативно-розшуковою справою $(\mathrm{OPC})$.

Робота слідчого в межах ОРС здійснюється в умовах викриття $90 \%$ злочинів, вчинених у кіберпросторі з антидержавно-політичних мотивів, 40\% злочинів, що порушують встановлений порядок обігу певних речей, і 10\% злочинів, пов'язаних з анархістськими діями в кіберпросторі (ч. 2 ст. 361, ч. 3 ст. 362 КК України) та 3 насильницько-егоїстичними діями (ч. 3 ст. 120; ч. 3-5 ст. 301 КК України). Матеріали оперативно-розшукових заходів слідчий використовує надалі як докази. Це дає підстави стверджувати, що, крім слідчих (розшукових) дій, до комплексу пізнавальних засобів слідчого під час розслідування тяжких та особливо тяжких злочинів, вчинених у кіберпросторі, належатимуть й оперативно-розшукові заходи. Знання оперативних можливостей дасть змогу слідчому на практиці оцінити наявну на момент початку кримінального провадження оперативну ситуацію, обгрунтовано обрати найбільш доцільні комплекси слідчих (розшукових) дій та організаційних заходів на криміналістичних етапах розслідування злочинів, вчинених у кіберпросторі.

4. Кримінальне провадження розпочинають в результаті виявлення безпосередньо слідчим іншого кримінального правопорушення під час здійснення досудового розслідування в уже дорученому для здійснення розслідування кримінальному провадженні.

Лише 16\% кримінальних проваджень щодо досліджуваної категорії злочинів відкриває слідчий унаслідок здійснення розслідування в іншому кримінальному провадженні, зазвичай випадково, під час виявлення ознак вчинення злочину іншої кваліфікації, під час провадження обшуку, в результаті отримання результатів судової експертизи (зокрема, так виявляються 50\% злочинів, що 
порушують механізми захисту від монополізму та недобросовісної конкуренції, або злочини, пов'язані з насильницько-дискримінаційними діями; $20 \%$ злочинів, що спрямовані на заволодіння чужим майном, і пов'язаних із ними злочинів у сфері функціонування електронних розрахунків; $10 \%$ злочинів, що порушують встановлений порядок обігу певних речей, злочинів, пов'язаних із насильницькоегоїстичними діями, і злочинів, пов'язаних з анархістськими діями в кіберпросторі). Тому таку форму початку кримінального провадження складно вважати типовою стосовно злочинів, вчинених у кіберпросторі. 3 огляду на те, що фактично в кіберпросторі триває багатоепізодна злочинна діяльність, така ситуація спричинена формальним ставленням слідчих до планування розслідування, незалученням до цього процесу потенціалу оперативних підрозділів або перекладанням своїх повноважень щодо здійснення слідчих (розшукових) дій у таких справах на оперативного працівника. Останній часто не втрачає можливості, отримавши за дорученням слідчого інформацію про «можливий» новий епізод злочинної діяльності, перевірити його, що звісно позначається на статистичному показнику щодо суб'єкту виявлення злочину.

Така форма початку провадження реалізується в межах одного з основних завдань розслідування - виявлення всієї сукупності епізодів злочинної діяльності в кіберпростоpi, яке виконують шляхом здійснення комплексу слідчих (розшукових) дій та організаційних заходів. Зазначене призводить до реєстрації додаткових епізодів кримінального правопорушення певної правової кваліфікації (залежно від типового поєднання злочинів у злочинну технологію або всієї множини одиничних схожих злочинів).

Висновки. Наведені форми початку кримінального провадження щодо злочинів, вчинених у кіберпросторі, свідчать про ключову роль взаємодії слідчого і спеціалізованих оперативних підрозділів у визначенні оптимального моменту початку досудового розслідування. Значною мірою це зумовлено тим, що здебільшого кримінальні провадження цієї категорії відкриваються саме за матеріалами оперативно-розшукової діяльності.

\section{Список використаних джерел:}

1. Кримінальний процесуальний кодекс України : Закон України від 13 квіт. 2012 р. № 4651-VI. URL: https://zakon.rada.gov.ua/ laws/ show/4651-17

2. Журавель В. Проблеми періодизації досудового розслідування. Вісник Наиіональної академії правових наук України. 2014. № 2 (77). С. 136-143.

From the standpoint of forensic science, the article describes four forms of commencement of criminal proceedings regarding crimes committed in cyberspace, in particular:

1) the criminal proceedings begin as a result of the receipt of the application of the victim / the message of the person about the criminal offense;

2) criminal proceedings are initiated as a result of familiarization with the materials of the operational unit for checking operational information;

3) criminal proceedings begin as a result of work on the operational-search case;

4) criminal proceedings are initiated as a result of the discovery by the investigator of another criminal offense during the conduct of the pre-trial investigation in the criminal proceedings already entrusted for the investigation.

The first form is inherent in each classification subgroup of crimes committed in cyberspace. Special attention is paid to the second and third of these forms of commencement of criminal proceedings. They indicate the key role of interaction between the investigator and specialized operational units in determining the optimal moment of the start of the pre-trial investigation. Inclusion of information about a crime in the Unified Register of Pre-Trial Investigations completely depends on the skill of the investigator / prosecutor to evaluate the materials of the primary check. Therefore, the investigator needs to be guided in the operational environment in cyberspace. Names with the recommendations of the investigator can be implemented operational staff. The problem of actual deprivation of the possibility to carry out operational-search measures when checking operational information about the commission of a small or medium gravity of crimes is emphasized.

As a result of the examination of the forms, the author comes to the conclusion that most cases of criminal proceedings of this category of crimes are opened precisely from the materials of the operational-search activity. The provisions formulated by the author indicate the need for in-depth consideration of the issues of the implementation of operational-search activities for a certain category of crimes and for the investigator to understand the specifics of such activities.

Key words: crime, information, criminal proceedings, cyberspace, operational-search activity, commencement of production, form. 
УДК 347.96:378

DOI https://doi.org/10.32849/2663-5313/2019.8.42

Яна Шевцова,

заступник директора

Харківського регіонального відділення

Національної школи суддів України

\section{ОРГАНІЗАЦЙНО-ПРАВОВІ ЗАСАДИ СИСТЕМИ СУДДІВСЬКОЇ ОСВІТИ}

Однією з причин неправомірних рішень, прийнятих із порушенням норм закону, визначають некваліфікованість суддів та недостатній рівень професійної підготовки, яка разом із систематичним підтриманням кваліфікаиї суддів має належати до пріоритетних завдань держави. Така ситуація виникає через відсутність законодавчого підходу до визначення системи суддівської освіти та недостатню увагу, приділену иим питанням науковиями.

Автором досліджено етимологію терміна «освіта» та розглянуто ї в різних сферах: політииі, педагогіщі, юриспрудениї. У статті запропоновано авторський підхід до визначення системи такої освіти та рекомендовано розглядати ї у двох аспектах: організаиійно-правовому та змістовному.

Так, під системою суддівської освіти варто розуміти сукупність навчальних закладів, які здійснюють навчання, підготовку та підвищення кваліфікачї суддів, сукупність нормативно-правових актів, які регулюють освітні відносини та сукупність освітніх програм, планів, матеріалів тощо, за допомогою яких здійснюється таке навчання. Виходячи з наведеного, автор пропонує систему освіти розглядати в таких аспектах: 1) організаційно-правовому, який включає: а) сукупність навчальних закладів, які здійснюють навчання (дошкільні, загальні середні, вищі навчальні заклади, спеціально створені заклади, які здійснюють післядипломну освіту незалежно від їх підпорядкування Міністерству освіти і науки України, наприклад - Наиіональна школа суддів України) та б) сукупність нормативно-правових актів, які так чи інакше регулюють освітні питання; 2) змістовному як сукупності освітніх програм, планів, матеріалів тощо, за допомогою яких здійснюється навчання.

Автор переконана, що комплексний підхід до визначення суті цього поняття дасть змогу по-іншому розглядати та удосконалювати суддівську освіту, що підвищить не лише якість судочинства, а й рівень довіри громадян до судової гілки влади в иілому.

Ключові слова: судоустрій, освіта, суддівська освіта, підготовка суддів, навчання суддів, система освіти, професійна підготовка суддів.

Постановка проблеми. Ефективне функціонування системи судоустрою як гарантії забезпечення справедливого правосуддя, належний захист прав і свобод, неупереджений розгляд справ взаємозалежні від компетенції та професійної підготовки суддів. Часто причиною неправомірних рішень, прийнятих із порушенням норм закону, є некваліфікованість суддів та недостатній рівень професійної підготовки. Підготовка та систематичне підтримання кваліфікації суддів належать до пріоритетних завдань держави. В Україні з років набуття незалежності до цього часу триває процес створення, становлення та розвитку суддівської освіти.

Крім того, за даними досліджень Центру політико-правових реформ (червень 2019 року), 15\% опитаних вважають, що проведення додаткових навчань для суддів могло б найбільш позитивно вплинути на рівень довіри до суду в Україні [1]. Вважаємо це додатком аргументом на користь актуальності досліджуваної проблематики, адже для

здійснення належної підготовки суддів існуе необхідність у визначенні системи такої освіти, її ключових елементів та напрямків розвитку.

Аналіз останніх досліджень і публікацій свідчить, що питанням системи суддівської освіти серед вітчизняних науковців було приділено замало уваги. Фрагментарно питання професійної підготовки суддів висвітлені в працях В. Городовенка, Л. Зуєвої, Л. Москвич, О. Овсяннікової, А. Ребриш, I. Самсіна, В. Сущенка, Н. Шукліної, I. Юревич тощо.

Мета статті - комплексно дослідити поняття «система суддівської освіти», виокремити їі складники та визначити основні вектори розвитку такої освіти для поліпшення здійснення правосуддя в Україні загалом та підвищення рівня довіри громадян до судової гілки влади в цілому.

Виклад основного матеріалу. Дослідження системи професійної освіти судді в 


\section{8/2019 судоустРІй}

сучасних глобальних умовах можливе лише за обставини розуміння самої природи освіти. Значення, в якому поняття «освіта» вживається зараз, усталилося наприкінці XVIII століття, особливо під впливом Гете, Песталоцці та неогуманістів, і означало тоді загальний духовний процес формування людини на противагу виховним методам прихильників просвітителів. Буквальне значення терміна «освіта» - «формування образу». У цьому тлумаченні його ввів Йоганн Генріх Песталоцці. Це поняття багато в чому подібне до широкого розуміння виховання, тому термін «освіта» у широкому змісті використовується у деяких роботах останніх років і для позначення навчально-виховного процесу, що є немало важливим і для суддівської підготовки. У педагогічній та юридичній літературі поняття «освіта» ставиться насамперед до передачі й засвоєння знань, умінь і навичок, формування пізнавальних інтересів і здатностей, до спеціальної підготовки до професійної діяльності [2, с. 109].

На думку українського вченого В. Шевченка, освіта - це поняття філософії і культури, що теоретично фіксує, виражає і пояснює соціокультурне самовідтворення конкретно взятої нації i, зрештою, всього людства. Педагогічно освіта розуміється як школа, в якій спеціально створений у суспільстві «цех» учителів (викладачів, тренерів) навчає учнів і студентів. Політично освіта - це найдешевший засіб реалізації довгострокової державної політики, мета якої - максимально пристосувати молоде покоління до вимог режиму влади й правопорядку. Загалом зміст поняття «освіта» досить складний. Функціонально воно усталює в сучасному вимірі суспільного буття створені в різних місцях і в різні часи людьми такі знання, уміння, вигадки, знаки і символи, що забезпечують соціокультурне самозбереження, ідентичність націй [3, с. 182].

Досліджуючи освіту в юридичній площині, аналізуючи нормативно-правові акти, які регулюють відносини у цій сфері, доходимо висновку, що наявна в Україні система освіти - це сукупність всіх навчальних та навчально-виховних закладів, які ведуть свою діяльність у сфері здобуття освіти, а також спеціалізуються на підготовці чи перепідготовці кадрів.

Так, Закон України «Про освіту» визначає, що система освіти - сукупність складників освіти, рівнів і ступенів освіти, кваліфікацій, освітніх програм, стандартів освіти, ліцензійних умов, закладів освіти та інших суб'єктів освітньої діяльності, учасників освітнього процесу, органів управління у сфері освіти, а також нормативно-правових актів, що регулюють відносини між ними [4].

Вважаємо, що систему освіти можна розглядати в двох аспектах: 1) організаційно-правовому, який включає: а) сукупність навчальних закладів, які здійснюють навчання (дошкільні, загальні середні, вищі навчальні заклади, спеціально створені заклади, які здійснюють післядипломну освіту незалежно від їх підпорядкування Міністерству освіти і науки України, наприклад - Національна школа суддів України) та б) сукупність нормативно-правових актів, які так чи інакше регулюють освітні питання; 2) змістовному як сукупність освітніх програм, планів, матеріалів тощо, за допомогою яких здійснюється навчання.

Таким чином, під час визначення системи суддівської освіти пропонуємо розглядати комплексно діяльність вищих юридичних навчальних закладів та Національної школи суддів України (далі - НШСУ).

Так, на етапі отримання вищої юридичної освіти майбутні судді отримують базові знання про теорію держави та права, основи деонтології, вивчають норми матеріального та процесуального права (кримінального, цивільного, адміністративного, господарського), криміналістики, кримінології, юридичної психології тощо. Причому сьогодні існує велика кількість вищих навчальних закладів (далі - ВНЗ), які готують фахівців за спеціальністю «правознавство». Вбачаємо в цьому першочергову проблему, адже підготовку в спеціалізованих ВНЗ можна вважати більш якіснішою. По-перше, це залежить від рівня підготовки самих викладачів та їх кількості; по-друге - від матеріально-технічного забезпечення ВНЗ, що включає в себе не лише навчальні матеріали, а й можливість проведення різних додаткових лекцій, семінарів, тренінгів, конференцій з вузькопрофільних тематик, долучення практикуючих спеціалістів до навчального процесу та офіційну співпрацю з іноземними і міжнародними фондами, організаціями, спілками.

Національна школа суддів України своєю чергою є державною установою зі спеціальним статусом у системі правосуддя, яка здійснює:

1) спеціальну підготовку кандидатів на посаду судді;

2) підготовку суддів, у тому числі обраних на адміністративні посади в судах;

3) періодичне навчання суддів 3 метою підвищення рівня їхньої кваліфікації;

4) проведення курсів навчання, визначених кваліфікаційним або дисциплінарним органом, для підвищення кваліфікації суддів, які тимчасово відсторонені від здійснення правосуддя; 
5) підготовку працівників апаратів судів та підвищення рівня їхньої кваліфікації;

6) проведення наукових досліджень 3 питань удосконалення судового устрою, статусу суддів і судочинства;

7) вивчення міжнародного досвіду організації та діяльності судів;

8) науково-методичне забезпечення діяльності судів, Вищої кваліфікаційної комісії суддів України та Вищої ради правосуддя [5].

Під час дослідження системи суддівської освіти неможливо оминути сукупність нормативно-правових актів, які регулюють питання як освіти, так і судоустрою, судочинства та статусу суддів. Так, Конституція України визначає право кожного на освіту (ст. 53), встановлює вимоги до суддів (ч. 2 ст. 127) та вказує на виключність законодавчого врегулювання питань освіти (п. 6 ч. 1 ст. 92), судоустрою, судочинства та статусу суддів (п. 14 ч. 1 ст. 92) тощо. До того ж Основний Закон вказує на рівність громадян у своїх конституційних правах і свободах, які стосуються також здобуття освіти і професійної підготовки (ч. 2 ст. 24) [6].

Про визнання важливості професійної підготовки працівників судових органів свідчить також прийняття цілого ряду міжнародних норм: Основні принципи ООН з питання незалежності судової спільноти; документи Ради Європи, зокрема Рекомендація CM/Rec (2010) 12 щодо суддів: незалежність, ефективність та обов'язки [7]; Свропейська хартія про статус суддів [8]; п. 10-13 Висновків Консультативної ради європейських суддів (далі - КРСС) № 1 (2001) і Висновок № 3 (2002). Найважливішим документом, де ретельно розглядаються питання початкової та безперервної підготовки суддів, є Висновок КРСС № 4 про належну початкову підготовку працівників судових органів та підвищення кваліфікації суддів на національному та європейському рівнях [9].

У Висновках КРСС № 4 визнається, що між європейськими країнами існують великі відмінності в тому, що стосується початкової та безперервної підготовки суддів, та що ці відмінності частково можна пояснити конкретними особливостями різних судових систем (пункт 6). У цьому ж документі підкреслюється важливість того, щоб судді, обрані з числа осіб, які мають повну юридичну освіту, отримували ретельну, глибоку і різнобічну професійну підготовку, що дозволяе їм належно виконувати свої обов'язки. Така професійна підготовка також є гарантією їх незалежності і безсторонності відповідно до вимог Конвенції про захист прав людини і основних свобод, і особливо наголошується, що незалежно від різноманіття національних систем і проблем, що виникають в окремих країнах, професійна підготовка повинна вважатися істотним фактором у зв'язку з необхідністю вдосконалення не тільки навичок співробітників судової публічної служби, але й самого функціонування цієї служби (пункт 7) [9].

У більшості європейських країн підготовці суддів присвячені спеціальні положення. У них не наводяться докладні відомості про зміст підготовки. Замість цього нормативи покладають функцію деталізації змісту підготовки на спеціальний орган, який відповідає за розробку навчальної програми, проведення підготовки та нагляд за їі здійсненням. У зв'язку з цим КРСС рекомендує забезпечувати, щоб в кожній країні законодавчі норми про статус суддів передбачали підготовку суддів.

Слід також зазначити, що Європейський союз підкреслює важливість підготовки судових фахівців, в тому числі суддів. У законодавстві $€ С$ є кілька нормативних актів, які регулюють підготовку суддів. В основному вони присвячені ролі судового навчання для розвитку судової співпраці по цивільних кримінальних питаннях в рамках Свропейського союзу та підготовці суддів в області права СС.

Крім того, в Україні діють профільні освітні Закони - «Про освіту», «Про вищу освіту», а НШСУ в своїй діяльності керується Законом України «Про судоустрій і статус суддів», «Про запобігання корупції», Указом Президента України «Про Стратегію реформування судоустрою, судочинства та суміжних правових інститутів на 2015-2020 роки», актами Ради суддів України, Вищої кваліфікаційної комісії суддів України та локальними нормативно-правовими актами як - Статут НШСУ, Регламент НШСУ, Стратегія розвитку НШСУ на 2016-2020 роки тощо.

Під змістовним складником поняття «система суддівської освіти» треба розуміти сукупність освітніх програм в юридичних ВНЗ та в НШСУ. Як вже зазначалося раніше, під час навчання в юридичних ВНЗ майбутні судді отримують фундаментальні знання в різних галузях права. Крім того, детально вивчають юридичні інститути та норми законодавчих актів різного рівня, різної правової сили і значущості, наприклад, на базі курсу «Організація судових та правоохоронних органів». Під час його вивчення студенти здобувають фундаментальні знання про систему судоустрою, органів прокуратури, адвокатури, нотаріату, Служби безпеки України тощо, що надзвичайно важливо i для подальшого навчання, і для майбутньої 


\section{$8 / 2019$ \\ судоУстРІй}

практичної роботи на посаді судді. Крім того, вітчизняні ВНЗ пропонують авторські профільні курси і програми, розроблені спеціально для навчання за вузьким профілем. Так, наприклад, Національний юридичний університет імені Ярослава Мудрого на базі кафедри судоустрою та прокурорської діяльності пропонує своїм студентам для вивчення такі навчальні дисципліни: «Судове право», «Судове адміністрування», «Судові системи та порівняльне судове право», «Організація роботи органів юстиції та Державної судової адміністрації», «Організація роботи суду», «Правове забезпечення роботи суду», «Управління кадрами та ресурсами в суді», «Комунікація у суді», «Судовий кадровий менеджмент», «Актуальні питання судової реформи» та іншими. Під час навчання цих курсів студенти здобувають необхідні теоретичні знання для майбутньої суддівської діяльності, а під час виробничої практики можуть їх реалізувати.

Своєю чергою НШСУ під час підготовки суддів перед зайняттям посад поглиблюють здобуті раніше знання та надають нові. Навчання в цій установі проходить по різним курсам, починаючи від застосування Конвенції про захист прав людини та основоположних свобод та практики Свропейського суду 3 прав людини в різних видах судочинства, вивчення суддівської етики та доброчесності, практики застосування норм матеріального та процесуального права України, закінчуючи вивченням питань стосовно управління залою та часом судового засідання.

\section{Висновки}

Підводячи підсумок, можна сформулювати таке визначення поняття «система суддівської освіти» - це сукупність навчальних закладів, які здійснюють навчання, підготовку та підвищення кваліфікації суддів, сукупність нормативно-правових актів, які регулюють освітні відносини та сукупність освітніх програм, планів, матеріалів тощо, за допомогою яких здійснюється таке навчання.

\section{Список використаних джерел:}

1. Судова реформа очима громадян: що може позитивно вплинути на довіру до суду? Результати опитування Центру політико-правових реформ. URL: http://pravo.org.ua/img/zstored/files/2019 $07 \quad 12 \% 20$ \%D0\%9F\%D1\%80\%D0\%B5\%D1\%81\%D1\%80\%D $0 \% \mathrm{~B} \% \mathrm{D} 0 \% \mathrm{BB} \% \mathrm{D} 1 \% 96 \% \mathrm{D} 0 \% \mathrm{~B} 7 \% 20 \% \mathrm{D} 0 \%$ A $1 \% \mathrm{D} 1 \% 83 \% \mathrm{D} 0 \% \mathrm{~B} 4 \% \mathrm{D} 0 \% \mathrm{BE} \% \mathrm{D} 0 \% \mathrm{~B} 2 \% \mathrm{D} 0$ \%B0\%20D1\%80\%D0\%B5\%D1\%84\%D0\%BE\%D1\%80\%D0\%BC\%D0\%B0.pdf?fbclid=IwAR0F_eopY w1BuEFMQP16si0h ynXzPJUswWwhz5yn3wbaXT S3GiJQuRrw (дата звернення: 15.07.2019).

2. Педагогика. Под ред. Г. Нойера, Ю.К. Бабанского. Москва. Педагогика. 1984. 368 с.

3. Красовська О.Ю. Роль освіти в сучасних глобальних умовах. Бюлетень Міжнародного Нобелівського економічного форуму. 2011. №1(4). С. 182-188.

4. Про освіту: Закон України від 05.09.2017 р. № 2145-VIII Законодавство України: база даних / Верхов. Рада Украӥни. URL: https:// zakon.rada.gov.ua/laws/show/2145-19 (дата звернення: 13.07.2019).

5. Про судоустрій і статус суддів: Закон Украіни від 02.06.2016 р. № 1402-VIII. Законодавство Украйни: база даних / Верхов. Рада України. URL: http://zakon2.rada.gov.ua/laws/show/140219 (дата звернення: 13.07.2019).

6. Конституція України прийнята на п'ятій сес. Верхов. Ради України 28 черв. 1996 р. Відомості Верховної Ради Украӥни. 1996. № 30. Ст. 141.

7. Рекомендація CM/Rec (2010) 12 Комітету Міністрів Ради Європи державам-членам щодо суддів: незалежність, ефективність та обов'язки : від 17.11.2010 р. № (2010)12. Законодавство України:база даних / Верхов. Рада України. URL: http:// zakon3.rada.gov.ua/laws/show/994 a38 (дата звернення: 16.07.2019).

8. Европейская хартия о законе «О статусе судей» от 10.07.1998 г. Законодавство Украйни: база даних / Верхов. Рада України. URL: http:// zakon2.rada.gov.ua/laws/show/994_236 (дата звернення: 16.07.2019)

9. ВИСНОВОК № 4 (2003) Консультативної ради європейських суддів до уваги Комітету міністрів Ради Європи про належну початкову підготовку та підвищення кваліфікації суддів на національному та європейському рівнях/ Виша Рада правосуддя: oфiu. caüm. URL: http://www.vru.gov.ua/content/file/ Opinion_1-18.pdf (дата звернення 14.07.2019).

One of the reasons for illegal decisions taken in violation of the law is the lack of qualified judges and insufficient level of professional training, which, together with the systematic maintenance of the qualifications of judges, should belong to the priority tasks of the state. This situation arises because of the lack of a legislative approach to the definition of a system of judicial education and the lack of attention paid by scientists to these issues.

The author studies the etymology of the term "education" and examines it in various areas: politics, pedagogy, jurisprudence. The article proposes an author's approach to the definition of a system of such education and it is recommended to consider it in two aspects: organizational, legal and informative.

Thus, the system of judicial education is a collection of educational institutions that carry out training, training and qualification of judges, a set of normative legal acts regulating educational relations and a set of educational programs, plans, materials, etc., through which such training is carried out. Proceeding from the above, the author proposes to consider the system of education in the following aspects: 1) organizational and 
legal, which includes: a) the aggregate of educational institutions that carry out training (preschool, general secondary, higher educational establishments, specially created institutions, which carry out postgraduate education irrespective of their subordinate to the Ministry of Education and Science of Ukraine, for example - the National School of Judges of Ukraine); and $b$ ) a set of normative legal acts that regulate education in one way or another Polls; 2) informative as a collection of educational programs, plans, materials, etc., through which training is provided.

The author is convinced that a comprehensive approach to the definition of the essence of this concept will allow to look and improve judge education differently, will increase not only the quality of proceedings, but also the level of citizens' trust in the judicial branch of government as a whole.

Key words: judicial system, education, judge education, training of judges, training of judges, system of education, professional training of judges. 
УДК 341.9

DOI https://doi.org/10.32849/2663-5313/2019.8.43

\section{Вікторія Демчишина,}

аспірант кафедри міжнародного приватного права

Інституту міжнародних відносин

Київського начіонального університету імені Тараса Шевченка

\section{РОЛЬ ІНСТИТУЦИЙНОГО МЕХАНІЗМУ ЄВРОПЕЙСЬКОГО СОЮЗУ У МІГРАЦЙНІЙ СФЕРІ}

Стаття присвячена аналізу інституиійного механізму Європейського Союзу у розвитку міграційної сфери. Встановлено, що функціонування інституційного механізму регулюється установчими договорами ЄС та Хартією основоположних прав $Є С$. Автором визначено, що основу інституиійного механізму ЄС у міграційній сфері становить діяльність основних інститутів Свропейського Союзу Ради Європейсъкого Союзу, Свропейського парламенту, Європейської ради і Комісії Свропейського Союзу. Кожний з інститутів діє в межах повноважень, покладених на нього установчими договорами, та згідно зі встановленими в них процедурами, умовами та иілями.

У дослідженні підкреслено, що такі інститути, завдяки ухваленню низки документів, програм, проведенню самітів та запровадженню єдиних дій у регулюванні міграційними процесами в межах кордонів держав - членів СС, сприяють формуванню і подальшому розвитку імміграційної політики Євросоюзу.

Автором проаналізовано Гаазьку та Стокгольмську програми, у яких було запроваджено иілісний та комплексний підхід до проблем імміграиї. Результатом ухвалення програм стало виокремлення основних сфер співпрачі держав - членів ЄС, а саме: політика ЄС у питаннях надання притулку, мігращії та кордонів держав - членів $6 C$; політика інтеграиії громадян третіх країн на територію Європейсъкого Союзу; політика надання притулку та міграиї̈ в межах зовнішнього виміру СС шляхом укладення угод про реадмісію; політика управління міграційними потоками, яка передбачає перевірку на кордонах держав - членів СС та боротьбу з нелегальною міграчією, тошо.

Встановлено, що діяльність інститутів ЄC започаткувала процес узгодження нормативноправової бази у сфері міграиї та становлення спільної імміграиійної політики Свропейського Союзу. Окрім иього, більшість документів, ухвалених органами ЄС, сприяли створенню спільних інструментів ЄС для удосконалення та уніфікащї правової бази організачї у сфері спільної імміграчійної політики Свропейського Союзу.

Ключові слова: імміграційна політика, держави - члени СС, уніфікація, установчі документи, правові інструменти, угоди про реадмісію.

Постановка проблеми. Економіка Євросоюзу є однією з найбільш конкурентоспроможних та динамічних у світі, яка супроводжується кількісним та якісним зростанням зайнятості та соціальною єдністю держав - членів ЄС. Задля зростання економіки, забезпечення зайнятості на теренах EC та задоволення потреб держав - членів ЄC ухвалюються правові акти та вживаються заходи, які спрямовані на залучення трудових ресурсів з третіх країн. Саме тому проаналізуємо правові та інституційні основи регулювання міграційної політики в Свропейському Союзі.

Аналіз останніх досліджень і публікацій. Останнім часом окремі аспекти міграційної політики висвітлені у працях таких вітчизняних науковців, як С. Книш, О. Малиновська, В. Муравйов, Н. Мушак, О. Стрєльцова, Р. Хорольськиц та інші. Питання, пов'язані з легальною та нелегальною міграцією, дослі- джуються також іноземними фахівцями, серед яких слід відмітити М. Купіжевськи, С. Пірса, М. Кремону тощо. Однак роль та значення інституційного механізму Свросоюзу в імміграційній сфері потребує більш детальної уваги та відповідного наукового аналізу.

Мета наукового дослідження полягає у визначенні ролі інституційного механізму $\mathrm{CC} \mathrm{у} \mathrm{становленні} \mathrm{та} \mathrm{розвитку} \mathrm{спільної}$ імміграційної політики Європейського Союзу.

Виклад основного матеріалу. Сьогодні більшість питань, пов'язаних як із легальною, так і нелегальною міграцією, регулюється установчими документами Європейського Союзу. Зокрема, у ст. 79 Договору про функціонування ЄС (далі - ДФЄС) зазначається, що Союз розвиває спільну імміграційну політику, спрямовану на те, щоб на всіх етапах забезпечити ефективне регулювання міграційних потоків, 
справедливе поводження з громадянами третіх країн, які на законних підставах перебувають на території держав-членів, запобігати та вживати посилених заходів з боротьби проти нелегальної імміграції й торгівлі людьми [1].

Положеннями установчих договорів $\mathrm{CC}$ передбачено процес укладення угод про реадмісію до країн походження або країн прибуття мігрантів у тих випадках, коли громадяни третіх країн не відповідають або перестали відповідати вимогам щодо в'їзду, перебування або проживання на території однієї з держав членів СС (ст. 79, п. 3). На цей час Євросоюзом укладено 17 таких угод з Гонконгом, Макао, Шрі-Ланкою, Албанією, Росією, Україною, Боснією і Герцеговиною, Чорногорією, Македонією, Сербією, Молдовою, Пакистаном, Грузією, Вірменією, Азербайджаном, Туреччиною та Кабо-Верде. Детальний аналіз зазначених угод буде проведено у підрозділі 2.2 нашого дисертаційного дослідження.

Водночас на рівні Європейського Союзу діють заходи, запроваджені Свропейським парламентом та Радою ЄС, які забезпечують сприяння та підтримку дій держав - членів СС 3 метою інтеграції громадян третіх країн, що законно проживають на їхній території. Такі заходи регулюються п. 4 ст. 79 ДФСС. Йдеться насамперед про Фонд притулку, міграції та інтеграції (AMIF) (англ. Asylum, Migration and Integration Fund), створений на період 2014-2020 років з бюджетом 3,137 мільярда євро [2]. Основне завдання фонду полягає у забезпеченні ефективного управління міграційними потоками та впровадження спільного підходу Євросоюзу з питань надання притулку та імміграції. Цей фонд сприяє досягненню чотирьох основних цілей завдань, а саме: посилення та розвиток Спільної європейської системи притулку шляхом забезпечення ефективного застосування законодавства ЄС у цій сфері; підтримка легальної міграції до держав - членів СС відповідно до потреб ринку праці та сприяння ефективній інтеграції громадян третіх країн; посилення відповідної стратегії повернення громадян третіх країн для боротьби з нелегальною міграцією; забезпечення принципу солідарності для того, щоб держави - члени $\mathrm{CC}$, які найбільше постраждали від міграційних потоків, могли розраховувати на солідарність від інших держав - членів ЄС.

Усі держави - члени СС, окрім Данії, беруть участь у реалізації цього Фонду. Бенефіціарами програм, що реалізуються в рамках цього Фонду, є державні та федеральні органи, місцеві державні органи, неурядові організації, приватні та публічні компанії, освітні та наукові організації.

Виняток із даного правила становить будьяка гармонізація законів та підзаконних актів держав - членів Євросоюзу (п.5 ст. 79 ДФСС). Однак положення вказаною статті не впливають на право держав - членів СС визначати обсяги прийому громадян третіх країн, що прибувають на їхню територію у пошуках самостійної роботи або роботи за наймом.

Однакову юридичну силу 3 установчими договорами СС має інший документ, а саме Хартія основоположних прав ЄС 2000 р. (далі - Хартія), яка із набуттям чинності Лісабонських договорів у 2009 р. стала юридично обов'язковою для держав - членів СС. Про це йдеться у пар.1. ст. 6 ДЄС.

В основу Хартії покладено новий світоглядний підхід до людини і їі місце у світі. У Преамбулі Хартії зазначається, що у центрі діяльності Союзу знаходиться людина та її інтереси. На відміну від більшості міжнародноправових документів, де за основу класифікації основних прав взято предмет суб’єктивного права, класифікація прав і свобод в Хартії зроблена на основі цінностей, на захист яких вони спрямовані. До таких цінностей віднесені людська гідність, свобода особи, рівність, солідарність. Права і свободи особи, які захищають ці цінності, закріплені у розділах під відповідними назвами (глави I-IV). Окремі розділи присвячені громадянству та правосуддю (глави $\mathrm{V}$ та VI) [3, с. 7-8].

Саме у Хартії вперше на європейському континенті було передбачене право на притулок. Відповідно до ст. 18 це право є безумовним, оскільки воно гарантується відповідно до положень Женевської конвенції від 28 липня 1951 р., Протоколу від 31 січня 1967 року щодо статусу біженців, ДЄС та ДФЄС. Ст.19 Хартії забороняє висилати та піддавати екстрадиції будь-яку особу у державу, де існує серйозна небезпека того, що особі може бути винесений смертний вирок, вона може піддатися катуванню та іншим видам жорстокого або такого, що принижує гідність людини, поводження чи покарання.

Окрім зазначених статей, інші положення Хартії також є, на наш погляд, актуальними в контексті міграції. Зокрема, ст. 47 закріплює право кожної особи на ефективний засіб правового захисту і містить принципи, що стосуються справедливого судового розгляду. Цікаво, що у ст. 52 документу додатково передбачено, що мінімальним захистом, що забезпечується положеннями Хартії, є захист, наданий у межах Свропейської конвенції з прав людини (далі - СКПЛ). Тим не менше, СС може застосувати більш широке тлумачення прав, ніж це встановлено ЄКПЛ.

Для того, щоб втілити ці завдання на практиці, важливе місце відводиться інституційному механізму СС. Він спрямований на поширення цінностей $\mathrm{CC}$, реалізацію цілей $\mathrm{CC}$, 
забезпечення інтересів Союзу, його громадян та держав - членів СС та гарантування узгодженості, ефективності і послідовності політик та дій Союзу.

Невіддільним складником інституційного механізму ЄС у міграційній сфері є діяльність основних інститутів Європейського Союзу Ради СС, Свропейського парламенту, Свропейської ради і Комісії ЄС. Кожний інститут діє в межах повноважень, покладених на нього установчими договорами, та згідно зі встановленими в них процедурами, умовами та цілями. Інститути взаємодіють на засадах відкритої співпраці.

Зокрема, зазначені інститути, завдяки ухваленню низки документів, програм, проведенню самітів та запровадженню єдиних дій у регулюванні міграційними процесами в межах кордонів держав - членів СС, сприяють формуванню і подальшому розвитку імміграційної політики Свросоюзу.

У реалізації цих завдань важливу роль відіграє діяльність Європейської ради. Зокрема, завдяки низці рішень, ухвалених Свропейською радою в Тампере (1999р.), Фейре (2000р.), планам дій, прийнятим у Брюсселі (2002 р.), Севільї (2002 р.) та Гаазькій (2005р.) та Стокгольмській (2009р.) програмах, були визначені стратегічні та майбутні напрями діяльності й інших інститутів СС.

Наприклад, за результатами саміту Свропейської ради у 1999 р. у м. Тампере (Фінляндія) був визначений новий підхід до імміграційної політики ЄС. Йдеться про співробітництво ЄC із третіми країнами з одночасним виокремленням зовнішнього аспекту внутрішньої безпеки організації. Ухвалений у м. Тампере програмний документ (Розділ IV) включав у собі окремі положення, пов'язані з реадмісією осіб. Європейська Рада згідно з документом заохочувала співробітництво між третіми країнами та $Є С$ щодо повернення осіб, які нелегально перетнули територію однієї з держав - членів ЄC на територію їх походження. Повноваженнями щодо укладення угод про реадмісію між ЄC та третіми країнами наділена Рада ЄС. При цьому угоди про реадмісію могли бути укладені двома основними способами: а) як окремі угоди про реадмісію між $Є С$ та третіми країнами або б) шляхом встановлення певних положень щодо регулювання питань, пов'язаних із реадмісією, в інших угодах, укладених між $\mathrm{CC}$ та третіми країнами [4, с. 207].

Надалі подальший розвиток положень імміграційної політики Євросоюзу знайшов своє нормативне закріплення на саміті Європейської Ради, який відбувся 21-22 червня 2002 р. у м. Севільї (Іспанія). За підсумками зустрічі було ухвалено Висновки Свропейської Ради. У документі передбачалася ціла низка практичних заходів для подолання нелегальної імміграції, серед яких щорічний перегляд переліку осіб із третіх країн, отримання візи для яких не є необхідним; запровадження єдиної візової системи бази даних; сприяння укладенню угод про реадмісію із третіми краінами тощо (п. 30 Розділу 3 ).

Своєю чергою у Гаазькій (2005р.) та Стокгольмській (2009р.) програмах було запроваджено цілісний та комплексний підхід до проблем імміграції. Так, було виокремлено основні сфери співпраці держав - членів СC, а саме: політика СС у питаннях надання притулку, міграції та кордонів держав-членів СС; політика інтеграції громадян третіх країн на територію Європейського Союзу; політика надання притулку та міграції в межах зовнішнього виміру $Є С$ шляхом укладення угод про реадмісію; політика управління міграційними потоками, яка передбачає перевірку на кордонах держав - членів СС та боротьбу з нелегальною міграцією, тощо.

Окрім документів, ухвалених Свропейською Радою у сфері імміграційної політики, Комісія СС, до повноважень якої насамперед належить підготовка пропозицій щодо законодавства $\mathrm{CC}$ та розвитку співробітництва між державами-членами та керівними органами Євросоюзу, також активно долучилася до процесу становлення та подальшого розвитку міграційної політики СС

Зокрема, Комісією ЄС було розроблено низку пропозицій щодо: інтегрування міграційних питань у відносини СС 3 третіми країнами від 3 грудня 2002 р.; циклічної імміграції та мобільного партнерства між СС та третіми країнами від 16 травня 2007 р.; застосування глобального підходу до міграції до Східних та Південно-східних регіонів, які межують з СС від 16 травня 2007 р.; глобального підходу до міграції: до спільної європейської міграційної політики від 27 грудня 2006 р., тематичної програми співробітництва 3 третіми країнами у сфері імміграції та притулку від 23 листопада 2006 р. Спільним для цих документів $€$ наголос на важливості інтеграції міграційних аспектів у зовнішню політику ЄС [4, с. 209].

Пізніше, а саме 13 травня 2015 р., Комісія СС оприлюднила документ під назвою «Свропейський порядок денний 3 міграції» [5], де визначалися необхідні заходи як для припинення неконтрольовано припливу мігрантів та трагедій на морі, так і покращення всієї системи управління міграційними процесами. У найближчій перспективі передбачалося активізувати операції на морі; ухвалити загальноєвропейську схему переселень біженців; розбудувати мережу пунктів прийому біженців, передовсім у Греції та Італії. План на більш тривалу перспективу мав бути 
розбудований за чотирма напрямами: зменшення мотивів до неврегульованої міграції; удосконалення управління кордоном; формування чіткої спільної політики СС щодо притулку; нова політика щодо легальної міграції з метою збереження привабливості Свропи для економічних мігрантів та максимізація переваг від міграції для країн-членів.

У 2015 р. прийнято План дій проти контрабанди людьми, розрахований до 2020 р. [6], де було сформульовано чотири пріоритети в імміграційній сфері: посилення поліцейської та правової протидії; удосконалення системи збору та обміну інформацією; попередження контрабанди людьми і допомога мігрантам, які опинилися у скрутному становищі; посилення співпраці з третіми країнами. Керуючись Планом дій проти контрабанди, Свропол у 2016 р. створив Європейський центр проти незаконного переправлення мігрантів (European Migrant Smuggling Centre) з метою координувати зусилля правоохоронних відомств країнчленів та сприяти спільним розслідуванням. Спільні зусилля спрямовані на руйнування бізнесу контрабандистів, виявлення, затримання та ліквідацію їхніх плавзасобів, а також навчання лівійських прикордонників та моряків, оскільки саме від берегів Лівії починається найбільш небезпечний маршрут переправлення нелегалів до Свропи.

Однією з останніх ініціатив Комісії ЄС є Пропозиція щодо концепції про створення контрольованих центрів СС для мігрантів, а також запровадження короткострокових заходів для покращення процесу обробки заяв від біженців, які прибули на територію СС від 24 липня 2018 р. [7, с. 300]. У документі передбачено створення у майбутньому регіональних механізмів щодо прийому мігрантів 3 третіми країнами. Завдання регіональних механізмів полягають у гарантуванні швидкого та безпечного сходження на берег з обох боків Середземномор'я врятованих людей відповідно до норм та принципів міжнародного права, включаючи дотримання принципу невисилання.

Такі регіональні механізми разом із контрольованими центрами в СС будуть спрямовані на забезпечення спільної регіональної відповідальності, беручи до уваги масштабні виклики та проблеми міграції.

Основна мета створення «контрольованих центрів» в СС полягає у поліпшенні процесу розмежування осіб, які потребують міжнародного захисту, та нелегальних мігрантів, які не мають права залишатися в СС, одночасно прискорюючи їх повернення.

Також передбачається, що центри будуть керуватися приймаючою державою - членом ЄС за умови повної підтримки з боку агентств ЄС та можуть мати тимчасовий або спеціаль- ний характер залежно від місця розташування. Свросоюз, зокрема, пропонує повну фінансову підтримку добровільних дій держав - членів ЄC для покриття інфраструктурних та операційних витрат; а також фінансову підтримку державам-членам, що приймають переміщених мігрантів (6000 євро на особу) [8].

Окрім Свропейської ради та Комісії СС, на наш погляд, слід також відзначити цілу низку ухвалених правових актів в імміграційній сфері іншим інститутом ЄС, а саме Радою СС. Серед них ключову роль у питаннях, пов'язаних із легальною міграцією, відіграють: Директива 2009/50/СС про умови в'їзду та проживання громадян третіх країн для цілей висококваліфікованої роботи, Директива 2003/86/СС про право на возз'єднання сім'ї, Директива 2003/109/СС зі змінами, внесеними Директивою 2011/51/ЄС, що регулює статус громадян третіх країн, які проживають у СС на довготривалій основі, Регламент № 1030/2002 та Регламент № 380/2008, які встановлюють однаковий формат дозволу на проживання для громадян третіх країн та єдину форму дозволу на проживання для громадян третіх країн відповідно.

Що стосується проблем нелегальної міграції, то серед ухвалених документів Радою СС слід назвати такі: Директива 2002/90/СС про встановлення визначення для допомоги незаконному в'їзду, транзиту і перебуванню, Рамкове рішення 2002/946/ПВС про підвищення стандартів кримінальної відповідальності з метою покарання за допомогу у незаконному в'їзді, транзиті і перебуванні, Рішення 2004/573/ЄС щодо організації спільних рейсів для виселення з території двох або більше держав - членів СС громадян третіх держав, щодо яких винесені рішення стосовно виселення, Регламент № 2007/2004 СС про створення Європейського агентства управління оперативним співробітництвом на зовнішніх кордонах та інші.

Однак більшість правових актів та заходів в імміграційній сфері на рівні СС ухвалена за допомогою звичайної законодавчої процедури Європейським парламентом та Радою ЄС. Ця процедура передбачена ст. 77 п.2 ДФСС. Керуючись нею, було ухвалено, зокрема, Директиву 2011/98/СС про єдину процедуру подачі заявки на отримання єдиного дозволу для громадян третіх країн 3 метою проживання та праці на території держави-члена (далі - Директива про єдиний дозвіл), Директиву 2014/36/СС про умови в'їзду і перебування на території СС громадян третіх країн з метою працевлаштування на сезонній основі, Директиву 2014/66/СС про умови в'їзду і постійного проживання громадян третіх країн на території Свропейського Союзу в рамках внутрішньокорпоративного 
трансферу, Директиву 2008/115/ЄС про спільні стандарти та процедури в державах - членах $\mathrm{CC}$, які стосуються повернення незаконно перебуваючих на їх території громадян третіх країн, Директиву 2009/52/СС про встановлення мінімальних стандартів щодо санкцій і заходів до роботодавців нелегальних громадян третіх країн, Регламент 2016/1953 про запровадження європейського проїзного документа для повернення громадян третіх країн, які незаконно перебувають на території СС, Регламент № 863/2007 ЄС від 11 липня 2007 р. щодо запровадження механізму для створення прикордонних груп швидкого реагування (Рабіт), Регламент № 1168/2011 від 25 жовтня 2011 р., яким внесено зміни до Регламенту № 2007/2004 СС від 26 жовтня 2004 р., Регламент 2016/1624 про створення Європейської системи прикордонної та берегової охорони тощо.

\section{Висновки}

Таким чином, основу інституційного механізму у сфері регулювання міграційних відносин ЄС становить діяльність основних інститутів ЄС - Ради СС, Комісії ЄС, Свропейського парламенту та Європейської ради. Їх діяльність, що регламентується установчими документами $\mathrm{CC}$ та низкою актів вторинного законодавства ЄС, започаткувала процес узгодження нормативно-правової бази у сфері міграції та становлення спільної імміграційної політики Європейського Союзу. Окрім цього, більшість документів, ухвалених органами $Є \mathrm{C}$, сприяли створенню спільних інструментів СС для удосконалення та уніфікації правової бази організації у сфері спільної імміграційної політики ЄС.

\section{Список використаних джерел:}

1. Treaty of Lisbon amending the Treaty on European Union and the Treaty establishing the European Community, signed at Lisbon, 13 December 2007. URL: http://eur-lex.europa.eu/ JOHtml.do?uri=OJ:C:2007:306:SOM: EN:HTML (дата звернення: 25.06.2019).

2. Asylum, Migration and Integration Fund. URL: https://ec.europa.eu/home-affairs/ financing/fundings/migration-asylum-borders/ asylum-migration-integration-fund_en (дата звернення: 25.06.2019).

3. Муравйов В.І., Святун О.В. Організаційно-правовий механізм захисту прав людини в Європейському Союзі. Актуальні проблеми міжнародних відносин. Випуск 117 (частина I), 2013. C. 3-16.

4. Європейське право: право Європейського Союзу : підручник: у 3 кн. / за заг. ред. В.І. Муравйова. Київ : Ін Юре, 2015. Кн. 3. 406 с.

5. Порядок денний асоціації Україна - ЄC від 16.03.2016 р. URL: https://zakon.rada.gov. ua/laws/show/994_990 (дата звернення: 25.06.2019).

6. EU Action Plan against migrant smuggling (2015-2020) (COM (2015) 285 fi nal). URL: http://ec.europa.eu/dgs/home-aff airs/ elibrary/ documents/policies/asylum/general/docs/eu action_plan_against__migrant_smuggling_en.pdf (дата звернення: 25.06.2019).

7. Міграційна політика: глобальний контекст та українські реалії : монографія. Київ : НІСД, 2018. 472 c.

8. Єврокомісія запропонувала концепцію контрольованих центрів ЄС для мігрантів від 24липня 2018p.URL:https://www.eurointegration. com.ua/news/2018/07/24/7084747/ (дата звернення: 25.06.2019).

The article is devoted to the analysis of the institutional mechanism of the European Union in the development of migration sphere. It stipulates that the functioning of the institutional mechanism is governed by the founding treaties of the EU and the Charter of Fundamental Rights of the EU. The author has determined that the basis of the EU institutional mechanism in the field of migration is the activity of the main institutions of the European Union - the Council of the European Union, the European Parliament, the European Council and the Commission of the European Union. Each institution shall act within the limits of the powers conferred on it by the founding treaties and in accordance with the procedures, conditions and objectives set out therein.

The study emphasizes that such institutions, through the adoption of a number of documents, programs, summits and the introduction of common actions to regulate migration processes within the borders of the EU Member States, contribute to the formation and further development of EU immigration policy.

The author analyzes that Hague and Stockholm programs have adopted a holistic and integrated approach to immigration issues. The endorsement of the programs resulted in the identification of the main areas of cooperation of the EU Member States, namely: EU asylum, migration and borders policies of the EU Member States; the policy of integrating third-country nationals into the European Union; asylum and migration policies within the EU's external dimension through readmission agreements; a policy on managing migration flows, providing for checks at the borders of EU Member States and combating illegal migration, etc.

The research states that the activities of the EU institutions initiated the process of harmonization of the legal framework in the field of migration and the establishment of a common European Union immigration policy. In addition, most of the documents adopted by the EU bodies have facilitated the creation of common EU instruments to improve and unify the legal framework of the organization in the field of EU common immigration policy.

Key words: immigration policy, EU Member States, unification, founding treaties, legal instruments, readmission agreements. 
УДК 341.4

DOI https://doi.org/10.32849/2663-5313/2019.8.44

\section{Вадим Попко,}

канд. юрид. наук, дочент,

дочент кафедри порівняльного і європейського права

Інституту міжнародних відносин

Київського начіонального університету імені Тараса Шевченка

\section{СУСПІЛЬНІ ПЕРЕДУМОВИ ТА РОЛЬ ГЛОБАЛІЗАЦЇ̈ У ФОРМУВАННІ ТРАНСНАЦІОНАЛЬНОГО КРИМІНАЛЬНОГО ПРАВА}

У статті розглядаються суспільні передумови, які склалися наприкіниі XX - початку XXI ст. у світі та привели до змін у розвитку міжнародного права й формування трансначіонального кримінального права. Трансначіональне кримінальне право розглядається як підгалузь міжнародного кримінального права, що сформувалася під впливом зростання міжнародної злочинності, різновидом якої є трансначіональна організована злочинність. Серед основних чинників, що сприяли виникненню й розвитку иих явиш, - геополітичні зміни, глобалізачія, трансначіональна організована злочинність, зростання ролі міжнародного права в міжнародному правопорядку та інші.

Глобалізачія як світова тендениія новітнього часу має як позитивний вплив на розвиток національного й міжнародного права, так і негативний. Одним із найбільш серйозних негативних наслідкіе глобалізачії є зростання злочинності у світі, а також виникнення нових, більи небезпечних форм злочинності, яка не обмежується нащіональними кордонами й набуває транснаціонального характеру. Вплив глобалізаиї̈ на чей прочес відбувається не прямо, а опосередковано, через економічні, політичні й інші чинники зростання злочинності. Трансначіональна організована злочинність - ие виклик, відповідь на який може бути дана тільки спільними зусиллями всіх суб'єктів міжнародного права. Протидія транснаціональній злочинності є важливим аспектом у житті кожної держави й усвого світу загалом, а розробка кониепиії протидії трансначіональній злочинності є необхідним елементом розвитку кримінальної політики в сучасних умовах світової нестабільності. Визнання міжнародної і начіональної злочинності як однієї із загроз стабільності світового життя передбачає розробку й регламентацію державами в національному праві єдиних приниипів правової політики, а також об'єднання зусиль зі створення юридичних інструментів, що сприяють уніфікації міжнародного й начіональних механізмів протидї злочинності.

Важливу роль у протидії трансначіональній організованій злочинності відіграє $О O H$, у рамках якої проводиться постійна робота Генеральної Асамблеї, конгресів, форумів, конферениій тощо, спрямована на вивчення й дослідження всіх можливих видів взаємозв'язку між злочинністю і деякими аспектами розвитку.

Автор звертає увагу на такі злочини, як тероризм, торгівля людьми, дитяча проституиія, міжнародний наркобізнес, корупиія, що викликають у наш час найбільшу тривогу.

Ключові слова: транснаціональне кримінальне право, глобалізація, транснаціональна організована злочинність, Організація Об'єднаних Націй, конвенції, конгреси.

Постановка проблеми. У наш час світова спільнота стикнулась із серйозною проблемою розвитку міжнародної, і зокрема транснаціональної, злочинності. Це безпрецедентне за історичними мірками зростання терористичної загрози; загострення політичних, релігійних і міжетнічних конфліктів, під час яких відбуваються масові й грубі порушення прав людини; інтернаціоналізація організованої злочинності у сфері поширення наркотиків, торгівлі людьми, контрабанди зброєю, яка супроводжується корупцією й легалізацією злочинних доходів тощо. Ситуація, що склалася, вимагає від держав переосмислення окремих напрямів співробітництва 3 метою напрацювання нових методів протидії міжнародній злочинності. Одночасно з практичною реалізацією такої співпраці стали затребуваними й наукові дослідження в різних напрямах. У доктрині міжнародного права такими напрямами вважаються розробка концепції транснаціонального кримінального права; питання кримінальної юрисдикції держав та міжнародної кримінальної 
юрисдикції; кримінального переслідування осіб, що скоїли транснаціональні злочини; криміналізація транснаціональних діянь проблеми взаємної допомоги й співробітництва держав тощо. У XXI ст. глобальні виклики міжнародній безпеці й розвитку вимагають комплексної відповіді з боку міжнародної спільноти, вибудовування системи зв'язків і взаємодій як держав, так і недержавних утворень для консолідації світової спільноти з метою ефективного вирішення глобальних проблем сучасного світу.

Метою статті є вивчення суспільних передумов, що сприяли виникненню й розвитку транснаціонального кримінального права як складової частини міжнародного кримінального права.

Аналіз останніх досліджень. Формування транснаціонального кримінального права вимагає аналізу цього явища. Теоретичною й методологічною основою дослідження суспільних передумов його виникнення стали праці вітчизняних і зарубіжних вчених, зокрема Д. Анцилотті, М. Баймуратова, М. Бассіоуні, П. Біленчука, І. Блищенко, А. Боссарда, М. Буроменського, В. Буткевича, М. Вербенського, Г. Верле, М. Гнатовського, А. Дмитрієва, Н. Зелінської, Л. Іногамової-Хегай, А. Кассезе, О. Кибальника, О. Козаченка, М. Костенка, I. Лукашука, А. Наумова, В. Панова, В. Пелла, Т. Сироїд, Ю. Трунцевського, Дж. Шварценбергера, Ю. Шемшученка та інших. У працях фахівців із кримінального права та кримінологів вивчається феномен транснаціональної злочинності, концепція транснаціонального злочину, його ознаки та види, питання криміналізації транснаціональних злочинів та юрисдикція, структура організованої злочинності, окремі складники механізму функціонування злочинних угрупувань, питання кримінального переслідування та видачі, узагальнюється міжнародний досвід співробітництва в боротьбі з цим видом злочинності тощо. Вченими (М. Бассіоуні, М. Браник, Н. Бойстер, Г. Верле, М. Ветнцель, П. ГалліХарт, Г. Гриффт, Г. Джилберт, М. Костенко, I. Лукашук, В. Маляренко, Е. Мюллер-Рапар, А. Наумов, В. Панов, Д. Понсе, Ю. Решетов, К. Родіонов, Ж. Рони, Н. Сафаров, Д. Спинелліс, М. Таганцев, В. Тертишник, У. Шабас) відзначається безпрецедентне зростання міжнародної злочинності, особливо наприкінці XX - початку XXI ст., та обгрунтовується необхідність удосконалення міжнародно-правових актів і національного законодавства в цій сфері. У правовій літературі велика увага приділяється передумовам і причинам таких злочинів, як тероризм, геноцид, агресія, воєн- ні злочини, корупція, відмивання коштів, піратство тощо. Особливо актуальними стали дослідження глобалізації як світового явища у вітчизняній та зарубіжній літературі у працях К. Гаджиєва («Введение в геополитику»), Н. Зелінської («Міжнародне кримінальне право в умовах глобалізації злочинності»), I. Лукашука («Глобалізація, держава, право, XXI ст.»), В. Лунеєва («Злочинність ХХ ст.»), C. Примакова («Світ після 11 вересня»), А. Уткіна («Глобалізація: процес і усвідомлення»), Т. Фрідмена («LEXUS і олива. Розуміючи глобалізацію»), Д. Хелла, Е. Макгрю, Д. Гольдблата та Дж. Ператона («Глобальні трансформації»), редакторів німецького журналу «Шпігель» Г.-П. Мартіна і Х. Шумана («Западня глобалізації. Атака на процвітання і демократію»). Поява нових злочинів міжнародного характеру й безпрецедентне зростання злочинності вимагають аналізу та з'ясування суспільних передумов, зокрема глобалізації, їх виникнення з метою удосконалення міжнародно-правового регулювання в цій сфері.

Виклад основного матеріалу. Міжнародна протидія злочинності стала однією 3 найактуальніших проблем сучасності й входить до порядку денного міжнародної безпеки. У Доповіді Групи високого рівня із загроз, викликів і змін, створеної за дорученням Генерального Секретаря ООН, «Більш безпечний світ: наша спільна відповідальність» зазначені шість блоків загроз, якими світ повинен займатися у наступні десятиліття. Кожен із цих блоків пов'язаний із міжнародною злочинністю, а три 3 них - «геноцид та інші масові звірства», «тероризм», «транснаціональна організована злочинність» - $е$ її безпосередніми проявами. «Напади, скоєні 11 вересня 2001 р., показали, що держави, а також установи, які забезпечують колективну безпеку, відстали від змін у характері загроз <...> Нова загроза - транснаціональна організована злочинність - підриває верховенство права всередині держави та на міжнародній арені. Нам ще потрібно повною мірою усвідомити значимість цих змін, але вони є передвісниками принципово нового положення щодо безпеки, коли унікальні можливості для співпраці існують із безпрецедентними можливостями руйнування», - йдеться у Доповіді [3, с. 60]. Поширення транснаціональної організованої злочинності підвищує ризики з боку інших загроз безпеки, тоді як здатність держави протистояти цим загрозам послаблена корупцією. Тому транснаціональна злочинність - пряма загроза для безпеки і держави, і людини.

Необхідність реагування міжнародної спільнотиназлочиниміжнародногохарактеру 
(транснаціональні злочини) має наслідком формування транснаціонального кримінального права, теоретичним підгрунтям якого є доктрина міжнародного кримінального права як галузі міжнародного публічного права та міжнародного правопорядку на основі верховенства права. Вчення про верховенство міжнародного права «покликане захищати універсальні цінності сучасного глобалізованого світу, найбільш важливими серед яких є права людини та громадянина» [4, c. 170].

Міжнародне кримінальне право є комплексною галуззю міжнародного права, у системі якого виділяють правові норми, що мають як міжнародно-правове, так і національно-правове походження, і можуть бути за предметом правового регулювання об'єднані в підгалузь - трансначіональне кримінальне право. Характеризуючи транснаціональне кримінальне право, професор Н. Зелінська зазначає: «Транснаціональне кримінальне право охоплює всю сферу міжнародного публічного права, що має відношення до міжнародного співробітництва у протидії злочинності, за винятком тих ï аспектів, які стосуються міжнародного кримінального права stricto sensu. Таким чином, міжнародне кримінальне право як галузь публічного міжнародного права складається із міжнародного кримінального права stricto sensu, яке регламентує підстави і порядок притягнення індивіда до міжнародної кримінальної відповідальності судами, що володіють міжнародною кримінальною юрисдикцією, і транснаціонального кримінального права, що не виходить за межі національних юрисдикцій. Метою транснаціонального кримінального права як підгалузі міжнародного кримінального права є кооперація і координація функціонування національних кримінально-правових систем, тобто їх інтернаціоналізація» [8, с. 201-202]. Схожу позицію висловлюють M. Гнатовський та 3. Тропін, які пишуть, що «до міжнародного кримінального права lato sensu доцільно включати традиційні для міжнародного права та практики міжнародні аспекти кримінального права, зокрема взаємну правову допомогу, міжнародні процедури та механізми боротьби зі злочинністю, договірні режими, спрямовані на криміналізацію в національному праві певних діянь (конвенційних або транснаціональних злочинів чи, за традиційною термінологією вітчизняної науки міжнародного права, злочинів міжнародного характеру) тощо». Саме ці норми останнім часом все частіше позначають як «транснаціональне кримінальне право» [16, с. 292-293]. У зарубіжній правовій літературі поняття «транснаціональне кримі- нальне право» також має широке застосування (Н. Бойстер, А. Боссард) [20, 21].

Серед багатьох чинників основними факторами, що сприяли формуванню транснаціонального кримінального права, виділимо розвиток суспільних відносин та зміни в структурі міжнародного права. У другій половині XX відбулися зміни на політичній мапі світу, що спричинили трансформацію світової економічної системи й загострили економічні проблеми, особливо залежність слаборозвинутих держав від лідерів економічного розвитку. Глобалізація розвитку сучасного світу стала найбільш значимою характеристикою, а сучасним фактором небезпеки стало формування «антигромадянського суспільства», всередині якого «трансформуються два інститути - організована злочинність і тероризм» [7, с. 316-317].

Глобалізація як явище світового характеру проявила себе вже у XX ст., але повний розмах отримала у XXI і характеризується тим, що, з одного боку, глобалізація - це позитивний загальносвітовий процес, що взаємопов'язує національні соціально-економічні утворення в єдину світову економічну й суспільну систему. Як наголошує I. Лукашук, «основна роль у розвитку глобалізації належить соціально-економічним процесам» й охоплює «всі сфери життя суспільства и держави - як матеріальної, так і духовної» [12, с. 1]. Головним завданням у Декларації тисячоліття, ухваленій ООН 8 вересня 2000 р., визначається забезпечення універсального і позитивного впливу глобалізації на всі країни і народи [1]. 3 іншого боку, глобалізація породжує численні проблеми, серед яких: завдання забезпечення миру й безпеки людства; подолання небезпеки поширення ядерної, біологічної і хімічної зброї, вірусів тощо; збереження навколишнього середовища; глобальні проблеми, пов'язані з охороною здоров'я, культурою, наукою, засобами зв'язку тощо. Крім того, серед наявних, пише I. Лукашук, «виникають нові глобальні проблеми: організована транснаціональна злочинність, включаючи корупцію й різні види високотехнічного тероризму» [12, с. 7]. Особливе значення в структурі негативних наслідків мають «криміногенні й інші кримінологічно значимі наслідки глобалізації» [15, с. 119]. Товари, капітали, наркотики, зброя, знання та люди стали легко перетинати кордони. Транснаціональні мережі проникли майже в усі сфери людської діяльності [6, с. 89]. Як зазначалось на Одинадцятому конгресі ООН із попередження злочинності та поводження 3 правопорушниками (Бангкок, Таїланд, 2005), глобалізація і розвиток технологій принесли 
суспільству численні блага, проте вони відкрили також нові можливості для здійснення злочинів та для злочинців [11, с. 37-46].

Однак, як застерігає Н. Бойстер, слід бути обережним у прямій детермінованості таких складних явищ, як глобалізація i транснаціональна злочинність, адже «з розвитком ринкового контролю правового аспекту економіки та відмовою від державного контролю злочинцям стало простіше перевозити товари, людей та гроші». Левицький вважає «темною стороною глобалізації» той факт, що транснаціональні злочинці швидше зреагували на можливість експлуатувати ці нові ринкові можливості, аніж держави встигли вжити заходів попередження злочинів. Однак без достатніх доказів варто бути обережними з тим, щоб звинувачувати глобалізацію в розвитку транснаціональної злочинності» [19, с. 6]. Об'єктивне начало, що лежить в основі глобалізації, з одного боку, і можливість управління даним процесом - з іншого, вказують на необхідність установлення ефективних засобів і способів здобуття з нього максимальних переваг і попередження негативних наслідків. Як стверджує I. Лукашук, глобалізований світ вимагає більш високої організації світової системи [13, с. 115], і важливу роль у рішенні цього завдання покликане відіграти право. Тому слід погодитися з С. Лук'яновою в тому, що «в сучасних умовах перед правом постає ще одне важливе завдання - проблема управління глобалізацією, гармонізації її процесів. Право виступає в якості інструмента глобалізації і одночасно засобу управління iï процесами. Зазначені обставини зумовлюють глибокі зміни як внутрішньодержавного, так і міжнародного права, включаючи характер їх взаємодії» [14, с. 85]. Як зазначає В. Лунеєв, «глобалізація (транснаціоналізація) злочинності хоча й детермінована глобалізаційними процесами в економіці й інших сферах людської діяльності, але проявилась набагато раніше та йде набагато скоріше, оскільки злочинцям не потрібно створення міжнародно-правових умов, їм досить реальних можливостей. Заснування Міжнародної організації кримінальної поліції (МОУП/ Інтерпол) у 1923 р. було у цьому відношенні перспективним міжнародним рішенням, що констатувало вихід злочинності за національні кордони і прогнозувало появу ще більш небезпечної міжнародної злочинності. Його створення випереджало появу масової транснаціональної злочинності, але не запобігло їй» [15, с. 139]. Слід зазначити, що в умовах глобалізації суттєво активізуються процеси зближення міжнародних та внутрішньодержавних проблем, зміни їх пріо- ритетів, виникають нові аспекти взаємодії міжнародного права та національного, «під питання ставиться класичний феномен державності та її основний критерій та ознака державний суверенітет» [5, с. 10].

Факти говорять про розширення сфери діяльності організованої злочинності як у географічному, так і в галузевому відношенні. У результаті цього транснаціональна злочинність, орієнтована на конкретну діяльність, поступово набуває характеру трансконтинентальної і багатопрофільної злочинності: сучасні злочинні організації займаються контрабандою усього, що дає прибуток, починаючи 3 наркотиків, культурних цінностей, ядерних матеріалів i зброї та закінчуючи людьми. Тісне змикання криміналу з економічними структурами, що створює за допомогою корупції систему захисту від державного й суспільного контролю, - одна з найнебезпечніших характеристик організованої злочинності.

Найбільшу тривогу викликають такі види міжнародної злочинності, як тероризм, торгівля людьми, дитяча проституція, міжнародний наркобізнес, корупція. Глобального значення набуває необхідність співробітництва всіх суб'єктів міжнародного права у протидії міжнародному тероризму, який небезпідставно називають однією 3 глобальних проблем сучасності. «Тероризм продовжує залишатися однією 3 найбільш серйозних загроз миру і безпеки, від якої не застрахована ні одна держава, й стрімко адаптується до сучасних реалій, набуває нових вимірів гостроти» $[18$, с. 76$]$

Глобалізаційні процеси створюють великі можливості для транснаціоналізації організованої злочинності й роблять розширення співробітництва держав та міжнародних організацій у цій сфері неминучим. Як слушно зазначає Н. Зелінська, «міжнародна злочинність - це глобальна проблема, яка зумовлює необхідність глобальної реакції» [17, c. 7].

Основним органом розроблення стратегії протидії транснаціональній злочинності є Організація Об'єднаних Націй. У рамках ООН склався комплекс багатосторонніх міжнародних універсальних конвенцій, кожна 3 яких спрямована на співробітництво держав щодо конкретного транснаціонального злочину. Крім того, численні міжнародні договори містять положення про співробітництво у сфері боротьби з тим чи іншим видом міжнародної злочинності. Важливим кроком у боротьбі зі злочинністю стало підписання Конвенції ООН проти транснаціональної організованої злочинності, що відбулося 15 листопада 2000 р. в м. Палермо 
(Італія) [2], ухваленням якої підкреслено, що на початку XXI ст. саме транснаціональна організована злочинність фактично стала реальною загрозою для безпеки всього людства як за своїми масштабами, так і за руйнівним впливом.

Конвенція ООН 2000 р. (Палермська конвенція) застосовується щодо злочинів транснаціонального характеру, здійснених за участю організованої злочинної групи. Організована злочинність розуміється через призму характеристики організованих кримінальних груп та серйозність злочинів, що ними здійснюються. Конвенція визначає організовану злочинну групу як «структурно оформлену групу в складі трьох або більше осіб, що існує протягом визначеного періоду часу і діє узгоджено з метою здійснення одного або декількох серйозних злочинів або злочинів, визнаних такими відповідно до цієї Конвенції, для того, щоб одержати, прямо або посередньо, фінансову або іншу матеріальну вигоду» (ст. 2). Транснаціональний характер злочину може виявлятися у низці варіацій (ст. 3 п. 2), якщо «а) він вчинений у більш ніж одній державі; b) він вчинений в одній державі, але істотна частина його підготовки, планування, керівництва або контролю має місце в іншій державі; c) він вчинений в одній державі, але за участю організованої злочинної групи, яка здійснює злочинну діяльність у більш ніж одній державі; або d) він вчинений в одній державі, але його істотні наслідки мають місце в іншій державі» (ст. 3 п. 2).

У Конвенції не дається визначення організованої злочинності (транснаціональної організованої злочинності), цей термін не згадується у тексті, проте відображені такі характеристики транснаціональної організованої злочинності, як їі транснаціональність, склад злочинних груп і тривалий характер їхньої діяльності. До протизаконних дій належать: участь в організованій злочинній групі (ст. 5), відмивання доходів від злочинів (ст. 6), корупція (ст. 8), перешкоджання здійсненню правосуддя (ст. 23). Додаткові протоколи до Конвенції більш детально розкривають кримінальний характер торгівлі людьми, незаконної міграції, незаконного обігу вогнепальної зброї.

Конвенція містить статті, що регулюють питання екстрадиції, взаємної правової допомоги, співробітництва між правоохоронними органами, обмін інформацією, а також попередження транснаціональної організованої злочинності (ст. 31). Останнє положення передбачає прийняття належних законодавчих, адміністративних й інших заходів 3 метою захисту національних ринків від проникнення транснаціональних злочинних груп (наприклад, засуджені за злочини позбавляються права займати посади керівників юридичних осіб, створюється спеціальний національний реєстр таких осіб; вводиться механізм контролю над процедурами торгів, видачі субсидій і ліцензій тощо).

Окрім цієї важливої нормотворчої діяльності з ухвалення конвенцій, у рамках Організації Об'єднаних Націй проводяться численні форуми, симпозіуми, конференції, конгреси. На Всесвітній конференції з організованої транснаціональної злочинності (Італія, Неаполь, 1994), в якій взяли участь представники 142 держав, було обгрунтовано десять загроз, що несе в собі транснаціональна організована злочинність: загрози суверенітету держав, суспільству, окремим особам, національній стабільності й державному контролю, демократичним цінностям і суспільним інститутам, національній економіці, фінансовим установам, демократизації і приватизації, розвитку, глобальним режимам і кодексам поведінки. Вперше до проблеми транснаціональної організованої злочинності звернулись на П'ятому конгресі $\mathrm{OOH}$ із попередження злочинності та поводження з правопорушниками (Женева, 1975) [9, с. 122] (пізніше було постановлено іменувати конгреси «з питань попередження злочинності й кримінальному правосуддю» згідно з Резолюцією ГА 56/119 від 19 грудня 2001 р.), де було визнано, що злочинність у формі міжнародного бізнесу являє собою більш серйозну загрозу, ніж традиційні форми злочинної поведінки. Згодом ця проблема стала предметом обговорення на всіх наступних конгресах - міжнародних форумах загальносвітового значення, які проводяться починаючи з 1955 р. у рамках ООН кожні п'ять років відповідно до Резолюції 415(V) Генеральної Асамблеї від 1 грудня 1950 р. (п. d). На Восьмому конгресі (м. Гавана, 1990) було прийнято Резолюцію Конгресу, в якій зазначалося, що організована злочинність створює пряму загрозу національній і міжнародній безпеці й стабільності [10, с. 102]. На Дев’ятому конгресі ООН (м. Каїр, 1995) було визначено вісімнадцять категорій транснаціональних злочинів, які організовуються й вчиняються в межах більше ніж однієї країни. У Доповіді Генерального секретаря ООН на Десятому конгресі (м. Відень, 2000) [21] визначено поняття глобалізації як «розмивання політичних кордонів і відкриття економічних ринків, які раніше були закритими чи жорстко регулювались державами», тобто глобалізація розглядається як соціально-економічне і політичне явище, що характеризуе сучасний етап розвитку світової економіки. 
$\mathrm{y}$ «Бангкокській декларації» Одинадцятого конгресу ООН (м. Бангкок, Таїланд, 2005) знову була підкреслена глибока стурбованість поширенням і масштабами транснаціональної організованої злочинності, у тому числі незаконного обігу наркотиків, відмивання грошей, торгівлі людьми, незаконного ввозу мігрантів, незаконного обігу зброї, тероризму, та наявними зв'язками між ними, а також все більшою витонченістю й диверсифікацією діяльності організованих злочинних груп. Останній, Тринадцятий, конгрес $\mathrm{OOH}$ із попередження злочинності та кримінального правосуддя (м. Доха, Катар, 2015), як зазначає Н. Зелінська, «знову підтвердив завдання забезпечення верховенства права й попередження та протидії злочинності у всіх iï формах і проявах на національному й міжнародному рівнях; необхідність забезпечення ефективності, справедливості, гуманності та підзвітності систем кримінального правосуддя, надання доступу до правосуддя для всіх, створення ефективних, підзвітних, неупереджених та інклюзивних установ на всіх рівнях і забезпечення дотримання принципу поваги людської гідності й загального дотримання і поваги всіх прав людини та основних свобод» [17, с. 6$]$.

Під егідою ООН регулярно скликаються сесії Міжнародного форуму «Злочинність і кримінальне право в епоху глобалізації», 3 яких перші вісім було проведено в Пекіні під головуванням професора Пекінського політико-юридичного університету Хе Бінсуна. 3 обранням президентом Форуму відомого індійського фахівця з віктимології і кримінальної психології, директора Інституту поведінкових наук Університету імені О.П. Джиндала, доктора Санджива П. Сахни (Sahjeev P. Sahni) наступні сесії Форуму перенесені в Індію. На цих форумах висловлюється стурбованість зростанням рівня міжнародної злочинності й приймаються важливі документи. Зокрема на Шостій сесії Міжнародного форуму «Злочинність і кримінальне право в епоху глобалізації» (2014) обговорювалась тема «Недоброякісна і фальсифікована продукція і медикаменти: злочинність і безпека». У пленарній доповіді Глави форуму знаного китайського вченого Хе Бінсуна, у доповідях представників країн-учасниць і виступах делегатів форуму висловлювалась серйозна стурбованість поширеністю і небезпекою злочинів, пов'язаних із виготовленням і збутом фальсифікованих і недоброякісних продуктів харчування, напоїв, лікарських засобів і медичних виробів, небезпечних для життя і здоров'я споживачів. У Декларації форуму зазначалось, що це явище набуло глобального характеру й вимагає протидії, тобто назріла необхідність укладення відповідної міжнародної угоди про криміналізацію незаконного обігу фальсифікованих i недоброякісних продуктів харчування, лікарських препаратів і медичних виробів, що становлять загрозу життю і здоров'ю споживачів ${ }^{1}$. На Сьомій сесії (2015) ключовими питаннями стали проблеми, пов'язані з теорією і практикою покарання, що сприяло розширенню представницького складу делегацій із країн Європи, Латинської Америки, Азійсько-Тихоокеанського регіону тощо. На Одинадцятій сесії Форуму, що відбувся вже в Індії (2017), у Міжнародному університеті імені О.П. Джиндала (O.P. Jindal Global University), обговорювалась тема «Перспективи біженців і глобальної міграції».

На регулярній основі працює Комісія 3 попередження злочинності і кримінального правосуддя 31991 р. як функціональна комісія Економічної і соціальної ради ООН. Прагнення держав знайти консенсус у рішенні цілого комплексу проблем, пов'язаних із різними міжнародно-правовими аспектами кримінальної юрисдикції держав, підтверджується активною діяльністю Комісії міжнародного права і Шостого Комітету ГА ООН із кодифікації права.

\section{Висновки}

Транснаціональне кримінальне право як підгалузь міжнародного кримінального права сформувалось наприкінці XX - початку XXI ст. як закономірне явище розвитку міжнародного права під впливом багатьох чинників суспільного, політичного, економічного й правового характеру. Розвиток суспільних відносин, який характеризується як глобалізація, зміни на політичній мапі світу, інтеграційні процеси тощо призвели до загострення проблем економічного й іншого характеру i, як наслідок, зростання міжнародної злочинності, різновидом якої $€$ транснаціональна організована злочинність. Глобалізація як світова тенденція новітнього часу має як позитивний вплив на розвиток національного й міжнародного права (постійний процес зближення змісту правового регулювання й зовнішніх форм його вираження, запозичення зарубіжного досвіду, творче врахування позитивних рис правових систем інших країн, гармонізація внутрішньодержавного кримінального права), так і негативний. Одним із найбільш

${ }^{1}$ Нині зазначене питання врегульовано прийняттям Резолюції 20/6 «Про фальсифіковану медичну продукцію», ухваленій на 20-й сесії Комісії з питань боротьби зі злочинністю та кримінальної юстиції OOH, в якій міститься програма дій у цій сфері. 
серйозних негативних наслідків глобалізації є зростання злочинності у світі, а також виникнення нових, більш масштабних i більш небезпечних форм злочинності, яка не обмежується національними кордонами й набуває транснаціонального характеру. Вплив глобалізації на цей процес відбувається не прямо, а опосередковано, через економічні, політичні й інші чинники зростання злочинності. Транснаціональна організована злочинність - це виклик, відповідь на який може бути дана тільки спільними зусиллями всіх суб'єктів міжнародного права. Протидія транснаціональній злочинності є важливим аспектом у житті кожної держави й усього світу загалом, а розробка концепції протидії транснаціональній злочинності є необхідним елементом розвитку кримінальної політики в сучасних умовах світової нестабільності. Визнання міжнародної і національної злочинності однією із загроз стабільності світового життя передбачає розробку й регламентацію державами в національному праві єдиних принципів правової політики, а також об'єднання зусиль зі створення юридичних інструментів, що сприяють уніфікації міжнародного й національних механізмів протидії злочинності.

Важливу роль у протидії транснаціональній організованій злочинності відіграє ООН, у рамках якої проводиться постійна робота Генеральної Асамблеї, конгресів, форумів, конференцій тощо, спрямована на вивчення й дослідження всіх можливих видів взаємозв'язку між злочинністю і деякими аспектами розвитку, такими як структура i зростання населення, урбанізація, житлові умови, міграція населення, охорона здоров'я, освіта і можливості працевлаштування 3 метою підвищення здатності оперативно реагувати на зміни соціально-економічних, культурних і політичних умов у рамках політики, що проводиться у сфері попередження злочинності й кримінального правосуддя.

\section{Список використаних джерел:}

1. Декларація тисячоліття Організації Об'єднаних Націй. URL: http://www.un.org/ russian/ documen/declarat/summitdecl.htm (дата звернення: 07.08.2019).

2. Конвенція Організації Об'єднаних Націй проти транснаціональної організованої злочинності : ухвалена Резолюцією 55/25 Генеральної Асамблеї від 15 листопада 2000 р. URL: http://zakon.rada.gov.ua/laws/show/995 789 (дата звернення: 07.08.2019).

3. Доповідь Групи високого рівня із загроз, викликів і змін «Більш безпечний світ: наша спільна відповідальність» на засіданні ГА
OOH, 2004 p. C. 60. URL: http://www.un.org/ russian/secureworld/report.htm (дата звернення: 07.08.2019).

4. Базов О. Міжнародне кримінальне право як юридична основа міжнародного кримінального правосуддя. Право України. 2017. № 10. С. 170-176.

5. Баймуратов М.О. Правова модернізація Ради Безпеки ООН: проблеми теорії та практики: монографія / за ред. проф. М.О. Баймуратова. Одеса: Фенікс, 2013. 270 с.

6. Гаджиев К. С. Введение в геополитику : учебник для вузов. 2-е изд., доп. Москва : Логос, 2002. C. 89.

7. Глобализация : учебник / под общ. ред. В. А. Михайлова и В. С. Буянова. Москва : Издательство РАГС, 2008. 844 c.

8. Зелинская Н.А. Международные преступления и международная преступность : монография. Одеса : Юридична література, 2006. 568 с.

9. Конгрессы ООН по предупреждению преступности и уголовному правосудию: сборник материалов : в 3-х книгах / под общ. ред. В.В. Голины. Київ-Харків: Право, 2013. Кн. 1. 188 с.

10. Конгрессы $\mathrm{OOH}$ по предупреждению преступности и уголовному правосудию: сборник материалов : в 3-х книгах / под общ. ред. В.В. Голины. Київ-Харків : Право, 2013. Кн. 2. 184 с.

11. Конгрессы ООН по предупреждению преступности и уголовному правосудию: сборник материалов : в 3-х книгах / под общ. ред. В.В. Голины. Київ-Харків : Право, 2013. Кн. 3.168 с.

12. Лукашук И.И. Глобализация, государство, право, XXI век. Москва : Спарк, 2000. 279 с.

13. Лукашук И.И. Задачи международного права в глобальном мире. По материалам Московского юридического форума «Глобализация, государство, право, XX1 век»). Государство и право. 2003. № 10. C. 113-119.

14. Лукьянова Е.Г. Основные тенденции развития российского права в условиях глобализации. Государство и право. 2004. № 7. С. 84-89.

15. Лунеев В.В. Преступность XX века: мировые, региональные и российские тенденции. 2 изд., перераб. и доп. Москва : Волтерс Клувер, $2005.912 \mathrm{c}$.

16. Міжнародне публічне право : підручник: у 2-х т. / В.В. Мицик та ін.; за заг. ред. В.В. Мицика. Харків: Право, 2018. Т. 2. 624 с.

17. Теорія та практика міжнародного кримінального права : підручник / Зелінська Н.А. та ін.; за ред. проф. Зелінської Н. А. Одеса: Фенікс, 2017. 582 с.

18. Троицкий С.В. Международно-правовые формы сотрудничества государств по противодействию терроризму. Государство и право. 2014. № 2. C. 76-84.

19. Boister N. An Introduction to Transnational Criminal Law. Oxford: University Press, 2012.512 p.

20. Boister N. Transnational Criminal Law. European Journal of International Law. 2003. Vol. 14, № 5. P. 953-976. P. 956, 963.

21. Bossard A. Transnational Crime and Criminal Law. Chicago: The Office of International Criminal Justice. The University of Illinois at Chicago, 1990.155p. 
The article discusses the social prerequisites that emerged at the end of XX - beginning of XXI centuries in the world and have led to changes in the development of international law and the formation of transnational criminal law. Transnational criminal law is seen as a sub-branch of international criminal law, which has been shaped by the rise of international crime, a type of transnational organized crime. Among the mail factors contributing to the emergence and development of these phenomena are geopoliticalc hanges, globalization, transnational organized crime, the growing role of international law in the international legal order and others.

Globalization as a global trend of modern times has both a positive impact on the development of national and international law, and a negative one. One of the most serious negative effects of globalization is the rise in crime in the world, as well as the emergence of new, more dangerous forms of crime, which are not limited to national borders and are transnational in nature. The impact of globalization on this process does not occur directly but indirectly through economic, political and other factors of increasing crime. Transnational organized crime is a challenge that can only be answered by the concerted efforts of all actors of international law. Countering transnational crime is an important aspect in the life of every country and the world at large, and developing a concept of countering transnational crime is a necessary element in the development of criminal policy in today's world of instability.

Recognition of international and national crime as one of the threats to the stability of world life involves the development and regulation by states of national law of uniform principles of legal policy, as well as joint efforts to create legal instruments that promote the unification of international and national mechanisms to combat crime.

An important role in the fight against transnational organized crime is played by the UN, in which the work of the General Assembly, congresses, forums, conferences, etc. is carried out, aimed at studying and exploring all kinds of relationships between crime and certain aspects of development.

The author drates attention to such crimes as terrorism, human trafficking, child prostitution, international drug business, corruption, which are of great concern in our time.

Key words: transnational criminal law, globalization, transnational organized crime, United Nations, conventions, congresses. 
DOI https://doi.org/10.32849/2663-5313/2019.8.45

Олена Бусол,

докт. юрид. наук, с.н.с., провідний науковий співробітник відділу проблем кримінального права, кримінологї та судоустрою Інституту держави і права імені В. М. Корещького Начіональної академії наук Украӥни

\section{РЕЦЕНЗІЯ НА МОНОГРАФІЮ М. І. КАРПЕНКА «ВІЙСЬКОВІ ЗЛОЧИНИ: ПИТАННЯ ТЕОРІЇ, ЗАКОНОДАВСТВА І ПРАКТИКИ ${ }^{1}$}

Зміст зазначеної монографії, що вийшла друком у червні 2019 р., певною мірою розкриває окремі положення національного законодавства держави у галузі безпеки і оборони України, яке потребує змістовного наукового аналізу, роз'яснення і подальшого вдосконалення. Зокрема, це стосується тих правових норм, які передбачають кримінальну відповідальність за їх недотримання і впливають на неї.

Правові норми чинного законодавства передбачають, що оборона України, захист iii суверенітету, територіальної цілісності і недоторканності покладаються на Збройні Сили України та інші військові формування, утворені відповідно до законів України. А громадяни України проходять військову службу відповідно до Закону України «Про військовий обов'язок і військову службу». Тому держава та ії̈ інституції повинні створювати їм належні умови для проходження військової служби. А військовослужбовці зобов’язані неухильно додержуватися Конституції України та законів України, не порушувати права і свободи, честь і гідність інших людей. У разі недотримання зазначених вимог передбачена кримінальна відповідальність. Серед питань, які розкриті у монографії, - питання методології та стану дослідження військових злочинів, історичного розвитку їх законодавства та нинішньої системи; питання військового правопорядку як об'єкта кримінально-правової охорони, об'єктно-суб'єктна характеристика військових злочинів, питання кваліфікації та заходи кримінально-правового характеру за їх вчинення. Одночасно автором вперше на теренах України надана детальна порівняльноправова характеристика військових злочинів за кримінальним законодавством України та інших держав світу. Він не оминув і питання,

${ }^{1}$ Карпенко M.I. Військові злочини: питання теорії, законодавства і практики : монографія / за заг. ред. В.К. Матвійчука. Київ : ЗВО «Національна академія управління», 2019. 458 с. що випливають із тих змін до Кримінального кодексу України щодо передбачення кримінальних правопорушень, які набудуть чинності 01 січня 2020 року.

М. Карпенком змістовно розкрита наукова новизна одержаних результатів, що стосуються теоретико-методологічного дослідження злочинів проти встановленого порядку несення військової служби за Кримінальним кодексом Украӥни. Його пропозиції стосуються вдосконалення кримінально-правових норм, передбачених розділом XIX Особливої частини КК, які у разі успішної реалізації посприяють удосконаленню правових норм цього розділу та практики їх застосування.

Автором уперше на підставі історіографії, яка грунтується на достовірних джерелах визначено періодизацію розвитку законодавства про кримінальну відповідальність за військові злочини на теренах України. Здійснено порівняльний аналіз системи військових злочинів за кримінальним законодавством часів Петра I («Воинский устав» 1715 р.») і КК України 200 року і констатовано, що частина 2 зазначеного акта законодавства («Артикул воинский с кратким толкованием») фактично заклала основу системи військових злочинів, яка простежується у чинному КК.

Досить великий пласт пропозицій М. Карпенка, що обгрунтовані у монографії і потребують розгляду, стосуються удосконалення об'єктивної сторони військових злочинів.

Одна з пропозицій стосується тих положень, що військовослужбовці $є$ особами, які постійно, тимчасово чи за спеціальним повноваженням здійснюють функції представників влади, тому це необхідно законодавчо передбачити.

Що стосується військових службових злочинів, то викладені й інші пропозиції, які у разі врахування суттєвоудосконалятьзмістдиспозицій правових норм, передбачених ст. 425-426-1 КК України. Йдеться про ознаки цих злочинів у разі спричинення матеріальних збитків. Напри- 
клад, у разі вчинення загальнокримінальних злочинів, передбачених ст. 364, 365 та 367 КК, розмір істотної шкоди і тяжких наслідків становить відповідно сто, двісті п’ятдесят і більше неоподатковуваних мінімумів доходів громадян, тоді як у разі вчинення зазначених військових злочинів цей розмір становить відповідно двісті п’ятдесят і більше НМДГ (істотна шкода) і п'ятсот і білыше НМДГ (тяжкі наслідки). Урахування цієї пропозиції автора відновить конституційну рівність суб'єктів вчинення службових злочинів перед законом про кримінальну відповідальність.

Вартою уваги є і пропозиція, яка доводить, що термінологія «військові службові особи» і «військові посадові особи», яка використовується відповідно у КК і Законі України «Про військовий обов'язок і військову службу», недопустима, тому запропоновано уточнити визначення військової посадової особи, яке дано законодавцем у ч. 12 ст. 6 Закону України «Про військовий обов'язок і військову службу».

Слушною є пропозиція М. Карпенка, яка сформульована ним уперше, і щодо необхідності змістовно поліпшити об'єктивну сторону злочинів, передбачених ст. 427 («Здача або залишення ворогові засобів ведення війни»), 429 («Самовільне залишення поля бою або відмова діяти зброєю»), 430 («Добровільна здача в полон»), 432 («Мародерство») КК, оскільки зазначені статті передбачають лише простий склад злочину. Тому доцільно, на думку автора, передбачити кримінальну відповідальність за їх вчинення з кваліфікуючими ознаками і посилити покарання.

Також автор звертає увагу на відсутність у КК визначення терміна «особливий період», який є кваліфікуючою ознакою 11 злочинів та особливо кваліфікуючою ознакою 25-ти злочинів розділу ХІХ Особливої частини КК відповідно «вчинене в умовах особливого періоду, крім воєнного стану» та «вчинені в умовах воєнного стану або в бойовій обстановці». Обгрунтовано, що трактування терміна «особливий період» і його зміст, які містяться у законах України «Про оборону України», «Про мобілізаційну підготовку та мобілізацію», «Про правовий режим воєнного стану», необхідно привести до єдиного визначення і поліпшити його, передбачивши, що особливий період охоплює також і заходи, пов'язані з демобілізацією.

Відсутність чіткого визначення терміна «особливий період», як зазначає дослідник, не сприяє належному здійсненню кваліфікації військових злочинів, скоєних в умовах особливого періоду, що підтверджується і судовою практикою. Тому він пропонує це відобразити у примітці до ст. 402 КК України.
М. Карпенко обгрунтовано доводить необхідність передбачити кримінальну відповідальність за вчинення правопорушень проти порядку мобілізації і забезпечення режиму особливого періоду у разі ухилення від направлення на роботи на посадах цивільного персоналу, передбачених штатами воєнного часу; невиконання воєнно-транспортного обов'язку у період мобілізації й у воєнний час; невиконання повинностей в особливий період і у воєнний час; невиконання організаціями обов'язків в особливий період і у воєнний час, результатом чого стало спричинення істотної шкоди або тяжких наслідків. Нині за порушення правового режиму воєнного стану передбачена лише адміністративна відповідальність. Тому автор цілком правомірно пропонує розширити як зміст родового об'єкта злочинів проти встановленого порядку несення військової служби, так і систему цих злочинів. І з цією метою передбачити в Особливій частині КК розділ «Кримінальні правопорушення проти воєнної безпеки України», одна із глав якого має містити кримінальну відповідальність за «кримінальні правопорушення проти порядку забезпечення режиму особливого періоду».

Доречною є і пропозиція щодо реформування системи військових злочинів у КК.

Із цього приводу він пропонує на першому етапі розглянути і реалізувати пропозиції, які не потребують суттєвих змін у структурі Особливої частини КК. На другому етапі, під час прийняття нової редакції Особливої частини, родовий об'єкт військових злочинів розширити 3 огляду на необхідність посилення кримінально-правової охорони воєнної безпеки України. Тому, на думку М. Карпенка, необхідно змінити не лише назву розділу XIX Особливої частини на «Кримінальні правопорушення проти воєнної безпеки України», але і його зміст. Зокрема, глава 1 цього розділу повинна передбачати кримінальну відповідальність за «Кримінальні правопорушення проти порядку комплектування воєнної організації держави», до якої мають бути включені кримінальні правопорушення за: 1) ухилення від призову на військову службу у мирний час; 2) ухилення від призову на військову службу за мобілізацією; 3) ухилення від проходження служби цивільного захисту в особливий період чи у разі проведення цільової мобілізації; 4) ухилення від військового обліку або спеціальних зборів; ці злочини мають бути вилучені із розділу XIV «Злочини у сфері охорони державної таємниці, недоторканності державних кордонів, забезпечення призову та мобілізації».

Глава 2 «Військові кримінальні правопорушення» повинна передбачати кримінальну 
відповідальність за діяння, що нині передбачені ст. 402-421, 425-432 КК.

Глава 3 «Кримінальні правопорушення проти порядку забезпечення режиму особливого періоду» має передбачати кримінальну відповідальність за: ухилення від направлення на роботи на посадах цивільного персоналу, передбачених штатами воєнного часу; невиконання воєнно-транспортного обов'язку у період мобілізації і у воєнний час; невиконання повинностей в особливий період і у воєнний час; невиконання організаціями обов'язків в особливий період і у воєнний час та ін.

Одночасно М. Карпенком обгрунтовано низку положень науки кримінального права, які ним удосконалені. Зокрема, це стосується:

- визначення поняття військового злочину;

- дефініції терміна «родовий об'єкт злочинів проти встановленого законодавством порядку несення або проходження військової служби»;

- положення щодо ознак суб'єктів військових злочинів, які передбачені не лише КК, а й іншими актами законодавства військової сфери;

- тлумачення змісту диспозицій правових норм розділу ХІХ Особливої частини КК щодо того, що військовозобов'язані та резервісти під час проходження зборів можуть бути суб'єктами лише злочинів, передбачених ч. 1-2 ст. 402, ч. 1 ст. 403 , ч. $1-2$ ст. $404-405$, ч. $1-2$ ст. $411-412$, ч. 1 ст. 413, ст. 414-415, 422 КК;

- положення про те, що за умисну співучасть у військових злочинах, передбачених розділом XIX Особливої частини КК, на умовах, визначених ст. 26-27, 29 КК, підлягають кримінальній відповідальності й інші фізичні особи (не військовослужбовці) як організатори, підбурювачі та пособники;

- визначення військового дисциплінарного правопорушення (дисциплінарного проступку), яким є суспільно небезпечне винне діяння (дія або бездіяльність), яке посягає на військовий правопорядок i пов'язане 3 недотриманням військової дисципліни, а також встановленого законодавством порядку несення або проходження військової служби, вчинене військовослужбовцем або військовозобов'язаним та резервістом під час проходження зборів;

- системи військових злочинів за КК України. Насамперед це стосується злочинів, відповідальність за які передбачена міжнародними договорами (злочини проти порядку дотримання законів та звичаїв війни - ст. 433-435), оскільки кримінальна відповідальність за їх вчинення передбачена ще і ст. 438, 445 КК України. Зазначена теза М. Карпенка підтверджується тим фактом, що нині до Верховної Ради України Кабінетом Міністрів України 20 грудня
2018 року надісланий для розгляду законопроект № 9438 «Про внесення змін до деяких законодавчих актів щодо забезпечення гармонізації кримінального законодавства 3 положеннями міжнародного права».

Ряд положень у дослідженні, оприлюдненому у монографії, дістали подальшого розви тку. Зокрема, це: обгрунтування кваліфікації окремих військових злочинів, коли має місце виконання явно злочинного наказу або розпорядження чи випадки сумісного вчинення насильницьких дій військовослужбовцями, що перебувають і не перебувають у відносинах підлеглості (ст. 402, 404-406, 426-1 КК).

Як наголошує автор, певну складність має кваліфікація дій військової службової особи у разі вчинення злочинів, передбачених ст. 364 КК України, після того як злочин, передбачений ст. 423 («Зловживання військовою службовою особою владою або службовим становищем») КК, був декриміналізований передбачено аналогічне адміністративне правопорушення (ст. 172-13 КУПАП), хоча чіткого розмежування між ними законодавцем не здійснено. Аналогічна ситуація, на його думку, може виникнути й у разі перевищення військовою службовою особою влади чи службових повноважень або у разі бездіяльності військової влади на рівні злочину (ст. 426, 426-1 КК) військового адміністративного правопорушення (ст. 172-14 і 172-16 КУпАП). Тому позитивно сприймається його пропозиція щодо відновлення у КК ст. 423 у тій редакції, як це було до 21 лютого 2014 року.

Вартими уваги є й аргументи автора 3 приводу того, що військове кримінальне законодавство провідних держав світу і України $€$ схожим, але з певними відмінностями, які насамперед пов'язані $з$ їх приналежністю до різних правових систем. Це стосується як змісту диспозицій правових норм, так і їх санкцій і $€$ результатом різного підходу законодавців до використання законодавчої техніки, яка зумовлена станом правової системи відповідних держав. У монографії відображені відмінності, які характерні для кримінального законодавства Англії, Данії, Норвегії, США, Швеції, Японії та інших держав, що створюють додаткові труднощі у правозастосовній діяльності. Тому зроблено висновок, що їх імплементація у кримінальне законодавство України недоцільна.

На завершення варто зазначити, що наукові здобутки, отримані автором і оприлюднені у монографії «Військові злочини: питання теорії, законодавства і практики» (2019 р. видання), посприяють подальшому більш активному пошуку шляхів вирішення відповідних завдань, а реалізація цих здобутків має на меті поліпшення стану як військового правопорядку у військових формуваннях, так і зміцнення воєнної безпеки України. 
Оксана Васильченко,

докт. юрид. наук, професор,

професор кафедри конституиійного права

Київського начіонального університету імені Тараса Шевченка

\section{РЕЦЕНЗІЯ НА МОНОГРАФІЮ КАНДИДАТА ЮРИДИЧНИХ НАУК, ЗДОБУВАЧА КАФЕДРИ КОНСТИТУЦЙНОГО ПРАВА ТА ПОРІВНЯЛЬНОГО ПРАВОЗНАВСТВА УЖГОРОДСЬКОГО НАЦІОНАЛЬНОГО УНІВЕРСИТЕТУ К. В. ГОЛОВКО «СИСТЕМАТИЗАЦІЯ МУНІЦИПАЛЬНОГО ЗАКОНОДАВСТВА: УКРАЇНСЬКИЙ ДОСВІД» ${ }^{1}$}

У передмові до аналізованої монографії автор справедливо зауважує, що актуальність систематизації муніципального законодавства України є важливою для нормотворчості, для правозастосування, а також для правового просвітництва пересічних членів територіальних громад, наводячи відповідні приклади. У цілому слід погодитись з тим, як К.В. Головко обгрунтовує актуальність проведеного нею дослідження.

Актуальність тематики систематизації муніципального законодавства України полягає також і в тому, що, на жаль, в українській юридичній літературі питання такого упорядкування законодавства залишаються малодослідженими, навіть коли йдеться про законодавство у цілому (тобто не тільки фахівцями 3 конституційного та муніципального права, а також і фахівцями з теорії права). Багато вчених вбачають в цьому певну громадянську позицію, яка не дозволяе їм звертатись до тоталітарного минулого. Дійсно, в СРСР приділялось багато уваги дослідженням систематизації законодавства. Однак здебільшого вони не були ідеологізованими, а спрямовувались на підвищення ефективності розробки нових кодексів, інкорпораційних збірників законодавства тощо. Наразі суспільні відносини все більше ускладняються, а тому нові напрацювання у сфері систематизації законодавства загалом та систематизації галузевого законодавства зокрема слід всіляко вітати.

К.В. Головко побудувала своє дослідження доволі традиційно. Вона почала 3

${ }^{1}$ Головко К.В. Систематизація муніципального законодавства: український досвід : монографія. Херсон : Видавничий дім «Гельветика», 2019. 450 с теоретичних та методологічних проблем систематизації муніципального законодавства України (Розділ 1), після чого перейшла до проблем окремих форм його систематизації - інкорпорації та консолідації (Розділ 2), а також кодифікації (Розділ 3). Автор сформулювала низку цікавих висновків та пропозицій, які значно збагатили науку конституційного та муніципального права України, а також і теорію права.

Так, заслуговують на всіляку підтримку авторські узагальнення щодо відмінностей між формами систематизації законодавства та видами систематизації законодавства, ознаки окремих форм систематизації законодавства, які автор уточнила, а також сформульований К.В. Головко висновок щодо того, що далеко не усі підстави для виокремлення видів систематизації законодавства слід застосовувати до самої систематизації законодавства загалом, адже інколи вони стосуються лише окремої iï форми або форм (наприклад, тільки інкорпорації, або тільки таких нормотворчих форм систематизації законодавства, як кодифікація та консолідація).

3 погляду дослідження систематизації муніципального законодавства України вагомим внеском у доктрину юридичної науки є формулювання понять «систематизація муніципального законодавства України», «інкорпорація муніципального законодавства України», «консолідація муніципального законодавства України», «кодифікація муніципального законодавства України». Крім термінологічних проблем, автор приділила значну увагу формулюванню ознак кожної з форм систематизації муніципального законодавства України. Наприклад, щодо кодифікації муніципального законодавства 
України К.В. Головко зазначила, що «галузевими ознаками кодифікації муніципального законодавства України є: а) наявність як реальної можливості, так і практичної необхідності здійснення кодифікації муніципального законодавства України як на загальнодержавному, так і на місцевому рівнях; б) те, що до числа компетентних органів, які мають повноваження здійснювати кодифікацію муніципального законодавства України, належать як органи державної влади, так і органи місцевого самоврядування; в) те, що здійснення кодифікації муніципального законодавства України може відбуватись як в межах власної компетенції органів публічної влади, так і під час здійснення ними делегованих повноважень; г) можливість уміщення підсумків кодифікації муніципального законодавства України у нормативно-правові акти різних видів - кодекси, закони, статути, рішення тощо; д) недоцільність проведення повної кодифікації муніципального законодавства України (навіть якщо розглядати поняття «законодавство» у вузькому розумінні, тобто винятково як сукупність законів); е) перспективність застосування бланкетної кодифікації актів муніципального законодавства України на місцевому рівні». Такий глибокий підхід до дослідження аналізованих явищ слід всіляко вітати.
Варто підкреслити, що автор не обмежилась застосуванням традиційних поглядів на систематизацію муніципального законодавства та на їі форми, а застосувала найновіші напрацювання вчених у цій сфері. Вона веде мову про бланкетну кодифікацію муніципального законодавства України, про інтерпретаційну інкорпорацію муніципального законодавства України, про його дефінітивну інкорпорацію тощо.

Водночас деякі положення монографії викликають зауваження. Наприклад, доволі незначна увага приділена консолідації муніципального законодавства України. Автор аналізує консолідацію разом 3 інкорпорацією і приділяє останній значно більше уваги в межах як підрозділу 2.1., так і підрозділу 2.2. Водночас автор зазначає, що консолідація має значний потенціал для галузі муніципального законодавства України. У цьому вбачається певне протиріччя та база для подальших наукових пошуків. Однак це зауваження не впливає на загальну позитивну оцінку аналізованого монографічного дослідження.

Монографія К.В. Головко є актуальною, своєчасною, інноваційною, їй притаманний належний рівень наукової новизни. Слід підтримати наукові пошуки автора, підкреслити їхню високу практичну цінність та всіляко підтримати подальші дослідження в обраному напрямі. 
НОТАТКИ 
НОТАТКИ 
НОТАТКИ 


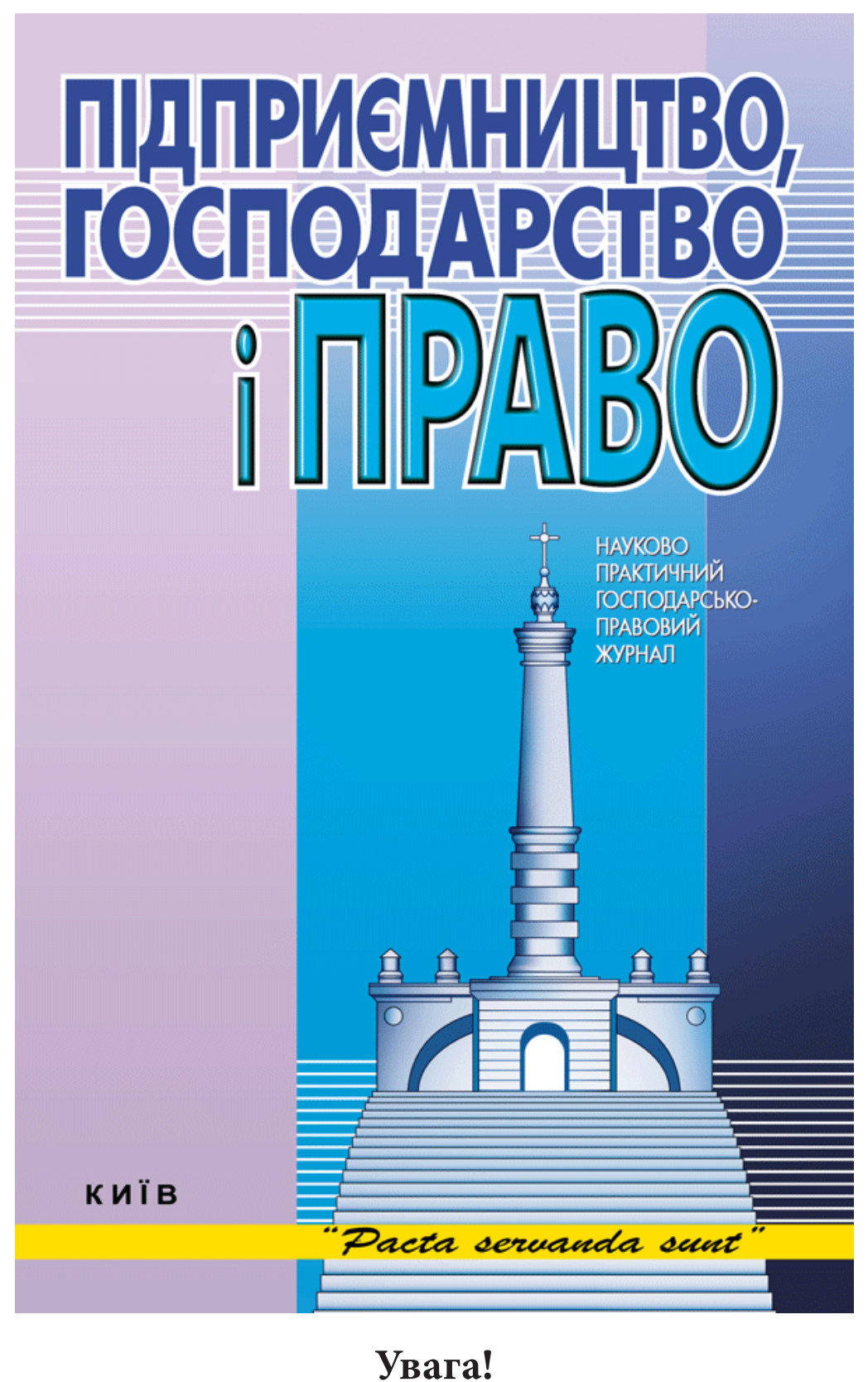

Триває передплата на журнал

«Підприємництво, господарство і право», яку можна оформити в будь-якому відділенні поштового зв'язку ПАТ «Укрпошта».

Наш передплатний індекс - 74576. 